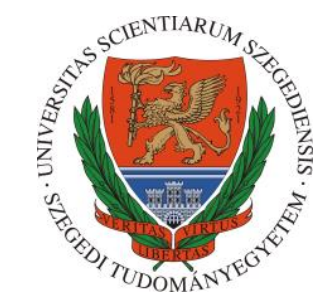

\title{
Protection of Employees' Right to Privacy ANd Right to Data Protection on Social NetWork Sites - With SPECIAL REgARD TO FRANCE AND HUNGARY
}

\section{0}

\section{Adrienn LUKÁCS}

\author{
Supervisors \\ Francis KeSSLER, University Paris 1 Panthéon Sorbonne, France \\ József HAJDÚ, University of Szeged, Hungary \\ Joint $\mathrm{PhD}$ between: \\ University Paris 1 Panthéon Sorbonne and \\ University of Szeged, Faculty of Law and Political Sciences
}


Manuscript closed: $10^{\text {th }}$ January 2020 


\section{ACKNOWLEDGEMENTS}

I was fortunate enough to pursue my $\mathrm{PhD}$ studies in the frame of a joint $\mathrm{PhD}$. Having the possibility to participate in the $\mathrm{PhD}$ programs of two countries was a unique and defining experience, as I had the opportunity to write one $\mathrm{PhD}$, to live in two countries, and to use three languages on an everyday basis - which gave me never-to-forget memories. However, not only the joy was double, but the obstacles as well. Luckily, I did not have to face these challenges alone: many people helped me during my $\mathrm{PhD}$ studies and without them, this dissertation would never have been written.

Amongst them, first of all, I would like to express my sincere gratitude to my two supervisors: I would like to thank József HAJDÚ, especially for introducing me to the path of research and for fully supporting me in realizing my various academic projects throughout the years. I would like to thank Francis KESSLER for supporting my ambitions to do research abroad by receiving me at University Paris 1 . I am very grateful to both of them for their guidance, and I am indebted to them for always taking the time to help my research and for continuously providing feedback on my work.

This dissertation would never have been accomplished without the Scholarship of the French Republic for joint PhD studies. I am very grateful to the staff members of Campus France and of the Doctoral Schools of the two Institutions for the help that I received to solve the administrative hurdles. I am especially grateful to my colleagues at the Department of Labour Law and Social Law at the University of Szeged for their constant support and for always welcoming me back in Szeged. I am grateful especially to Erika ENGI for her essential help with the administrative procedures.

I am also grateful to György KISS and Nicolas MOIZARD for accepting to be the reviewer for my public debate, and to Celia ZOLYNSKI for being a member of the jury. I also wish to thank Zsolt György BALOGH, who undertook the task of reviewing my dissertation for my preliminary debate and who also enriched it with his feedback.

Many thanks go especially to my mother for proofreading my translations during all these years, for reviewing my different articles, papers, and last but not least, my thesis.

I would like to say thanks to Dóra for continuosly offering me "PhD-saver" advice on how to survive in the administrative jungle, which is an essential part of the FrenchHungarian joint $\mathrm{PhD}$ life. I would also like to thank Morgane and Syrine for their valuable 
support and help during my stays in Paris. I am also grateful for the friendship of fellow joint PhD students John and Petr, who I could always count on when I needed comfort and who made my last semester in Paris truly memorable.

I would also like to thank my family and friends for fully supporting me in living this difficult but at the same time wonderful life shared between the two countries. Because of them, these years were not only about research; they made it a journey filled with lifelong memories and adventures - for which I am very grateful to them.

Szeged, $25^{\text {th }}$ June 2020 


\section{SUMMARY}

Online social network sites have gained considerable importance in everyday life. Their use results in the unprecedented share of personal data: individuals from all over the globe share personal information in a quality and quantity never seen before. Employees and prospective employees are amongst users as well, which raises privacy and data protection issues specific to the context of employment.

Although the "traditional" ways of employee monitoring, such as CCTV surveillance, monitoring of the use of Internet and e-mail, etc. are already regulated both at the international and at the national (French and Hungarian) level, the comprehensive regulation of social network sites with regard to the context of employment is yet to be elaborated. Social network sites have fundamentally influenced conceptions of privacy and data protection, resulting in the boundaries of work and personal life becoming increasingly blurred, both within and outside working hours. Yet, the processing of personal data obtained from social network sites increasingly raises the question of the protection of employees' rights - particularly the protection of the right to privacy and the right to data protection. These rights must be balanced notably against the employer's right to control and monitor, which ensue from the employer's right to property (ensuring the equipment provided by the employer is used in accordance with the purpose of the employment relationship), the right to protect his/her economic interest (e.g. through ensuring productivity, the protection of reputation) and occupational safety and health (which confers obligations on the employer).

Thus, the dissertation examines how the existing rules of labour law and of data protection law in France and in Hungary can be applied to social network sites and what the main challenge posed by them are, particularly in the phase of recruitment and during the use of social networks during and outside working hours. The main question to be answered by the dissertation is: in the light of the increasingly blurred boundaries, where should the balance be struck between the employees' and the employer's rights? 


\section{RÉSUMÉ}

Les sites de réseaux sociaux en ligne ont acquis une importance considérable dans la vie quotidienne. Leur utilisation conduit à une circulation sans précédent de données personnelles: des individus du monde entier partagent des données à caractère personnel dans une qualité et une quantité jamais vues auparavant. Parmi les utilisateurs de ces réseaux sociaux en ligne se trouvent des salariés et des candidats à l'embauche. Cela pose des problèmes spécifiques dans le contexte de l'emploi en ce qui concerne la vie privée et la protection des données.

Bien que les moyens «traditionnels» de surveillance des salariés, tels que la surveillance CCTV ou encore la surveillance de l'utilisation d'internet et du courrier électronique,soient déjà réglementés à la fois au niveau international et au niveau national (français et hongrois), la réglementation complète des réseaux sociaux en ce qui concerne le contexte de l'emploi nécessite encore une élaboration. Les sites de réseaux sociaux ont fondamentalement influencé les conceptions de la vie privée et de la protection des données, ce qui a pour conséquence une dilution des limites entre vie professionnelle et vie personnelle, tant pendant qu'au-delà des heures de travail. Or, le traitement des données personnelles des réseaux sociaux pose de plus en plus la question de la protection des droits des salariés, et notamment la protection du droit au respect de la vie privée et du droit à la protection des données. Ces droits doivent être mis en balance avec les pouvoirs de l'employeur, qui découle du droit de l'employeur à la propriété (s'assurer que l'équipement fourni par l'employeur est utilisé conformément à la finalité de la relation de travail), du droit de protéger son intérêt économique (par exemple en assurant la productivité, la protection de la réputation) ou encore de la sécurité et la santé au travail (ce qui confère des obligations à l'employeur).

Ainsi, la thèse examine comment les règles existantes du droit du travail et du droit de la protection des données en France et en Hongrie peuvent être appliquées aux sites de réseaux sociaux et quels sont les principaux défis qu'ils posent, notamment dans la phase de recrutement et en ce qui concerne l'utilisation des réseaux sociaux pendant et en dehors des heures de travail. La principale question à laquelle la thèse répond est la suivante : à la lumière des frontières de plus en plus floues entre vies privée et professionnelle, où trouver un équilibre entre les droits des salariés et ceux de l'employeur en matière d'usage des réseaux sociaux numériques et des données qui y sont produites? 


\section{ÖSSZEFOGLALÓ}

Az online közösségi oldalak jelentős szerepet játszanak a mindennapi életben. Használatuk során az egyének soha nem látott minőségben és mennyiségben osztják meg személyes adataikat, szerte az egész világon. A munkavállalók és a leendő munkavállalók szintén a felhasználók közé tartoznak, ami a foglalkoztatás kontextusában specifikus kérdéseket vet fel a magánélet és a személyes adatok védelme terén.

Bár a munkavállalók megfigyelésének ,hagyományos” módszereit, mint például a kamerás megfigyelést, az internet és az e-mail használatának megfigyelését, már mind nemzetközi, mind tagállami (francia és magyar) szinten szabályozzák, a közösségi oldalak foglalkoztatással összefüggő kimerítő szabályozása még kidolgozás alatt áll. A közösségi hálózati oldalak alapjaiban hatnak a magánéletre és a személyes adatok védelmére, aminek eredményeként a munka és magánélet határai egyre inkább elmosódnak, mind a munkaidőn belül, mind azon kívül. Ugyanakkor a közösségi oldalakról származó személyes adatok kezelése fokozottan felveti a munkavállalók jogainak védelmének kérdését - különös tekintettel a magánélet védelmére és a személyes adatok védelméhez való jogra. Ezeket a jogokat össze kell vetni különösen a munkáltató ellenőrzési és felügyeleti jogával, amely a munkáltató tulajdonhoz füződő jogából (pl.: annak biztosítása, hogy a munkáltató által biztosított felszerelést a munkavállaló a munkaviszony céljának megfelelően használja), valamint a jogos gazdasági érdekeinek védelméből. (pl. produktivitás biztosítása, jó hírnév védelme) és a munkahelyi biztonság és egészségvédelemből (amely kötelezettségeket ró a munkáltatóra) következik.

Következésképp, a disszertáció azt vizsgálja, hogy a Franciaországban és Magyarországon már létező munkajogi és adatvédelmi rendelkezések miként alkalmazhatók a közösségi oldalakra, és melyek az általuk felvetett legfőbb kihívások, különösen a munkaeröfelvétel, valamint a közösségi oldalak munkaidöben és azon kívül történő használata terén. A disszertáció által megválaszolandó fő kérdés az, hogy a fokozottan elmosódó határok fényében hol kell megtalálni az egyensúlyt a munkavállalók és a munkáltatók jogai között? 


\section{KEY-WORDS}

workplace privacy, online social network sites, employees' right to data protection, employee monitoring, employees' human rights and employer's rights and obligations in the digital age

\section{MOTS-CLÉS}

la vie privée dans l'entreprise, les réseaux sociaux en ligne, le droit à la protection de données personnelles des salariés, la surveillance des salariés, les droits de l'homme des salariés et les droit et obligations des employeurs à l'ère numérique

\section{KuLCSSZAVAK}

magánszférához való jog a munkahelyen, online közösségi oldalak, munkavállallók személyes adatok védelméhez való joga, munkavállalók megfigyelése, a munkavállalók emberi jogai és a munkáltató jogai és kötelezettségei a digitális korban 


\section{TABLE OF CONTENT}

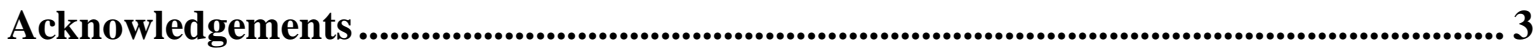

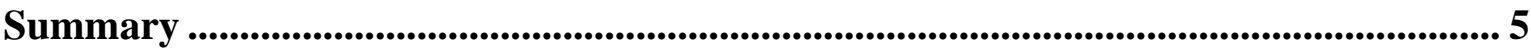

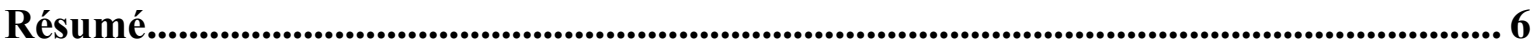

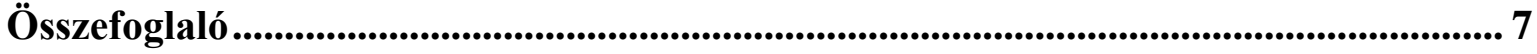

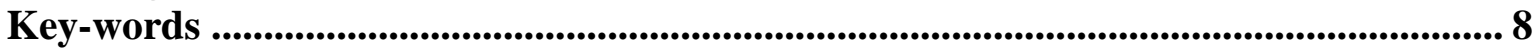

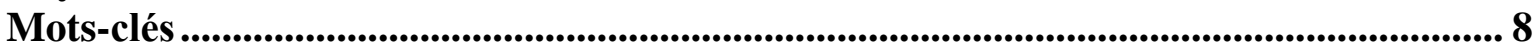

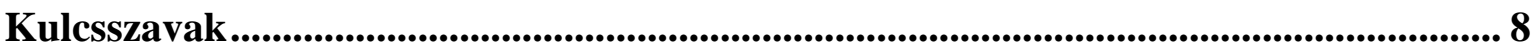

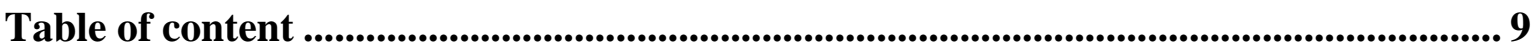

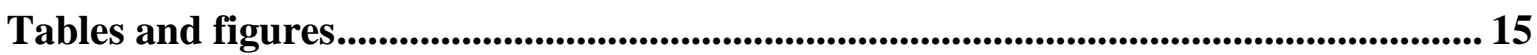

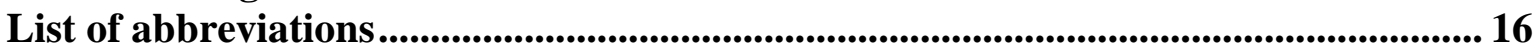

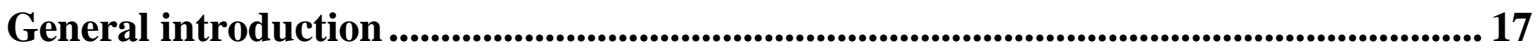

Part I. Protection of employees' private life and personal data in the context of online

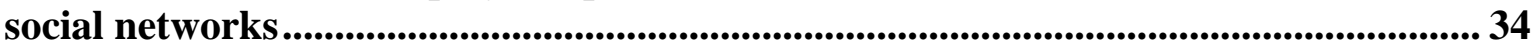

Title 1: Collision of the employees' right to privacy and to data protection and the employer's rights ...........................................................................................................37

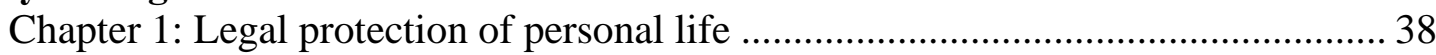

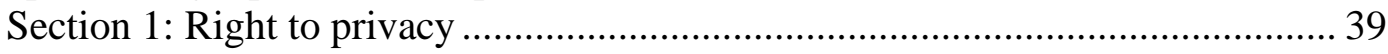

$\S 1$. The challenges in defining (the right to) privacy: definitions and history .... 40

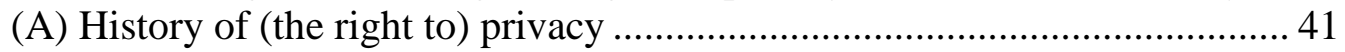

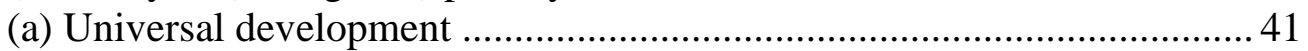

(b) Legal acknowledgement of the right to privacy: France and Hungary.... 45

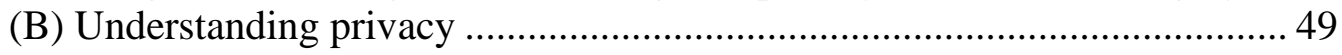

(a) Definitions and classification of definitions ........................................... 49

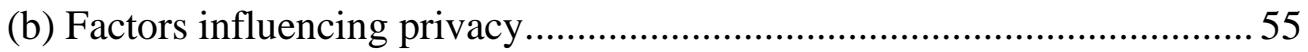

$\S 2$. The legal regulation of the right to privacy................................................ 58

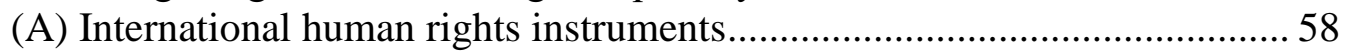

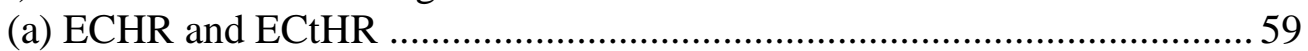

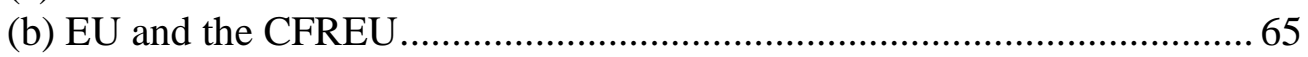

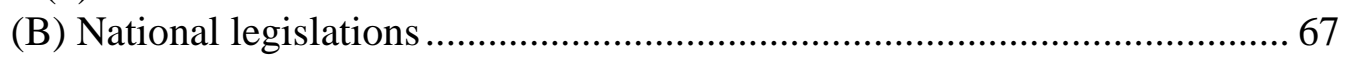

(a) Protection of private life in France and in Hungary................................67 67

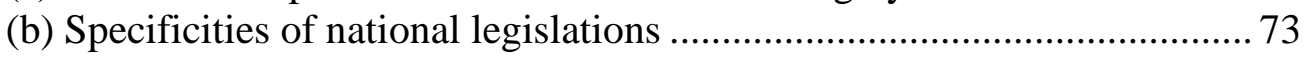

$(\alpha)$ The concept of personal life in French labour law............................. 74

$(\beta)$ Hungarian Act on the Protection of Private Life ............................... 77

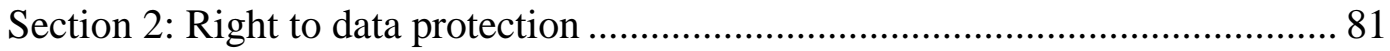

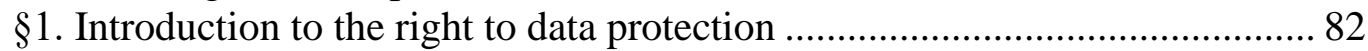

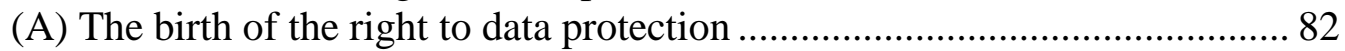

(B) Defining data protection: substantial delimitation from the right to privacy 87

$\S 2$. Legal regulation of the right to data protection........................................... 93

(A) Formal distinction from the right to privacy: norms regulating the right to

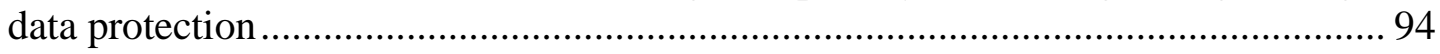

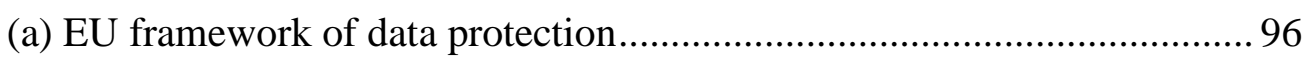

(b) General Data Protection Regulation - rules of data processing ............. 99

(B) The right to informational self-determination in France and in Hungary 114

(a) Conceptual foundations...................................................................... 115

(b) Right to informational self-determination in France and in Hungary.... 118

Chapter 2: Employee control and monitoring .................................................. 122

Section 1: The employer's right to monitor...................................................... 124 
$\S 1$. Rights and obligations arising from the employment relationship ............ 125

$\S 2$. Appearance of the right to monitor in national legal orders ...................... 128

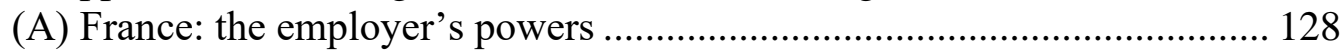

(B) Hungary: the employer's legitimate interests....................................... 134

Section 2: Legal rules relating to employee monitoring................................... 140

$\S 1$. Workplace privacy in the European legal order....................................... 140

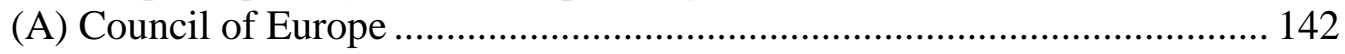

(a) ECtHR case law related to workplace monitoring .............................. 143

(b) Recommendations of the CoE ........................................................ 149

(c) (Revised) European Social Charter and the European Committee of Social

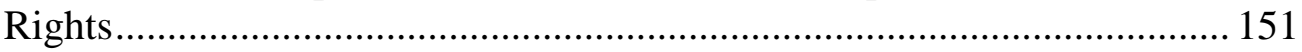

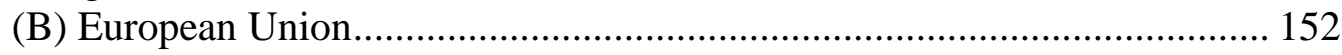

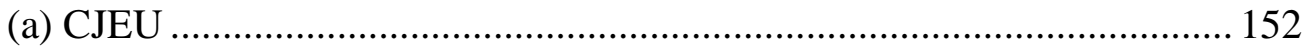

(b) The Article 29 Data Protection Working Party and the European Data

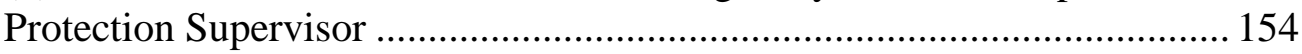

$\S 2$. Workplace privacy/data protection in France and in Hungary .................... 161

(A) Protecting employees' rights in the labour codes ................................... 163

(a) Article L1121-1 of the French Labour Code........................................ 164

(b) Protection of rights relating to personality in the Hungarian Labour Code

(B) Data protection and employee monitoring ........................................... 169

(a) Principles applicable to the processing of personal information in the

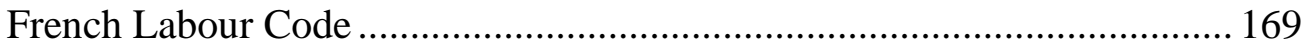

(b) Data processing and employee monitoring in the Hungarian Labour Code

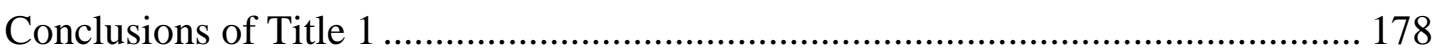

Title 2: Blurred boundaries of work and personal life in the digital age ................ 181

Chapter 1: Information and communication technology and blurred boundaries of

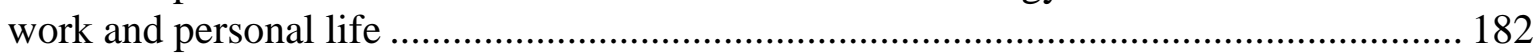

Section 1: New forms of employment .......................................................... 183

Section 2: "ATAWAD": AnyTime, AnyWhere, AnyDevice - eroding physical

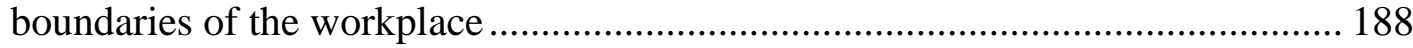

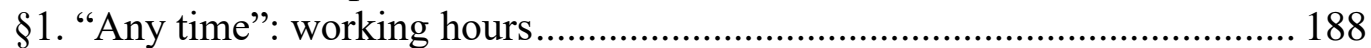

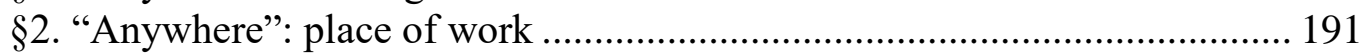

§3. "Any device": equipment used for work................................................. 192

Chapter 2: The rise of social network sites and its effects on employment............. 194

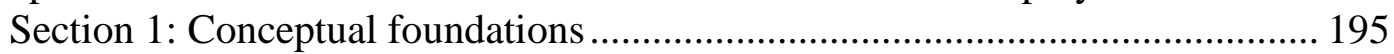

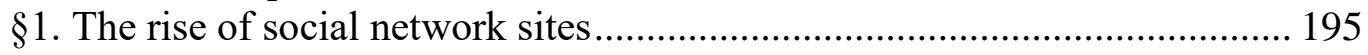

(A) History of social network sites ......................................................... 195

(B) Delimitation of social media and social network sites ......................... 199

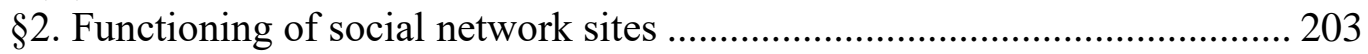

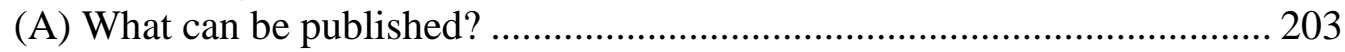

(B) Content relating to whom can be published? .......................................... 204

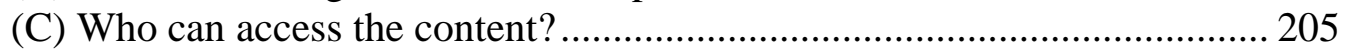

Section 2: Legal implications and social network sites ..................................... 209

$\S 1$. Documents addressing social network sites and privacy/data protection ... 210

$\S 2$. Social network sites and data protection................................................... 213

Section 3: Social network sites and blurred boundaries ................................... 219

$\S 1$. Changed expectations of privacy ....................................................... 219

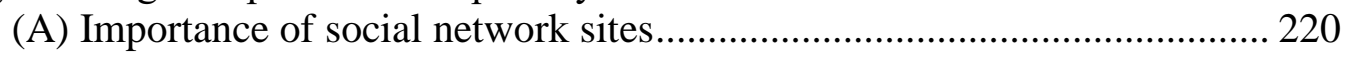


(B) Social network sites and the boundaries of privacy .............................. 224

$\S 2$. Blurring of work and personal life within social network sites .................. 229

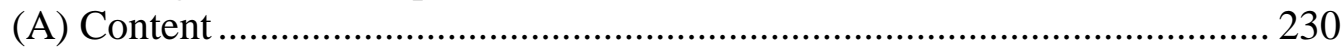

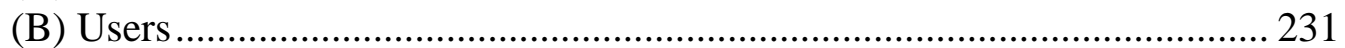

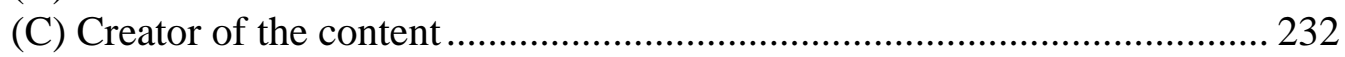

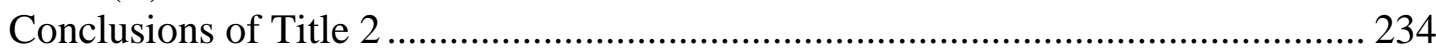

Part II. Right to privacy and right to data protection during the monitoring and controlling of the use of social network sites in the employment context................... 236

Title 1: Concluding an employment contract in the context of online social network sites.

Chapter 1: Labour law aspects of recruitment ..................................................... 243

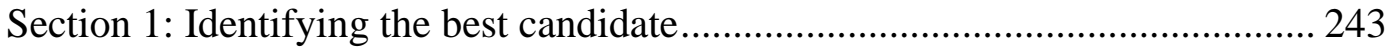

§1: The employer's side: freedom of contract ............................................ 243

(A) The employer's interests in obtaining information ................................ 243

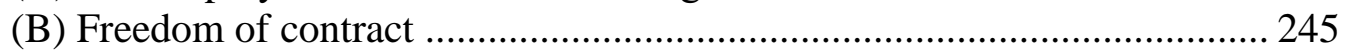

$\S 2$ : Methods of recruitment: Internet and social network sites ....................... 248

Section 2: The traditional recruitment procedure ........................................... 251

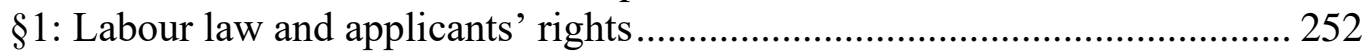

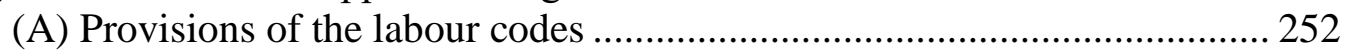

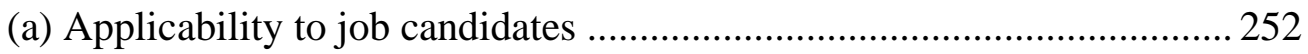

(b) Applicants' right to data protection in the labour codes ....................... 255

(B) Practice of the data protection supervisory bodies ................................ 257

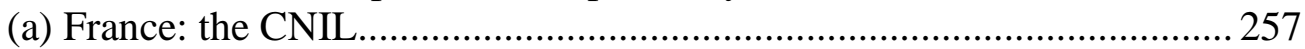

(b) Hungary: the Data Protection Commissioner and the NAIH................. 258

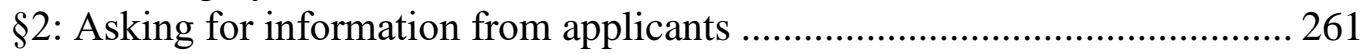

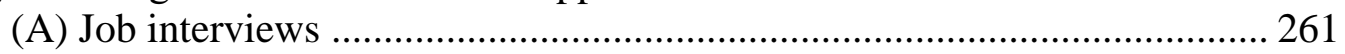

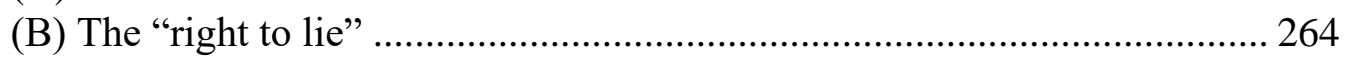

Chapter 2: Social network sites and arising data protection questions .................... 266

Section 1: Questions relating to data processing principles ............................... 267

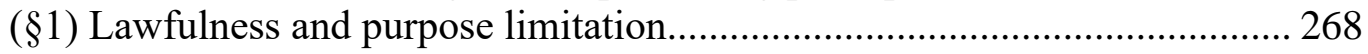

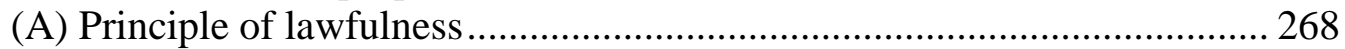

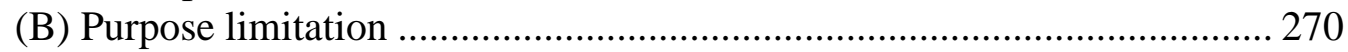

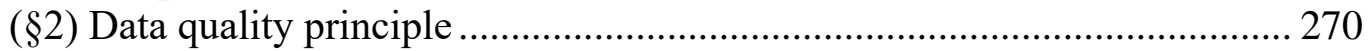

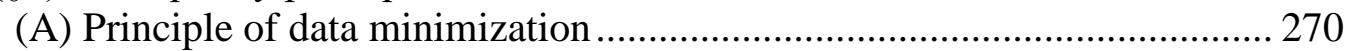

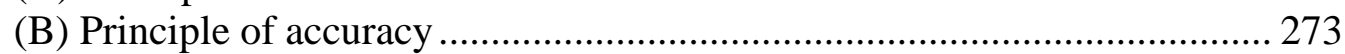

( 33$)$ Conducting the background checks..................................................... 277

Section 2. Access and transparency of processing .......................................... 280

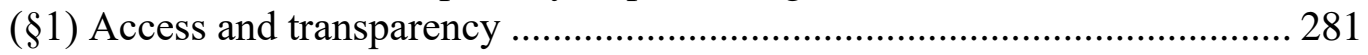

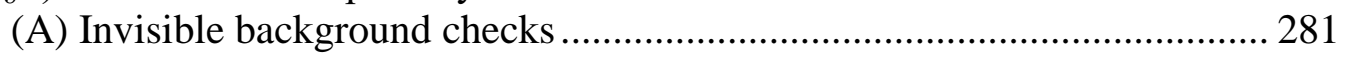

(B) Other ways of access .................................................................. 283

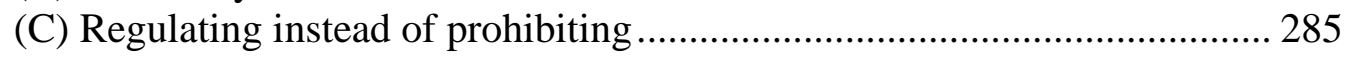

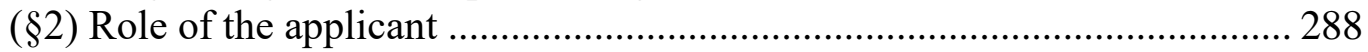

(A) Increased consciousness during the use of SNSs .................................. 288

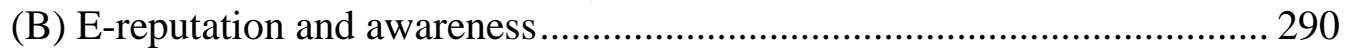

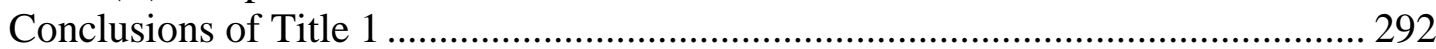

Title 2: The use of social network sites at the expense of working hours ............... 296

Chapter 1: Possible prohibition of personal use of SNSs during working hours..... 301

Section 1. Employees' right to personal life within the workplace: regulating personal use of the Internet and e-mail during working hours ............................ 302

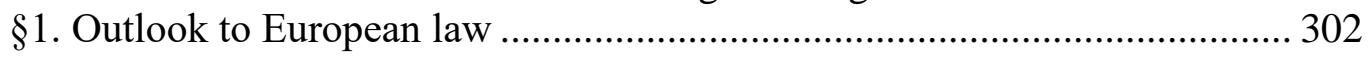




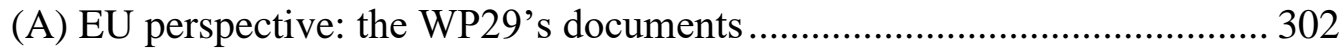

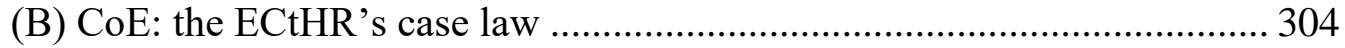

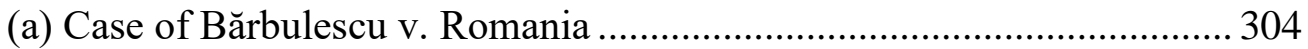

(b) Case of Libert v. France...................................................................... 305

$\S 2$. Regulation at the national level: France and Hungary .............................. 306

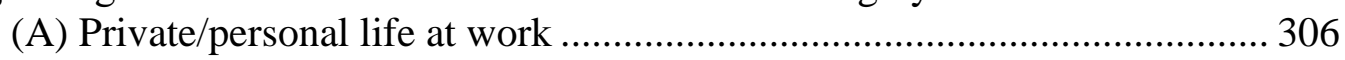

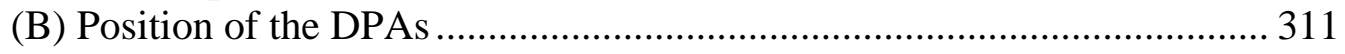

(C) Case law: abusive personal use and "Facebook firings" ....................... 313

Section 2. New challenges brought by social network sites............................. 321

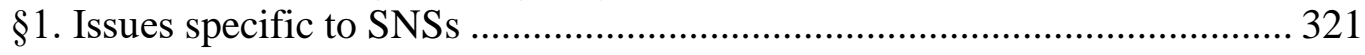

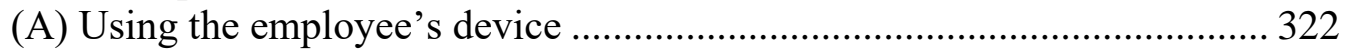

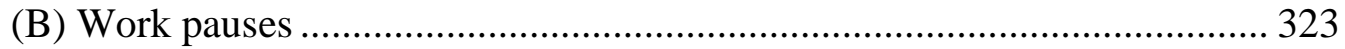

(C) SNSs as proof of unauthorized absences................................................ 325

§2. Additional factors to be considered ........................................................ 327

Chapter 2: Employees' right to data protection: monitoring employee use of SNSs

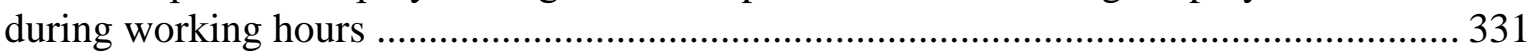

Section 1. Starting point: monitoring of the Internet and e-mail....................... 332

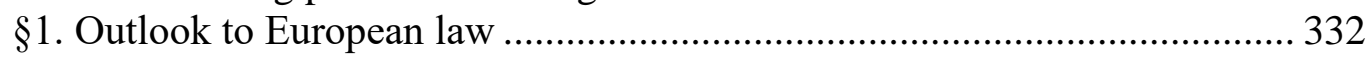

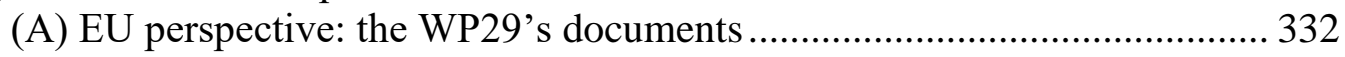

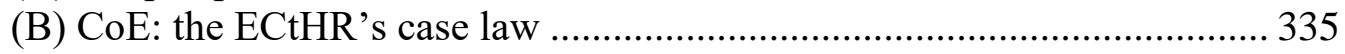

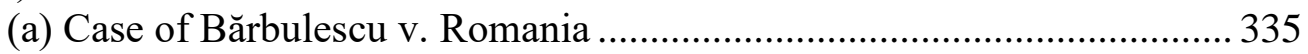

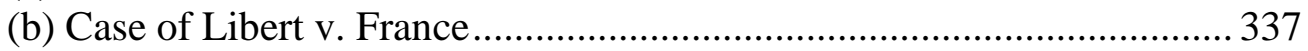

$\S 2$. Regulation at the national level: France and Hungary .............................. 339

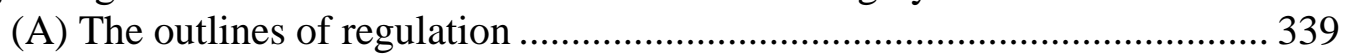

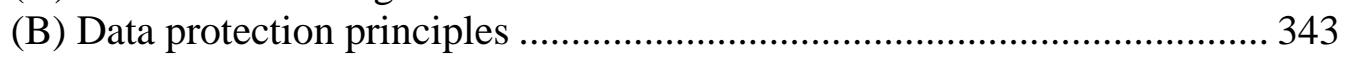

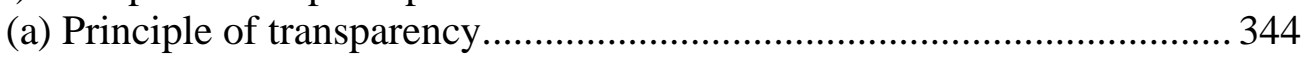

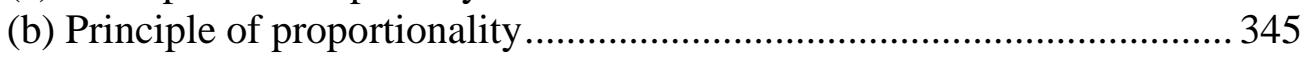

Section 2. New factors to be considered - highlighted by SNSs ...................... 347

$\S 1$. Specific issues raised by SNSs............................................................... 347

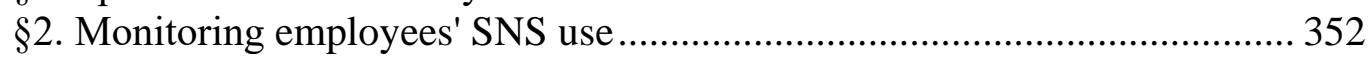

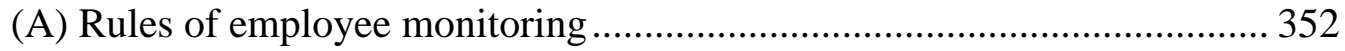

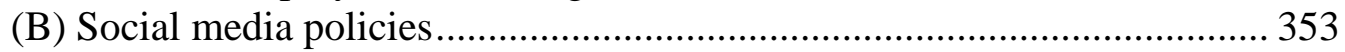

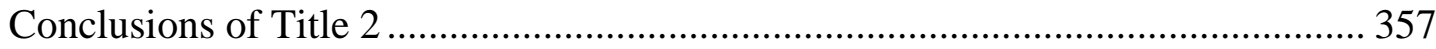

Title 3: Employees' engaging in social network sites with special regard to off-duty

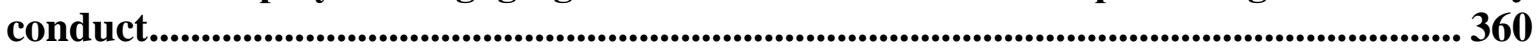

Chapter 1: Off-duty conduct and private/personal life ......................................... 363

Section 1. Online activity with direct connection to the employment.................. 368

$\S 1$. Employees expressing themselves on social network sites ...................... 369

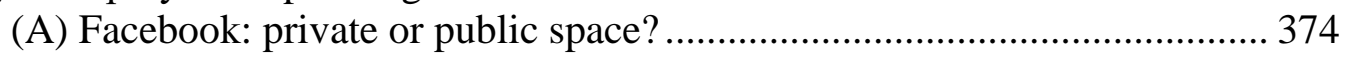

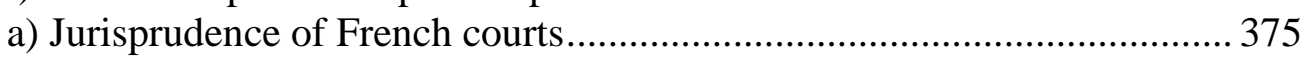

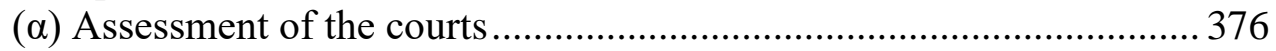

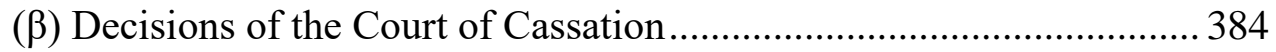

b) Activities beyond working hours: the Hungarian Labour Code ............. 389

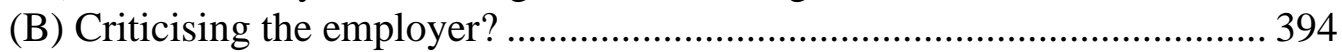

a) Abusing freedom of expression: France................................................ 395

b) Freedom of expression: Hungary ........................................................ 400

c) Is a "like" considered as expressing opinion? ......................................... 402

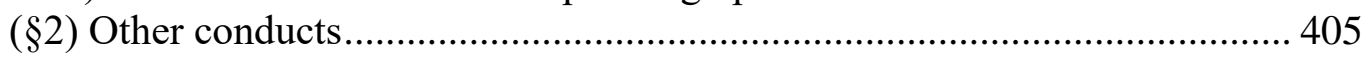

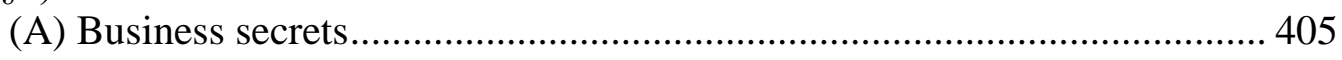

(B) Employer's legitimate economic interests and rights and competition.... 408 


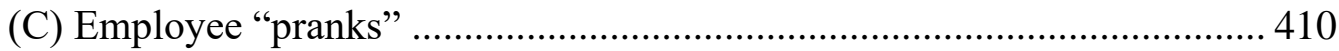

Section 2. Off-duty conduct without direct connection to the employment........ 413

$(\S 1)$ Non-disciplinary dismissals and characterised serious disorder .............. 415

(A) Characterised serious disorder .............................................................. 416

(B) Characterised serious disorder and social network sites ........................ 418

(§2) Off-duty conduct and the Hungarian Labour Code................................. 419

(A) Behaviour outside of working hours ................................................... 420

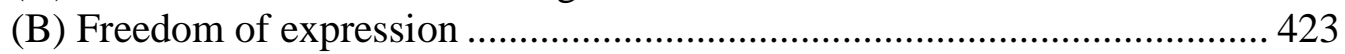

Chapter 2: Regulating and monitoring employees' presence on SNSs.................... 426

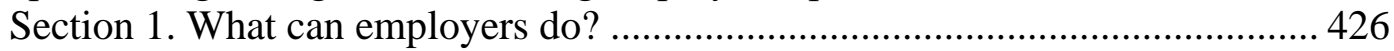

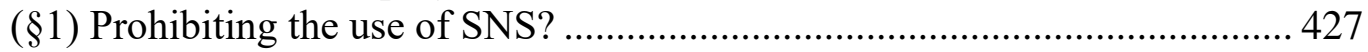

(§2) Employee monitoring and data protection .............................................. 429

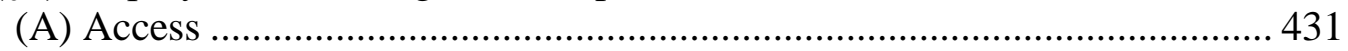

(B) Data protection principles ................................................................. 433

(a) Purpose limitation, necessity and proportionality ............................... 434

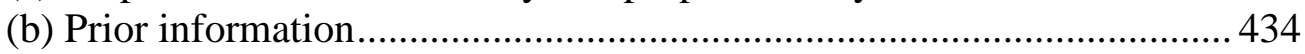

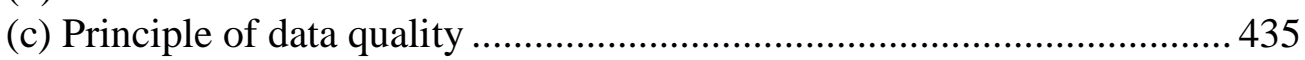

Section 2. Best practices and recommendations............................................ 437

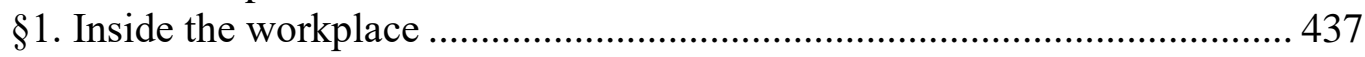

(A) Adopting internal social media policies............................................... 437

(B) Recommended content of the policy .....................................................439

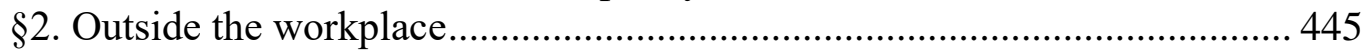

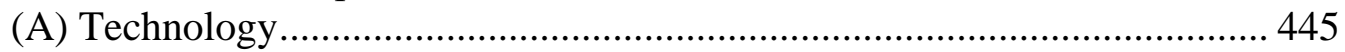

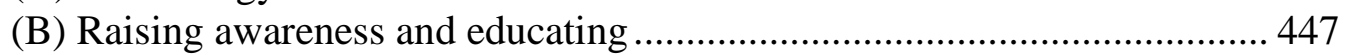

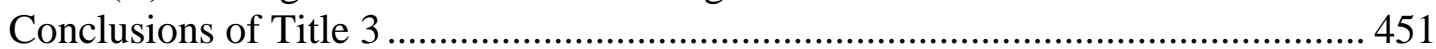

General conclusions...............................................................................................454

Bibliography - List of literature and sources ............................................................... 462

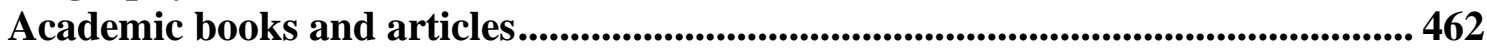

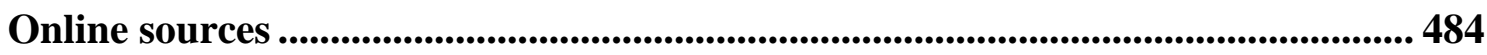

List of legislation, case law and other law related documents........................................ 492

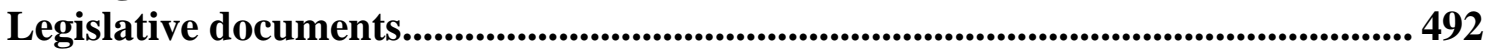

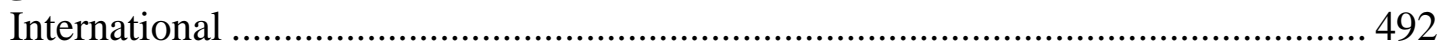

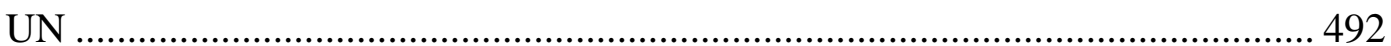

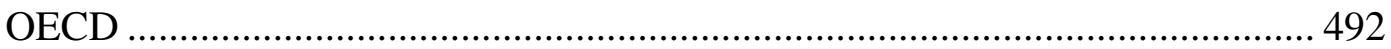

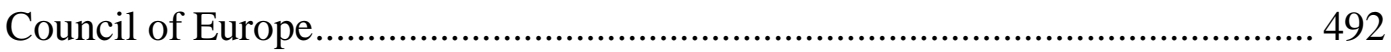

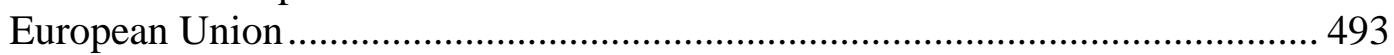

Other international institutions and bodies .................................................. 494

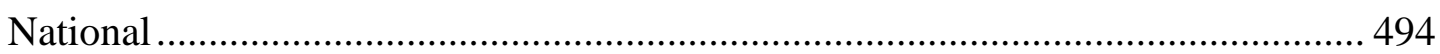

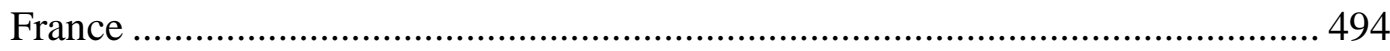

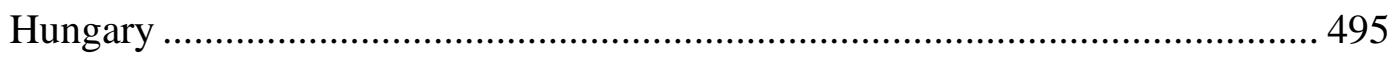

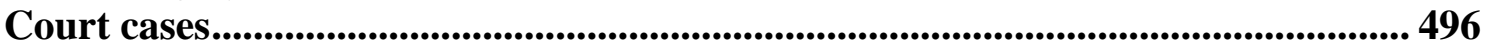

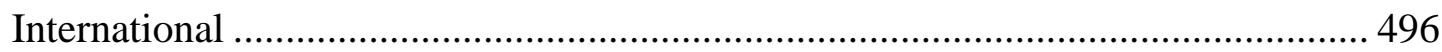

Court of Justice of the European Union ............................................................. 496

European Court (and Commission) of Human Rights ...................................... 496

Decisions of national courts and state institutions ................................................ 497

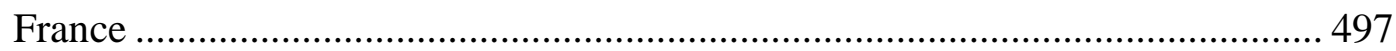

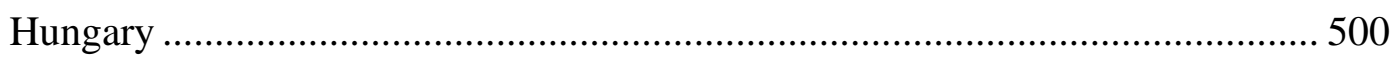

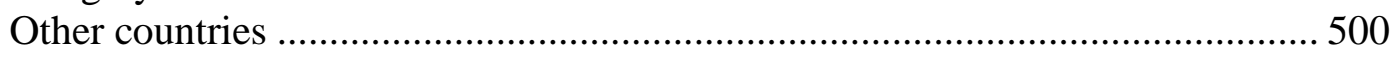

Documents of the data protection supervisory authorities ................................. 501

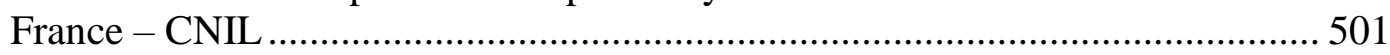


Hungary - Data Protection Commissioner and NAIH ................................... 502

Other, international, law related documents - reports, recommendations, activity

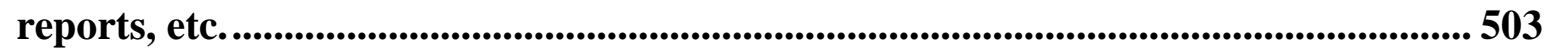

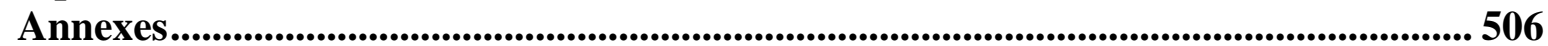

Annex I. - Most important international documents in the fields of privacy - data protection - employment - social network sites (UN, CoE, EU) .................................. 506 


\section{TABLES AND FIGURES}

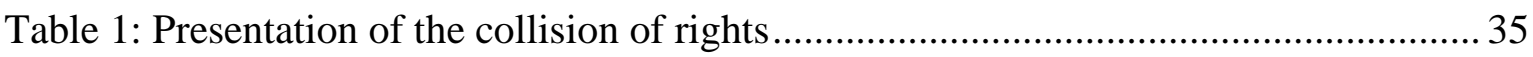

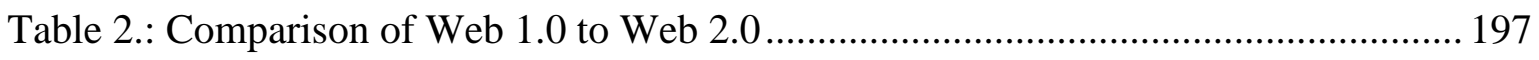

Table 3: Most important distinctive criteria between social media and social network sites 202

Table 4: Functioning of social network sites: what, whose personal data can be published

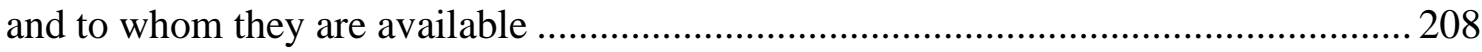

Table 5: Assessment of Section 8 of the Hungarian Labour Code.................................... 373 


\section{LIST OF ABBREVIATIONS}

\begin{tabular}{|c|c|}
\hline APEC & Asia-Pacific Economic Cooperation \\
\hline BYOD & bring your own device \\
\hline CCTV & closed-circuit television \\
\hline CFREU & Charter of Fundamental Rights of the European Union \\
\hline CJEU & Court of Justice of the European Union \\
\hline CNIL & $\begin{array}{l}\text { Commission Nationale de l'Informatique et des Libertés (French } \\
\text { National Commission on Informatics and Freedoms) }\end{array}$ \\
\hline CoE & Council of Europe \\
\hline DPA & data protection authority \\
\hline DPD & $\begin{array}{l}\text { Directive } 95 / 46 / \mathrm{EC} \text { on the protection of individuals with regard to } \\
\text { the processing of personal data and on the free movement of such } \\
\text { data }\end{array}$ \\
\hline ECHR & European Convention on Human Rights \\
\hline ECOWAS & Economic Community of West African States \\
\hline ECSR & European Committee of Social Rights \\
\hline ECtHR & European Court of Human Rights \\
\hline EDPB & European Data Protection Board \\
\hline EDPS & European Data Protection Supervisor \\
\hline ELLN & European Labour Law Network \\
\hline ENISA & European Union Agency for Network and Information Security \\
\hline ESC & European Social Charter \\
\hline $\mathbf{E U}$ & European Union \\
\hline FDPA & $\begin{array}{l}\text { French Data Protection Act (Act No. } 78-17 \text { of } 6 \text { January } 1978 \text { on } \\
\text { Information Technology, Data Files and Civil Liberties) }\end{array}$ \\
\hline FLC & French Labour Code (Code du travail) \\
\hline GDPR & General Data Protection Regulation \\
\hline HDPA & $\begin{array}{l}\text { Hungarian Data Protection Act (Act CXII of } 2011 \text { on the Right to } \\
\text { Informational Self-determination and Freedom of Information) }\end{array}$ \\
\hline HLC & Hungarian Labour Code (Act I of 2012 on the Labour Code) \\
\hline ICCPR & International Covenant on Civil and Political Rights \\
\hline ICO & Information Commissioner's Office \\
\hline ICT & information and communication technology \\
\hline ILO & International Labour Organization \\
\hline IWGDPT & $\begin{array}{l}\text { International Working Group on Data Protection in } \\
\text { Telecommunications }\end{array}$ \\
\hline NAIH & $\begin{array}{l}\text { Nemzeti Adatvédelmi és Információszabadság Hatóság (Hungarian } \\
\text { National Authority for Data Protection and Freedom of Information) }\end{array}$ \\
\hline OECD & Organisation for Economic Co-operation and Development \\
\hline $\begin{array}{l}\text { Privacy Act } \\
\text { SNS }\end{array}$ & $\begin{array}{l}\text { Hungarian Act LIII of } 2018 \text { on the Protection of Private Life } \\
\text { social network site }\end{array}$ \\
\hline TFEU & Treaty on the Functioning of the European Union \\
\hline UDHR & Universal Declaration of Human Rights \\
\hline WP29 & Article 29 Data Protection Working Party \\
\hline
\end{tabular}




\section{GENERAL INTRODUCTION}

1. New information and communications technologies (hereinafter referred to as: ICT) ${ }^{1}$ are omnipresent and exert a fundamental impact on everyday life in the $21^{\text {st }}$ century - including the world of work as well: ${ }^{2}$ digitalisation fundamentally changes not only working conditions, but also the possibilities in workplace monitoring. ${ }^{3}$ Innovations of ICT, such as personal computers, Internet, e-mail, blogs or social network sites essentially influence and transform the way individuals live their lives - together with working, creating new challenges for labour market participants. ${ }^{4,5}$ These challenges can relate to a number of matters, such as the arrangement of working time, ${ }^{6}$ occupational health and safety, ${ }^{7}$ organisation of work or controlling and monitoring employees.

1 According to Eurostat the term ICT "covers all technical means used to handle information and aid communication." Source: Eurostat (no date) Glossary: Information and communication technology (ICT). Available at: https://ec.europa.eu/eurostat/statisticsexplained/index.php/Glossary:Information_and_communication_technology_(ICT) (Accessed: 25 October 2019). According to the Cambridge Dictionary, ICT refers to "the use of computers and other electronic equipment and systems to collect, store, use, and send data electronically." Source: Cambridge Dictionary (no date) 'ICT' in Business English. Available at: https://dictionary.cambridge.org/dictionary/english/ict (Accessed: 22 September 2019)

${ }^{2}$ Rey, B. (2013) 'La vie privée au travail. Retour sur la place du privé en contexte hiérarchique à l'ère du numérique', Les Cahiers du numérique, 9(2), p. 108.

${ }^{3}$ Fritsch, C. (2015) 'Data Processing in Employment Relations; Impacts of the European General Data Protection Regulation Focusing on the Data Protection Officer at the Worksite', in Gutwirth, S., Leenes, R., and de Hert, P. (eds) Reforming European Data Protection Law. Dordrecht, Heidelberg, New York, London: Springer, p. 149.

${ }^{4}$ In its report the French Employment Orientation Council ("Conseil d'orientation pour l'emploi") drew attention to the diversified impacts social network sites, and in general Internet exercise on the world of work, notably in the field of recruitment through the appearance of online job forums, social network sites (professional or personal ones used for professional purposes) or even platform work. See more in: Conseil d'orientation pour l'emploi (2015) L'impact d'internet sur le fonctionnement du marche du travail : synthese $d u$ diagnostic $d u \quad$ conseil. Available at: http://www.coe.gouv.fr/IMG/pdf/Synthese_rapport_Version_finale.pdf (Accessed: 25 October 2019)

${ }^{5}$ On the impacts of technological development on the organisation of work, see more in the following article discussing the impacts through the examples of a textile factory and a fish factory. Lovesio, B. (1993) 'Changements techniques et procès de travail. Qualification et déqualification de la main d'œuvre', Cahiers du GEDISST (Groupe d'étude sur la division sociale et sexuelle du travail), (7), pp. 41-59. The organisation of work was essentially influenced by the appearance of division of work (partly possible due to the appearance of machines), described in "An Inquiry into the Nature and Causes of the Wealth of Nations" by economist Adam Smith published in 1776. On its effects on the organisation of work and different theories relating to it see more in: Boyer, R. and Schméder, G. (1990) 'Division du travail, changement technique et croissance. Un retour à Adam Smith.', Revue française d'économie, 5(1), pp. 125-194.

${ }^{6}$ Especially it is the case of knowledge workers who - notably due to mobile and smartphones, personal computers and e-mail - are capable of working anytime, anywhere, considerably challenging the previous separation of the concept office equals working time, home equals private life. These matters will be addressed in detail in Part I.

${ }^{7}$ Being available to the employer constantly has important implications for the employees' right to rest and can possibly affect their health as well. These matters will be further addressed in Part I. 
2. As part of ICT, online social network sites (hereinafter referred to as: SNSs) have caused profound changes through shaking up the previously existing forms of communication and self-expression. SNSs are gaining growing importance in individuals' everyday lives: according to Eurostat, in 2017 one of the most frequent online activities in the European Union (hereinafter referred to as: EU) was the use of SNSs. ${ }^{8}$ As Alissa Del Riego et al. phrased it, the use of SNSs "[...] is not a luxury or a lifestyle choice, but part of the reality of the modern world. "9 The first SNS - SixDegrees - appeared in 1997, ${ }^{10}$ and since then several others have followed. ${ }^{11}$ Today the most popular SNSs have millions of users worldwide. Facebook is the biggest "country" in the world with its 2.2 billion users, while YouTube, Twitter and Instagram has 1.9 billion, 335 million and 1 billion active users, respectively, just to mention a few examples. ${ }^{12}$ There exist hundreds of different international and national (social media) and SNSs. ${ }^{13}$ The reasons lying behind such popularity are threefold, according to James Grimmelmann. In one of his articles, ${ }^{14}$ he identifies and describes three main forms of motivations, all three originating from basic human needs that existed before the invention of SNSs, but gained a new form through their appearance. ${ }^{15}$ These human needs are self-expression (identity), communication

8 Digital economy and society statistics - households and individuals (2018) Eurostat. Available at: https://ec.europa.eu/eurostat/statistics-explained/index.php/Digital_economy_and_society_statistics__households_and_individuals\#Internet_usage (Accessed: 4 January 2018)

${ }_{9}$ Del Riego, A., Sánchez Abril, P. and Levin, A. (2012) 'Your Password or Your Paycheck?: A Job Applicant's Murky Right to Social Media Privacy', Journal of Internet Law, 16(3), p. 23.

10 boyd, danah $\mathrm{m}$. and Ellison, N. B. (2008) 'Social Network Sites: Definition, History and Scholarship', Journal of Computer Mediated Communication, 13(1), p. 214.

${ }^{11}$ For example, Myspace and LinkedIn were launched in 2003, Facebook in 2004, YouTube in 2005, Twitter in 2006, Instagram in 2010 and Snapchat in 2011.

${ }^{12}$ Most famous social network sites worldwide as of October 2018, ranked by number of active users (in millions) (2018) Statista. Available at: https://www.statista.com/statistics/272014/global-social-networksranked-by-number-of-users/ (Accessed: 4 January 2018). These sites enjoy a likewise popularity in France and in Hungary: in France approximately $45 \%$ of the population is estimated to use SNSs (65\% of these users possess a Facebook account), while in Hungary 5.4 million users are present on Facebook. Sources: L'usage des réseaux sociaux en France - Faits et chiffres (no date) Statista. Available at: https://fr.statista.com/themes/2761/l-usage-des-reseaux-sociaux-en-france/ (Accessed: 4 January 2019) and Lévai, R. (2017) Magyarok a közösségi médiában 2017 elején, Közösségi kalandozások. Available at: http://kozossegikalandozasok.hu/2017/01/04/magyarok-a-kozossegi-mediaban-2017-elejen/ (Accessed: 4 January 2019)

${ }^{13}$ For an illustrative list of the most popular SNSs see more in: List of social networking websites (no date) Wikipedia. Available at: https://en.wikipedia.org/wiki/List_of_social_networking_websites (Accessed: 4 January 2018); Mehra, G. (2017) 105 Leading Social Networks Worldwide, PracticalEcommerce. Available at: https://www.practicalecommerce.com/105-leading-social-networks-worldwide (Accessed: 4 January 2019); 2019: Top 57 Social Media Platforms Every Executive Should Know (Updated) (2010) 60 Second Marketer. Available at: https://60secondmarketer.com/blog/2010/04/09/top-52-social-mediaplatforms-2/ (Accessed: 4 January 2019)

As such, it is impossible to examine all SNSs, therefore the dissertation focuses on the most commonly used ones.

${ }^{14}$ Grimmelmann, J. (2009) 'Saving Facebook', Iowa Law Review, 94(4), pp. 1137-1206.

${ }^{15}$ Grimmelmann, J. (2009) 'Saving Facebook', Iowa Law Review, 94(4), p. 1159. 
(relationships) and being part of a community; constituting the basic elements of social interaction. ${ }^{16}$ During the use of such services, the personal data of individuals become publicly available in a quantity and quality never experienced before, on a global scale, ${ }^{17}$ which results in the appreciation of the examination of their right to privacy and right to data protection.

3. Employees are among SNS users as well, which can raise several challenges in multiple fields relating to employment: starting from recruitment, ${ }^{18}$ through SNSs' effects on working hours, ${ }^{19}$ leaking business secrets ${ }^{20}$ or the collective enforcement of employees' rights, ${ }^{21}$ till questions relating to employees' freedom of expression on SNSs. ${ }^{22}$ These fields notably raise the question of ensuring the employer's rights (manifested in controlling and monitoring employees) during employee use of SNSs, which can enter into collision with the above-mentioned right to privacy and right to data protection.

4. As opposed to the right to privacy and right to data protection, the employer has different rights, the enforcement of which might justify employee control and

\footnotetext{
${ }^{16}$ First, users can express their identity through their profiles, by allowing the individual to carefully shape what kind of image of himself/herself he/she wants to express towards other users. Second, they can communicate and maintain different relations with other users in several ways. Third, users can feel that they are a part of a community and they can establish their social position within the community. Source: Grimmelmann, J. (2009) 'Saving Facebook', Iowa Law Review, 94(4), pp. 1151-1159.

${ }^{17}$ International Working Group on Data Protection in Telecommunications (2008) Report and Guidance on Privacy in Social Network Services - "Rome Memorandum” -. 675.36.5. Rome. p. 10.

${ }^{18}$ See more on the roles and importance of (online and offline) social networks in relation to employment and recruitment in: Fondeur, Y. and Lhermitte, F. (2006) 'Réseaux sociaux numériques et marché du travail', $L a$ Revue de l'Ires, (52), pp. 101-131.; Fontaine, F. (2006) 'Les réseaux de relations : quelles perspectives pour l'économie du marché du travail ?', Revue française d'économie, 21(1), pp. 127-172.

${ }^{19}$ Illustrated by cases where the termination of employment was a response to the employee's excessive use of SNSs at the expense of working hours. See, for example: Cour de cassation, chambre sociale, 18 mars 2009, $\mathrm{N}^{\circ}$ 07-44247 and Cour de cassation, chambre sociale, 26 février 2013, $\mathrm{N}^{\circ} 11-27372$

${ }^{20} \mathrm{See}$, for example, the case of a French police officer who revealed confidential information relating to the organization of the municipal police, and especially to the video surveillance system applied in the municipality. Source: Conseil d'État (2017): № 393320 (ECLI:FR:CECHR:2017:393320.20170320), 3ème 8 ème chambres réunies, 20 mars

${ }^{21}$ For more information on this subject see: Larher, Y.-M. (2017) Les relations numériques de travail. Doctoral dissertation. Université Paris 2 Panthéon-Assas and Ray, J.-E. (2012) 'CGT, CFDT, CNT, CE et TIC. Rapports collectifs de travail et nouvelles technologies de l'information et de la communication', Droit social, (4), pp. 362-372.

${ }^{22}$ This phenomenon is supported by the growing number of "Facebook firings": employees being dismissed for content published on SNSs. On this issue - which will be addressed in detail in Part II. - see more, for example, in: Ray, J.-E. (2018) 'Des “licenciements Facebook” à la sanction d'un "Like"?', Semaine sociale Lamy, (1830), pp. 10-12.; Julien-Paturle, D. (2018) 'Critiquer son employeur sur internet peut entraîner un licenciement au titre d'un abus de la liberté d'expression', Jurisprudence sociale Lamy, (456), pp. 26-28.; Mihos, S. (2012) 'Social networking and the employment relationship', in Maria, B., Eugenia, A., and Iglezakis, I. (eds) Values and Freedoms in Modern Information Law and Ethics. (Proceedings of the 4th International Conference on Information Law and Ethics), Available at: https://www.linkedin.com/redir/redirect?url=http\%3A\%2F\%2Fbit\%2Ely \%2F1m9O6SY\&urlhash=n43A\& trk=public_profile_publication-button (Accessed: 11 December 2019). pp. 565-569.
} 
monitoring. These rights notably include the right to property (including the economic freedom to decide how to use the employer's property), the right to protect his/her economic interest (e.g. through ensuring productivity, the protection of reputation, the protection of business secrets, the protection of legitimate economic interests) and occupational safety and health (which mostly confers obligations on the employer). In order to ensure the protection of these rights, the employer is entitled to control employees' behaviour and to monitor whether employees respect the relevant rules and requirements.

5. Controlling and monitoring employees is not a new phenomenon as early examples, such as Jeremy Bentham's Panopticon, ${ }^{23}$ the scientific management of Frederick Taylor $^{24}$ of Henry Ford's Sociological Department ${ }^{25}$ illustrate it. ${ }^{26}$ Controlling and monitoring are inherent to the employment relationship as the employee is subordinated to the employer: he/she is usually integrated into the organisation of the employer, uses the materials provided by him/her and is expected to follow his/her instructions regarding the work. ${ }^{27}$ According to general labour law principles, employers have "a contractually based right to control contract fulfilment and to monitor work performance and the proper

\footnotetext{
${ }^{23}$ He created a surveillance model, the Panopticon, which could be applied in "any sort of establishment, in which persons of any description are to be kept under inspection; and in particular to penitentiary-houses, prisons, houses of industry, work-houses, poor-houses, lazarettos, manufactories, hospitals, mad-houses, and schools[.]" [Source: Bentham, J. (1995) The Panopticon Writings. Edited by M. Božovič. London, New York: Verso. p. 29.] His Panopticon was a circular-shaped prison, where one guard placed in the centre could monitor every inmate through mirrors. An essential part of his project was giving guards the ability of "seeing without being seen" as the inmates would be aware of the possibility of being watched at any time but would never know when they are watched in reality. This would motivate inmates to act as if they were watched all the time, regulating their own behaviour. [Bentham, J. (1995) The Panopticon Writings. Edited by M. Božovič. London, New York: Verso. p. 43.

${ }^{24}$ In his quest of improving efficiency, Frederick Taylor established the direction of scientific management and wrote his book The Principles of Scientific Management in 1911. His method consisted of increasing efficiency through the extreme monitoring of workers, who were under constant surveillance by a manager, who watched and measured every move they made. [Source: Sprague, R. (2007) 'From Taylorism to the Omnipticon: Expanding Employee Surveillance Beyond the Workplace', The John Marshall Journal of Information Technology \& Privacy Law, 25(1), p. 1.]

${ }^{25}$ At the beginning of the 20th century, Henry Ford, owner of the Ford Motor Company decided to put his employees under extreme surveillance, by investigating their private lives in order to be able to decide whether they live their lives according to the "American standards". These investigations covered every aspect of their private lives, such as their marital status, living conditions and behaviour. The Ford Motor Company also indicated, by issuing guidance, how employees should live their lives. [Source: Meyer, S. (1980) 'Adapting the Immigrant to the Line: Americanization in the Ford Factory, 1914-1921', Journal of Social History, 14(1), p. 70.]

${ }^{26}$ On the different organizational theories see more at: Desreumaux, A. (2014) 'Un inventaire des principales écoles ou courants en théorie des organisations', in Présentation générale des théories des organisations. Available at: http://bricks.univ-lille1.fr/M29/cours/co/chap01_01.html (Accessed: 25 October 2019)

${ }^{27}$ European Network of Legal Experts in the field of Labour Law (2009) Characteristics of the Employment Relationship. Thematic Report 2009. Contract No. VC/2008/1211. p. vi.
} 
use by employees of company equipment facilities. "28 However, since these historical examples of work organisation and employee monitoring, technology has experienced such a leap that it put this existing phenomenon into a different light through facilitating control and monitoring from a technological point of view. ${ }^{29}$

6. Employee control and monitoring have a close relationship with technological development: ${ }^{30}$ various innovations make it possible to monitor one's every step in an extremely detailed way, giving privacy and data protection an increased value. ${ }^{31}$ Employers also benefit from these developments and use them to control and monitor their employees in order to ensure the protection of their rights. While earlier monitoring took place in the form of closed-circuit television (hereinafter referred to as: CCTV) surveillance, geo-localisation, monitoring of telephone use and computer/e-mail use, and concentrated mainly on employees' activities within the workplace, today new ways of monitoring - such as obtaining information through SNSs - go beyond the physical workplace and enable the employer to try to monitor activity taking place outside the workplace. Although from a technological point of view everything is possible, everything will not be legally permissible. ${ }^{32}$

7. From a legal aspect both the right to privacy and the right to data protection are regulated by different legal documents. From the international level particularly various human rights agreements ${ }^{33}$ must be mentioned, guaranteeing that everyone has the right to privacy, altogether with the relevant documents in the field of data protection, issued by

${ }^{28}$ Hendrickx, F. (2002) 'Protection of workers' personal data in the European Union, Two studies'. EC. p. 114.

${ }^{29}$ Moreira, T. C. (2016) 'The Electronic Control of the Employer in Portugal', Labour \& Law Issues, 2(1), p. 5.

${ }^{30}$ For the purposes of the thesis, "technological development" or "technological innovations" will relate to the means used for employee control and monitoring. By "traditional means" of monitoring, CCTV monitoring, monitoring the use of e-mail, Internet, work computer, telephone, GPS monitoring will be meant. The expression "traditional" is employed due to the fact that the detailed rules relating to these types of monitoring are already elaborated (in doctrine, in case law, in the practice of the data protection supervisory authorities) - compared to the "new" forms of monitoring, not (yet) being subject to detailed and exhaustive regulations due to their relatively recent appearance (e.g. SNSs).

${ }^{31}$ For example, already two decades ago according to Scott McNealy, former CEO of Sun Microsystems: "[y]ou have zero privacy. Get over it." Source: Smith-Butler, L. (2009) 'Workplace Privacy: We'll Be Watching You', Ohio Northern University Law Review, 35(1), p. 55.

${ }^{32}$ Ray, J.-E. (2017) Droit du travail: droit vivant. 25th edn. Paris: Wolters Kluwer France. p. 118.

33 United Nations (1948) Universal Declaration of Human Rights, Article 12.; United Nations (1966) International Covenant on Civil and Political Rights, Article 17.; Council of Europe (1950) European Convention of Human Rights, Article 8.; European Union (2000) Charter of Fundamental Rights of the European Union, Article 7 
the International Labour Organization (hereinafter referred to as: ILO),${ }^{34}$ the Organisation for Economic Co-operation and Development (hereinafter referred to as: OECD), ${ }^{35}$ the Council of Europe (hereinafter referred to as: $\mathrm{CoE})^{36}$ and the EU. ${ }^{37}$ At the national level both in France and in Hungary constitutional protection is guaranteed to these rights, ${ }^{38}$ as well as civil law protection. ${ }^{39}$ Also, both countries enacted a data protection act. ${ }^{40}$ With regard to privacy and data protection challenges specific to the context of employment, both labour codes address the question of respecting employees' rights at a general level. ${ }^{41}$ Also, the "traditional" ways of employee monitoring are already regulated - both in France and in Hungary -: the relevant applicable rules and their interpretation were already elaborated notably through case law and the practice of the data protection authorities, and doctrine as well.

However, specific privacy and data protection challenges brought by SNSs are not (yet) addressed in an exhaustive manner (neither in France, nor in Hungary). Although existing case law, ${ }^{42}$ the practice of the data protection authorities ${ }^{43}$ and a number of

${ }^{34}$ ILO (1997) Protection of workers' personal data. An ILO code of practice. Geneva: International Labour 35 OECD (1980) Guidelines on the Protection of Privacy and Transborder Flows of Personal Data, OECD (2013) Guidelines on the Protection of Privacy and Transborder Flows of Personal Data - revised

${ }^{36} \mathrm{CoE}$ : Council of Europe (1981) Convention for the Protection of Individuals with regard to Automatic Processing of Personal Data, ETS No.108, 28 January; Council of Europe (2018) Modernised Convention for the Protection of Individuals with Regard to the Processing of Personal Data. CM/Inf(2018)15-final, Elsinore, Denmark, 18 May; Council of Europe (2015) Recommendation CM/Rec(2015)5 of the Committee of Ministers to Member States on the processing of personal data in the context of employment. (Adopted by the Committee of Ministers on 1 April 2015, at the 1224th meeting of the Ministers' Deputies)

37 European Union (2000) Charter of Fundamental Rights of the European Union, Article 8.; Directive 95/46/EC of the European Parliament and of the Council of 24 October 1995 on the protection of individuals with regard to the processing of personal data and on the free movement of such data. OJ L 281, 23/11/1995 P. 31 - 50; Regulation (EU) 2016/679 of the European Parliament and of the Council of 27 April 2016 on the protection of natural persons with regard to the processing of personal data and on the free movement of such data, and repealing Directive 95/46/EC (General Data Protection Regulation). OJ L 119, 4.5.2016, p. 1-88

${ }^{38}$ Conseil constitutionnel: décision $\mathrm{n}^{\circ}$ 94-352 DC du 18 janvier 1995; Conseil constitutionnel: décision $\mathrm{n}^{\circ}$ 94-352 DC du 18 janvier 1995; Conseil constitutionnel: décision n 99-416 DC du 23 juillet 1999 and Article VI of the Fundamental Law of Hungary (2011)

${ }^{39}$ Article 9 of the French Civil Code and Items b) and e) of Section 2:43 of the Hungarian Civil Code

${ }^{40}$ In France it is the "Loi informatique" [Act No. 78-17 of 6 January 1978 on Information Technology, Data Files and Civil Liberties ("loi relative à l'informatique, aux fichiers et aux libertés")] and in Hungary it is Act CXII of 2011 on the Right to Informational Self-determination and Freedom of Information.

${ }^{41}$ See especially Article L1121-1 of the French Labour Code stating: "[n]o one may limit the rights of the individual or individual or collective liberties by any restriction which is not justified by the nature of the task to be performed and proportionate to the aim sought[,]" and Subsection (2) of Section 9 of the Hungarian Labour Code stating that " $[t]$ he rights relating to personality of workers may be restricted if deemed absolutely necessary for reasons directly related to the intended purpose of the employment relationship and if proportionate for achieving its objective."

${ }^{42}$ Especially in France. See notably the decisions of the Court of Cassation: Cour de cassation, Civ. 1re, 10 avr. 2013, n¹1-19530; Cour de cassation, chambre sociale, 20 déc. 2017, n¹6-19609; Cour de cassation, chambre sociale, 12 sept. $2018, \mathrm{n}^{\circ} 16-11.690$. 
existing legal articles ${ }^{44}$ already examined SNSs in the context of employment, usually they concentrate on one or two aspects of the subject, thus its exhaustive analysis is yet to be

${ }^{43}$ For example, both the French and the Hungarian data protection authorities have addressed the question of data protection and recruitment. Sources: CNIL (no date) Recrutement: l'employeur peut-il rechercher des données sur moi sur Internet? Available at: https://www.cnil.fr/fr/cnil-direct/question/354. (Accessed: 29 October 2019) and NAIH (2016) A Nemzeti Adatvédelmi és Információszabadság Hatóság tájékoztatója a munkahelyi adatkezelések alapvető követelményeiről. Budapest

${ }^{44}$ Articles co-examining labour law and data protection and SNSs include, but are not limited to: Allix, B. (2014) 'L'employeur, le salarié et Facebook', Feuillet Rapide Social F Lefebvre. ; Baugard, D. (2015) 'L'usage par les salariés des réseaux sociaux', in Ndior, V. (ed.) Droit et réseaux sociaux. Issy-lesMoulineaux: Lextenso (Collection LEJEP), pp. 75-89.; Bello, A. (2012) 'Le licenciement pour motif tiré de Facebook : un changement ... dans la continuité', JCP S (édition sociale), (26), pp. 12-16. ; Cantero, I. and Coupez, F. (2014) 'L'utilisation des réseaux sociaux par l'entreprise : des risques maîtrisés ?', Revue Banque, (769), pp. 36-39. ; Caprioli, É. A. (2012) 'Les propos tenus par une salarié sur Facebook peuvent justifier son licenciement', Communication Commerce Électronique, (4), pp. 37-40. ; Caprioli, É. A. (2013) 'Faute grave du salarié ayant tenu des propos dénigrants sur son "mur public" Facebook', Communication Commerce Électronique, (5), pp. 47-49. ; Caprioli, É. A. (2018) 'Licenciement: obtention loyale de la preuve sur le réseau social Facebook afin de caractériser une faute grave', Communication Commerce Électronique, (6), pp. 43-43. ;Caprioli, É. A. (2018) 'Licenciement sans cause réelle et sérieuse et propos injurieux sur Facebook', Communication Commerce Électronique, (6), pp. 43-43. ; Caron, M. (2018) 'Les limites à la liberté d'expression d'un salarié sur Facebook', Les Cahiers Sociaux, (305), pp. 131-133.; Castel, Delphine: Licenciement - Réseaux sociaux - De l'utilisation des preuves venant de Facebook Juris tourisme 2018, n²05, p.13.; Corrignan-Carsin, D. (2018) 'Tenir des propos injurieux sur Facebook au sein d'un groupe fermé ne justifie pas un licenciement', JCP G Semaine Juridique (édition générale), (40), pp. 1762-1762.; Costes, L. (2010) 'Licenciement de salariés qui avaient dénigré leur hiérarchie sur Facebook', Revue Lamy droit de l'immatériel, (66), pp. 42-42. ; Costes, L. (2011) 'Réseaux sociaux : nouveaux enjeux et nouveaux défis pour les entreprises', Revue Lamy droit de l'immatériel ex Lamy droit de l'informatique, (74), pp. 131-38.; Fel, C. and Sordet, E. (2010) 'L'utilisation des réseaux sociaux par l'entreprise et ses collaborateurs', JCP S (édition sociale), (29), pp. 19-24.; Grégoire, F. (2018) 'L'usage immodéré de Facebook peut conduire directement à Pôle emploi', JCP G Semaine Juridique (édition générale), (9), pp. 437-437.; Griguer, M. (2010) 'Les réseaux sociaux sous le contrôle des DSI', Cahiers de droit de l'entreprise, (6), pp. 62-64.; Hardouin, R. (2011) 'Facebook ou l'établissement de la frontière entre espace public et sphère privée', Revue Lamy droit de l'immatériel ex Lamy droit de l'informatique, (67), pp. 54-55.; INFOREG (2015) 'Pouvoir disciplinaire : vie personnelle, vie professionnelle et Facebook', Cahiers de droit de l'entreprise, (6), pp. 67-69.; Julien-Paturle, D. (2018) 'Critiquer son employeur sur internet peut entraîner un licenciement au titre d'un abus de la liberté d'expression', Jurisprudence sociale Lamy, (456), pp. 26-28.; Le Clainche, J. (2012) 'Expression des salariés sur internet : attention aux «faux amis »', Revue Lamy droit de l'immatériel ex Lamy droit de l'informatique, (81), pp. 45-50.; Le Clainche, J. (2011) 'Licenciement pour des propos tenus sur Facebook ou les dangers de la porosité des sphères publique et privée', Revue Lamy droit de l'immatériel, (67), pp. 51-53.; Le Cohu, P. (2018) 'Un salarié peut-il critiquer son employeur sans être sanctionné ?', La Gazette du Palais, (10), pp. 58-59.; Loiseau, G. (2018) 'Réseaux sociaux et abus de la liberté d'expression : l'exception de cercle privé', La Semaine Juridique Social, (41), pp. 22-25.; Mayoux, S. (2018) 'Licéité de la preuve recuillie sur Facebook par l'employeur', Jurisprudence sociale Lamy, (449), pp. 23-26.; Netter, E. (2015) 'La liberté d'expression sur les réseaux sociaux en droit français', in Ndior, V. (ed.) Droit et réseaux sociaux. Issy-les-Moulineaux: Lextenso (Collection LEJEP), pp. 39-63.; Picq, M. (2011) 'Facebook et les salariés : vie privée, liberté d'expression et humour', Revue des droits et libertés fondamentaux, (11); Pierroux, E. (2015) 'Facebook, Twitter et autres résaux sociaux: petites injures entres "amis", La Gazette du Palais, (336-337), pp. 4-8.; Pottecher, M.-C. and Bakhtiari, Z. (2016) 'Travailler ou tweeter, le salarié n'a pas (forcément) à choisir', Cahiers sociaux du Barreau de Paris, (285), pp. 233-234.; Ray, J.-E. (2010) 'Little Brothers are watching you', Semaine sociale Lamy, 1470, pp. 10-13.; Ray, J.-E. (2011) 'Facebook, le salarié et l'employeur', Droit social, (2), pp. 128-40.; Ray, J.-E. (2013) 'Facebook, espace public plus que privé. A propos de l'arrêt de la 1 ère Chambre civile du 10 avril 2013', Semaine sociale Lamy, (1599), pp. 14-19.; Ray, J.-E. (2018) 'Des "licenciements Facebook" à la sanction d'un 'Like”?', Semaine sociale Lamy, (1830), pp. 10-12.; Tricoit, J.-P. (2013) 'Recrutement, rupture du contrat de travail et TIC', La Semaine Juridique Social, (40), pp. 9-14.; Verkindt, P.-Y. (2010) 'Les “amis” de nos “amis”..', JCP S (édition sociale), (48), pp. 3-5. 
elaborated. This is one of the voids that the dissertation aims to fill, by addressing this question through the examination of the conclusion, management and termination of the employment relationship. The other specific feature of the dissertation is that it adopts a comparative approach and co-examines France and Hungary, providing a currently nonexistent angle of examination of the subject.

8. Scope of the dissertation. Regarding the material scope, the dissertation will focus on the collision between the employees' rights (notably right to privacy and right to data protection) and the employer's rights (notably right to property, right to the protection of business secrets, right to reputation, right to the protection of economic interests) during the use of SNSs, manifested in the employer's right to control and monitor. On the one hand, the employee is entitled to the right to privacy and the right to data protection during controlling and monitoring. ${ }^{45}$ On the other hand, it is inherent to the employment contract that the employer has the power/right to control and monitor ${ }^{46}$ employees' activities in order to enforce different rights. ${ }^{47}$ These rights are manifested in different dimensions: e.g. choosing the most adequate candidate during recruitment, monitoring whether the employee truly spends working hours working or controlling and monitoring that the employee does not violate the employer's right to reputation. The rights of the employee and the employer are in close interaction, as what is a right on one side is manifested as an obligation on the other side (e.g. employees' obligation to perform

Horváth, L. and Gelányi, A. (2011) 'Lájkolni vagy nem lájkolni? A közösségi oldalak használatának munkajogi kérdései', Infokommunikáció és jog, (2), pp. 60-66. ; Kajtár, E. (2015) 'Európai ügyek a Facebook sötét oldaláról - A munkavállalók közösségi oldalakon tanúsított kötelezettségszegő magatartása', in Horváth, I. (ed.) Tisztelgés: ünnepi tanulmányok Dr. Hágelmayer Istvánné születésnapjára. Budapest: ELTE Eötvös Kiadó, pp. 199-213. Kajtár, E. and Mestre, B. (2016) 'Social networks and employees' right to privacy in the pre-employment stage: some comparative remarks and interrogations', Hungarian Labour Law E-journal, (1), pp. 22-39.; Kun, A. (2013) 'Közösségi média és munkajog - avagy „online” munkaidőben és azon túl', Munkaügyi Szemle, (3), pp. 12-19.; Németh, J. (2013) 'Internet és közösségi háló mint munkaeszköz', Infokommunikáció és jog, (1). pp. 37-40.; Németh, J. (2013) 'Az internet nem felejt közösségi media-használatra alapított munkáltatói és munkavállalói felmondások', Infokommunikáció és jog, (2), pp. 96-98.; Pók, L. (2012) ‘A közösség hálójában - Közösségi oldalak munkajogi vonatkozásai', Infokommunikáció és jog, (1), pp. 10-17.; Pók, L. (2012) 'Lájkolni szabad? Munkavállalói véleménynyilvánítás az új Munka Törvénykönyve tükrében’, Infokommunikáció és jog, (4), pp. 160-165.; Rácz, I. (2015) 'A közösségi média használatának árnyoldalai a munkaviszonyban', in Deres, P. and GradGyenge, A. (eds) Acta Iuvenum Caroliensia VII.Budapest: Károli Gáspár Református Egyetem Állam- és Jogtudományi Kar, pp. 279-305.

45 Hendrickx, F. (2002) 'Protection of workers' personal data in the European Union, Two studies'. EC, pp. 23-24.

${ }^{46}$ In French law it is called "pouvoir" meaning power, while in Hungarian doctrine the expression "jog" meaning right is used.

47 Blanpain, R. (2002) 'Employment and Labour Law Aspects. Setting the Scene. Asking the Right Questions?', in Blanpain, R. (ed.) On-line Rights for Employees in the Information Society. Use and Monitoring of E-mail and Internet at Work. The Hague: Kluwer Law International, p. 43-44. 
work, obligation of loyalty, obligation to respect business secrets, etc.). ${ }^{48}$ Therefore, there is a collision between the employer's and the employees' rights, and the task of the law is to weigh the two sides and to find an appropriate balance between them. As "labour law is the law protecting the employee to counterbalance the employee's subordination [,] "49 the dissertation will primarily approach the subject from the employees' perspective and will focus on the question how their right to respect for private life and right to data protection should be ensured.

Relations between privacy and data protection are complex and far from being unequivocal, however, it seems to be undeniable that there is a certain connection between these two rights. ${ }^{50}$ Because of their more personal nature in comparison to social media, the thesis will focus on SNSs, although social media will not be completely excluded from the discussion considering the fact that they also constitute platforms used in the course of the private life of the employee. As the main focus is on the examination of the right to respect for private life and the right to personal data protection, the dissertation will address the subject of how employees can use these platforms in the course of their private lives and whether/to what extent this use might be controlled or monitored. The employer's use of social media and SNSs for public relations purposes (even if it is executed by the employee) constitutes a separate field, distinct from the subject of the present work. The dissertation aims to exhaustively address the employment context, through the examination of SNSs and employees' right to privacy and right to data protection during the conclusion, management and termination of the employment relationship.

9. The dissertation is on the position that in order to effectively address SNSs, a double, privacy-data protection approach is applied, which assesses controlling from the aspect of privacy, while monitoring from the aspect of data protection. The question of controlling and monitoring SNSs can be observed from two separate, but interconnected approaches: it can be addressed through a privacy approach and also through a data protection approach. While acknowledging that the right to privacy and the right to data protection are separate rights, when it comes to SNSs, both are necessary to ensure the protection of employees' personal lives. Although both rights are "present" during the

${ }^{48}$ Gyulavári, T. (ed.) (2017) Munkajog. ELTE Eötvös Kiadó. Budapest. p. 235.; Breznay, T. (ed.) (2006) A munkajog nagy kézikönyve. Budapest: Complex Kiadó, p. 329.

49 Kiss, Gy. (2015) Opportunities and limits of application principles and Civil Code rules in Hungarian labour law Crisis management with means of civil law. ELLN Working Paper No. 4. p. 4.

50 Bygrave, L. A. (2001) The Place of Privacy in Data Protection Law. Available at: http://www.austlii.edu.au/au/journals/UNSWLJ/2001/6.html (Accessed: 28 February 2018) 
whole existence of the employment relationship, depending on various factors either the right to privacy or the right to data protection is more emphatic and raises more substantial challenges.

Which approach being more dominant depends on several factors, such as the activity (controlling or monitoring), the phase of the employment relationship (recruitment, fulfilment or termination) or the examined country (France or Hungary). Controlling employees (regulating what conduct they can or cannot adopt) relates mostly to privacy, while monitoring whether employees comply with the former regulations raises mostly data protection questions. While during the recruitment process the application of the data protection requirements pose more significant challenges, when it comes to employees' expressing themselves on SNSs, the right to privacy gains more importance. Concerning the use of SNSs at the expense of working hours, both approaches are equally significant. Also, in relation to employee monitoring in French labour law, the foundations of privacy seem to be more emphatic, ${ }^{51}$ while in Hungary emphasis is put on a data protection approach. ${ }^{52}$ As it will be demonstrated in the dissertation, due to the connection between privacy and data protection, the privacy and the data protection approaches complement each other and are both necessary to ensure the protection of employees' rights while engaging in SNSs.

The dissertation will focus on the private sector employment law. The dissertation will focus on individual labour law, as the aim is to analyse the employee's right to privacy and right to data protection, which are individually enforceable, while the use of SNSs as a collective mostly raises questions in relation to collective enforcement of interest and not in relation to the boundaries and respect of the right to privacy. ${ }^{53}$ The use of SNSs and collective enforcement of interests constitute a separate field, distinct from the subject of the present dissertation.

\footnotetext{
${ }^{51}$ Especially manifested in the central concept of personal life ("vie personnelle") unique to labour law.

52 This can be confirmed by the fact that when it comes to employee monitoring, though privacy is present in Hungarian law as well, when the detailed rules applying to certain types of employee monitoring were elaborated, the Hungarian data protection authority had a preponderant role.

${ }^{53}$ On issues related to collective labour law see especially: Larher, Y.-M. (2017) Les relations numériques de travail. Doctoral dissertation. Université Paris 2 Panthéon-Assas; or: Ray, J.-E. (2007) 'Droit du travail et TIC (III). Droit syndical et TIC : sites, blogs, messagerie’, Droit social, (4), pp. 423-444.; Ray, J.-E. (2009) 'Actualité des TIC. Rapports collectifs de travail', Droit social, (1), pp. 22-37.; Ray, J.-E. (2012) 'CGT, CFDT, CNT, CE et TIC. Rapports collectifs de travail et nouvelles technologies de l'information et de la communication', Droit social, (4), pp. 362-372.
} 
10. In this context the dissertation aims to answer the overarching question - in the light of employees' right to privacy and right to data protection - whether the employer is entitled to control and/or monitor employees' activities on online SNSs during the different phases of the employment relationship, and if yes, to what extent. The dissertation aims to provide answers to questions in relation to how the existing rules ${ }^{54}$ of control and monitoring should be applied to the case of SNSs, such as what the conditions of such monitoring are, what data protection requirements the employer must respect and how, what legal risks arise in relation to such monitoring, etc.

11. While keeping in mind that the examined phenomenon is universal in societies where SNSs are available ${ }^{55}$ the examination will focus on the jurisdictions of France and Hungary. The aim of examining two jurisdictions is to identify separate or common good practices, as well as to introduce the jurisdiction of both countries for research, legislative and teaching reasons.

The comparison of the two countries will not be implemented through pure comparative research, but the two systems will be assessed (mostly) in the light of EU legislation. ${ }^{56}$ In recent years individuals could witness the adoption and the entering into force of the new EU data protection framework. Driven by the occurring societal and technological changes, the EU decided to modernize its data protection legislation and adopted new rules, notably the General Data Protection Regulation ${ }^{57}$ (hereinafter referred to as: GDPR), which replaced the previously existing Data Protection Directive ${ }^{58}$ (hereinafter referred to as: DPD), which regulated matters of data protection for two decades. By opting to regulate data protection in the form of a regulation instead of a

\footnotetext{
${ }^{54}$ Laid down in the labour codes, or elaborated by case law, by doctrine or by the practice of the data protection authorities.

55 Which is supported by the fact that, as these platforms are used worldwide, cases related to SNSs and employment emerge in most of the advanced countries. For an extensive presentation of issues relating to the subject see more in: Lambert, P. (2014) International Handbook of Social Media Laws. Haywards Heath: Bloomsbury.

56 Besides the EU, both France and Hungary are members in the same international organisations. As such, examining national legislations in a vacuum is not possible: due to both countries being members in the same European (e.g. CoE, EU) and international organizations (e.g. UN, OECD), it is indispensable to examine the international environment into which national legislations are integrated. Thus, the most important international organizations for our subject are also referred to in the research.

57 Regulation (EU) 2016/679 of the European Parliament and of the Council of 27 April 2016 on the protection of natural persons with regard to the processing of personal data and on the free movement of such data, and repealing Directive 95/46/EC (General Data Protection Regulation). OJ L 119, 4.5.2016, p. 1-88.

${ }^{58}$ Directive 95/46/EC of the European Parliament and of the Council of 24 October 1995 on the protection of individuals with regard to the processing of personal data and on the free movement of such data. Official Journal L 281, 23/11/1995 p. $31-50$.
} 
directive, the EU unified data protection law throughout Member States, ${ }^{59}$ including France and Hungary as well. However, in certain fields the GDPR itself authorizes Member States to adopt more specific rules. ${ }^{60}$ One of these fields is data processing in the context of employment, as Article 88 of the GDPR allows Member States to adopt specific rules in relation to data protection and employment. As such, differences might arise between Member States in the field of workplace data protection.

Consequently, it is worth examining what differences might arise, despite the common EU legal background, between different Member States with regard to employment. This narrowing of the scope of investigation is justified by practical and theoretical considerations. Its theoretical reason is that data protection was of different significance regarding its historical development in France and Hungary. The choice of jurisdictions is also supported by France being a country with considerable history in data protection law. ${ }^{61}$ With its data protection act, the "Loi informatique", ${ }^{62}$ France was amongst the first countries in the world to enact a data protection act, which considerably influenced subsequent regulations, ${ }^{63}$ such as the Council of Europe's Convention 108, ${ }^{64}$ the EU's DPD ${ }^{65}$ or the United Nations' data protection guidelines. ${ }^{66,67}$ In contrast to such a background, Hungary - a country formerly attached to the Eastern Bloc countries - lagged behind and adopted its first data protection act in 1992, ${ }^{68} 14$ years after the adoption of France's pioneer legislation. The aim of the dissertation is to demonstrate that in these two states with different historical, cultural, economic and legal traditions - despite their common membership in international organisations -: what different approaches are

\footnotetext{
${ }^{59}$ European Commission (2018) The GDPR: new opportunities, new obligations. What every business needs to know about the EU's General Data Protection Regulation. Luxembourg: Publications Office of the European Union: European Union. Available at: https://ec.europa.eu/commission/sites/betapolitical/files/data-protection-factsheet-sme-obligations_en.pdf (Accessed: 30 October 2019). p. 2.

${ }^{60}$ E.g. in relation to the processing of deceased persons' personal data [Recital (27) of the GDPR] or in the field of obligations of secrecy (Article 90 of the GDPR).

${ }^{61}$ Grynbaum, L., Le Goffic, C. and Morlet-Haïdara, L. (2014) Droit des activités numériques. Paris: Dalloz. p. 747.

62 Act No. 78-17 of 6 January 1978 on Information Technology, Data Files and Civil Liberties ("loi relative à l'informatique, aux fichiers et aux libertés")

${ }^{63}$ Hennette-Vauchez, S. and Roman, D. (2017) Droits de l'homme et libertés fondamentales. 3rd edn. Paris: Dalloz. p. 553.

${ }^{64}$ Council of Europe (1981) Convention for the Protection of Individuals with regard to Automatic Processing of Personal Data. ETS No.108. Strasbourg

${ }^{65}$ Directive 95/46/EC of the European Parliament and of the Council of 24 October 1995 on the protection of individuals with regard to the processing of personal data and on the free movement of such data

${ }^{66}$ United Nations (1990) Guidelines for the Regulation of Computerized Personal Data Files. Adopted by General Assembly resolution 45/95 of 14 December

${ }^{67}$ Féral-Schuhl, C. (2010) Cyberdroit: le droit à l'épreuve de l'internet. 6th edn. Paris: Dalloz (Praxis Dalloz). p. 35.

${ }^{68}$ Act LXIII of 1992 on the Protection of Personal Data and the Disclosure of Information of Public Interest
} 
present in these two systems and what are the existing common and separate good practices that could be introduced to lawmakers. On the other hand, its practical reason is that, as the dissertation was prepared in the frame of a French-Hungarian joint $\mathrm{PhD}$ programme, the examination of both France and Hungary was an inevitable requirement set by the two universities.

12. Main hypotheses. The dissertation aims to answer several hypotheses. Hypothesis 1 is that in the case of SNSs, the collision between the employees' rights and the employer's rights appears in a more intense form compared to the "traditional" methods of employee monitoring. It was already mentioned that the employee has certain rights (right to privacy and right to data protection) that must be balanced against the employer's rights (e.g. right to control and monitor, right to reputation, protection of business secrets, etc.). In the case of monitoring SNSs, due to the increasingly blurred boundaries of work and private life, this collision of rights is more intense than in the case of "traditional" employee monitoring, both from the employees' and the employer's point of view. Through allowing being available all the time, ICT (and SNSs) blurred the boundaries of work and private life: ${ }^{69}$ they did not only allow work to flow into the private life of the employees but vice versa. ${ }^{70}$ From the employees' perspective, a change of paradigm in the scale of employee monitoring can be observed, as the control and monitoring of SNS use not only goes beyond the physical workplace and the physical working hours, but also constitutes a more severe intrusion into employees' private lives due to the role SNSs play in modern societies. As on SNSs employees often share details regarding their private lives, controlling and monitoring provide the possibility for the employer to glimpse into the employees' private lives to an unprecedented extent. From the employer's perspective, the employer's rights are increasingly at stake as well for several reasons. In relation to the right to property (and the use of the employer's equipment according to the purpose of the employment relationship), the respect of working hours and the appropriate use of the employer's equipment must be mentioned. With this urge to be connected all the time, a change of paradigm took place, as SNSs can create a veritable addiction resulting in employees spending their working hours on these platforms, and failing to perform one of the main obligations arising from the employment

\footnotetext{
${ }^{69}$ Rey, B. (2013) 'La vie privée au travail. Retour sur la place du privé en contexte hiérarchique à l'ère du numérique', Les Cahiers du numérique, 9(2), p. 108.

${ }^{70}$ El Wafi, W. (2016) Perméabilité des frontières vies «personnelle et professionnelle» et usage des TIC: modèles d'articulation. Université de Lorraine, p. 13., p. 15.
} 
relationship might possibly lead to the termination of their employment. ${ }^{71}$ As regards the employer's right to reputation, SNSs provide a unique platform for employees to express themselves. While prior to SNSs such expressions usually took place either in an oral form or in front of a small audience (e.g. gossiping with or complaining to friends or colleagues), SNSs brought a change of paradigm through fundamentally altering the publicity and the discoverability of such expressions. As a result, both parties of the employment relationship are more intensely interested in enforcing their rights, as the possible harm - on both sides - is more significant than prior to the age of SNSs.

13. The remaining hypotheses relate to the examined matters of the employment relationship and SNSs. Hypothesis 2 holds that in the phase of recruitment, the protection of job applicants' rights can be better ensured through regulating pre-employment SNS screenings, instead of prohibiting them. As it will be addressed in detail, applying preemployment SNSs screenings raise several (privacy) and data protection challenges. As a response to these challenges, different solutions were proposed from the complete ban of these screenings, ${ }^{72}$ through acknowledging their existence, ${ }^{73}$ to the involvement of an independent third party in the decision-making. ${ }^{74}$ Due to the difficulties connected to the enforcement of a prohibition (e.g. invisibility of background checks), the dissertation holds that adopting a more flexible regulation, through aiming to make employers realize that respecting data protection requirements will lead to more reliable decision-making, is a more effective way to protect job applicants' rights instead of completely prohibiting these searches.

71 As it is demonstrated by the number of cases related to the personal use of the employer's computer/Internet connection, more precisely employees surfing Facebook during working hours instead of performing work.

${ }_{72}$ Gros, M. (2010) Recrutement: une Charte pour contrer les dérives liées aux réseaux sociaux, Le Monde Informatique. Available at: https://www.lemondeinformatique.fr/actualites/lire-recrutement-une-charte-pourcontrer-les-derives-liees-aux-reseaux-sociaux-29715.html(Accessed: 13 August 2019); CNIL (no date) Recrutement: l'employeur peut-il rechercher des données sur moi sur Internet? Available at: https://www.cnil.fr/fr/cnil-direct/question/354.; Kajtár, E. and Mestre, B. (2016) 'Social networks and employees' right to privacy in the pre-employment stage: some comparative remarks and interrogations', Hungarian Labour Law E-journal, (1), p. 36.; McGeveran, W. (2006) Finnish Employers Cannot Google Applicants. Available at: https://blogs.harvard.edu/infolaw/2006/11/15/finnish-employerscannot-google-applicants/ (Accessed: 2 July 2018)

73 Information Commissioner's Office (2011) The employment practices code. Available at: https://ico.org.uk/media/for-

organisations/documents/1064/the_employment_practices_code.pdf(Accessed: 8 October 2018), p. 23.; NAIH (2016): A Nemzeti Adatvédelmi és Információszabadság Hatóság tájékoztatója a munkahelyi adatkezelések alapvetö követelményeiröl, p. 19.

${ }^{74}$ Ebnet, N. J. (2012) 'It Can Do More Than Protect Your Credit Score: Regulating Social Media PreEmployment Screening with the Fair Credit Reporting Act', Minnesota Law Review, 97(1), p. 327. 
14. Hypothesis 3 intends to prove that in most regards, the personal use of SNSs during working hours can be adequately addressed through the already existing rules relating to the monitoring of Internet and e-mail use, as all of them are Internet based. No specific law aiming to regulate SNSs exists either in France, or in Hungary: in both countries the general labour law and data protection rules are applicable to these relatively new platforms. Although SNSs put the existing provisions into different light and raise questions regarding their exact application and possible adjustments, it is the matter of personal SNS use at the expense of working hours where the already existing rules need the least adjustment, as in most regards ${ }^{75}$ the already elaborated regulations to the personal use of Internet and e-mail can be adequately applied to SNSs.

15. Hypothesis 4 aims to prove that as regards employees' activities and presence on $\mathrm{SNSs}^{76}$ mainly beyond working hours, in the light of the intensification that SNSs brought to the collision of rights, employers have found themselves in an even more vulnerable position, rendering it necessary to tilt the balance towards the protection of employer's rights. Although the limits of employees' off-duty conduct are already determined both in France and in Hungary, SNSs put these existing rules into new light. In connection with the intensified collision between the employee's and the employer's rights (particularly the right to reputation), the dissertation holds that these changes put the employer into an even more vulnerable position.

16. As the outcome of the research, the dissertation aims to answer two main research questions. First, in the light of the more intense collision of rights and interests (whether and) how the employer is entitled to control employees' conduct on online SNSs with regard to their right to privacy. Second, in the light of the more intense collision of rights and interests, (whether and) how the employer can process employees' personal data obtained from these platforms?

17. Methodology used and structure of the dissertation. The research is based on a mixture of descriptive-analytical methods, as the dissertation systematically examines the existing legal framework while it also contains the critical evaluation of the relevant legislation, court decisions, soft law documents or academic literature. The primary

\footnotetext{
75 Also, the differences and specific characteristics of SNSs will be examined in detail.

${ }^{76}$ For example, through posting, sharing, liking either matters directly relating to the workplace (e.g. opinion on or criticism of the employer) or matters indirectly relating to the workplace (e.g. posting racist content, etc.).
} 
sources of the research were international, European (EU and Council of Europe), French and Hungarian legislation, jurisdictions and doctrine. Amongst the secondary sources a wide range of publications was used, especially focusing on - but not limited to ${ }^{77}-$ the works of French and Hungarian scholars. It should be noted in the beginning that one of the greatest difficulties (and differences between the two examined countries) was that while in France courts - both lower and supreme - already addressed cases related to SNSs in a number of cases, in Hungary such cases are very recent. ${ }^{78,} 79$ Also, brief outlooks to other European or international cases and proposed solutions will be made in order to enrich the research. Furthermore, as the examined phenomenon is universal, in order to raise awareness to certain universal aspects of the subject, these sources will be referred to as well - while keeping France and Hungary in the focus of the dissertation. When examining these norms, throughout the dissertation several criteria will be taken into consideration and followed when determining the order of discussion. Usually the analysis of a sub-topic will start from the international (universal, regional) norms before focusing on national ones. Also, first general matters will be discussed before examining more specific ones. The analysis will also move from the analysis of the legal framework to existing jurisprudence and existing practice of the data protection authorities or other authorities.

18. In relation to the terminology used, as today the most popular SNS is Facebook, throughout the thesis references will often be made to Facebook instead of SNSs in general, as well as Facebook terminology will often be used.

19. As regards the structure, the dissertation is composed of two Parts: Part I. analyses the collision of the rights, while Part II. focuses on how this collision is manifested particularly in the context of SNSs. Part I. will examine the collision of rights in detail, through analysing the colliding rights both on the side of the employee and the employer and will address how this collision is influenced by the innovations of ICT. Part I. provides the conceptual and theoretical background of the research. More precisely, Part I. will address (1) the conceptual fundaments of the two sides of the collision: the right to respect for private life, right to data protection and employee monitoring and then (2) will

77 The dissertation also contains sources in English from several authors outside these two countries, especially from Europe and the United States, as the examined phenomenon is universal.

${ }^{78}$ Particularly, the case should be mentioned where a Hungarian prosecutor was dismissed due to three (political) Facebook posts. The case will be discussed in detail in Part II.

${ }^{79}$ This also applies to publications, as in Hungary the number of publications related to the subject of employee monitoring and SNSs is lower compared to France. 
examine how this collision has become more intense, and how the boundaries of work and private life have become increasingly blurred due to ICT, particularly to SNSs.

After addressing the conceptual and theoretical foundations, Part II. will especially focus on this collision in relation to SNSs and will analyse French and Hungarian law regulating the right to privacy and right to data protection during the controlling and monitoring of the use of SNSs in the employment context. Part II. identifies the main areas where specific challenges arise regarding employee control and monitoring and SNSs, aiming to provide an extensive analysis covering the conclusion, management and termination of the employment relationship. Three subjects will be examined in detail: (1) recruitment and the protection of prospective employees' rights, (2) SNS use at the expense of working hours and (3) off-duty conduct and SNSs. It will be explored, in the light of the collision of rights and interests presented in Part I., where exactly boundaries are/should be established in France and Hungary; what privacy and/or data protection questions arise and what answers can be provided to them. 


\section{PART I.}

\section{PROTECTION OF EMPLOYEES' PRIVATE LIFE AND PERSONAL DATA IN THE CONTEXT OF ONLINE SOCIAL NETWORKS}

20. Technological innovations have not only made a fundamental impact on how expectations of privacy have changed ${ }^{80}$ but they have also caused profound changes in the world of work, blurring the boundaries between work and non-work. ${ }^{81}$ However, as a preliminary point it must be emphasized that this phenomenon is mainly relevant to employees performing office work, and especially knowledge work. ${ }^{82}$ In an age when on social media and SNSs users share such a rich amount of data that a few decades ago would have been called a "dossier" ${ }^{83}$ the appearance of such a huge "database" has serious implications for the employment relationship as well. ${ }^{84}$

As a consequence, the use of SNSs can have different impacts on the employment relationship: during such a use, notably employees' right to privacy and right to data protection might raise challenges. The growing number of internal social media policies and "Facebook firings" raise questions in relation to where the boundaries of personal and professional life are, while the monitoring of such a use can also raise data protection challenges.

21. The respect of employees' rights when applying "traditional forms of monitoring" or regulating their conduct is already regulated both at international and national levels. When it comes to employee monitoring, the fundamental legal challenge that arises is the collision of the employer's and the employee's rights. On the one side, there are the employees' rights (especially the right to privacy and the right to data protection), while on the other side the employer's rights can be found (e.g. right to

\footnotetext{
${ }^{80}$ Flint, D. (2009) 'Law shaping technology: Technology shaping the law', International Review of Law, Computers \& Technology, 23(1-2), p. 7.

${ }^{81}$ Peck, S. (2012) Social media, monitoring and surveillance at work - a practical guide for trade unionists. London: LRD Publ. (Labour Research Department Booklets). p. 5.

${ }^{82}$ Eurofound and International Labour Office (2017) Working anytime, anywhere: The effects on the world of work. Joint ILO-Eurofound report. Luxembourg, Geneva: Publications Office of the European Union, International Labour Office. p. 3. The report acknowledges that certain kinds of occupations require the physical presence at the workplace or simply do not involve the use of ICT. Source: Ibid. pp. 17-18.

${ }^{83}$ Tobok, D. (2013) 'Social Network Recruiting: Implications of this New Hiring Model', in Law Society of Upper Canada, Employment law and the new workplace in the social media age. Toronto: Irwin Law, p. 95.

${ }^{84}$ Starting from employers screening job applicants' SNS profiles, through monitoring how employees behave on SNSs, to monitoring whether they surf on SNSs during working hours.
} 
reputation, protection of business secrets, protection of legitimate economic interests, etc.), manifested in the employer's right to control and to monitor. No right is absolute; they must be carefully weighed against each other in order to find a proper balance between the two sides. ${ }^{85}$

However, technological development has a huge effect on the already established regulations, as employee misconducts can have more serious consequences, and the employer's intrusion into employees' personal lives can also be deeper. ${ }^{86}$ Hypothesis 1 of the dissertation holds that the collision of rights is more intense in the case of monitoring employees' activities on SNSs - compared to the already regulated, traditional forms of employee monitoring.

22. In addition, privacy and data protection play an important role in ensuring the exercise of other fundamental rights as well, as SNSs also constitute an important forum of freedom of expression and represent an important source of accessing information. Privacy (and data protection) also plays a crucial role in SNSs considering that their guarantee and respect by the employer is a condition for being able to fully enjoy the possibilities given by SNSs. If users are afraid to use SNSs because of the fear that someone - in the present case the employer - might use the information available on these sites, the freedom and fundamental rights of the individual will be impaired. ${ }^{87}$

Table 1: Presentation of the collision of rights

\begin{tabular}{|c|c|c|}
\hline \multicolumn{3}{|c|}{ Rights at stake in relation to $\mathrm{SNSs}$} \\
\hline Employees' rights & Employer's rights & \\
\hline $\begin{array}{l}\text { - Right to privacy } \\
\text { - Right to data protection } \\
\text { - (Right to freedom of } \\
\text { expression) }\end{array}$ & $\begin{array}{l}- \text { Right to reputation } \\
- \text { Right to the protection of business } \\
\text { secrets } \\
\bullet \text { Right to property } \\
- \text { Right to the protection of legitimate } \\
\text { economic interests }\end{array}$ & $\checkmark$ \\
\hline
\end{tabular}

Source: the author's own summary

23. Aim and structure of Part I. The aim of Part I. is to analyse and to prove Hypothesis 1 of the dissertation, according to which in the case of SNSs, the collision

\footnotetext{
${ }^{85}$ Hajdú, J. (2005) A munkavállalók személyiségi jogainak védelme. Szeged: Pólay Elemér Alapítvány, p. 20.

${ }^{86}$ Michel, S. (2018) 'TIC et protection de la vie privée du salarié', Bulletin Joly Travail, (2), p. 149.

87 Clark, L. A. and Roberts, S. J. (2010) 'Employer's Use of Social Networking Sites. A Socially Irresponsible Practice', Journal of Business Ethics, 95(4), p. 518.
} 
between the employees' rights and the employer's rights appears in a more intense form compared to the "traditional" methods of employee monitoring. Therefore, first, Title 1 will discuss the employees' relevant rights at stake, and then present how they collide with the employer's different rights. Then, Title 2 will focus on how these already established boundaries between work and private life are changed due to the proliferation of ICT, and especially to SNSs. As a result of Part I., the conceptual background of the collision will be explored, which will serve as a theoretical foundation for Part II., addressing the specific challenges raised by SNSs. 


\section{Title 1: Collision of the employees' right to privacy and to data protection and the employer's rights}

24. Scope of Title 1. In the dissertation's focal point employees' personal life and the rights aiming to protect personal life - are found. ${ }^{88}$ Despite certain common characteristics, ${ }^{89}$ the right to privacy and the right to data protection are two separate rights, both playing an important role in ensuring the protection of personal life. On the one hand, employees, just as any individual, are entitled to the enjoyment of the right to privacy and the right to data protection..$^{90}$ On the other hand, the enjoyment of these rights is naturally influenced by being qualified as an employee: the employee status will automatically limit these rights. ${ }^{91}$ Originating from the employment relationship, the employer has rights that justify the limitations on privacy and data protection, ${ }^{92}$ such as right to property, right to the protection of legitimate economic interests, etc. The rights of the two parties are interconnected: what is a right on one side will be an obligation on the other side, ${ }^{93}$ and during their enforcement a balance must be found. ${ }^{94}$

25. Aim and structure of Title I. The aim of this title is to provide conceptual foundations for the dissertation, through analyzing in detail the rights with utmost importance for the main topic of the dissertation. Consequently, the employees' and the employer's relevant rights will be analysed. ${ }^{95}$ Chapter 1 of Title I will analyse the rights

\footnotetext{
88 The expression personal life is used to designate a concept very similar to the personal life employed by the Social Chamber of the French Court of Cassation, having a close connection with private life (aiming to protect the parts of employees' life which they wish to conceal from the public) and also with the concept of privacy in public (private life interpreted in a broad way, breaking with the concept of secrecy). The (legal) definitions of these concepts are to be found in Chapter 1.

89 "The roots of the right to data protection lie in the right to privacy." Source: Kranenborg, H. (2014) 'Protection of Personal Data', in Peers, S. et al. (eds) The EU Charter of Fundamental Rights. A commentary. Oxford, Portland: Hart Publishing, p. 228.

${ }^{90}$ See, for example, the ILO Code of practice 1997 or documents issued by the EU's former Article 29 Data Protection Working Party in the field of workplace privacy and data protection.

${ }^{91}$ Hendrickx, F. (2002) 'Privacy and Employment Law: General Principles and Application to Electronic Monitoring', in Blanpain, R. (ed.) On-line Rights for Employees in the Information Society. Use and Monitoring of E-mail and Internet at Work. The Hague: Kluwer Law International, p. 49.

${ }^{92}$ See especially the labour codes (Article L1121-1 of the French Labour Code and Sections 9-11/A of the Hungarian Labour Code) laying down the rules on limiting employees' rights.

93 Prugberger, T. (2011) 'A munkaszerződés és a munkaviszonyból származó alapvető jogok és kötelezettségek a Munka Törvénykönyvének rekodifikációs tervezetében', Gazdasági élet és társadalom, (12), p. 283.

${ }^{94}$ Hajdú, J. (2005) A munkavállalók személyiségi jogainak védelme. Szeged: Pólay Elemér Alapítvány, p. 20.

95 Title 1 will limit itself to the examination of these rights from an angle focusing on the context of employment in general: the specific changes and challenges brought by SNSs will be addressed under Title 2 .
} 
that are evoked in relation to the dissertation's subject: first, the right to privacy; then, the right to data protection. ${ }^{96}$ Then, Chapter 2 of Title I will bring the focus on the employment relationship, by concentrating on employee control and monitoring. First, it will examine the rights and obligations arising from the employment relationship, and the rights granted to the employer that can justify control and monitoring. Then, it will discuss the already established legal framework for employee monitoring.

\section{Chapter 1: Legal protection of personal life}

26. When it comes to the protection of employees' personal lives, traditionally two rights can gain significant importance: the right to privacy and the right to data protection. They are both acknowledged at the international ${ }^{97}$ and at the national level ${ }^{98}$ as it will be discussed in Chapter 1 - confirming their utmost importance. Both the right to privacy and the right to data protection aims to protect the person ${ }^{99}$ and are fundamental rights. ${ }^{100}$ The respect of these rights is a necessary precondition of the enjoyment of other fundamental rights. ${ }^{101}$ The right to data protection is regarded as a guarantee to ensure the inviolability of the individual's privacy, aiming to guarantee non-interference. ${ }^{102}$

27. Both rights are closely connected to technological developments and largely influenced by them, giving rise to new challenges. Amongst these developments, the proliferation of social media and SNSs has a huge impact on employees' right to privacy and data protection, as during the use of these services individuals often reveal events that

\footnotetext{
96 As György Kiss noted, employees are entitled to the same fundamental rights just as any individual, however, their exact appearance is influenced by the specific characteristics of the employment context. Source: Kiss, Gy. (2010) Alapjogok kolliziója a munkajogban. Pécs: Justis Tanácsadó Betéti Társaság, p. 226.

97 The relevant international organizations that adopted international norms in the field of privacy and/or data protection are the UN, OECD, CoE and EU. The analysis of international norms relating to the specific field of workplace privacy/data protection will take place in Chapter 2.

98 Both rights are explicitly present in the Hungarian constitution (Article VI) and gained constitutional recognition by the French Constitutional Council.

${ }^{99}$ Despite what its appellation might suggest, the right to data protection does not aim to protect personal data, but the individual to whom personal data relates. Source: Majtényi, L. (2002) 'Az információs szabadságok és az adatvédelem határai’, Világosság, XLIII (2-3), pp. 57-58.

100 Both rights are acknowledged in the CFREU (Article 7 and Article 8), are explicitly present in the Hungarian constitution (Article VI) and gained constitutional recognition by the French Constitutional Council.

${ }^{101}$ Rouvroy, A. and Poullet, Y. (2009) 'The Right to Informational Self-Determination and the Value of SelfDevelopment: Reassessing the Importance of Privacy for Democracy', in Gutwirth, S. et al. (eds) Reinventing Data Protection? Springer, p. 61.

102 Vissy, B. (2015) ‘Az információs önrendelkezési jog', in Pozsár-Szentmiklósy, Z. and Somody, B. (eds) Alkotmányos alapok. 2nd edn. Budapest: HVG-ORAC Lap- és Könyvkiadó, p. 206., pp. 200-201.
} 
are traditionally considered private and share a vast amount of personal data - giving rise to several questions in relation to privacy and data protection. ${ }^{103}$

28. Aim and structure of Chapter 1. The aim of Chapter 1 is to present the conceptual fundaments of one side of the collision of rights, namely the employees' side. As two rights are addressed in detail in this Chapter, Section 1 will focus on the right to privacy, while Section 2 will discuss the right to data protection. ${ }^{104}$

\section{Section 1: Right to privacy}

29. One of the rights in the focus of the dissertation that must be balanced against the employer's legitimate interests is the (employees') right to privacy. However, when it comes to defining privacy, scholars usually face difficulties, as there exists no universal standpoint regarding its meaning. ${ }^{105}$ Due to its complexity, creating one single definition leads to a contended result. ${ }^{106}$ However, presenting the most prevailing ones throughout Section 1 is necessary for the purposes of the dissertation, as such an analysis can contribute to improving instincts on privacy ${ }^{107}$ - the understanding of which will be inevitable to address the question of privacy protection from a legal point of view. Then, it will be addressed what legal regulations aim to protect under the right to privacy (or right to respect for private life).

30. Aim of Section 1. The aim of Section 1 is to provide a general conceptual basis regarding the scope and meaning of (the right to) privacy - which will be an essential precondition to addressing the specific challenges caused by the proliferation of SNSs and

${ }^{103}$ E.g. is publishing something on an SNS considered to be part of private life? Can the employer monitor how employees use these sites? Can the employer tell the employees how they can use these sites? These and other specific questions will be addressed under Title 2 .

${ }^{104}$ Within both Chapters the different matters in relation to the right to privacy and right to data protection will be first approached from a general/universal angle, and then the discussion will be brought to France and to Hungary.

105 As Avner Levin and Patricia Sánchez Abril phrased it: "[p]rivacy has always been difficult to define. It seems that everyone wants it, but there is no consensus as to its meaning or value." Source: Levin, A. and Sánchez Abril, P. (2009) 'Two Notions of Privacy Online', Vanderbilt Journal of Entertainment and Technology Law, 11(4), p. 1007. Or see as Daniel Solove aptly formulated: "[p]rivacy seems to be about everything, and therefore it appears to be nothing." Source: Solove, D. J. (2006) 'A Taxonomy of Privacy', University of Pennsylvania Law Review, 154(3), p. 479. Cited in: Hughes, R. L. D. (2015) 'Two concepts of privacy', Computer Law and Security Review, 31(4), p. 528.

106 Clarke, R. (2014) 'Privacy and Social Media: An Analytical Framework', Journal of Law, Information and Science, 23(1), p. 174.

${ }^{107}$ As Fabienne Kéfer and Sabine Cornélis cited J. Velu's apt observation that "Privacy can be "felt" rather than defined." Source: Kéfer, F. and Cornélis, S. (2009) 'L'arrêt "Copland" ou l'espérance légitime du travailleur quant au caractère privé de ses communications', Revue Trimestrielle des Droits de l'Homme, (79), p. 781. 
their effects on individuals' and society's expectations of privacy. Although references will be made to these matters, they will be addressed in detail under Title 2. Section 1 also aims to provide - after examining the different concepts, definitions, approaches and understandings in relation to privacy - a definition of privacy for the purposes of the dissertation.

31. Structure of Section 1. $\S 1$ will address the history and scope of privacy and the way it is apprehended by scholars. Then, $\$ 2$ will focus on how the different legal regulations regulate the right to privacy, with special regard to the most important international organisations, and to the two countries in the focal point of the dissertation: France and Hungary.

\section{\$1. The challenges in defining (the right to) privacy: definitions and history}

32. Challenges in defining privacy. In spite of the numerous attempts ${ }^{108}$ that have been made to define privacy, privacy remains a complex and contested concept, ${ }^{109}$ relating to which no universal definition could be formulated. ${ }^{110}$ Although the claim for privacy in universal, its concrete form differs according to the prevailing societal characteristics, the economic and cultural environment. ${ }^{111}$ It means that privacy must be reinterpreted in the light of the current era and be examined in the current context. Naturally, this ever-changing nature leads to challenges when it comes to defining what should be protected. ${ }^{112}$

\footnotetext{
108 See more on the different definitions of privacy established by scholars in part (B).

${ }^{109}$ As Michael D. Birnhack stated: "[p]rivacy is a contested legal concept, with several understandings and more misunderstandings, covering distant areas of human activities. Privacy is under constant attacks from many different angles. Despite the criticism, its inherent vagueness, and instability, privacy is a fundamental human right and a hallmark of democracy." Source: Birnhack, M. D. (2008) 'The EU Data Protection Directive: An engine of a global regime.', Computer Law \& Security Review, 24(6), p. 508.

110 As Serge Gutwirth formulated it: "[t]he notion of privacy remains out of the grasp of every academic chasing it." Source: Gutwirth, S. (2002) Privacy and the Information Age. Lanham: Rowman \& Littlefield Publishers Inc. p. 31.

Robert C. Post also expressed his doubts regarding whether a universal definition of privacy could be created by stating that "[p]rivacy is a value so complex, so entangled in competing and contradictory dimensions, so engorged with various and distinct meanings, that I sometimes despair whether it can be usefully addressed at all." Source: Post, R. C. (2001) 'Three Concepts of Privacy', Georgetown Law Journal, 89(6), p. 2087.

111 Majtényi, L. (2006) Az információs szabadságok: adatvédelem és a közérdekü adatok nyilvánossága. Budapest: Complex. p. 211.; Simon, É. (2005) 'Egy XIX. századi tanulmány margójára', Információs Társadalom, (2), pp. 33-34.; Szabó, M. D. (2005) 'Kísérlet a privacy fogalmának meghatározására a magyar jogrendszer fogalmaival', Információs Társadalom, (2), p. 45.

${ }^{112}$ With regard to these ever-changing circumstances, it is not only impossible but also without interest to establish a definition of privacy. Fatou Ba Sene citing François Rigaux in: Ba Sene, F. (2015) 'La protection constitutionnelle de la vie privée et familiale sur les réseaux sociaux en France', in Ndior, V. (ed.) Droit et réseaux sociaux. Issy-les-Moulineaux: Lextenso (Collection LEJEP), p. 93.
} 
33. Privacy vs. the right to privacy. It must also be anticipated that what is considered to be private and what is legally protected as private can differ: ${ }^{113}$ the dissertation focuses on the legal aspects of privacy. Although privacy has been in existence for a long time, as certain needs for privacy have their early origins in ancient societies, it only became a generally accepted right in the 19th-20th century. ${ }^{114}$

34. In the light of the challenges presented above, it is not the aim of the dissertation to establish an exhaustive or universal notion of privacy. However, a discussion on privacy is inevitable when addressing the question of workplace privacy protection and social media, in order to understand what privacy means in the context of SNSs and employment. Thus, the most important definitions and approaches to effectively addressing privacy will be presented, with the aim of creating a definition for the purpose of the dissertation.

\section{(A) History of (the right to) privacy}

35. Before addressing the exact content and scope of privacy, it is needed to define the main context in which (the right to) privacy appeared and continued to develop. Therefore, the main steps of its history will be addressed in the next paragraphs, followed by the presentation of how privacy gained legal recognition in French and Hungarian legal order, providing the framework of protection. ${ }^{115}$

\section{(a) Universal development}

36. Origins of privacy. Privacy can be traced back to a long history: in a broad sense, early origins of privacy can be observed even in ancient societies. ${ }^{116}$ The idea of

\footnotetext{
${ }^{113}$ For example, someone might find all kinds of physical connection - accidental physical contact in a bus during the rush hour or a friendly tap on the shoulder by a distant acquaintance - an intrusion into his/her private sphere, although in the legal sense it is not considered privacy infringement.

${ }^{114}$ Notably see the famous article entitled "The Right to Privacy" written by Samuel D. Warren and Louis D. Brandeis [Warren, S. D. and Brandeis, L. D. (1890) 'The Right to Privacy', Harvard Law Review, 4(5), pp. 193-220.] or the adoption of the different international human rights documents throughout the 20th century - to be presented in a later part of the dissertation.

115 The substance of the international and national norms to be presented in this part will be examined in $\S 2$.

${ }^{116}$ For example, even the Bible has some passages where the violation of privacy appeared in its early form, where shame and anger followed the intrusion into someone's private sphere. It is enough to think of Adam and Eve, who started to cover their bodies with leaves in order to preserve their privacy. (Source: Konvitz, M. R. (1966) 'Privacy and the Law: a Philosophical Prelude.', Law and Contemporary Problems, 31(2), p. 272.) From a legal point of view, the Code of Hammurabi contained a paragraph against the intrusion into someone's home, and the Roman law also regulated the same question. (Source: Solove, D. J. (2011) Nothing to hide: the false tradeoff between privacy and security. New Haven \& London: Yale University Press, p. 4.)
} 
privacy traditionally comes from the difference between "private" and "public", ${ }^{117}$ which distinction comes from the natural need - as old as mankind - of the individual to make a distinction between himself/herself and the outer world. ${ }^{118}$ Of course, the limits between private and public differ according to the given era and society, ${ }^{119}$ which will cause the ongoing change throughout history of what people consider private. ${ }^{120,} 121$ Thus, contemporary conceptions of privacy and its protection will considerably differ from its early forms.

37. Appearance of the right to privacy. It was the $19^{\text {th }}$ century which brought a huge leap in the history of privacy as the new changes in the economy and in the society led to the transformation of the way people lived, and these new changes had consequences for privacy too, as physical and mental privacy were separated and started to evolve in two different ways. Due to urbanization, the population of cities started to grow, and it led to the physical loss of privacy as people in cities had to live in crowded places. On the other hand, citizens could experience a new "type" of privacy, as they ceased to live under the always watching eyes of their village neighbors and the constant moral control set up by them. ${ }^{122}$

117 Szabó, M. D. (2005) 'Kísérlet a privacy fogalmának meghatározására a magyar jogrendszer fogalmaival', Információs Társadalom, (2), p. 45.

118 Konvitz, M. R. (1966) 'Privacy and the Law: a Philosophical Prelude.', Law and Contemporary Problems, 31(2), p. 274.

119 Szabó, M. D. (2005) 'Kísérlet a privacy fogalmának meghatározására a magyar jogrendszer fogalmaival', Információs Társadalom, (2), p. 45.

${ }^{120}$ In the ancient societies people had a relatively limited possibility for self-determination as their (private) lives were strongly influenced by the state. Plato illustrates this phenomenon in his dialogue the Laws, where the complete life of the individual was determined by the state and its aims, there was no place for individual freedom and autonomy. Thus, the book describes a very extreme state (which in its totality was never realised), some elements of it came true in ancient societies, and the life of the individual was strongly influenced by the public interests. In the Medieval Age there was no privacy as a societal value in today's sense, the individual existed as a member of a community, so his/her private life was affected by the constant "monitoring" conducted by other members. A significant change in the history of privacy happened in the $19^{\text {th }}$ century, with the appearance of the industrial society. Source: Lukács, A. (2016) 'What is Privacy? The History and Definition of Privacy', in Gábor Keresztes (ed.): Tavaszi Szél 2016 Tanulmánykötet I. Budapest: Doktoranduszok Országos Szövetsége, p. 257.

${ }^{121}$ Daniel Solove made an illustrative example to present the on-going change regarding what people consider private: even the aspects of life that nowadays are commonly considered as private (the family, the body and the home, etc.) had been through considerable changes as initially they were far from being private. For example, marriage was initially considered to be a contract, while nowadays it is one of the most intimate decisions made by the individual. See more: Solove, D. J. (2002) 'Conceptualizing Privacy', California Law Review, 90(4), pp. 1132-1140.

${ }^{122}$ Simon, É. (2005) ‘Egy XIX. századi tanulmány margójára’, Információs Társadalom, (2), p. 36. 
38. It was against this background that the need for the right to privacy appeared. ${ }^{123}$ Its first appearance dates back to 1890 , when Samuel Warren and Louis Brandeis first stated the need for the legal recognition of the right to privacy in their article titled "The Right to Privacy" (published in the Harvard Law Review). ${ }^{124}$ The reason behind was the dangers underlying the appearance and growth of (tabloid) newspapers, combined with the invention of the portable cameras, which were a fertile area for gossip and photojournalism. ${ }^{125}$ Their writing became a famous article among legal scholars; an "unquestioned "classic", ${ }^{126}$ the "most influential law review article of all". ${ }^{127}$ In the abovementioned article Warren and Brandeis defined the right to privacy as "the right to be let alone". ${ }^{128}$ The article also influenced jurisprudence as numerous endeavors to define privacy originated from Warren's and Brandeis' work. ${ }^{129}$

39. International human rights agreements. Even before the drafting of the relevant international document(s), certain early forms of privacy protection (e.g. sanctity of the home and secrecy of correspondence) were to be found in the national legal systems, especially in France, England and Germany. However, it was only after the Second World War that the development of the right to privacy took a pace and has not slowed down ever since. ${ }^{130}$ The cruelties of the Second World War - during which the use of large databases facilitated the deportation of millions - led to the drafting of the first international human rights agreements, ${ }^{131}, 132$ both at the universal and at the regional level. ${ }^{133}$ The very first

123 Early forms of protection existed as well, relating, for example, to the immunity of the home ("an Englishman's home is his castle") or to the protection of correspondence.

${ }^{124}$ Warren, S. D. and Brandeis, L. D. (1890) 'The Right to Privacy', Harvard Law Review, 4(5), pp. 193220.

${ }^{125}$ On the background and the more detailed analysis of this high-impact article see more in: Bratman, B. E. (2002) 'Brandeis and Warren's The Right to Privacy and the Birth of the Right to Privacy', Tennessee Law Review, 69(3), pp. 623-651.; Gormley, K. (1992) 'One Hundred Years of Privacy', Wisconsin Law Review, (5), pp. 1343-1357.

${ }^{126}$ Shapiro, F. R. (1985) 'The Most-Cited Law Review Articles', California Law Review, 73(5), p. 1545.

${ }^{127}$ Kalven, H. J. (1966) 'Privacy in Tort Law - Were Warren and Brandeis Wrong?', Law and Contemporary Problems, 31(2), p. 327.

${ }^{128}$ Warren, S. D. and Brandeis, L. D. (1890) 'The Right to Privacy', Harvard Law Review, 4(5), p. 193.

${ }^{129}$ Simon, É. (2005) 'Egy XIX. századi tanulmány margójára’, Információs Társadalom, (2), p. 32.

The Right to Privacy influenced the law especially in the US, where this article is regarded as the origin of the four privacy torts (appropriation, publicity, false light, and intrusion) that emerged from the US case law. (See: Posner, R. A. (1978) 'The Right of Privacy', Georgia Law Review, 12(3), p. 409; Prosser, W. L. (1960) 'Privacy', California Law Review, 48(3), p. 389.) Europe started to examine the right to privacy after the US and created a different kind of protection. On the differences between EU and US privacy protection see more: Whitman, J. Q. (2004) 'The Two Western Cultures of Privacy: Dignity versus Liberty', The Yale Law Journal, 113(6), pp. 1151-1221.

${ }^{130}$ Rigaux, M. F. (1991) 'La liberté de la vie privée', Revue internationale de droit comparé, 43(3), p. 540, 545.

${ }^{131}$ Buitelaar, J. C. (2012) 'Privacy: Back to the Roots', German Law Journal, 13(3), p. 174. 
international document that acknowledged the right to privacy as a fundamental human right was the Universal Declaration of Human Rights (United Nations, 1948, Article 12, hereinafter referred to as: UDHR). ${ }^{134,}{ }^{135}$ At the regional level, the Council of Europe and the European Union must be mentioned. One of the most important documents regulating the right to privacy is the European Convention on Human Rights (Council of Europe, 1950, Article 8, hereinafter referred to as: ECHR), which served as a genesis for several pieces of privacy legislation throughout Europe, ${ }^{136}$ and marks the beginning of contemporary privacy protection in Europe. ${ }^{137}$ Last but not least, the Charter of Fundamental Rights of the European Union (European Union, 2000, hereinafter referred to as: CFREU) must be mentioned.

40. Technological development. Although the adoption of these norms constitutes a significant step in relation to privacy protection, the history of the right to privacy has not come to its end. Being an evolutive concept, privacy must be regularly reinterpreted according to the given era: when discussing the subject of privacy, the impacts of technological development pose inevitable questions as privacy has a close connection to technology, making it a very fertile area of research even after more than a century. ${ }^{138}$

David Flaherty explains the relationship between technology and privacy, through pointing out how the latter is connected to technology and was challenged by the great

\footnotetext{
132 Although Whitman demonstrates that in contrast to the popular opinion according to which dignity - and the fundamental right based on dignity, such as the right to privacy - became increasingly important in response to the cruelties of the world war, and especially the Nazi regime, it was already present and protected in (the French and German) legal systems. Source: Whitman, J. Q. (2004) 'The Two Western Cultures of Privacy: Dignity versus Liberty', The Yale Law Journal, 113(6), p. 1165.

${ }^{133}$ See Annex I. on the summary table concerning the most important international documents in the field of privacy, data protection, data protection and employment, and data protection and social network sites.

${ }^{134}$ Mendel, T. et al. (2013) Étude mondiale sur le respect de la vie privée sur l'Internet et la liberté d'expression. Paris: Éditions Unesco (Collection Unesco sur la liberté de l'Internet), p. 12.

135 Among the documents drafted by the United Nations, the International Covenant on Civil and Political Rights (United Nations, 1966, hereinafter referred to as: ICCPR) shall also be mentioned, and its Article 17 guaranteeing the respect of private life.

${ }^{136}$ Rustad, M. L. and Paulsson, S. R. (2005) 'Monitoring Employee E-Mail and Internet Usage: Avoiding the Omniscient Electronic Sweatshop: Insights from Europe', U. Pa. Journal of Labor and Employment Law, 7(4), pp. 870-871.

137 Otto, M. (2016) The Right to Privacy in Employment: a Comparative Analysis. Oxford, Portland: Hart Publishing, p. 69.

138 As Robert Sprague noted, "[o]ne of the greatest impacts on one's expectation of privacy-and, hence, one's right to privacy - is technology.” [Source: Sprague, R. (2008) 'Orwell Was an Optimist: The Evolution of Privacy in the United States and Its De-Evolution for American Employees', The John Marshall Law Review, 42(1), p. 89.]
} 
inventions ever since the Industrial Revolution. ${ }^{139}$ Compared to the big technological threat in the era of Warren and Brandeis, the instant camera, owned only by a few, the change is considerable: today individuals have far overstepped those challenges by carrying around in their pockets complex devices that are capable of tracking, locating and recording every move they make. ${ }^{140}$ Lawrence Lessig explains in one of his articles how monitoring - a natural societal phenomenon - was completely changed in its paradigm due to the technological development, by making it permanent, pervasive and recordable. ${ }^{141}$ Not only scholars, but several international documents have also acknowledged the importance of human rights and among them the right to privacy in this technologically changed environment. ${ }^{142}$ Title 2 will explore in detail the challenges brought by technology in the focus of the dissertation and its societal impacts: social media and SNSs.

\section{(b) Legal acknowledgement of the right to privacy: France and Hungary}

41. Privacy and constitutional law. In addition to the protection afforded by international norms, national systems as well guarantee the protection of the right to privacy. Both in France and in Hungary constitutional protection is accorded to the right to privacy. However, France is one of those countries which do not expressively state the protection of the right to respect for private life in its constitution. ${ }^{143}$

42. In France, the Constitutional Council first recognized the right to respect for private life in its 1995 "vidéosurveillance" decision. ${ }^{144}$ Before this date, only the home received protection, but not the right to respect for private life in general. ${ }^{145}$ Although it does not refer expressly to the respect of private life as such, the "inspection of vehicles"

\footnotetext{
${ }^{139}$ Flaherty, D. H. (1999) 'Some reflections on privacy and technology', Manitoba Law Journal, 26(2), p. 224.

${ }^{140}$ Hughes, R. L. D. (2015) 'Two concepts of privacy’, Computer Law and Security Review, 31(4), p. 527.

${ }^{141}$ Lessig, L. (2005) 'A privát szféra architektúrája', Információs Társadalom, (2), pp. 55-74.

142 See, for example, the UN's document "The promotion, protection and enjoyment of human rights on the Internet." (United Nations, 2012, A/HRC/20/L.13) or the "Resolution adopted by the General Assembly on 18 December 2013 - The right to privacy in the digital age" (United Nations, 2013, A/RES/68/167). These documents reaffirm that individuals shall enjoy the same fundamental human rights - and among them the right to privacy - also in the digital and Internet era.

${ }^{143}$ Though the Advisory Committee on the Revision of the Constitution proposed in 1993 to complement Article 66 with the provision "Everyone shall have the right to respect for his/her private life [...] ." Comité consultatif pour une révision de la Constitution, présidé par le doyen Georges Vedel (1993) Propositions pour une révision de la Constitution. Rapport au Président de la République. p. 53.

${ }^{144}$ Conseil constitutionnel: décision n ${ }^{\circ}$ 94-352 DC du 18 janvier 1995

145 Burgorgue-Larson, L. (2005) 'L'appréhension constitutionnelle de la vie privée en Europe: Analyse croisée des systèmes constitutionnels allemand, espagnol et français.', in Sudre, F. (ed.) Le droit à la vie privée au sens de la Convention européenne des droits de l'homme. Bruxelles: Bruylant, p. 98.
} 
decision from $1977^{146}$ is considered to be the first step towards recognizing the constitutional value of the right to respect for private life. ${ }^{147}$ It was finally granted constitutional value in 1995, in the "vidéosurveillance" decision, when the Constitutional Council stated that " [...] the infringement of the right to respect for private life may pose a threat to the individual liberty. "148 By this, it attached the right to respect for private life to individual liberty, founded on Article 66 of the Constitution. ${ }^{149}$ Following this decision, in its universal health insurance decision in $1999,{ }^{150}$ the Constitutional Council found a new legal base, detaching it from individual liberty and acknowledged that it is founded on Article 2 of the Declaration of the Rights of Man and of the Citizen, ${ }^{151}$ therefore associated with personal liberty. ${ }^{152,153}$

43. Hungary's constitution, the Fundamental Law (adopted in 2011) expressis verbis states the protection of the right to privacy, through stating in Subsection (1) of Article VI that "[e]veryone shall have the right to respect for his or her private and family life, home, communications and reputation.” The right to respect of private life as such did

146 Conseil constitutionnel: décision $n^{\circ} 76-75$ DC du 12 janvier 1977. See more on this decision in: Favoreu, L. (1979) 'Le Conseil constitutionnel et la protection de la liberté individuelle et de la vie privée. A propos de la décision du 12 janvier 1977 relative à la fouille des véhicules', in Études offertes à Pierre Kayser. Aix-enProvence: Presses Universitaires d'Aix-Marseille, pp. 411-425.

${ }^{147}$ Mazeaud, V. (2015) 'La constitutionnalisation du droit au respect de la vie privée', Les Nouveaux Cahiers du Conseil constitutionnel, (48) p. 10.

${ }^{148}$ Conseil constitutionnel: décision $n^{\circ}$ 94-352 DC du 18 janvier 1995, par 3.

149 Burgorgue-Larson, L. (2005) 'L'appréhension constitutionnelle de la vie privée en Europe: Analyse croisée des systèmes constitutionnels allemand, espagnol et français.', in Sudre, F. (ed.) Le droit à la vie privée au sens de la Convention européenne des droits de l'homme. Bruxelles: Bruylant, pp. 69-115. Available at: https://hal.archives-ouvertes.fr/hal-01743616/document (Accessed: 16 August 2019) p. 17.

150 Conseil constitutionnel: décision $\mathrm{n}^{\circ}$ 99-416 DC du 23 juillet 1999. See more in this decision in: 'Commentaire de la décision $\mathrm{n}^{\circ}$ 99-416 DC du 23 juillet 1999' (Cahier 7). Les Cahiers du Conseil constitutionnel. Available at: http://www.conseil-constitutionnel.fr/conseilconstitutionnel/root/bank/download/99416DCccc_416dc.pdf (Accessed: 21 May 2018).

151 Conseil constitutionnel: décision $\mathrm{n}^{\circ}$ 99-416 DC du 23 juillet 1999, par. 45. "Considering that under Article 2 of the Declaration of the Rights of Man and of the Citizen 'the aim of all political associations is the preservation of the natural and imprescriptible rights of the Man. These rights are liberty, property, security and resistance to oppression.' the freedom proclaimed by this article implies respect for privacy."

152 Crouzatier-Durand, F. (2013) Fiches de libertés publiques et droits fondamentaux. 2nd edn. Paris: Ellipses, p. 58.; Bioy, X. (2016) Droits fondamentaux et libertés publiques. 4e édition. Issy-les-Moulineaux: LGDJ-Lextenso éditions (Collection Cours). pp. 454-456.

153 The notion of personal liberty ("liberté personnelle") appeared in a 1988 decision of the Constitutional Council (Décision n ${ }^{\circ}$ 88-244 DC du 20 juillet 1988. See more about it in: Dupré de Boulois, X. (ed.) (2017) Les grands arrêts du droit des libertés fondamentales. Paris: Dalloz. pp. 323-340.) and is considered to have utmost importance ("liberté mère"), serving as a single point of origin ("porte d'entrée unique") for the manifestations of personal autonomy (Bioy, X. (2016) Droits fondamentaux et libertés publiques. 4e édition. Issy-les-Moulineaux: LGDJ-Lextenso éditions (Collection Cours). p. 452.). On the notions of individual liberty and personal liberty, and their role in the Constitutional Council's decisions see more in: Vadillo, F. (2015) 'Liberté individuelle vs liberté personnelle: l'article 66 de la Constitution dans la jurisprudence du Conseil constitutionnel ou la progressive reconnaissance d'un habeas corpus à la française', Petites affiches, (80), p. 4-11.; Roussillon, H. and Bioy, X. (eds) (2006) La liberté personnelle: une autre conception de la liberté? Toulouse: Presses de l'Université des Sciences sociales. 
not appear explicitly till the adoption of the Fundamental Law, ${ }^{154}$ although it does not mean that before this period no legal protection was afforded: the previous constitution already ensured protection to certain aspects of privacy, such as private secrets and the home. ${ }^{155}$

In June 2018, the seventh modification of the Fundamental Law ${ }^{156}$ introduced certain changes relevant to the right to respect for private life, with regard to the new challenges arising due to technological development, digitalization, and the growing media attention. ${ }^{157}$ As a result of the modification, Subsection (1) of Article VI was completed with the phrase "[t]he exercise of freedom of expression and the right of assembly cannot result in the violation of private and family life or home of others." Subsection (2) was inserted into the same Article stating that the State legally protects the tranquility of the home.

44. Civil law protection. Early forms of legal privacy protection appeared even before the right to respect of private life was explicitly declared by the Civil Codes - 1970 in France and 1977 in Hungary. In France its early history is mostly connected to the freedom of press and to the insults relating to private life. ${ }^{158}$ Before 1970 , when the right to respect for private life was inserted ${ }^{159}$ into the Civil Code, ${ }^{160}$ protection could be afforded on the basis of the previous Article 1382 on civil responsibility. ${ }^{161}$

\footnotetext{
${ }^{154}$ Although it appeared in the practice of the Constitutional Court - which will be addressed in $\S 2$.

155 Act XX of 1949. The original text (Section 57) guaranteed protection to the individuals' individual liberty and its inviolability, the respect of private secrets and the home. The amendment of 1972 ensured the same protection but to the citizens. The final text of the previous constitution was adopted in 1989, with Subsection (1) of Section 59 stating that "[i]n the Republic of Hungary everyone has the right to reputation, right to inviolability of the domicile, the right to the protection of private secrets and the right to the protection of personal data.” Source: Jóri, A. (2009) 'A magánszférajogok', in Jakab, A. (ed.) Az Alkotmány kommentárja II. Budapest: Századvég Kiadó, pp. 2171-2172.

156 Article 4 of the seventh amendment of the Fundamental Law of Hungary, 28 June 2018

157 T/332. számú javaslat Magyarország Alaptörvényének hetedik módositása (2018). Előadó: Dr. Trócsányi László igazságügyi miniszter. Budapest, p. 5.

158 See more on the early history of French privacy law in: Whitman, J. Q. (2004) 'The Two Western Cultures of Privacy: Dignity versus Liberty', The Yale Law Journal, 113(6), pp. 1171-1180.

${ }^{159}$ Inserted by the Act No. 70-643 of 17 July 1970 on strengthening the guarantee of individual rights of citizens ("Loi n ${ }^{\circ}$ 70-643 du 17 juillet 1970 tendant à renforcer la garantie des droits individuels des citoyens").

${ }^{160}$ Article 9: "Everyone has the right to respect for his private life."

Without prejudice to the right to recover indemnification for injury suffered, judges may prescribe any measures, such as sequestration, seizure and others, suited to the prevention or the ending of an infringement of the intimate character of private life; in case of emergency those measures may be provided for by summary proceedings."

${ }^{161}$ Rigaux, M. F. (1991) 'La liberté de la vie privée’, Revue internationale de droit comparé, 43(3), p. 546. Article 1382 stated that " $\mathrm{t}]$ he perpetrator of any act that causes damage to another person is obliged to make reparation."
} 
45. The previous Hungarian Civil Code (Act IV of 1959) did not ensure sui generis protection to privacy, it received protection on the ground of personality rights. ${ }^{162}$ It is the primary objective of personality rights to ensure protection to rights which make humans human, which are parts of human personality, without examining the societal circumstances - excluding from their scope political, cultural and social rights. ${ }^{163}$ The essence of personality rights is to ensure the free expression of the personality and to prevent anyone from hindering them, within the limits that the community imposes. ${ }^{164}$ Naturally, the exercise of these rights is not without limits, it is only in accordance with their social purpose, if it does not infringe other individuals' rights or laws guaranteeing these rights. ${ }^{165,166}$ It appeared in the Civil Code (Act V of 2013), which explicitly declares the protection of right to privacy. ${ }^{167}$ Another important step was the adoption of the act on the protection of private life ${ }^{168}$ in 2018.

46. Criminal law protection. Besides constitutional and civil law protection, criminal law also guarantees the protection against infringements of the right to privacy.

162 The general personality right was afforded protection even before the Second World War. Source: Jóri, A. (2009) 'A magánszférajogok', in Jakab, A. (ed.) Az Alkotmány kommentárja II. Budapest: Századvég Kiadó, p. 2170.

${ }^{163}$ Fézer, T. (2014) 'Harmadik rész: személyiségi jogok', in Osztovits, A. (ed.) A Polgári Törvénykönyvröl szóló 2013. évi $V$. törvény és a kapcsolódó jogszabályok nagykommentárja. I. kötet. Budapest: Opten Informatikai Kft. p. 250.

164 Petrik, F. (2014) 'Személyiségi jogok', in Wellmann, G. (ed.) Polgári jog: Bevezető és záró rendelkezések. Az ember mint jogalany. Öröklési jog. 2nd edn. Budapest: HVG-ORAC Lap- és Könyvkiadó, pp. 173-174.

165 BH. 1992.387.

166 See more on privacy and personality rights in: Görög, M. (2016) 'A magánélethez való jog mint a személyiségi jog újabb, magánjogi kódexben nevesített vonatkozása’, in Balogh, E. (ed.) Számadás az Alaptörvényröl: tanulmányok a Szegedi Tudományegyetem Állam-és Jogtudományi Kar oktatóinak tollából. Budapest: Magyar Közlöny Lap- és Könyvkiadó, pp. 61-63.

On the personality rights see more in: Nótári, T., Péterfalvy, A. and Sándor, I. (2006) A Polgári Törvénykönyv magyarázata. I. kötet: A személyek joga. Edited by G. Török. Budapest: Magyar Hivatalos Közlönykiadó. pp. 297-337.; Fézer, T. (2014) 'Harmadik rész: személyiségi jogok', in Osztovits, A. (ed.) A Polgári Törvénykönyvről szóló 2013. évi V. törvény és a kapcsolódó jogszabályok nagykommentárja. I. kötet. Budapest: Opten Informatikai Kft., pp. 249-355.; Zoltán, Ö. (2007) 'A személyhez és a szellemi alkotásokhoz füződő jogok’, in Gellért, G. (ed.) A Polgári Törvénykönyv magyarázata 1.7th edn. Budapest: Complex, pp. 256-326.; Petrik, F. (2014) 'Személyiségi jogok', in Wellmann, G. (ed.) Polgári jog: Bevezetö és záró rendelkezések. Az ember mint jogalany. Öröklési jog. 2nd edn. Budapest: HVG-ORAC Lap- és Könyvkiadó, pp. 166-211.; Navratyil, Z. (2016) 'Személyiségi jogok', in Csehi, Z. (ed.) Az új Polgári Törvénykönyv magyarázata. Kommentár a 2013. évi V. törvényhez. 2nd edn. Budapest: Menedzser Praxis Szakkiadó és Gazdasági Tanácsadó Kft., pp. 105-124.; Kecskés, L. (2007) Polgári jog: A személyek joga. 3rd edn. Budapest-Pécs: Dialóg Campus Kiadó. pp. 413-451.

${ }^{167}$ Subsection (1) of Section 2:42 of the Hungarian Civil Code: "[e]veryone is entitled to freely practice his or her personality rights, in particular the right to privacy and family life, home and communications with others in any way or form, and the right to protection against defamation of character, within the framework of the law and within the rights of others, and to not be impeded by others in exercising such rights."

168 Act LIII of 2018 on the protection of private life. To be presented in detail in a later section of the dissertation. 
When introducing civil law protection in 1970, Act No. 70-643 of 17 July 1970 on strengthening the guarantee of individual rights of citizens also inserted provisions into the French Penal Code against different invasions of privacy, at present found in Articles 2261-226-7 of the French Penal Code. The Hungarian Penal Code (Act C of 2012) also contains certain provisions aiming to sanction the most serious actions infringing certain components of the right to respect for private life. ${ }^{169}$

47. Conclusions of Part (A). Despite the fact that during the last decades the right to privacy gained legal recognition (both at the international and at the national level) and constitutes a dynamically evolving field of law due to its dependence on societal and technological circumstances, it does not mean that a universal definition, valid in all circumstances could be created. The next paragraphs will explore the different notions that were created attempting to define privacy.

\section{(B) Understanding privacy}

48. Enumerating exhaustively all existing (philosophical) and legal notions of privacy is an impossible task ${ }^{170}$ and would also go beyond the primary scope of the dissertation. Therefore, the dissertation had to limit itself to presenting only a certain number of approaches relevant for the main topic of the dissertation. The aim of the following paragraphs is to provide insight into the various facets of privacy through reviewing the $(a)$ most common types of definitions, then their existing categorizations by several scholars. Then, part $(b)$ will demonstrate the factors that can have a considerable influence on understanding privacy - making it an ever-changing concept. The knowledge of this background will be necessary to understand how the legal protection of privacy functions, and what aspects of privacy receive legal protection in the examined jurisdictions.

(a) Definitions and classification of definitions

\footnotetext{
169 Such as: Misuse of personal data - Section 219; Illegal Entry into Private Property - Section 221; Harassment - Section 222; Invasion of Privacy - Section 223; Mail Fraud-Section 224.

${ }^{170}$ I share the opinion of the ECtHR, which stated in Niemietz v. Germany that "[t]he Court does not consider it possible or necessary to attempt an exhaustive definition of the notion of "private life." ECtHR: Niemietz v. Germany, application no. 13710/88, 16 December 1992, par. 29.
} 
49. Multiple definitions. ${ }^{171}$ Besides the ever-changing nature of privacy, numerous attempts to define privacy have been made during the last 120 years. ${ }^{172}$ Traditionally, privacy can relate to concealment or secrecy, giving the individual the possibility to separate himself/herself from the outside world. As already presented, Warren and Brandeis defined privacy as "the right to be let alone". ${ }^{173}$ Sidney M. Jourard links privacy to concealment and argues that privacy "is an outcome of a person's wish to withhold from others certain knowledge, past and present experience and action and his intentions for the future." 174 Privacy can also be understood as a quasi "aura" around the individual, which constitutes the boundary between him/her and the outside world. ${ }^{175}$ László Sólyom puts interference into the center of privacy and argues that the common feature of perceptions of privacy is that it means the (physical and mental) area which is controlled by the individual, and which is thus free from external interference. ${ }^{176}$

50. Accessibility can also play a part in these definitions: according to Ruth Gavison "our interest in privacy [...] is related to our concern over our accessibility to others: the extent to which we are known to others, the extent to which others have physical access to us, and the extent to which we are the subject of others' attention." 177 According to Hyman Gross "privacy is the condition of human life in which acquaintance with a person or with affairs of his life which are personal to him is limited." ${ }^{178}$ Another definition captures privacy as an "interest that individuals have in sustaining a 'personal space', free from interference by other people and organisations. " 179 Ernest Van Der Haag provides a similar definition through understanding privacy as "the exclusive access of a

${ }^{171}$ How privacy is comprehended in France and in Hungary will be addressed in detail under $\S 2$.

172 On the existing definitions see more notably in: Solove, D. J. (2002) 'Conceptualizing Privacy', California Law Review, 90(4), pp. 1087-1156.; Davis, S. (2009) 'Is There a Right to Privacy?', Pacific Philosophical Quarterly, 90(4), pp. 450-475.

173 Warren, S. D. and Brandeis, L. D. (1890) 'The Right to Privacy', Harvard Law Review, 4(5), p. 193.

174 Jourard, S. M. (1966) 'Some Psychological Aspects of Privacy', Law and Contemporary Problems, 31(2), p. 307.

${ }^{175}$ Hajdú, J. (2005) A munkavállalók személyiségi jogainak védelme. Szeged: Pólay Elemér Alapítvány. p. 8. referring to Davis, S. (1996) Big Brother: Britain's web of surveillance and the new technological order. London: Pan.

176 Sólyom, L. (1983) A személyiségi jogok elmélete. Budapest: Közgazdasági és Jogi Könyvkiadó. p. 315.

177 Gavison, R. (1980) 'Privacy and the Limits of Law', The Yale Law Journal, 89(3), p. 423.

${ }^{178}$ Gross, H. (1967) 'The Concept of Privacy', New York University Law Review, 42(1), pp. 35-36.

179 Clarke, R. (2014) 'Privacy and Social Media: An Analytical Framework', Journal of Law, Information and Science, 23(1), p. 174. 
person to a realm of his own. The right to privacy entitles an individual to exclude others from (a) watching, (b) utilizing, (c) invading his private [personal] realm."

51. Privacy can be approached through control over information relating to the individual: Alan F. Westin defined privacy as "the claim of an individual to determine what information about himself or herself should be known to others" ${ }^{181}$ while Charles Fried stated that "privacy [...] is the control we have over information about ourselves." "182, 183 Richard A. Posner argued that "one aspect of privacy is the withholding or concealment of information." ${ }^{184}$ Richard B. Parker goes beyond identifying privacy as control over information and argues that privacy "is control over when and by whom the various parts of us can be sensed by others. "185 According to Ferdinand D. Schoeman this control can relate not only to information and sensory access but also to the intimacies of personal identity. ${ }^{186}$

52. Privacy can also be connected to human dignity and autonomy: Edward Bloustein argued that intrusion into privacy has a close connection with personhood, individuality and human dignity. ${ }^{187}$ Tom Gerety understands privacy as "the control over or the autonomy of the intimacies of personal identity”. ${ }^{188}$ Máté Dániel Szabó argued that "privacy is the right of the individual to decide about himself/herself". ${ }^{189}$ According to the Supreme Court of Canada, privacy is closely connected to the concept of freedom, as it constitutes "an essential component of what it means to be free". ${ }^{190}$ Privacy attached to dignity is connected to the free development of personality and inner self, enabling the

\footnotetext{
${ }^{180}$ Cited in: McCullagh, K. (2008) 'Blogging: self presentation and privacy', Information \& Communications Technology Law, 17(1), p. 4.

${ }^{181}$ Westin, A. F. (2003) 'Social and political dimensions of privacy', Journal of Social Issues, 59(2), p. 431.

182 Fried, C. (1968) 'Privacy', The Yale Law Journal, 77(3), p. 393.

${ }^{183}$ Erik Van Hove adopts the same opinion and complements this definition by adding the right to a private sphere. Cited in: McCullagh, K. (2008) 'Blogging: self presentation and privacy', Information \& Communications Technology Law, 17(1), p. 4.

${ }^{184}$ Posner, R. A. (1978) 'The Right of Privacy', Georgia Law Review, 12(3), p. 393.

185 Parker, R. B. (1974) ‘A Definition of Privacy’, Rutgers Law Review, 27(2), p. 281.

186 Schoeman, F. D. (2007) 'Privacy: philosophical dimensions of the literature', in Schoeman, F. D. (ed.) Philosophical Dimensions of Privacy: An Anthology. Cambridge: Cambridge University Press, p. 2.

187 Bloustein, E. J. (1964) 'Privacy as an Aspect of Human Dignity: an Answer to Dean Prosser', New York University Law Review, 39(6), p. 973, p. 974.

${ }^{188}$ Gerety, T. (1977) 'Redefining Privacy’, Harvard Civil Rights-Civil Liberties Law Review, 12(2), p. 281.

189 Szabó, M. D. (2005) 'Kísérlet a privacy fogalmának meghatározására a magyar jogrendszer fogalmaival', Információs Társadalom, (2), p. 46.

190 Flaherty, P. and Whitmore, S. (2013) 'Privacy Protection in the Digital Workplace', in Law Society of Upper Canada, Employment Law and the New Workplace in the Social Media Age. Toronto: Irwin Law, p. 9.
} 
individual to create different public personas through being able to decide which areas of his/her life is the individual going to share with others. ${ }^{191}$

53. Intimacy also appears in definitions: according to Julie Inness all these approaches - information, access or intimate decisions - are linked by the common denominator of intimacy, being in the center of privacy. ${ }^{192}$ According to Charles Fried, privacy serves as a basis for intimate relationships, such as friendship, love and trust; and constitutes a necessary pre-condition of establishing relationships with others and shaping one's own identity. ${ }^{193,194}$

54. Having knowledge of these definitions is crucial for the main topic of the dissertation, as in relation to SNSs, several of these definitions gain importance - as it will be discussed in detail. Privacy interpreted as one's right to decide about himself/herself can be understood as deciding whether to engage in SNSs and if yes, to what extent. Developing one's personality can also take place on SNSs, as SNS profiles play an important role in self-expression and identity. Interpreting secrecy, withholding and the concealment of information in the SNS context is not without difficulties as the whole functioning of these sites is powered by the share of personal information. However, through the use of privacy settings, the individual can decide to withhold from one part of the community and only share information with a chosen audience.

55. Classification of the definitions. Instead of providing a unique definition of privacy, it is worth examining what clusters of privacy or categorization of the definition of privacy exist, as they can provide important guidance in relation to the far-reaching nature of privacy and can improve instincts on privacy relating to which areas of life should receive legal protection.

191 Levin, A. and Sánchez Abril, P. (2009) 'Two Notions of Privacy Online', Vanderbilt Journal of Entertainment and Technology Law, 11(4), p. 1013.

192 Julie C. Inness, J. C. (1992) Privacy, Intimacy, and Isolation. Cited in: Solove, D. J. (2002) 'Conceptualizing Privacy', California Law Review, 90(4), p. 1121.

${ }^{193}$ Cited in: Levin, A. and Sánchez Abril, P. (2009) 'Two Notions of Privacy Online', Vanderbilt Journal of Entertainment and Technology Law, 11(4), p. 1013.

194 As Daniel Solove analysed in his article entitled "Conceptualizing Privacy", most of the existing definitions are either too narrow or too broad and presented his thorough criticism regarding these notions. He argued that definitions do not lack merit, as they might provide valuable insight into privacy, but none of them in itself succeed in perfectly capturing the essence of privacy. (Source: Solove, D. J. (2002) 'Conceptualizing Privacy', California Law Review, 90(4), p. 1099.) Also, for the purpose of the dissertation not all "types" of privacy will be relevant - for example, the privacy of the home or physical privacy instead, focus will be put on control over information and the autonomy or self-determination of the individual. 
56. Certain scholars avoided providing a unique definition but defined different categories or clusters of privacy. Judith Wagner DeCew differentiated between three clusters of privacy claims: informational privacy, accessibility privacy and expressive privacy. ${ }^{195}$ Jerry Kang argued that privacy is composed of three overlapping clusters: spatial privacy (physical space), decisional privacy (choice) and information privacy (flow of information). ${ }^{196}$ The Supreme Court of Canada distinguished between three "zones of privacy": territorial privacy, personal privacy and informational privacy. ${ }^{197}$ According to József Hajdú, privacy protection can take four forms: data protection, protection of the human body, protection of communication and protection of space. ${ }^{198}$

57. Other scholars regrouped the existing definitions into different groups: according to Ken Gormley, the different privacy notions that appeared after Warren's and Brandeis's ground-breaking work can be grouped into four categories: (1) privacy as the expression of one's personality, (2) privacy as autonomy, (3) privacy as the ability to regulate information and (4) privacy composed of different essential components. ${ }^{199}$ In addition to these four categories defined by Gormley, Éva Simon identified two more to be added to this list: (5) concepts according to which privacy is approached from societal interests, (6) while the sixth category is composed of theories according to which the right to privacy cannot and should not be reduced to one single definition. ${ }^{200}$

Another study from 2013, entitled "Seven Types of Privacy", written by Rachel L. Finn, David Wright and Michael Friedewald, made a huge contribution towards how to approach privacy. In this article the authors also opted for categorizing the types of privacy in a structured, logical way instead of creating a universal definition. They based their analysis on the four privacy subsets defined by Roger Clarke in 1997 and revised and expanded these categories while taking into account the technological developments that occurred during the past decades. They differentiated between seven types of privacy: (1) privacy of the person, (2) privacy of behaviour and action, (3) privacy of personal

\footnotetext{
195 Solove, D. J. (2002) 'Conceptualizing Privacy', California Law Review, 90(4), p. 1125. See more on their analysis in: McCullagh, K. (2008) 'Blogging: self presentation and privacy', Information \& Communications Technology Law, 17(1), pp. 4-6.

${ }^{196}$ Kang, J. (1998) 'Information Privacy in Cyberspace Transactions', Stanford Law Review, 50(4), pp. 12021203.

${ }^{197}$ McKay-Panos, L. (2007) 'Workplace Surveillance', LawNow, 32(2), p. 45

198 Hajdú, J. (2005) A munkavállalók személyiségi jogainak védelme. Szeged: Pólay Elemér Alapítvány. p. 10.

${ }^{199}$ Gormley, K. (1992) ‘One Hundred Years of Privacy’, Wisconsin Law Review, (5), pp.1137-1138.

${ }^{200}$ Simon, É. (2005) ‘Egy XIX. századi tanulmány margójára’, Információs Társadalom, (2), p. 33.
} 
communication, (4) privacy of data and image, (5) privacy of thoughts and feelings, (6) privacy of location and space and (7) privacy of association. ${ }^{201}$ In order to be able to successfully assess the future challenges posed by new emerging technologies, the authors argued that "[...] privacy is an inherently heterogeneous, fluid and multidimensional concept, and [...] suggest that this multidimensionality may be necessary to provide a platform from which the effects of new technologies can be evaluated."202

58. One important example of those who think that privacy should not be reduced to a single definition is Daniel Solove's approach. In his article, “Conceptualizing Privacy" he argues that instead of creating an overarching concept, privacy should be better understood as "drawing from a common pool of similar characteristics". ${ }^{203}$ In his article Solove differentiated between six categories of privacy and regrouped the existing definitions into these categories. According to him, privacy can be interpreted as (1) the right to be let alone, (2) limited access to the self, (3) secrecy, (4) control of personal information, (5) personhood and (6) intimacy. ${ }^{204} \mathrm{He}$ pointed out that there is a problem with all these definitions: their scope is either too narrow or too broad. He emphasized that it does not mean that these concepts lack merit, the problem is that these authors use a traditional method of conceptualizing privacy, and as a result their definitions only highlight either some aspects of privacy, or they are too broad and do not give an exact view on the elements of privacy. ${ }^{205}$

These headings defined by Solove can be understood as the main elements when it comes to the content of privacy, as knowing all these definitions, we can have a clue what areas of life privacy covers, and it can help to broaden and to improve instincts on privacy. Instead of applying these methods of conceptualizing privacy, Solove adopts a pragmatic approach by seeking to provide not one exhaustive definition but rather an approach to better understand privacy. ${ }^{206} \mathrm{He}$ takes into account that privacy depends on several factors - such as societal norms, technology and context - and argues that a practical approach is

201 Finn, R. L. et al. (2013) 'Seven Types of Privacy', in Gutwirth, S. (ed.) European Data Protection: Coming of Age. Dordrecht: Springer, p. 7.

${ }^{202}$ Finn, R. L. et al. (2013) 'Seven Types of Privacy', in Gutwirth, S. (ed.) European Data Protection: Coming of Age. Dordrecht: Springer, p. 26.

${ }^{203}$ Solove, D. J. (2002) 'Conceptualizing Privacy’, California Law Review, 90(4), p. 1088.

204 Solove, D. J. (2002) ‘Conceptualizing Privacy’, California Law Review, 90(4), p. 1094.

205 Solove, D. J. (2002) ‘Conceptualizing Privacy’, California Law Review, 90(4), p. 1099.

${ }^{206}$ Solove, D. J. (2002) ‘Conceptualizing Privacy’, California Law Review, 90(4), pp. 1126-1128, p. 1129 
needed to address privacy related issues, instead of creating one overarching definition of privacy. ${ }^{207}$

59. The complexity of the subject was also highlighted by Koop et al. who have provided in their article, entitled "A Typology of Privacy" a typology of privacy "that is more systematic and comprehensive than any existing model." ${ }^{208}$ In their typology they positioned the main types of privacy in a two-dimensional model, composed of the degree of privateness ${ }^{209}$ and the spectrum of positive to negative freedom. ${ }^{210}$ They identified eight types of privacy (bodily, intellectual, spatial, decisional, communicational, associational, proprietary, and behavioral privacy) and an extra "one", informational privacy which - as it overlaps but does not coincide with each identified privacy type - constitutes an overarching concept instead of a separate type of privacy. ${ }^{211}$

60. Again, these classifications are important as they can indicate that privacy in relation to SNSs cannot be reduced to one element, but several aspects of privacy gain significance in relation to SNSs (e.g. communication through using the messenger functions of these platforms, the ability to express one's personality through posting a variety of content, deciding who can have access to the shared content through the application of privacy settings, etc.).

\section{(b) Factors influencing privacy}

61. Privacy should not and cannot be interpreted in a vacuum: what is considered to be private is highly dependent on the circumstances: there are huge differences between particular societies and cultures, or scientific development can also lead to a different, urging need for ensuring the protection of privacy. ${ }^{212}$ Different factors might influence privacy norms in a given society, such as, for example, the political, the socio-cultural and the personal level, ${ }^{213}$ the new generations of technology and new generation of users, ${ }^{214}$ or dimensions of time, place, economy and technology. ${ }^{215}$ All these

\footnotetext{
207 On this approach see: Solove, D. J. (2002) 'Conceptualizing Privacy', California Law Review, 90(4), pp. 1129-1154.

${ }^{208}$ Koops, B-J. et al. (2017) 'A Typology of Privacy', U. Pa. J. Int'l L., 38(2), p. 483

${ }^{209}$ Koops, B-J. et al. (2017) 'A Typology of Privacy', U. Pa. J. Int'l L., 38(2), p. 564

${ }^{210}$ Koops, B-J. et al. (2017) 'A Typology of Privacy', U. Pa. J. Int'l L., 38(2), p. 565.

${ }^{211}$ Koops, B-J. et al. (2017) 'A Typology of Privacy', U. Pa. J. Int'l L., 38(2), pp. 566-568.

${ }^{212}$ Fried, C. (1968) 'Privacy', The Yale Law Journal, 77(3), p. 486., p. 475.

${ }^{213}$ Westin, A. F. (2003) 'Social and political dimensions of privacy', Journal of Social Issues, 59(2), pp. 431434.

${ }^{214}$ Tene, O. (2011) 'Privacy: The new generations', International Data Privacy Law, 1(1), p. 15.
} 
factors make it even more difficult to establish one single definition of privacy. Among the possible factors influencing the understating of privacy, attention will be drawn to technology, social norms and the individual and the context.

62. Technology has always had a close connection with privacy as new innovations of technology change how privacy might be violated, as they gave rise to different kinds of privacy intrusions ${ }^{216}$ - which is also in the focus point of the dissertation. Technological innovations, such as profiling, location tracking, mobile devices, biometrics, RFID, cloud computing, etc. evoke new kinds of privacy challenges. ${ }^{217}$ Existing threats to privacy have become increasingly important due to the growth of Internet and online activities. $^{218}$ As part of technological inventions, social media and SNSs will have their influence on privacy as well - but these questions will be discussed in detail in Title 2. As it will be demonstrated in relation to the possible existence of "social media law", these technological innovations do not raise the question of the existence of a fundamentally new online privacy law, they rather challenge existing conceptions of privacy. ${ }^{219,220}$

63. As technology advances, it naturally influences individuals' behaviour and social norms relating to privacy and expectations of privacy: social media and the

${ }^{215}$ Report of the Special Rapporteur on the right to privacy (2016). A/HRC/31/64. United Nations, General Assembly. par. 21.

216 For example, taking someone's photograph has become considerably easier - an example also used by Warren and Brandeis back in 1890: while formerly, in order to capture one's image, the individual had to pose for hours to get his/her portrait taken. The invention of cameras changed this landscape. Ever since, these devices have become smaller and cheaper, available to the general public. Today basically every smartphone has a built-in camera, making it possible to capture one's image, without the individual's knowledge. Development has not stopped here: Google glasses or Google contact lenses will raise different types of challenges. Or, eavesdropping also changed through time: the invention of printing, the invention of telephone, e-mails changed how the confidentiality of communications can be infringed.

Though technology can indeed pose a threat to privacy, it must be seen that technological evolution is not an enemy of privacy, as in certain cases it can contribute to protecting privacy in more effective ways, enabling individuals to experience more privacy than their ancestors. Source: Schoeman, F. D. (2007) 'Privacy: philosophical dimensions of the literature', in Schoeman, F. D. (ed.) Philosophical Dimensions of Privacy: An Anthology. Cambridge: Cambridge University Press, p. 2.

${ }^{217}$ See more on how technology affects and challenges privacy in: Weber, R. H. (2015) 'The digital future A challenge for privacy?', Computer Law and Security Review, 31(2), pp. 236-239.; Tene, O. (2011) 'Privacy: The new generations', International Data Privacy Law, 1(1), pp. 16-21. and Türk, A. (2011) La vie privée en péril: des citoyens sous contrôle. Paris: OJacob.

218 One example is identity theft, which is greatly facilitated in the online environment, compared to its offline counterpart. Source: Knight, A. and Saxby, S. (617) 'Global challenges of identity protection in a networked world', Computer Law and Security Review, 30(6), p. 619.

${ }^{219}$ See more on this matter in Title 2.

220 The UN special rapporteur on privacy also calls attention to the re-examination of understandings of privacy, such as distinctions between "individual and collective privacy", expectations of privacy in public and in private places, with special regard to the free development of one's personality in the light of technological development. Source: Report of the Special Rapporteur on the right to privacy (2016). A/HRC/31/64. United Nations, General Assembly. par. 27. 
unprecedented extent of online self-exposure can be mentioned as one example. ${ }^{221}$ For example, while a few decades ago it was completely unimaginable to publicly share with an undetermined or a very high number of people what someone ate for breakfast, which itinerary this person used for his/her morning run, or who he/she is dating, today the share of such information is commonplace on SNSs.

64. The individual also plays a central role, as expectations of privacy can vary from individual to individual. ${ }^{222}$ Anders J. Persson and Sven Ove Hansson also took into consideration the individual's expectations and they divided privacy into two parts: a core part, which is protected "by default" - regardless of the individual's acts - and a discretionary part, which is considered to be private depending on the individual's attitudes. ${ }^{223}$ Privacy is highly dependent on the given context as well: Helen Nissenbaum emphasizes the importance of "contextual integrity" when it comes to privacy, pointing out that depending on the concrete situation, on the context in which the same information is shared might be considered private differently. ${ }^{224,225}$

65. Conclusions of Part (B). To conclude, all these factors, such as technology, ever-changing social norms, and perceptions of the individual, hinder the creation of a universal definition of privacy. Consequently, what is considered to be private (e.g. by a society or by an individual) is not always going to be subject to legal protection. Despite the lack of the ability to define privacy and despite its ever-changing nature, legal regulations must find an average standard that must receive legal protection. In $\$ 2$ these international and national legislations will be discussed.

66. In spite of the difficulties in creating a uniform definition, a definition must be adopted in order to determine what will be understood by privacy for the purpose of the dissertation. As it became apparent, privacy can comprise different aspects. In the context of SNSs, mostly two aspects of privacy, the informational aspect of privacy and decisional privacy will gain utmost importance. Although at the outset it can be concluded that the

221 Tene, O. (2011) 'Privacy: The new generations', International Data Privacy Law, 1(1), p. 22.

${ }^{222}$ What one might consider as intrusion into private life - e.g. opening up about his/her relationship to a distant relative - another might consider as completely normal - e.g. sharing the same information documented in detail with photos, videos, etc. on social media with several hundreds of contacts.

${ }^{223}$ Persson, A. J. and Hansson, S. O. (2003) 'Privacy at Work - Ethical Criteria', Journal of Business Ethics, 42(1), pp. 61-62.

${ }^{224}$ Nissenbaum, H. (1998) 'Protecting Privacy in an Information Age: the Problem of Privacy in Public', Law and Philosophy, 17(5-6), p. 581.

${ }^{225}$ For example, sharing information relating to one's health might feel appropriate if the recipient is the individual's doctor, but sharing exactly same information might feel inappropriate and as an intrusion into privacy if the employer asks for the same information. 
informational aspect of the question will also be directly regulated by the right to data protection. Therefore, when addressing privacy, particular attention should be paid to autonomy, meaning the individual's right to decide on his/her own. On the basis of the above, for the purposes of the dissertation, privacy is understood broadly, as the control over the autonomy of the individual, meaning that the individual should be able to decide how to live his/her life. In the context of SNSs - as it will be addressed under Title 2 - it should primarily mean that the employee is free to decide whether to engage in SNSs, and how he/she can use these sites (what content to share, with whom, etc).

\section{$\S 2$. The legal regulation of the right to privacy}

67. As it was already referred to, several international human rights agreements guarantee the protection of privacy/respect for private life. ${ }^{226}$ In the following, the substance of the relevant $(A)$ international (with the European legal order at the focus point) and $(B)$ national norms will be addressed, with the aim of understanding what circumstances receive legal protection under the right to privacy.

\section{(A) International human rights instruments}

68. United Nations. Among the UN's international documents ensuring the right to respect for private life, the UDHR and the ICCPR must be mentioned. However, for lack of space, these provisions will not be addressed in detail, ${ }^{227}$ as focus will be rather put on the examination of the ECHR and the CFREU, as they are concentrated on the European legal order. Under the aegis of the UN, the UN special rapporteur on privacy

\footnotetext{
226 So far, the expressions "privacy" and "right to privacy" were employed, but (European) legal regulations mostly refer to the expression "right to respect for private life". It must be emphasized that privacy and private life are not synonyms, private life supposes a narrower scope, traditionally connected to secrecy or concealment, to protection against certain interferences - as it will be presented in the following paragraphs. However, there is a tendency indicating that the right to respect for private life is understood in a broader way (see, for example, the analysis on the ECtHR's practice), incorporating also the autonomy of the individual which matter is connected to privacy rather than to private life.

${ }^{227}$ Both documents guarantee the right for respect of private life by stating that it is a fundamental human right and no one shall be subjected to arbitrary interference with his/her privacy, family, home and correspondence, or to attacks against his/her honour and reputation and they have the right to protect themselves against such unlawful interference (Article 12 of the UDHR and Article 17 of the ICCPR). Certain differences exist between the wording of these provisions: for example, compared to the ICCPR, the UDHR protects only against arbitrary interference and not unlawful interference. Also, regarding honour and reputation, the UDHR gives protection against any kind of attacks, while the ICCPR ensures protection against arbitrary attacks. Source: Mendel, T. et al. (2013) Étude mondiale sur le respect de la vie privée sur l'Internet et la liberté d'expression. Paris: Éditions Unesco (Collection Unesco sur la liberté de l'Internet). p. 59.
} 
must also be mentioned, who is an independent expert appointed by the Human Rights Council, whose task is to examine, report and raise awareness on the right to privacy. ${ }^{228}$

69. Protection in Europe. ${ }^{229}$ In Europe, two regional organisations have to be mentioned, both of them having an elaborate system and regulation: the $\mathrm{CoE}$ and the European Union. It is the Council of Europe's European Court of Human Rights (hereinafter referred to as: ECtHR) and the European Union's European Court of Justice (hereinafter referred to as: CJEU) which created a detailed case law.

\section{(a) ECHR and ECtHR}

70. The centrepiece of the European protection of human rights, ${ }^{230}$ one of the most important documents regulating the right to privacy is the European Convention on Human Rights (Council of Europe, 1950, Article 8), which served as a genesis for several pieces of privacy legislation throughout Europe. ${ }^{231}$ Also, the European Court of Human Rights created very important case law regarding Article 8, characterized by rich legal development. ${ }^{232}$

71. Article 8 of the ECHR: right to respect for private and family life. The ECHR guarantees in Article 8 the right to respect for private and family life through stating that:

"1. Everyone has the right to respect for his private and family life, his home and his correspondence.

2. There shall be no interference by a public authority with the exercise of this right except such as is in accordance with the law and is necessary in a

\footnotetext{
${ }^{228}$ The right to privacy in the digital age (2015). A/HRC/28/L.27. United Nations, General Assembly.

${ }^{229}$ Even though the dissertation focuses mainly on the European legal order, it must be mentioned that it is not only Europe which ensures the right to privacy at a regional level. Article 11 of the American Convention on Human Rights (1969) also guarantees the right to privacy. The bodies responsible for ensuring compliance with the convention are the Inter-American Commission on Human Rights and the Inter-American Court of Human Rights. (Source: Mendel, T. et al. (2013) Étude mondiale sur le respect de la vie privée sur l'Internet et la liberté d'expression. Paris: Éditions Unesco (Collection Unesco sur la liberté de l'Internet). p. 61.) Also, the African Charter on Human and Peoples' Rights (1981) can be mentioned in relation to regional human rights protection, aiming to ensure fundamental civil and political and economic and social rights in the African region. (Source: Velu, R. and Ergec, J. (2014) Convention européenne des droits de l'homme. Bruxelles: Bruylant, pp. 24-25.)

${ }^{230}$ Moderne, F. (2012) La Convention européenne des Droits de l'Homme. 3rd edn. Paris: Dalloz, p. 2.

${ }^{231}$ Rustad, M. L. and Paulsson, S. R. (2005) 'Monitoring Employee E-Mail and Internet Usage: Avoiding the Omniscient Electronic Sweatshop: Insights from Europe', U. Pa. Journal of Labor and Employment Law, 7(4), pp. 870-871.

232 Schabas, W. A. (2015) The European Convention on Human Rights: a Commentary. Oxford: Oxford University Press, p. 366.
} 
democratic society in the interests of national security, public safety or the economic wellbeing of the country, for the prevention of disorder or crime, for the protection of health or morals, or for the protection of the rights and freedoms of others."

Article $8^{233}$ defines four categories receiving protection: in addition to private life it contains family life, home and correspondence - which can be understood as specific aspects of private life. ${ }^{234}$ In relation to the subject of the dissertation, mostly private life and auxiliary correspondence ${ }^{235}$ will have significant importance, amongst which, due to its ambiguous scope, the next paragraphs will focus on private life. ${ }^{236}$

Although the ECHR guarantees the right to respect for private life through determining when an interference cannot be established, it makes it obvious that the right to privacy is not an absolute right. ${ }^{237}$ When the ECtHR examines whether there was a violation of Article 8, it examines two conditions in its decisions: first, whether there was an interference with the right to respect for private life under Paragraph 1 of Article 8 and second, whether the interference was legitimate according to the criteria set in Paragraph $2 . .^{238}$

\footnotetext{
${ }^{233}$ Although it is not only Article 8 that can guarantee the respect of private life: other Articles of the ECHR as well might be of importance in this field. See more in: Guide sur l'article 8 de la Convention européenne des droits de l'homme. Droit au respect de la vie privée et familiale (2019). Conseil de l'Europe. Available at: https://www.echr.coe.int/Documents/Guide_Art_8_FRA.pdf (Accessed: 5 November 2019), pp. 12-19. and Velu, R. and Ergec, J. (2014) Convention européenne des droits de l’homme. Bruxelles: Bruylant, pp. 649-650.

${ }^{234}$ Velu, R. and Ergec, J. (2014) Convention européenne des droits de l'homme. Bruxelles: Bruylant, p. 659.

235 The most important relevant decisions in relation to correspondence will be addressed in Part II. of the dissertation when examining SNS use during working hours. However, it must be emphasized that under correspondence protection is afforded not only to traditional letters, but rather to communication in general, regardless of the form it takes. As such it covers, for example, telephone conversations, telegraphs, electronic and radio electronic means of communication. (Source: Velu, R. and Ergec, J. (2014) Convention européenne des droits de l'homme. Bruxelles: Bruylant, p. 691.) See more on the ECtHR's jurisprudence on communication in: Guide sur l'article 8 de la Convention européenne des droits de l'homme. Droit au respect de la vie privée et familiale (2019). Conseil de l'Europe. Available at: https://www.echr.coe.int/Documents/Guide_Art_8_FRA.pdf (Accessed: 5 November 2019), pp. 91-111; Velu, R. and Ergec, J. (2014) Convention européenne des droits de l’homme. Bruxelles: Bruylant, pp. 687691.

${ }^{236}$ Family life covers matters such as marriage, parenthood, relationship between parents and children, imprisonment of parents, etc. Home covers matters such as peaceful enjoyment of one's home (protection against environmental nuisances), or expulsions, while correspondence covers matters such as telephone interception, traditional and electronic messages. See more on these rights in: Schabas, W. A. (2015) The European Convention on Human Rights: a Commentary. Oxford: Oxford University Press, pp. 388-401.

237 Paragraph 2 of Article 8 of the ECHR; Kéfer, F. and Cornélis, S. (2009) 'L'arrêt "Copland" ou l'espérance légitime du travailleur quant au caractère privé de ses communications', Revue Trimestrielle des Droits de l'Homme, (79), p. 786.

${ }^{238}$ See more on the legitimate interference and Article 8 of the ECHR: Berger, V. (1998) Jurisprudence de la Cour Européenne des Droits de l'Homme. Paris: Éditions Dalloz, pp. 311-406.; Grád, A. and Weller, M.
} 
72. Scope of Article 8: private life. Being a broad notion, private life encompasses numerous aspects, making it difficult, if not impossible, to provide an exhaustive definition. ${ }^{239}$ The ECtHR is on the position that it is not "possible or necessary to attempt an exhaustive definition of the notion of "private life,",240 and argued on several occasions that the concept of private life "is a broad term not susceptible to exhaustive definition," 241 as Article 8 covers very broad areas of life, "encompassing the sphere of personal autonomy within which everyone can freely pursue the development and fulfilment of his or her personality and to establish and develop relationships with other persons and the outside world. "242

73. Also, the technological and scientific developments that appeared after the adoption of the ECHR encouraged the ECtHR to create a flexible interpretation of private life under the current circumstances. ${ }^{243}$ The preamble of the ECHR itself declares that its aim is to guarantee and further develop human rights, ${ }^{244}$ suggesting the constant evolution of the rights guaranteed in the text of the ECHR, ensuring that the ECHR is interpreted in the light of the era. ${ }^{245}$ Societal changes, ${ }^{246}$ and the development of ICT technologies ${ }^{247}$ led to a broad interpretation of private life, responding to the occurring changes, ${ }^{248}$ and

(2011) A strasbourgi emberi jogi bíráskodás kézikönyve. Budapest: HVG-ORAC Lap- és könyvkiadó, pp. 448- 456, pp. 483-526; Pettiti, L.-E., Decaux, E. and Imbert, P.-H. (eds) (1995) La Convention Européenne des Droits de l'Homme, commentaire article par article. Paris: Economica, pp. 323-351.; Guide sur l'article 8 de la Convention européenne des droits de l'homme. Droit au respect de la vie privée et familiale (2019). Conseil de l'Europe. Available at: https://www.echr.coe.int/Documents/Guide_Art_8_FRA.pdf (Accessed: 5 November 2019), pp. 10-12.

${ }^{239}$ Velu, R. and Ergec, J. (2014) Convention européenne des droits de l’homme. Bruxelles: Bruylant, p. 659.; Sudre, F. (2015) La Convention européenne des droits de l'homme. 10th edn. Paris: Presses Universitaires de France, p. 101.

${ }^{240}$ EctHR (1992): Niemietz v. Germany, application no. 13710/88, 16 December, par. 29.

${ }^{241}$ EctHR (2002): Pretty v. the United Kingdom, application no. 2346/02, 29 April, par. 61.; ECtHR (2003): Peck v. the United Kingdom, application no. 44647/98, 28 January, par. 57.; ECtHR (2008): S. and Marper v. the United Kingdom, application nos. 30562/04 and 30566/04, 4 December, par. 66.

${ }^{242}$ ECtHR (2010): Jehovah's witnesses of Moscow and Others v. Russia, application no. 302/02, 10 June, par. 117. See also: ECtHR (2007): Evans v. the United Kingdom, application no. 6339/05, 10 April, par. 71.

${ }^{243}$ Grabarczyk, K. (2011) 'Vie privée et nouvelles technologies', Revue des droits et libertés fondamentaux, (7).

${ }^{244}$ Pettiti, L.-E., Decaux, E. and Imbert, P.-H. (eds) (1995) La Convention Européenne des Droits de l'Homme, commentaire article par article. Paris: Economica, p. 308.

${ }^{245}$ Velu, R. and Ergec, J. (2014) Convention européenne des droits de l'homme. Bruxelles: Bruylant, p. 33. , p. 49.

${ }^{246}$ Sudre, F. (2015) La Convention européenne des droits de l'homme. 10th edn. Paris: Presses Universitaires de France, p. 101.

${ }^{247}$ Moderne, F. (2012) La Convention européenne des Droits de l'Homme. 3rd edn. Paris: Dalloz, p. 29.

248 Guide sur l'article 8 de la Convention européenne des droits de l'homme. Droit au respect de la vie privée et familiale (2019). Conseil de l'Europe. Available at: https://www.echr.coe.int/Documents/Guide_Art_8_FRA.pdf (Accessed: 5 November 2019), p. 20. 
implying that with the constantly changing societal-economic conditions, what falls under the scope of Article 8 also changes.

74. As a result, the ECtHR goes beyond the "traditional" interpretation of private life connected mainly to intimacy/secrecy ${ }^{249}$ and also guarantees the respect of certain public aspects of the individual's private life. ${ }^{250}$ Thus, protection is also afforded to the autonomy of the individual and to the development of personality, which can be manifested in establishing relationships with others, or can even cover professional activities.

In relation to the matters belonging to the scope of private life, ${ }^{251}$ different authors created different categorisations. However, despite the exact appellations of these categories, a common feature is that the "traditional" protection of private life appears alongside with ensuring the protection of matters having a connection with the outside world. From the relevant case law Olivier Rijckaert and Noël Lambert identified three subdivisions of the right to respect for private life from the ECtHR's jurisprudence: the right to intimacy, the right to maintain social relationships and the right to self-determination. ${ }^{252}$ According to Rusen Velu and Jacques Ergec, two elements of private life exist: first, the

${ }^{249}$ Velu, R. and Ergec, J. (2014) Convention européenne des droits de l'homme. Bruxelles: Bruylant, p. 659. This concept is closely connected to a so-called inner circle "in which the individual may live his own personal life as he chooses and to exclude therefrom entirely the outside world not encompassed within that circle". (Source: EctHR (1992): Niemietz v. Germany, application no. 13710/88, 16 December, par. 29.)

${ }^{250}$ Guide sur l'article 8 de la Convention européenne des droits de l'homme. Droit au respect de la vie privée et familiale (2019). Conseil de l'Europe. Available at: https://www.echr.coe.int/Documents/Guide_Art_8_FRA.pdf (Accessed: 5 November 2019), p. 20.

${ }^{251}$ The ECtHR stated in its case law that interference in the following conditions of life fell under the scope of Article 8 (and further examined whether the interference was legitimate or not as it is not an absolute right): access to personal data (ECtHR: Leander v. Sweden, application no. 9248/81, 26 March 1987, par. 46, 48; ECtHR: Gaskin v. the United Kingdom, application no. 10454/83, 7 July 1989, par. 36-37), telephone interception (ECtHR: Klass and Others v. Germany, application no. 5029/71, 6 September 1978, par. 41; ECtHR: Halford v. the United Kingdom, application no. 20605/92 , 25 June 1997, par. 41, 44, 46; ECtHR: Malone v. the United Kingdom, application no. 8691/79, 2 August 1984, par. 64; ECtHR: Huvig v. France, application no. 11105/84, 24 April 1990, par. 25; ECtHR: Kruslin v. France, application no. 11801/85, 24 April 1990, par. 26.), physical and moral integrity (ECtHR: $X$ and $Y$ v. The Netherlands, application no. 8978/80, 26 March 1985, par 22.), protection of image (ECtHR: Reklos and Davourlis v. Greece, application no. 1234/05, 15 April 2009, par. 40.), choice or change of name (ECtHR: Guillot v. France, application no. 22500/93, 24 October 1993, par. 21-22; ECtHR: Burghartz v. Switzerland, application no. 16213/90, 22 February 1994, par. 24.), sexual life (ECtHR: Dudgeon v. the United Kingdom, application no. 7525/76, 22 October 1981, par. 40-41.), profession or domicile (ECtHR: Niemietz v. Germany, application no. 13710/88, 16 December 1992, par. 28-33.), honour and reputation (ECtHR: Chauvy and Others $v$. France, application no. 64915/01, 29 September 2004, par. 70.), protection against environmental nuisances (ECtHR: López Ostra v. Spain, application no.16798/90, 9 December 1994, par. 51.), the right to establish and develop relationships with others (ECtHR: Niemietz v. Germany, application no. 13710/88, 16 December 1992, par. 29.).

${ }^{252}$ Rijckaert, O. and Lambert, N. (2012) Le respect de la vie privée dans la relation de travail. Waterloo: Wolters Kluwer Belgium, pp. 6-7. 
right to respect for private life, which aims to ensure the individual a sphere where third persons do not have access, connected to secrecy; and the second element is related to the relationships that the individual can make with others. Both of these aspects aim to ensure the protection of the personality of the individual. ${ }^{253}$ Frédéric Sudre differentiates between four areas: ${ }^{254}$ the first is the right to privacy ("le droit à la vie privée personnelle"), which is composed of the right to the intimacies of private life and of the right to the liberty of sexual life. The second area is the right to a social private life, covering the establishment of relationships with others, as well as professional activities. The third area is the right to personal developments, which involves areas such as knowing one's origins, or choosing how to end one's life. The fourth area guarantees the right to live in a healthy environment. A study published by the $C o E$ differentiates between three categories: physical, psychological and moral integrity of the individual, private life and identity and autonomy. ${ }^{255}$ Martyn Bond takes a different approach and differentiates between rights requiring certain protection of the individual ("droit d'être à l'abri de") and freedoms ("libertés de"). Amongst the rights, he notes that individuals have the right to be free from attacks against physical and psychological integrity, the right to be free from unwanted information gathering practices and the right to be free from serious environmental nuisances. The two freedoms relate to the right to develop relationship with others and the freedom in choosing one's lifestyle. ${ }^{256}$

75. Personality and autonomy of the individual. Although the ECHR and Article 8 do not contain a right to self-determination as such, ${ }^{257}$ the ECtHR found that it remains an important principle when it comes to interpreting Article 8 - altogether with the

\footnotetext{
${ }^{253}$ Velu, R. and Ergec, J. (2014) Convention européenne des droits de l'homme. Bruxelles: Bruylant, p. 660.

${ }^{254}$ Sudre, F. (2015) La Convention européenne des droits de l'homme. 10th edn. Paris: Presses Universitaires de France, pp. 101-104.

255 Guide sur l'article 8 de la Convention européenne des droits de l'homme. Droit au respect de la vie privée et familiale (2019). Conseil de l'Europe. Available at: https://www.echr.coe.int/Documents/Guide_Art_8_FRA.pdf (Accessed: 5 November 2019), p. 20.

256 Bond, M. (2018) Une introduction à la Convention européenne des droits de l'homme. Strasbourg: Conseil de l'Europe, p. 39.

${ }^{257}$ The Council of Europe's Parliamentary Assembly interpreted the right to privacy as " [...] the right to live one's own life with a minimum of interference." Then, it adds that "[i]t concerns private, family and home life, physical and moral integrity, honour and reputation, avoidance of being placed in a false light, nonrevelation of irrelevant and embarrassing facts, unauthorised publication of private photographs, protection against misuse of private communications, protection from disclosure of information given or received by the individual confidentially." Source: Council of Europe, Parliamentary Assembly: Declaration on mass communication media and Human Rights, Resolution 428 (1970) 23 January 1970, Available at: http://assembly.coe.int/nw/xml/XRef/Xref-XML2HTML-en.asp?fileid=15842\&lang=en Accessed: 2018.02. 28.
} 
concept of quality of life. ${ }^{258}$ Physical and moral integrity is guaranteed through ensuring the development of the personality of the individual without outside interference. ${ }^{259}$ Personal autonomy comprises the right to establish details of the individual's identity as a human being. ${ }^{260}$

76. Albeit the formulation of Article 8 suggests a negative right, the right to be left alone ${ }^{261}$ the interpretation of the ECtHR acknowledges that private life can comprise a zone of interaction between individuals, even in the public context. ${ }^{262}$ Establishing and developing relationships is closely related to the development and fulfilment of one's personality. ${ }^{263}$ Article 8 also protects a right to identity and personal development, and the right to establish and develop relationships with other human beings and the outside world. ${ }^{264}$ Dress and other "public" features - the desired appearance of the individual might also concern private life, as it can constitute a way of expressing one's personality. ${ }^{265}$ Article 8 is not limited to the protection of a mere inner circle rigidly delimiting the individual and the public, outside world; it rather ensures the right to establish and develop relationships with others. ${ }^{266}$ Such observations have high topicality and importance in the age when social media might be considered an important area of self-expression and establishing relationship with others. ${ }^{267}$

77. Employees' right to respect for private life. The ECtHR explicitly addressed the right to privacy in the employment context with regard to employee monitoring in several cases, such as Niemietz v. Germany (1992), ${ }^{268}$ Halford v. United Kingdom (1997), ${ }^{269}$ Copland v. the United Kingdom (2007), ${ }^{270}$ Bărbulescu v. Romania

${ }^{258}$ ECtHR: Pretty v. the United Kingdom, application no. 2346/02, 29 July 2002, par. 61. and par. 65.

259 Schabas, W. A. (2015) The European Convention on Human Rights: a Commentary. Oxford: Oxford University Press, p. 370.

${ }^{260}$ ECtHR: Christine Goodwin v. the United Kingdom, application no. 28957/95, 11 July 2002, par. 90.

${ }^{261}$ Schabas, W. A. (2015) The European Convention on Human Rights: a Commentary. Oxford: Oxford University Press, p. 366.

${ }^{262}$ ECtHR: Von Hannover v. Germany, applications nos. 40660/08 and 60641/08, 7 February 2012, par. 95. Also see more on how Article 8 includes intimacy, social aspects and environmental well-being in: Bugorgue-Larsen, L. (2015) La Convention européenne des droits de l’homme. 2nd edn. Issy-lesMoulineaux: LGDJ. pp.133-142.

${ }^{263}$ Commission of the ECtHR: $X v$ Iceland, application no. 6825/74, 8 May 1976

${ }^{264}$ ECtHR: Peck v. the United Kingdom, application no. 44647/98, 28 January 2003, par. 57.

265 ECtHR: S.A.S. v. France, application no. 43835/11, 1 July 2014, par. 107.

${ }^{266}$ ECtHR: Niemietz v. Germany, Application no. 13710/88, 16 December 1992

${ }^{267}$ To be further addressed in Title 2 how privacy and private life should be understood in the social media age.

${ }^{268}$ ECtHR: Niemietz v. Germany, Application no. 13710/88, 16 December 1992

${ }^{269}$ ECtHR: Halford v. the United Kingdom, Application no. 20605/92, 25 June 1997

${ }^{270}$ ECtHR: Copland v. the United Kingdom, Application no. 62617/00, 3 April 2007 
(2017), ${ }^{271}$ Libert v. France (2018). ${ }^{272}$ These cases, and the analysis of where the boundary of employee privacy lies will be addressed in detail in Chapter 2 focusing on workplace privacy.

(b) EU and the CFREU

78. Charter of Fundamental Rights. The EU's main human's rights document, the CFREU also guarantees in Article 7 the protection of private life. ${ }^{273}$ Article 7 reads as follows:

"Everyone has the right to respect for his or her private and family life, home and communications."

Similarly to other international legal documents, the CFREU identifies the "traditional" interests that must be protected: private life, family life, home and communications. ${ }^{274,} 275$ In the EU as well, the right to respect for private life is not absolute, as Article 52 of the CFREU contains a provision in relation to the possible limitation of the rights recognized by the CFREU, making it possible to limit these rights if certain conditions are met. ${ }^{276,277}$

${ }^{271}$ ECtHR: Bărbulescu v. Romania, Application no. 61496/08, 5 September 2017

${ }^{272}$ ECtHR: Libert v. France, Application no. 588/13, 22 February 2018

${ }^{273}$ However, even prior to the CFREU, the right to privacy was a recognized general principle of the EU law. See, for example: Commission of the European Communities v Federal Republic of Germany (1992) Case C62/90, Court of Justice of the European Union, 8 April, par. 23.; Judgment of the Court of 26 June 1980. National Panasonic (UK) Limited $\mathrm{v}$ Commission of the European Communities. - Competition: investigations by the Commission. - Case 136/79. (Source: Cariat, N. (2017) 'Respect de la vie privée et familiale', in Charte des droits fondamentaux de l'Union européenne. Bruxelles: Bruylant, p. 162.)

${ }^{274}$ Nyman-Metcalf, K. (2014) 'The Future of Universality of Rights', in Kerikmäe, T. (ed.) Protecting Human Rights in the EU. Controversies and Challenges of the Charter of Fundamental Rights. Heidelberg: Springer, p. 28.

${ }^{275}$ Incidentally, other articles can also aim at the protection of private life, such as Article 3 on the right to the integrity of the person, Article 8 on the right to data protection, Article 24 on the rights of the child and Article 37 on environmental protection. Source: Lock, T. (2019) 'Article 7 CFR. Respect for private and family life', in Kellerbauer, M., Klamert, M., and Tomkin, J. (eds) Commentary on the EU Treaties and the Charter of Fundamental Rights. United Kingdom: Oxford University Press, p. 2115.

${ }^{276}$ Article 52 of the CFREU: Scope of guaranteed rights "1. Any limitation on the exercise of the rights and freedoms recognised by this Charter must be provided for by law and respect the essence of those rights and freedoms. Subject to the principle of proportionality, limitations may be made only if they are necessary and genuinely meet objectives of general interest recognised by the Union or the need to protect the rights and freedoms of others."

${ }^{277}$ For example, limitations can take place as regards the use of names, abortions or freezing of assets if given conditions are met. See more in: Lock, T. (2019) 'Article 7 CFR. Respect for private and family life', in Kellerbauer, M., Klamert, M., and Tomkin, J. (eds) Commentary on the EU Treaties and the Charter of Fundamental Rights. United Kingdom: Oxford University Press, pp. 2116-2117. 
79. The CFREU has a close connection with the ECHR, as according to Article 52(3) the rights which also appear in the ECHR have the same meaning and scope in the Charter, too. ${ }^{278}$ However, this implies a minimum requirement: the EU can grant a higher level of protection compared to the ECHR. ${ }^{279}$ Also, the CJEU refers many times intentionally to the practice of the ECtHR, ${ }^{280}$ as the content of privacy can be derived from the case law of the ECtHR. ${ }^{281} \mathrm{Also}$, it is not uncommon for scholars to refer to the case law of the ECtHR when it comes to analysing the case law of the CJEU. ${ }^{282}$

As such, Article 7 of the CFREU corresponds to Article $8 \mathrm{ECHR},{ }^{283}$ as the wording of the CFREU reflects Article 8 of the ECHR, with one difference. The CFREU is deliberately broader in a way that it does not employ the expression "correspondence" but refers to "communications", as it has taken into account the technological changes that occurred. ${ }^{284}$ However, from a substantial point of view it does not make a difference, as the ECtHR interpreted the expression "correspondence" broadly to all communications. ${ }^{285}$

80. For the above reasons, as regards the meaning of "private life" it is identical to the interpretation of the ECtHR, meaning that none of the court interprets "private life"

\footnotetext{
${ }^{278}$ Naturally, the CFREU is not a simple repetition of the ECHR but introduces certain new rights - such as the right to data protection for example. Source: Gaïa, P. (2004) 'La Charte des droits fondamentaux de l'Union européenne', Revue française de droit constitutionnel, (2), p. 234.

${ }^{279}$ Cariat, N. (2017) 'Respect de la vie privée et familiale', in Charte des droits fondamentaux de l'Union européenne. Bruxelles: Bruylant, p. 163.

${ }^{280}$ See, for example: CJEU (2010): PPU. J. McB. v L. E., Case C-400/10, ECLI:EU:C:2010:582, 5 October, par. 53; "The wording of Article 8(1) of the ECHR is identical to that of the said Article 7, except that it uses the expression 'correspondence' instead of 'communications'. That being so, it is clear that the said Article 7 contains rights corresponding to those guaranteed by Article 8(1) of the ECHR. Article 7 of the Charter must therefore be given the same meaning and the same scope as Article 8(1) of the ECHR, as interpreted by the case law of the European Court of Human Rights [...]." CJEU (2008): Productores de Música de España (Promusicae) v Telefónica de España SAU, Case: C-275/06. ECLI:EU:C:2008:54, 29 January, par. 64. stating that "Article 7 substantially reproduces Article 8 of the [ECHR]".

${ }^{281}$ Gellert, R. and Gutwirth, S. (2013) 'The legal construction of privacy and data protection', Computer Law and Security Review, 29(5), p. 524.

${ }^{282}$ See, for example: Lock, T. (2019) 'Article 7 CFR. Respect for private and family life', in Kellerbauer, M., Klamert, M., and Tomkin, J. (eds) Commentary on the EU Treaties and the Charter of Fundamental Rights. United Kingdom: Oxford University Press, pp. 2115-2120.; Eriksson, M. (2006) 'Article 7. Respect for private and family life', in EU Network of Independent Experts on Fundamental Rights, Commentary of the Charter of Fundamental Rights of the European Union, pp. 78-89.; Nyman-Metcalf, K. (2014) 'The Future of Universality of Rights', in Kerikmäe, T. (ed.) Protecting Human Rights in the EU. Controversies and Challenges of the Charter of Fundamental Rights. Heidelberg: Springer, pp. 21-36.

${ }^{283}$ Explanation on Article 7. Explanations relating to the Charter of Fundamental Rights (2007). 2007/C 303/02.

${ }^{284}$ Explanation on Article 7. Explanations relating to the Charter of Fundamental Rights (2007). 2007/C 303/02.

${ }^{285}$ Lock, T. (2019) 'Article 7 CFR. Respect for private and family life', in Kellerbauer, M., Klamert, M., and Tomkin, J. (eds) Commentary on the EU Treaties and the Charter of Fundamental Rights. United Kingdom: Oxford University Press, pp. 2119-2120.
} 
restrictively. ${ }^{286}$ The preamble of the CFREU explicitly states that the strengthening of fundamental rights must take place in the light of the changes in society, social progress and scientific and technological developments, ensuring a dynamic interpretation of the right to respect for private life. ${ }^{287}$ As such the ECtHR can serve as example, ${ }^{288}$ private life covers certain aspects of professional and commercial activities, can relate to the health status of the individual, relationships with others, marital status, physical integrity, reputation, image of the individual, family name, sexual orientation. ${ }^{289}$

\section{(B) National legislations}

81. After addressing how privacy is understood in the most important international organisations, it is necessary to have a look at national legislations. First $(a)$ common characteristics - such as affording constitutional and civil law protection will be addressed, then $(b)$ the specific, unique features of each country will be examined in detail.

\section{(a) Protection of private life in France and in Hungary}

82. Protection of private life. Private life can be assessed as opposing to collective life: traditionally private life was conceived as “[...] the individual's right to dispose a private space, distinct from the collective life of the community." ${ }^{290}$ In France, the Constitutional Council opted for a particular interpretation, adopting a restrictive approach: it links private life to the concept of secrecy - unlike national lower courts and the jurisprudence of the ECtHR. ${ }^{291}$ In this regard, the right to respect for private life is

\footnotetext{
286 Kokott, J. and Sobotta, C. (2013) 'The distinction between privacy and data protection in the jurisprudence of the CJEU and the ECtHR', International Data Privacy Law, 3(4), p. 223.

By contrast, Christophe Vigneau notes that it is not precluded that certain public spheres of private life are excluded from the protection of private life. Vigneau, C. (2006) 'Protection of personal data (Article 8)', in Bercusson, B. (ed.) European Labour Law and the EU Charter of Fundamental Rights. Baden-Baden: Nomos, p. 120.

${ }^{287}$ Lock, T. (2019) 'Article 7 CFR. Respect for private and family life', in Kellerbauer, M., Klamert, M., and Tomkin, J. (eds) Commentary on the EU Treaties and the Charter of Fundamental Rights. United Kingdom: Oxford University Press, 2115.

288 Eriksson, M. (2006) 'Article 7. Respect for private and family life', in EU Network of Independent Experts on Fundamental Rights, Commentary of the Charter of Fundamental Rights of the European Union, p. 78 .

${ }^{289}$ Cariat, N. (2017) 'Respect de la vie privée et familiale', in Charte des droits fondamentaux de l'Union européenne. Bruxelles: Bruylant, pp. 165-168.

${ }^{290}$ Détraigne, Y. and Escoffier, A.-M. (2009) La vie privée à l'heure des mémoires numériques. Pour une confiance renforcée entre citoyens et société de l'information. Rapport d'information 441. Sénat. p. 11. However, as it will be discussed in Title 2, SNSs considerably challenge the boundaries of private and public life, posing new challenges in defining the limits of private life.

${ }^{291}$ Source: Mazeaud, V. (2015) 'La constitutionnalisation du droit au respect de la vie privée', Les Nouveaux Cahiers du Conseil constitutionnel, (48), pp. 16-17.
} 
understood as protection against public or private intrusions into the intimate sphere of the individual, ${ }^{292,} 293$ but it does not include the freedom of private life. ${ }^{294}$ Vincent Mazeaud points it out that the Constitutional Council's practice was initially centred around the concept of secrecy and mainly focuses on aspects such as domicile, correspondence or intimacies of private life, aspects where the concept of secrecy dominates. ${ }^{295}$ In its jurisprudence, the Constitutional Council examined matters in relation to intrusion and divulgation, such as intrusion into the home, search of vehicles, camera surveillance, GPS localisation, data protection or intercepting communication. ${ }^{296}$

83. However, despite the prevailing concept of secrecy in the jurisprudence of the Constitutional Council, when examining the doctrine, several authors differentiate between two layers or "spheres" when it comes to private life: a hard core, ${ }^{297}$ closely connected to the concept of secrecy and another layer, moving beyond the narrow concept of secrecy. Vanessa Barbé distinguished between personal private life and social private life. ${ }^{298}$ Xavier Bioy interpreted the hard core as "to be let alone", which refers to matters such as correspondence, inviolability of the home - and also data protection. To this hard core, the right to autonomy of private life is added, comprising fields such as the freedom to choose an occupation, identity or relations. ${ }^{299}$ Florence Crouzatier-Durand enumerated elements pertaining to the protection of private life and to the expression of private life. ${ }^{300}$ For Laurence Burgorgue-Larsen, the hard core is associated with intimacy and secret,

${ }^{292}$ Commentaire: Conseil constitutionnel: décision n 2012-248 QPC du 16 mai 2012

293 According to Hubert Alcatraz, the right's original aim is to ensure a "bubble of secrecy around the individual". Cited in: Favoreu, L. et al. (2015) Droit des libertés fondamentales. 7th edn. Paris: Dalloz. p. 273.

${ }^{294}$ Favoreu, L. et al. (2015) Droit des libertés fondamentales. 7th edn. Paris: Dalloz, pp. 273-275.

${ }^{295}$ Mazeaud, V. (2015) 'La constitutionnalisation du droit au respect de la vie privée', Les Nouveaux Cahiers du Conseil constitutionnel, (48), p. 8.

${ }^{296}$ Mazeaud, V. (2015) 'La constitutionnalisation du droit au respect de la vie privée', Les Nouveaux Cahiers du Conseil constitutionnel, (48), p. 9.; Favoreu, L. et al. (2015) Droit des libertés fondamentales. 7th edn. Paris: Dalloz, p. 277.

${ }^{297}$ When assessing what constitutes the hard core of respect for private life, the Code on Internal Security and the Penal Code could serve as useful reference. Articles 226-1-226-7 of the Penal Code provide protection against different invasions of privacy, such as against the home, against image or words uttered, against identity theft, while Subsection 1 of Article L801-1 of the Code on Internal Security stipulates that "[t]he respect of private life and all of its components, notably the secrecy of correspondence, the protection of personal data and the inviolability of the home are guaranteed by law." Source: Bioy, X. (2016) Droits fondamentaux et libertés publiques. 4e édition. Issy-les-Moulineaux: LGDJ-Lextenso éditions (Collection Cours), pp. 496-497.

${ }^{298}$ Barbé, V. (2018) Essentiel du Droit des libertés fondamentales. Issy-les-Moulineaux: Gualino, pp. 112121.

299 Bioy, X. (2016) Droits fondamentaux et libertés publiques. 4e édition. Issy-les-Moulineaux: LGDJLextenso éditions (Collection Cours). pp. 496-497

300 Crouzatier-Durand, F. (2013) Fiches de libertés publiques et droits fondamentaux. 2nd edn. Paris: Ellipses. pp. 58-72. 
encompassing protection against intrusions and divulgations. It is completed by recognizing personality - not the right to personality - by attaching the right to respect for private life to the legal fundaments of personal liberty. ${ }^{301,302}$

84. Assessments of the Hungarian Constitutional Court. The Constitutional Court clarified the content of the right to privacy in several decisions, among which the most important ones will be addressed. ${ }^{303}$ In decision No. 8/1990 (IV. 23.), the Constitutional Court linked the right to privacy to the right to human dignity ${ }^{304}$ and considered the latter to be the formulation of the general right to personality and then identified the right to privacy as one aspect of it. ${ }^{305}$ In decision No. 56/1994 (XI. 10.), the Constitutional Court identified the "right to the freedom of privacy" ("magánélet szabadságához való jog") as a fundamental right aiming to ensure the protection of the autonomy of the individual, originating from the inherent human dignity. ${ }^{306}$ In a decision relating to secret collection of information, ${ }^{307}$ the Constitutional Court extended the scope of protection ensured by the right to privacy to the intimate/private sphere, to communication, to the home and to the right to reputation. ${ }^{308,309}$

\footnotetext{
301 Burgorgue-Larson, L. (2005) 'L'appréhension constitutionnelle de la vie privée en Europe: Analyse croisée des systèmes constitutionnels allemand, espagnol et français.', in Sudre, F. (ed.) Le droit à la vie privée au sens de la Convention européenne des droits de l'homme. Bruxelles: Bruylant, p. 72.

302 See more on the constitutional aspects on the right to privacy in: Mazeaud, V. (2015) 'La constitutionnalisation du droit au respect de la vie privée', Les Nouveaux Cahiers du Conseil constitutionnel, (48), pp. 7-20.; Ba Sene, F. (2015) 'La protection constitutionnelle de la vie privée et familiale sur les réseaux sociaux en France', in Ndior, V. (ed.) Droit et réseaux sociaux. Issy-les-Moulineaux: Lextenso (Collection LEJEP), pp. 91-100.; Burgorgue-Larson, L. (2005) 'L'appréhension constitutionnelle de la vie privée en Europe : Analyse croisée des systèmes constitutionnels allemand, espagnol et français.', in Sudre, F. (ed.) Le droit à la vie privée au sens de la Convention européenne des droits de l'homme. Bruxelles: Bruylant, pp. 69-115.

${ }^{303}$ See more on the relevant decisions of the Constitutional Courts in: Majtényi, L. (2002) 'Az információs szabadságok és az adatvédelem határai', Világosság, XLIII (2-3), pp.72-78.; Szüts, K., Karsai, D. and Mándi, G. (2006) Az Alkotmánybíróság egyes határozatainak ismertetése. Budapest: Rejtjel Kiadó. pp. 222229.

${ }^{304}$ Sári, J. and Somody, B. (2008) Alapjogok. Budapest: Osiris Kiadó, p. 127.

305 Lábady, T. (1995) 'A magánélet alkotmányos védelme (A házasság és a család védelme, a magánszférához való jog)’, Acta Humana: Emberi jogi közlemények, (18-19), p. 85.; Majtényi, L. (2008) ‘Az információs jogok', in Halmai, G. and Tóth, G. A. (eds) Emberi jogok. Budapest: Osiris Kiadó, p. 277.

306 Decision No. 56/1994 (XI. 10.) Part II.; Fézer, T. (2014) 'Harmadik rész: személyiségi jogok', in Osztovits, A. (ed.) A Polgári Törvénykönyvröl szóló 2013. évi V. törvény és a kapcsolódó jogszabályok nagykommentárja. I. kötet. Budapest: Opten Informatikai Kft., p. 263.

${ }^{307}$ Decision No. 32/2013. (XI. 22.) of the Constitutional Court

${ }^{308}$ Decision No. 32/2013. (XI. 22.) of the Constitutional Court, par. 84.

309 However, Béla Pokol expressed his parallel reasoning regarding this reasoning and found that the Constitutional Court overstepped its competence and created a general right to privacy from the separate rights declared in the Fundamental Law. Par. 143. of Decision No. 32/2013. (XI. 22.) of the Constitutional Court
} 
85. In relation to camera surveillance, ${ }^{310}$ László Kiss and István Kukorelli expressed in a dissenting opinion their view regarding surveillance as the exercise of informational power, drawing attention to the negative consequences of such a monitoring and its adverse effects on individuals' behaviour. Although the decision relates to CCTV monitoring and dates back to 2002, one paragraph already referred to how this monitoring affects and changes the boundaries of private life $\mathrm{e}^{311}$ - gaining particular importance in the social media era. In another decision relating to camera surveillance, the Constitutional Court stated that "the core element of privacy is that no intrusion or insight into the private sphere of the individual shall be conducted against his or her will". In the case of an unwanted intrusion not only the right to privacy is infringed but also other aspects of the right to dignity (e.g. self-determination or physical and personal integrity of the person). ${ }^{312}$

86. The French Civil Code. Traditionally, civil law aims to provide protection to this already mentioned "hard core", governed by the concept of secrecy. ${ }^{313}$ Article 9 of the French Civil Code regulates the right to respect for private life. ${ }^{314}$ Although in paragraph 1 the expression right to respect for private life is used, paragraph 2 uses a confusing expression and refers to "the infringement of the intimate character of private life." Historically, France has a narrow conception of privacy, based on the concept of secret (the right to the secrecy of private life) - and treated questions such as family, sex, identity and self-determination separately from privacy. ${ }^{315}$ Jean Carbonnier understood it

\footnotetext{
${ }^{310}$ Decision No. 35/2002. (VII. 19.) of the Constitutional Court

311 "By the end of the 20th century, this form of control has become widespread in both the public sector and the business sector. The almost constant surveillance redefines the boundaries of private life. It becomes traceable how and with whom we spend our free time; with whom, when and about what we are talking; what kind of newspapers we read or what other habits we have. The risk relating to the misuse of technical achievements does not appear as a threat only on the part of the state, the private sector also uses camera surveillance as a means of increasing efficiency."

${ }^{312}$ Decision No. 36/2005. (X. 5.) of the Constitutional Court

313 Burgorgue-Larson, L. (2005) 'L'appréhension constitutionnelle de la vie privée en Europe: Analyse croisée des systèmes constitutionnels allemand, espagnol et français.', in Sudre, F. (ed.) Le droit à la vie privée au sens de la Convention européenne des droits de l'homme. Bruxelles: Bruylant, p. 72.

${ }^{314}$ Article 9: "Everyone has the right to respect for his or her private life.

Without prejudice to the right to recover indemnification for injury suffered, judges may prescribe any measures, such as sequestration, seizure and others, suited to the prevention or the ending of an infringement of the intimate character of private life; in case of emergency those measures may be provided for by summary proceedings."

315 Bioy, X. (2016) Droits fondamentaux et libertés publiques. 4e édition. Issy-les-Moulineaux: LGDJLextenso éditions (Collection Cours). p. 493.
} 
as a secret sphere of life from which the individual can exclude third persons, where he/she could be left alone. ${ }^{316}$

Elements of private life. The elements of private life cannot be exhaustively defined, "every arbitrary interference in one's private life is unlawful". 317 The right to respect for private life ${ }^{318}$ is not an absolute right: it has to be balanced against other rights. ${ }^{319}$ Also, although "every person, regardless of their rank, wealth, current or future functions, has the right to respect for his/her private life", 320 the limits of that protection can vary according to the status of the given person. ${ }^{321}$ Private life can cover elements such as domicile, correspondence, the body, image, health, personal convictions, family life, marital life, sexual life, identity (name, sex, origins). ${ }^{322}$ Although recently a broader definition was provided by Jean-Christophe Saint-Pau (according to whom the right to respect for private life can be defined as the individual's right to demand the State and other individuals to respect his/her freedom to act and as the secrecy of personal information), ${ }^{323}$ traditionally the Civil Code's right to respect for private life was centred around the concept of secrecy - and originally, the Social Chamber of the Court of Cassation took over the secrecy concept of private life. ${ }^{324}$

87. Hungarian Civil Code. The Hungarian Civil Code affords protection to the right to respect for private life (and to the right to data protection) on the ground of

\footnotetext{
316 Carbonnier, J. (1971) Droit civil. 1, Introduction. Les Personnes. 9th edn. Paris: Presses universitaires de France. p. 254.

${ }^{317}$ Cour de cassation, chambre civile 1, 6 mars 1996, N 94-11273

${ }^{318}$ Here again, various terminologies are used: secrecy of private life, freedom of private life, respect for private life (incorporating the former two notions). Kayser, P. (1995) La protection de la vie privée par le droit: protection du secret de la vie privée. 3rd edn. Aix-en-Provence; Paris: Presses universitaires d'AixMarseille; Economica. p. 17.

319 Alleaume, C. (2016) 'La notion de droit à la vie privée', in Batteur, A. (ed.) Les grandes décisions du droit des personnes et de la famille. 2nd edn. Issy-les-Moulineaux: LGDJ, p. 454.

${ }^{320}$ Cour de cassation, chambre civile 1, 23 octobre 1990, N $89-13163$

${ }^{321}$ On the duality of the right to respect for private life - conceived as secrecy and as liberty - in labour law see: Morgenroth, T. (2016) La vie privée en droit du travail. Doctoral dissertation. Université Lille 2 - Droit et Santé. See also on the right to respect for private life in employment in: Jacquelet, C. (2008) La vie privée du salarié à l'épreuve des relations de travail. Aix-en-Provence: Presses universitaires d'Aix-Marseille.

${ }^{322}$ See more on the content and regulation of (the right to respect for) private life: Alleaume, C. (2016) 'La notion de droit à la vie privée', in Batteur, A. (ed.) Les grandes décisions du droit des personnes et de la famille. 2nd edn. Issy-les-Moulineaux: LGDJ, pp. 453-464.; Terré, F. and Fenouillet, D. (2012) Droit civil : les personnes. Personnalité, incapacité, protection. 8th edn. Paris: Dalloz. pp. 114-136.; Saint-Pau, J.-C. (2013) 'Le droit au respect de la vie privée', in Saint-Pau, J.-C. (ed.) Droits de la personnalité. Paris: LexisNexis SA (Traités), pp. 673-943. On the notion of private life defined by courts in: Lepage, A. (2009) 'Droits de la personnalité', Répertoire de droit civil. Dalloz. par. 67-95.

${ }^{323}$ Saint-Pau, J.-C. (2016) 'Art. 9 - Fasc. 10 : Jouissance des droits civils. - Droit au respect de la vie privée. - Définition conceptuelle du droit subjectif’, JurisClasseur Civil Code. par. 26.

${ }^{324}$ Savatier, J. (1992) 'La protection de la vie privée des salariés’, Droit social, (4), p. 330.
} 
personality rights. It is the primary objective of personality rights to ensure protection to rights which make humans human, which are parts of human personality, without examining the societal circumstances - excluding from their scope political, cultural and social rights. ${ }^{325}$ The essence of personality rights is to ensure the free expression of the personality and to prevent anyone from hindering, within the limits that the community imposes. ${ }^{326}$ Naturally, the exercise of these rights is not without limits, it is in accordance with their social purpose only if it does not infringe other individuals' rights or laws guaranteeing these rights. ${ }^{327}$

The Civil Code states in general the protection of personality rights by declaring that "[e]veryone is entitled to freely practice his or her personality rights, in particular the right to privacy and family life, home and communications with others in any way or form, and the right to protection against defamation of character, within the framework of the law and within the rights of others, and to not be impeded by others in exercising such rights. "328 The Civil Code identifies a list of infringements of personality rights, although the legal protection is extended also to the personality rights not identified in the Civil Code. Among the specified infringements of personality rights, the infringement of private life and of the right to data protection is mentioned. ${ }^{329}$

88. The right to respect for private life is one of the most private components and one of the manifestations of the single and indivisible personality. ${ }^{330}$ According to Hungarian jurisprudence, interference in the private life of the individual infringes personality rights if it is arbitrary, unjustified and unnecessary. An interference is considered to be arbitrary if it expressly contradicts the will and intention of the person concerned or he/she is not aware of it and if it is not justified based on the carefully

\footnotetext{
325 Fézer, T. (2014) 'Harmadik rész: személyiségi jogok', in Osztovits, A. (ed.) A Polgári Törvénykönyvröl szóló 2013. évi V. törvény és a kapcsolódó jogszabályok nagykommentárja. I. kötet. Budapest: Opten Informatikai Kft. p. 250.

326 Petrik, F. (2014) 'Személyiségi jogok', in Wellmann, G. (ed.) Polgári jog: Bevezetö és záró rendelkezések. Az ember mint jogalany. Öröklési jog. 2nd edn. Budapest: HVG-ORAC Lap- és Könyvkiadó, pp. 173-174.

${ }^{327}$ BH. 1992.387.

${ }^{328}$ Subsection (1) of Section 2:42 of the Hungarian Civil Code

${ }^{329}$ Items b) and e) of Section 2:43 of the Hungarian Civil Code

330 Görög, M. (2016) 'A magánélethez való jog mint a személyiségi jog újabb, magánjogi kódexben nevesített vonatkozása', in Balogh, E. (ed.) Számadás az Alaptörvényröl: tanulmányok a Szegedi Tudományegyetem Állam- és Jogtudományi Kar oktatóinak tollából. Budapest: Magyar Közlöny Lap- és Könyvkiadó, p. 61
} 
assessed circumstances. ${ }^{331}$ In another decision, the High Court of Budapest ("Fővárosi Ítélötábla") interpreted the right to privacy as the individual's right to decide about his/her faith, actions, body and information relating to him/her. ${ }^{332}$ The individual shall be able to decide whether to show himself/herself to the world or whether to hide from it. ${ }^{333}$ By this, the High Court basically identified this right with the right to informational selfdetermination. ${ }^{334}$

\section{(b) Specificities of national legislations}

89. In addition to this general apprehension of the right to privacy, both France and Hungary have unique assets to address the question of privacy protection. This uniqueness is especially present in French law, where in the employment context the notion of personal life has substituted the notion of private life since $1997 .^{335}$

This solution is specific to France, in Hungarian labour law there is no distinction between the concepts of private life or personal life. The Hungarian language does not even have expressions to differentiate between these two concepts. Usually, the expression private life ("magánélet") is used when referring to the protection of the individuals' rights (right to respect for private life, act on the protection of private life). Mainly in the common language the expression personal sphere ("privát szféra") is used to refer to the secret aspects, to the intimacies of a person. The expression private sector (which in Hungarian can also be translated as "magánszféra", literally meaning private sphere) is used to describe employment relations as opposed to the public sector.

90. In Hungary, the adoption of the Act on the protection of private life ${ }^{336}$ can be mentioned as a "national specificity". Since the adoption of this act, the protection of

331 LB Pfv. IV. 21 028/2000. - BH2001/61. See more on this case and the privacy and data protection questions it raised in: Szoboszlai, J. (2002) 'A magánélet és a személyes adatok védelme a Dávodi ítéletek apropóján', Fundamentum, 6(2), pp. 76-82.

${ }^{332}$ Fővárosi Ítélőtábla 2.Pf.20.429/2010/3

${ }^{333}$ Fézer, T. (2014) 'Harmadik rész: személyiségi jogok', in Osztovits, A. (ed.) A Polgári Törvénykönyvröl szóló 2013. évi V. törvény és a kapcsolódó jogszabályok nagykommentárja. I. kötet. Budapest: Opten Informatikai Kft., p. 264.

334 Sulyok, M. (2017) Magánszféravédelem a tisztességes eljárásban - Az alapjogsértő bizonyítás összehasonlító alkotmányjogi vizsgálata. Doctoral dissertation. Szegedi Tudományegyetem. p. 224.

${ }^{335}$ Waquet, P. (2002) 'Retour sur l'arrêt Nikon', Semaine sociale Lamy, (1065), p. 6.

${ }^{336}$ Act LIII of 2018 on the protection of private life 
private life is not only ensured by the Fundamental Law and the Civil Code but also constitutes the subject of a separate act, hitherto inexistent. ${ }^{337}$

\section{(a) The concept of personal life in French labour law}

91. Protection of employees' rights. Even though the right to respect for private life has been guaranteed in the French legal system since 1970, during the decades courts had to establish the boundaries of exercising employees' rights in opposition to the employer's legitimate interests and powers, as employees' rights can only be exercised in consistently with these powers and with the legitimate interests of the undertaking. Balance should be found between these two sides, closely connected to the concepts of professional life and the personal life of the employee. ${ }^{338}$

92. The complete separation of professional and private spheres is not possible: private life flows into professional life and vice versa. By concluding an employment contract, the employee partially resigns his/her liberties - but keeps an inalienable part of them, an inherent condition of being a human. ${ }^{339}$ Also, following from the rights and obligations of the parties of the employment relationship, as the employer must respect employees' rights within the workplace, the employee must also accept certain limitations while acting outside of the workplace. ${ }^{340}$

93. Attempts to separate these two spheres have come a long way. ${ }^{341}$ Traditionally, the first distinction was made between professional life and extraprofessional life ("vie extraprofessionnelle"), ${ }^{342}$ making a distinction between the acts of the employee in the workplace and outside of it. Then the concept of extra-professional life

\footnotetext{
337 Though in French law private life is not regulated by a specific act, the adoption of the Act for a Digital Republic in 2016 should be mentioned, which contains a chapter entitled "protection of private life online". However, as the act mainly focuses on data protection and information society, its relevant provisions will be further addressed in Section 2.

${ }^{338}$ Pizzio-Delaporte, C. (2001) 'Libertés fondamentales et droits du salarié le rôle du juge', Droit Social, (4), p. 404.

339 Rivero, J. (1982) 'Les libertés publiques dans l'entreprise', Droit social, (5), p. 422.

${ }^{340}$ Adam, P. (2013) 'Vie personnelle/vie professionnelle : une distinction en voie de dissolution ?', Le Droit Ouvrier, (780), p. 436.

341 The first case regarding the opposition between personal life and professional life can be traced back to 1955, when a worker was dismissed due to statements he made in his private space. The Court of Cassation declared that the dismissal violated the worker's freedom of opinion, as with his acts he did not exceeded the limits of his individual powers. Source: Bello, A. (2012) 'Le licenciement pour motif tiré de Facebook: un changement ... dans la continuité', JCP S (édition sociale), (26) p. 13.

342 This expression was first used by Michel Despax in 1963 in his article entitled "La vie extraprofessionnelle du salarié et son incidence sur le contrat de travail” [Juris-Classeur Périodique. La Semaine Juridique. éd. G., (1776)].
} 
was replaced by the respect for private life ("vie privée"), to finally settle with the concept personal life ("vie personnelle").

94. From extra-professional life to private life. Although the concepts of both extra-professional life and private life have their own merits, in themselves they were not suitable to ensure the protection required. ${ }^{343}$ The notion of extra-professional life covered the acts of employees conducted outside the workplace, opposing to professional life, conducted within the workplace; in principle firmly separating the extra-professional and the professional life of the employee. ${ }^{344}$ As it was contested, this notion did not take into consideration that within the workplace, too, employees have their rights to a certain degree. $^{345}$

95. Then, the notion of extra-professional life was replaced by the notion of private life. On the $20^{\text {th }}$ November 1991, the Court of Cassation confirmed the first time the principle that "an employee cannot be dismissed for a reason originating from his/her private life". ${ }^{346}$ In 1992 this principle was reinforced, and was completed with a direct reference to Article 9 of the Civil Code. ${ }^{347}$ Although private life can cover acts taken within the workplace, it did not protect the extra-professional life as such, instead was primarily centred on the concept of secret, covering only the intimacies of the person. Therefore, it did not cover acts relating to the public life of the employee, such as participating in a political reunion, practicing religion, etc. ${ }^{348}$

96. Adopting the notion of personal life. For these reasons, adopting the notion of personal life was a logical and welcomed step. ${ }^{349}$ The notion of personal life therefore became the terminology used - specific to labour law ${ }^{350}$ - to describe the spheres of the

\footnotetext{
343 Waquet, P., Struillou, Y. and Pécaut-Rivolier, L. (2014) Pouvoirs du chef d'entreprise et libertés du salarié: du salarié-citoyen au citoyen-salarié. Rueil-Malmaison: ÉdLiaisons (Droit vivant). p. 183.

344 Despax, M. (1963) 'La vie extra-professionnelle du salarié et son incidence sur le contrat de travail', Juris-Classeur Périodique. La Semaine Juridique. éd. G., (1776). par. 2.

345 Waquet, P., Struillou, Y. and Pécaut-Rivolier, L. (2014) Pouvoirs du chef d'entreprise et libertés du salarié: du salarié-citoyen au citoyen-salarié. Rueil-Malmaison: ÉdLiaisons, p. 183.

${ }^{346}$ Cour de cassation, chambre sociale, 20 novembre $1991, \mathrm{~N}^{\circ} 89-4460$

${ }^{347}$ Cour de cassation, chambre sociale, 22 janvier 1992, N ${ }^{\circ} 90-42517$

${ }^{348}$ Waquet, P. (2003) L'entreprise et les libertés du salarié. Paris: Editions Liaisons, pp. 116-117.

${ }^{349}$ Pizzio-Delaporte, C. (2001) 'Libertés fondamentales et droits du salarié le rôle du juge', Droit Social, (4), p. 406.

${ }^{350}$ Indeed, private life is a civil law concept - alien in labour law, while personal life and professional life are concepts unknown to civil law. Molfessis, N. (2004) 'Vie professionnelle, vie personnelle et responsabilité des commettants du fait de leurs préposés', Droit social, (1), p. 31.
} 
employee's life that are not subject to the subordination. ${ }^{351}$ This notion of personal life was elaborated by Philippe Waquet ${ }^{352}$ and was later adopted by the Court of Cassation. In 1997 the Court of Cassation noted that "the acts of the employee pertaining to his/her personal life cannot constitute a reason for dismissal", ${ }^{353}$ referring to personal life for the first time. Soon, it reinforced this principle in another decision stating that an element pertaining to the personal life of the employee cannot constitute a fault ("faute"). ${ }^{354,355}$

97. Personal life encompasses not only the private life, but also the public life of the employee, and not only outside the workplace, but also within the workplace, during working hours. Personal life is composed of private life (e.g. home, secrets, correspondence), the exercise of civil rights (e.g. marriage, divorce, properties) and the exercise of civil liberties (e.g. political life, participating in associations). ${ }^{356}$

98. Private life is located at the core of personal life: it encompasses the "secret" part of the employee's life - in accordance with the traditional conception of private life - such as sentimental relations, correspondence or domicile. ${ }^{357}$ But the concept of personal life does not stop here: it aims to provide protection to the "irreducible core of autonomy $" 358$ of the employee. Acknowledging the impossibility to define the exact scope of the elements pertaining to personal life, Waquet notes that physical appearance, free time activities, consumer activity, militant and sport activity, religious activities all make part of personal life. ${ }^{359}$ These activities are not secret at all: they all take place in the light of the public, constituting the public life of the employee.

\footnotetext{
${ }^{351}$ Waquet, P. (2001) 'La vie personnelle du salarié', in Droit syndical et droits de l'homme à l'aube du XXIe siècle : mélanges en l'honneur de Jean-Maurice Verdier. Paris: Dalloz, p. 513.

352 Waquet, P. (1994) 'Vie professionnelle et vie personnelle du salarié', Cahier Sociaux du Barreau de Paris, (64), p. 289.

${ }^{353}$ Cour de cassation, chambre sociale, 14 mai $1997, \mathrm{~N}^{\circ} 94-45473$

${ }^{354}$ Cour de cassation, chambre sociale, 16 décembre 1997, $\mathrm{N}^{\circ} 95-41326$

${ }^{355}$ However, as Agathe Lepage pointed out, the Court of Cassation was not always consistent with the use of the expressions of personal life and private life: that the latter was still used after the general acceptation of the expression personal life. Lepage, A. (2006) 'La vie privée du salarié, une notion civiliste en droit du travail', Droit social, (4), p. 373-374. See especially: "[A]n element pertaining to the private life cannot constitute a reason for dismissal[.]" (Cour de cassation, chambre sociale, 9 juillet 2002, $\mathrm{N}^{\circ}$ 00-45068); "[A] dismissal cannot take place based on a reason founded on the private life of the employee[.]" (Cour de cassation, chambre sociale, 30 novembre 2005, $\mathrm{N}^{\circ} 04-41206$ )

356 Waquet, P. (1994) 'Vie professionnelle et vie personnelle du salarié', Cahier Sociaux du Barreau de Paris, (64), p. 290.

${ }^{357}$ Waquet, P. (2003) L'entreprise et les libertés du salarié. Paris: Editions Liaisons, p. 122.

358 Waquet, P. (2004) 'La vie personnelle du salarié', Droit social, (1), p. 25.

359 Waquet, P. (2003) L'entreprise et les libertés du salarié. Paris: Editions Liaisons, pp. 123-124.
} 
99. The primary principle of the concept of personal life (private life and public life) is to ensure that in his/her extra-professional life (beyond working hours), the employee is free to act as he/she wishes. However, personal life is also present in the professional life of the employee: at the workplace, during working hours. The Court of Cassation explicitly stated in its famous Nikon decision that " [...] the employee is entitled, even at the time and place of work, to respect for his/her private life [...] "360 In principle, activities not having a secret character are also protected under the scope of personal life even within the workplace: e.g. talking with colleagues, choices relating to physical appearance, etc.

100. The significance of the elaboration of the notion of personal life is that through its application the Social Chamber has broken with the civil law - secrecy based concept of privacy. Instead, personal life incorporates not only private life, but also the public private lives of employees. In this regard this notion is similar to the ECtHR's interpretation of privacy. As a result, when it comes to the protection of employees' rights, a forward-thinking notion is applied.

101. Despite the recognition of protecting employees' personal life, it does not guarantee its inviolability without barriers: even in his/her personal life, the employee is bound by certain obligations (e.g. obligation of loyalty): both in his/her professional life and extra-professional life. As it was already stated, in such cases a balance must be found between the employer's legitimate economic interests and the employees' rights. Establishing the balance with regard to SNSs will constitute the main subject of Part II. of the dissertation.

\section{( $\beta$ ) Hungarian Act on the Protection of Private Life}

102. Aim and provisions of the act. In order to ensure the effective protection of private life in the light of the seventh amendment of the Fundamental Law, the Hungarian Parliament adopted Act LIII of 2018 on the Protection of Private Life (hereinafter referred

\footnotetext{
${ }^{360}$ Though this judgement employs the expression private life and not personal life. The Nikon case aimed to protect employees' correspondence within the workplace, by stating that the right to respect for private life "[...] implies the secrecy of correspondence." On the same day, in the Abram case (Cour de cassation, chambre sociale, 2 octobre 2001, $\mathrm{N}^{\circ}$ 99-42727), the Court of Cassation also addressed the question of another inherent part of private life by limiting the expansion of professional life into the employee's home ("the employee is not obliged either to accept to work from home, or to install there folders and work equipment”).
} 
to as: Privacy Act). ${ }^{361}$ The Privacy Act lays down aims pervading the entire legal system in order to ensure a more comprehensive protection of private life and refers to the essential elements of this right, laid down in different acts, ${ }^{362}$ such as the Civil Code, Penal Code and Data Protection Act. ${ }^{363}$ In addition, the Privacy Act guarantees that the fundamental rules regulating the protection of private life shall only be stated in acts, and the laws governing the right to privacy shall be interpreted in accordance with the Fundamental Law and with the Privacy Act itself. ${ }^{364}$

103. According to the Privacy Act, the right to private life is part of the right to the free development of personality and means that the individual has the freedom to responsibly and independently shape his/her life and to create and preserve human relationships. ${ }^{365}$ It is the essence of the right to private life that - with the exceptions specified in a separate Act - against the will of the individual others cannot breach it. ${ }^{366}$

104. The aim of the right to respect for private life is to protect especially the right to bear a name, personal data, private secrets, image and voice recordings, honour and good reputation. ${ }^{367}$ Its infringement can occur especially through the abuse of personal data, secret, image and voice recording intended to be protected by the individual in relation to his/her private life and through the infringement of honour and good reputation. ${ }^{368}$

105. Novelties brought by the act. Relating to the subject of the dissertation, the act contains one considerable novelty. The preamble of the Privacy Act acknowledges that the tools of ICT changed the way of communication, and that the protection of private life is extended to physical and to online harassment as well. Although it relates to harassment, after the preamble it states that the individual's dignity and right to respect for private life shall be ensured in social media as well. For this reason, the legislator's intention guarantees the security of the private sphere regarding content shared and published for private purposes. Subsection (3) of Article 8 of the Privacy Act stipulates that personal

\footnotetext{
3612018 . évi LIII. törvény indokolása a magánélet védelméről

362 2018. évi LIII. törvény indokolása a magánélet védelméről

363 Section 6 of the Privacy Act

364 2018. évi LIII. törvény indokolása a magánélet védelméről

365 Subsection (1) of Section 2 of the Privacy Act

366 Subsection (3) of Section 2 of the Privacy Act

367 Subsection (1) of Section 8 of the Privacy Act

${ }^{368}$ Subsection (2) of Section 8 of the Privacy Act
} 
data provided on the Internet for exclusively private purposes can be processed based on the unambiguous consent of the data subject, except for the cases of mandatory processing.

The general reasoning of the Privacy Act gives no guidance regarding the exact meaning of these provisions: it only declares that in addition to the traditional forms of harassment, protection against every form of online harassment should be guaranteed. ${ }^{369}$ In the reasoning relating to Article 8 , it is stated that the general principle according to which it is the essence of the right to respect for private life - unless otherwise prescribed by law - that it shall not not be infringed by others applies here, too.

106. Shortcomings of the act. It is too early to assess the implications of the Privacy Act, due to the lack of doctrine and jurisprudence because of its recent adoption. Although at first sight it might be welcomed that an act assembles the existing regulations in relation to privacy present in different acts, ${ }^{370}$ substantially, except for a few provisions, ${ }^{371}$ the Privacy Act does not bring essential novelty. It is forward-thinking to declare that the online world merits protection just as the offline world, however, even without the declaration of that principle this was a rule deduced from the general rule of law.

Also, the Privacy Act employs different terminology, sometimes in a confusing manner. For example, in the very first paragraph of its preamble, the act refers to two notions [right to respect for private life (“magánélet tiszteletben tartásához füződő jog”) and right to privacy ("magánélethez való jog")]; In the third paragraph the expression "private sphere" ("privátszféra”) is employed, without giving further explanation regarding the meaning or scope of this notion, raising the question whether it has an autonomous meaning or simply used as a synonym to privacy/private life. ${ }^{372}$ Also, the Privacy Act mainly uses the expression right to private life: it only refers to the right to respect for private life in Article 8. Neither the Fundamental Law, nor the Civil Code employs the expression "right to private life".

\footnotetext{
369 2018. évi LIII. törvény indokolása a magánélet védelméről

${ }^{370}$ As it was, for example, expressed by Mariann Arany-Tóth. Source: Arany-Tóth, M. (2019) 'A magánélet védelméhez való jog újraszabályozásának hatása a munkaviszonyban a magánélet védelméről szóló törvény alapján (2. rész)', Munkajog, (3), p. 34.

${ }^{371}$ See the provisions relating to social media. Besides, the rules relating to public figures was considerably changed, as now the protection of their private life is strengthened through the stricter separation of their public life and private life. [Preamble and Subsection (2) of Section 7]

${ }^{372}$ In addition, Subsection (2) of Section 2 employs the expression "private sphere" ("magánszféra").
} 
107. In addition, these provisions relating to social media and the Internet raise several questions, especially the expressions "content shared and published for private purposes" and "personal data provided on the Internet for exclusively private purposes" (“magáncéllal megosztott és közzétett tartalmak" and "magáncélból közölt személyes adat"). What does the security of private sphere in relation to this shared or published content enshrined in the preamble mean? Is protection afforded to a personal Facebook post available to ten Facebook friends? Or to several hundreds of Facebook friends? Is it only applicable to chat messages within these sites?

The use of the expression "publish" suggest the sharing of a content with a larger audience, going beyond the scope of personal communication. Is the right to private life guaranteed when the user publicly shares a personal content relating to his/her private life, without using any privacy settings? In relation to Subsection (3) of Article 8, similar questions can be asked regarding personal data provided on the Internet for exclusively private purposes. Moreover, the phrasing of Subsection (3) of Article 8 is confusing, as it seems to implicate terminology referring to the outdated dual concept of legal grounds of the former Hungarian data protection act based on the dichotomy between consent and authorisation of the law. ${ }^{373}$ These questions are yet to be answered.

108. Conclusions of Section 1. Despite the numerous attempts to define privacy, no universal definition could be created due to privacy's embeddedness in the societal, technological and individual circumstances. In addition, what is considered to be private and what is legally protected as private might differ: the scope of privacy and the scope of the right to respect for private life are not always in overlap. The right to privacy covers a broader range of matters, while the right to respect for private life - terminology usually applied in the European legal order - is traditionally centred on the narrower concept of secrecy. However, even in these legal orders the concept of public privacy, or privacy as autonomy or self-determination appeared (first of all, see the ECtHR jurisprudence in relation to Article 8 of the ECHR), providing broader protection.

109. In the French legal order especially the concept of personal life, specific to the employment context should be mentioned: personal life encompasses private life, as a hard core of protection; but it also includes some elements of (public) extra-professional

\footnotetext{
373 Although the Privacy Act introduced changes in this regard. Balogh, Zs. Gy. et al. (2012) 'Munkahelyi adatvédelem a gyakorlatban', Infokommunikáció és Jog, 9(3), p. 97.
} 
life. In the Hungarian legal order, this broader apprehension of right to respect for private life also appeared in the Constitutional Court's practice, and in civil courts.

110. In view of the foregoing, when the protection of employees' privacy is discussed in the thesis, what will be understood by employees' privacy is - in accordance with the definition previously proposed - ensuring the employees' ability to act upon their wishes.

\section{Section 2: Right to data protection}

111. The right to privacy and the right to data protection are often mentioned together, ${ }^{374}$ and typically there is clearly a connection between these two rights. ${ }^{375}$ However, formally they are regulated in separate documents, and when it comes to their substantial scope, there exist different theories describing the relations between these two rights, and the additional role fulfilled by the right to data protection. ${ }^{376}$ What is clear is that besides privacy, data protection can also play an important role in protecting employees' private lives, in consequence its analysis must be included in the dissertation.

112. The right to data protection does much more than simply protect personal data. Despite what its appellation might suggest, the right to data protection does not aim to protect personal data, but the individual to whom personal data relates. ${ }^{377}$ Pál Könyves Tóth emphasizes the connection between the right to data protection and human dignity, stating that it is an essential condition to human dignity that individuals be able to take decisions regarding the disclosure of personal data relating to them. ${ }^{378}$ Máté Dániel Szabó points out that personal data is more and more valued, as the individual's personality can be increasingly expressed through personal data. ${ }^{379}$ To the outside world, the individual is more and more often perceived through (mainly) his/her personal data - instead of as a

\footnotetext{
${ }^{374}$ See, for example, Article 1 of the DPD, and Convention 108.

375 Bygrave, L. A. (2001) The Place of Privacy in Data Protection Law. Available at: http://www.austlii.edu.au/au/journals/UNSWLJ/2001/6.html (Accessed: 28 February 2018).

376 Orla Lynskey identified three models of understanding the relation between privacy and data protection: they can be understood as separate but complementary rights; data protection can be understood as a subset of privacy; or data protection can be perceived as a separate, independent right in service of different functions, but not limited to privacy. Source: Lynskey, O. (2015) The Foundations of EU Data Protection Law. Oxford: Oxford University Press. p. 90 and pp. 91-106.

377 Majtényi, L. (2002) 'Az információs szabadságok és az adatvédelem határai', Világosság, XLIII (2-3), pp. 57-58.

${ }^{378}$ Könyves Tóth, P. (1990) 'Adatvédelem és információszabadság', Világosság, 31(8-9), p. 621.

379 Szabó, M. D. (2005) 'Kísérlet a privacy fogalmának meghatározására a magyar jogrendszer fogalmaival', Információs Társadalom, (2), p. 47.
} 
physical person. ${ }^{380}$ Because of such an enhanced role, if the processing (e.g. collection and use of such information) does not take place according to the established guarantees and rules, the individual might suffer serious consequences. ${ }^{381}$

113. The Section will first address what additional role data protection can fulfill in comparison to privacy, aiming to clarify the relations between these two rights. Then, it will present how exactly the individuals' rights must be respected, through examining the most important points of the relevant legislation.

\section{$\S 1$. Introduction to the right to data protection}

114. The first data protection regulation appeared a few decades after the right to respect for private life, ${ }^{382}$ followed by several other instruments both at the international and the national level. Although they will be addressed in detail in part $\S 2$, even at this point it must be noted that today data protection is subject to detailed regulations. For its importance, focus will be put on EU regulations: though ever since 1995 the question of data protection has been regulated, ${ }^{383}$ in 2016 the adoption of the GDPR brought considerable changes and became a central piece of legislation.

In the following part, first, $(A)$ it will be explored what the reasons for the emergence of data protection rules were. Then, $(B)$ it will be examined why there was a need when the right to respect for privacy had already existed. To put it differently, it will be explored in what regards there are substantial differences (if there are) between the two rights, which would justify the existence of two rights.

\section{(A) The birth of the right to data protection}

115. Origins of data protection. The right to data protection is a relatively recent right: it appeared in the 1970s. Similarly to the right to privacy, the right to data protection

\footnotetext{
380 Szabó, M. D. (2005) 'Kísérlet a privacy fogalmának meghatározására a magyar jogrendszer fogalmaival', Információs Társadalom, (2), p. 47.

${ }^{381}$ For example, as it will be addressed in a later part of the dissertation, if the employer does not process personal data according to the pertinent regulations, it not only infringes the employees' or prospective employees' rights but can also have serious consequences for his/her employment - e.g. termination of employment or unfavorable hiring decision.

382 It was adopted in 1970 in Germany. Source: Simitis, S. (2010) 'Privacy - An Endless Debate', California Law Review, 98(6), p. 1995.

${ }^{383}$ See: Directive 95/46/EC of the European Parliament and of the Council of 24 October 1995 on the protection of individuals with regard to the processing of personal data and on the free movement of such data. Official Journal L 281, 23/11/1995 P. 0031 - 0050
} 
also emerged as a reaction to technological development: owing to the appearance of computers, the collection, storage, transfer, etc. had never been easier, and the plan for establishing different state registers was evoked by the states. Under the shadow of how state registers had contributed to the horrible events of the Second World War, ${ }^{384}$ combined with the growing fear of a surveillance state, ${ }^{385}$ the public feared the consequences of unregulated automated processing of personal data. Still, prior to the 1960s and 1970s, technology did not make it possible to conduct automatic data processing; also, mass surveillance came at high costs, and thus the protection of the individual was naturally ensured. ${ }^{386}$ However, due to the technological development, the situation had changed, and as a response to the arising threats, data protection appeared, ${ }^{387}$ as these innovations offered unprecedented opportunities for the state to keep records in order to fulfil its functions (e.g. in relation to taxation, etc.). ${ }^{388}$ At the same time, plans appeared throughout Europe aiming to unify or to connect national databases. ${ }^{389}$ It was against this background that the first documents regulating data protection appeared. The world's first data protection act was adopted in 1970, in the German federal state of Hesse, ${ }^{390}$ and was soon followed by other countries (Sweden in 1973, Germany in 1977, France in 1978). ${ }^{391}$ After adopting these national data protection acts, it became also necessary to regulate the transborder flow of personal data, which led to the adoption of international data protection norms. ${ }^{392}$

116. French and Hungarian origins. France adopted its data protection act, the "Loi informatique" in 1978 [Act No. 78-17 of 6 January 1978 on Information Technology,

384 Galántai, Z. (2003) E-privacy olvasókönyv. Dialógusok a privacyröl és az internetröl - meg a cyberpornóról, a megfigyelésekröl és egyebekröl. Available at: https://mek.oszk.hu/04100/04134/html/ (Accessed: 18 November 2019).

385 These fears are well illustrated in literature as well. Scholars usually refer to George Orwell's "1984", and Franz Kafka's "The Trial". In Hungary, scholars often cite a certain verse of a poem entitled "Air!" written by the famous Hungarian poet, Attila József in 1935: "They keep track of my phone calls,/ who I call and when and why./ They keep a transcript of my dreams/ and what they mean / and according to whom./ I don't know what's in my file of latel but soon they'll make a movel and violate my rights." Source: Hargitai, P. (tran.) (2005) Attila József Selected Poems. New York: iUniverse, pp. 35-36.

386 Jóri, A. (2005) Adatvédelmi kézikönvy. Budapest: Osiris Kiadó, p. 22.

${ }^{387}$ Szőke, G. L. (2015) Az európai adatvédelmi jog megújitása. Tendenciák és lehetőségek az önszabályozás területén. Budapest: HVG-ORAC, p. 27

388 Sári, J. and Somody, B. (2008) Alapjogok. Budapest: Osiris Kiadó, p. 133.

${ }^{389}$ Szőke, G. L. (2015) Az európai adatvédelmi jog megújítása. Tendenciák és lehetőségek az önszabályozás területén. Budapest: HVG-ORAC, p. 31.

${ }^{390}$ Simitis, S. (2010) 'Privacy - An Endless Debate', California Law Review, 98(6), p. 1995.

${ }^{391}$ On the history of data protection see more in: Szőke, G. L. (2015) Az európai adatvédelmi jog megújítása. Tendenciák és lehetőségek az önszabályozás területén. Budapest: HVG-ORAC, pp. 27-34.; Jóri, A. (2005) Adatvédelmi kézikönvy. Budapest: Osiris Kiadó, pp. 21-66.

392 Jóri, A. (2005) Adatvédelmi kézikönvy. Budapest: Osiris Kiadó, p. 28. 
Data Files and Civil Liberties ("loi relative à l'informatique, aux fichiers et aux libertés") hereinafter referred to as: FDPA - standing for French Data Protection Act], ${ }^{393}$ as a result of the SAFARI scandal concerning a project to interconnect certain files of the French administration - revealed to the public in an article in the newspaper Le Monde. ${ }^{394}$ In 1978 the FDPA also established the French national data protection authority, named French National Commission on Informatics and Freedoms ("Commission nationale de l'informatique et des libertés") (hereinafter referred to as: CNIL). The FDPA was significantly amended in $2004^{395}$ in order to transpose the EU's data protection directive, ${ }^{396}$ and in 2016 by the Act for a Digital Republic aiming to address the new challenges of the information society. ${ }^{397}$ Although the GDPR is directly applicable, it did not repeal national data protection acts: in the case of conflicting provisions, the former will be applied. ${ }^{398}$ The amendment of the FDPA was realized in June 2018 by Act No. 2018-493 of 20 June 2018 on the Protection of Personal Data ("Loi n 2018-493 du 20 juin 2018 relative à la protection des données personnelles"). ${ }^{399}$

117. While France was amongst the first countries in the world to adopt a data protection act in 1978, in Hungary this process was slower: Hungary adopted its first data protection act, Act LXIII of 1992 on the protection of personal data and access to data of public interest in 1992. The act also established the institution of the Hungarian data protection commissioner, ${ }^{400}$ who was first appointed in 1995 . This act was amended due to

393 See more on French data protection and on the FDPA in: Desgens-Pasanau, G. (2012) La protection des données à caractère personnel: la loi 'Informatique et libertés'. Paris: LexisNexis (Carré droit); FéralSchuhl, C. (2018) Cyberdroit. Le droit à l'épreuve de l'Internet. 7th edn. Paris: Dalloz.; Forest, D. (2011) Droit des données personnelles. Paris: Gualino (Droit en action).

394 Boucher, P. (1974) ‘"Safari » ou la chasse aux Français', Le Monde, 21 March. p. 9.

${ }^{395}$ Loi n ${ }^{\circ} 2004-801$ du 6 août 2004 relative à la protection des personnes physiques à l'égard des traitements de données à caractère personnel et modifiant la loi $\mathrm{n}^{\circ}$ 78-17 du 6 janvier 1978 relative à l'informatique, aux fichiers et aux libertés

396 On the history of French data protection and the adoption of the FDPA see more in: Braibant, G. (1998) Données personnelles et société de l'information: transposition en droit français de la directive $n^{\circ}$ 95-46. Paris: la Documentation française (Collection des rapports officiels). pp. 31-36. and Rey, B. (2012) La vie privée à l'ère du numérique. Cachan: Lavoisier. pp. 66-82.

397 See more on the Act for a Digital Republic in: Masnier-Boché, L. (2016) 'Loi «pour une République numérique »: état des lieux en matière de protection des données personnelles', Revue Lamy droit de l'immatériel ex Lamy droit de l'informatique, 131, pp. 50-55.; Richard, J. (2016). Le numérique et les données personnelles : quels risques, quelles potentialités ? Revue Du Droit Public (RDP), 1, 87-100.

398 Bourgeois, M. (2017) Droit de la donnée: principes théoriques et approche pratique. Paris: LexisNexis. p. 13.

399 See more on the GDPR's effect on the FDPA in: Beaugrand, T. et al. (2017) Protection des données personnelles : se mettre en conformité d'ici le 25 mai 2018. Montrouge: Editions législatives. pp. 76-79. On the amendment of the FDPA see more in: CNIL (2018) Rapport d'activité 2017. La documentation française. pp. 34-37.

${ }^{400}$ Section 23 of Act LXIII of 1992 on the protection of personal data and access to data of public interest 
Hungary's accession to the EU in $2003^{401}$ and replaced in 2011 by Act CXII of 2011 on the Right to Informational Self-determination and Freedom of Information ${ }^{402}$ (hereinafter referred to as: HDPA - standing for the Hungarian Data Protection Act $\left.{ }^{403}\right) .{ }^{404}$ The HDPA also introduced significant changes to the national data protection authority: it replaced the institution of the data protection commissioner by establishing the Hungarian National Authority for Data Protection and Freedom of Information ("Nemzeti Adatvédelmi és Információszabadság Hatóság ", hereinafter referred to as: NAIH). After the entering into application of the GDPR, the Hungarian legislators adopted Act XXXIV of 2019 on legislative amendments required for the implementation of the European Union's data protection reform (hereinafter referred to as: Enforcing Act) in April 2019, aiming to adapt the Hungarian legal system to the GDPR, by amending more than 80 acts. ${ }^{405,406}$

118. Generations of data protection regulations. Despite the recent birth of the right to data protection, scholars already distinguish between different generations of data protection regulations. However, these generations are not universal, different authors established different stages in the history of data protection regulations. According to Michael D. Birnhack, the first stage was the very appearance of these regulations, the second was the appearance of international regimes instead of solely national regulation and the third was the emphasis being put on the transfer of personal data instead of the collection. ${ }^{407}$ In 2005 , law professor Yves Poullet differentiated between three generations

\footnotetext{
${ }^{401}$ By Act XLVIII of 2003 on the amendment of Act LXIII of 1992 on the protection of personal data and access to data of public interest. Source: Könyves Tóth, P. (2010) 'Az adatvédelmi törvény metamorfózisai', Fundamentum, (2), p. 55.

${ }^{402}$ On the history of Hungarian data protection regulation se more in: Péterfalvi, A. (ed.) (2012) Adatvédelem és információszabadság a mindennapokban. Budapest: HVG-ORAC, pp. 50-55.; Könyves Tóth, P. (2010) 'Az adatvédelmi törvény metamorfózisai', Fundamentum, (2), pp. 53-61.

${ }^{403}$ Although the Hungarian data protection authority employed the expression "Privacy Act" when referring to the data protection act, the use of such an expression is unfortunate, with regard to the adoption of the Privacy Act (act on the protection of private life). For this reason, the acronym HDPA will be employed in the dissertation.

${ }^{404}$ In Hungary as well, the adoption of a landmark decision in the field of data protection is connected to a so-called universal identification number and its suppression by the Constitutional Court in Decision No. 15/1991. (IV. 13.).

${ }^{405}$ On the most important changes occurring in 2019 see more in: Bölcskei, K. (2019) GDPR Kézikönyv 2.0. Budapest: Vezinfó Kiadó és Tanácsadó Kft.

${ }^{406}$ On Hungarian data protection see more in: Jóri, A. (2005) Adatvédelmi kézikönvy. Budapest: Osiris Kiadó.; Majtényi, L. (2006) Az információs szabadságok: adatvédelem és a közérdekü adatok nyilvánossága. Budapest: Complex.; Jóri, A., Hegedüs, B. and Kerekes, Z. (eds) (2010) Adatvédelem és információszabadság a gyakorlatban. Budapest: Complex.; Könyves Tóth, P. (2010) 'Az adatvédelmi törvény metamorfózisai', Fundamentum, (2), pp. 53-61.; Péterfalvi, A. (ed.) (2012) Adatvédelem és információszabadság a mindennapokban. Budapest: HVG-ORAC.; Jóri, A. and Soós, A. K. (2016) Adatvédelmi jog: magyar és európai szabályozás. Budapest: HVG-ORAC.

${ }^{407}$ Birnhack, M. D. (2008) 'The EU Data Protection Directive: An engine of a global regime.', Computer Law \& Security Review, 24(6), pp. 511-512.
} 
of data protection regulations, starting with Article 8 of the ECHR, continuing with the EU's Data Protection Directive and the CoE's Convention 108, and ending with the EU's E-privacy Directive. ${ }^{408}$ Back in 1997, Viktor Mayer-Schönberger already distinguished four generations of data protection regulations. The first one dates back to the very appearance of data protection laws, when these acts aimed to regulate the technology, when processing was conducted only by a few controllers. Then, when processing became differentiated and available not only for states but for businesses too, data protection regulations shifted from regulating technology to guaranteeing individual liberty. The third generation is characterized by the right to informational self-determination, while the fourth (e.g. the EU Data Protection Directive) manifests an intention to strengthen the rights of the individual and to create a mandatory protection of certain data, and a shift and an opening towards sectoral regulation. ${ }^{409}$

119. Gergely László Szőke differentiates between three generations: the first generation is characterized by the aim of regulating the automated processing of certain data controllers (mainly the state) who processed a huge amount of personal data. With the appearance and spread of the personal computer in the 1980s, this landscape changed, as the processing of personal data became available to a wider audience (to businesses or to private individuals): a second type of regulation was needed. These regulations are characterized by the aim of providing the individual the right to informational selfdetermination in general, instead of regulating the processing of only a few data controllers. The European Data Protection Directive, the OECD Guidelines, the CoE's Convention 108 are typical examples of the second generation of data protection regulations. However, since then, technology has not stopped evolving: the mass adoption of the Internet, social network sites, profiling, the use of mobile devices, etc. have evoked the necessity for a third generation of regulation. According to Szőke, the EU's General Data Protection Regulation (then proposal) represents new tendencies in personal data protection, by taking into account the obligations of data controllers (instead of the individual's right to self-determination), differentiating between certain types of

\footnotetext{
408 Poullet, Y. (2005) 'Pour une troisième génération de réglementations de protection des données', Jusletter. Available at: http://www.crid.be/pdf/public/5188.pdf (Accessed: 24 February 2018). pp.4-8.

${ }^{409}$ Mayer-Schönberger, V. (1997) 'Generational Development of Data Protection in Europe', in Agre, P. E. and Rotenberg, M. (eds) Technology and Privacy: The New Landscape. Cambridge: MIT Press, pp. 221-233.
} 
controllers, aiming to regulate technology and strengthening the role of the internal regulations of controllers. ${ }^{410}$

120. Either categorization we agree with, it is undisputed that the changes posed by the mass adoption of the Internet, social media, mobile devices and the shift in users' behaviour represent a challenge both for the right to privacy and for the right to data protection. As the dissertation focuses on labour law, it is beyond the dissertation's scope and aim to propose another classification of the generations of data protection regulations, for the purposes of the dissertation it is sufficient to identify the common characteristics of the development of data protection regulations.

121. From the generations identified above, it can be observed that data protection went through different phases: since its appearance in the second half of the $20^{\text {th }}$ century, the technological, societal and legal environment has been completely transformed. The conclusion that can be drawn from these generations is that data protection as well should be adequately adjusted to the given circumstances. While data protection at the beginning was regulated at the national level, it was soon recognized that the absence of an international legal framework would inhibit the international transfer of personal data ${ }^{411}$, , resulting in the adoption and existence of a complex regulation. While at the beginning data protection regulations had to cope with a limited number of huge databases, nowadays data processings have multiplied due to the rapid advancement of technological development. These changes had an effect on the regulations as well, as at the beginning these regulations constituted mainly technical regulations, but later shifted towards guaranteeing the freedom of the individual. ${ }^{412}$ Existing rules are constantly challenged - for example by social media and SNSs, as it will be examined under Title 2 .

\section{(B) Defining data protection: substantial delimitation from the right to privacy}

\footnotetext{
${ }^{410}$ Szőke, G. L. (2013) 'Az adatvédelem szabályozásának történeti áttekintése', Infokommunikáció és jog, (3), pp. 108-111. In his article Szöke also refers to the different existing theories amongst Hungarian scholars. According to László Majtényi, the first generation consists of norms regulating data processing by computers, while the second generation is technology-neutral, and the third focuses on challenges arising in different sectors. (Majtényi, L. (2008) 'Az információs jogok', in Halmai, G. and Tóth, G. A. (eds) Emberi jogok. Budapest: Osiris Kiadó, pp. 582-583.) According to András Jóri, the first generation of norms focuses on big data controllers and processing by computers, the second generation is centred around the right to informational self-determination, while the third one is concentrated on the new arising challenges. (Jóri, A. (2005) Adatvédelmi kézikönvy. Budapest: Osiris Kiadó, pp. 23-66.)

${ }^{411}$ Jóri, A. (2005) Adatvédelmi kézikönvy. Budapest: Osiris Kiadó, p. 28.

${ }^{412}$ Marta Otto referring to Mark Freedland in: Otto, M. (2016) The Right to Privacy in Employment: a Comparative Analysis. Oxford, Portland: Hart Publishing, pp. 106-107.
} 
122. It was already established how privacy is understood in the dissertation. As a starting point, data protection can be comprehended as "the regulation and organisation of the conditions under which personal data can be lawfully processed." ${ }^{413}$ However, it must also be established what is data protection and what is its relation to privacy? There is an uncontested connection between these two rights, ${ }^{414}$ however, just like regarding the exact meaning of privacy, there is no uniform standpoint in this question, as there is still no universal consensus with respect to the relationship between these two rights. ${ }^{415}$ Even at this point it must be noted that data protection and privacy are not considered to be synonymous concepts in the dissertation. ${ }^{416}$

123. Data protection as a subset of privacy. Different interpretations suggest that data protection is a subset of privacy and not a separate right. ${ }^{417}$ On the one hand, different grammatical formulations support this view: data protection can be associated with privacy, as Patrik Hiselius' formulation suggests: “[i]n the European Union, instead of using the term 'Privacy', in general the notion 'right to data protection' is used." 418 In the literature, the expressions informational privacy ${ }^{419}$ or data privacy ${ }^{420}$ are also used to describe data protection.

\footnotetext{
${ }^{413}$ Gellert, R. and Gutwirth, S. (2013) 'The legal construction of privacy and data protection', Computer Law and Security Review, 29(5), p. 525.

${ }^{414}$ According to László Sólyom, it is undisputed that the right to data protection originates from the right to privacy, although it has to be seen that both rights have grown beyond the concept of mere secrecy or intimacy. Source: Sólyom, L. (1988) ‘Adatvédelem és személyiségi jog', Világosság, 29(1), p. 55.

415 Purtova, N. (2010) 'Private Law Solutions in European Data Protection: Relationship to Privacy, and Waiver of Data Protection Rights', Netherlands Quarterly of Human Rights, 28(2), p. 181.

${ }^{416}$ Kokott, J. and Sobotta, C. (2013) 'The distinction between privacy and data protection in the jurisprudence of the CJEU and the ECtHR', International Data Privacy Law, 3(4), p. 223. According to Paul de Hert and Eric Schreuders, they are not synonymous concepts, but rather can be described as "twins but not identical". Source: De Hert, P. and Schreuders, E. (2001) 'The Relevance of Convention 108'. Proceedings of the Council of Europe Conference on Data Protection, Warsaw, 19-20 November. Cited in: Kuner, C. (2009) 'An international legal framework for data protection: Issues and prospects', Computer Law and Security Review, 25(4), p. 308.

${ }^{417}$ For example, Endre Ferenczy argues that data protection is one component of privacy. Source: Ferenczy, E. (2010) 'Az adatvédelem külföldi szabályozása', Tudományos közlemények, (23), p. 48.

${ }^{418}$ Hiselius, P. (2010) 'ICT/Internet and the Right to Privacy', Scandinavian Studies in Law, 56, p. 203.

${ }^{419}$ See, for example: Mayer-Schönberger, V. (1997) 'Generational Development of Data Protection in Europe', in Agre, P. E. and Rotenberg, M. (eds) Technology and Privacy: The New Landscape. Cambridge: MIT Press, p. 226.

${ }^{420}$ Lee A. Bygrave argues that instead of the use of the expression "data protection", the expression of "data privacy" is better suited as it can constitute a bridge between the US and the European concept of privacy and data protection, and it better reflects the values to be protected. Bygrave, L. A. (2004) 'Privacy Protection in a Global Context - A Comparative Overview', Scandinavian Studies in Law, 47, pp. 321-322.
} 
On the other hand, Juliane Kokott and Christoph Sobotta also point out that both the ECtHR and the CJEU consider data protection as an expression of the right to privacy. ${ }^{421}$ Even in the EU, where the CFREU contains two separate articles for these two rights (Article 7 and Article 8), it is not excluded that data protection still forms a part of privacy. ${ }^{422}$ In the jurisprudence of the CJEU, though in certain decisions it acknowledged that the right to privacy and the right to data protection are two separate rights, ${ }^{423}$ the two rights are consistently conflated in most of its practice. ${ }^{424}$ In contrast to the CFREU, the ECHR does not contain a separate provision corresponding to the right to data protection, still, the ECtHR deducted certain data protection rules from Article $8,{ }^{425}$ treating data protection as a privacy interest. ${ }^{426}$ Lee A. Bygrave refers to the existence of an "almost universal consensus" that data protection mostly aims to protect privacy. ${ }^{427}$ Indeed, privacy

421 Kokott, J. and Sobotta, C. (2013) 'The distinction between privacy and data protection in the jurisprudence of the CJEU and the ECtHR', International Data Privacy Law, 3(4), p. 222.

422 Purtova, N. (2010) 'Private Law Solutions in European Data Protection: Relationship to Privacy, and Waiver of Data Protection Rights', Netherlands Quarterly of Human Rights, 28(2), p. 185.

${ }^{423}$ In the Bavarian Lager case, the CJEU referred to the existence of a specific system of protection in relation to personal data protection [CJEU (2010): Commission v Bavarian Lager, Case C-28/08 P, ECLI:EU:C:2010:378, 29 June, par. 60.]. In its opinion in the Volker case, it was stated that "[t]wo separate rights are evoked here: a classic right (protection of privacy under Article 8 ECHR) and a more modern right (the data protection provisions of Convention No 108)" acknowledging the existence of a separate right to data protection. (par. 71.) However, in the Volker judgement the CJEU employed the confusing expression of "the right to respect for private life with regard to the processing of personal data" (par. 52.) Source: CJEU (2010) Volker und Markus Schecke GbR and Hartmut Eifert v Land Hessen, Joined cases C-92/09 and C93/09, Opinon, ECLI:EU:C:2010:353, 9 November

${ }^{424}$ For example, in the Rundfunk case he CJEU interpreted the DPD in the light of Article 8 of the ECHR. [CJEU (2003): Rechnungshof v. Österreichischer Rundfunk, Joined Cases C-465/00, C-138/01 and C-139/01, ECLI:EU:C:2017:131, 20 May, par. 21.] In the case of Promusicae the CJEU employed the term "the right that guarantees protection of personal data and hence of private life" to refer to one fundamental right, treating privacy and data protection as one right. [CJEU (2008): Productores de Música de España (Promusicae) v Telefónica de España SAU, Case: C-275/06. ECLI:EU:C:2008:54, 29 January, par. 63.] See more on the conflating position of the CJEU in: Lynskey, O. (2014) 'Deconstructing Data Protection: the "Added-Value" of a Right to Data Protection in the EU Legal Order', International and Comparative Law Quarterly, 63(3), pp. 569-597.

425 Though Kokott and Sobotta argue that the ECtHR gave rise to a right to data protection, De Hert and Gutwirth are more cautious when it comes to this subject. They argue that though the ECtHR indeed went further than the narrow concept of privacy as intimacy and acknowledged several data protection aspects under Article 8 case law, basic data protection assumptions are not incorporated in its protection. (Kokott, J. and Sobotta, C. (2013) 'The distinction between privacy and data protection in the jurisprudence of the CJEU and the ECtHR', International Data Privacy Law, 3(4), p. 223. and De Hert, P. and Gutwirth, S. (2009) 'Data Protection in the Case Law of Strasbourg and Luxemburg: Constitutionalisation in Action', in Gutwirth, S. et al. (eds) Reinventing Data Protection? Springer, p. 24. and p. 27.

426 Purtova, N. (2010) 'Private Law Solutions in European Data Protection: Relationship to Privacy, and Waiver of Data Protection Rights', Netherlands Quarterly of Human Rights, 28(2), p. 198.

427 Bygrave, L. A. (2001) The Place of Privacy in Data Protection Law. Available at: http://www.austlii.edu.au/au/journals/UNSWLJ/2001/6.html (Accessed: 28 February 2018), par. 2. 
occupies a central role in data protection, as supported by numerous legal documents and by scholars as well. According to these views, data protection aims to ensure privacy. ${ }^{428}$

124. Scope of data protection. In contrast to interpreting data protection as a subset of privacy, different authors understand data protection as having a wider scope than privacy. ${ }^{429}$ For example, Orla Lynskey argues that the right to data protection - though overlapping with the right to privacy - offers an additional protection for individuals. ${ }^{430}$ Several other authors draw attention to the fact that despite the connection between privacy and data protection, data protection cannot be limited to the protection of privacy, but aims to ensure the protection of other rights, being broader than privacy. ${ }^{431}$ Bygrave also

${ }^{428}$ For example, according to András Jóri, data protection is "a unique legal way to protect the private sphere of the individual" and "can be interpreted within the protection of private sphere, as the legal instrument protecting privacy in the current societal and technological environment." Source: Jóri, A. and Soós, A. K. (2016) Adatvédelmi jog: magyar és európai szabályozás. Budapest: HVG-ORAC, p. 15 and p. 20.

Nadezhda Purtova also interpreted existing doctrine as suggesting that the right to data protection and the right to privacy - though not completely synonymous - can be reduced to the same core, which is the protection of the private sphere of the individual. Source: Purtova, N. (2010) 'Private Law Solutions in European Data Protection: Relationship to Privacy, and Waiver of Data Protection Rights', Netherlands Quarterly of Human Rights, 28(2), pp. 182-183.

According to Article 1 of the DPD, its objective was to "[...] protect the fundamental rights and freedoms of natural persons, and in particular their right to privacy with respect to the processing of personal data." The CoE's Convention 108 also contained a similar paragraph. However, the WP29 expresses the contrary by stating that this formulation suggests that the purpose of the right to data protection is wider than the mere protection of privacy. WP29 (2007) Opinion 4/2007 on the concept of personal data. 01248/07/EN WP 136. p. 7.

A "separation" of data protection from privacy might also be observed in the GDPR, as, with the data protection reform, the world privacy is gone from the GDPR: Article 1 aims to protect "[...] fundamental rights and freedoms of natural persons and in particular their right to the protection of personal data. " Also, a change in the terminology can be observed, adopting the concepts data protection by design and data protection impact assessment, replacing the "traditional" expressions privacy by design and privacy impact assessment. Source: Costa, L. and Poullet, Y. (2012) 'Privacy and the regulation of 2012', Computer Law and Security Review, 28(3), p. 255.

According to Section 1 of the HDPA, the purpose of the act is to "[...] define rules in relation to data processing in order to make data controllers respect the private lives of individuals[.]"

${ }^{429}$ However, as it was also pointed out, data protection has a narrower scope compared to privacy, regarding the protection of moral persons: while data protection is solely offered to natural persons, the ECtHR expanded protection to moral persons. Source: ECtHR: Société Colas Est and others v. France, Application No. 37971/97, 16 April 2002, par. 40. and Kokott, J. and Sobotta, C. (2013) 'The distinction between privacy and data protection in the jurisprudence of the CJEU and the ECtHR', International Data Privacy Law, 3(4), p. 225

${ }^{430}$ Lynskey, O. (2014) 'Deconstructing Data Protection: the "Added-Value” of a Right to Data Protection in the EU Legal Order', International and Comparative Law Quarterly, 63(3), p. 582.

431 Bygrave, L. A. (2001) The Place of Privacy in Data Protection Law. Available at: http://www.austlii.edu.au/au/journals/UNSWLJ/2001/6.html (Accessed: 28 February 2018), par. 18.

Similarly, according to Isabelle Falque-Pierrotin, in the age of the Internet the right to privacy no longer covers all aspects of the right to data protection - which is conceived to be a right at the intersection of property rights, the right to freedom of expression and the right to privacy. Source: Falque-Pierrotin, I. (2012) 'La Constitution et l'Internet', Les nouveaux cahiers du Conseil constitutionnel, 36, p. 36.

Raphaël Gellert and Serge Gutwirth also argued that privacy protects not only privacy but other fundamental rights as well. Gellert, R. and Gutwirth, S. (2013) 'The legal construction of privacy and data protection', Computer Law and Security Review, 29(5), p. 530. Data protection regulation can cover other significant values besides privacy, such as requirement of fair processing, consent, legitimacy and non- 
expresses that while data protection aims to benefit society as a whole, privacy has a narrower aim, and concentrates on the individual. ${ }^{432,}{ }^{433}$ András Jóri et al. also noted that data protection can be wider as it covers personal data not necessarily falling under privacy. ${ }^{434}$ Usually such statement is supported by the fact that data protection rules apply regardless of the private or public nature of personal data, while traditionally privacy enjoys limited protection outside the private sphere. ${ }^{435}$ This question gains significant importance in the context of SNSs, as on SNSs users typically (publicly) share a vast amount of personal data, raising several questions in relation to whether they fall under the scope of privacy and/or data protection. ${ }^{436}$

125. Instead of solely stating that the right to data protection is wider than the right to privacy, Raphaël Gellert and Serge Gutwirth found that it is wider and narrower at the same time. They argued that as regards the content of these two rights, there are overlaps, still data protection is wider and narrower than privacy and vice versa. ${ }^{437}$ Data protection is wider, as the data protection regulation applies to all kinds of personal data processing, even when the right to privacy is not infringed by the processing. ${ }^{438}$ It is also

discrimination. Source: De Hert, P. and Gutwirth, S. (2009) 'Data Protection in the Case Law of Strasbourg and Luxemburg: Constitutionalisation in Action', in Gutwirth, S. et al. (eds) Reinventing Data Protection? Springer, p. 9.

432 Bygrave, L. A. (2001) The Place of Privacy in Data Protection Law. Available at: http://www.austlii.edu.au/au/journals/UNSWLJ/2001/6.html (Accessed: 28 February 2018), par. 20.

${ }^{433}$ In contrast to such an opinion Anoinette Rouvroy and Yves Poullet refer to other scholars who suggested that privacy aims to protect the society as a whole. Rouvroy, A. and Poullet, Y. (2009) 'The Right to Informational Self-Determination and the Value of Self-Development: Reassessing the Importance of Privacy for Democracy', in Gutwirth, S. et al. (eds) Reinventing Data Protection? Springer, p. 60.

${ }^{434}$ Jóri, A., Hegedűs, B. and Kerekes, Z. (eds) (2010) Adatvédelem és információszabadság a gyakorlatban. Budapest: Complex. p. 34. In contrast, Attila Péterfalvi argued in an interview that the right to data protection is narrower than the right to privacy. Source: Szabó, M. D. (2004) “„Erős jogvédő szemlélettel, de a törvényi felhatalmazás keretein belül kell dolgoznunk.” Péterfalvi Attila adatvédelmi biztossal Szabó Máté Dániel beszélget', Fundamentum, VIII(4), p. 40.

${ }^{435}$ Lynskey, O. (2014) 'Deconstructing Data Protection: the "Added-Value" of a Right to Data Protection in the EU Legal Order', International and Comparative Law Quarterly, 63(3), p. 583.; Gellert, R. and Gutwirth, S. (2013) 'The legal construction of privacy and data protection', Computer Law and Security Review, 29(5), p. 526,; Kokott, J. and Sobotta, C. (2013) 'The distinction between privacy and data protection in the jurisprudence of the CJEU and the ECtHR', International Data Privacy Law, 3(4), p. 225.

436 These questions will be addressed in detail in Title 2.

${ }^{437}$ Gellert, R. and Gutwirth, S. (2013) 'The legal construction of privacy and data protection', Computer Law and Security Review, 29(5), p. 526.

De Hert and Gutwirth also argued that data protection is both wider and more specific than the protection of privacy. De Hert, P. and Gutwirth, S. (2009) 'Data Protection in the Case Law of Strasbourg and Luxemburg: Constitutionalisation in Action', in Gutwirth, S. et al. (eds) Reinventing Data Protection? Springer, p. 6.

438 "[...] storing of data relating to the "private life" of an individual falls within the application of Article $8 \S$ 1 [...]" [ECtHR (2000) Amann v. Switzerland, Application no. 27798/95,16 February, par. 65.] However, when the processing does not concern the private life of the individual - for example, in the case of public camera surveillance, more precisely in the case of the use of "photographic equipment which does not record the visual data" - the Commission held that there was no interference with the applicant's private life. 
more specific because it only deals with personal data, while the right to privacy covers more aspects. Privacy is also wider and more specific, as it could apply to cases concerning the processing of not personal data, ${ }^{439}$ but which nevertheless can have an effect on one's privacy; but it will not apply to a processing which does not infringe privacy. ${ }^{440}$

126. Tools of protection. While privacy remains a relatively vague concept, with a highly context-dependent nature, data protection is characterized by a more exact terminology. It is enough to look at basically any international or national piece of legislation: these documents usually contain the most important definitions, such as data protection, data processing, etc. having a more exact nature, leaving less place for interpretational questions. Naturally, it does not mean that data protection would not have to adapt to technological and societal changes ${ }^{441}$ (see, for example, the EU data protection reform), or that no interpretational questions would arise (see, for example, the pre-GDPR discourse on IP addresses).

127. Another important difference is that while privacy aims to protect against intrusions (thus prohibiting intrusion), data protection regulations usually do not prohibit data processing but rather regulate how this processing can take place. ${ }^{442}$, 443 While the right to privacy is a "redress" right, which ensures the protection from interference by public powers, the right to data protection is a "control" right, which aims to give the right to control the processing of personal data relating to the individual. ${ }^{444}$ Another approach is to interpret the right to privacy as an opacity tool, ensuring the individual's "invisibility" towards the state; while the right to data protection as a transparency tool, regulating the processing of personal data in order to achieve transparency. ${ }^{445,}{ }^{446}$ Instead of providing

European Commission on Human Rights (1998) Pierre Herbecq and the Association Ligue des droit de l'homme v. Belgium, Applications No 32200/96 and 32201/96 (joined), 14 January.

${ }^{439}$ It is enough to think of physical privacy, or of the protection of home or family life. See, for example, Kuner, C. (2009) 'An international legal framework for data protection: Issues and prospects', Computer Law and Security Review, 25(4), p. 309.

${ }^{440}$ Gellert, R. and Gutwirth, S. (2013) 'The legal construction of privacy and data protection', Computer Law and Security Review, 29(5), p. 526.

${ }^{441}$ De Hert, P. and Gutwirth, S. (2009) 'Data Protection in the Case Law of Strasbourg and Luxemburg: Constitutionalisation in Action', in Gutwirth, S. et al. (eds) Reinventing Data Protection? Springer, p. 4.

442 De Hert, P. and Gutwirth, S. (2009) 'Data Protection in the Case Law of Strasbourg and Luxemburg: Constitutionalisation in Action', in Gutwirth, S. et al. (eds) Reinventing Data Protection? Springer, p. 3.

${ }^{443}$ In contrast to this view, Gloria González Fuster and Serge Gutwirth point out that data protection can be interpreted as being of prohibitive nature. Source: González Fuster, G. and Gutwirth, S. (2013) 'Opening up personal data protection: A conceptual controversy’, Computer Law and Security Review, 29(5),

${ }^{444}$ Knight, A. and Saxby, S. (617) 'Global challenges of identity protection in a networked world', Computer Law and Security Review, 30(6), p. 626.

445 González Fuster, G. and Gutwirth, S. (2013) 'Opening up personal data protection: A conceptual controversy’, Computer Law and Security Review, 29(5), p. 536. And De Hert, P. and Gutwirth, S. (2009) 
protection against data processing, the right to data protection protects individuals from unlawful processing and regulates under which conditions personal data can be processed. ${ }^{447}$

128. In the light of the above, for the purposes of the dissertation, data protection will be considered as the set of rules governing the processing of personal data relating to the employee. Indeed, privacy is at the core values of data protection, as there are often overlaps between the two rights. However, the two rights have different sets of tools to ensure the protection of employees' rights, therefore they cannot be treated as synonyms. While data protection channels the processing of personal data, privacy aims to ensure the employee to be able to decide about himself/herself. This can be interpreted as privacy enabling the employee to decide whether and how to use $\mathrm{SNSs},{ }^{448}$ as data protection aiming to regulate whether employers can process personal data obtained from SNSs and if they can, they perform it according to the guarantees laid down in pertinent regulations.

\section{§2. Legal regulation of the right to data protection}

129. Besides the substantial differences, the right to data protection also became a formally separate right, laid down in several international ${ }^{449}$ and national documents. Due to their utmost importance and the space limitations of the dissertation, amongst the international instruments the EU's data protection framework will be focused on here, while other global and regional regulations will be addressed incidentally. Special attention will be paid to the GDPR, as it introduced considerable changes to EU data protection law. Its significance is mainly due to the form of the instrument chosen by the EU legislator: by regulating data protection in a regulation, EU law was unified in this field.

Although - as it will be demonstrated - data protection is already subjected to detailed regulation, it does not mean that this right lacks paths to evolve. The development

\footnotetext{
'Data Protection in the Case Law of Strasbourg and Luxemburg: Constitutionalisation in Action', in Gutwirth, S. et al. (eds) Reinventing Data Protection? Springer, p. x.

${ }^{446}$ In contrast to this view, Marta Otto emphasizes the deficiency of this opacity-transparency approach, as according to her it does not take into consideration the established case law of the ECtHR interpreting privacy beyond a negative right. Source: Otto, M. (2016) The Right to Privacy in Employment: a Comparative Analysis. Oxford, Portland: Hart Publishing, p. 112.

${ }^{447}$ De Hert, P. and Gutwirth, S. (2009) 'Data Protection in the Case Law of Strasbourg and Luxemburg: Constitutionalisation in Action', in Gutwirth, S. et al. (eds) Reinventing Data Protection? Springer, pp. 3-4.

448 Or reconnecting to the "traditional" concept of secrecy, it can be formulated as aiming to guarantee protection against the intrusions into the autonomy of private life.

${ }^{449}$ See Annex I. on the summary table concerning the most important international documents in the field of privacy, data protection, data protection and employment, and data protection and social network sites.
} 
of informational communicational technology constantly challenges existing conceptions of data protection, giving rise to new questions or aspects to consider - for example, through the appearance of the right to informational self-determination. In some countries this right has been present for decades, ${ }^{450}$ in others it constitutes a new issue ${ }^{451}$ - but its existence and scope must be (re)examined in the light of technological and societal developments.

(A) Formal distinction from the right to privacy: norms regulating the right to data protection

130. Universal level. Although no binding regime of data protection exists ${ }^{452}$ at the global level, the United Nations ${ }^{453}$ Guidelines for the Regulation of Computerized Personal Data Files (hereinafter referred to as: UN Guidelines) should be mentioned. ${ }^{454}$ The UN Guidelines contain recommendations to nations and also to governmental international organizations on what requirements and principles they should respect during the processing of personal data. The other document that must be mentioned is the OECD's Guidelines on the Protection of Privacy and Transborder Flows of Personal Data (hereinafter referred to as: OECD Guidelines). These guidelines were revised in 2013. Despite the lack of binding effect, the OECD Guidelines have particular importance as the principles $^{455}$ laid down in them are reflected worldwide in different privacy and data protection regulations. ${ }^{456}$

${ }^{450}$ See, for example, the German population census judgement from 1983.

${ }^{451}$ For example in France, where the Act for a Digital Republic introduced this right in 2016.

${ }^{452}$ On the possibilities of a global data protection regime see: Kuner, C. (2009) 'An international legal framework for data protection: Issues and prospects', Computer Law and Security Review, 25(4), pp. 307317.

${ }^{453}$ In 1968 at the United Nations International Conference on Human Rights the first serious international discussion on data protection took place. Source: Cate, F. H. (1995) 'The EU Data Protection Directive, Information Privacy, and the Public Interest', Iowa Law Review, 80(3), p. 431.

${ }^{454}$ United Nations: Guidelines for the Regulation of Computerized Personal Data Files. Adopted by General Assembly resolution 45/95 of 14 December 1990, 1990

${ }^{455}$ These principles are the following (OECD Guidelines, 1980, par. 7-14.): collection limitation principle, data quality principle, purpose specification principle, use limitation principle, security safeguards principle, openness principle, individual participation principle, accountability principle. See more on these principles at: Majtényi, L. (2008) 'Az információs jogok', in Halmai, G. and Tóth, G. A. (eds) Emberi jogok. Budapest: Osiris Kiadó, p. 586.

456 Hendrickx, F. (2000) 'Data protection and codes of conduct: self-regulation versus legislative intervention', in Blanpain, R. (ed.) Multinational Enterprises and the Social Challenges of the XXIst Century: the ILO Declaration on Fundamental Principles at Work, Public and Private Corporate Codes of Conduct. (Bulletin of Comparative Labour Relations, 37), p. 254. 
131. Regional regulation in Europe. ${ }^{457}$ The CoE's Convention for the Protection of Individuals with regard to Automatic Processing of Personal Data ${ }^{458}$ (hereinafter referred to as: Convention 108) was the first binding international document regulating the processing of personal data, ${ }^{459}$ serving as the foundation for several European countries' data protection regulation. ${ }^{460}$ Throughout the years, the adoption of Convention 108 was followed by a series of sectoral recommendations and resolutions in various fields, ${ }^{461}$ such as in the field of employment, and the Convention itself was modernized in $2018 .{ }^{462}$

132. Even though the ECHR does not contain any article expressively stating the right to the protection of personal data, the ECtHR has found a way to ensure the protection of personal data, more precisely certain data protection principles (e.g. access to personal files, deletion and correction of personal data, purpose limitation principle) under its case law relating to Article $8 .{ }^{463}$

133. National legislation: FDPA and HDPA. Although the GDPR leaves a certain margin of maneuver to the Member States, for example in the field of employment, ${ }^{464}$ it unified data protection in the EU. As neither the HDPA nor the FDPA contains employment specific provisions, their detailed general analysis will not be discussed. ${ }^{465}$ In accordance with Article 88 of the GDPR - which legitimizes Member

457 Besides the European regulation, other regional regimes exist too, such as the Asia-Pacific Economic Cooperation's (hereinafter referred to as: APEC) Privacy Framework of 2005 (revised in 2015) the Economic Community of West African States' (hereinafter referred to as: ECOWAS) Supplementary Act A/SA.1/01/10 on Personal Data Protection within ECOWAS or the Organisation of American States' General Assembly Resolution 2661 on Access to Public Information and Protection of Personal Data. Source: Mendel, T. et al. (2013) Étude mondiale sur le respect de la vie privée sur l'Internet et la liberté d'expression. Paris: Éditions Unesco (Collection Unesco sur la liberté de l'Internet), p. 73.

458 Council of Europe: Convention for the Protection of Individuals with regard to Automatic Processing of Personal Data, ETS No.108, 28 January 1981.

459 Which document was highly inspired by the French national data protection act. Source: Bioy, X. (2016) Droits fondamentaux et libertés publiques. 4e édition. Issy-les-Moulineaux: LGDJ-Lextenso éditions (Collection Cours). p. 524.

460 Council of Europe: Explanatory Report to the Protocol amending the Convention for the Protection of Individuals with regard to Automatic Processing of Personal Data. Strasbourg, 10. October 2018, par. 1.

461 See these documents at: Council of Europe (no date) Data protection. Legal instruments. Available at: https://www.coe.int/en/web/data-protection/legal-instruments(Accessed: 7 March 2018).

462 Council of Europe: Modernised Convention for the Protection of Individuals with Regard to the Processing of Personal Data. CM/Inf(2018)15-final, Elsinore, Denmark, 18 May 2018

${ }^{463}$ Gellert, R. and Gutwirth, S. (2013) 'The legal construction of privacy and data protection', Computer Law and Security Review, 29(5), p. 526. Also, see more in: Council of Europe (2017) Case Law of the European Court of Human Rights Concerning the Protection of Personal Data. T-PD(2017)23. Strasbourg. Available at: https://rm.coe.int/case-law-on-data-protection/1680766992(Accessed: 8 March 2018). Also, see what has been said in relation to the substantial differentiation between privacy and data protection.

${ }^{464}$ Article 88 of the GDPR - to be addressed later in the dissertation.

465 For more information on the French data protection legislation see more in: Frayssinet, J. (1978) La Loi du 6 janvier 1978 relative à l'informatique aux fichiers et aux libertés et le décret du 17 juillet 1978. Paris: Libr. générale de droit et de jurisprudence, Desgens-Pasanau, G. (2012) La protection des données à 
States to adopt specific provisions in the field of employment - both France and Hungary enacted employment specific data protection provisions, laid down not in the data protection acts but in the labour codes. ${ }^{466}$ Therefore, national specificities of the data protection acts will not be addressed, instead, emphasis will be put on the general provisions of the GDPR in part (b), while the employment specific privacy and data protection provisions in France and in Hungary will be addressed in Chapter 2.

\section{(a) EU framework of data protection}

134. Data protection as a fundamental right. The European Union also has its own data protection regime. The right to data protection is recognized at the EU constitutional level. Even though the right to data protection had existed before the adoption of the CFREU, the CFREU went further and - contrary to the ECHR - regulated the right to data protection as a fundamental right, separate from the right to respect for private life. ${ }^{467,468}$ The Treaty of Lisbon (2007/2009) has a great significance as it provided

caractère personnel: la loi 'Informatique et libertés'. Paris: LexisNexis; Féral-Schuhl, C. (2010) Cyberdroit: le droit à l'épreuve de l'internet. 6e édition, à jour au 15 juillet 2010 [2011-2012]. Paris: Dalloz (Praxis Dalloz). pp. 31-109.; Grynbaum, L., Le Goffic, C. and Morlet-Haïdara, L. (2014) Droit des activités numériques. Paris: Dalloz. pp. 747-784, 803-851. On the joint examination of French data protection law and the GDPR see: Bourgeois, M. (2017) Droit de la donnée : principes théoriques et approche pratique. Paris: LexisNexis. pp. 5-274.

On Hungarian data protection see more in: Jóri, A. and Soós, A. K. (2016) Adatvédelmi jog: magyar és európai szabályozás. Budapest: HVG-ORAC; Péterfalvi, A. (ed.) (2012) Adatvédelem és információszabadság a mindennapokban. Budapest: HVG-ORAC. On the 1992 data protection act see more in: Jóri, A., Hegedűs, B. and Kerekes, Z. (eds) (2010) Adatvédelem és információszabadság a gyakorlatban. Budapest: Complex; Jóri, A. (2005) Adatvédelmi kézikönvy. Budapest: Osiris Kiadó; Majtényi, L. (2006) Az információs szabadságok: adatvédelem és a közérdekü adatok nyilvánossága. Budapest: Complex.

${ }^{466}$ As they notified the European Commission: Notification à la Commission européenne de la législation française en vigueur en application des articles 49, 51, 84, 85, 88, 90 du règlement (UE) 2016/679 relatif à la protection des personnes physiques à l'égard du traitement des données à caractère personnel et à la libre circulation de ces données, et abrogeant la directive 95/46/CE - Note des autorités françaises (2018). Paris. Available

https://ec.europa.eu/info/sites/info/files/fr_notification_gdpr_articles_49_51_84_85_88_90_publish.pdf

(Accessed: 19 April 2019) and A természetes személyeknek a személyes adatok kezelése tekintetében történö védelméröl és az ilyen adatok szabad áramlásáról, valamint a 95/46/EK rendelet hatályon kivül helyezéséröl szóló (EU) 2016/679 rendeletben (általános adatvédelmi rendelet) elöírt tájékoztatási kötelezettségek teljesitéséhez szükséges informaciók(2018). XX-EUJMFO/ID/194/2/2018. Budapest. Available at: https://ec.europa.eu/info/sites/info/files/hu_notification_art_51.4_84.2_85.3_88.3_90.2_publish.pdf (Accessed: 19 April 2019).

467 De Hert, P. and Gutwirth, S. (2009) 'Data Protection in the Case Law of Strasbourg and Luxemburg: Constitutionalisation in Action', in Gutwirth, S. et al. (eds) Reinventing Data Protection? Springer, pp. 7-8. However, in contrast to this opinion, according to certain authors such as Marta Otto, the right to data protection should rather be considered as an emanation of the right to informational privacy, while Nadezhda Purtova concluded that data protection is considered to be a privacy interest in the EU legal order. Source: Otto, M. (2016) The Right to Privacy in Employment: a Comparative Analysis. Oxford, Portland: Hart Publishing. p. 113. and Purtova, N. (2010) 'Private Law Solutions in European Data Protection: Relationship to Privacy, and Waiver of Data Protection Rights', Netherlands Quarterly of Human Rights, 28(2), p. 198. ${ }^{468}$ CFREU: Article 8, Protection of personal data: 
the CFREU legally binding force and also incorporated the right to data protection into Article $16^{469}$ of the Treaty on the Functioning of the European Union (hereinafter referred to as: TFEU). ${ }^{470}$

135. The (previous) data protection directive. In 1995 the EU adopted Directive 95/46/EC on the protection of individuals with regard to the processing of personal data and on the free movement of such data, ${ }^{471}$ which was described as "the most comprehensive and successful international instrument of data protection laws" $" 472,473$ and which was highly inspired by Convention $108 .{ }^{474}$ The DPD adopted a technology-neutral approach. The CJEU also dealt with data protection in several of its cases. ${ }^{475}$

136. Data protection reform. For more than 20 years the DPD was the central document of data protection in the EU. In 2016 - though the process started back in $2009^{476}$ - an important event happened in the history of data protection: in the frame of the

"1. Everyone has the right to the protection of personal data concerning him or her.

2. Such data must be processed fairly for specified purposes and on the basis of the consent of the person concerned or some other legitimate basis laid down by law. Everyone has the right of access to data which has been collected concerning him or her, and the right to have it rectified.

3. Compliance with these rules shall be subject to control by an independent authority."

${ }^{469}$ Article 16 of the TFEU (ex Article 286 TEC):

"1. Everyone has the right to the protection of personal data concerning them.

2. The European Parliament and the Council, acting in accordance with the ordinary legislative procedure, shall lay down the rules relating to the protection of individuals with regard to the processing of personal data by Union institutions, bodies, offices and agencies, and by the Member States when carrying out activities which fall within the scope of Union law, and the rules relating to the free movement of such data. Compliance with these rules shall be subject to the control of independent authorities."

470 González Fuster, G. and Gutwirth, S. (2013) 'Opening up personal data protection: A conceptual controversy’, Computer Law and Security Review, 29(5), p. 531.

${ }^{471}$ Directive 95/46/EC of the European Parliament and of the Council of 24 October 1995 on the protection of individuals with regard to the processing of personal data and on the free movement of such data. Official Journal L 281, 23/11/1995 P. 31 - 50

${ }^{472}$ Michael D. Birnhack referring to Bennett, C. J. and Raab, C. D. (2006) The governance of privacy: policy instruments in global perspective. Cambridge: MIT Press and Swire, P. P. and Litan, R. E. (1998) None of your business: world data flows, electronic commerce and the European privacy directive. Washington DC: Brookings Institution Press in: Birnhack, M. D. (2008) 'The EU Data Protection Directive: An engine of a global regime.', Computer Law \& Security Review, 24(6), p. 512.

${ }^{473}$ On the background of the adoption of the DPD see more in: Simitis, S. (1995) 'From the Market to the Polis: The EU Directive on the Protection of Personal Data, Iowa Law Review, 80(3), pp. 445-470.

${ }^{474}$ Wong, R. (2012) 'The Data Protection Directive 95/46/EC: Idealisms and realisms', International Review of Law, Computers \& Technology, 26(2-3), p. 229.

${ }^{475}$ For lack of space, these cases will not be addressed in detail. See more on the CJEU's jurisprudence in the field of data protection in: Wong, R. (2012) 'The Data Protection Directive 95/46/EC: Idealisms and realisms', International Review of Law, Computers \& Technology, 26(2-3), pp. 229-244.; Laudati, L. (2016) Summaries of EU Court Decisions Relating to Data Protection 2000-2015. OLAF. Available at: https://ec.europa.eu/anti-fraud/sites/antifraud/files/caselaw_2001_2015_en.pdf (Accessed: 28 April 2019).; European Union Agency for Fundamental Rights and Council of Europe (2018) Handbook on European data protection law: 2018 edition. Luxembourg: Publications Office of the European Union

476 De Hert, P. and Papakonstantinou, V. (2012) 'The proposed data protection Regulation replacing Directive 95/46/EC: A sound system for the protection of individuals', Computer Law and Security Review, 28(2), p. 131. 
EU's data protection reform, the DPD was replaced by the GDPR. ${ }^{477}$ Almost two decades after the adoption of the DPD, the revision of the EU data protection framework became necessary, as the developments in technology and globalization made the processing of personal data become more elaborated and less detectable. ${ }^{478}$ Also, the DPD did not result in the desired harmonisation effect. ${ }^{479}$ A reform was needed in order that the EU could ensure the effective protection of personal data in the $21^{\text {st }}$ century, too. ${ }^{480}$ This reform was composed of two documents: the GDPR was one of them. ${ }^{481}$ It is important to state that the core principles and values laid down in the DPD remain valid, and the GDPR kept the technology-neutral approach of the regulation. ${ }^{482}$ The relevant provisions of the GDPR will be further detailed in part $b$.

137. Sectoral data protection. Besides the general requirement set by the GDPR, sectoral rules must also be mentioned, as they react to the specific data protection questions raised in certain fields. The EU has also adopted sectoral data protection norms in the fields of the electronic communications sector, ${ }^{483}$ data processing by the Community Institutions and Bodies, ${ }^{484}$ data processing and criminal matters, ${ }^{485}$ data retention ${ }^{486}$ and on

477 Regulation (EU) 2016/679 of the European Parliament and of the Council of 27 April 2016 on the protection of natural persons with regard to the processing of personal data and on the free movement of such data, and repealing Directive 95/46/EC (General Data Protection Regulation). OJ L 119, 4.5.2016, p. $1-88$

${ }^{478}$ European Commission: Communication from the Commission to the European Parliament, the Council, the Economic and Social Committee and the Committee of the Regions - A comprehensive approach on personal data protection in the European Union. COM(2010) 609 final. Brussels, 4 November 2010, p. 2.

479 De Hert, P. and Papakonstantinou, V. (2012) 'The proposed data protection Regulation replacing Directive 95/46/EC: A sound system for the protection of individuals', Computer Law and Security Review, 28(2), p.131.

${ }^{480}$ de Terwangne, C., Rosier, K. and Losdyck, B. (2016) 'Lignes de force du nouveau Règlement relatif à la protection des données à caractère personnel', Revue du droit des technologies de l'information, (62), p. 6.

481 The other document was Directive (EU) 2016/680 of the European Parliament and of the Council of 27 April 2016 on the protection of natural persons with regard to the processing of personal data by competent authorities for the purposes of the prevention, investigation, detection or prosecution of criminal offences or the execution of criminal penalties, and on the free movement of such data, and repealing Council Framework Decision 2008/977/JHA. OJ L 119, 4.5.2016, p. 89-131

482 European Commission: Communication from the Commission to the European Parliament, the Council, the Economic and Social Committee and the Committee of the Regions - A comprehensive approach on personal data protection in the European Union. COM(2010) 609 final. Brussels, 4 November 2010, p. 3.

${ }^{483}$ Directive 2002/58/EC of the European Parliament and of the Council of 12 July 2002 concerning the processing of personal data and the protection of privacy in the electronic communications sector. OJ L 201, 31.7.2002, p. 37-47

${ }^{484}$ Regulation (EU) 2018/1725 of the European Parliament and of the Council of 23 October 2018 on the protection of natural persons with regard to the processing of personal data by the Union institutions, bodies, offices and agencies and on the free movement of such data, and repealing Regulation (EC) No 45/2001 and Decision No 1247/2002/EC

485 Council Framework Decision 2008/977/JHA of 27 November 2008 on the protection of personal data processed in the framework of police and judicial cooperation in criminal matters. OJ L 350, 30.12.2008, p. 60-71. replaced by Directive (EU) 2016/680 of the European Parliament and of the Council of 27 April 2016 on the protection of natural persons with regard to the processing of personal data by competent authorities 
the transfer of personal data. ${ }^{487}$ For the dissertation the specific rules laid down in the field of employment are of special importance - which will be presented in Chapter 2.

Also, the Article 29 Data Protection Working Party (hereinafter referred to as: WP29) should be mentioned. The WP29 was an independent advisory board set up by Article 29 of the DPD, which addressed various sectoral questions of data protection - e.g. employee monitoring - in several of its documents. However, as a result of the data protection reform, the WP29 was replaced by the European Data Protection Board (hereinafter referred to as: EDPB), an independent body of the EU. ${ }^{488}$ The dissertation will focus on the documents issued by the WP29, as at the time of the submission of the dissertation the EDPB has not yet addressed any document relating to data protection in the context of employment. In these documents the WP29 basically translated the general provisions set in the DPD to the special context of employment. ${ }^{489}$ Even though they did not have legally binding force, - partly due to the WP29's composition - they provide useful guidance for the Member States, and national data protection authorities take into consideration these opinions when it comes to the enforcement of national data protection rules. $^{490}$

\section{(b) General Data Protection Regulation - rules of data processing}

138. The following paragraphs will address the most important rules set by the GDPR regarding data processing. Instead of giving an exhaustive presentation of the entire

for the purposes of the prevention, investigation, detection or prosecution of criminal offences or the execution of criminal penalties, and on the free movement of such data, and repealing Council Framework Decision 2008/977/JHA. OJ L 119, 4.5.2016, p. 89-131.

${ }^{486}$ Directive 2006/24/EC of the European Parliament and of the Council of 15 March 2006 on the retention of data generated or processed in connection with the provision of publicly available electronic communications services or of public communications networks and amending Directive 2002/58/EC. OJ L 105, 13.4.2006, p. 54-63

487 2000/520/EC: Commission Decision of 26 July 2000 pursuant to Directive 95/46/EC of the European Parliament and of the Council on the adequacy of the protection provided by the safe harbour privacy principles and related frequently asked questions issued by the US Department of Commerce (notified under document number C(2000) 2441) (Text with EEA relevance.) OJ L 215, 25.8.2000, p. 7-47 replaced by Commission Implementing Decision (EU) 2016/1250 of 12 July 2016 pursuant to Directive 95/46/EC of the European Parliament and of the Council on the adequacy of the protection provided by the EU-U.S. Privacy Shield (notified under document C(2016) 4176. OJ L 207, 1.8.2016, p. 1-112

${ }^{488}$ Recital (139) of the GDPR

489 These documents will be addressed in a later part of the dissertation.

490 Otto, M. (2016) The Right to Privacy in Employment: a Comparative Analysis. Oxford, Portland: Hart Publishing p. 97. and Retzer, K. and Lopatowska, J. (2011) 'How to Monitor Workplace E-Mail and Internet in Europe: The Polish Perspective'. Privacy \& Security Law Report, Bureau of National Affairs. Available at: https://media2.mofo.com/documents/110718-privacy-and-security-law-report.pdf (Accessed: $2 \quad$ May 2018). p. 2. 
data protection regime, or the most important changes compared to the DPD, ${ }^{491}$ the dissertation will only focus on the provisions which have higher relevancy in the context of employee monitoring and the protection of employees' right to privacy and right to data protection $^{492}$ and on the challenges raised by SNSs in relation to employment. Adequate knowledge of these provisions is necessary in order to be able to address the specific challenges raised by SNSs in the employment context. ${ }^{493}$

139. Changes brought by the GDPR. The GDPR kept the technology-neutral nature and the core values ${ }^{494}$ of the DPD and applies to all kinds of processing, regardless of the technology used. ${ }^{495}$ One of the most striking differences between the instruments is that the EU legislators choose to regulate data protection by a regulation instead of the previous directive, unifying data protection law throughout Europe.

140. Data processing in the employment context. Although having a regulation instead of a directive indeed leads to more uniformity, it does not mean that no differences will exist between Member State regulations, as in certain questions the GDPR empowers Member States to adopt specific rules. Particularly, Article 88 of the GDPR contains special provisions regarding processing in the employment context, stating that Member

491 On the differences between the DPD and the GDPR with special regard to SNSs see more in: Lukács, A. (2017) 'Adatvédelmi irányelv és rendelet, avagy hogyan változott a közösségi oldalakra vonatkozó szabályozás az Európai Unió adatvédelmi reformjával?’, in Homoki-Nagy, M. and Hajdú, J. (eds) Ünnepi kötet dr. Zakar András c. egyetemi tanár 70. születésnapjára. Szeged: Szegedi Tudományegyetem Állam- és Jogtudományi Kar, pp. 125-139.

492 On the detailed and exhaustive analysis of the GDPR see: Jay, R. et al. (2017) Guide to the General Data Protection Regulation: a companion to data protection law and practice (4th edition). London: Sweet \& Maxwell; Rücker, D. and Kugler, T. (eds) (2018) New European General Data Protection Regulation. A Practitioner's Guide. München, Oxford, Baden-Baden: C.H. Beck, Hart, Nomos; Bensoussan, A. (ed.) (2018) Règlement européen sur la protection des données: textes, commentaires et orientations pratiques. Bruxelles: Bruylant; Beaugrand, T. et al. (2017) Protection des données personnelles: se mettre en conformité d'ici le 25 mai 2018. Montrouge: Editions législatives; Prévost, S. and Royer, E. (eds) (2018) Le RGPD. Paris: Dalloz. Jóri, A. et al (2018) A GDPR magyarázata. Edited by A. Jóri. Budapest: HVG-ORAC; Péterfalvi, A., Révész, B. and Buzás, P. (eds) (2018) Magyarázat a GDPR-ról. Budapest: Wolters Kluwer Hungary; Bölcskei, K. (2019) GDPR Kézikönyv 2.0. Budapest: Vezinfó Kiadó és Tanácsadó Kft.; de Terwangne, C., Rosier, K. and Losdyck, B. (2016) 'Lignes de force du nouveau Règlement relatif à la protection des données à caractère personnel', Revue du droit des technologies de l'information, (62), pp. 556.

493 Throughout this part references will be made to the text of the GDPR and also to the different documents issued by the WP29 to clarify how these general provisions should be interpreted in the employment context. Though the WP29 existed under the auspices of the DPD, and not the GDPR, the inclusion of its documents is justified by the following: as it was already noted, despite the reform, the core values and principles of data protection remain valid, therefore the statements of the WP29 can keep providing guidance adequately and with caution.

${ }^{494}$ European Commission (2010) Communication from the Commission to the European Parliament, the Council, the Economic and Social Committee and the Committee of the Regions - A comprehensive approach on personal data protection in the European Union. COM(2010) 609 final. Brussels, p. 3.

${ }^{495}$ Recital (15) of the GDPR 
States can provide for more specific rules in order to ensure employees' right to data protection. ${ }^{496}$ Such rules should include suitable and specific measures to safeguard the data subject's human dignity, legitimate interests and fundamental rights, with particular regard to, amongst others, monitoring systems at the workplace. ${ }^{497}$ This means - as there is no unified "EU labour law" - that some differences between Member State regulations might still exist in the future in the field of employment monitoring, giving rise to certain national specificities.

141. Definition of personal data according to the GDPR. On SNSs users (employees) share a myriad of personal data. According to Paragraph 1 of Article 4 of the GDPR, personal data "means any information relating to an identified or identifiable natural person ('data subject') [...]'. The EU purposefully adopted such a wide definition, ${ }^{498}$ and the GDPR provides more guidance by adding a list of examples: "[...] in particular by reference to an identifier such as a name, an identification number, location data, an online identifier or to one or more factors specific to the physical, physiological, genetic, mental, economic, cultural or social identity of that natural person[.]" An employee's name, phone number, e-mail address, image, the metadata regarding their communication, IP address, online identifiers, ${ }^{499}$ etc. all qualify as personal data. ${ }^{500}$ The GDPR requires to fulfil stricter conditions ${ }^{501}$ when it comes to the processing of "special categories of personal data", such as personal data revealing racial or ethnic origin, political opinions, religious or philosophical beliefs, or trade union membership, and the processing of genetic data ${ }^{502}$, biometric data ${ }^{503}$ for the purpose of uniquely identifying a

${ }^{496}$ Schultis, C. (2017) 'Le traitement de données dans le cadre des relations de travail dans le règlement sur la protection des données personnelles', Dalloz IP/IT, (5), p. 266. Article 88 of the GDPR: Processing in the context of employment: "1. Member States may, by law or by collective agreements, provide for more specific rules to ensure the protection of the rights and freedoms in respect of the processing of employees' personal data in the employment context, in particular for the purposes of the recruitment, the performance of the contract of employment, including discharge of obligations laid down by law or by collective agreements, management, planning and organisation of work, equality and diversity in the workplace, health and safety at work, protection of employer's or customer's property and for the purposes of the exercise and enjoyment, on an individual or collective basis, of rights and benefits related to employment, and for the purpose of the termination of the employment relationship."

${ }^{497}$ WP29 (2017) Opinion 2/2017 on data processing at work. 17/EN WP 249. p. 9.

${ }^{498}$ WP29 (2007) Opinion 4/2007 on the concept of personal data. 01248/07/EN WP 136. p. 4.

499 Recital (30) of the GDPR

${ }^{500}$ As concerns what is qualified as personal data see more in: WP29 (2007) Opinion 4/2007 on the concept of personal data. 01248/07/EN WP 136.

${ }^{501}$ As a main rule, Article 9 of the GDPR prohibits the processing of such data and then provides exception from this prohibition.

502 Paragraph 13 of Article 4 of the GDPR: “'genetic' data means personal data relating to the inherited or acquired genetic characteristics of a natural person which give unique information about the physiology or 
natural person, data concerning health ${ }^{504}$ or data concerning a natural person's sex life or sexual orientation, per se prohibiting their processing with certain exceptions (Article 9) and defines genetic data, biometric data and data concerning health. On SNSs, a user often shares information that is qualified as sensitive data. For example, through sharing relationship status and identifying with whom the employee is in relationship can reveal his/her sexual orientation. The liking of the pages of certain political parties or politicians, posts, or comments made under posts, confirming the attendance at certain political events can reveal one's political opinions. The same goes for religious and philosophical beliefs.

142. Definition of data processing according to the GDPR. Data processing is defined as "any operation or set of operations which is performed on personal data or on sets of personal data, whether or not by automated means, such as collection, recording, organisation, structuring, storage, adaptation or alteration, retrieval, consultation, use, disclosure by transmission, dissemination or otherwise making available, alignment or combination, restriction, erasure or destruction [.]" (Paragraph 2 of Article 4) It is also a wide definition, basically any operation made on personal data falls under the notion of processing (e.g. consulting a Facebook profile, making a screenshot of it, etc.). Even though nowadays most processings are conducted by automatic means (e.g. with the help of a computer or a mobile device), ${ }^{505}$ the GDPR does not exclude manual processing, as these kinds of activities are also capable of posing a threat to the rights and interests of data subjects, protected by the GDPR. ${ }^{506}$

143. Participants of the processing according to the GDPR. As concerns the parties participating in the processing: the data controller ${ }^{507}$ is the actor (natural or legal person, public authority, agency or other body) who, alone or jointly with others, determines the purpose and means of the processing of personal data; or the data

the health of that natural person and which result, in particular, from an analysis of a biological sample from the natural person in question;"

${ }^{503}$ Paragraph 14 of Article 4 of the GDPR: "'biometric data' means personal data resulting from specific technical processing relating to the physical, physiological or behavioural characteristics of a natural person, which allow or confirm the unique identification of that natural person, such as facial images or dactyloscopic data;",

504 Paragraph 15 of Article 4 of the GDPR: “'data concerning health' means personal data related to the physical or mental health of a natural person, including the provision of health care services, which reveal information about his or her health status; ",

${ }^{505}$ European Union Agency for Fundamental Rights and Council of Europe (2018) Handbook on European data protection law: 2018 edition. Luxembourg: Publications Office of the European Union. p. 99.

506 Rücker, D. and Kugler, T. (eds) (2018) New European General Data Protection Regulation. A Practitioner's Guide. München, Oxford, Baden-Baden: C.H. Beck, Hart, Nomos. p. 11.

${ }^{507}$ Paragraph 7 of Article 4 of the GDPR 
processor, ${ }^{508}$ who processes personal data on behalf of the controller. ${ }^{509}$ The GDPR introduces the notion of joint controllers: if two or more controllers jointly determine the purposes and means of processing, they will qualify as joint controllers. They should adopt an arrangement detailing their respective responsibilities in order to comply with their obligations regarding the data processing. ${ }^{510}$ Depending on the circumstances of the processing, the employer can qualify either as controller/joint controller or processor. The employee/former employee/job candidate will qualify as the data subject: ${ }^{.11}$ the identified or identifiable natural person to whom the personal data relates.

144. Scope of the GDPR. Regarding the material scope of the GDPR: it applies to data processing conducted wholly or partly by automated means, and also to processing which is not conducted by automatic means but which forms or is intended to form part of a filing system. ${ }^{512,} 513$ The WP29 clearly stated that monitoring employees' e-mail or Internet use, video surveillance or the processing of sound data clearly falls under the scope of the regulation and also stated that usually most manual records are also likely to fall under the scope of the regulation. ${ }^{514,515}$ The WP29 also declared that the data protection requirements are to be applied to the case of processing prospective employees' personal data obtained from SNSs during the recruitment process. ${ }^{516}$ By analogy, I suggest that it should also apply to the processing of employees ' personal data obtained from SNSs.

145. According to its territorial scope, the GDPR applies to processing when the controller or the processor has an establishment in the EU (Paragraph 1 of Article 3) or when the controller or the processor does not have an establishment within the territory of

\footnotetext{
${ }^{508}$ Paragraph 9 of Article 4 of the GDPR

${ }^{509}$ On the notion of controller and processor see more in: WP29 (2010) Opinion 1/2010 on the concepts of 'controller' and 'processor'. 00264/10/EN WP 169.

${ }^{510}$ Article 26 of the GDPR

${ }^{511}$ Paragraph 1 of Article 4 of the GDPR

512 Paragraph 6 of Article 4 of the GDPR: “'filing system' means any structured set of personal data which are accessible according to specific criteria, whether centralised, decentralised or dispersed on a functional or geographical basis[.]"

${ }^{513}$ Paragraph 1 of Article 2 of the GDPR

514 WP29 (2001) Opinion 8/2001 on the processing of personal data in the employment context. 5062/01/EN/Final WP 48. p. 13.

${ }^{515}$ Article 2 of the GDPR defines some exceptions from its scope, such as processing:

- relating to activities falling outside the scope of EU law,

- relating to the common foreign and security policy of the EU,

- by a natural person for purely personal or household activity,

- relating to criminal matters and public security,

- conducted by EU bodies and institutions.
}

However, these provisions do not affect the applicability of the GDPR to processing in the employment context.

${ }^{516}$ WP29 (2017) Opinion 2/2017 on data processing at work. 17/EN WP 249. p. 11. 
the EU but the processing relates either to the offering of goods or services to data subjects in the EU, or to the monitoring of data subjects' behaviour within the EU. (Paragraph 2 of Article 3). Therefore, the GDPR applies if the employer is situated within the EU or the monitoring aims at employees' behaviour on SNS within the EU.

146. Data protection principles according to the GDPR. Principles of data processing are orienting principles ${ }^{517}$ and constitute the cornerstone of the GDPR. ${ }^{518}$ They apply to every data processing activity and play a huge part in interpreting the provisions of the GDPR, thus helping the data controller to establish a lawful processing ${ }^{519}$ and also courts to interpret the GDPR. ${ }^{520}$ These principles govern the processing of personal data and aim to ensure the protection of the individual. They are not new, the core of them is the same as those defined by previous data protection instruments. ${ }^{521}$ These principles are wide and general provisions, which have to be considered as a guideline and framework for the processing. Throughout the GDPR specific provisions complement these general principles. $^{522}$ Every data processing has to comply with the following principles: lawfulness, ${ }^{523}$ purpose limitation, ${ }^{524}$ fairness, ${ }^{525}$ data minimization, ${ }^{526}$ accuracy, ${ }^{527}$ transparency, ${ }^{528}$ storage limitation, ${ }^{529}$ integrity and confidentiality, ${ }^{530}$ accountability. ${ }^{531}$

\footnotetext{
${ }^{517}$ Péterfalvi, A., Révész, B. and Buzás, P. (eds) (2018) Magyarázat a GDPR-ról. Budapest: Wolters Kluwer Hungary, p. 95.

518 Mali, P. (no date) GDPR Articles with Commentary \& EU Case Laws, p. 14.

519 Bölcskei, K. (2019) GDPR Kézikönyv 2.0. Budapest: Vezinfó Kiadó és Tanácsadó Kft, p. 74.

520 Voigt, P. and von dem Bussche, A. (2017) The EU General Data Protection Regulation (GDPR). A Practical Guide. Springer, p. 84.

${ }^{521}$ de Terwangne, C., Rosier, K. and Losdyck, B. (2016) 'Lignes de force du nouveau Règlement relatif à la protection des données à caractère personnel', Revue du droit des technologies de l'information, (62), p. 18.

522 Rücker, D. and Kugler, T. (eds) (2018) New European General Data Protection Regulation. A Practitioner's Guide. München, Oxford, Baden-Baden: C.H. Beck, Hart, Nomos. pp. 49-50.

${ }^{523}$ Item a) of Paragraph 1 of Article 5 of the GDPR

${ }^{524}$ Item b) of Paragraph 1 of Article 5 of the GDPR

${ }^{525}$ Item a) of Paragraph 1 of Article 5 of the GDPR

${ }^{526}$ Item c) of Paragraph 1 of Article 5 of the GDPR. This principle was previously called "Proportionality principle" in the documents of the WP29.

${ }^{527}$ Item d) of Paragraph 1 of Article 5 of the GDPR

${ }^{528}$ Item a) of Paragraph 1 Article 5 of the GDPR

${ }^{529}$ According to this principle, personal data shall be "kept in a form which permits identification of data subjects for no longer than is necessary for the purposes for which the personal data are processed" (Item e) of Paragraph 1 of Article 5 of the GDPR) with certain exceptions. Recital (39) of the GDPR expressively states that the period of storing personal data is limited to a strict minimum. This principle can be understood as the temporal aspect of the necessity principle. Source: Rücker, D. and Kugler, T. (eds) (2018) New European General Data Protection Regulation. A Practitioner's Guide. München, Oxford, Baden-Baden: C.H. Beck, Hart, Nomos. p. 70.

${ }^{530}$ Integrity and confidentiality: personal data shall be processed "in a manner that ensures appropriate security of the personal data, including protection against unauthorised or unlawful processing and against accidental loss, destruction or damage, using appropriate technical or organisational measures. ” [Item f) of Paragraph 1 of Article 5 of the GDPR] This provision aims to ensure the security of the personal data themselves, by obliging the employer to implement appropriate technical or organizational measures in order
} 
Especially the principles of purpose limitation, accuracy, data minimization and transparency are considerably challenged by SNSs. These specific challenges will be dealt with in Part II. of the dissertation, here, the following paragraphs will focus on their general presentation.

147. Lawfulness means that the data processing must have one of the six legal grounds defined in Article 6 of the GDPR. ${ }^{532}$ In the employment context some of them (namely consent, performance of a contract, legitimate interests) ${ }^{533}$ are more commonly applied than the others, therefore only these are going to be addressed in detail.

One of the possible legal grounds is consent. However, the WP29 expressed on several occasions that the applicability of consent as a legal ground of processing in the employment context is highly questionable. According to the GDPR, consent is a " [...] freely given, specific, informed and unambiguous indication of the data subject's wishes by which he or she, by a statement or by a clear affirmative action, signifies agreement to the processing of personal data relating to him or her[.]" (Paragraph 11 of Article 4) In

to ensure that the personal data processed are secure and safe from outside intrusion. [WP29 (2002) Working document on the surveillance of electronic communications in the workplace. 5401/01/EN/Final WP 55. p. 18.] Further provisions on data security can be found in Articles 32-34 of the GDPR detailing the obligations of controllers and processors.

${ }^{531}$ Accountability: the employer, as data controller is responsible for compliance with these principles and also shall be able to demonstrate compliance. Article 24 further develops the responsibility of the controller by stating that depending on the circumstances of the processing, the controller shall adopt appropriate technical and organisational measures to ensure and to be able to demonstrate that processing is performed in accordance with the GDPR. The controller shall also review those measures. (Paragraph 1 of Article 24) Compliance might be demonstrated through the adherence to approved code of conducts or approved certification mechanisms. (Paragraph 3 of Article 24) The controller can demonstrate compliance - amongst others - through the adoption of internal policies, implementing the principles of data protection by design and by default, appointing a data protection officer implementing data minimisation and transparency or using pseudonymisation. [Recital (78) of the GDPR] The stakes are high: data subjects have the right to an effective judicial remedy against a controller or processor and can lodge a complaint with a supervisory authority if they consider that controllers or processors infringe or are in non-compliance with the regulation. (Article 79 of the GDPR) In the most severe cases, administrative fines up to 20 million euros, (or up to $4 \%$ of the total worldwide annual turnover of the preceding financial year in the case of an undertaking) can be imposed. (Paragraph 5 of Article 83 of the GDPR)

${ }^{532}$ Recital (40) of the GDPR

These six possible legal grounds are:

- consent,

- performance of a contract or when processing is necessary in order to take steps at the request of the data subject prior to entering into a contract,

- compliance with a legal obligation to which the controller is subject,

- vital interests of the data subject or of another natural person,

- performance of a task carried out in the public interest or in the exercise of official authority vested in the controller,

- legitimate interests.

${ }^{533}$ Kajtár, E. and Mestre, B. (2016) 'Social networks and employees' right to privacy in the pre-employment stage: some comparative remarks and interrogations', Hungarian Labour Law E-journal, (1), p. 33 Note: the authors' statement relates to pre-employment background checks. 
Recital (43) the GDPR further states that consent shall not constitute a valid legal ground when its freely given nature is not ensured, such as in cases when there is a clear imbalance between the controller and the data subject. This provision is in harmony with the WP29's previously manifested opinion, according to which the reliance on consent should be limited, as there is a hierarchal relationship between the parties, questioning the genuinely free nature of consent. ${ }^{534}$ If the employer asked the employees to consent to the installation of a monitoring or surveillance system (e.g. monitoring their use of SNSs or processing personal data obtained from SNSs), employees might not consent freely, as they fear the possible consequences of a refusal. Therefore, consent should not constitute the valid legal ground of employee monitoring. ${ }^{535,536}$

SNSs raise questions, as the employer might take advantage of his/her position to obtain access to certain content posted by the employees. For example, in the US case Pietrylo v. Hillstone Restaurant the employer accessed a private chat room where employees had a discussion, by obtaining the login credentials of one of the employee, who gave them to the employer in the fear of getting in trouble in the case of not complying with the request. ${ }^{537}$ Also, there are no clear social conventions about social media use, ${ }^{538}$ which can have an effect on consent - for example, what should the employee do if the employer adds him/her as a "friend"? Can the employee ignore the friend request without consequences or is he/she "obliged" to accept it? However, Emmanuel Plasschaert points out that the formulation of Recital (155) ${ }^{539}$ implicitly implies that the EU legislator did not want to prohibit completely the use of consent as a legitimate

534 WP29 (2001) Opinion 8/2001 on the processing of personal data in the employment context. 5062/01/EN/Final WP 48. p. 23., WP29 (2017) Opinion 2/2017 on data processing at work. 17/EN WP 249. p. 23.

535 WP29 (2002) Working document on the surveillance of electronic communications in the workplace. 5401/01/EN/Final WP 55. p. 21.

536 This does not mean that consent as a valid legal ground is completely missing from the employment relationship. The WP29 provides an example of employees consenting to the upload of their photos into their intranet profiles. Source: WP29 (2011) Opinion 15/2011 on the definition of consent. 01197/11/EN WP187. p. 14.

${ }^{537}$ Pietrylo v. Hillstone Restaurant Group (2009), Civil Case No. 06-5754 (FSH). United States District Court, D. New Jersey, 25 September.

538 Van Eecke, P. and Truyens, M. (2010) 'Privacy and social networks', Computer Law and Security Review, 26(5), p. 536.

539 “Member State law or collective agreements, including 'works agreements', may provide for specific rules on the processing of employees' personal data in the employment context, in particular for the conditions under which personal data in the employment context may be processed on the basis of the consent of the employee [...]." 
ground in the employment context. ${ }^{540}$ In my opinion, because of the hierarchal relationship between the parties, employee's consent should not constitute a legitimate legal ground for the processing of his/her personal data present on SNSs.

148. Another possible legal ground - especially during recruitment - is performance of a contract or when processing is necessary in order to take steps at the request of the data subject prior to entering into a contract: when without the processing of personal data the contract between the parties could not be executed, the processing of these data will be considered lawful. For example, one of the main obligations of the employer - to pay the employee - necessarily comes with the processing of his/her bank account number. ${ }^{541} \mathrm{Or}$, in order to enter into contract with a prospective employee, the processing of certain personal data - such as name, date of birth, data relating to education and professional experience, etc. - is inevitable during the recruitment process. However, employee monitoring is likely to be considered as processing going beyond the performance of a contract, ${ }^{542}$ necessitating the application of another legal ground. Also, prior to entering into contract, a detailed background check following a candidate's application should not be understood as necessary for entering into contract. ${ }^{543}$

Data processing is lawful when it is necessary for the purposes of the legitimate interests pursued by the employer, except when these interests are overridden by the data subjects' fundamental rights and freedoms. ${ }^{544}$ This provision requires a balancing, an assessment of whether the controller's legitimate interests can override the data subject's reasonable expectations of privacy and data protection. ${ }^{545}$ The WP29 pointed out that the legitimate interests of the employer can constitute a valid legal ground of employee monitoring. ${ }^{546}$ The WP29 emphasizes that this legal ground should not be treated as a last resort, which applies automatically when no other legal ground can be evoked, but has to

\footnotetext{
540 Plasschaert, E. (2017) 'La licéité du traitement de données personnelles du travailleur au regard du nouveau Règlement (UE) n 2016/679 sur la protection des données', in Ragheno, N. (ed.) Data protection \& privacy: le GDPR dans la pratique. Limal: Anthemis, pp. 113-114.

541 WP29 (2001) Opinion 8/2001 on the processing of personal data in the employment context. 5062/01/EN/Final WP 48. p. 15.

542 WP29 (2014) Opinion 06/2014 on the notion of legitimate interests of the data controller under Article 7 of Directive 95/46/EC. 844/14/EN WP 217. p. 17.

543 WP29 (2014) Opinion 06/2014 on the notion of legitimate interests of the data controller under Article 7 of Directive 95/46/EC. 844/14/EN WP 217. p. 18.

${ }^{544}$ Item $\mathrm{f}$ ) of Paragraph 1 of Article 6 of the GDPR

545 Recital (47) of the GDPR

546 WP29 (2002) Working document on the surveillance of electronic communications in the workplace. 5401/01/EN/Final WP 55. pp. 16-17., WP29 (2017) Opinion 2/2017 on data processing at work. 17/EN WP 249. pp. 7-8.
} 
fulfil severe conditions and involve a careful balancing of the two opposite sides in order to be considered lawful. ${ }^{547}$ The field of employee monitoring is considered to be a field where the balancing of legitimate interests can take place. ${ }^{548}$ Besides the employer's legitimate interests, the employees' rights also have to be taken into consideration: what impact would the processing have on these rights (e.g. what kind of data will be processed and how, what is the relation between the controller and the data subject) ${ }^{549}$ Also, the implementation of additional safeguards is crucial when striking the balance. ${ }^{550}$ This means that although the legitimate interest can constitute a valid legal ground for employee monitoring, it does not apply automatically: the balancing test must be implemented, ${ }^{551}$ carefully assessing the two sides. In my opinion, this is the legal ground that in most cases can be applied to the cases of SNS monitoring. 552

149. Purpose limitation is a principle bearing utmost importance ${ }^{553}$ and requires that every data processing shall have a specified, explicit and legitimate purpose and shall not be further processed in a manner incompatible with the original purpose. ${ }^{554}$ This means that - even when there is a valid legal ground justifying the processing - every processing shall have a specific purpose, the employer cannot process data "just in case" it is useful one day. This principle has huge importance, as determining the purpose is considered to be a precondition for the whole processing and application of the other principles. It also sets the boundaries of the processing. ${ }^{555}$ In the employment context different purposes

\footnotetext{
547 WP29 (2014) Opinion 06/2014 on the notion of legitimate interests of the data controller under Article 7 of Directive 95/46/EC. 844/14/EN WP 217. p. 9. Then the WP29 provides further guidance in this Opinion regarding how the balancing test should be implemented. See also: Péterfalvi, A., Révész, B. and Buzás, P. (eds) (2018) Magyarázat a GDPR-ról. Budapest: Wolters Kluwer Hungary, p. 131.

548 WP29 (2014) Opinion 06/2014 on the notion of legitimate interests of the data controller under Article 7 of Directive 95/46/EC. 844/14/EN WP 217. pp. 24-25.; Péterfalvi, A., Révész, B. and Buzás, P. (eds) (2018) Magyarázat a GDPR-ról. Budapest: Wolters Kluwer Hungary, p. 133.

549 WP29 (2014) Opinion 06/2014 on the notion of legitimate interests of the data controller under Article 7 of Directive 95/46/EC. 844/14/EN WP 217.pp. 36-41.

${ }^{550}$ WP29 (2014) Opinion 06/2014 on the notion of legitimate interests of the data controller under Article 7 of Directive 95/46/EC. 844/14/EN WP 217.pp. 42-48.

${ }^{551}$ Bölcskei, K. (2019) GDPR Kézikönyv 2.0. Budapest: Vezinfó Kiadó és Tanácsadó Kft., pp. 62-63.

552 However, as remarked by Edit Kajtár and Bruno Mestre, when it comes to pre-employment background checks, the application of the 'balancing test' is also dubious, as the employer's legitimate interest to find the best candidate possible can be achieved through less intrusive methods. Kajtár, E. and Mestre, B. (2016) 'Social networks and employees' right to privacy in the pre-employment stage: some comparative remarks and interrogations', Hungarian Labour Law E-journal, (1), p. 33.

${ }^{553}$ Péterfalvi, A., Révész, B. and Buzás, P. (eds) (2018) Magyarázat a GDPR-ról. Budapest: Wolters Kluwer Hungary, p. 96.

554 WP29 (2001) Opinion 8/2001 on the processing of personal data in the employment context. 5062/01/EN/Final WP 48. p. 20; Jóri, A. et al. (2018) A GDPR magyarázata. Edited by A. Jóri. Budapest: HVG-ORAC, p. 195.

555 Péterfalvi, A., Révész, B. and Buzás, P. (eds) (2018) Magyarázat a GDPR-ról. Budapest: Wolters Kluwer Hungary, p. 96.; WP29 (2013) Opinion 03/2013 on purpose limitation. 00569/13/EN WP 203. p. 4.
} 
might have relevancy originating from the employer's legitimate interests and rights (such as assessing whether a job candidate is adequate for the position, monitoring employees' performance, monitoring the adequate use of the employer's equipment, safety or monitoring the compliance with a non-compete clause). ${ }^{556}$ The purpose determines the whole processing activity: for example, if an employer started a processing for the purpose of ensuring safety, then this original purpose determines the rest of the processing: this data cannot be used to monitor, for example, employees' behaviour. ${ }^{557}$

In the case of SNS, the legitimate purpose might be, for example, to monitor whether employees truly spend working hours working (and not surfing on Facebook instead), whether they respect the possible restrictions imposed by the employer on the personal use of work computers, whether employees respect the employer's reputation (and do not post defamatory content on SNSs or bring shame to the employer in other ways), whether the job candidate is the best who could be employed, etc.

150. According to the WP29, in order for processing to be fair, personal data "must be processed in a way that does not bring about unfairness to the data subject." 558 This imposes an additional test on controllers. However, the definition of fairness is not given, leaving room for the interpretation of this principle. ${ }^{559}$ It is closely connected to the principle of transparency - the Recitals of the GDPR ${ }^{560}$ mention fairness together with the principle of transparency ("fair and transparent processing") ${ }^{561}$-, but they are not synonymous concepts. The principle of fairness goes beyond transparency and can be interpreted as the requirement to process personal data in an ethical way. ${ }^{562,563}$

151. According to data minimisation, personal data must be adequate, relevant and limited to what is necessary in relation to the purposes for which they are processed. It

556 WP29 (2001) Opinion 8/2001 on the processing of personal data in the employment context. 5062/01/EN/Final WP 48. pp. 6-7.

557 WP29 (2002) Working document on the surveillance of electronic communications in the workplace. 5401/01/EN/Final WP 55. p. 14.

558 WP29 (2001) Opinion 8/2001 on the processing of personal data in the employment context. 5062/01/EN/Final WP 48. p. 18.

${ }^{559}$ See more examples in: Bölcskei, K. (2019) GDPR Kézikönyv 2.0. Budapest: Vezinfó Kiadó és Tanácsadó Kft, p. 80.

${ }^{560}$ Recitals (39), (60) and (71) of the GDPR

561 Rücker, D. and Kugler, T. (eds) (2018) New European General Data Protection Regulation. A Practitioner's Guide. München, Oxford, Baden-Baden: C.H. Beck, Hart, Nomos. pp. 51-52.

562 European Union Agency for Fundamental Rights and Council of Europe (2018) Handbook on European data protection law: 2018 edition. Luxembourg: Publications Office of the European Union. p. 119.

${ }^{563}$ An example is ensuring the presence of the employee when searching through his/her professional e-mail account. Source: NAIH/2019/51/11., p. 19. 
places further limitations regarding what personal data the employer can process: the processing of personal data has to be necessary in order to achieve the purpose: ${ }^{564}$ the employer must consider whether the monitoring is truly needed, or the same result could be achieved through traditional forms of monitoring. ${ }^{565}$ Any monitoring shall be proportionate and the least intrusive possible ${ }^{566}$ compared to the purpose of the processing. For example, if the employer prohibits the use of social media at the workplace during working hours, then he/she should only monitor whether employees visit these sites, he/she must not monitor the content of these websites. ${ }^{567}$ The WP29 emphasizes that when it comes to electronic monitoring, prevention should be more important than detection. ${ }^{568}$ Instead of monitoring the access to these "prohibited" sites, blocking of access or the use of pop-up warning windows should be considered. ${ }^{569}$ Monitoring should be tailored to the circumstances of the processing: continuous and automatic monitoring should be avoided. ${ }^{570}$ It is advisable that in accord with the purpose, the risks, etc., limitation in scope, time or place are applied.

152. The principle of accuracy means that personal data shall be accurate and, where necessary, kept up-to-date. When personal data are inaccurate, every reasonable step, with regard to the purpose of the processing, shall be taken that these data are erased or rectified without delay. ${ }^{571}$ The GDPR does not provide a definition of 'accurate': data are considered to be inaccurate if they do not correspond with reality and also if they are not complete or are embedded into the wrong context. ${ }^{572}$

153. Transparency requires that employees shall be aware of the characteristics of the processing (e.g. identity of the controller, what kind of personal data are processed,

\footnotetext{
${ }^{564}$ Péterfalvi, A., Révész, B. and Buzás, P. (eds) (2018) Magyarázat a GDPR-ról. Budapest: Wolters Kluwer Hungary, p. 101.

565 WP29 (2002) Working document on the surveillance of electronic communications in the workplace. 5401/01/EN/Final WP 55. p. 13.

566 Jóri, A. et al. (2018) A GDPR magyarázata. Edited by A. Jóri. Budapest: HVG-ORAC, p. 208.; WP29 (2001) Opinion 8/2001 on the processing of personal data in the employment context. 5062/01/EN/Final WP 48. p. 4, p. 21, p. 25.; WP29 (2017) Opinion 2/2017 on data processing at work. 17/EN WP 249. p. 7.

567 WP29 (2002) Working document on the surveillance of electronic communications in the workplace. 5401/01/EN/Final WP 55. p. 24.

568 WP29 (2017) Opinion 2/2017 on data processing at work. 17/EN WP 249. p. 23.

569 WP29 (2002) Working document on the surveillance of electronic communications in the workplace. 5401/01/EN/Final WP 55. p. 15, p. 18.

570 WP29 (2002) Working document on the surveillance of electronic communications in the workplace. 5401/01/EN/Final WP 55. p. 17

${ }^{571}$ Jóri, A. et al. (2018) A GDPR magyarázata. Edited by A. Jóri. Budapest: HVG-ORAC, p. 215.

572 Rücker, D. and Kugler, T. (eds) (2018) New European General Data Protection Regulation. A Practitioner's Guide. München, Oxford, Baden-Baden: C.H. Beck, Hart, Nomos. p. 68.
} 
for what purpose, risks associated with the processing, what rights they have as data subjects and how they can exercise them), these pieces of information shall be easily accessible and easy to understand by using clear and pain language. ${ }^{573}$ This means that employers need to be open and clear about data processing, as a main rule covert monitoring is not permitted. ${ }^{574}$ Naturally, if employees are not aware of the processing/monitoring, they will not be able to exercise their rights, ${ }^{575}$ therefore transparency of processing is a precondition for being able to exercise data subjects' rights. It relates also back to the population census judgement and to the core of the right to informational self-determination, as the German Federal Constitutional Court considered it crucial for the exercise of fundamental rights that the individual is aware of who processes, what data and why, etc. ${ }^{576}$ It is not enough to state that the use of the Internet or social network sites will be monitored, further details regarding the processing shall be provided. The principle of transparency is further strengthened by Articles 12-14 regulating the controller's obligation to inform data subjects regarding the processing (the data subject's right to information) $)^{577}$ and also by the data subject's right to access (Article 15).

154. Rights of the data subject according to the GDPR. Already existing rights were reinforced and new ones were introduced in order to ensure effective protection of the individuals. ${ }^{578}$ The employee has the right to information - which was already discussed in relation to the employer's obligation to inform employees regarding the processing. However, employees have the right to obtain information not only at the time of the collection of personal data, but also during the processing. Therefore, in the frame of the right to access, the employee has the right to know whether the employer processes his/her personal data, and if there is processing taking place, the employee can obtain further information regarding it (e.g. what the purpose is, what personal data are processed, etc.) and also has the right to obtain a copy of the processed personal data. ${ }^{579}$ The right to

\footnotetext{
${ }^{573}$ Recital (39) of the GDPR

574 WP29 (2002) Working document on the surveillance of electronic communications in the workplace. 5401/01/EN/Final WP 55. p. 14.

575 WP29 (2017) Opinion 2/2017 on data processing at work. 17/EN WP 249. p. 10.

576 Simitis, S. (1995) 'From the Market to the Polis: The EU Directive on the Protection of Personal Data, Iowa Law Review, 80(3), pp. 447-448.

577 Depending on the given country's regulation - that is the case, for example, in Hungary and in France, further requirements, such as the information of works council might be necessary in order to make the processing lawful.

578 Bounedjoum, A. (2016) 'Réforme européenne des données personnelles : les nouveautés pour les droits des personnes', JCP E Semaine Juridique, (22), p. 44.

${ }^{579}$ Article 15 of the GDPR
} 
rectification guarantees that at the demand of the employee, inaccurate personal data shall be rectified, incomplete personal data completed. ${ }^{580}$

155. The right to be forgotten is one of the novelties introduced by the GDPR, though not completely new as it already existed in the Directive. ${ }^{581}$ It means "the right of individuals to have their data no longer processed and deleted when they are no longer needed for legitimate purposes." 582 This right has two aspects. ${ }^{583}$ The first one is the "traditional" right to erasure, which means that "[t]he data subject shall have the right to obtain from the controller the erasure of personal data concerning him or her without undue delay and the controller shall have the obligation to erase personal data without undue delay [...]" if other conditions are met. (Paragraph 1 of Article 17) It is completed by a second provision in order to strengthen the data subjects' rights in the online world: with the obligation of the data controller to take all the reasonable steps to inform other controllers processing those data that the data subject wants these controllers to erase the data, any links to it, any copies or replication if the controller has made the data - subject to the right to erasure - public. [Recital (66), Paragraph 2 of Article 17] Of course, the right to be forgotten is not an absolute right; there exist some interests that justify that the right to be forgotten does not prevail in some cases: e.g. freedom of expression, or historical, scientific research. (Paragraph 3 of Article 17)

The reason for the acceptance of the right to be forgotten is that, while the human mind has its limits in remembering, the Internet does not have any limits. ${ }^{584}$ However, the concrete way of the implementation of this right is still a question, as right now the Internet is not capable of forgetting, as it is not possible to permanently remove content. ${ }^{585}$ Still, this right is a great step in protecting personal data, however, it might be more accurate to interpret it as the right to not to be found, as complete erasure from the Internet is

\footnotetext{
580 Article 16 of the GDPR

${ }^{581}$ See more on this subject: Bunn, A. (2015) 'The curious case of the right to be forgotten', Computer Law and Security Review, 31(3), pp. 336-350.

582 European Commission (2010) Communication from the Commission to the European Parliament, the Council, the Economic and Social Committee and the Committee of the Regions - A comprehensive approach on personal data protection in the European Union. COM(2010) 609 final. Brussels. p. 8.

${ }^{583}$ European Digital Rights (no date) 'Key aspects of the proposed General Data Protection Regulation explained: What are they? Why are they important? What are common misconceptions? What can be improved?' Available at: https://edri.org/files/GDPR-key-issues-explained.pdf(Accessed: 1 May 2018). p. 6. ${ }^{584}$ Kindt, E. (2015) 'Privacy and Data Protection Law: An Introduction'. IC1206 Training School: Deidentification for privacy protection in multimedia content 07-11 October 2015, Limassol, Cyprus, 11 October.

585 Bolton, R. L. (2014) 'The Right to Be Forgotten: Forced Amnesia in a Technological Age', The John Marshall Journal of Information Technology \& Privacy Law, 31(2), p. 133.
} 
technically not possible. ${ }^{586}$ Several users have possessed an SNS profile for years now: if these platforms are used actively, a considerable amount of personal data is accumulated with a huge part of them being irrelevant to the purposes of the employment. ${ }^{587}$

156. Novelties brought by the GDPR. The GDPR introduces new ways beyond the traditional legal protection, by regulating the technology itself, by making it more privacy-friendly. Three principles make this possible: data protection by design, data protection by default and data protection impact assessment. ${ }^{588}$ Data protection by design ${ }^{589}$ basically means - after the analogy of privacy by design - the use of built-in data protection-friendly solutions into the whole designing of the processing. ${ }^{590}$ Data protection by default ${ }^{591}$ means that controllers should ensure that personal data is processed with the highest privacy protection. Data protection impact assessment means the evaluation of the possible risks related to the protection of personal data, prior to the processing. In cases when data processing comes with higher risks for the rights of the individual, the controller should evaluate these risks in a data protection impact assessment, by taking into

586 International Working Group on Data Protection in Telecommunications (2013) Working Paper and Recommendations on the Publication of Personal Data on the Web, Website Contents Indexing and the Protection of Privacy. 675.46.32. pp. 1-2.

587 The right to data portability, introduced by the GDPR, is another Internet specific right, it enables interoperability between different service providers. [Recital (68) of the GDPR] It consists of two parts: the first part is the right to obtain a copy of the personal data processed by the controller in a structured way, and the second one is the right to transmit this personal data to another service provider. Source: Costa, L. and Poullet, Y. (2012) 'Privacy and the regulation of 2012', Computer Law and Security Review, 28(3), p. 257.

According to the right to restriction of processing, the data subject has the right to obtain the restriction of processing from the controller when certain conditions are met. (Article 18 of the GDPR) Employees have the right to object when the processing is based on the legitimate interest ground (or on the performance of a task carried out in the public interest), on grounds related to their particular situations. In such a case the burden of proof is on the employer to demonstrate that his/her legitimate interest overrides the interests or the fundamental rights and freedoms of the employees (or the processing is for the establishment, exercise or defence of legal claims). [Article 21 and Recital (69) of the GDPR] Finally, the employees also have the right not to be subject to a decision based solely on automated processing, including profiling, which would produce a legal effect concerning him/her or would similarly significantly affect the employee. (Paragraph 1 of Article 22 of the GDPR) This means that employees have the right not to be subject to decisions made without human intervention. [Recital (71) of the GDPR]

588 Costa, L. and Poullet, Y. (2012) 'Privacy and the regulation of 2012', Computer Law and Security Review, 28(3), p. 259.

589 " [...] the controller shall, both at the time of the determination of the means for processing and at the time of the processing itself, implement appropriate technical and organisational measures, such as pseudonymisation, which are designed to implement data-protection principles, such as data minimisation, in an effective manner and to integrate the necessary safeguards into the processing in order to meet the requirements of this Regulation and protect the rights of data subjects." (Par. 1 of Article 25 of the GDPR)

590 De Hert, P. and Papakonstantinou, V. (2012) 'The proposed data protection Regulation replacing Directive 95/46/EC: A sound system for the protection of individuals', Computer Law and Security Review, 28(2), p. 260.

591 " $[\mathrm{t}]$ he controller shall implement appropriate technical and organisational measures for ensuring that, by default, only personal data which are necessary for each specific purpose of the processing are processed. That obligation applies to the amount of personal data collected, the extent of their processing, the period of their storage and their accessibility." (Paragraph 2 of Article 25) 
consideration the characteristics of the processing. [Recital (83), Article 35] Employee monitoring will likely fall under the notion of "high risk" processing, placing an obligation on employers to conduct a data protection impact assessment. ${ }^{592,593}$

157. In conclusion, the GDPR is one of the most recent milestones in the history of data protection. Regulating the question of data protection in the form of a regulation strengthened and unified data protection law throughout the EU - even with the possibility of adopting more specific regulations in certain fields, for example, in the field of employment; leaving room for certain divergences between Member States. In spite of these divergences, the provisions presented above are cornerstones of the data protection framework. Their knowledge will be essential in assessing the processing of employees' personal data obtained from SNSs, as these are the principles and rights that are going to be tested.

\section{(B) The right to informational self-determination in France and in Hungary}

158. Nowadays, the right to privacy and the right to data protection continue to be challenged by new innovations. Isabelle Falque-Pierrotin, president of the French data protection authority drew attention to the changes regarding the relations between the right to privacy and the right to data protection caused by the appearance of a certain grey zone. This grey zone emerges when individuals want to share certain aspects of their personal life and to use their personal data to create a "public life": who, instead of seeking protection, wish to be able to have control over their personal data. ${ }^{594}$ Therefore, besides the right to privacy and the right to data protection, another concept, the right to informational self-determination appeared as well in legal literature and order. Before addressing how the right to informational self-determination is regulated in France and in

\footnotetext{
592 Employee monitoring update (2017) TaylorWessing. Available at: https://www.taylorwessing.com/globaldatahub/article-employee-monitoring-update.html (Accessed: 1 May 2018).

${ }^{593}$ The aim of the assessment is to ensure the security and confidentiality of the processing. When there is a high risk which might cause difficulties to the controller in ensuring the appropriate measures, a consultation of the supervisory authority shall take place. [Recital (84) of the GDPR] It is considered to be easier to ensure the protection of privacy and personal data if the risks endangering them are taken into account in the early stages of the planning of the processing. Source: European Commission (2010) Comparative study on different approaches to new privacy challenges, in particular in the light of technological developments. JLS/2008/C4/011 - 30'CE'0219363/00'28. par. 131.

594 Assemblé Nationale: Commission de réflexion et de propositions sur le droit et les libertés à l'âge du numérique, Mercredi 26 novembre 2014, Séance de 17 heures, Compte rendu $\mathrm{n}^{\circ}$ 08, Available at: http://www.assemblee-nationale.fr/14/cr-comnum/14-15/c1415008.asp Accessed: 2017. 02. 26.
} 
Hungary, it is necessary to clarify the conceptual foundations of the right and what the right to informational self-determination means in the international context.

\section{(a) Conceptual foundations}

159. Population census judgement. The right to informational self-determination first appeared in 1983 in the famous population census judgement of the German Federal Constitutional Court. In the background of this decision there is an act regulating a planned population census. This act resulted in a public outcry, as citizens feared the consequences of processing such a wide range of personal data, with a considerable amount of time for retention and used for several purposes. The Act was challenged before the German Federal Constitutional Court, which upheld the general aim of the population census, but required several obligations to safeguard the processing of personal data. ${ }^{595}$

In its reasoning the Court argued that the provisions to be applied are the provisions of the Basic Law guaranteeing the general right to the free development of one's personality [Article 2(1)] and the right to dignity [Article 1 (1)]. These two provisions aim to protect the value and the dignity of the individual, who functions as a member of a free society in free self-determination. The Court emphasized that in the light of the rapid technological developments allowing more elaborate data processing, the individual's decisional authority needs special protection. ${ }^{596}$ Protection shall be granted not only to the processing of personal data having a "special private or intimate character", but also to "trivial data" as with modern data processing - through the combination of data conclusions about the individual could be drawn even from these data ${ }^{597}$ Even under these circumstances of modern data processing, the individual shall be granted the freedom to make decisions freely and without influence. ${ }^{598}$ The right to informational selfdetermination means that individuals are free to decide whether, who, for what purposes, etc. can process personal data relating to them. ${ }^{599}$

\footnotetext{
${ }^{595}$ Hornung, G. and Schnabel, C. (2009) 'Data protection in Germany I: The population census decision and the right to informational self-determination', Computer Law \& Security Review, 25(1), p. 85.

${ }^{596}$ Kommers, D. P. and Miller, R. A. (2012) The constitutional jurisprudence of the Federal Republic of Germany. 3rd edn. Durham and London: Duke University Press. p. 409.

597 Lauth, M. (2009) Thematic Legal Study on assessment of data protection measures and relevant institutions. Report on Germany. FRA. Available at: https://fra.europa.eu/sites/default/files/role-dataprotection-authorities-2009-de.pdf. p. 8.

${ }^{598}$ Kommers, D. P. and Miller, R. A. (2012) The constitutional jurisprudence of the Federal Republic of Germany. 3rd edn. Durham and London: Duke University Press. p. 410.

${ }^{599}$ Simitis, S. (2010) 'Privacy - An Endless Debate', California Law Review, 98(6), p. 1997.
} 
The Court emphasized the interconnectedness of the ensuring of the right to informational self-determination and other fundamental rights, noting that if the individual is uncertain about whether, who, for what purposes etc. processes his/her personal data, instead of acting according to his/her will -, he/she will conform and adopt a behaviour that he/she thinks is considered to be in conformity with the data processors' expectations. ${ }^{600}$ This could lead to the impairment of other fundamental rights (e.g. right to freedom of expression), damaging also the functioning of a free democratic society. Therefore, the protection against the unlimited processing of personal data must be guaranteed - based on the right to freely develop his/her personality and the right to dignity. The Court also notes that this right is not unlimited, and the individual shall accept certain limitations on the grounds of a compelling public interest. ${ }^{601}$ Instead of providing exclusive control to the individual, the State should process the personal data in a manner respecting the rights of the individuals, a legitimate aim, and compliance with certain principles - such as proportionality, data minimisation, obligations of the data controller, rights of the data subject - is required. ${ }^{602}$ Incidentally, although these data protection principles appeared in the population census judgement, up to now they constitute the key data protection principles. ${ }^{603}$

160. Right to informational self-determination according to the legal literature. Since the appearance of the right to informational self-determination, scholars have also addressed this right. The right to informational self-determination can be connected both to privacy and to data protection: De Hert and Gutwirth point out that the right to informational self-determination can be interpreted as one of the values underlying the right to privacy and to data protection. ${ }^{604}$

\footnotetext{
${ }^{600}$ Simitis, S. (1995) 'From the Market to the Polis: The EU Directive on the Protection of Personal Data, Iowa Law Review, 80(3), pp. 447-448.

${ }^{601}$ Kommers, D. P. and Miller, R. A. (2012) The constitutional jurisprudence of the Federal Republic of Germany. 3rd edn. Durham and London: Duke University Press. p. 410.

${ }^{602}$ Schwartz, P. (1989) 'The Computer in German and American Constitutional Law: Towards an American Right of Informational Self-Determination', The American Journal of Comparative Law, 37(4), p. 690, Kommers, D. P. and Miller, R. A. (2012) The constitutional jurisprudence of the Federal Republic of Germany. 3rd edn. Durham and London: Duke University Press. p. 410., Hornung, G. and Schnabel, C. (2009) 'Data protection in Germany I: The population census decision and the right to informational selfdetermination', Computer Law \& Security Review, 25(1), p. 87.

${ }^{603}$ Hornung, G. and Schnabel, C. (2009) 'Data protection in Germany I: The population census decision and the right to informational self-determination', Computer Law \& Security Review, 25(1), p. 87.

${ }^{604}$ De Hert, P. and Gutwirth, S. (2009) 'Data Protection in the Case Law of Strasbourg and Luxemburg: Constitutionalisation in Action', in Gutwirth, S. et al. (eds) Reinventing Data Protection?Springer, p. 5.
} 
161. Different scholars emphasize the connectedness of informational selfdetermination's to privacy: Eva Fialová associates it with informational privacy, and also remarks that informational self-determinations aims to ensure the control over personal data - similarly to informational privacy suggested by Westin. ${ }^{605}$ Jacky Richard goes even beyond privacy and data protection and interprets the right to data protection as a defensive concept, while self-determination implies a positive content. It goes beyond the protection of the right to privacy by ensuring - instead of guaranteeing protection from interference that the individual is able to freely decide how to exercise his/her rights. ${ }^{606} \mathrm{He}$ also states that in this regard, the right to informational self-determination does not constitute a separate right, but rather a fundamental principle which gives meaning to the interpretation and guaranteeing of other fundamental rights. ${ }^{607}$

162. In contrast, Antoinette Rouvroy and Yves Poullet limit the scope of informational self-determination and argue that it should not be interpreted as selfdetermination, but rather as a precondition to exercising self-determination. ${ }^{608}$ Others emphasize its connection to data protection: the right to informational self-determination can be understood as a step in the evolution of data protection - for example, Viktor Mayer-Schönberger examined a shift towards self-determination as part of the third generation of data protection rules. ${ }^{609}$ Similarly, González Fuster and Gutwirth understood the appearance of the right to informational self-determination in German law as the redefinition of the main rules relating to data protection. ${ }^{610,611}$ De Hert calls for the need of

\footnotetext{
${ }^{605}$ Fialová, E. (2014) 'Data Portability and Informational Self-determination', Masaryk University Journal of Law and Technology, 8(1), p. 47.

${ }^{606}$ However, it should not be forgotten that the individual is not completely free to decide regarding every processing: in many instances he/she cannot withdraw from the data processing. Therefore, the use of the expression informational co-determination might be more appropriate. Source: Bygrave, L. A. (2001) The Place of Privacy in Data Protection Law. Available at: http://www.austlii.edu.au/au/journals/UNSWLJ/2001/6.html(Accessed: 28 February 2018), par. [8]

607 Richard, J. (2016) 'Le numérique et les données personnelles: quels risques, quelles potentialités ?', Revue du Droit public (RDP), 1, p. 91.

${ }^{608}$ Rouvroy, A. and Poullet, Y. (2009) 'The Right to Informational Self-Determination and the Value of SelfDevelopment: Reassessing the Importance of Privacy for Democracy', in Gutwirth, S. et al. (eds) Reinventing Data Protection? Springer, p. 51.

${ }^{609}$ Mayer-Schönberger, V. (1997) 'Generational Development of Data Protection in Europe', in Agre, P. E. and Rotenberg, M. (eds) Technology and Privacy: The New Landscape. Cambridge: MIT Press, p. 229.

${ }^{610}$ González Fuster, G. and Gutwirth, S. (2013) 'Opening up personal data protection: A conceptual controversy', Computer Law and Security Review, 29(5), p. 534.

${ }^{611}$ Nadezhda Purtova went even further and called the right to information self-determination the German equivalent of data protection. Purtova, N. (2010) 'Private Law Solutions in European Data Protection: Relationship to Privacy, and Waiver of Data Protection Rights', Netherlands Quarterly of Human Rights, 28(2), p. 186.
} 
revising existing data protection regulation in order to decrease the traditionally protective aspect and the passive role of the individual by providing him/her a more active role. ${ }^{612}$

\section{(b) Right to informational self-determination in France and in Hungary}

163. Act for a Digital Republic. In France, data protection is traditionally considered as a defensive concept, but the developments of ICT challenged this concept. ${ }^{613}$ Recognizing the changes brought by these developments, the legislator decided to step towards a more proactive protection. By adopting the Act for a Digital Republic in 2016, 614 significant changes were introduced to the FDPA.615 Among these changes, the appearance of the concept of informational self-determination should be mentioned in the first place.

Inspired by the German Federal Constitutional Court's population census judgement, now the FDPA refers to the right to informational self-determination through stating that "[t]he individuals' right to decide and to control the uses of personal data relating to him/her" must be ensured as provided by the GDPR and by the FDPA. ${ }^{616}$ Although the already existing data subject rights provided the possibility for the individual to participate in the processing, they did not ensure the true control over that data. ${ }^{617}$ According to the reasoning of the Act, this amendment was an answer to the loss of control over personal data and contributes to the interpretation of the already existing data protection rights. ${ }^{618}$

164. Instead of considering it a separate right, Falque-Pierrotin understands the right to informational self-determination as "[...] a kind of 'umbrella right' which covers the specific rights on the protection of personal data. "619 The right to informational self-

${ }^{612}$ De Hert, P. (2008) 'Identity management of e-ID, privacy and security in Europe. A human rights view', Information Security Technical Report, 13(2), p. 74.

613 Falque-Pierrotin, I. (2012) 'La Constitution et l'Internet', Les nouveaux cahiers du Conseil constitutionnel, 36, pp. 36-37.

${ }^{614}$ Act No. 2016-1321 of 7 October 2016 for a Digital Republic (“Loi n 2016-1321 du 7 octobre 2016 pour une République numérique)

${ }^{615}$ Such as the right to be forgotten for minors or provisions relating to post-mortem data protection. See more on the reforms introduced by the act in: Richard, J. (2016) 'Le numérique et les données personnelles : quels risques, quelles potentialités ?', Revue du Droit public (RDP), 1, pp. 87-100.; Masnier-Boché, L. (2016) 'Loi «pour une République numérique»: état des lieux en matière de protection des données personnelles', Revue Lamy droit de l'immatériel, 131, pp. 50-55.

${ }^{616}$ Article 1 of the FDPA

${ }^{617}$ CNIL (2017) Rapport d'activité 2016. Paris, La documentation française, p. 40.

${ }^{618}$ Exposé des motifs: Act No. 2016-1321 of 7 October 2016 for a Digital Republic

619 "[...] une sorte de droit chapeau qui abriterait les droits spécifiques sur la protection des données personnelles. "Source: Assemblé Nationale: Commission de réflexion et de propositions sur le droit et les 
determination should not be considered as a new right of the data subject, ${ }^{620}$ but a principle providing sense to all these rights, a guiding principle of the French data protection act, aiming to provide the data subject the control over his/her personal data. ${ }^{621}$

165. Informational self-determination in the Hungarian legal order. The right to informational self-determination has been present in the Hungarian system since the Constitutional Court's Decision No. 15/1991. (IV. 13.), in which the Constitutional Court defined the right to informational self-determination ${ }^{622}$ as "the right to decide about the disclosure and use of [the individual's] personal data." "623 Since 1991 the Constitutional Court has interpreted the right to data protection as a right to informational selfdetermination. One of the greatest and most disputed decisions in the field of data protection $^{624}$ was decision No. 15/1991. (IV. 13.), in which the Constitutional Court stated as a general legal principle that the right to data protection shall be interpreted as a right to informational self-determination, interpreting it as an active right, rather than a defensive one. ${ }^{625,} 626$ The Constitutional Court provided a detailed analysis regarding the content of this right - requirement of purpose limitation, rights of the data subject, legal ground of processing, etc. - laying down the fundaments of Hungarian data protection regulation and the fundaments of the data protection act to be adopted. ${ }^{627,628}$

166. In Hungarian doctrine, instead of interpreting them as separate rights, the notions of data protection and informational self-determination are closely connected: András Jóri interpreted the right to data protection as a right conferring the right on the

libertés à l'âge du numérique, Mercredi 26 novembre 2014, Compte rendu $\mathrm{n}^{\circ}$ 08, Available at: http://www.assemblee-nationale.fr/14/cr-comnum/14-15/c1415008.asp Accessed: 2017. 02. 26. p. 9.

${ }^{620}$ Conseil d'Etat (2014) Le numérique et les droits fondamentaux. Les rapports du Conseil d'Etat, p. 26.

${ }^{621}$ Bruguière, J.-M. et al. (2017) 'Actualité du droit de l'internet (février - octobre 2016)', Revue Lamy Droit civil, (144). p. 32., Richard, J. (2016) 'Le numérique et les données personnelles : quels risques, quelles potentialités ?', Revue du Droit public (RDP), 1, p. 91., Geffray, E. (2014) 'La protection des données personnelles, élément clé à l'ère numérique', Légipresse, (320), p. 515.

622 Szüts, K., Karsai, D. and Mándi, G. (2006) Az Alkotmánybíróság egyes határozatainak ismertetése. Budapest: Rejtjel Kiadó, p. 222.

${ }^{623}$ Constitutional Court's Decision No. 15/1991. (IV. 13.), Part II.

${ }^{624}$ Majtényi, L. (2002) 'Az információs szabadságok és az adatvédelem határai', Világosság, XLIII (2-3), p. 74.

${ }^{625}$ Decision No. 15/1991. (IV. 13.) of the Constitutional Court

${ }^{626}$ Even preceding this decision, the right to data protection was already conceived as a right to informational self-determination in László Sólyom's dissenting opinion to decision No. 2/1990 (II. 18.).

${ }^{627}$ Majtényi, L. (2002) 'Az információs szabadságok és az adatvédelem határai', Világosság, XLIII (2-3) p. 74. and Sólyom, L. (2001) Az alkotmánybiráskodás kezdetei Magyarországon. Budapest: Osiris Kiadó. p. 466.

${ }^{628}$ Similar to the French precedents, this cornerstone decision concerned the adoption of a general and unified personal identification number - which the Constitutional Court found unconstitutional. 
individuals to determine the processing of their personal data. ${ }^{629}$ Gergely László Szöke interprets the right to informational self-determination as a phenomenon affecting the development of the second generation of data protection rules. ${ }^{630}$ Similarly to data protection, the right to informational self-determination aims to ensure the protection of the private sphere. ${ }^{631}$ As it is interpreted as an active right, this primarily relates to privacy interpreted as the right to choose how to live one's life, ${ }^{632}$ and not to privacy interpreted as secrecy.

167. Despite the interpretation of the right to data protection as a right to informational self-determination, inconsistencies can be found in Hungarian legislation. Regarding the wording of the previous constitution ("protection of personal data"), former Hungarian data protection commissioner, László Majtényi, expressed his opinion according to which the wording as such is erroneous because it suggests that the right to data protection is a defensive right, while in reality it shall be conceived as the right to informational self-determination. ${ }^{633}$ It is interesting to note that the legislator did not correct this mistake when adopting the new constitution, despite the fact that the Constitutional Court interpreted the right to data protection as a right to informational selfdetermination and that the new data protection act is also entitled as the act on the right to informational self-determination. ${ }^{634}$ The HDPA is entitled as the "Act on the Right to Informational Self-Determination and on Freedom of Information", however, the expression "informational self-determination" is not present in the text of the HDPA. Naturally, through the regulation of the purpose limitation principle or the rights of the data subjects, the right to information self-determination prevails without being specified.

168. In conclusion, though the appellation suggests that it constitutes a separate right, I understand the above-presented views as suggesting that instead of a separate right,

${ }^{629}$ Jóri, A. and Soós, A. K. (2016) Adatvédelmi jog: magyar és európai szabályozás. Budapest: HVG-ORAC, p. 15.

${ }^{630}$ Szőke, G. L. (2013) 'Az adatvédelem szabályozásának történeti áttekintése', Infokommunikáció és jog, (3), p. 110.

${ }^{631}$ Péterfalvi, A. (2014) 'Személyiségi jogok - adatvédelem - információszabadság', Magyar jog, 61(9), p. 487.

${ }^{632}$ For example, Máté Dániel Szabó interprets this right in an extensive way, as according to him the right to informational self-determination implies that the individuals are entitled to decide to "show themselves to the world”. Source: Szabó, M. D. (2008) ‘Nyilvános magánszféra - Hol a határ?’, in Dezső, M. and Kukorelli, I. (eds) Ünnepi kötet Sári János egyetemi tanár 70. születésnapja tiszteletére. Budapest: Rejtjel Kiadó, p. 335.

${ }^{633}$ Majtényi, L. (1995) 'Az adatvédelem és az információszabadság az alkotmányban', Acta Humana: Emberi jogi közlemények, (18-19), p. 96.

${ }^{634}$ Béla Pokol expressed in his paralell reasoning that the Constitutional Court shall respect the decision of the legislator not to insert into the Fundamental Law the terminology suggested by the Constitutional Court. Source: par. 144 of Decision no. 32/2013 (XI. 22.) 
the right to informational self-determination constitutes a guiding principle of privacy and/or data protection law, emphasizing the active aspect of these rights. This is also supported by the fact that the expression "right to informational self-determination" is not mentioned either in the DPD or in the GDPR ${ }^{635}$ Neither in France, nor in Hungary does the right to informational self-determination constitute a right separate from data protection. The right to information self-determination appeared relatively late in French data protection law, but not as a separate right. Incorporated into the FDPA, it is conceived as a guiding principle of French data protection law, emphasizing the importance of ensuring that the individual exercises true control over his/her personal data. In Hungary, the right to data protection is interpreted as a right to informational self-determination, being an active right. According to the preamble of the HDPA, the Act was adopted in order to ensure the right to informational self-determination. Like in French law, instead of constituting a separate right, it rather remains a guiding principle.

169. Conclusions of Chapter 1. When it comes to the protection of employees' personal life while using SNSs, the examination of notably the right to privacy and the right to data protection (and the right to informational self-determination) is necessary. Knowing the scope of these rights is necessary to address the question from a narrower viewpoint: Chapter 2 will focus on their enforcement in the employment context. Although privacy seems to be an ever-changing, highly context-dependent concept and right, international and national legal regulations declare the protection of this right. Secrecy and concealment have traditionally played an important role, however, recently the protection of privacy in public has gained more recognition, moving it away from the original concept of secrecy. It appeared notably through the evolving practice of the ECtHR, and the creation of the concept "personal life", specific to labour law, by the French Social Chamber. Therefore, privacy is interpreted in a broad way for the purposes of the dissertation, guaranteeing for the individual to be able to decide how to live his/her life. With regard to social media, it will mean that the employee should be free to decide whether and how to use these sites.

Compared to the right to privacy, the right to data protection possesses a more exact set of tools with regard to ensuring the protection of employees' rights, as in contrast to the quite general declaration of respect of private life, data protection is composed of detailed

${ }^{635}$ Even though Recital (7) of the GDPR declares that "[n]atural persons should have control of their own personal data." 
provisions, regulating the whole data processing. In relation to SNSs, the importance of data protection will consist of providing the rules that must be respected when the employer processes personal data obtained through these sites, including the case of monitoring such use.

The third right addressed in the Chapter was the right to informational selfdetermination. However, it was concluded that instead of being a separate right, it rather fulfills the role of an overarching guiding principle of data protection, despite its ambiguous appellation. In relation to privacy, it has a narrower scope: as its appellation implies, informational self-determination is concentrated on information (and personal data), therefore focuses on the informational aspect of privacy. In this regard, for the purposes of the dissertation informational self-determination will be understood within the right to data protection, aiming to ensure the employee to be an active participant in data processing - and not as the right of the employee to decide whether to engage in using SNSs, or as a separate right.

\section{Chapter 2: Employee control and monitoring}

170. The employer is in control of the employment relationship: he/she can unilaterally determine the conditions of the employment relationship, resulting in the subordinate position ${ }^{636}$ of the employee. ${ }^{637,}{ }^{638}$ It means that the employer is entitled to choose amongst applicants, to organize the work, and instruct employees, monitor compliance with instructions or even to sanction them. It is important to emphasize that controlling and monitoring employees is not an arbitrary decision of the employer: the employer is not only entitled to monitor employees, it is also his/her obligation at the same time. ${ }^{639}$

171. Although these rights/powers are inherent to the employment relationship itself, they are not absolute, as employees' rights - such as the right to privacy and the

\footnotetext{
${ }^{636}$ Under subordination the employee provides his/her workforce (and not his/her whole life or personality), according to his/her best knowledge, while following the employer's instructions.

${ }^{637}$ Kiss, Gy. (2003) ‘A munkajog jogforrási rendszere és az alapjogok I.', Jura, 9(1), p. 80.

${ }^{638}$ However, Jean-Emmanuel Ray raises the question whether technological development has weakend the employee's subordination through providing more autonomy to the employee. Source: Ray, J.-E. (1992) 'Nouvelles technologies et nouvelles formes de subordination', Droit social, (6), p. 1. [Page number referring to the online version of the article downloaded from: https://www-dalloz-fr.bcujas-ezp.univparis1.fr/documentation/Document?id=DS/CHRON/1992/0081 (Accessed: 19 November 2019)]

${ }^{639}$ Gyulavári, T. (ed.) (2013) Munkajog. ELTE Eötvös Kiadó. Budapest. pp. 248-249.
} 
right to data protection - impose limitations on the employer's right to monitor. ${ }^{640}$ During enforcing these powers/rights, the employer limits employees' rights, such as their right to privacy or right to data protection. Controlling and monitoring employees interfere with privacy and data protection, as posing limitations on the use of SNSs might concern the employees' personal life, while consulting whether the employee complies with such a regulation implies data processing and as such concerns data protection. However, such a limitation must not be without limits or abusive: the employer's rights must be balanced against the employees' rights - such as the right to privacy and right to data protection. As the WP29 neatly formulated: "[w]orkers do not abandon their right to privacy and data protection every morning at the doors of the workplace. " ${ }^{641}$ However, these rights are not absolute either, as they are also limited by the employer's right to monitor. ${ }^{642}$ Therefore a balance must be found between the two sides. ${ }^{643}$

172. Aim and structure of Chapter 2. The aim of Chapter 2 is to present and prove the existence of the employer's right to control and monitor, and then the present state of legal rules regulating employee monitoring, mostly using a descriptive method. The knowledge of these rules is crucial as they constitute the general framework of different emergences of employee monitoring - and amongst them social media. Chapter 2 serves as a conceptual basis for the detailed analysis of monitoring and SNSs, discussed in Part II. of the dissertation. The aim of this Chapter is to prove the existence of the employer's right to control and to monitor, but the question of how exactly this right is enforceable in the context of SNSs will be answered in Part II.

Chapter 2 is composed of two Sections: Section 1 will present what is at stake on the other side against the right to privacy and right to data protection. It will deal with how the right to monitor is acknowledged in labour law. Then, Section 2 will deal with how exactly this collision appears in the context of employment, what the already established rules at the international and national level in the field of employee monitoring are.

\footnotetext{
${ }^{640}$ Hendrickx, F. (2002) 'Protection of workers' personal data in the European Union, Two studies'. EC, pp. 23-24.

641 WP29 (2002) Working document on the surveillance of electronic communications in the workplace. 5401/01/EN/Final WP 55. p. 4.

${ }^{642}$ Plasschaert, E. (2017) 'La licéité du traitement de données personnelles du travailleur au regard du nouveau Règlement (UE) n 2016/679 sur la protection des données’, in Ragheno, N. (ed.) Data protection \& privacy: le GDPR dans la pratique. Limal: Anthemis, p. 106.

${ }^{643}$ Hajdú, J. (2005) A munkavállalók személyiségi jogainak védelme. Szeged: Pólay Elemér Alapítvány, p. 20 .
} 


\section{Section 1: The employer's right to monitor}

173. Privacy and employment. Anders J. Persson and Sven Ove Hansson emphasized the significance and specificity of the employment relationship: according to them it is the rights and obligations ensuing from the employment contract which makes workplace privacy/monitoring issues such a specific subject, compared to other kinds of relations. ${ }^{644,645}$ They argue that an intrusion into the privacy of employees must be justified by what the parties can require from each other based on the rights and obligations set forth in the employment contract. ${ }^{646}$ This supposes that the privacy issues are specific regarding the employment relationship (other kinds of legal relations such as self-employment, entrepreneurship or mandates give rise to different kinds of privacy challenges) and that the employer's right to monitor can be derived from the obligations and rights imposed on the parties.

174. Subordination and the employment relationship. Given the importance of the employment relationship, it must be examined what employment is and what its main characteristics are, making it special in the field of workplace privacy and data protection. It follows from the subordination between the employer and employee that the employer has power to exercise authority over employees. ${ }^{647}$ Frank Hendrickx identified monitoring as an element of authority and subordination, which is essential in the employment relationship. ${ }^{648}$ The Section will first explore the main characteristics of the employment relationship, and the rights and obligations ensuing from it, which also give rise to the employer's right to monitor.

175. Structure of the Section. These characteristics and the main observations drawn from them are common to industrialized societies, therefore the right to monitor will

${ }^{644}$ Persson, A. J. and Hansson, S. O. (2003) 'Privacy at Work - Ethical Criteria', Journal of Business Ethics, 42(1), p. 63.

${ }^{645}$ The ILO highlighted the significance of processing in the employment context from a different aspect stating that "[i]n hardly any other case are so many personal data processed over such a long period of time as in connection with the employment relationship." Source: ILO (1997) Protection of workers' personal data. An ILO code of practice. Geneva: International Labour Office, p. 8. (Commentary)

${ }^{646}$ Persson, A. J. and Hansson, S. O. (2003) 'Privacy at Work - Ethical Criteria', Journal of Business Ethics, 42(1), p. 64.

${ }^{647}$ Hendrickx, F. (2002) 'Privacy and Employment Law: General Principles and Application to Electronic Monitoring', in Blanpain, R. (ed.) On-line Rights for Employees in the Information Society. Use and Monitoring of E-mail and Internet at Work. The Hague: Kluwer Law International, p. 49.

648 Hendrickx, F. (2001) 'Electronic Monitoring and Employment Privacy', in Blanpain, R. (ed.) The Evolving Employment Relationship and the New Economy. The Hague/London/New York: Kluwer Law International, pp. 248. 
first be approached from $(\S 1)$ a more general angle, based on international standards and rules. The exact appearance of these general principles and rights can differ from state to state, therefore then $(\$ 2)$ it will be addressed how the right to monitor materializes in the French and in the Hungarian legal order.

\section{\$1. Rights and obligations arising from the employment relationship}

176. ILO and the employment relationship. The ILO addressed the question of the employment relationship - which is a concept common in every legal system ${ }^{649}$ - on several occasions. In a document entitled “The employment relationship. Report V(1)”, the ILO demonstrated through several examples that when it comes to the employment relationship, the most commonly used factors to describe this relationship (in order to delimitate it from other concepts) are dependency, subordination, authority, direction, supervision, control. ${ }^{650}$

177. A report and questionnaire were sent out to the Member States' governments containing different questions regarding the possible content of an ILO document. Question eleven [Qu. 11 (1)-(3)] was related to the factors and indicators determining the existence of an employment relationship, and to the question what indicators should be used in order to achieve this [Qu. 11 (3)]. Dependency, subordination, supervision, control of work, direction, authority were often evoked by governments. ${ }^{651}$ Finally, the adopted Recommendation included amongst the possible indicators that the work " [...] is carried out according to the instructions and under the control of another party $[\ldots]^{\prime \prime 652}$ The annotated guide to the Recommendation, while referring to Paragraph

${ }^{649}$ ILO (2006) The employment relationship. Report V(1). International Labour Conference, 95th Session $\mathrm{p}$. 6.

${ }^{650}$ ILO (2006) The employment relationship. Report V(1). International Labour Conference, 95th Session p. 20., p. 21.

${ }^{651}$ ILO (2006) The employment relationship. Report V(2A). International Labour Conference, 95th Session pp. $155-160$

652 ILO (2006) Recommendation concerning the employment relationship. No. 198. Geneva, 95th ILC session, par. 13 a) 
12 of the Recommendation, ${ }^{653}$ identifies control and dependence (or subordination) amongst the most important criteria. ${ }^{654}$

178. Control is considered to be an important indicator of subordination. ${ }^{655}$ In every industrial country, the employment relationship is centred on subordination and is conceived as a relation where the employer can command and the employee shall obey. ${ }^{656}$ Although the ILO is a universal organisation, the fundamental concepts laid down in these documents are relevant for European countries as well. A report prepared by members of the European Labour Law Network (hereinafter referred to as: ELLN) addressing the question of the characteristics of the employment relationship in the EU argued that " $[i] n$ all countries, the main criterion for establishing an employment relationship or an employment contract is that one person is subordinated to or dependent on another person. "657 It basically refers to the organisational subordination, ${ }^{658}$ meaning that "the employee is subjected to supervisory power exercised by the employer." ${ }^{\circ 59}$ The CJEU also confirmed that " $[t]$ he essential characteristic of the employment relationship is that for a certain period of time a person performs services for and under the direction of another person in return for which he receives remuneration". 660

This could be described by four characteristics. First, organisational subordination, which encompasses the employer's power to give instructions regarding the work: both personal and functional instructions. Second, the control of work and the supervision of employees are also considered to be crucial in most Member States. Third, the integration

653 "For the purposes of the national policy referred to in this Recommendation, Members may consider clearly defining the conditions applied for determining the existence of an employment relationship, for example, subordination or dependence."

${ }^{654}$ ILO (2007) 'The employment relationship: An annotated guide to ILO Recommendation No. 198' p. 33. On dependence and subordination see more in: ILO (2007) 'The employment relationship: An annotated guide to ILO Recommendation No. 198' pp. 33-35.

655 ILO (2007) 'The employment relationship: An annotated guide to ILO Recommendation No. 198' pp. 3536.

${ }^{656}$ Supiot, A. (2002) Critique du droit du travail. Paris: Presses universitaires de France. p. 109.

${ }^{657}$ European Network of Legal Experts in the field of Labour Law (2009) Characteristics of the Employment Relationship. Thematic Report 2009. Contract No. VC/2008/1211. p. 16.

${ }^{658}$ Economic dependency also exists, but its mere existence is not enough to establish the existence of an employment relationship. When it comes to economic dependency, the indicators of remuneration, bearing of financial risks and work performed solely or mainly for the benefit of the employer shall be examined. See more in: European Network of Legal Experts in the field of Labour Law (2009) Characteristics of the Employment Relationship. Thematic Report 2009. Contract No. VC/2008/1211. pp. 19-21.

${ }^{659}$ European Network of Legal Experts in the field of Labour Law (2009) Characteristics of the Employment Relationship. Thematic Report 2009. Contract No. VC/2008/1211. p. 16.

${ }^{660}$ CJEU (1991): Union de Recouvrement des Cotisations de Sécurité Sociale et d'Allocations Familiales de la Savoie (URSSAF) v Hostellerie Le Manoir SARL, Case C-27/91, ECLI:EU:C:1991:441, 21 November, par 7. 
of the employee into the organisation is often a relevant indicator. Finally, amongst the 'other' indicators, the provision of tools and materials by the employer and the fact that work is carried out within specific hours or at an agreed time can also be an indicator of organizational dependence. ${ }^{661}$ Another, more recent study in 2013 affirmed the importance of dependency and/or subordination when determining the existence of an employment relationship, which often involves control and the power to give instructions to employees, and provided several examples from EU Member States' legal systems. ${ }^{662}$

179. Employee monitoring. A study ${ }^{663}$ conducted back in 2001 under the supervision of Frank Hendrickx analysed the labour law regulations of EU Member States with regard to employee data protection and monitoring. This study also stated that the authority of the employer and the (legal) subordination of the employee are common factors in all Member States when it comes to the employment relationship. ${ }^{664}$ It refers to the general labour law principles and acknowledges that "these principles imply that employers have a contractually based right to control contract fulfilment and to monitor work performance and the proper use by employees of company equipment facilities. "665 Ensuing from authority and from the right to manage the workplace, the employer - who is also the owner of the company equipment - is entitled to impose certain limitations on its use. ${ }^{666}$ For example, health and safety requirements, the protection and the correct use of the employer's equipment, monitoring production processes and work performance and conducting quality control can justify employee monitoring. ${ }^{667,668}$ Moreover, the employee

${ }^{661}$ European Network of Legal Experts in the field of Labour Law (2009) Characteristics of the Employment Relationship. Thematic Report 2009. Contract No. VC/2008/1211.pp. 16-19.

662 International Labour Office, Governance and Tripartism Department and European Labour Law Network (2013) Regulating the employment relationship in Europe: A guide to Recommendation No. 198. Geneva: ILO. pp. 36-40.

${ }^{663}$ Hendrickx, F. (2002) 'Protection of workers' personal data in the European Union, Two studies'. EC.

${ }^{664}$ Hendrickx, F. (2002) 'Protection of workers' personal data in the European Union, Two studies'. EC. pp. 12-13.

${ }^{665}$ Hendrickx, F. (2002) 'Protection of workers' personal data in the European Union, Two studies'. EC. p. 114.

${ }^{666}$ Hendrickx, F. (2002) 'Protection of workers' personal data in the European Union, Two studies'. EC. p. 101.

${ }^{667}$ Hendrickx, F. (2002) 'Protection of workers' personal data in the European Union, Two studies'. EC. p. 119. More specifically, the monitoring of the use of the employer's equipment (e.g. telephone, computer, Internet) may be justified by the following lawful purposes: monitoring work performance and quality control, monitoring compliance with different standards and procedures, investigating and detecting the security of the system, preventing crimes, collecting evidence of business transactions.

${ }^{668}$ Roger Blanpain also identified property rights, the right to manage and employer's liability amongst the employer's legitimate interest to monitor (the employees' use of computer). Source: Blanpain, R. (2002) 'Employment and Labour Law Aspects. Setting the Scene. Asking the Right Questions?', in Blanpain, R. (ed.) On-line Rights for Employees in the Information Society. Use and Monitoring of E-mail and Internet at Work. The Hague: Kluwer Law International, p. 43-44. 
has not only rights, but also certain obligations such as carrying out work in person, respect and cooperate with his/her colleagues, loyalty towards the employer - where controlling the compliance with these obligations can justify monitoring.

180. Employee monitoring and SNSs. Monitoring employees' use of SNSs might contribute to the enforcement of several of these rights. In the hiring phase, it is notably the employer's right to choose the most adequate applicant that might be enforced though conducting social media background checks. Monitoring SNS use during working hours at the expense of working hours might constitute a method for the employer to enforce his/her interests and rights in the field of productivity, work performance and the protection of the work equipment. Monitoring SNS use beyond working hours can serve the purposes of protecting against employee conducts detrimental to the employer's reputation or the leaking of business interests. On the details and the possibility of monitoring employees' use of SNSs in order to achieve these interests will be dealt with in detail in Part II. of the dissertation.

\section{\$2. Appearance of the right to monitor in national legal orders}

181. It is worth noting that in the different languages used for the research different terminology is used. Hungarian literature mentions legitimate economic interests of the employer ("jogos gazdasági érdek"), as the main value is materialized in the form of the right of the employer to direct, to give orders and to control ("irányítási, utasítási és ellenörzési jogkör"). In English literature the expression right to monitor is used, while in French literature the expression employer's power ("pouvoir") is employed, comprising the prerogative to control work.

\section{(A) France: the employer's powers}

182. Employment and subordination. In both countries subordination has great importance when it comes to determining the existence of an employment relationship. In French law, subordination is a key element of the employment relationship. The Court of Cassation defined the employment contract in its jurisprudence as "a convention according to which a person engages in performing work for another person under its subordination 
for remuneration. "669 The employment contract - originally based on the idea that the worker leases his workforce ${ }^{670}$ - supposes the leasing of the employees' workforce. As the employer could not take possession of the employees' workforce, this lack was compensated by the employees' subordination to the employer. ${ }^{671}$

183. In order to be qualified as an employment contract, three attributes must be present: the employee has to (1) perform work (2) under the legal subordination of the employer (3) in exchange for remuneration. ${ }^{672}$ These main elements also appear in the definition of labour law provided by Gérard Lyon-Caen, who argued that labour law is "all the legal rules applicable to individual and collective relations between private employers and employees who work under their authority for a remuneration called salary. "673 Subordination means that the employee is under the authority of the employer and is manifested in the employer's power to give orders, and the employees' correlative obligation to obey those orders. ${ }^{674}$ According to a landmark decision of the Court of Cassation, subordination is characterised by the "execution of work under the authority of an employer who has the power to give orders and directives, to control their execution, and to sanction the breaches of the subordinates." ${ }^{675}$ Different indicators can help to determine the existence of subordination, such as the exercise of authority, the right to

669 « Le contrat de travail est une convention par laquelle une personne s'engage à travailler pour le compte d'une autre et sous sa subordination moyennant une remuneration. » la Cour de cassation du 22 juillet 1954 (Bull. civ. IV, no 576) referred to in : Le Lamy social (2019) 150. Définition du contrat de travail. Available at: shorturl.at/adoty (Accessed: 12 August 2019)

670 The origins of employment contracts can be found in Roman law, which regulated it in the form of a locatio conductio operarum, which meant the "lease of a free person's workforce for work in exchange for remuneration according to the time spent working" Although some forms of legal work existed in the age of feudalism, it was the changes caused by the industrial revolution that resulted in the transformation of work, leading to the appearance of "modern" labour law. Sources: Molnár, I. and Jakab, É. (2008) Római jog. Szeged: Leges. p. 299.; Kiss, Gy. (2005) Munkajog. Budapest: Osiris Kiadó. pp. 50-53.; Lehoczkyné Kollonay, Cs. (1997) A magyar munkajog I. Budapest: Kulturtrade Kiadó. p. 17.

${ }^{671}$ Supiot, A. (2000) 'Les nouveaux visages de la subordination', Droit social, (2), p. 132.

${ }^{672}$ Peskine, E. and Wolmark, C. (2016) Droit du travail. 11th edn. Paris: Dalloz (Hypercours Dalloz cours \& travaux dirigés). p. 27. et pp. 27-34.; Bailleul, C. and Jourdan, D. (2011) Contrat de travail: du recrutement à la rupture. 8th edn. Paris: Delmas. p. 20. et pp. 20-22.; Mementos LMD - Droit du travail 2018 p. 25. ; HessFallon, B., Maillard, S. and Simon, A.-M. (2015) Droit du travail. 24th edn. Paris: Sirey-Dalloz (Aidemémoire). p. 88, et pp.88-90. Petit, F. (2011) Droits des contrats de travail. Paris: Gualino. p. 74.

673 'L'ensemble des règles juridiques applicables aux relations individuelles et collectives qui naissent entre les employeur privés et les salariés qui travaillent sous leur autorité, moyennant une rémunération appelée salaire." Source : Ray, J.-E. (2018) Droit du travail: droit vivant. Paris: Wolters Kluwer France, p. 14.

${ }^{674}$ Kéfer, F. and Cornélis, S. (2009) 'L'arrêt "Copland” ou l'espérance légitime du travailleur quant au caractère privé de ses communications', Revue Trimestrielle des Droits de l'Homme, (79), p. 782.

675 «[...] que le lien de subordination est caractérisé par l'exécution d'un travail sous l'autorité d'un employeur qui a le pouvoir de donner des ordres et des directives, d'en contrôler l'exécution et de sanctionner les manquements de son subordonné. " Cour de cassation, chambre sociale, 13 novembre 1996, $\mathrm{N}^{\circ}$ 94-13187 
control whether employees comply, the right to impose sanctions (essential criteria), ${ }^{676}$ the employer bearing the risk of his/her activity, integration into the organisation, ${ }^{677}$ the equipment and raw material provided by the employer, work hours defined by the employer, ${ }^{678}$ the localisation of work. ${ }^{679}$ The subordinate relation originates from the submission to the employer's regulatory, directive and disciplinary power in order to perform work on behalf of the employer. ${ }^{680,681}$

184. Rights and obligations arising from the employment contract. From the definition of the employment contract itself, the main obligations and rights of the parties (connected to the three central attributes: work, remuneration and subordination) can be identified. On the one hand, the employer shall provide work for the employee; ${ }^{682}$ while on the other hand, the employee is obliged not only to work but also to be at the disposal of the employer. ${ }^{683}$ One of the employer's main obligations is to pay remuneration for the work, while the employee has the right to be remunerated.

185. Following from the criteria of subordination, the employer has different powers in relation to ensuring the appropriate functioning of the workplace. The employer has the power to manage, to regulate and to discipline, while the employee must respect the instructions of the employer. ${ }^{684}$ The power to manage comprises several elements in order to organise work and is implemented through the right to give detailed orders. Giving instructions is not only a right: the employer is also obliged to do this, as it is his/her task to tell the employee how to perform the work. At the same time, it is also his/her right and

${ }^{676}$ Bailleul, C. and Jourdan, D. (2011) Contrat de travail: du recrutement à la rupture. 8th edn. Paris: Delmas. p. 22.

${ }^{677}$ Peskine, E. and Wolmark, C. (2016) Droit du travail. 11th edn. Paris: Dalloz (Hypercours Dalloz cours \& travaux dirigés). p. 31-33.

${ }^{678}$ Hess-Fallon, B., Maillard, S. and Simon, A.-M. (2015) Droit du travail. 24th edn. Paris: Sirey-Dalloz (Aide-mémoire). p. 90.

${ }^{679}$ Petit, F. (2011) Droits des contrats de travail. Paris: Gualino. p. 75

${ }^{680}$ Mazeaud, A. (2016) Droit du travail. 10th edn. Issy-les-Moulineaux: LGDJ - Lextenso éditions. p. 339.

${ }^{681}$ Emmanuel Dockès draws attention to the fact that labour law was originally conceived based on the work performed by industrial workers. Therefore, attention should be paid when assessing the new forms of performing work. Jean-Emmanuel Ray has pointed out in one of his articles that technological changes may question the assessment of these indicators, and especially their effects on working hours and place of work might be "challenged". Sources: Dockès, E. (2004) 'Le pouvoir dans les rapports de travail: essor juridique d'une nuisance économique', Droit social, (6), p. 1. [Page number referring to the online version of the article downloaded from: https://www-dalloz-fr.bcujas-ezp.univparis1.fr/documentation/Document?id=DS/CHRON/2004/0122 (Accessed: 19 November 2019)] ; Ray, J.-E. (1992) 'Nouvelles technologies et nouvelles formes de subordination', Droit social, (6), pp. 1-4. [Page number referring to the online version of the article downloaded from: https://www-dalloz-fr.bcujasezp.univ-paris1.fr/documentation/Document?id=DS/CHRON/1992/0081 (Accessed: 19 November 2019)]

${ }^{682}$ Cour de cassation, chambre sociale, 17 février 2010, $\mathrm{N}^{\circ} 08-45298$

${ }^{683}$ Article L3121-1 of the FLC

${ }^{684}$ Article L3121-1 of the FLC 
obligation to control work and maintain work discipline. ${ }^{65}$ In accordance with these powers/rights, the employee shall perform work according to the instructions of the employer. ${ }^{686}$

186. Common rules of conduct. Both the French Labour Code ${ }^{687}$ (hereinafter referred to as: FLC) and the Hungarian Labour Code ${ }^{688}$ (hereinafter referred to as: HLC) contain some general provisions, which are present in both jurisdictions. The FLC states that the contract has to be executed in good faith, ${ }^{689}$ specify the employee's obligation of loyalty ${ }^{690}$ and contain provisions relating to the declarations of employees. ${ }^{691}$ French labour law declares that the employee has to perform work with diligence and obligation of discretion. ${ }^{692}$ The employer shall provide the necessary working conditions, ${ }^{693}$ which connects back to his/her authority: he/she shall adequately organise the work, shall manage, instruct and inform employees regarding work, shall provide the necessary knowledge for work, shall control work and shall discipline employees. In both countries in accordance with EU regulation ${ }^{694}$ - the employer has important obligations in the field of workplace safety and health: he/she shall ensure the conditions of occupational health and safety, ${ }^{695}$ while the employee shall respect safety instructions. ${ }^{696}$ The FLC also expressively regulates the issue of psychological ${ }^{697}$ and sexual harassment, ${ }^{698}$ making it the employer's obligation to prevent these issues.

187. The employer's powers. In French law, the employer, who is responsible for the organisation, management and the general functioning of the workplace, ${ }^{699}$ has certain

\footnotetext{
${ }^{685}$ Casaux-Labrunée, L. (2012) 'Vie privée des salariés et vie de l'entreprise', Droit social, (4), p. 335.

${ }^{686}$ Article L3121-1 of the FLC

${ }^{687}$ Code du travail

688 Act I of 2012 on the Labour Code

${ }^{689}$ Article L1222-1 of the FLC and Subsection (2) of Section 6 of the HLC

${ }^{690}$ Subparagraph 3 of Article L1222-5 of the FLC and Section 8 of the HLC

${ }^{691}$ From Article L1222-2 to Article L1222-4 of the FLC

${ }^{692}$ Hess-Fallon, B., Maillard, S. and Simon, A.-M. (2015) Droit du travail. 24th edn. Paris: Sirey-Dalloz, pp. 106-107.

${ }^{693}$ Hess-Fallon, B., Maillard, S. and Simon, A.-M. (2015) Droit du travail. 24th edn. Paris: Sirey-Dalloz, p. 106.

${ }^{694}$ European Union: Council Directive of 12 June 1989 on the introduction of measures to encourage improvements in the safety and health of workers at work (89/391/EEC)

${ }^{695}$ Subparagraph 1 of Article L4121-1 of the FLC

${ }^{696}$ Subparagraph 1 of Article L4122-1 of the FLC

${ }^{697}$ From Article L1152-1 to Article L1152-6 of te FLC (Also from Article L1154-1 to L1154-2 and from Article L1155-1 to Article L1155-2)

${ }^{698}$ From Article L1153-1 to Article L1153-6 of the FLC (Also from Article L1154-1 to L1154-2 and Article L1155-1 to Article L1155-2)

${ }^{699}$ Cour de cassation, chambre sociale, 25 février 1988, № $85-40821$
} 
powers to ensure its effective functioning. ${ }^{700}$ Originally, in the Brinon decision, the employer was perceived - as he/she is the one having responsibility - as the "only judge" to determine what decisions to make as regards the employees and the functioning of the workplace while complying with the legal regulations, ${ }^{701}$ which granted extensive powers to the employer. Later, these powers were limited, especially by the adoption of the Act Auroux in 1982, which regulated, and therefore imposed limitations on the internal regulations and sanctions. ${ }^{702}$ The next significant act in the subject was the act of 31 st December $1992,{ }^{703}$ which (inspired by the "Lyon-Caen report"704) inserted the famous article L120-2 $2^{705}$ into the FLC, guaranteeing the general protection of the employee's liberties and rights - at the same time imposing limitations on the employer's powers. With this article, the legislator laid down the foundations of the protection of the employee's rights and freedoms. Three different employer prerogatives are distinguished: power to manage ("pouvoir de direction"), power to regulate ("pouvoir législatif" or "pouvoir réglementaire") and power to discipline (“pouvoir disciplinaire”). ${ }^{706}$

188. The power to manage suggests two different elements: the management of the company and the management of the personnel. It follows from the principle of the entrepreneurial freedom that the employer has the prerogative to decide how to manage his/her business. As presented above, the Brinon decision acknowledged the employer's power to freely - while complying with the legal regulations - take decisions regarding his/her business. ${ }^{707,708}$ Resulting from the subordinate relationship between the parties, the

\footnotetext{
700 Originally, two theories aimed to define the source of these powers. According to the "théorie contractuelle", these powers originate from the employment contract itself, where the employee accepts the subordination by contracting, while according to "théorie institutionnelle" - notably represented by Paul Durand - these powers are born from the reality that the employee is part of the undertaking. Source: Peskine, E. and Wolmark, C. (2016) Droit du travail. 11th edn. Paris: Dalloz (Hypercours Dalloz cours \& travaux dirigés), p. 161.

${ }^{701}$ Cour de cassation, chambre sociale, 31 mai 1956, N $56-04323$

702 Act No. 82-689 of 4 August 1982 on the freedoms of employees in the workplace ("Loi n'82-689 du 4 août 1982 relative aux libertés des travailleurs dans l'entreprise")

703 Act No. 92-1446 of 31 December 1992 on employment, the development of part-time work and unemployment insurance

${ }^{704}$ Lyon-Caen, G. (1992) Les libertés publiques et l'emploi. Paris: la Documentation française (Collection des rapports officiels)

705 Article L120-2 of the FLC: "No one may limit the right of the individual or individual or collective liberties by any restriction which is not justified by the nature of the task to be performed and proportionate to the aim sought."

${ }^{706}$ Durand, P. and Jaussaud, R. (1947) Traité de droit du travail. Tome I. Paris: Dalloz, p 423.

${ }^{707}$ Cour de cassation, chambre sociale, 31 mai 1956, $\mathrm{N}^{\circ}$ 56-04323

${ }^{708}$ However, the legislator and the jurisprudence established certain limits and even obligations regarding entrepreneurial freedom. See more in: Waquet, P., Struillou, Y. and Pécaut-Rivolier, L. (2014) Pouvoirs du chef d'entreprise et libertés du salarié: du salarié-citoyen au citoyen-salarié. Rueil-Malmaison: ÉdLiaisons (Droit vivant), pp. 28-33.
} 
employer has the power to manage not only the undertaking itself, but also the personnel: he/she can decide who to hire or who to dismiss, can give instructions, can determine the tasks, can organise workflow and (not only can, but is also obliged to) control, monitor the execution. ${ }^{709}$

189. The employer's power to regulate means that the employer is empowered to establish general and permanent rules, norms relating to the functioning of the workplace, notably through the adoption of an internal regulation. ${ }^{710}$ Strict limitations were imposed on the internal regulation by the act of 4 August 1982, detailing the requirements set towards an internal regulation. Especially Article L. 122-35 inserted into the FLC is significant for the subject of the dissertation. This article (inspired by the Corona decision of the State Council) ${ }^{711}$ stated that "[the internal regulation] may not limit the rights of the individual or individual or collective liberties by any restriction which is not justified by the nature of the task to be performed and proportionate to the aim sought." The Act of 31 December 1992 extended this protection by changing the expression internal regulation to "no one". The prerogative to adopt an internal regulation has also become an obligation for employers who usually employ at least 20 employees. ${ }^{712}$ The internal regulation shall regulate the question of health and safety and work discipline (with special regard to the nature and scale of the possible sanctions). ${ }^{713}$ The FLC also addresses in detail the procedure of adopting an internal regulation ${ }^{714}$ and the rules relating to the administrative and judicial control over the internal regulation. ${ }^{715,716}$

190. The power to discipline is inherent to the employer ${ }^{717}$ and is a necessary complement to enforcing the other prerogatives. ${ }^{718}$ The employer has the power to apply

\footnotetext{
709 Waquet, P., Struillou, Y. and Pécaut-Rivolier, L. (2014) Pouvoirs du chef d'entreprise et libertés du salarié: du salarié-citoyen au citoyen-salarié. Rueil-Malmaison: ÉdLiaisons, pp. 33-39.

${ }^{710}$ Petit, F. (2011) Droits des contrats de travail. Paris: Gualino, p. 275.

${ }^{711}$ In the Corona decision the State Council stated that the examined provisions of the internal regulation in question were not justified because when the employer exercises his/her powers to ensure workplace health and safety, he/she can only limit employees' rights by a restriction necessary to achieve the aim sought. Conseil d'Etat (1980): $\mathrm{N}^{\circ} 06361$, Section, 1 février

712 Subparagraph 1 of Article L1311-2 of the FLC

${ }^{713}$ Item $1^{\circ}$ of Subparagraph 1 of Article L1321-1 of the FLC

714 Submission for the opinion of the social and economic committee and communication to the labour inspector and to labour courts and making it available to every person who has access to the place where work or recruitment takes place. Article L1321-4 and Article R1321-2 of the FLC

${ }^{715}$ From Article L1322-1 to Article L1322-3 of the FLC; Article L1322-4 and Article R1322-1 of the FLC

716 The Court of Cassation ruled that in the absence of the required consultation, the dismissal of an employee based on the infringement of the provisions of the internal regulation was considered to be void of real and serious cause. Source: Cour de cassation, chambre sociale, 9 mai 2012, $\mathrm{n}^{\circ}$ 11-13.687

${ }^{717}$ Cour de cassation, chambre sociale, 16 juin 1945

${ }^{718}$ Durand, P. and Jaussaud, R. (1947) Traité de droit du travail. Tome I. Paris: Dalloz. pp. 436-437.
} 
sanctions for the wrongful acts of the employees. ${ }^{719}$ The act of 4 August 1982 also introduced several limitations, creating a legal framework for the employer's power. ${ }^{720}$ When exercising this power, the employer has to respect procedural rules. ${ }^{721}$ Also, it is forbidden to impose monetary sanctions on employees, ${ }^{722}$ or to impose a sanction which was not prescribed by the internal regulation. ${ }^{723}$

191. The employer's powers and SNSs. With regard to SNSs, following from the rights and obligations of the parties, the above means that employers do have the power to regulate how employees can use SNSs and control whether they have complied with such a regulation. The exact outlines of this power are to be addressed in detail in Part II. dealing with certain aspects of SNS use.

(B) Hungary: the employer's legitimate interests

192. Subordination in Hungarian labour law. The HLC defines the employment contract as a contract where the employee is required to work as instructed by the employer, while the employer is required to provide work for the employee and to pay wages. ${ }^{724}$ As such, an employment relationship supposes the employee's subordination and dependency. ${ }^{725}$ In order to determine the existence of an employment relationship, a joint administrative directive issued by the Ministry of Labour and the Ministry of Finance in 2005 provides certain primary and secondary criteria. The primary criteria - which can be in themselves decisive when determining the existence of an employment relationship contain subordination, the obligation to perform work personally, the obligation to provide work and the nature of the activity, the specification of the tasks to be performed in the job.

193. In this context subordination supposes a hierarchal relation between the parties, where the employee performs work while being integrated into the business, resulting in the employer's right to direct and to give orders. The secondary criteria which, not in themselves but together with the presence of other criteria, can indicate the

\footnotetext{
719 Article $1331-1$ of the FLC

${ }^{720}$ As Waquet et al formulated: in the history of the employer's disciplinary powers two eras can be found: one before the act of 4 August 1982 and one after the act of 4 August 1982. Source: Waquet, P., Struillou, Y. and Pécaut-Rivolier, L. (2014) Pouvoirs du chef d'entreprise et libertés du salarié: du salarié-citoyen au citoyen-salarié. Rueil-Malmaison: ÉdLiaisons, p. 49.

${ }^{721}$ They are contained in the FLC from Article 1332-1 to Article 1332-5

722 Subparagraph 1 of Article L1331-2 of the FLC

${ }^{723}$ Cour de cassation, chambre sociale, 26 octobre $2010, \mathrm{~N}^{\circ} 09-42740$

${ }^{724}$ Subsection (2) of Section 42 of the HLC

${ }^{725}$ Hajdú, J. and Kun, A. (eds) (2012) Munkajog I. Budapest: Patrocinium, p. 108.
} 
existence of an employment relationship - contain indicators such as the employer's right to direct, to give orders and to control; the determination of the duration of work and the schedule of working time by the employer, the determination of the place of employment/work by the employer; remuneration for the work; use of the employer's assets, resources and raw materials; the employer's obligation to ensure the conditions for occupational safety and health and contract in writing. ${ }^{726}$ György Kiss argues that legal subordination and the long-term nature of the employment relationship are the two crucial criteria. ${ }^{727}$ Tamás Gyulavári emphasizes as well that the most important characteristic of the employment relationship is dependency, ${ }^{728}$ which is manifested in the hierarchal relationship between the employer and the employee, resulting in the wide-ranging right of the employer to direct, to give orders and to control, ${ }^{729}$ meaning that the employer can give orders relating to any aspect of the employment: he/she can define the means, place and time of working. ${ }^{730}$ However, giving orders is not without limits, other provisions of the HLC must be respected. ${ }^{731}$ Employees perform work in a subordinate and dependent manner, according to the employer's instructions: as the work is done on the behalf of the employer, the employer bears the risks and results of the work, the employee simply offers his/her workforce. ${ }^{732}$

194. Rights and obligations of the parties. Similarly to French law, the rights and obligations of the parties are interconnected: what is a right on one side will be an obligation on the other side. ${ }^{733}$ The main obligations consist of providing work for the employee, ${ }^{734}$ who has to work ${ }^{735}$ and be at the employer's disposal ${ }^{736}$ and of providing

726 7001/2005. (MK 170.) FMM-PM együttes irányelv a munkavégzés alapjául szolgáló szerződések minősítése során figyelembe veendő szempontokról. Although this directive has since been repealed, its main principles still remain valid.

727 Kiss, Gy. (2015) Opportunities and limits of application principles and Civil Code rules in Hungarian labour law Crisis management with means of civil law. ELLN Working Paper No. 4. p. 5.; Kiss, Gy. (2017) 'A munkajog szabályozásának dilemmái', Miskolci Jogi Szemle, XII(2), p. 273.

${ }^{728}$ Also stated in the explanations relating to Section 42 of the HLC in T/4786. számú törvényjavaslat a Munka Törvénykönyvéről (2011). Előadó: Dr. Matolcsy György nemzetgazdasági miniszter. Budapest

${ }^{729}$ Gyulavári, T. (ed.) (2017) Munkajog. ELTE Eötvös Kiadó. Budapest. p. 34.

${ }^{730}$ Kardkovács, K. (ed.) (2012) Az új Munka Törvénykönyvének magyarázata. Budapest: HVG-ORAC, p. 91.

${ }^{731}$ Radnay, J. (2003) Munkajog. 4th edn. Budapest: Szent István Társulat, p. 64.

${ }^{732}$ Lehoczkyné Kollonay, Cs. (ed.) (1997) A magyar munkajog I. Budapest: Kulturtrade Kiadó, pp. 8-9.

${ }^{733}$ Gyulavári, T. (ed.) (2017) Munkajog. ELTE Eötvös Kiadó. Budapest. p. 235.; Prugberger, T. (2011) ‘A munkaszerződés és a munkaviszonyból származó alapvető jogok és kötelezettségek a Munka Törvénykönyvének rekodifikációs tervezetében', Gazdasági élet és társadalom, (1-2), p. 283.

${ }^{734}$ Subsection (1) of Section 51 of the HLC

735 The HLC [Item c) of Subsection (1) of Section 52] defines it among the main obligations of the employee as the obligation to perform work in person with the level of professional expertise and workmanship that can be reasonably expected, in accordance with the relevant regulations, requirements, instructions and customs. 
remuneration for the work - while the employee has the right to be remunerated. ${ }^{737}$ Following from the criteria of subordination, the employer is entitled and at the same time obliged to create the conditions necessary for work, which includes organizing the work, managing employees, giving instructions and information, controlling work and maintaining work discipline. ${ }^{738}$ In accordance with these rights, the employee must perform work according to the instructions of the employer. ${ }^{739}$

195. Common rules of conduct in the HLC. Similarly to the FLC, the HLC also stipulates that the contract has to be executed in good faith ${ }^{740}$ and the employee is subjected to an obligation of loyalty. ${ }^{741}$ In addition, the HLC regulates among the common rules of conduct the requirement of what can reasonably be expected in the given circumstances (“általában elvárhatóság”), ${ }^{74}$ the respect of the principles of fairness, mutual cooperation, ${ }^{743,} 744$ the requirement of taking into account the interests of the employees $^{745}$ and the requirement of providing information. ${ }^{746}$ Moreover, the abuse of rights is prohibited. ${ }^{747,} 748$

\footnotetext{
${ }^{736}$ Item a) of Subsection (1) of Section 52 of the HLC (on the obligation to appear at the place and time specified by the employer, in a condition fit for work) and Item b) of Subsection (1) of Section 52 of the HLC (on the obligation to be at the employer's disposal in a condition fit for work during their working time for the purpose of performing work)

${ }^{737}$ Item b) of Subsection (1) of Section 42 of the HLC

${ }^{738}$ Gyulavári, T. (ed.) (2013) Munkajog. 2nd edn. Budapest: ELTE Eötvös Kiadó, p. 247.

${ }^{739}$ Kajtár, E. (2014) 'A munkáltatói utasítás helye a 21. század munkajogában', Jura, 20(2), p. 215. and Subsection (2) of Section 42 of the HLC

${ }^{740}$ Subsection (2) of Section 6 of the HLC

${ }^{741}$ Section 8 of the HLC

${ }^{742}$ Subsection (1) of Section 6 of the HLC "Employment contracts shall be executed as it might normally be expected in the given circumstances, unless any legal provision exists to the contrary. A person may not rely, in support of his or her claim, on an unlawful act he or she has committed. A person who himself or herself engaged in an unlawful act may rely on the wrongful act committed by others."

${ }^{743}$ Subsection (2) of Section 6 of the HLC "In exercising rights and discharging obligations, the parties involved shall act in the manner consistent with the principle of good faith and fair dealing, they shall be required to cooperate with one another, and they shall not engage in any conduct to breach the rights or legitimate interests of the other party. The requirements of good faith and fair dealing shall be considered breached where a party's exercise of rights is contradictory to his or her previous actions which the other party had reason to rely on."

For example, adopting a workplace communication style according to the rules of civilized human behaviour or adopting a behaviour that takes into account mutual respect and human dignity fall under the obligation of cooperation. [Source: Kozma, A. (2013) 'Mire köteles a munkavállaló?', HR \& Munkajog, 4(10) p. 8. and BH2006. 201.]

${ }^{744}$ In the employment relationship both the employer and the employee must actively contribute to the legal relationship: the employer organizes and directs the work, gives instructions, while the employee performs the work itself; which makes cooperation between the parties indispensable. Source: Miholics, T. (2015) 'Általános magatartási követelmények a munkaviszonyban', Magyar jog, 62(4), p. 247.

${ }^{745}$ Subsection (3) of Section 6 of the HLC "Employers shall take into account the interests of workers under the principle of equitable assessment; where the mode of performance is defined by unilateral act, it shall be done so as not to cause unreasonable disadvantage to the worker affected."
} 
196. The HLC also adds that the employee has to behave in a way that demonstrates the trust vested in him/her for the job in question: ${ }^{749}$ when exercising his/her rights, the employee has to take into consideration the employer's interests, not only during working hours but also beyond them. ${ }^{750}$ Also, he/she shall not jeopardize the legitimate economic interests of the employer. ${ }^{751}$ The employee shall also cooperate with coworkers. ${ }^{752}$ The employer shall provide the necessary working conditions, ${ }^{753}$ which connects back to his/her authority: he/she shall adequately organise the work, shall manage, instruct and inform employees regarding work, shall provide the necessary knowledge for work, shall control work and shall discipline employees. ${ }^{754,}{ }^{755}$ Also, he/she is obliged to ensure conditions of occupational health and safety ${ }^{756}$ while the employee shall respect safety instructions. ${ }^{757}$

197. The right to direct. The right to direct comprises several elements in order to organise work and is implemented through the right to give detailed orders. Giving instructions is not only a right: the employer is also obliged to this, as it is his/her task to tell the employee how to perform the work. ${ }^{758}$ The employer's right to give instructions covers every aspect of working, during the whole lifetime of the employment relationship and he/she can exercise complete and detailed control over their implementation. ${ }^{759}$ At the same time, it is also his/her right and obligation to monitor work ${ }^{760,761}$ and maintain work

\footnotetext{
746 Subsection (4) of Section 6 of the HLC "The parties falling within the scope of this Act shall inform each other concerning all facts, information and circumstances, and any changes therein, which are considered essential from the point of view of employment relationships and exercising rights and discharging obligations as defined in this Act."

747 Subsection (1) of Section 7 of the HLC

748 See more on these common rules of conduct in: Miholics, T. (2015) 'Általános magatartási követelmények a munkaviszonyban', Magyar jog, 62(4), pp. 245-249.

${ }^{749}$ Item d) of Subsection (1) of Section 52 of the HLC

${ }^{750}$ Gyulavári, T. (ed.) (2013) Munkajog. ELTE Eötvös Kiadó. Budapest, p. 262.

${ }^{751}$ Ember, A. (2015) 'A munkáltató jogos gazdasági érdekének a védelme', in Lajkó, D. and Varga, N. (eds) Alapelvek és alapjogok. Szeged: Szegedi Tudományegyetem Állam- és Jogtudományi Doktori Iskola, p. 113.; Section 8 of the HLC. These provisions will be addressed in detail in Part II.

${ }^{752}$ Item e) of Subsection (1) of Section 52 of the HLC

753 Subsection (1) of Section 51 of the HLC

${ }^{754}$ Gyulavári, T. (ed.) (2013) Munkajog. ELTE Eötvös Kiadó. Budapest, p. 247.

755 On the rights and obligations of the parties see more in: Prugberger, T. and Nádas, Gy. (2014) Európai és magyar összehasonlitó munka- és közszolgálati jog. Budapest: Wolters Kluwer, pp. 199-208.

756 Subsection (4) of Section 51 of the HLC

${ }^{757}$ Section 1 of Article 60 of Act XCIII of 1993 on labour safety

${ }^{758}$ Kardkovács, K. (ed.) (2016) A Munka Törvénykönyvének magyarázata. 3rd edn. Budapest: HVG-ORAC Lap- és Könyvkiadó, p. 135.

${ }^{759}$ Gyulavári, T. (ed.) (2013) Munkajog. ELTE Eötvös Kiadó. Budapest. p. 38.

${ }^{760}$ Szücs, P. (2013) A munka törvénykönyve, 2012-1992. Budapest: CompLex. p. 15.

761 The HLC contains further provisions regarding the monitoring of work in Section 11 and 11/A.
} 
discipline. ${ }^{762}$ As explained above, the employee shall perform work according to the instructions of the employer. ${ }^{763}$

198. Internal policies ${ }^{764}$ can be understood as the employer's instruction. ${ }^{765}$ The employer is entitled to regulate in internal policies matters covered by his/her right to instruct. ${ }^{766}$ Internal policies, the employer's power to regulate originate from the right to give instructions, which can be traced back to the hierarchal relation present between the parties. ${ }^{767}$ In consequence, the matters regarding which an internal policy can be drafted are various, such as regulating conflict of interests, behaviour at work, norms relating to clothing or even behaviour outside the workplace $-{ }^{768,769}$ resulting in the employer being able to control, impose limitations on the behaviour of employees.

199. Right to monitor. According to Hungarian labour law regulation, the employer shall provide the necessary working conditions, ${ }^{770}$ which means that he/she shall adequately organise the work, shall manage, instruct and inform employees regarding work, shall provide the necessary knowledge for work, shall control work and shall discipline employees. ${ }^{771}$ It follows from the employer's obligation to ensure safe working environment and the obligation to organize work that he/she is also entitled to monitor whether employees comply with the given orders. ${ }^{772}$ As such, monitoring employees will not only be a right of the employer, ${ }^{773}$ but at the same time it is an obligation as well. ${ }^{774}$

\footnotetext{
762 Gyulavári, T. (ed.) (2013) Munkajog. ELTE Eötvös Kiadó. Budapest. p. 249.

763 Subsection (2) of Section 42 of the HLC

${ }^{764}$ Subsection (1) of Section 17 of the HLC: “(1) Employers shall be able to implement the legal acts referred to in Sections 15-16 [relating to Unilateral acts, statements and commitments] by means of internal rules established of its own accord or by way of a procedure formulated unilaterally (hereinafter referred to as: "employer's internal policy")."

${ }^{765}$ Kiss, Gy. (2005) Munkajog. 2nd edn. Budapest: Osiris Kiadó, p. 80.

${ }^{766}$ Gyulavári, T. (ed.) (2017) Munkajog. 3rd edn. Budapest: ELTE Eötvös Kiadó. p. 98.

${ }^{767}$ Gyulavári, T. and Kun, A. (2013) 'A munkáltatói szabályzat az új Munka Törvénykönyvében', Magyar jog, 60(9), p. 557.

${ }^{768}$ Berke, Gy. and Kiss, Gy. (eds) (2014) Kommentár a munka törvénykönyvéhez: kommentár a munka törvénykönyvéröl szóló 2012. évi I. törvényhez. Budapest: Wolters Kluwer, p. 91.

${ }^{769}$ Additional provisions require that "[e]mployers shall consult the works council prior to passing a decision in respect of any plans for actions and adopting regulations affecting a large number of employees." [Subsection (1) of Section 264 of the HLC] The processing and protection of personal data of employees and the implementation of technical means for the surveillance of workers are among the matters concerned by the obligation of consultation. [Items c) and d) of Subsection (2) of Section 264 of the HLC]

${ }^{770}$ Subsection (1) of Section 51 of the HLC

${ }^{771}$ Gyulavári, T. (ed.) (2013) Munkajog. ELTE Eötvös Kiadó. Budapest, pp. 238-239.; Kajtár, E. (2014) ‘A munkáltatói utasítás helye a 21. század munkajogában', Jura, 20(2), p. 214.

${ }^{772}$ Horinka, É. (2018) ‘A munkavállaló és a munkáltató személyiségi jogainak védelme a munkaviszonyban’, in Mailáth György Tudományos Pályázat 2017. Díjazott dolgozatok. Budapest: Országos Bírósági Hivatal, p. 627.; Ember, A. (2012) 'Meddig terjedhet a munkáltató ellenőrzési joga: avagy a munkavállaló munkáltató általi kamerás megfigyelésének aggályai’, Humánpolitikai szemle, (9), p. 30.

${ }^{773}$ Hajdú, J. and Kun, A. (eds) (2014) Munkajog. Budapest: Patrocinium, p. 88.
} 
However, such a monitoring cannot be unlimited: as it will be explored in a later part of the dissertation, employees' rights, notably rights relating to the personality, ${ }^{775}$ limit the enforcement of the employer's right to monitor to a certain extent.

200. Right to discipline. The employer is entitled to issue a warning to an employee, in case he/she founds that the employee is committing a breach of duty. ${ }^{776}$ It follows from these rights and obligations that the employer is entitled to discipline employees through different sanctions in case of wrongful breach of obligations. ${ }^{777}$ Detrimental legal consequences - proportionate to the breach of duty - may be applied if the employee infringed an obligation arising from the employment relationship, he/she was culpable and the detrimental legal consequence is prescribed by a collective agreement, or - if the employer or the employee is not covered by the collective agreement - by the employment contract. ${ }^{778}$ The employer can modify the sphere of duties or the salary of the employee, withdraw benefits or impose fines - while respecting the employee's right to dignity and personality rights. ${ }^{779,780}$ In the most serious cases the employer can terminate the employment by dismissal. ${ }^{781}$

201. Conclusions of the Section. In conclusion, following from the specific rights and obligations imposed on the parties, the employer's rights/powers in the field of control and monitoring enable him/her to control employees, to give them instructions, and to monitor compliance. In the context of the dissertation it means that on the one hand, the employer can determine certain rules in relation to the use of SNSs (e.g. maintaining work discipline, defending his/her reputation, etc.), and on the other hand, he/she can verify whether the employee complies with instructions and legal obligations imposed on

\footnotetext{
774 Szücs, P. (2013) A munka törvénykönyve, 2012-1992. Budapest: CompLex. p. 15.

${ }^{775}$ Horinka, É. (2018) 'A munkavállaló és a munkáltató személyiségi jogainak védelme a munkaviszonyban', in Mailáth György Tudományos Pályázat 2017. Díjazott dolgozatok. Budapest: Országos Bírósági Hivatal, p. 627.

${ }^{776}$ Cséffán, J. (2018) A Munka Törvénykönyve és magyarázata. Szeged: Szegedi Rendezvényszervező Kft, p. 206.

777 Gyulavári, T. (ed.) (2013) Munkajog. ELTE Eötvös Kiadó. Budapest. p. 249.

778 Subsection (1) of Section 56 of the HLC; See more on detrimental legal consequences in: Cséffán, J. (2018) A Munka Törvénykönyve és magyarázata. Szeged: Szegedi Rendezvényszervezö Kft, p. 217-221.

${ }^{779}$ Kardkovács, K. (ed.) (2016) A Munka Törvénykönyvének magyarázata. 3rd edn. Budapest: HVG-ORAC Lap- és Könyvkiadó, pp. 144-145.

${ }^{780}$ Subsection (2) of Section 56 of the HLC adds: "The detrimental legal consequence aforementioned may be a sanction related to the employment relationship, altering its terms and conditions for a fixed period, which shall not violate the employee's rights relating to personality and dignity. Where the sanction is of a financial nature, it may not - on the whole - exceed the employee's monthly base wage in effect at the time when the sanction is imposed."

${ }^{781}$ Gyulavári, T. (ed.) (2017) Munkajog. 3rd edn. Budapest: ELTE Eötvös Kiadó. p. 240.
} 
him/her, such as obligation of loyalty, obligation of work, etc. (e.g. monitoring whether the employee surfs on Facebook instead of working during working hours, or inspecting SNS profiles to ascertain whether the employee damages the employer's reputation through a post, etc.).

\section{Section 2: Legal rules relating to employee monitoring}

202. Besides the already presented general data protection framework, it also became necessary to adopt employment specific regulations in order to effectively ensure employees' right to data protection. The data protection regulation recognizes the legitimacy of employee monitoring, by not prohibiting the processing of employees' data in relation to monitoring, but by channeling it through requiring the respect of certain privacy and data protection measures. Although the right to privacy and the right to data protection are both concerned, it is mainly through the data protection approach that the different organizations and institutions, as well as national jurisdictions approached this question. $^{782}$

\section{§1. Workplace privacy in the European legal order}

203. The Section will examine the international organizations - notably the EU and the $\mathrm{CoE}$ - which already addressed the question of processing employees' data and adopted legal norms and documents in this field. These documents already addressed the traditional forms of monitoring - e.g. CCTV monitoring, monitoring of e-mail and Internet use, geo-localisation, etc. However, new innovations challenge the established rules, and

${ }^{782}$ As the ILO stated, technological development made it necessary to create data protection rules for the employment context "[...] in order to safeguard the dignity of workers, protect their privacy and guarantee their fundamental right to determine who may use which data for what purposes and under what conditions." (ILO (1997) Protection of workers' personal data. An ILO code of practice. Geneva: International Labour Office. p. 1.). The CoE in Recommendation No. (89) 2, - similarly to an almost identical phrasing in recommendation (2015)5 - stated that "[...] the use of automatic data processing methods by employers should be guided by principles which are designed to minimise any risks which such methods could possibly pose for the rights and fundamental freedoms of employees, in particular their right to privacy[.]" [Council of Europe (1989) Recommendation No. R (89) 2 of the Committee of Ministers to Member States on the Protection of Personal Data Used for Employment Purposes. (Adopted by the Committee of Ministers on 18 January 1989 at the 423rd meeting of the Ministers' Deputies), Preamble] A similar formulation also appeared in the EU's Second stage consultation of social partners on the protection of workers' personal data. The document noted that studies were prepared with the aim of assessing whether existing regulations "[...] provide appropriate protection of workers' fundamental rights and freedoms, and in particular the right to privacy or whether there is a need to further particularise and complement them, with regard to the particular context of the processing: the employment context." (European Commission (2004) 'Second stage consultation of social partners on the protection of workers' personal data', p. 4.) The exception might be the ECtHR's case law, which approaches the question of employee monitoring from a more privacy related perspective, based on the right to respect for private life guaranteed by Article 8 . 
raise several questions. The most recent international documents already touched upon the question of SNSs, but they only devote brief provisions to the subject. ${ }^{783}$ An exhaustive regulation of data processing and SNSs in the employment context has not yet been elaborated, neither by the CoE nor by the EU.

204. International Labour Organization. Although focus will be put on the European legal order, because of its significance, the International Labour Organization (hereinafter referred to as: ILO) must also be mentioned briefly. At the universal level, in 1997, the ILO issued a code of practice regulating the processing of employees' personal data. ${ }^{784}$ The code of practice is an instrument without binding force; however, it contains detailed regulation regarding the processing of employees' personal data. ${ }^{785}$ Despite the lack of binding effect, given the ILO's importance and the rapid adopting of such an instrument, it was by the adoption of a code of conduct that the ILO could quickly and effectively join the growing international conversation on data protection. ${ }^{786}$ The Code underlined the importance of the sectoral regulation of data processing in the employment context and regulated the most important rules, definitions and principles regarding the processing of personal data and employee monitoring. ${ }^{787}$

783 Council of Europe (2015) Recommendation CM/Rec(2015)5 of the Committee of Ministers to member States on the processing of personal data in the context of employment. (Adopted by the Committee of Ministers on 1 April 2015, at the 1224th meeting of the Ministers' Deputies) and WP29 (2017) Opinion 2/2017 on data processing at work. 17/EN WP 249.

${ }^{784}$ ILO (1997) Protection of workers' personal data. An ILO code of practice. Geneva: International Labour Office.

${ }^{785}$ Spiros Simitis explained this by pointing out that by choosing the form of a code of practice, the ILO gave up on adopting a document with binding force, but in exchange it did not have to make compromises regarding the content. As a result, compared to other international documents in the field, this Code succeeded in regulating the question of employee monitoring in a more detailed way. Source: Simitis, S. (1998) 'From the General Rules on Data Protection to a Specific Regulation of the Use of Employee Data: Policies and Constraints of the European Union', Comparative Labor Law and Policy Journal, 19(3), pp. 362-363.

${ }^{786}$ Simitis, S. (1999) 'Reconsidering the Premises of Labour Law: Prolegomena to an EU Regulation on the Protection of Employees' Personal Data', European Law Journal, 5(1), p. 50.

${ }^{787}$ For example: the Code applies to both the public and the private sector and both to manual and automated processing of employees' (and job candidates') personal data. (Article 4.) As concerns the purpose limitation principle, the Code clarifies with regard to employment that processing can only be conducted for reasons directly relevant to the employment of the worker. (Article 5. 1.) The Code expressly states that "[w]orkers may not waive their privacy rights[,]" (Article 5. 13.) meaning that consent cannot be considered as a legal ground for legitimate processing of personal data. The Code also states in Article 5.3. that when "personal data are to be processed for purposes other than those for which they were collected, the employer should ensure that they are not used in a manner incompatible with the original purpose, and should take the necessary measures to avoid any misinterpretations caused by a change of context[,]" taking into consideration that an employment relationship is often a long-term relationship. Source: De Hert, P. and Lammerant, H. (2013) Protection of Personal Data in Work-related Relations. Study PE 474.440. 
205. Since the adoption of the code of practice, the ILO did not adopt a document explicitly aiming employee privacy. ${ }^{788}$ What it did was contributing to the professional development of judges and staff, by organizing meetings in order to provide a platform for exchange relating to common challenges. ${ }^{789}$ Notably, the Meeting of European Labour Court Judges should be mentioned, which at its $17^{\text {th }}$ meeting examined the question of privacy, where participating countries all noted in their national reports that, providing certain safeguards are respected, it is possible to interfere with employees' privacy. ${ }^{790}$ The $22^{\text {nd }}$ meeting addressed the question of the impact of information communication technologies on the world of work. National reports by the 11 participating countries were issued, covering the fields of both individual and collective labour law, and addressing subjects such as the use of ICT in the hiring process, during employment, ICT activity and termination of employment, etc. ${ }^{791}$

206. European legal order. As both France and Hungary are members of the $\mathrm{CoE}$ and the EU, emphasis will be put on these two international organizations. These organizations addressed the question of privacy and/or data protection with special regard to employment on several forums, making it a very important subject. In the following parts $(A)$ the CoE's and $(B)$ the EU's relevant regulation will be discussed in detail, presenting the European rules on employee monitoring and privacy.

\section{(A) Council of Europe}

207. Just like the ILO, the CoE has also recognized the importance of data processing in the employment context. For decades now, the ECHR's Article 8 has had great significance: $(a)$ the ECtHR developed a very important case law regarding the field of workplace privacy (data protection), also dealing explicitly with the question of

Directorate General for Internal Policies, Policy Department C: Citizens' Rights and Constitutional Affairs. Civil Liberties, Justice and Home Affairs. p. 20. See more in: Ibid. pp. 19-22.

${ }^{788}$ Fritsch, C. (2015) 'Data Processing in Employment Relations; Impacts of the European General Data Protection Regulation Focusing on the Data Protection Officer at the Worksite', in Gutwirth, S., Leenes, R., and de Hert, P. (eds) Reforming European Data Protection Law. Dordrecht, Heidelberg, New York, London: Springer, p. 156.

789 ILO (no date) Meetings of the European Labour Court Judges. Available at: http://www.ilo.org/global/about-the-ilo/how-the-ilo-works/departments-and-offices/governance/labourlaw/judges/lang--en/index.htm(Accessed: 1 May 2018)

${ }^{790}$ XVIIth Meeting of European Labour Court Judges (2009) General and national reports. Privacy in the workplace. ILO

791 National reports. Topic 1. "Impact on Information Technologies (IT) on industrial and employment relations" - review of national case law (2014). Dublin, Ireland: XXIInd Meeting of European Labour Court Judges 
employee monitoring. The Committee of Ministers also adopted certain documents, explicitly addressing the question of employee data protection - which will be dealt with under section $(b)$. This led to the adoption of sectoral regulation addressing explicitly the issue of the processing of personal data related to employees. Finally, although up to now they do not have a key role regarding employee privacy and data protection, (c) the (Revised) European Social Charter and the European Committee of Social Rights also have a moderate link to data protection, and as such they must be mentioned.

\section{(a) ECtHR case law related to workplace monitoring}

208. When it comes to employee privacy/data protection, the ECtHR's jurisprudence has paramount importance, as for decades now the ECtHR has regularly had to deal with the question of employee privacy. In its jurisprudence, the ECtHR adopts a privacy approach, instead of a more technical data protection analysis, and deals with the question whether the monitoring of certain aspects of the employees' life fell under the notion of "private life" [Article 8 (1)] and whether the infringement was necessary in a democratic society [Article 8 (2)]. ${ }^{792}$ This Section will present the key cases relating to employee monitoring, which are important to be discussed as they designate - to a certain extent - what the limits of employees' private life are.

209. Niemietz v. Germany. In the case Niemietz v. Germany (1992) the ECtHR applied the protection provided by Article 8 to the workplace, by stating that "[r]espect for private life must also comprise to a certain degree the right to establish and develop relationships with other human beings [,] "793 and pointing out that during the working life, the greatest opportunity to establish relationship with others happens at the workplace, blurring the boundaries of personal and professional life. ${ }^{794,}{ }^{795}$ By this the ECtHR made clear that the right to respect for private life must not be interpreted narrowly, instead it

\footnotetext{
${ }^{792}$ I had the impression that the emphasis in these cases is mostly put on answering the question whether the private life of the employee was concerned, instead of how exactly monitoring shall take place.

${ }^{793}$ ECtHR (1992) Niemietz v. Germany, Application no. 13710/88, 16 December, par. 29.

${ }^{794}$ ECtHR (1992) Niemietz v. Germany, Application no. 13710/88, 16 December, par. 29.

795 This is especially the case in liberal professions, where separating the two fields can be extremely challenging. Source: Lambert, P. and Rigaux, F. (1993) 'Perquisition au cabinet d'un avocat et droit au respect de la vie privée, de la correspondance et du domicile', Revue Trimestrielle des Droits de l'Homme, (15), p. 478.
} 
covers the social aspects of one's life, even at the workplace: therefore the employer shall respect employees' privacy even at the workplace. ${ }^{796}$

210. Halford v. the United Kingdom. A few years after the Niemietz case, the ECtHR had to decide in another significant employee monitoring case. In the case Halford v. the United Kingdom (1997) the applicant, Miss Halford worked as a police officer and brought discrimination claims against her employer for being refused a promotion and alleged that her telephone calls were intercepted in order to obtain information against her for the proceedings. ${ }^{797}$ Miss Halford was provided two telephones: one for work purposes and one for private purposes; and received no restrictions on their use. ${ }^{798}$ Moreover, she was told that she could use her office telephone in her sex-discrimination case. ${ }^{799}$ As concerns the applicability of Article 8, the ECtHR stated that phone calls made from business premises (as well as from home) fall under the notion of "private life" and "correspondence" mentioned in Article $8{ }^{800}$ Naturally, it does not mean that the employer cannot monitor these calls, but when conducting such a monitoring, he/she shall respect the provisions laid down in Paragraph 2 of Article $8 .^{801}$

211. Copland $v$. the United Kingdom. In the case Copland v. the United Kingdom (2007) the applicant, Ms. Copland, worked at a college and alleged that her phone calls, e-mails and Internet use were monitored by her employer. The ECtHR found that from its precedent case law stating that phone calls made from business premises are covered by Article 8, "[i]t follows logically that e-mails sent from work should be similarly protected under Article 8, as should information derived from the monitoring of personal Internet usage." 802 With this statement the ECtHR interpreted Article 8 in the light of the technological development, ${ }^{803}$ and guaranteed protection against the new types

${ }^{796}$ Rijckaert, O. and Lambert, N. (2012) Le respect de la vie privée dans la relation de travail. Waterloo: Wolters Kluwer Belgium. p. 19.

${ }^{797}$ ECtHR (1997) Halford v. the United Kingdom, Application no. 20605/92, 25 June, par 9-12.

${ }^{798}$ ECtHR (1997) Halford v. the United Kingdom, Application no. 20605/92, 25 June, par. 16.

${ }^{799}$ Hendrickx, F. (2002) 'Privacy and Employment Law: General Principles and Application to Electronic Monitoring', in Blanpain, R. (ed.) On-line Rights for Employees in the Information Society. Use and Monitoring of E-mail and Internet at Work. The Hague: Kluwer Law International, p. 54.

${ }^{800}$ ECtHR (1997) Halford v. the United Kingdom, Application no. 20605/92, 25 June, par. 44.

${ }^{801}$ In this case the ECtHR stated the violation of Article 8 as regards calls made from the office telephone, as domestic law did not guarantee adequate protection for the applicant. However, it did not state the violation of Article 8 in relation to the calls made from the home telephone. ECtHR (1997) Halford v. the United Kingdom, Application no. 20605/92, 25 June, par. 51. and par. 60.

${ }^{802}$ ECtHR (2007) Copland v. the United Kingdom, Application no. 62617/00, 3 April, par. 41.

${ }^{803}$ Kéfer, F. and Cornélis, S. (2009) 'L'arrêt "Copland" ou l'espérance légitime du travailleur quant au caractère privé de ses communications', Revue Trimestrielle des Droits de l'Homme, (79), p. 785. 
of interferences. ${ }^{804}$ The ECtHR held that the interference was not in accordance with the law, as there was no domestic law regulating the case of monitoring and stated the violation of Article $8 .{ }^{805}$

212. Bărbulescu v. Romania. In the Bărbulescu v. Romania (2017) case, for the first time, the ECtHR had to decide in a case regarding the electronic monitoring by a private employer. ${ }^{806}$ The applicant, Mr. Bărbulescu was dismissed for using the Internet and a Yahoo account, created at the initiative of the employer, for private purposes against the prohibition of the employer. The employer found this out by monitoring the use of the equipment. Although Mr. Bărbulescu was informed that the personal use if IT equipment is prohibited, he was not informed as concerns the details of the implementation of the monitoring - which turned out to have registered all the content of his communication for a certain period. Reversing the fourth section's decision from 2016, ${ }^{807}$ the ECtHR's Grand Chamber ruled in 2017 that Article 8 was violated and the national authorities could not provide an effective protection of the applicant's right to respect for private life. ${ }^{808} \mathrm{In}$ accordance with the ECtHR's previous case law, the ECtHR held that the applicant's communications conducted from the workplace fell under the scope of Article $8 .{ }^{809}$

213. In accordance with the ECtHR's previous case law, the ECtHR held in the Bărbulescu case as well that the applicant's communications conducted from the workplace fell under the scope of Article $8 .{ }^{810}$ In this case the ECtHR acknowledged the existence of "social private life" and ruled that “[...] an employer's instructions cannot reduce private social life in the workplace to zero." 811,812 However, it is important to emphasize that it does not mean that employers cannot monitor the activities of employees:

\footnotetext{
804 Baugard, D. (2010) 'L'utilité de la Convention européenne des droits de l'homme en droit du travail', Droit et Patrimoine, (195), p. 37.

${ }^{805}$ ECtHR (2007) Copland v. the United Kingdom, Application no. 62617/00, 3 April, par. 48-49.

806 ECtHR, Press Unit (2017) 'Q \& A. Grand Chamber judgment in the case of Bărbulescu v. Romania (application no. 61496/08)'. Available at: https://www.echr.coe.int/Documents/Press_Q_A_Barbulescu_ENG.PDF(Accessed: 1 May 2018). p. 2.

${ }^{807}$ ECtHR (2016) Bărbulescu v. Romania, Application no. 61496/08, 12 January

${ }^{808}$ On the details of the case see more in: Gheorghe, M. (2017) 'Considerations on the conditions under which the employer may monitor their employees at the workplace', Juridical Tribune, 7(2) pp. 62-69. and Rózsavölgyi, B. (2018) 'Mikor lehet jogszerü a munkáltató ellenőrzése? - az Emberi Jogok Európai Bírósága Nagykamarája Bărbulescu kontra Románia ügyben hozott ítéletének iránymutatásai’, Munkajog, 2(1), pp. 43-48.

${ }^{809}$ ECtHR (2017) Bărbulescu v. Romania, Application no. 61496/08, 5 September, par. 81.

${ }^{810}$ ECtHR (2017) Bărbulescu v. Romania, Application no. 61496/08, 5 September, par. 81.

${ }^{811}$ ECtHR (2017) Bărbulescu v. Romania, Application no. 61496/08, 5 September, par. 80.

812 The ECtHR also had important remarks as regards the monitoring of itself, which will be further discussed in $\S 2$.
} 
they can exercise discretion when it comes to determining the regulations relating to private communications at the workplace. However, they have to respect certain requirements arising from the already existing privacy and data protection regulation. ${ }^{813}$

214. In this context private social life means the possibility for the individual to develop his/her social identity, ${ }^{814}$ and instant messaging services constitute one form of leading a private social life. ${ }^{815}$ The ECtHR also stated that restrictions on an individual's professional life may fall within Article 8 in the case that they have "repercussions on the manner in which he or she constructs his or her social identity by developing relationships with others". ${ }^{816}$ Even in the workplace, respect for private life and for the privacy of correspondence continues to exist, but they may be restricted to a necessary extent. ${ }^{817}$ Therefore the complete ban of personal communication seems to restrict the private social life of employees to an unreasonable extent.

215. The ECtHR elaborated in paragraph 121 of the Bărbulescu judgement what relevant factors should be taken into account when assessing whether the employee monitoring was lawful or not. ${ }^{818}$ These are:

- whether the employee has been notified of the possibility of monitoring correspondence and other communications, and of how this monitoring is implemented,

- the extent of the monitoring and the degree of intrusion into the employee's privacy (e.g. whether only the flow of information was monitored or the content too, or whether the scope of monitoring was limited in time and space),

- whether the employer has legitimate reasons to justify the monitoring and the access to their content,

- whether the use of less intrusive methods would have been possible (e.g. instead of accessing the content of communication),

- the consequences of the monitoring and how the result of the monitoring will be used by the employer,

${ }^{813}$ Kállai, P. (2017) 'Bărbulescu Románia elleni ügye', Fundamentum, 21(3-4), p. 101.

${ }^{814}$ ECtHR (2017) Bărbulescu v. Romania, Application no. 61496/08, 5 September, par. 70.

${ }^{815}$ ECtHR (2017) Bărbulescu v. Romania, Application no. 61496/08, 5 September, par. 74.

${ }^{816}$ ECtHR (2017) Bărbulescu v. Romania, Application no. 61496/08, 5 September, par 71.

${ }^{817}$ ECtHR (2017) Bărbulescu v. Romania, Application no. 61496/08, 5 September, par 80.

${ }^{818}$ Costes, L. (2017) 'CEDH : surveillance des courriels d'un employé à son insu constitutive d'une violation du droit au respect de la vie privée et de la correspondance', Revue Lamy droit de l'immatériel, (140), p. 35. 
- whether the employee was provided adequate safeguards.

216. This case is significant because it specified the rules in relation to employee monitoring and using the obtained information in disciplinary proceedings. ${ }^{819,} 820$ The decision did not only evoke the general principles to be considered during finding a balance between the two sides, but also found a reasonable balance between employees' rights and the margin of discretion available to the Member States in relation to reasonably limiting the private use of the Internet in the workplace. ${ }^{821}$ The ECtHR laid down detailed criteria making monitoring legitimate ${ }^{822}$ - the detailed rules applying to employee monitoring will be reviewed in Part II.

217. Case of Libert v. France. The Libert v. France (2018) case - relating to the storage of personal files on the employer's computer - contains some important observations, in which the ECtHR did not question the established French rules. ${ }^{823,} 824$ The case related to the opening of personal files stored on a professional computer. The applicant, employee of the French national railway company (SNCF), was dismissed after the seizure of his work computer revealed that he stored a considerable number of pornographic files and forged documents. The applicant argued that the employer violated Article 8 , by accessing those files in his absence.

${ }^{819}$ Costes, L. (2017) 'CEDH : surveillance des courriels d'un employé à son insu constitutive d'une violation du droit au respect de la vie privée et de la correspondance', Revue Lamy droit de l'immatériel, (140), p. 35.

${ }^{820}$ While recognizing the importance of establishing these "Bărbulescu criteria", Jean-Pierre Marguénaud and Jean Mouly also draw attention to certain uncertanties regarding the application of these criteria. Notably, they question whether they are cumulative criteria or if not, what hierarchy is between them, how they should be taken into consideration when assessing whether Article 8 of the ECHR was breached. Source: Marguénaud, J.-P. and Mouly, J. (2017) 'De l'accès des salariés à Internet à la rationalisation de l'influence de la Cour EDH sur les relations individuelles du travail', La Semaine Juridique - Édition Générale, (44-45), p. 1996.

821 Andriantsimbazovina, J. (2017) 'L'encadrement stricte du contrôle par l'employeur de l'usage de la messagerie électronique du salarié ; Note sous Cour Européenne des Droits de l'Homme, grande Chambre, 5 septembre 2017, Barbulescu c/ Roumanie, numéro 61496/08', La Gazette du Palais, (41), p. 2. [Page number referring to the online version of the article downloaded from: https://www.lextenso.fr/gazette-dupalais/GPL307d0 (Accessed: 15 August 2019)]

${ }^{822}$ Colonna, J. and Renaux-Personnic, V. (2017) 'Vie privée et surveillance des communications du salarié : la position de la Cour européenne des droits de l'Homme; Note sous Cour Européenne des Droits de l'Homme, grande Chambre, 5 septembre 2017, arrêt numéro 61496/08', La Gazette du Palais, (43), p. 2. [Page number referring to the online version of the article downloaded from: https://www.gazette-dupalais.fr/article/GPL309w2/ (Accessed: 15 August 2019)]

${ }^{823}$ Loiseau, G. (2018) 'La CEDH valide la jurisprudence de la Chambre sociale', La Semaine Juridique Social, (12), p. 11. [Page number referring to the online version of the article downloaded from: https://www.lexis360.fr/Document/vie_privee_du_salarie_la_cedh_valide_la_jurisprudence_de_la_chambre_ sociale_/zyiP_3vLY_y5rVWLGA3TgdU3HoxJt_utRta5bm5vCvQ1?data=c0luZGV4PTEmckNvdW50PTgw MiY=\&rndNum=1282688306\&tsid=search6_ (Accessed: 15 August 2019)]; Nasom-Tissandier, H. (2018) 'L'importance de la charte informatique dans la justification de mesures de surveillance des salariés', Jurisprudence sociale Lamy, (451), p. 14.

${ }^{824}$ See more on French regulation in Part II. 
218. The ECtHR reminds that the employer has the right to ensure that employees use the equipment provided by him/her for executing their work in compliance with their contractual obligations and applicable regulation, ${ }^{825}$ confirming the existence of the employer's right to monitor. ${ }^{826}$ The employee's files identified as personal receive more protection, as according to French law they can only be opened if there is a risk or a particular event and in the presence of the employee, or if he/she has been properly notified of it - contrary to files presumed to be of professional nature. ${ }^{827}$ The ECtHR confirmed the principle that the employee is entitled to the right to respect for private life even within the workplace, and that files obviously identified as personal, stored on the computer provided by the employer for work purposes, might pertain to the private life of the employee, ${ }^{828}$ and confirmed that the relevant part of French law is in accordance with the ECHR. ${ }^{829}$

219. Conclusions drawn from the jurisprudence of the ECtHR. From the case law of the ECtHR ${ }^{830}$ several conclusions can be drawn. First, the ECtHR made it clear that employees are entitled to the right to privacy, and they do not cease to have this right even within the workplace. Second, the ECtHR interpreted the right to privacy in a flexible way, taking into account the changes that had occurred in technology and society; through interpreting correspondence in a broad way and affording protection to a wide range of communication means. Third, in the field of employment as well, the ECtHR went beyond a narrow interpretation of privacy limited to secrecy: it recognized the importance of workplaces in establishing and developing relationships with other human beings. Fourth, the ECtHR made it clear that employees' right to privacy is not an absolute right, and it can be limited if certain requirements are met. In its case law, in the Bărbulescu judgement the ECtHR provided detailed criteria in order to be able to trace a balance between employees'

${ }^{825}$ ECtHR (2018) Libert v. France, Application no. 588/13, 22 February, par. 46.

826 Sipka, P. and Zaccaria, M. L. (2018) 'A munkáltató ellenőrzési joga a munkavállaló munkahelyi számítógépén tárolt magánadatai fölött’, Munkajog, 2(2), p. 47.

${ }^{827}$ Cour de cassation, chambre sociale, 17 mai 2005, $\mathrm{N}^{\circ} 03-40017$

${ }^{828}$ ECtHR (2018) Libert v. France, Application no. 588/13, 22 February, par 25.

829 Porta, J. et al. (2018) 'Libertés fondamentales, égalité de traitement et discrimination', Bulletin d'information de la Cour de Cassation, (887), p. 17.

${ }^{830}$ The ECtHR has not only ruled in the cases of Internet or telephone monitoring at the workplace, but also regarding CCTV surveillance. These cases will not be discussed in the frame of the thesis, as they have a looser connection with the main subject of the dissertation, social network sites. On the most important cases see the following Factsheet: ECtHR, Press Unit (2018) 'Factsheet - Surveillance at workplace'. Available at: https://www.echr.coe.int/Documents/FS_Workplace_surveillance_ENG.pdf(Accessed: 1 May 2018). 
and employer's rights and clarified the most important requirements in relation to employee monitoring. ${ }^{831}$

\section{(b) Recommendations of the CoE}

220. Recommendation 1989. Early in 1989 the CoE adopted a Recommendation on the Protection of Personal Data Used for Employment Purposes, ${ }^{832}$ [hereinafter referred to as: Recommendation No. (89) 2] representing a shift towards sectoral regulation. Recommendation No. (89) 2 covers data processing both in the private and in the public sector. ${ }^{833}$ Spiros Simitis identified five key principles of the document: ${ }^{834}$ (1) the data should be obtained directly from the employee, ${ }^{835}$ (2) the personal data should only be processed for the purposes of the employment relationship, ${ }^{836}$ (3) employees should be informed regarding the most important characteristics of the processing, (4) the employee should have a right to access, to rectification and to erasure and (5) the personal data should only be kept as long as they are needed for the purposes of the processing. In addition, the data stored should be accurate, kept up-to-date and "represent faithfully the situation of the employee". ${ }^{837}$ Recommendation No. (89) 2 also contains provisions

831 It is worth noting that in the 2018 case of Denisov v. Ukraine the ECtHR further specified and systematised case law relating to the private life of employees. (Source: Sudre, F. (2018) 'La «vie privée» dans un contexte professionnel', La Semaine Juridique Edition Générale, (41), p. 1054.) Despite holding that in the given case no breach of Article 8 of the CEHR was established, the ECtHR recalled the criteria which must be met. [ECtHR (2018) Denisov v. Ukraine, Application no. 76639/11, 25 September par. 92-134.)

${ }^{832}$ Council of Europe (1989) Recommendation No. R (89) 2 of the Committee of Ministers to Member States on the Protection of Personal Data Used for Employment Purposes. (Adopted by the Committee of Ministers on 18 January 1989 at the 423rd meeting of the Ministers' Deputies)

${ }^{833}$ Article 1 (1) of Council of Europe (1989) Recommendation No. R (89) 2 of the Committee of Ministers to Member States on the Protection of Personal Data Used for Employment Purposes. (Adopted by the Committee of Ministers on 18 January 1989 at the 423rd meeting of the Ministers' Deputies)

${ }^{834}$ Simitis, S. (1998) 'From the General Rules on Data Protection to a Specific Regulation of the Use of Employee Data: Policies and Constraints of the European Union', Comparative Labor Law and Policy Journal, 19(3), pp. 361-362.

${ }^{835}$ In addition, the data processed should also be relevant and not excessive. This requirement should be enforced also during the recruitment process. Article 4 (1)-(3) of Council of Europe (1989) Recommendation No. $R(89) 2$ of the Committee of Ministers to Member States on the Protection of Personal Data Used for Employment Purposes. (Adopted by the Committee of Ministers on 18 January 1989 at the 423rd meeting of the Ministers' Deputies)

${ }^{836}$ According to Article 1 (3) of Council of Europe (1989) Recommendation No. R (89) 2 of the Committee of Ministers to Member States on the Protection of Personal Data Used for Employment Purposes. (Adopted by the Committee of Ministers on 18 January 1989 at the 423rd meeting of the Ministers' Deputies) employment purposes relate to "[...]relations between employers and employees which relate to recruitment of employees, fulfilment of the contract of employment, management, including discharge of obligations laid down by law or laid down in collective agreements, as well as planning and organisation of work."

${ }^{837}$ Article 5 (2) of Council of Europe (1989) Recommendation No. R (89) 2 of the Committee of Ministers to Member States on the Protection of Personal Data Used for Employment Purposes. (Adopted by the Committee of Ministers on 18 January 1989 at the 423rd meeting of the Ministers' Deputies) 
regarding the communication of data (Articles 7-8), the transborder flow of personal data (Article 9) and special categories of data (Article 10).

221. Updated Recommendation. Since then, the changes in technology, the employers' tendency to collect personal data outside of the workplace and the appearance of processing carrying specific risks made it necessary to revise the existing framework on employee data protection. ${ }^{838}$ These were the main reasons underlying the adoption of Recommendation on the processing of personal data in the context of employment ${ }^{839}$ in 2015. Despite the changed context, the core values of Recommendation (89) 2 still remain valid, however, the profound changes in technology and the world of work need to be taken into consideration. ${ }^{840}$ Similarly to the ILO's Code of Practice, these Recommendations - as their denomination suggests - are also soft law instruments. It is important to state that in contrast to the previous documents, provisions related to SNSs appeared in this document.

222. They are discussed in one paragraph stating "[e]mployers should refrain from requiring or asking an employee or a job applicant access to information that he or she shares with others online, notably through social networking. ${ }^{, 841}$ It is clear that the provision covers both employees and prospective employees, and prohibits the employer from accessing information shared on these platforms - unless the user decides to share it. The explanatory memorandum highlights that the employer should not use intermediaries, another name or a pseudonym in order to obtain access to personal data without the knowledge of employees or job candidates. ${ }^{842}$ The explanatory memorandum also explicitly states that employers shall not ask for employees' or job candidates' password,

838 Council of Europe (2015) Explanatory memorandum to Recommendation CM/Rec(2015)5 of the Committee of Ministers to member States on the processing of personal data in the context of employment. pp. 1-2.

${ }_{839}$ Council of Europe (2015) Recommendation CM/Rec(2015)5 of the Committee of Ministers to member States on the processing of personal data in the context of employment. (Adopted by the Committee of Ministers on 1 April 2015, at the 1224th meeting of the Ministers' Deputies)

${ }^{840}$ Buttarelli, G. (2010) Study on Recommendation No. R (89) 2 on the protection of personal data used for employment purposes and to suggest proposals for the revision of the above-mentioned Recommendation. TPD-BUR(2010)11. Strasbourg: The Bureau of the Consultative Committee of the Convention for the Protection of Individuals with Regard to Automatic Processing of Personal Data. p. 5.

${ }^{841} \mathrm{CoE}$ (2015) Recommendation CM/Rec(2015)5 of the Committee of Ministers to member States on the processing of personal data in the context of employment. (Adopted by the Committee of Ministers on 1 April 2015, at the 1224th meeting of the Ministers' Deputies) 5. 3.

${ }^{842} \mathrm{CoE}$ (2015) Explanatory memorandum to Recommendation CM/Rec(2015)5 of the Committee of Ministers to member States on the processing of personal data in the context of employment. p. 7. 
in order to access content on their profiles. ${ }^{843}$ According to my opinion, this article can be interpreted as follows: the employer cannot access in any way content on SNSs which are not accessible to him/her (e.g. because the employee uses privacy settings.) He/she cannot ask a co-worker, create a fake profile or ask for login credentials in order to obtain access. However, this would also imply that information publicly available on these sites can be processed by the employer - naturally respecting the existing data protection requirements, such as proportionality or purpose limitation, etc.

(c) (Revised) European Social Charter and the European Committee of Social Rights

223. European Social Charter and Revised European Social Charter. When it comes to the $\mathrm{CoE}$ and fundamental rights, the (Revised) European Social Charter (hereinafter referred to as: ESC), ${ }^{844}$ the "Social Constitution of Europe" ${ }^{845}$ must also be mentioned. This document guarantees the most important social and economic rights - just as the ECHR guarantees the fundamental civil and political rights. However, neither the European Social Charter, nor the Revised European Social Charter regulates expressively the right to privacy or the right to data protection.

224. European Committee of Social Rights. Still, the European Committee of Social Rights (hereinafter referred to as: ECSR), an independent body responsible for monitoring compliance with the ESC, has already expressed itself in this field and identified legal fundaments of the right to privacy. The ECSR recognized that technological development has made it possible for employers to constantly supervise employees, blurring the boundaries of work and personal life. More severe intrusions even after working hours and outside the workplace - have become possible. ${ }^{846}$

The ECSR found that Article 1:2 $\S$ of the ECS, guaranteeing the right to undertake work freely, ${ }^{847}$ comprises the right to privacy and acknowledges the importance of

${ }^{843} \mathrm{CoE}$ (2015) Explanatory memorandum to Recommendation CM/Rec(2015)5 of the Committee of Ministers to member States on the processing of personal data in the context of employment. p. 7.

${ }^{844}$ CoE (1961) European Social Charter, ETS No.035, 18 October and Council of Europe (1996) European Social Charter (revised), ETS No.163, 3 May

${ }^{845} \mathrm{CoE}$ (no date) The European Social Charter. Available at: https://www.coe.int/en/web/european-socialcharter (Accessed: 12 August 2019).

${ }^{846}$ European Committee of Social Rights (2013) Activity Report 2012. Council of Europe, p. 26.

847 "Article 1 - The right to work

With a view to ensuring the effective exercise of the right to work, the Parties undertake: [...]

2. to protect effectively the right of the worker to earn his living in an occupation freely entered upon[.]" 
ensuring workers' right to privacy. ${ }^{848}$ In its 2016 report, the ECSR states in a straightforward manner that Article 1:2 $\S$ concerns the right to privacy at work. ${ }^{849}$ In its observations relating to Article 1:2 $\S$ the ECSR recognized the relevancy of protecting employees' private or personal lives against unlawful infringements. It linked the fundaments of the protection to the right to freely engage in occupation, meaning that employees remain free, which imposes a limit on employer's powers. It also evoked the principle of dignity and its relation to the right to privacy and the possible cases of infringement (such as asking certain questions from prospective employees or employees and processing personal data). ${ }^{850,}{ }^{851}$ Still, the ESC and the ECSR do not have a prominent role in ensuring employees' right to privacy and data protection in spite of their importance in the protection of employees' rights - compared to the ECtHR.

\section{(B) European Union}

225. Like other international organizations, the EU as well has developed certain employment specific data protection requirements in addition to the general EU data protection framework. ${ }^{852}$ Similarly to the CoE and the ECtHR, the EU's court's, $(a)$ the CJEU's relevant case law in relation to employee privacy/data protection will be addressed. Then, (b) the WP29's and the European Data Protection Supervisor's relevant documents will be examined as - in spite of not having binding force - they provide important guidance in specific fields as well.

\section{(a) CJEU}

From amongst the case law of the CJEU notably three cases must be mentioned, dealing with the applicability of data protection rules in the employment context: the Rechnungshof v. Österreichischer Rundfunk case, the V and European Data Protection Supervisor v. European Parliament case and the Bodil Lindquist case.

\footnotetext{
${ }^{848}$ European Committee of Social Rights (2013) Activity Report 2012. Council of Europe. p. 26.

${ }^{849}$ European Committee of Social Rights (no date) Activity Report 2016. Council of Europe. p. 32.

${ }^{850}$ European Committee of Social Rights (2006) Statements of interpretation - Article 1-2. 2006_Ob_12/Ob/EN. Council of Europe

${ }^{851}$ On the possible protection provided by the ESC see more in: Perraki, P. (2013) La protection de la vie personnelle du salarié en droit comparé et européen [étude comparative des droits français, hellénique, britannique et européen]. Thèse en droit. Université de Strasbourg, pp. 75-79.

${ }^{852}$ In relation to the GDPR, the already examined Article 88 must be mentioned.
} 
226. Rechnungshof v. Österreichischer Rundfunk. In the Rechnungshof $v$. Österreichischer Rundfunk case the CJEU had to take a stand on regarding the applicability of the DPD to the processing of information (salaries and pensions) related to civil servants. ${ }^{853}$ In the case, the Austrian regulation required certain public bodies to communicate the salaries and pensions of civil servants to the Court of Audit, who would create an annual report and transfer them to the Parliament and later make them available to the general public. ${ }^{854}$ The CJEU linked the applicability of the DPD to whether there was an interference with private life, and whether that interference was justified according to Article 8 of the ECHR. ${ }^{855}$ The CJEU states that while the mere recording of data relating to the salaries by the employer does not constitute in itself interference in the private life of the employees, the communication of that data to third parties infringes the right to privacy of the employees. ${ }^{856}$

227. V and European Data Protection Supervisor v. European Parliament. In the case V and European Data Protection Supervisor v. European Parliament the applicant contested at the European Union Civil Service Tribunal the use of a previous medical opinion - declaring her unfit for a previous position at the European Commission - which resulted in her rejection at the European Parliament. She alleged that her right to respect for private life was violated. ${ }^{857}$ Referring to the Rechnungshof v. Österreichischer Rundfunk case, the CJEU ruled that the transfer of personal data constituted an interference with the right to respect for private life enshrined in Article 8 of the ECHR. ${ }^{858}$ Although the processing of the sensitive medical data served a legitimate interest, it does not justify the transfer of medical data from one institution to another, without the consent of the data subject, and it would have been possible to achieve the legitimate objective by less interference. ${ }^{859}$

853 Otto, M. (2016) The Right to Privacy in Employment: a Comparative Analysis. Oxford, Portland: Hart Publishing. p. 98.

${ }^{854}$ CJEU (2003): Rechnungshof v. Österreichischer Rundfunk, Joined Cases C-465/00, C-138/01 and C139/01, ECLI:EU:C:2017:131, 20 May, par 2.

855 CJEU (2003): Rechnungshof v. Österreichischer Rundfunk, Joined Cases C-465/00, C-138/01 and C139/01, ECLI:EU:C:2017:131, 20 May, par. 72.

${ }^{856}$ CJEU (2003): Rechnungshof v. Österreichischer Rundfunk, Joined Cases C-465/00, C-138/01 and C139/01, ECLI:EU:C:2017:131, 20 May, par. 73-74.

${ }^{857}$ CJEU (2011): V v. European Parliament, Case F-46/09, ECLI:EU:F:2011:101, 5 July, par. 65.

${ }^{858}$ CJEU (2011): $V$ v. European Parliament, Case F-46/09, ECLI:EU:F:2011:101, 5 July, par. 111-112.

${ }^{859}$ CJEU (2011): V v. European Parliament, Case F-46/09, ECLI:EU:F:2011:101, 5 July, par. 125. 
228. Bodil Lindquist. In the case of Bodil Lindquist the applicant worked at a parish, and set up web pages at home - "in order to allow parishioners preparing for their confirmation to obtain information they might need" 860 -, where she - without the knowledge or consent of her colleagues - uploaded personal data (such as hobbies, family members, phone numbers) related to them. ${ }^{861}$ Although the case primarily concerned the applicability of the DPD in the online environment, ${ }^{862}$ it has three potential implications for employment. First, it confirms that employment-related information falls under the category of personal data under the DPD. ${ }^{863}$ Second, it questions employers' practices to publish personal data on company websites. Third, it provides no possibility to bypass the DPD by employers, as employees' activities are also covered (for example, he/she cannot ask an intern to process employees' personal data in order to be qualified nonprofitable). ${ }^{864}$

229. The above cases show that several acts might constitute an interference in the employees' private life and infringe his/her right to data protection. However, - in contrast to the ECtHR's jurisprudence - these cases are more remote from employee monitoring, they rather concern whether there was an interference and are more concentrated on data processing. For this reason, it is necessary to further examine the specific matter of employee monitoring - which was explicitly addressed by the WP29.

(b) The Article 29 Data Protection Working Party and the European Data Protection Supervisor

230. Employee monitoring. In its documents the WP29 basically translated the general provisions set in the DPD to the special context of employment, offering concrete solutions in the field of data protection and employee monitoring. ${ }^{865}$ They did not have

${ }^{860}$ CJEU (2003): Bodil Lindqvist, Case C-101/01, ECLI:EU:C:2003:596, 6 November, par. 12.

${ }^{861}$ CJEU (2003): Bodil Lindqvist, Case C-101/01, ECLI:EU:C:2003:596, 6 November, par. 12-14.

862 One of the questions referred to the CJEU for preliminary ruling was whether the exemptions provided in the DPD apply to the processing concerned. For the subject of the thesis, the household exception has relevancy. The CJEU ruled that this exception "[...]must therefore be interpreted as relating only to activities which are carried out in the course of private or family life of individuals, which is clearly not the case with the processing of personal data consisting in publication on the internet so that those data are made accessible to an indefinite number of people." CJEU (2003): Bodil Lindqvist, Case C-101/01, ECLI:EU:C:2003:596, 6 November, par. 47.

${ }^{863}$ CJEU (2003): Bodil Lindqvist, Case C-101/01, ECLI:EU:C:2003:596, 6 November, par. 24.

864 Otto, M. (2016) The Right to Privacy in Employment: a Comparative Analysis. Oxford, Portland: Hart Publishing. p. 101.

${ }^{865}$ Fritsch, C. (2015) 'Data Processing in Employment Relations; Impacts of the European General Data Protection Regulation Focusing on the Data Protection Officer at the Worksite', in Gutwirth, S., Leenes, R., 
legally binding force, however, partly due to the WP29 being composed of representatives from each national data protection authority (hereinafter referred to as: DPA), they provided useful guidance for Member States, and national data protection authorities took these opinions into consideration when it came to the enforcement of the national data protection rules. ${ }^{866}$ As such, the findings made by the WP29 have importance for France and for Hungary as well, as national DPAs took them into account during the enforcement of national data protection regulation. ${ }^{867}$

231. The most important documents issued by the WP 29 are Opinion 8/2001 on the processing of personal data in the employment context, ${ }^{868}$ Working document on the surveillance of electronic communications in the workplace (2002) $)^{869}$ and Opinion 2/2017 on data processing at work, ${ }^{870}$ which provide guidance regarding the regulation and the monitoring of employees' Internet use. ${ }^{871}$ In these documents the WP29 emphasized that the general data protection principles also apply to the case of processing employee data, and within this case, to employee monitoring, and provided guidance on how exactly these general provisions shall be translated into the employment context. Opinion 8/2001 addresses the question of processing in the employment context in general, without detailing how the general rules should be applicable to specific cases of employee monitoring. The Working document focuses on the question of surveillance and monitoring of electronic communication, with special regard to e-mail monitoring and the monitoring of Internet access. Opinion 2/2017 on data processing at work complements Opinion

and de Hert, P. (eds) Reforming European Data Protection Law. Dordrecht, Heidelberg, New York, London: Springer, p. 155.

866 Otto, M. (2016) The Right to Privacy in Employment: a Comparative Analysis. Oxford, Portland: Hart Publishing p. 97. and Retzer, K. and Lopatowska, J. (2011) 'How to Monitor Workplace E-Mail and Internet in Europe: The Polish Perspective’. Privacy \& Security Law Report, Bureau of National Affairs. Available at: https://media2.mofo.com/documents/110718-privacy-and-security-law-report.pdf (Accessed: 2 May 2018). p. 2.

867 It must not be forgotten that due to the EU's data protection reform, the WP29 was replaced by the European Data Protection Board. However, at the time of submitting the dissertation, the EDPB has not yet addressed any document relating to data protection in the context of employment.

868 WP29 (2001) Opinion 8/2001 on the processing of personal data in the employment context. 5062/01/EN/Final WP 48

869 WP29 (2002) Working document on the surveillance of electronic communications in the workplace. 5401/01/EN/Final WP 55

${ }^{870}$ WP29 (2017) Opinion 2/2017 on data processing at work. 17/EN WP 249

${ }^{871}$ Among the already regulated cases of monitoring, the monitoring of e-mail and Internet use are need to be discussed in detail, as they have the closest connection and relevancy when it comes to SNSs. Provisions relating to employee monitoring by means of CCTV and geo-localisation are to be found in WP29 (2004) Opinion 4/2004 on the Processing of Personal Data by means of Video Surveillance. 11750/02/EN WP 89; WP29 (2005) Working Party 29 Opinion on the use of location data with a view to providing valueadded services. 2130/05/EN WP 115 and WP29 (2011) Opinion 13/2011 on Geolocation services on smart mobile devices. 881/11/EN WP 185 
8/2001 and the Working document and takes into consideration the societal-technological and legal changes that occurred since and provides guidance regarding several types of processing and monitoring.

232. Already regulated cases of monitoring. In the light of these general rules, the rules to be applied to certain types of employee monitoring are already elaborated in the "practice" of the WP29. Such monitoring includes, for example, closed-circuit television or video surveillance, ${ }^{872}$ or the collection of location data. ${ }^{873}$ In this part the focus will be on the WP29's documents relating to monitoring of e-mail and Internet use, followed by SNSs.

233. Although the principles laid down in Opinion 8/2001 are valid in the case of e-mail and Internet monitoring, it was in the 2002 Working document that the WP29 addressed in detail the question of monitoring of e-mail and Internet use at the workplace. The Working document also points out the importance of the general data protection requirements, and then addresses the question of e-mail and Internet monitoring. In its Opinion 2/2017 the WP29 takes into account the technological development that occurred since the adoption of its previous documents, while stating that the conclusions laid down in the Working Document still remain valid. ${ }^{874}$ The Working Party emphasizes the importance of proportionality, transparency (e.g. through the way of adopting policies). ${ }^{875}$ Under the item "Processing operations resulting from monitoring ICT usage at the

\footnotetext{
872 The legitimate purpose of the CCTV system can be to secure the workers' health and safety. They cannot be used to monitor the employees' productivity and work intensity. It is strictly forbidden to place video cameras in premises which employees use only for private purposes or which are not related to work, e.g. toilets, lockers, resting rooms, bathrooms. Also, appropriate information shall be given to employees regarding the processing. Source: WP29 (2004) Opinion 4/2004 on the Processing of Personal Data by means of Video Surveillance. 11750/02/EN WP 89. p. 25.

${ }^{873}$ The monitoring of employees' location is possible through several ways, such as GPS, mobile telephone, Wi-Fi network or an RFID tag. The monitoring of location is acceptable when a specific purpose related to the work of the employee justifies it. Such a reason can be, for example, the transfer of people or valuable goods, or the improvement of the distribution of resources for services in scattered locations. The protection of persons or goods can also be acceptable if it is aimed at providing the security of the employee, the vehicle or other objects entrusted to him/her. The least intrusive means should be applied (continuous monitoring should be avoided) and the employee shall be able to turn off the monitoring device outside of working hours. The behaviour of the employees cannot be monitored this way. Sources: WP29 (2005) Working Party 29 Opinion on the use of location data with a view to providing value-added services. 2130/05/EN WP 115. p. 10. and WP29 (2011) Opinion 13/2011 on Geolocation services on smart mobile devices. 881/11/EN WP 185. p. 14.

874 WP29 (2002) Working document on the surveillance of electronic communications in the workplace. 5401/01/EN/Final WP 55. p. 12.

${ }^{875}$ WP29 (2002) Working document on the surveillance of electronic communications in the workplace. 5401/01/EN/Final WP 55. p. 14.
} 
workplace" the Opinion expressively deals with e-mail and Internet monitoring at the workplace.

234. Monitoring of employees' e-mail. As concerns $e$-mail monitoring, it might pose a challenge that two persons' personal data are processed: the recipient's and the sender's. As for the employee, information can be given easily, and as for the third parties, warnings should be included in the messages to inform them about the monitoring. Another solution might be to provide the employee with two e-mail accounts: one for professional and one for personal purposes ${ }^{876}$ For the personal e-mail the monitoring of its content would be possible only in very rare circumstances (e.g. in relation to criminal activities), ${ }^{877}$ while for the monitoring of professional e-mail accounts the rules are less severe.

Still, even in these cases, the general principles (necessity, proportionality, etc.) apply, ${ }^{878}$ and the monitoring of e-mail should first be limited to monitoring the traffic. Employees should not only be informed that a monitoring takes place, but also if there is a detected misuse, putting the emphasis on prevention, rather than detection. ${ }^{879}$ In several cases a misuse can be detected by accessing traffic data (e.g. the participants and time of the communication), without accessing the content of the mail. ${ }^{880}$ Access to the content of the messages should only be permitted when the legitimate purpose cannot be achieved through less intrusive means.

235. Monitoring of employees' Internet use at the workplace. Regarding the monitoring of Internet use, the starting point is that the employer is free to decide whether he/she allows workers to use the Internet for personal purposes, and if so, to what extent. Though the employer is entitled to monitor whether employees comply with the regulation,

876 Otto, M. (2016) The Right to Privacy in Employment: a Comparative Analysis. Oxford, Portland: Hart Publishing, p. 105.

877 WP29 (2002) Working document on the surveillance of electronic communications in the workplace. 5401/01/EN/Final WP 55. p. 21.

878 Basically, the WP29 provides an explanation of the application of these general rules to the specific context of monitoring. Source: Kambellari, E. (2013) 'Employee email monitoring and workplace privacy in the European perspective', Iustinianus Primus Law Review, 8. Available at: https://cutt.ly/1rv83w7 (Accessed: 19 January 2019), p. 4.

879 Retzer, K. and Lopatowska, J. (2011) 'How to Monitor Workplace E-Mail and Internet in Europe: The Polish Perspective'. Privacy \& Security Law Report, Bureau of National Affairs. Available at: https://media2.mofo.com/documents/110718-privacy-and-security-law-report.pdf (Accessed: 2 May 2018), p. 2. and WP29 (2002) Working document on the surveillance of electronic communications in the workplace. 5401/01/EN/Final WP 55. pp.4-5.

${ }^{880}$ WP29 (2002) Working document on the surveillance of electronic communications in the workplace. 5401/01/EN/Final WP 55. pp. 17-18. 
certain restrictions must be considered. The WP29 expressed its view that instead of monitoring, the emphasis should be placed on preventing the misuse of computers. ${ }^{881}$ This could be achieved by using programs that remind the employee of the misuse (e.g. warning windows, which pop up and alert the employee). ${ }^{882,} 883$ This can suffice to prevent the misuse and the employee's visit to the website can be avoided. It would also be effective if the employer warned the worker of the misuse as the first step. According to the basic principles the least intrusion possible must be made, so it is advisable that the employer avoid automatic and constant monitoring. ${ }^{884}$ It follows from the requirement of subsidiarity that monitoring might not even be necessary, as the blocking of certain websites can prevent employees from the personal use of the Internet; accent should be put on prevention, rather than detention. ${ }^{885}$ However, already in 2002 the WP29 underlined that a complete ban on the personal use of the Internet does not seem reasonable, as it does not take into consideration how much employees use it in their everyday lives. ${ }^{886}$ The WP29 even referred to employees' "legitimate right to use work facilities for some private usage". 887

236. Social network sites. Although the question of processing of employees' personal data obtained from SNSs is not exhaustively regulated, in Opinion $2 / 2017$, the WP29 addressed the question of SNSs in two regards: processing during the recruitment process and in-employment screenings.

237. Under the title "Processing operations during the recruitment process" the WP29 expressively refers to personal data obtained from SNSs. ${ }^{888}$ The WP29

881 Otto, M. (2016) The Right to Privacy in Employment: a Comparative Analysis. Oxford, Portland: Hart Publishing, p. 105. and WP29 (2002) Working document on the surveillance of electronic communications in the workplace. 5401/01/EN/Final WP 55. p. 24.

882 Retzer, K. and Lopatowska, J. (2011) 'How to Monitor Workplace E-Mail and Internet in Europe: The Polish Perspective'. Privacy \& Security Law Report, Bureau of National Affairs. Available at: https://media2.mofo.com/documents/110718-privacy-and-security-law-report.pdf (Accessed: 2 May 2018), p. 2.

883 According to the EDPS, it is more useful to watch the indicators (for example, volume of data downloaded) than the visited websites themselves and to take further steps only when there is a strong suspicion of misuse. Source: Buttarelli, G. (2009) 'Do you have a private life at your workplace? Privacy in the workplace in EC institutions and bodies'. 31st International Conference of Data Protection and Privacy, Madrid, 4-6 November

884 WP29 (2002) Working document on the surveillance of electronic communications in the workplace. 5401/01/EN/Final WP 55. p. 17.

${ }^{885}$ WP29 (2017) Opinion 2/2017 on data processing at work. 17/EN WP 249. p. 15.

${ }^{886}$ WP29 (2002) Working document on the surveillance of electronic communications in the workplace. 5401/01/EN/Final WP 55. p. 4.

${ }^{887}$ WP29 (2017) Opinion 2/2017 on data processing at work. 17/EN WP 249. p. 14.

${ }^{888}$ WP29 (2017) Opinion 2/2017 on data processing at work. 17/EN WP 249. p.11. 
acknowledged the phenomenon of the growing use of SNSs, and the employer's belief according to which during the recruitment he/she is free to use these - because of the lack of using the privacy settings - publicly available personal data. The WP29 stresses that just because these data might be publicly available, it does not mean that the employer can freely process this data for his/her own purposes. Just like in the case of processing other data, the existence of a valid legal ground (such as legitimate interest), the application of the necessity and relevancy principle is required. The employer should consider in advance whether it is a profile related to personal or business purposes. The inspection of these profiles is only permitted when it is necessary and relevant to the performance of the job that the candidate is applying for. The personal data should only be stored for a limited period (until it becomes clear that the candidate will not be employed) and it is crucial that candidates are informed of the processing. If the employee used the privacy settings, and therefore the employer cannot access the profile, he/she cannot ask the prospective employee to friend him/her or gain access to the profile through another way. ${ }^{889}$

238. The WP29 also refers to the issue of in-employment screening (as from a technological point of view the employer is able to continuously screen and gain information relating to the personal lives, opinions, beliefs, etc. of employees by inspecting their social network profiles). The body states that such a screening should not take place on a generalized basis and should be limited in scope. Also, if an employee limits the access to his/her profile, the employer should not gain access to it. If in the limited cases when the employee is required to use a social network profile created by the employer (e.g. spokesperson), the employee should retain the possibility - specified in the terms and conditions of the employment contract - of having a non-work related profile that he/she can use. ${ }^{890}$

239. Conclusions drawn from the WP29's activity. The significance of the above documents is to be found in concretizing the abstract data protection rules to the context of modern-day employment and, despite the lack of their binding force, they provide useful guidance when it comes to employee monitoring and data protection. Therefore, they provide guidance not only to Member States and legislators, but also to employers who process employees' personal data or conduct some kind of monitoring.

${ }^{889}$ WP29 (2017) Opinion 2/2017 on data processing at work. 17/EN WP 249. p.11.

${ }^{890}$ WP29 (2017) Opinion 2/2017 on data processing at work. 17/EN WP 249. p.12. 
240. The European Data Protection Supervisor. The European Data Protection Supervisor (hereinafter referred to as: EDPS) was established by Regulation (EC) No 45/2001 of the European Parliament and of the Council of 18 December 2000 on the protection of individuals with regard to the processing of personal data by the Community institutions and bodies and on the free movement of such data. ${ }^{891}$ The EDPS is an independent supervisory authority, ${ }^{892}$ responsible for monitoring whether EU institutions and bodies respect rules regulating the processing of personal data, and give advice to them and to data subjects regarding data protection. ${ }^{893}$

241. As concerns processing in the employment context, the EDPS's guidelines should be mentioned. Even though these documents relate to processing conducted by EU institutions and bodies, the EDPS itself stated that it does not mean that these documents are only useful for them, as Regulation $45 / 2001^{894}$ is similar to the DPD and the GDPR in many regards. ${ }^{895}$ The EDPS adopted guidelines - amongst others - on the electronic communication, ${ }^{896}$ on the use of mobile devices, ${ }^{897}$ on camera surveillance, ${ }^{898}$ on the processing of health data ${ }^{899}$ and on processing related to recruitment. ${ }^{900}$

${ }^{891}$ Regulation (EC) No 45/2001 of the European Parliament and of the Council of 18 December 2000 on the protection of individuals with regard to the processing of personal data by the Community institutions and bodies and on the free movement of such data, Article 41 (1)

892 Paragraph 1 of Article 41 of Regulation (EC) No 45/2001 of the European Parliament and of the Council of 18 December 2000 on the protection of individuals with regard to the processing of personal data by the Community institutions and bodies and on the free movement of such data. Official Journal of the European Union (2001: L 008) Available at: https://eur-lex.europa.eu/legal-content/EN/TXT/?uri=OJ:L:2001:008:TOC (Accessed: 2 May 2018)

${ }^{893}$ Paragraph 2 of Article 41 of Regulation (EC) No 45/2001

${ }^{894}$ Which was replaced by Regulation (EU) 2018/1725 of the European Parliament and of the Council of 23 October 2018 on the protection of natural persons with regard to the processing of personal data by the Union institutions, bodies, offices and agencies and on the free movement of such data, and repealing Regulation (EC) No 45/2001 and Decision No 1247/2002/EC

${ }^{895}$ EDPS (2016) Guidelines on the protection of personal data processed through web services provided by EU institutions. Available at: https://edps.europa.eu/sites/edp/files/publication/16-1107_guidelines_web_services_en.pdf(Accessed: 12 August 2019), p. 3.

EDPS (2015) Guidelines on personal data and electronic communications in the EU institutions. Available at: https://secure.edps.europa.eu/EDPSWEB/webdav/site/mySite/shared/Documents/Supervision/Guidelines/ 15-12-16_eCommunications_EN.pdf(Accessed: 12 August 2019), p. 1.

896 EDPS (2015) Guidelines on personal data and electronic communications in the EU institutions. Available

at: https://secure.edps.europa.eu/EDPSWEB/webdav/site/mySite/shared/Documents/Supervision/Guidelines/ 15-12-16_eCommunications_EN.pdf(Accessed: 12 August 2019)

897 EDPS (2015) Guidelines on the protection of personal data in mobile devices used by European institutions. Available at: https://secure.edps.europa.eu/EDPSWEB/webdav/site/mySite/shared/Documents/Supervision/Guidelines/ 15-12-17_Mobile_devices_EN.pdf(Accessed: 12 August 2019) 
242. Conclusions. The adoption of international regulations and the relevant cases in the field of employee data protection and monitoring demonstrates the importance of this specific subject. As it was seen, the question of employee monitoring and data protection is not new, as the first relevant documents date back to decades. In consequence, early documents did not address the challenges raised by SNSs. What is more precisely elaborated by them and also has a direct connection to the main subject of the thesis is the monitoring of e-mail and Internet use, in that respect that SNSs are also web-based services and also allow the user to communicate. As SNSs have a growing importance, the most recent documents already address them explicitly. However, they only deal with one aspect of the subject (notably pre-employment) - the exhaustive regulation of SNSs in the field of employment is yet to be elaborated.

The rules established by the above-examined international institutions and bodies provide the Member States with an important guidance, which can therefore have an important impact on national legal systems. The following Paragraph will explore how France and Hungary have decided to regulate the question of employee privacy and data protection in their respective legislations.

\section{\$2. Workplace privacy/data protection in France and in Hungary}

243. Similarly to the international regulations presented above, employment specific rules appeared in Member States' legal orders as well. On the following pages it is going to be examined, as opposed to the already discussed employer's rights/powers, how the protection of employees' rights appears in national legal systems. These (labour law) rules constitute the conceptual fundaments of protecting employees' rights. The exact rules of monitoring employing a given technology are deducted from these general rules. Both the FLC and the HLC contain a general clause declaring the protection of employees' rights (which rights include, for example, the right to privacy and the right to data

\footnotetext{
898 EDPS (2010) The EDPS video-surveillance guidelines. Available at: https://secure.edps.europa.eu/EDPSWEB/webdav/site/mySite/shared/Documents/Supervision/Guidelines/ 10-03-17_Video-surveillance_Guidelines_EN.pdf(Accessed: 12 December 2016)

899 EDPS (2009) Guidelines concerning the processing of health data in the workplace by Community institutions and bodies. Available at: https://secure.edps.europa.eu/EDPSWEB/webdav/site/mySite/shared/Documents/Supervision/Guidelines/ 09-09-28_Guidelines_Healthdata_atwork_EN.pdf(Accessed: 12 December 2016)

${ }^{900}$ EDPS (2008) Guidelines concerning the processing operations in the field of staff recruitment. Available at: https://secure.edps.europa.eu/EDPSWEB/webdav/site/mySite/shared/Documents/Supervision/Guidelines/ 08-10-10_Guidelines_staff_recruitment_EN.pdf(Accessed: 12 December 2016)
} 
protection). Also, both labour codes contain certain provisions providing more detailed principles for data processing.

244. From this background it was already elaborated how these general requirements must be applied to existing forms of employee monitoring. In France, notably the courts and the CNIL, while in Hungary the doctrine and the NAIH (and the former Data Protection Commissioner) have already worked out how they should be applied to specific types of monitoring. Therefore, the rules relating to the areas of telephone monitoring, CCTV monitoring, geolocalisation, the use of electronic badges, etc. are already elaborated. ${ }^{901,902}$ The monitoring of the use of work computers, Internet and e-mail

${ }^{901}$ See more in: Brégou, P. (2012) Le pouvoir disciplinaire de l'employeur : surveillance, fautes, sanctions, procédures, contentieux. Rueil-Malmaison: Éd. Liaisons; Féral-Schuhl, C. (2018) Cyberdroit. Le droit à l'épreuve de l'Internet. 7th edn. Paris: Dalloz; Waquet, P., Struillou, Y. and Pécaut-Rivolier, L. (2014) Pouvoirs du chef d'entreprise et libertés du salarié: du salarié-citoyen au citoyen-salarié. RueilMalmaison: ÉdLiaisons

See more on documents issued by the CNIL in: CNIL Fiches Travail et données personnelles (Édition 2018); La Rédaction D.O. (2013) 'Diffusion des bonnes pratiques en matière de protection des données personnelles des salariés', JCP S (édition sociale), (7), pp. 3-7.; see more on the CNIL's good practices in: Griguer, M. (2013) 'Protection des données personnelles: conformité et bonnes pratiques des entreprises', Cahiers de droit de l'entreprise, (1), pp. 73-76, 2 guide, on the CNIL's practice: Wolton, E. and Pompey, S. (2013) 'Données à caractère personnel et droit du travail', Revue de Jurisprudence Sociale (RJS), (4), pp. 215-220. The CNIL also issued simplified standards ("norms simplifiées"), which they concern badges (CNIL (2002) Délibération concernant les traitements automatisés d'informations nominatives relatifs mis en oeuvre sur les lieux de travail pour la gestion des contrôles d'accès aux locaux, des horaires et de la restauration. Délibération $\mathrm{n}^{\circ} 02-001$ du 08 janvier 2002.); telephone conversations (CNIL (2014) Délibération $n^{\circ} 2014-474$ du 27 novembre 2014 portant adoption d'une norme simplifiée relative aux traitements automatisés de données à caractère personnel mis en oeuvre par les organismes publics et privés destinés à l'écoute et à l'enregistrement des conversations téléphoniques sur le lieu de travail (NS 057). Délibération n²014-474 du 27 novembre 2014.; CNIL (2005) Délibération no 2005-19 du 3 février 2005 portant création d'une norme simplifiée concernant les traitements automatisés de données à caractère personnel mis en oeuvre dans le cadre de l'utilisation de services de téléphonie fixe et mobile sur les lieux de travail (norme simplifiée no 47) et portant abrogation de la norme simplifiée no 40. Délibération no 2005-19 du 3 février 2005.); geolocalisation (CNIL (2015) Délibération $n^{\circ} 2015-165$ du 4 juin 2015 portant adoption d'une norme simplifiée concernant les traitements automatisés de données à caractère personnel mis en oeuvre par les organismes publics ou privés destinés à géolocaliser les véhicules utilisés par leurs employés (norme simplifiée $n^{\circ} 51$ ). Délibération $\mathrm{n}^{\circ} 2015-165$ du 4 juin 2015.) and on the management of the personnel (CNIL (2005) Norme simplifiée $n^{\circ} 46$ : Délibération $n^{\circ} 2005-002$ du 13 janvier 2005 portant adoption d'une norme destinée à simplifier l'obligation de déclaration des traitements mis en oeuvre par les organismes publics et privés pour la gestion de leurs personnels. Délibération n²005-002 du 13 janvier 2005.). Though after the application of the GDPR these standards do not have legal force, their examination is not without interest.

902 In general, see more on employee monitoring in Hungary in: Arany-Tóth, M. (2008) A munkavállalók személyes adatainak védelme a magyar munkajogban. Szeged: Bába Kiadó.; Arany-Tóth, M. (2016) Személyes adatok kezelése a munkaviszonyban. Budapest: Wolters Kluwer; Hajdú, J. (2005) A munkavállalók személyiségi jogainak védelme. Szeged: Pólay Elemér Alapítvány., Szőke, G. L. (ed.) (2012) Privacy in the workplace. Data protection law and self-regulation in Germany and in Hungary. Budapest: HVG-ORAC Lap- és Könyvkiadó; Szőke, G. L. et al. (2012) Munkahelyi adatvédelem. Nemzeti jelentés Magyarország.

Available at: http://pawproject.eu/en/sites/default/files/page/web_national_report_hungary_hu.pdf （Accessed: 21 October 2016) 
will be further addressed in detail in Part II. as they have a closer connection to SNSs compared to the other forms of monitoring. The dissertation focuses on SNSs: it will be Part II. which will address in detail how these general rules are to be applied to the case of SNSs - the present sections will provide the conceptual background for that analysis.

245. Besides these already regulated, "traditional" forms of employee monitoring, several other matters have also been regulated, which gain a new light in the SNS era. These matters are subjected to detailed existing regulation - which will be analysed in Part II. For example, in the field of dismissals, the protection of private life must be ensured: in French law the starting point is that dismissal cannot be based on an element pertaining to the personal life of the employee. The HLC ensures the same principle through stating that as a main rule, an employee may be dismissed only for reasons in connection with his/her behaviour in relation to the employment relationship, with his/her ability or in connection with the employer's operations. ${ }^{903}$ Or in the field of employees' freedom of expression - again, to be addressed in detail in Part II. - the already elaborated rules are considerably challenged by SNSs, giving rise to a multitude of questions to be answered. The following sections will focus on the more general rules, leaving the discussion of the more specific rules to Part II.

\section{(A) Protecting employees' rights in the labour codes}

On the monitoring of computer and Internet use see more in: Hegedüs, B. (2006a) 'A munkahelyi hagyományos és elektronikus levelezés ellenőrzése', Munkaügyi szemle, 50(6), pp. 47-49.; Hegedüs, B. (2006b) 'A munkahelyi számítógép és internet ellenőrzésével kapcsolatos gyakorlati kérdések', Munkaügyi szemle, 50(7-8), pp. 81-83.

On the monitoring of telephone use see more in: Hegedűs, B. (2007) 'A munkavállaló rendelkezésére bocsátott telefon használatának ellenőrzéséröl', Munkaügyi szemle, 51(1), pp. 50-52.

On CCTV surveillance see more in: Lukács, A. (2017) 'Privacy at Work: the Regulation of Camera Surveillance in Hungarian Labour Law', Acta Universitatis George Bacovia - Juridica, 6(1), pp. 77-118.; Lukács, A. (2013) 'A munkavállalók személyiségi jogainak védelme, különös tekintettel a munkahelyi kamerákra', De Iurisprudentia Et Iure Publico, 7(2).; Sum, S. (2007a) 'A munkavállalók személyes adatainak védelméről, különös tekintettel a munkahelyi kamerák alkalmazására I.', Munkajog: kérdések és válaszok, 3(2), pp. 28-35.; Sum, S. (2007b) 'A munkavállalók személyes adatainak védelméröl, különös tekintettel a munkahelyi kamerák alkalmazására II.’, Munkajog: kérdések és válaszok, 3(3), pp. 32-36.; Torma, G. (2016) 'Munkáltatói ellenőrzés', HR \& Munkajog, 7(7-8), pp. 19-23.

On the monitoring of alcohol and drug use: Rátkai, I. (2016) 'Alkohol- és drogfogyasztás ellenőrzése a munkahelyen', HR \& Munkajog, 7(10), pp. 6-9.

See more on documents issued by the NAIH in: NAIH (2013) A Nemzeti Adatvédelmi és Információszabadság Hatóság ajánlása a munkahelyen alkalmazott elektronikus megfigyelőrendszer alapvető követelményeiről. NAIH-4001-6/2012/V. Budapest and NAIH (2016) A Nemzeti Adatvédelmi és Információszabadság Hatóság tájékoztatója a munkahelyi adatkezelések alapvető követelményeiről. Budapest

${ }^{903}$ Subsection (2) of Section 66 of the HLC 
246. Both the FLC and the HLC declare the protection of employees' rights. The key provision enouncing this protection is Article L1121-1 of the FLC, regulating the limitation of the rights and individual liberties of the individual. The HLC contains a similar paragraph: Section 9 proclaims the protection of personality rights. These two provisions constitute the cornerstone of protecting employees' rights.

\section{(a) Article L1121-1 of the French Labour Code}

247. Origins of regulation: the Corona case. Besides accepting the co-existence of the personal sphere and the professional sphere, employees' rights in general have seen an important evolution. Before 1982 the employer had a quasi-unlimited power when it came to the drafting of internal regulations. ${ }^{904}$ It was the State Council's Corona decision in 1980 that first declared the principle that provisions of the internal regulation can be annulled due to the threat they can pose to the rights of the person. ${ }^{905}$ This principle was legitimized by Article L.122-35 of the Act of 4 August 1982 (the "loi Auroux"), 906 which stated that "[the internal regulation] may not limit the rights of the individual or individual or collective liberties by any restriction which is not justified by the nature of the task to be performed and proportionate to the aim sought." This was a first, as hitherto the idea of civil liberties entering the workplace was unknown. Also, Article L. 122-45 stated that "[n]o employee may be punished or dismissed because of his or her origins, sex, morals, family situation, membership in an ethnic group, in nation or race, political opinions, trade union or mutual activities, religious convictions."

248. The 1990 Lyon-Caen report and its repercussions. In 1990, Gérard LyonCaen was asked by the Ministry of Labour Law to prepare a report in order to find a balance between the employees' and job candidates' individual liberties and the employer's powers, in the light of the development of new technologies. ${ }^{907}$ As a result, he drew up his famous report, entitled "Civil liberties and employment", ${ }^{908}$ which is the origin

\footnotetext{
${ }^{904}$ For example, the internal regulation of Air France stipulated that if a flight attendant gets married, the marriage will automatically result in the cessation of the functions of the employee - which provision seems unimaginable nowadays.

905 Collomp, E. (2010) 'La vie personnelle au travail. Dernières évolutions jurisprudentielles', Droit social, (1), p. 40.

${ }^{906}$ Loi n ${ }^{\circ} 82-689$ du 4 août 1982 relative aux libertés des travailleurs dans l'entreprise

${ }^{907}$ Lyon-Caen, G. (1992) Les libertés publiques et l'emploi. Paris: la Documentation française (Collection des rapports officiels). p. 3.

${ }^{908}$ Lyon-Caen, G. (1992) Les libertés publiques et l'emploi. Paris: la Documentation française (Collection des rapports officiels).
} 
of legitimizing the protection of employees' rights. ${ }^{909}$ In his report he addressed two main subjects: hiring (what the limits of asking for information relating to job candidates are) and the evaluation of employees and the control of work (with regard to the subordination between the parties, to what extent the liberties and rights of the employee are restricted). He drew attention to the development of emerging technologies and its repercussions: the threat posed by their capacity to provide powerful means of knowledge, power and control to the employer. ${ }^{910}$

249. Article L1121-1 of the FLC. Originating from his report, with Article L. 120-2 of the Act of 31 December $1992^{911}$ the legislator laid down the foundations of the protection of the employee's rights and freedoms. Its text (Article L1121-1 of the FLC in force) reads as follows:

"No one may limit the rights of the individual or individual or collective liberties by any restriction which is not justified by the nature of the task to be performed and proportionate to the aim sought." "912

By this provision, the extent of the employer's powers - without denying their existence - was considerably narrowed. The legislator expanded the protection by replacing the previously used word "internal regulation" with the expression "no one", which includes not only the internal regulation, ${ }^{913}$ but also the collective agreement, the employment contract, the unilateral acts of the employer, etc., ${ }^{914}$ and besides the employer, social partners, too. ${ }^{915}$

250. Scope of Article L1121-1 of the FLC. What rights and liberties does the text aim to protect? Without analysing the differences between these two concepts in

\footnotetext{
${ }^{909}$ Lyon-Caen, A. (2014) 'Libertés et contrôle dans l'entreprise. 20 ans après', Revue droit du travail Dalloz, (6), pp. 386-390.

${ }^{910}$ Lyon-Caen, G. (1992) Les libertés publiques et l'emploi. Paris: la Documentation française (Collection des rapports officiels). p. 10. It is interesting to remember that the report was published in 1992: years and decades before the mass adoption of the Internet and SNSs.

911 Act No. 92-1446 of 31 December 1992 on employment, the development of part-time work and unemployment insurance

912 "Nul ne peut apporter aux droits des personnes et aux libertés individuelles et collectives de restrictions qui ne seraient pas justifiées par la nature de la tâche à accomplir ni proportionnées au but recherché."

913 Although Subparagraph 2 of Article L1321-3 of the FLC repeats Article L1121-1 stating that the internal regulation may not contain "[p]rovisions limiting the rights of the individual or individual or collective liberties by any restriction which is not justified by the nature of the task to be performed and proportionate to the aim sought."

914 Waquet, P. (2003) L'entreprise et les libertés du salarié. Paris: Editions Liaisons, pp. 101-109.

915 Waquet, P. (2003) L'entreprise et les libertés du salarié. Paris: Editions Liaisons, pp. 86-88. Although as Jean-Emmanuel Ray pointed out, originally this "no one" aimed to protect only job candidates. Source: Ray, J.-E. (2010) 'D’un droit des travailleurs aux droits de la personne au travail', Droit social, (1), p. 6.
} 
detail, the dissertation will limit itself to presenting Philippe Waquet's thoughts on this issue, according to whom it is not possible, nor desirable, to draft an exhaustive list. Under the rights of the individual, the right to dignity and the right to equality are protected, while under individual liberties, the right to respect for private life is included. ${ }^{916}$ The protection of the right to respect for private life also has a connection with regulations relating to nondiscrimination, ${ }^{917}$ a founding principle for the protection of the rights of the person. ${ }^{918}$

251. Conditions of restricting rights and liberties. Also, the text speaks about restriction of rights and liberties - suggesting that it is not possible to place a complete limitation on them ${ }^{919}$ - based on two principles: the necessity principle and the principle of proportionality. The necessity principle means that conciliation between the employer's interests and the employee's rights must be made, and only the restriction which is indispensable for protecting the employer's legitimate interests is justified. It means that the restriction must have a defined and legitimate purpose. The principle of proportionality limits excessive restrictions, by demanding to compare the employer's advantage with the employee's disadvantage. If there is an available method which restricts the rights and liberties of the employee less, this method shall be used. Also, the method chosen cannot be excessive. ${ }^{920}$

252. Although today the respect of employees' personal life is an important requirement of contemporary law, ${ }^{921}$ critical spirit should be adopted, as certain authors have raised the question of the necessity of re-examining the question from the employer's point of view. Without questioning that the employee is entitled to protection of personal life, Lise Casaux-Labrunée asks whether the opposite question should be asked, namely how employees can respect "business life" in the workplace. By taking advantage of the protective legal framework and the possibilities offered by modern means of communication, aren't employees bringing a bit too much of their personal life to the

\footnotetext{
916 Waquet, P. (2003) L'entreprise et les libertés du salarié. Paris: Editions Liaisons (Collection Droit vivant). pp. 93-96.

917 Article L1132-1 of the FLC

918 Tissot, O. de (1995) 'La protection de la vie privée du salarié', Droit social, (3), p. 227.

919 Waquet, P. (2003) L'entreprise et les libertés du salarié. Paris: Editions Liaisons, p. 90.

${ }^{920}$ Mouly, J. (2012) Droit du travail. 6e édition. Rosny-sous-Bois: Bréal (Lexifac Droit), p. 117. See also: Mazeaud, A. (2014) Droit du travail. 9e édition. Issy-les-Moulineaux: LGDJ-Lextenso éditions (Domat Droit privé), pp. 339-340.; Peskine, E. and Wolmark, C. (2016) Droit du travail. 11th edn. Paris: Dalloz, pp. 221224.; Waquet, P., Struillou, Y. and Pécaut-Rivolier, L. (2014) Pouvoirs du chef d'entreprise et libertés du salarié: du salarié-citoyen au citoyen-salarié. Rueil-Malmaison: ÉdLiaisons (Droit vivant), p. 235-236.

${ }^{921}$ Loiseau, G. (2011) 'Vie personnelle et licenciement disciplinaire', Recueil Dalloz Sirey, (23), p. 1568.
} 
workplace? ${ }^{922}$ This question is particularly pertinent in the age when employees spend a daily 1 hour 15 minutes of working time by surfing on the Internet (and in a large part on social media). ${ }^{923}$ Also, social media introduced a new paradigm regarding extraprofessional life: employees often feel free to say anything on these sites - supplying a quite rich case law of "Facebook firings" -, seriously compromising the employer's legitimate interests. These must be considered as well when determining the balance between the employer's and employees' rights.

\section{(b) Protection of rights relating to personality in the Hungarian Labour Code}

253. The $H L C$ came into force in 2012 and it brought fundamental changes to workplace data protection. ${ }^{924}$ Declaring the protection of personality rights is also a novelty of the HLC in force: the previous Labour Code did not set the general protection of these rights. ${ }^{925,926}$ After the entering into application of the GDPR, the Hungarian legislator adopted Act XXXIV of 2019 on legislative amendments required for the implementation of the European Union's data protection reform (hereinafter referred to as: Enforcing Act) in April 2019, aiming to adapt the Hungarian legal system to the GDPR, by amending more than 80 acts. The Enforcing Act also concerned the HLC, as in accordance with Article 88 of the GDPR, specific rules were introduced. These novelties will be presented in the corresponding places.

\footnotetext{
${ }^{922}$ Casaux-Labrunée, L. (2012) 'Vie privée des salariés et vie de l'entreprise', Droit social, (4) p. 334.

923 According to a study prepared by Olfeo regarding Internet use at the workplace in 2015. Olfeo (2016) Etude 2016: La réalité de l'utilisation d'Internet au bureau. Available at: https://www.euromedia.fr/public/2016/12/etude-olfeo-2016-realite-utilisation-web-aubureau.pdf (Accessed: 20 January 2019)

${ }^{224}$ The previous HLC (Act XXII of 1992) contained only very brief provisions regarding workplace privacy and data protection. It stated in Subsection (1) Section 77 that "[a]n employee shall only be requested to make a statement, fill out a data sheet, or take an aptitude test which does not violate his or her personal rights and which essentially provides substantive information for the aspects of the establishment of an employment relationship[,]" and in Subsection (4) of Section 3 that "[e]mployers may only disclose facts, data and opinions concerning an employee to third persons in the cases specified by law or with the employee's consent". Source: Balogh, Zs. Gy. et al. (2012) 'Munkahelyi adatvédelem a gyakorlatban', Infokommunikáció és Jog, 9(3), p. 99.

925 Arany Tóth, M. (2008) 'Gondolatok a munkavállalók személyiségi jogainak védelméról a magyar munkajogban', Jogtudományi közlöny, 63(3), p. 131. The lack of the general declaration of protection did not mean that no protection at all was afforded to employees: the majority of the doctrine identified within this the protection of personality among the employer's duty of care. Source: Arany Tóth, M. (2008) 'Gondolatok a munkavállalók személyiségi jogainak védelméről a magyar munkajogban’, Jogtudományi közlöny, 63(3), p. 129.

${ }^{926}$ A reference was made to them in Subsection 2 of Article 8 stating that "[a]n employee shall not waive his/her rights in protection of his/her wages and his/her person in advance, nor shall he/she conclude an advance agreement which may prejudice his/her rights to his/her detriment."
} 
254. Protection of rights relating to personality. Subsection (1) of Section 9 declares the protection of personality rights, referring explicitly to the Hungarian Civil Code, ${ }^{927}$ resulting in the joint application of labour law and civil law provisions. ${ }^{928}$ As Items b) and e) of Section 2:43 of the Hungarian Civil Code expressly specify the right to respect for private life and the right to data protection, these provisions are to be applied to these rights as well. Although it is regulated under a separate title, the respect of personality rights is considered to be a general requirement and belongs to the common rules of conduct of labour law. ${ }^{929}$ Limiting employees' personality rights to a certain extent is a natural characteristic of labour law: the exact content of personality rights protection in labour law can be determined in the light of labour rights and obligations. ${ }^{930}$

255. Conditions of restricting personality rights. Although according to Subsection (3) an employee may not waive his/her rights relating to personality in advance, it does not mean that no limitation of these rights can take place: Subsection (2) lays down the conditions for restricting these rights - which are very similar to those established by the FLC. This restriction has three concurrent conditions: it shall be absolutely necessary, directly related to the purpose of the employment relationship, and proportional to its objective.

256. A restriction is absolutely necessary if without it the employer would not be able to fulfil his/her obligations ensuing from the employment relationship. ${ }^{931}$ The requirements of necessity are met if the restriction is objectively necessary. ${ }^{932}$ The purpose of the employment relationship shall be interpreted narrowly, and the restriction shall relate exclusively and directly to this purpose. ${ }^{933}$ The purpose of the employment relationship

\footnotetext{
927 Subsection (1) of Section 9 of the HLC: "Unless otherwise provided for in this Act, the provisions of Sections 2:42-2:54 of Act V of 2013 of the Civil Code shall apply to the protection of the personality rights of employees and employers, with the proviso that in the application of Subsections (2) and (3) of Section 2:52 and Section 2:53 of the Civil Code the provisions of this Act relating to liability for damages shall be applicable."

${ }_{928}$ Kardkovács, K. (ed.) (2016) A Munka Törvénykönyvének magyarázata. 3rd edn. Budapest: HVG-ORAC Lap- és Könyvkiadó. p. 53.

929 Miholics, T. (2015) 'Általános magatartási követelmények a munkaviszonyban’, Magyar jog, 62(4), p. 245.

930 Arany Tóth, M. (2008) 'Gondolatok a munkavállalók személyiségi jogainak védelméről a magyar munkajogban’, Jogtudományi közlöny, 63(3), p. 134.

${ }^{931}$ Kardkovács, K. (ed.) (2016) A Munka Törvénykönyvének magyarázata. 3rd edn. Budapest: HVG-ORAC Lap- és Könyvkiadó. p. 52.

932 T/4786. számú törvényjavaslat a Munka Törvénykönyvéröl(2011). Előadó: Dr. Matolcsy György nemzetgazdasági miniszter. Budapest. p. 100.

933 T/4786. számú törvényjavaslat a Munka Törvénykönyvéről(2011). Előadó: Dr. Matolcsy György nemzetgazdasági miniszter. Budapest. p. 100
} 
shall be identified from the rights and obligations of the parties. In accordance with the main obligations of the parties (the employee shall work while the employer shall provide work and remuneration), the purpose of the employment relationship is employment in order to achieve the employer's legitimate economic interest. This must be interpreted narrowly and is limited by the HLC and by the personality rights of the employee. ${ }^{934}$ Regarding proportionality, the employer's objective and the employee's disadvantage must be balanced. ${ }^{935}$

257. Informing employees. In addition, Subsection 2 of Section 9 regulates the question of informing employees on the limitation of their personality rights. The Enforcing Act made this provision more severe, as it broadened the scope of the employer's obligation regarding his/her obligation to inform employees: the information should relate not only to the methods, conditions and length of limiting personality rights, but also to the circumstances justifying the necessity and proportionality of the limitation. ${ }^{936}$

\section{(B) Data protection and employee monitoring}

Besides the general declaration of the protection of rights and personality rights, both labour codes contain additional rules, expressively focusing on (certain aspects of) employee data protection. While the FLC regulates the most important rules in relation to the processing of personal information of employees and prospective employees, the HLC focuses on data protection rules, and then contains specific rules regarding employee monitoring.

(a) Principles applicable to the processing of personal information ${ }^{937}$ in the French Labour Code

\footnotetext{
934 Berke, Gy. and Kiss, Gy. (eds) (2014) Kommentár a munka törvénykönyvéhez: kommentár a munka törvénykönyvéröl szóló 2012. évi I. törvényhez. Budapest: Wolters Kluwer, p. 58.

935 Kardkovács, K. (ed.) (2016) A Munka Törvénykönyvének magyarázata. 3rd edn. Budapest: HVG-ORAC Lap- és Könyvkiadó. p. 52.

${ }^{936}$ Rátkai, I. (2019) 'Új adatvédelmi szabályok a munkaviszonnyal összefüggésben’, Munkajog, (2), pp. 6975. Available at: https://munkajogilap.hu/uj-adatvedelmi-szabalyok-a-munkaviszonnyalosszefuggesben/ (Accessed: 12 August 2019).

937 The FLC does not employ the expression personal data. Instead, it uses the expression "information relating personally to a candidate/employee" ("information concernant personnellement un candidat/un salarié").
} 
258. Besides the declaration of the general respect of rights and liberties, the FLC contains other rules relevant to the subject of the dissertation. Articles L1221-6 to L1221-9 relate to recruitment, regulating what information can be asked, how it should be processed and what requirements apply to the methods of recruitment. Articles L1222-3 to L1222-4 relate to the information asked from employees, and mirrors the former provisions relating to recruitment. The requirements set towards the processing of employees' and prospective employees' personal information echo those laid down in the FDPA, such as purpose limitation, proportionality or transparency. ${ }^{938}$ Through these principles, a more dominant data protection approach is reflected. This part will review the relevant principles: first their formulation in the FLC and then their appearance in the data protection framework.

259. Principle of purpose limitation. The principle of purpose limitation ${ }^{939}$ also explicitly appears in labour law, limiting the scope of processing to matters relating to the professional life: Article L1222-2 states that information requested from an employee regardless of its forms - shall only have the aim to assess the employee's professional competence, while Article L1221-6 states that information requested from a job candidateregardless of its forms - shall only have the aim to assess his/her fitness for the proposed employment or his/her professional competence. The purpose shall be determined prior to the processing. ${ }^{940}$ Although it is not expressly referred to, by stating that the aim of collecting shall relate to the professional capacities, the legislator indirectly refers to the protection of the (prospective) employees' personal life.

The purpose limitation principle is also enshrined in the data protection regulation. ${ }^{941}$ If the employer decides to monitor employees, first, he/she has to define its purpose. ${ }^{942}$ There are several legitimate aims that can justify monitoring: to determine whether an aim is legitimate the technological context also has to be taken into consideration. Often aims such as preventing damage to goods and persons, enhancing productivity, or ensuring the

\footnotetext{
938 Bouchet, H. (2004) La cybersurveillance sur les lieux de travail. Paris, la Documentation française: Commission nationale de l'informatique et des libertés, p. 8.

${ }^{939}$ Also enshrined in Paragraph 2 of Article 4 of the FDPA: "the data shall be obtained for specified, explicit and legitimate purposes, and shall not subsequently be processed in a manner that is incompatible with those purposes."

940 CNIL (2010) Guide pour les employeurs et les salariés. Les guides de la CNIL. p. 3.

${ }^{941}$ Item b) of Paragraph 1 of Article 5 of the GDPR, Paragraph 2 of Article 4 of the FDPA

942 Wolton, E. and Pompey, S. (2013) 'Données à caractère personnel et droit du travail', Revue de Jurisprudence Sociale (RJS), (4), p. 218.
} 
security of the network are referred to. ${ }^{943}$ Or, as a specific example, telephone monitoring might be mentioned, where listening to the phone calls of employees can be conducted for the purpose of training or evaluating employees, ameliorating the quality of the service or to provide proof in certain limited cases. ${ }^{944}$

260. Principle of proportionality. Besides its general formulation in Article L1121-1, the principle of proportionality requires that the information requested from job candidates or from employees shall have a direct and necessary link with the aimed purpose, and candidates and employees shall reply in good faith. ${ }^{945}$ Article L1222-3 adds that means and techniques of evaluation shall be relevant in regards of the purpose. The CNIL stated that as a main rule, during recruitment it is not compatible with these provisions to collect personal data relating to nationality, social security number, housing conditions, information concerning family members, etc. ${ }^{946}$

261. This principle requires that personal data shall be adequate, relevant and do not exceed the purpose for which they are processed. ${ }^{947}$ This principle provides that no intrusive monitoring shall take place, only the strict minimum of data shall be processed. When assessing the principle of proportionality, the given circumstances of the case shall be taken into consideration. ${ }^{948,}{ }^{949}$ For example, the use of permanent videosurveillance ${ }^{950}$ or the systematic search of employees' bags ${ }^{951}$ was considered to be disproportionate. The same is true for the use of keylogger programs: the CNIL stated that as they can constantly and permanently record every keystroke, they pose an unproportionate threat to employees' rights and their use is allowed only in very strict cases. ${ }^{952}$

\footnotetext{
943 Wolton, E. and Pompey, S. (2013) 'Données à caractère personnel et droit du travail', Revue de Jurisprudence Sociale (RJS), (4), p. 218.

944 CNIL (2018) L'écoute et l'enregistrement des appels. Fiches pratiques: Travail \& données personnelles.

945 Article L1222-2 and Article L1221-6 of the FLC

${ }^{946}$ CNIL (2002) Délibération portant adoption d'une recommandation relative à la collecte et au traitement d'informations nominatives lors d'opérations de recrutement. Délibération n02-017 du 21 mars 2002

${ }^{947}$ Item c) of Paragraph 1 of Article 5 of the GDPR, Paragraph 3 of Article 4 of the FDPA

948 Wolton, E. and Pompey, S. (2013) 'Données à caractère personnel et droit du travail', Revue de Jurisprudence Sociale (RJS), (4), p. 219.

${ }^{949}$ For example, while asking for the height of a job applicant for a secretary post does not seem to be proportionate, asking the same information from a stewardess can be considered proportionate, as they have to be able to easily reach the higher shelves in the plane. Or, asking for a driving licence is not proportionate when the job does not need driving, naturally in the case of a truck driver, asking for the driving licence is a proportionate measure.

${ }_{950}$ CNIL Délibération n²012-475 du 3 janvier 2013

951 CA Rennes 6 février $2003 n^{\circ} 02-2859$

952 Keylogger: des dispositifs de cybersurveillance particulièrement intrusifs(2013) CNRS. Available at: http://www.cil.cnrs.fr/CIL/spip.php?article1954 (Accessed: 1 October 2018)
} 
262. Transparency. The general principle of transparency (and the employer's obligation to inform employees of the processing of personal data) appears in the FLC, both in regards of employees and candidates. It holds that no information relating personally to an employee/candidate can be collected through a measure that has not been brought to his/her attention (Article L1222-4 and Article L1221-9) and employees/candidates shall be explicitly informed of methods and techniques used for professional evaluation/recruitment, prior to their application (Article L1222-3 and Article L1221-8).

This is closely related to the principle of fairness ("principe de loyauté" enshrined also in Paragraph 1 of Article 4 of the FDPA), prohibiting the collection of personal data by all fraudulent, unfair or unlawful means. ${ }^{953}$ The Court of Cassation ruled already in 1991 that although the employer has the right to control and monitor the activity of employees during working hours, any recording of their image or words, for any reason, without their knowledge, will constitute illegal proof. ${ }^{954}$ It means that no secret monitoring is allowed, ${ }^{955}$ which was also confirmed by the Court of Cassation, who stated in a case relating to the monitoring of telephone calls that "the employer has the right to control and to monitor employees' activities during working hours, only the use of covert monitoring is unlawful. "956, 957

263. Besides informing the employees individually, collective transparency is also required: the social and economic committee shall be informed prior to the application (and all modifications) of methods or techniques used for recruitment and of automated

953 Benalcázar, I. de (2003) Droit du travail et nouvelles technologies : collecte des données, Internet, cybersurveillance, télétravail. Paris: Montchrestien : Gualino. p. 35

${ }^{954}$ Cour de cassation, chambre sociale, 20 novembre 1991, N $88-43120$

955 For example, hiring a private detective (Cour de cassation, chambre sociale, 22 mai 1995, № 93-44078) or the use of letter bombs at the post in response to the high number of letters opened by the employees without their knowledge (Cour de cassation, chambre sociale, 4 juillet 2012, $\mathrm{N}^{\circ} 11-30266$ ) is considered to be an unlawful means of collecting evidence.

956 Cour de cassation, chambre sociale, 14 mars 2000, N 98-42090

957 Naturally, even without prior information of employees, their simple surveillance by their supervisors (Cour de cassation, chambre sociale, 26 avr. 2006, $\mathrm{n}^{\circ}$ 04-43.582) and, even in the absence of prior consultation, the simple surveillance by the employer or in-house service entrusted with this task (Cour de cassation chambre sociale 4 juillet $2012 \mathrm{~N}^{\circ}$ de pourvoi: 11-14241) will not be considered unlawful.

However, in a case relating to the personal use of telephone, the Court of Cassation ruled that the simple verification of the length, cost or the phone numbers of the calls made from work phones is not considered to be illegal monitoring just because it was not previously brought to the attention of the employer. (Source: Cour de cassation, chambre sociale, 29 janvier 2008, $\mathrm{N}^{\circ}$ 06-45279). Grynbaum et al. are of the opinion that this decision was due to the circumstances of the case, and this principle should not be extended to other types of employee monitoring (e.g.: Internet). Source: Grynbaum, L., Le Goffic, C. and Morlet-Haïdara, L. (2014) Droit des activités numériques. 1st edn. Paris: Dalloz. p. 895. 
processing in the field of HR management and they shall be informed and consulted before deciding of the adoption of means or techniques allowing to monitor employees' activities. $^{958}$ Regulating questions relating to the work discipline in the internal regulation ${ }^{959}$ are also subject to certain conditions such as submission for the opinion of the social and economic committee, communication to the labour inspector, labour courts and persons accessing the workplace, or administrative and judicial control. ${ }^{960}$

264. Whistleblowing. In order to ensure the enforcement of the rights of the individuals, the FLC also contains a provision on whistleblowing (Article L2313-2): if staff representatives notice that there exists a threat to the rights of individuals, to physical and mental health or to individual liberties, which is not justified by the nature of the task to be performed and is not proportionate to the aim sought, they have to contact the employer immediately. The employer has to investigate the case and remedy the situation by taking the necessary measures. If the employer does not act, or there are different opinions regarding the veracity of the threat and there is no solution found, the matter is taken to the labour court.

\section{(b) Data processing and employee monitoring in the Hungarian Labour Code}

265. Amendment of the HLC. In 2019 the Enforcing Act introduced some important changes in the field of data protection, considerably increasing the number of provisions dealing with this matter. Now these matters are regulated under a separate title ("Title 5/A: Data processing") containing three Sections: Section 10 regulating employee statements, disclosure of information and aptitude tests, Section 11 on the processing of sensitive data (biometric and criminal personal data) and Section 11/A relating to employee monitoring.

Section 10 and Section 11/A existed before the amendment as well, although the Enforcing Act modified them and enlarged them with additional rules. Section 11 on sensitive data is completely new. Also, its analysis will not be part of the dissertation as it

\footnotetext{
958 Article L2312-38 of the FLC

959 Or in-service notes or in any other document containing general and permanent obligations. (Article L1321-5 of the FLC)

${ }^{960}$ Article L1321-1 of the FLC; Article L1321-4 of the FLC; from Article L1322-1 to Article L1322-3 of the FLC; Article L1322-4 of the FLC, Article R1321-2 of the FLC; Article R1322-1 of the FLC.
} 
does not relate to the main subject of it, since there are no biometric data or criminal personal data on SNSs. ${ }^{961}$

266. Employee statements and disclosure of information. Section 10 regulates the question of data protection, through regulating disclosure of information and aptitude tests. As regards employee statements and disclosure of information, it declares that " $[a]$ worker may be requested to make a statement or to disclose certain information only if deemed necessary for the conclusion, fulfilment or termination of the employment relationship or for the enforcement of the need ensuing from this act. ${ }^{, 962}$ In data protection terminology, the latter condition is asserted by the purpose limitation principle, by requiring that personal data can only be processed if without processing the conclusion, fulfilment or termination of employment would not be possible, ${ }^{963}$ only to the extent that is essential to achieve those purposes. ${ }^{964}$ In the employment context processing can have numerous purposes, such as the administration of working time, ensuring workplace safety requirements or exercising the employer's right to monitor, choosing the best job candidate, etc. ${ }^{965}$

267. Aptitude tests. Regarding aptitude tests, the HLC contains two restrictions: it states that only an employment regulation can prescribe an aptitude test, or the test shall be necessary in order to exercise rights and to fulfil obligations in accordance with employment regulations. ${ }^{966}$ Employers often use different tests in order to assess employees' or prospective employees' competences or personality traits. Such tests might reveal sensitive traits of the individual; therefore, it is crucial that the individual's rights are ensured during their application. ${ }^{967}$

268. As a new provision, Subsection 2 of Section 10 of the HLC also states that the employer, trade unions and works councils can demand the employee to give a statement or disclose information in order to exercise their rights or comply with their

\footnotetext{
${ }^{961}$ See more on them in: Lukács, A. (forthcoming) 'A GDPR által okozott kihívások a munkajogban', in Strihó, K. and Szegedi, L. (eds.) Európai szabályozáspolitikai kihívások. Budapest: Nemzeti Közszolgálati Egyetem

962 Subsection (1) of Section 10 of the HLC

963 Péterfalvi, A. (ed.) (2012) Adatvédelem és információszabadság a mindennapokban. Budapest: HVGORAC. p. 292.

964 Péterfalvi, A. (ed.) (2012) Adatvédelem és információszabadság a mindennapokban. Budapest: HVGORAC. p. 293.

965 Arany-Tóth, M. (2016) Személyes adatok kezelése a munkaviszonyban. Budapest: Wolters Kluwer. p. 29.

966 Subsection (1) of Section 10 of the HLC

967 Berke, Gy. and Kiss, Gy. (eds) (2014) Kommentár a munka törvénykönyvéhez: kommentár a munka törvénykönyvéröl szóló 2012. évi I. törvényhez. Budapest: Wolters Kluwer, p. 61.
} 
duties in the field of labour relations. ${ }^{968}$ Subsection 3 regulates the presentation of documents - however, this matter does not have direct relevance to the subject of the thesis. As it was already mentioned, the same is valid for Section 11 regulating the processing of certain sensitive data.

269. Employee monitoring. Section 11/A regulates data processing resulting from the employer's right to monitoring and contains rules regulating the monitoring of electronic devices used by the employee. Subsection 1 declares employees' behaviour can be monitored to the extent pertaining to the employment relationship and the employer can employ technical means to conduct such a monitoring.

It follows from the employer's right to monitor that he/she has the right (it is even an obligation) to monitor whether employees are following the orders as the employer has not only a right, but also an obligation to ensure the order and discipline within the workplace. ${ }^{969}$ Prior to the Enforcing Act, the HLC contained three restrictions as regards employee monitoring: the monitoring could not go beyond the extent pertaining to the employment relationship, it could not infringe human dignity and the private life of employees could not be monitored. ${ }^{970}$ The latter two conditions were removed from the HLC. The legislator justified this removal by reminding that both the respect of human dignity and the prohibition of monitoring private life can be deduced from general rules, therefore repeating these requirements is not necessary. ${ }^{971}$

270. The employer's right to monitor the employees' behaviour in relation to the employment relationship is quite extensive: it can relate both to behaviour within the workplace and beyond the workplace ${ }^{972}$ - with respect to the requirements set in the HLC. It is important that the employee does not have the right to private life only outside the workplace: they are entitled to it inside the workplace as well. ${ }^{973}$ The behaviour is in

\footnotetext{
${ }^{968}$ Rátkai, I. (2019) ‘Új adatvédelmi szabályok a munkaviszonnyal összefüggésben’, Munkajog, (2), pp. 6975. Available at: https://munkajogilap.hu/uj-adatvedelmi-szabalyok-a-munkaviszonnyalosszefuggesben/ (Accessed: 12 August 2019)

${ }^{969}$ Kardkovács, K. (ed.) (2016) A Munka Törvénykönyvének magyarázata. 3rd edn. Budapest: HVG-ORAC Lap- és Könyvkiadó. p. 136.

${ }_{970}$ Subsection (1) of Section 11 of the HLC

${ }^{971}$ T/4479. számú törvényjavaslat az Európai Unió adatvédelmi reformjának végrehajtása érdekében szükséges törvénymódositásokról (2019). Előadó: Dr. Trócsányi László igazságügyi miniszter. Budapest, p. 102.

${ }^{972}$ Cséffán, J. (2018) A Munka Törvénykönyve és magyarázata. Szeged: Szegedi Rendezvényszervező Kft. p. 44.

${ }^{973}$ A Nemzeti Adatvédelmi és Információszabadság Hatóság tájékoztatója a munkahelyi adatkezelések alapvető követelményeiröl, p. 6.
} 
relation to the employment if it is connected to the fulfilment of his/her obligations or to the exercise of his/her rights originating from the employment relationship. ${ }^{974}$ Defining the scope of behaviour related to employment or the limits of the employee's private life is increasingly challenging in the social media context, for reasons already presented in the thesis.

271. The employer is also entitled to define the aim of monitoring, the time, the methods used, etc. ${ }^{975}$ However, he/she has to respect certain requirements. The methods applied should be suitable to achieve the purpose, namely the legitimate interests and rights that the employer aims to enforce. ${ }^{976}$ Necessity and proportionality should apply not only to the scope of the data processed, but also to the time period of processing and to the persons having access to that data. ${ }^{977}$ The monitoring must in every case respect employees' dignity. ${ }^{978}$ The right to monitor shall not be exercised abusively, it shall not intend to restrict the enforcement of employees' rights, or to constitute harassment or the suppression of employees' opinion. ${ }^{979}$

272. Use of electronic devices. As a completely new provision, the Enforcing Act enacted a Section to the HLC (Subsection 2 of Section 11/A) stipulating that electronic devices provided by the employer can be used exclusively for professional purposes unless the parties agree otherwise. It is also regulated how the employer can verify such a use, through stating that when monitoring compliance, the employer can only monitor data in connection with the employment - aiming to grant protection to the private life of the employee. The latter rule is also to be applied when the employee uses his/her own device for work. These rules will be examined in detail in Part II.

273. Obligation of information. The HLC specifies the employer's obligation of information. In consequence, the employer shall inform employees regarding the processing of employees' personal data ${ }^{980}$ and the technical means used for their

\footnotetext{
974 Arany-Tóth, M. (2016) Személyes adatok kezelése a munkaviszonyban. Budapest: Wolters Kluwer. p. 74. 975 Arany-Tóth, M. (2016) Személyes adatok kezelése a munkaviszonyban. Budapest: Wolters Kluwer. p. 74. 976 A Nemzeti Adatvédelmi és Információszabadság Hatóság tájékoztatója a munkahelyi adatkezelések alapvetö követelményeiről p. 6.

977 A Nemzeti Adatvédelmi és Információszabadság Hatóság tájékoztatója a munkahelyi adatkezelések alapvetö követelményeiről p. 6.

978 A Nemzeti Adatvédelmi és Információszabadság Hatóság tájékoztatója a munkahelyi adatkezelések alapvetö követelményeiröl p. 6.

979 Subsection (1) of Section 7 of the HLC

${ }^{980}$ Subsection (2) of Section 10 of the HLC
} 
surveillance. ${ }^{981}$ The explanatory memorandum of the HLC emphasizes the importance of the obligation of information and its increased importance in a world where personal life flows into professional life and vice versa. ${ }^{982}$

274. Additional provisions require that "[e]mployers shall consult the works council prior to passing a decision in respect of any plans for actions and adopting regulations affecting a large number of employees. "983 The processing and protection of personal data of employees and the implementation of technical means for the surveillance of workers are among the matters concerned by the obligation of consultation. ${ }^{984}$

275. Conclusions. Section 2 examined the provisions that constitute the core of employee privacy and data protection in French and Hungarian law. They have to be applied to the processing of personal data and to the monitoring of employees - which will be addressed in detail in Part II, dealing with analysing what kind of challenges SNSs raise in the light of these general requirements.

276. As a result of the above analysis, it can be concluded that the similarities between the two labour codes are that they both contain a general declaration of protecting employees' rights, followed by the enunciation of certain data protection rules. The difference between the two regulations is that while the HLC contains these rules in a unique title, the relevant provisions are to be found in a more fragmented way in the FLC. Also, while the HLC contains data processing provisions relevant in the field of employee monitoring, the FLC regulates the question in a more general way. Also, the FLC explicitly deals with job applicants' rights, while such a provision is not to found explicitly in the HLC.

277. In both of them these rules are quite general and do not explicitly address concrete methods of monitoring. An exception is the recently introduced provision in the HLC on the use of computer devices, declaring that unless agreed otherwise, these devices must be used exclusively for professional purposes. In any case, these constitute the rules that must be reinterpreted in the light of SNSs, which raises several questions to be addressed in detail in Part II.

\footnotetext{
${ }^{981}$ Subsection (2) of Section 11 of the HLC

982 T/4786. számú törvényjavaslat a Munka Törvénykönyvéről (2011). Előadó: Dr. Matolcsy György nemzetgazdasági miniszter. Budapest. pp. 102-103.

${ }^{983}$ Subsection (1) of Section 264 of the HLC

${ }^{984}$ Items c) and d) of Subsection (2) of Section 264 of the HLC
} 
278. Conclusions of Chapter 2. Every individual - and amongst them employees as well - is entitled to the right to privacy and to the right to data protection. However, these rights are not absolute: employers are entitled to - in accordance with labour law regulations - control employees' behaviour and monitor them; purely by being an employee, the individual's freedom is partially abandoned..$^{985}$

279. The importance of this subject is illustrated by a number of instruments regulating this issue - both at the international (e.g. ILO, CoE, EU) and at the national level. These instruments have drawn attention to the importance of workplace privacy and data protection and laid down the most important principles to be respected. While doing so they also addressed the, back at the time of their adoption, most common forms of employee monitoring (e.g. CCTV surveillance, e-mail and Internet monitoring, GPS localistaion, etc.) and provided detailed guidance during their application.

280. However, since the adoption of these documents new developments of ICT, such as SNSs, have appeared, giving rise to new types of privacy and data protection questions that are yet to be answered. Although the most recent documents already address the question of SNSs, ${ }^{986}$ which also confirms the need for determining their exact rules of application in the field of privacy and data protection, they do not provide exhaustive regulation, they only concentrate on certain aspects of the subject. Therefore, the balance between employees' and employer's rights is still to be determined in the field of SNSs.

\section{Conclusions of Title 1}

281. In conclusion, the collision between the employer's and the employees' rights is not new. The employee's subordination is present in the employment relationship, regardless of the current technological status. Rights and obligations arising from this subordination are the same (e.g. right to give orders, to control, to monitor), but can take different shapes according to the given circumstances. These circumstances can be highly influenced by technology: physical surveillance manifested through the watching eyes of a

\footnotetext{
985 Hendrickx, F. (2002) 'Privacy and Employment Law: General Principles and Application to Electronic Monitoring', in Blanpain, R. (ed.) On-line Rights for Employees in the Information Society. Use and Monitoring of E-mail and Internet at Work. The Hague: Kluwer Law International, p. 49.

986 E.g. WP29 (2017) Opinion 2/2017 on data processing at work. 17/EN WP 249, Council of Europe (2015) Recommendation CM/Rec(2015)5 of the Committee of Ministers to member States on the processing of personal data in the context of employment
} 
supervisor raises different questions compared to digital surveillance monitoring every step employees make in the online world.

282. When establishing the boundaries of the employer's right to control and to monitor, a balance must be found between the employer's side and the employees' side. On the employees' side several rights, notably the right to privacy, the right to data protection and the right to informational self-determination can be at stake during the different types of employee control and monitoring. Chapter 1 examined the scope and essence of these rights, and established that employees are entitled to them, as well as any individual. Although these rights must be ensured within the workplace, ${ }^{987}$ they are not limitless: it follows from the individual's status as an employee that they must be subjected to certain limitations. ${ }^{988}$

283. On the employer's side, originating from the subordination between the employer and employee, the employer is entitled to exercise authority over employees, ${ }^{989}$ including the right to control and to monitor: they are manifested in Hungarian law through the employer's legitimate economic interests, and in France through the employer's powers. However, just as employees' rights are not limitless, neither is the employer's right to control and monitor: during their enforcement, a balance should be found between the employees' rights and the employer's rights.

284. As it was already mentioned, these rights and their collision are not new, and they are addressed both by the FLC and by the HLC. However, these codes can only address the issue from a general point of view and cannot consider all technologies specifically. In relation to Hypothesis 1 of the dissertation - according to which in the case of SNSs, the collision between the employees' rights and the employer's rights appears in a more intense form compared to the "traditional" methods of employee monitoring - it was necessary to examine the two sides of this collision, in order to be able to answer whether it is intensified by SNSs. Thus, it still must be examined what novelties brought to

\footnotetext{
987 WP29 (2002) Working document on the surveillance of electronic communications in the workplace. 5401/01/EN/Final WP 55. p. 4

988 Hendrickx, F. (2002) 'Privacy and Employment Law: General Principles and Application to Electronic Monitoring', in Blanpain, R. (ed.) On-line Rights for Employees in the Information Society. Use and Monitoring of E-mail and Internet at Work. The Hague: Kluwer Law International, p. 49.

989 Hendrickx, F. (2002) 'Privacy and Employment Law: General Principles and Application to Electronic Monitoring', in Blanpain, R. (ed.) On-line Rights for Employees in the Information Society. Use and Monitoring of E-mail and Internet at Work. The Hague: Kluwer Law International, p. 49.
} 
this collision by SNSs are added to the intensity of this collision - which will be addressed in detail in Title 2. 


\section{Title 2: Blurred boundaries of work and personal life in the digital}

\section{age}

In Title 1 the collision between the employees' and the employer's rights was addressed, examining in detail the different rights that must be balanced against each other. However, the development of ICT exerts a fundamental effect on this collision by making the boundaries of professional and personal life increasingly blurred; new information and communications technologies had a great impact - amongst others - on the notions of working time and working place. ${ }^{990,}{ }^{991}$ Technological change is one of the several factors that can have an effect on work-life balance. ${ }^{992}$ Determining the boundaries between personal and professional spheres is crucial, as the enforcement of the parties' rights and interests is mainly concentrated within the professional life for the employer and within the personal life for the employee.

285. Hitherto the separation of these two spheres did not pose fundamental challenges: a key observation is that formerly work and personal life could be separated (and the applicability of labour law could be determined) more easily through the assessment of place and time: the concepts of "outside" and "inside" of the workplace, as well as "before" and "after" work still existed. However, the appearance of the Internet fundamentally altered such separation. ${ }^{993}$ The blurring of this boundary is two-way: not only work is omnipresent, but personal life is everywhere as well. ${ }^{994}$

286. The aim of Title 2 is to prove the existence of (mutually) blurred boundaries due to ICT and SNSs, and to show that the issue of the enforcement of rights and interests is more pronounced. As a result, on the one hand, the employer can gain "access" to the employee's personal life to a deeper extent. On the other hand, personal life has also gained ground to an unprecedented extent within the professional sphere, making both parties increasingly interested in enforcing their rights.

\footnotetext{
${ }^{990}$ Ray, J.-E. (2001) Le droit du travail à l'épreuve des NTIC. Rueil-Malmaison: Liaisons, p. 83.

${ }^{991}$ In addition to physical and temporal boundaries, Wafa El Wafi also mentions psychological boundaries as an important factor in the separation of work and private life. Source: El Wafi, W. (2016) Perméabilité des frontières vies "personnelle et professionnelle " et usage des TIC: modèles d'articulation. Université de Lorraine, p. 13.

992 Wilkens, M. et al. (2018) Striking a balance: Reconciling work and life in the EU. Publications Office of the European Union, Luxembourg: Eurofound.

993 Verkindt, P.-Y. (2010) 'Les “amis” de nos “amis”..', JCP S (édition sociale), (48), p. 4.

${ }^{994}$ Ray, J.-E. (2010) 'D’un droit des travailleurs aux droits de la personne au travail', Droit social, (1), p. 4.
} 
287. Main questions to be considered. Title 2 aims to answer questions such as: in what regards have ICT and especially SNSs blurred the boundaries of personal and professional life? As the dissertation primarily examines the subject from the viewpoint of the employees' right to privacy and right to data protection, the question of what privacy means in the context of SNSs also has to be addressed.

288. Structure of Title 2. First, Chapter 1 will focus on ICT in general and will address how new technologies have blurred the boundaries of personal and professional life. Then, Chapter 2 will focus on SNSs: first, by adopting a mainly descriptive approach, the basic functioning of these sites will be presented in order to be able to then appropriately assess the legal implications of such platforms and the questions in relation to the separation of these two spheres.

\section{Chapter 1: Information and communication technology and blurred boundaries of work and personal life}

289. The expansion of digital tools has fundamental effects on individuals' lives. ${ }^{995}$ Today, due to the development of ICT, the boundaries of work and personal life are increasingly blurred: personal life flows into professional life and vice versa. ${ }^{996}$ As SNSs are products of the information communication technologies, it is worth examining first in general how ICT affects the separation of work and personal life, before addressing the specific questions raised by SNSs.

290. Technology has not only blurred the lines of the physical workplace: it also blurred the lines of employment. The concept of employment itself is more and more blurred, as the employment contract is not the only way to perform work. Due to gig economy, platform economy, new forms of work have appeared (e.g. gig work, crowdworking, etc.).

\footnotetext{
995 Ray, J.-E. and Bouchet, J.-P. (2010) 'Vie professionnelle, vie personnelle et technologies d'information et de communication', Droit social, (1), p. 46.

On the possible future influence of technology (notably digitalisation) on labour law, see more in György Löricz's article on the imaginary Act I of 2032 on the Labour Code (of the future). The article contains a commentary on the most important features of the code, such as employee monitoring and data protection, establishing an employment contract, e-contracts, algorithyms giving orders, working time, etc. Source: Lörincz, G. (2018) 'Kommentár a munka törvénykönyvéről szóló 2032. évi I. törvényhez - Munkajogi scifi', Pécsi Munkajogi Közlemények, 11(1), pp. 7-34.

996 Kajtár, E. (2015) 'Till Facebook Do Us Part? Social Networking Sites and the Employment Relationship', Acta Juridica Hungarica, 56(4), p. 269.
} 


\section{Section 1: New forms of employment}

291. New forms of employment. In its Digital Single Market Strategy for Europe, the European Commission recognized that ICT, and amongst them Internet and digital technologies have a fundamental effect on the lives of individuals - including the world of work as well. ${ }^{997}$ As a response to the changes occurring due to societal and economic factors, Eurofound published a report ${ }^{998}$ in 2015 adressing new forms employment, ${ }^{999}$ which have increased importance nowadays. The expression "new forms of employment" refers to cases when the number of employer and employee differs from the usual (the usual is considered to be 1:1), when the work is not performed on a regular basis, when it implies increased networking and cooperation between self-employed, when it is not performed from the employer's premises or when the use of ICT is strong and widespread. ${ }^{1000}$ Among these new forms of employment ICT-based mobile work ${ }^{1001}$ and crowdworking ${ }^{1002}$ have high relevance to the subject of the thesis, as they are characterised by the use of ICT technology - being conducted anywhere and anytime, regardless of time and place. ${ }^{1003}$

292. The report acknowledged the advantages of these forms of employment and identified the main challenges that they represent. With regard to privacy, in relation to the use of ICT, on the one hand it was recognized that they provide more flexibility and improve the work-life balance of employees, through enabling them to perform work when

997 European Commission (2015) Digital Single Market Strategy for Europe. Communication from the Commission to the European Parliament, the Council, the European Economic and Social Committee and the Committee of the Regions COM(2015) 192 final. Brussels, p. 3.

998 Mandl, I. et al. (2015) New forms of employment. Publications Office of the European Union, Luxembourg: Eurofound.

${ }^{999}$ In the report Eurofound identified and examined nine types of "new forms of work". These are: employee sharing, job sharing, interim management, casual work, ICT-based mobile work, voucher-based work, portfolio work, crowd employment and collaborative employment.

1000 Mandl, I. et al. (2015) New forms of employment. Publications Office of the European Union, Luxembourg: Eurofound, pp. 4-5.

1001 The report identifies ICT-based mobile work as referring to "[...] work patterns characterised by the worker (whether employee or self-employed) operating from various possible locations outside the premises of their employer (for example, at home, at a client's premises or 'on the road'), supported by modern technologies such as laptop and tablet computers. This is different from traditional teleworking in the sense of being even less 'place-bound'." Source: Mandl, I. et al. (2015) New forms of employment. Publications Office of the European Union, Luxembourg: Eurofound, p. 7.

1002 The report refers to crowdworking as a not place-bound form of employment, where "[v]irtual platforms match a large number of buyers and sellers of services or products, often with larger tasks being broken down into small jobs." Source: Mandl, I. et al. (2015) New forms of employment. Publications Office of the European Union, Luxembourg: Eurofound, p. 7.

1003 Mandl, I. et al. (2015) New forms of employment. Publications Office of the European Union, Luxembourg: Eurofound, p. 72. 
it is the most suitable for them. ${ }^{1004}$ However, on the other hand, it was also recognized that implications on the boundaries of work and private life can occur as well, manifested for example in the requirement of being always available. ${ }^{1005,1006}$

293. These issues were also addressed by the European Commission's European agenda for the collaborative economy, ${ }^{1007}$ which notably raised the question of what effects collaborative economy ${ }^{1008}$ has on the boundaries of employment and in accordance with what criteria the existence of an employment relationship can be established. ${ }^{1009}$ The report entitled Working anytime, anywhere: the effects on the world of work, published jointly by the ILO and Eurofound, ${ }^{1010}$ examined the effects that the use of ICT for work purposes exercises on the world of work outside the workplace. ${ }^{1011}$ It emphasized that such work can represent advantages both for employers and employees, for example, regarding work-life balance, creating new jobs, contributing to economic growth, etc. ${ }^{1012}$ With regard to the main subject of the dissertation, one of the main driving forces of ICT-based work is

1004 Mandl, I. et al. (2015) New forms of employment. Publications Office of the European Union, Luxembourg: Eurofound, pp. 76-77.

1005 Mandl, I. et al. (2015) New forms of employment. Publications Office of the European Union, Luxembourg: Eurofound, p. 79.

${ }^{1006}$ Since then, the report was updated in 2018. In this document problems relating to supplementary working time (e.g. working during nights or weekends) was identified as one of the most challenging aspects of ICTbased mobile work.) Source: Mandl, I. and Biletta, I. (2018) Overview of new forms of employment - 2018 update. Publications Office of the European Union, Luxembourg: Eurofound, p. 11.

${ }^{1007}$ European Commission (2016) A European agenda for the collaborative economy. Communication from the Commission to the European Parliament, the Council, the European Economic and Social Committee and the Committee of the Regions $\operatorname{COM(2016)~} 356$ final. Brussels.

1008 In the agenda collaborative economy is defined as "business models where activities are facilitated by collaborative platforms that create an open marketplace for the temporary usage of goods or services often provided by private individuals." Source: European Commission (2016) A European agenda for the collaborative economy. Communication from the Commission to the European Parliament, the Council, the European Economic and Social Committee and the Committee of the Regions COM(2016) 356 final. Brussels, p. 3.

${ }^{1009}$ European Commission (2016) A European agenda for the collaborative economy. Communication from the Commission to the European Parliament, the Council, the European Economic and Social Committee and the Committee of the Regions COM(2016) 356 final. Brussels, pp. 11-13.

${ }^{1010}$ Eurofound and International Labour Office (2017) Working anytime, anywhere: The effects on the world of work. Joint ILO-Eurofound report. Luxembourg, Geneva: Publications Office of the European Union, International Labour Office

${ }^{1011}$ Eurofound and International Labour Office (2017) Working anytime, anywhere: The effects on the world of work. Joint ILO-Eurofound report. Luxembourg, Geneva: Publications Office of the European Union, International Labour Office, p. 1.

1012 Eurofound and International Labour Office (2017) Working anytime, anywhere: The effects on the world of work. Joint ILO-Eurofound report. Luxembourg, Geneva: Publications Office of the European Union, International Labour Office, p. 9. Moreover, the report addresses several areas where the use of ICT might have a considerable impact on working conditions. These include working time, individual and organisational performance, work-life balance and occupational health and well-being. 
flexibility and the better work-life balance that can be constructed through it. ${ }^{1013}$ However, while ensuring flexibility, ICT can also contribute to the expansion of working hours, ${ }^{1014}$ which can have detrimental effects on the separation of work and private life, as well as on availability and on the consequences associated with it. ${ }^{1015}$ In relation to work-life balance, ${ }^{1016,} 1017$ the report found that controversial results were observed in countries participating in the report: while certain ones stated that their work-life balance improved due to ICT, others (or even the same individuals) also reported negative effects due to the blurring of the boundaries. ${ }^{1018}$

294. Occupational health. Working with ICT can have consequences for occupational safety and health. ${ }^{1019}$ The health of the employees can be detrimentally influenced not only by physical risks: working conditions, such as work intensity or work duration, also play an important role with respect to the employees' health. While having the possibility to work beyond working hours can have positive effects through increasing employees' autonomy, it can also cause detrimental health issues to employees. ${ }^{1020}$ ICT also exercise important effect on workplace safety and health, particularly by resulting in

${ }^{1013}$ Eurofound and International Labour Office (2017) Working anytime, anywhere: The effects on the world of work. Joint ILO-Eurofound report. Luxembourg, Geneva: Publications Office of the European Union, International Labour Office, p. 9.

1014 Eurofound and International Labour Office (2017) Working anytime, anywhere: The effects on the world of work. Joint ILO-Eurofound report. Luxembourg, Geneva: Publications Office of the European Union, International Labour Office, p. 21.

1015 Eurofound and International Labour Office (2017) Working anytime, anywhere: The effects on the world of work. Joint ILO-Eurofound report. Luxembourg, Geneva: Publications Office of the European Union, International Labour Office, p. 23.

1016 In its Directive (EU) 2019/1158 of the European Parliament and of the Council of 20 June 2019 on worklife balance for parents and carers and repealing Council Directive 2010/18/EU the EU recognized the importance of work life balance manifested in the reconciliation of work and family life. Although it constitutes an important step, the directive focuses on gender equality of those who are parents or carers and does not address the question of how the reconciliation should be done with regard to ICT in general.

1017 The European Pillar of Social Rights (European Pillar on Social Rights (2017). Publications Office: Luxembourg.) also determines the principle of work-life balance through declaring that "[p]arents and people with caring responsibilities have the right to suitable leave, flexible working arrangements and access to care services. Women and men shall have equal access to special leaves of absence in order to fulfil their caring responsibilities and be encouraged to use them in a balanced way."

1018 Eurofound and International Labour Office (2017) Working anytime, anywhere: The effects on the world of work. Joint ILO-Eurofound report. Luxembourg, Geneva: Publications Office of the European Union, International Labour Office, p. 29.

1019 In addition to its effects on employees' health, it was also observed that a better work-life balance can increase mental well-being and engagement in the job (resulting in a better workforce) and thus has advantages both for the employer and for employees. Source: Wilkens, M. et al. (2018) Striking a balance: Reconciling work and life in the EU. Publications Office of the European Union, Luxembourg: Eurofound, p. 2.

1020 Kubicek, B. et al. (2019) Working conditions and workers' health. Publications Office of the European Union, Luxembourg: Eurofound, pp. 15-16. 
stress due to the blurred boundaries and constant availability for work. ${ }^{1021}$ According to the European Working Conditions Survey, performing work beyond the regular working hours can increase employees' autonomy, but at the same time makes employees more exposed to work-related health issues. ${ }^{1022}$

The importance of ensuring adequate rest period is guaranteed by different international documents, such as the CFREU, ${ }^{1023}$ the CoE's Revised European Social Charter ${ }^{1024}$ or the EU's European Pillar on Social Rights. ${ }^{1025}$ Also, within the EU, notably the Working Time Directive ${ }^{1026}$ must be mentioned, which has the aim of laying down minimum safety and health requirements for the organisation of working time. ${ }^{1027}$ However, this aim might be compromised due to the constant availability of employees and its effects on the boundaries of work and personal life, raising important questions with regard to occupational safety and health. Although the significance of this issue is recognized, the dissertation will not deal with it in detail for reasons of space limitations, as this subject is indirectly connected to the main focus of it.

295. Technology has not only blurred the lines between professional life and personal life, but also made the boundaries of the employment relationship itself porous, challenging the concepts of wage earners, subordination, occupational safety and health etc. ${ }^{1028}$ Standard employment seems not to be the norm anymore. ${ }^{1029}$ Platform work, ${ }^{1030}$

${ }^{1021}$ Eurofound and International Labour Office (2017) Working anytime, anywhere: The effects on the world of work. Joint ILO-Eurofound report. Luxembourg, Geneva: Publications Office of the European Union, International Labour Office, p. 36.

1022 Kubicek, B. et al. (2019) Working conditions and workers' health. Publications Office of the European Union, Luxembourg: Eurofound, p. 16.

1023 Article 31 on fair and just working conditions stipulates that: " 1 . Every worker has the right to working conditions which respect his or her health, safety and dignity. 2. Every worker has the right to limitation of maximum working hours, to daily and weekly rest periods and to an annual period of paid leave."

${ }^{1024}$ See Article 3 on the right to safe and healthy working conditions

1025 Declaring workers' right to healthy, safe and well-adapted work environment.

1026 Directive 2003/88/EC of the European Parliament and of the Council of 4 November 2003 concerning certain aspects of the organisation of working time. Article 3 stipulates that "Member States shall take the measures necessary to ensure that every worker is entitled to a minimum daily rest period of 11 consecutive hours per 24-hour period."

Article 5 stipulates that "Member States shall take the measures necessary to ensure that, per each seven-day period, every worker is entitled to a minimum uninterrupted rest period of 24 hours plus the 11 hours' daily rest referred to in Article 3."

1027 Article 1 of Directive 2003/88/EC of the European Parliament and of the Council of 4 November 2003 concerning certain aspects of the organisation of working time

1028 Bidet, A. and Porta, J. (2016) 'Le travail à l'épreuve du numérique', Revue droit du travail Dalloz, (5) p. 328.

${ }^{1029}$ International Labour Office (2015) World employment and social outlook 2015: The changing nature of jobs. Geneva: ILO. p. 13. and ILO (no date) The Future of Work We Want: A global dialogue. Available at: http://www.ilo.org/wcmsp5/groups/public/---dgreports/---

cabinet/documents/publication/wcms_570282.pdf (Accessed: 16 May 2018) p. 8 
clickworking ${ }^{1031}$ and crowdworking ${ }^{1032}$ challenge the existing concepts, and at first sight they might seem to escape from the scope of the employment relationship. ${ }^{1033,1034}$ As the existence of an employment relationship does not depend on the will expressed by the parties or on the designation the parties gave to their agreement but on the conditions in which the activity is performed, ${ }^{1035}$ it must be carefully analysed whether the conditions in order to qualify as an employment relationship are met. ${ }^{1036}$

296. Although analysing whether these new forms of work qualify as employment or not raises several interesting questions, its analysis would be beyond the scope of the dissertation. The dissertation focuses on how the boundaries of personal life and professional life are blurred, and not on the blurred boundaries of employment. For the main subject of the thesis the emphasis is put on how (prospective) employees' right to

1030 "Platform work is an employment form in which organisations or individuals use an online platform to access other organisations or individuals to solve specific problems or to provide specific services in exchange for payment. Source: Platform work (2018) Eurofound. Available at: https://www.eurofound.europa.eu/observatories/eurwork/industrial-relations-dictionary/platformwork (Accessed: 13 August 2019)

1031 They are "digital laborers who perform micro tasks via the platforms with the unique, main or secondary aim to receive an income or additional income." Julien, M. and Mazuyer, E. (2018) 'Le droit du travail à l'épreuve des plateformes numériques', Revue droit du travail Dalloz, (3) pp. 195-196.

1032 "[Crowdworking] refers to a form of work done by a "crowd" via a digital intermediary based on the outsourcing of activities, with piece rate payments. It is about calling a multitude of persons to do a task, the crowdworkers offering their labour force.” Julien, M. and Mazuyer, E. (2018) 'Le droit du travail à l'épreuve des plateformes numériques', Revue droit du travail Dalloz, (3) p. 190.

1033 Julien, M. and Mazuyer, E. (2018) 'Le droit du travail à l'épreuve des plateformes numériques', Revue droit du travail Dalloz, (3), p. 191.

${ }^{1034}$ For example, in the case of platform work, at first sight it is the client who gives orders, evaluates and controls the service, fixes the price, etc. while the platform "only" ensures a place to make the deal between the parties. The worker is free to accept or decline work. However, Mathilde Julien and Emmanuelle Mazuyer argue that these are just appearances and further analysis of the real conditions of the execution of the relationship is needed in order to apprehend the true role of platforms. Source: Julien, M. and Mazuyer, E. (2018) 'Le droit du travail à l'épreuve des plateformes numériques', Revue droit du travail Dalloz, (3), p. 191.

1035 Cour de cassation, chambre sociale, du 17 avril 1991, 88-40.121 (See more on this case in: Champaud, C. and Danet, D. (1992) 'Société en participation. Eléments constitutifs. Distinction du contrat de travail', RTD Com., (1), pp. 196-196.); Cour de cassation, chambre sociale, du 19 décembre 2000, 98-40.572 (See more on this case and on the qualification of the employment contract in: Jeammaud, A. (2001) 'L'avenir sauvegardé de la qualification de contrat de travail: à propos de l'arrêt Labbane', Droit social, (3), pp. 227-238.); BH2005. 102; 7001/2005. (MK 170.) FMM-PM együttes irányelv a munkavégzés alapjául szolgáló szerződések minősítése során figyelembe veendő szempontokról

${ }^{1036}$ For example, in November 2018 the Court of Cassation pronounced that a subordinate relationship was present between the delivery person and the "Take Eat Easy" society, and characterised the delivery person's contract as employment contract. (Cour de cassation, civile, chambre sociale, 28 novembre 2018, 17-20.079) In January 2019 the Court of Appeal of Paris ruled that there is an employment contract between an independent driver and between the platform Uber. (CA, Paris, Pôle 6, chambre 2, 10 Janvier 2019, $\mathrm{n}^{\circ}$ 18/08357) Also, in California, an Uber driver was qualified as an employee instead of being qualified as an independent contractor. (Superior Court of California, County of San Francisco, Uber Technologies, Inc., A Delaware Corporation vs. Barbara Berwick, CGC-15-54378, 2015) 
privacy and to data protection can be protected on SNSs, and not on who is considered to be an employee. ${ }^{1037}$

\section{Section 2: “ATAWAD”: AnyTime, AnyWhere, AnyDevice - eroding physical boundaries of the workplace}

297. ATAWAD. The blurring of the boundaries between professional and personal life can be effectively described by the acronym of ATAWAD (also a registered trademark by Xavier Dalloz since 2002) referring to a connection possible from AnyTime, AnyWhere, AnyDevice. ${ }^{1038}$ In accordance with the three aspects included in this expression, the blurring of boundaries will be presented through these three interconnected aspects, which were all shaken by technological advances: place of work, working hours and equipment used for work. However, as a preliminary point it must be emphasized that this phenomenon is mainly relevant for employees performing office work, and especially knowledge work. ${ }^{1039,} 1040$

\section{§1. "Any time”: working hours}

298. To put it simply, earlier, working time was easy do determine by the place of the employee: when the employee was in the workplace, he/she had to work, but when he/she was at home (or outside the workplace) he/she was not working. However,

1037 On this subject see more in: Desbarats, I. (2017) 'Quel statut social pour les travailleurs des plateformes numériques? La RSE en renfort de la loi', Droit social, (11), pp. 971-983; Gomes, B. (2016) 'Le crowdworking: essai sur la qualification du travail par intermédiation numérique', Revue droit du travail Dalloz, (7), pp. 464-471.; Fabre, A. and Escande-Varniol, M.-C. (2017) 'Le droit du travail peut-il répondre aux défis de l'ubérisation?', Revue droit du travail Dalloz, (3), pp. 166-174.; Prassi, J. (2017) 'Uber devant les tribunaux. Le futur travail ou juste un autre employeur', Revue droit du travail Dalloz, (6), pp. 439-445..; Kun, A. (2018) 'A digitalizáció kihívásai a munkajogban', in Homicskó, Á. O. (ed.) Egyes modern technológiák etikai, jogi és szabályozási kihívásai. Budapest: Károli Gáspár Református Egyetem Állam- és Jogtudományi Kar (Acta Caroliensia Conventorum Scientiarum Iuridico-Politicarum, XXII), pp. 119-138.; Rácz, I. (2017) 'A sharing economy munkajogi kihívásai, különös tekintettel az uberizált munkaeröre', in Keserü, B. A. (ed.) Doktori Mühelytanulmányok 2017. Győr: Széchenyi István Egyetem Állam- és Jogtudományi Doktori Iskola, pp. 273-284.

${ }^{1038}$ Bathelot, B. (2015) Définition : ATAWAD, Définitions marketing. Available at: https://www.definitionsmarketing.com/definition/atawad/ (Accessed: 15 May 2018); ATAWAD (no date) emarketing.fr. Available at: http://www.e-marketing.fr/Definitions-Glossaire/ATAWAD-240581.htm; (Accessed: 11 May 2018); Griguer, M. and Schwartz, J. (2017) 'Les risques liés à l'implémentation du droit à la déconnexion dans l'entreprise', Cahiers de droit de l'entreprise, (2), p. 51.

${ }^{1039}$ Eurofound and International Labour Office (2017) Working anytime, anywhere: The effects on the world of work. Joint ILO-Eurofound report. Luxembourg, Geneva: Publications Office of the European Union, International Labour Office. p. 3. The report acknowledges that certain kinds of occupations require the physical presence at the workplace or simply do not involve the use of ICT. Source: Ibid. pp. 17-18.

1040 The detailed rules regarding the matters arising in relation to the place and time of work, and the equipment used will be further adressed in Part II. of the dissertation. 
technological developments have shaken up the world of work in this regard, too. Personal life flows into professional life, as employees do not spend their working time exclusively working. The personal use of the employer's (or their own) equipment at the expense of working time is a growing issue: it is a growing phenomenon that employees often surf the Internet or are connected to their SNS at work, at the expense of working hours. ${ }^{1041}$

299. On the other hand, professional life also flows into the personal life of the employee, as in the hectic $21^{\text {st }}$ century it is often an expectation towards employees to instantly answer a work e-mail, phone call, instant message - even after working hours. Today it is not uncommon that work is not finished when working hours are over: work emails, calls, messages can be received and sent literally any time. ${ }^{1042}$ This 24 hour connectivity poses challenges not only to the separation of work and personal life, but also to the health of employees, ${ }^{1043}$ as it can lead to permanent stress by putting the expectation on employees to be available and react rapidly, at any time. ${ }^{1044}$ With the advent of the "Homo connectus" and the widespread use of technology, the rethinking of work-life balance must be considered. ${ }^{1045,1046}$

300. Right to disconnect. Although the question of the boundaries of work and personal life was already addressed by courts, ${ }^{1047}$ the development and widespread use of

1041 The time spent on social media during working hours can represent a considerable amount of time. According to a report prepared by Bambu by Sprout Social (US), $18 \%$ of the surveyed spend less than 15 minutes per day on these sites, however, $20 \%$ spend more than an hour on these sites (and $10 \%$ amongst them spend more than 2 hours.) According to a study prepared by Olfeo, French employees surf the Internet for private purposes for 2 hours 10 minutes daily, and connecting to Facebook is one of the most popular activity. According to the results of the PAW (Privacy in the workplace) project in 2012, $39 \%$ of the Hungarian employees participating in the survey check social networks at the workplace. Sources: Bambu by Sprout Social (no date) Putting Downtime to Work: A Marketing Data Report. Available at: https://getbambu.com/blog/data/downtime-to-work-marketing-report/(Accessed: 20 January 2019).; Olfeo (2016) Etude 2016: La réalité de l'utilisation d'Internet au bureau. Available at: https://www.euromedia.fr/public/2016/12/etude-olfeo-2016-realite-utilisation-web-au-

bureau.pdf (Accessed: 20 January 2019); Szőke, G. L. (ed.) (2012) Privacy in the workplace. Data protection law and self-regulation in Germany and in Hungary. Budapest: HVG-ORAC Lap- és Könyvkiadó, p. 173.

1042 Ray, J.-E. and Bouchet, J.-P. (2010) 'Vie professionnelle, vie personnelle et technologies d'information et de communication', Droit social, (1), p. 45.

1043 INFOREG (2017) 'De la difficulté d'appliquer le droit à la déconnexion à tous les salariés', Cahiers de droit de l'entreprise, (3), p. 71.

1044 Mettling, B. (2015) Transformation numérique et vie au travail. p. 35.

1045 Coelho Moreira, T. (2016) 'The Electronic Control of the Employer in Portugal', Labour \& Law Issues, 2(1), pp. 6-7.

${ }^{1046}$ However, ICT can have beneficial effects as well, as these activities might equilibrate themselves through transitioning into an implicit give-and-take: it is true that today an employee might spend a part of his/her working time buying, for example, a train ticket for the weekend, but the same employee might respond to urgent work messages on a Saturday morning. Source: Combrexelle, J.-D. (2010) 'Vie professionnelle et vie personnelle', Droit social, (1), p. 12.

1047 The Court of Cassation stated in 2001 that "the employee is obliged neither to accept to work from home, nor to install there folders and work equipment". In 2004 the Court of Cassation confirmed this principle by 
ICT raises this question with new intensity. France addressed this challenge by introducing ${ }^{1048}$ to its legislation the right to disconnect ("le droit à la déconnexion"), ${ }^{1049}$ which means "the employees' right to not to be connected to a professional digital tool during periods of rest and leaves". ${ }^{1050}$

301. According to the FLC, the annual negotiation on professional equality between men and women and on quality of worklife has to address the terms of exercising the employees' right to disconnect and the measures that employers adopt regarding the use of digital tools in order to ensure the respect of working time and periods of rest and leaves and the respect of personal and family life. In the lack of an agreement, the employer shall adopt a charter addressing the question of the right to disconnect. ${ }^{1051}$ However, when it comes to implementation, the regulation is deficient: although the employer faces sanctions if he/she does not negotiate on this question as prescribed by the law, there is no sanction if these negotiations do not finish with the adoption of a charter. ${ }^{1052}$ Still, protection can arise from the employer's obligation regarding the health of employees - connected to the overwork and stress caused. ${ }^{1053}$

The realisation of this right might take several forms, starting from the blocking of professional messaging services, through pop-up windows, to sending the messages with delay. ${ }^{1054}$ The Mettling report in $2015^{1055}$ drew attention to the fact that the right to

stating that "the fact that the employee could not be reached on his personal phone outside working hours is devoid of wrongfulness" therefore could not constitute a legitimate reason for disciplinary dismissal. (Cour de cassation, chambre sociale, du 2 octobre 2001, 99-42.727 and Cour de cassation, chambre sociale, du 17 février 2004, 01-45.889)

1048 However, Clément Cailleteau further nuanced this statement through referring to already existing appearances of this right, such as the right to rest, and was also the subject of certain initiatives of social partners. Source : Cailleteau, C. (2018) 'Temps de travail et droit à la déconnexion', Lexbase Hebdo - Edition Sociale, (750), p. 2. [Page number referring to the online version of the article downloaded fromhttp://www.lexbase-academie.fr.bcujas-ezp.univ-paris1.fr/revues-juridiques/46785641-document-

elastique (Accessed: 4 October 2019)]

1049 This right was inserted into the Labour Code by the Act No. 2016-1088 of 8 August 2016 on labour, the modernization of social dialogue and securing professional pathways (loi $\mathrm{n}^{\circ} 2016-1088$ du 8 août 2016 relative au travail, à la modernisation du dialogue social et à la sécurisation des parcours professionnels). In entered into force on the 1st January 2017.

${ }^{1050}$ Definition provided by Jean-Emmanuel Ray cited in: Griguer, M. (2017) '3 questions: Le droit à la déconnexion', La Semaine Juridique Entreprise et Affaires, (30-34), p. 5.

${ }^{1051}$ Subparagraph 7 of Article L2242-17 of the FLC

1052 Bourgeois, M.-B., Touranchet, L. and Alas-Luquetas, X. (2017) 'Le droit à la déconnexion', JCP S (Édition sociale), (24), p. 17. Griguer, M. and Schwartz, J. (2017) 'Les risques liés à l'implémentation du droit à la déconnexion dans l'entreprise', Cahiers de droit de l'entreprise, (2), p. 52.

1053 Bourgeois, M.-B., Touranchet, L. and Alas-Luquetas, X. (2017) 'Le droit à la déconnexion', JCP S (Édition sociale), (24), p. 17.

${ }^{1054}$ See more about the realization of the right to disconnect in: Bourgeois, M.-B., Touranchet, L. and AlasLuquetas, X. (2017) 'Le droit à la déconnexion', JCP S (Édition sociale), (24), p. 17.; Ayache-Revah, I. and 
disconnect is not only a right but also an obligation, and emphasised the co-responsibility of employers and employees in this regard. ${ }^{1056}$ However, it shall not be forgotten that although the right to disconnect aims to ensure the respect of working hours, it also contributes to more flexibility and certain employees choose it on purpose to work outside working hours. ${ }^{1057,1058}$

\section{§2. "Anywhere": place of work}

302. Traditionally, the place of work and time of work were mutually connected: while the place of work implied working hours, non-working hours were automatically associated with outside of the physical workplace. ${ }^{1059}$ Especially the latter is questioned by the development of ICT and through the increase of certain atypical forms of employment, such as homework or telework. These atypical forms of employment are more affected as they have (completely) demolished the physical separation of work and personal life. Personal life also flows into professional life, as the use of SNSs is - from a technical point of view - not limited to outside of the workplace. As their use is not dependent on the

Galvan, A. (2017) 'Garantir l'efficacité du droit à la déconnexion, entre obligation et utopie...', Les cahiers du DRH, (245) pp. 5-6.

${ }^{1055}$ The Mettling report addressed the question of the impacts of digital technology on the world of work and recognized that the digital revolution caused a change of paradigm in the world of work, affecting a wide range of its fields. (p. 5.) The report (1) identified the main impacts of digital technology and (2) the consequences that can be drawn from them and (3) proposed solutions to these new challenges. Amongst others, the report proposed the acknowledgment of the right and obligation of disconnect, but also addressed the questions of management, new forms of performing work, etc. For a summary of the report see: Reymann, A. (2015) 'Transformation numérique et vie au travail', Les cahiers du DRH, (225), pp. 61-65. and Pontif, V. (2016) “"Transformation numérique et vie au travail”: les pistes du rapport Mettling', Revue droit du travail Dalloz, (3), pp. 185-187.

${ }^{1056}$ Mettling, B. (2015) Transformation numérique et vie au travail. pp. 20-21.

${ }^{1057}$ For example, it is the case when an employee deliberately chooses to work on a Sunday night in order to be able to have a calmer Monday morning at work. Loiseau, G. (2017) 'La déconnexion-Observations sur la régulation du travail dans le nouvel espace-temps des entreprises connectées', Droit social, (5), p. 464.

${ }^{1058}$ See more on the right to disconnect in: Bourgeois, M.-B., Touranchet, L. and Alas-Luquetas, X. (2017) 'Le droit à la déconnexion', JCP S (Édition sociale), (24), pp. 15-18.; Ayache-Revah, I. and Galvan, A. (2017) 'Garantir l'efficacité du droit à la déconnexion, entre obligation et utopie...', Les cahiers $d u$ DRH, (245), pp. 2-7.; Griguer, M. and Schwartz, J. (2017) 'Les risques liés à l'implémentation du droit à la déconnexion dans l'entreprise', Cahiers de droit de l'entreprise, (2), pp. 50-52.; INFOREG (2017) 'De la difficulté d'appliquer le droit à la déconnexion à tous les salariés', Cahiers de droit de l'entreprise, (3), pp. 71-73.; Loiseau, G. (2017) 'La déconnexion-Observations sur la régulation du travail dans le nouvel espacetemps des entreprises connectées', Droit social, (5), pp. 463-470.; Disant, M. et al. (2017) 'Droit et risque ${ }^{\circ}$ 9 (Suite et fin)', Les Petites Affiches, (237), pp. 4-23.

1059 Morgenroth, T. (2016) La vie privée en droit du travail. Doctoral dissertation. Université Lille 2 - Droit et Santé. p. 29. 
exact geographical position of the employee ${ }^{1060}$ (but on an Internet connection and a device), they can be accessed from anywhere, even from the workplace.

303. The traditional methods of employee monitoring were only capable of "keeping an eye on" employees while they were at the workplace, during working hours, whereas now, due to technological innovations, monitoring is not limited anymore to the physical workplace, it is now possible to watch employees' every step not only within the workplace, but to "follow them home" and monitor their activities outside the workplace. ${ }^{1061}$ It is enough to think of the portable devices that the employee takes outside the workplace (work computers, work cell phones, GPS systems) or of the use of SNSs, during which the employee provides insight into his/her personal life, conducted beyond the boundaries of the workplace.

\section{§3. "Any device”: equipment used for work}

304. Before, most of the necessary work equipment was in the factory/office/etc. and no or very few employees possessed at home the equipment necessary for work. Today, a change can be observed regarding the use and spread of these technologies: for the first time since the industrial revolution, ICT impacts the personal lives of employees as individuals, just as much as their professional lives as employees. Moreover, employees often start to use these tools in the course of their personal lives, before entering the professional sphere. ${ }^{1062}$ Employees can bring their devices used for personal purposes (e.g. smartphone) or they can bring their devices to the workplace for the purpose of working, instead of the employer providing equipment. An example of the latter is the bring your own device (hereinafter referred to as: BYOD) phenomenon. ${ }^{1063}$ Professional devices also enter the personal sphere of the employee: employees often take home with them the devices provided by the employer (e.g. company phone, company laptop). Also, outside

\footnotetext{
${ }^{1060}$ Except for limited exceptions, such as China, where the biggest social network sites - such as Facebook cannot be accessed unless the user installs a VPN (Virtual Private Network).

1061 Bibby, A. (2016) You're being followed Electronic Monitoring and surveillance in the workplace. UNI/GS/06-2006/0035/EN. UNI Global Union. Available at: http://www.andrewbibby.com/pdf/Surveillance-en.pdf (Accessed: 11 May 2018). p. 2.

1062 Mettling, B. (2015) Transformation numérique et vie au travail, p. 5.

1063 See more on data protection requirement during the implementation of BYOD practices in the CNIL's information notice on BYOD (BYOD: what are the good practices?) or the WP29's Opinion on data processing at work. (CNIL (2015) 'BYOD: quelles sont les bonnes pratiques?' Available at: https://www.cnil.fr/fr/byod-quelles-sont-les-bonnes-pratiques (Accessed: 15 May 2018); WP29 (2017) Opinion 2/2017 on data processing at work. 17/EN WP 249. pp. 16-17.); Kun, A. and Rácz, I. (2017) 'A Bring Your Own Device (BYOD)-policy jelensége - munkajogi nézőpontból’, Munkajog, 1(1), pp. 40-44.
} 
the workplace employees might use their personal devices for professional purposes (e.g. sending an e-mail, receiving a phone call).

305. Such uses might result in a complete blurring of professional and private use: employees might use their own devices for work purposes, while those possessing a company owned equipment potentially use it for private purposes (e.g. checking Facebook from the company's computer). It raises data protection questions of separating personal and professional use of the device when the employer intends to exercise his/her right to monitor. One of the most important questions arising in relation to privacy and data protection is whether/how the employer can access and control these personal devices that are also used for work or control the use of equipment provided by him/her while respecting employees' right to privacy and data protection? ${ }^{1064}$

306. Conclusions of Chapter 1. The proliferation of ICT has fundamentally altered the way individuals live their lives - including their professional lives as well. Amongst the different advantages and disadvantages in relation to ICT and the world of work, Chapter 1 focused on how ICT has contributed to the blurred boundaries of work and private life, how it challenges and blurs the previously established boundaries through breaking down physical, temporal and material separation of work and personal life - as the analysis of ATAWAD illustrated. Such a phenomenon raises important questions in relation to the monitoring or the control of employees' work, to defining working hours, to the health of employees, etc. ${ }^{1065}$

307. As regards ICT use for work, the dichotomy between France and Hungary is not considered to be significant for the subject of the dissertation, as its proliferation is present in both countries. Naturally, differences in the exact appearance and use of ICT might occur between these two countries, but the phenomenon in itself is present in both of them - and for the thesis the latter has particular importance, as the possible differences in their use do not change the basic characteristic of ICT in relation to blurring the boundaries of work and personal life.

\footnotetext{
1064 These questions will be addressed in detail in Part II. when examining the monitoring of whether the employee respects working hours.

1065 However, besides the difficulties in separating professional and personal life, ICT can provide possibilities and facilitate performing working as well. For example, they provide more freedom to the employee and can allow performing work in a way which is more convenient to him/her: the employee can work from home, sparing hours of public transportation, or can choose his/her working hours in accordance with his/her most productive period. Employees in difficult situation (e.g. individuals with disability) might also benefit from these innovations.
} 
308. Through stating that due to ICT the boundaries of professional and personal life have become increasingly blurred, the analysis in Chapter 1 set the general context necessary for the further examination of SNSs. As SNSs belong to ICT as well, the statements of Chapter 1 are adequately applicable to them as well - however, their specificities must be addressed in detail in Chapter 2 .

\section{Chapter 2: The rise of social network sites and its effects on employment}

309. SNSs are worldwide phenomena: in 2017,71 percent of Internet users were social network users. ${ }^{1066}$ Given their extreme popularity and their embeddedness in individuals' lives, they naturally affect employment as well. With the collision between privacy and data protection and the employer's legitimate interests at the focal point of Part I, Chapter 2 aims to examine how employees' right to privacy and data protection are affected by SNSs.

The primary objective of Chapter 2 is to examine what privacy means in the context of SNSs, and in what regards SNSs increase the blur between the boundaries of professional and private life. It was demonstrated that the right to privacy protects against interference in the private life of the individuals. Jean-Emmanuel Ray recalls the phenomenon of the individualisation of private life ("l'individualisation de la vie privée") evoking the thoughts of the sociologist Daniel Cardon, who holds that although the right to privacy is traditionally conceived as a protective right, today it is more and more conceived as an (individual) liberty, which gains incredible importance in the age of social media self-exposure. ${ }^{1067}$ Regarding privacy protection in our age, the traditional "protective" nature of the right to privacy (e.g. the right to be let alone) remains valid, but it has to be reconsidered and co-exist with people's interests in living in a networked society. ${ }^{1068}$

In order to provide answers to these questions, first the conceptual foundations of SNSs should be clarified. Therefore, first, the main attributes of SNSs will be examined, such as their definition and functioning. Second, the legal implications of SNSs will be

1066 Number of social media users worldwide from 2010 to 2021 (in billions) (no date) Statista. Available at: https://www.statista.com/statistics/278414/number-of-worldwide-social-network-users/ (Accessed: 20 January 2019)

${ }^{1067}$ Ray, J.-E. (2015) ‘Actualité des TIC. Tous connectés, partout, tout le temps ?’, Droit social, (6), p. 521.

1068 Bylund, M. et al. (no date) PRIMA - Privacy Research through the Perspective of a Multidisciplinary Mash up. Available at: http://soda.swedish-ict.se/4046/1/PRIMA_final_DOC_17.pdf (Accessed: 12 March 2018). p. 142. 
addressed, with the focus being on the right to data protection. Third, privacy issues will be treated, through determining, in addition to ICT in general, how SNSs affect the boundaries of privacy and the boundaries of personal and professional life.

\section{Section 1: Conceptual foundations}

In order to be able to assess the legal implications of SNSs, it is necessary to understand what SNSs are and how they function. After presenting the history and providing a definition of SNSs, their functioning will be described in detail. Naturally, the aim of Section 1 is not to provide guidance merely on how these sites work, it rather serves as a preparatory Section for addressing privacy and data protection questions: it aims to regroup the mainly descriptive presentation of the characteristics of these sites that can possibly gain importance when it comes to employees' rights. It will also contribute to better understanding the facts of the relevant cases, analysed in Part II.

\section{§1. The rise of social network sites}

The following Paragraphs will focus on (A) the history of SNSs, starting with the brief presentation of two basic concepts inseparable from the functioning of SNSs: Internet and Web 2.0. The topicality and significance of the subject will be illustrated through presenting how popular these services have become. After placing SNSs in this context, $(B)$ it will be defined what exactly SNSs are.

\section{(A) History of social network sites}

310. Internet and Web 2.0. According to the statement of András Szekfü, Internet is where computer communication on a global and universal network occurs, in a packet switched system - by the use of TCP-IP protocol - and from the beginning of the 1990s, in a graphic user interface: in the system of World Wide Web. ${ }^{1069}$ The appearance and the proliferation of the Internet have completely transformed the way people can access information. The Internet as we know today was preceded by various military researches from the 1960s. The World Wide Web was created in 1989 by Tim Berners-Lee in the Conseil Européen pour la Recherche Nucléaire (CERN). From 1991 the access to the network was available to basically any user in education and research and from 1993

1069 Szekfü, A. (2007) Kommunikáció, nyilvánosság, esélyegyenlőség Magyarországon: a távírótól a Web 2.0-ig. Budapest: Gondolat, MTA-ELTE Kommunikációelméleti Kutatócsoport. p. 124. 
anyone could develop the network. ${ }^{1070}$ Since then, the Internet has conquered the world: while in 1995 it had 16 million users worldwide, this number increased up to 3,675 million by September $2016 .^{1071,1072}$

311. In addition to the proliferation of the Internet, the appearance and widespread use of Web 2.0 technologies is important for the subject of the dissertation. Compared to its predecessor, Web 1.0, Web 2.0 enables users to create and share content as opposed to the structure of the static Web 1.0. ${ }^{1073}$ Social media and SNSs are connected to Web 2.0 as users themselves fill them up with content within the limits ensured by the server host. ${ }^{1074,} 1075$ Like technological innovations in general, the Internet and Web 2.0 affect privacy and data protection, by placing the sharing of information data to their centre. As Spiros Simitis noted, Internet has redefined how personal data is processed; such processing is shifted to the Internet, as more and more areas of life are taking place online. ${ }^{1076}$ Robert Sprague also points out how the use of technology changed; today, instead of being merely a source of accessing information, the information sharing nature of the Internet is thriving. ${ }^{1077}$ The Internet goes beyond being merely a technological innovation and influences everyday life: it revolutionized the way individuals live, share, communicate and consume. ${ }^{1078}$

1070 Meixner, Z. (2004) Az Internet Rövid Története, HVG. Available at: http://hvg.hu/tudomany/20041203interhist (Accessed: 22 September 2017), Szüts, Z. (2015) 'A Munka Világának Online Kommunikációs Kérdései’, Opus et Educatio, 2(2), p. 28.

1071 Internet Growth Statistics (no date) Internet World Stats. Available at: http://www.internetworldstats.com/emarketing.htm (Accessed: 16 December 2016)

Regarding users in Europe, Viviane Reading vice president of the EU's Commission stated that in 1995 at the time of the adoption of the DPD, less than $1 \%$ of Europeans used the Internet. [European Commission (2012) Commission proposes a comprehensive reform of data protection rules to increase users' control of their data and to cut costs for businesses. Press release. Brussels. Available at: http://europa.eu/rapid/pressrelease_IP-12-46_en.htm(Accessed: 18 January 2019)]

1072 On the history of the Internet see more in: Leiner, B. M. et al. (1997) Brief History of the Internet, Internet Society. Available at: https://www.internetsociety.org/wp-content/uploads/2017/09/ISOCHistory-of-the-Internet_1997.pdf (Accessed: 22 September 2017)

1073 The next step of development is the appearance of Web 3.0 (also the so-called semantic web), which is based on the semantic tagging of content, integrated and integrable data. Source: Bányai, E. (2016) Közösségi média. Közösség vagy média? Pécs: Pécsi Tudományegyetem Közgazdaságtudományi Kar. p. 11.

1074 Bozarth, J. (2010) Social media for trainers: techniques for enhancing and extending learning. San Francisco: Pfeiffer, p. 11.

1075 On the main characteristics of Web 1.0, Web 2.0, Web 3.0 and social media see more in: Bányai, E. (2016) Közösségi média. Közösség vagy média? Pécs: Pécsi Tudományegyetem Közgazdaságtudományi Kar. pp. 9-36.

1076 Simitis, S. (2010) 'Privacy - An Endless Debate', California Law Review, 98(6), p. 2003.

1077 Sprague, R. (2008) 'Rethinking Information Privacy in an Age of Online Transparency', Hofstra Labor \& Employment Law Journal, 25(2), p. 396.

1078 Falque-Pierrotin, I. (2012) 'La Constitution et l'Internet', Les nouveaux cahiers du Conseil constitutionnel, (36), p. 31. 
Table 2.: Comparison of Web 1.0 to Web 2.0

\begin{tabular}{|l|l|}
\hline \multicolumn{1}{|c|}{ WEB 1.0 } & \multicolumn{2}{c|}{ WEB 2.0 } \\
\hline $\begin{array}{l}\text { Programmer created web pages, graphics, } \\
\text { Flash }\end{array}$ & $\begin{array}{l}\text { User-created Web pages, pictures, user } \\
\text { reviews, blogs, wikis, YouTube, social } \\
\text { networks }\end{array}$ \\
\hline Experts create content & Everyone creates content \\
\hline Individuals visit web pages, read content & People construct shared information \\
\hline Tightly controlled "sites" & Loosely controlled communities \\
\hline One-way (one-to-many) & Many-to-many (and peer-to-peer) \\
\hline Britannica Online & Wikipedia \\
\hline Publish & Participate \\
\hline Firewalls, hierarchies & Dynamic, non-hierarchal \\
\hline Static, stable content, few changes & $\begin{array}{l}\text { Constantly updated content } \\
\text { Wikipedia) }\end{array}$ \\
\hline
\end{tabular}

Source: Bozarth, J. (2010) Social media for trainers: techniques for enhancing and extending learning. San Francisco: Pfeiffer, p. 12.

312. Appearance and rise of SNSs. Although the first SNS, SixDegrees appeared back in $1997,{ }^{1079}$ SNSs only became truly widespread in the first decade of the $21^{\text {st }}$ century. Today's most known SNSs were launched during the 2000s (for example, MySpace and LinkedIn were launched in 2003, Facebook in 2004, YouTube in 2005, Twitter in 2006, Instagram in 2010 and Snapchat in 2011), and by the 2010s they "conquered the world", the most popular of them having several millions of users worldwide (LinkedIn 303 million, Facebook 2.2 billion, YouTube 1.9 billion, Instagram 1 billion, Snapchat 291 million active users). ${ }^{1080}$ Even though there exists no legal obligation to create a profile on an SNS, the importance of being present on these platforms suggests that it is questioned whether the individual has a true choice regarding engaging in such an activity - especially in certain communities, such as in schools. ${ }^{1081}$

313. (Future) employees as users. Employees do not make an exception from the "SNS fever": employees and prospective employees use these sites just like any other individual. Today not only students are present on these sites (who will grow up and become young employees one day), but also people of all generations are users of these

1079 boyd, danah m. and Ellison, N. B. (2008) 'Social Network Sites: Definition, History and Scholarship', Journal of Computer Mediated Communication, 13(1), p. 214.

${ }^{1080}$ Most famous social network sites worldwide as of October 2018, ranked by number of active users (in millions) (2018) Statista. Available at: https://www.statista.com/statistics/272014/global-social-networksranked-by-number-of-users/ (Accessed: 4 January 2018)

1081 Síthigh, D. M. (2008) 'The mass age of internet law', Information \& Communications Technology Law, $17(2)$, p. 83. 
sites. ${ }^{1082}$ It must also be mentioned that SNS use constitutes a "supraglobal" phenomenon: the most popular SNS platforms are available in most countries worldwide - with very few exceptions. ${ }^{1083}$ Although labour law regulations are mainly established at the national level, the behaviour in which employees engage is "supraglobal": everywhere where employees engage in SNSs, they behave in a similar way - although differences might arise in the legal response according to the given country's labour law regulations. ${ }^{1084}$

314. Younger users and the decline of SNSs? In contrast to the popularity of SNSs, certain interesting observations were made in relation to the migration of users towards other platforms, and also in relation to quitting social media completely. According to a social media use forecast of eMarketer, teenagers and young adults will start to leave Facebook in favour of other social media sites, such as Instagram, or Snapchat. ${ }^{1085}$ Dailymail has also released an interesting article, describing how teenagers have got tired of social media, wishing it had never been invented and what steps they made towards decreasing their dependence on these platforms. ${ }^{1086}$ Although with the amount of users they have today it seems unlikely that SNSs will suddenly disappear from one day to another, it should be kept in mind that changes in their use (e.g. migration from one certain SNS to another one) might occur.

1082 On the distribution of Facebook users of different ages see these statistics of 2014: Distribution of active Facebook users worldwide as of 4th quarter 2014, by age (no date) Statista. Available at: https://www.statista.com/statistics/376128/facebook-global-user-age-distribution/(Accessed: 17 January 2017)

1083 These countries include, for example, China, North-Korea and Iran. Source: List of countries that have banned Social Media for its citizens (no date) The Windows Club. Available at: https://www.thewindowsclub.com/list-of-countries-that-have-banned-social-media-for-its-

citizens (Accessed: 21 October 2019)

${ }^{1084}$ However, it is interesting to bring attention to certain possible differences in SNS use between different generations. Usually, younger people have less concern regarding their privacy, and all the content published in these years will be available when they enter the labour market. (Source: Crane, C. (2012) 'Social Networking v. The Employment- at-Will Doctrine: A Potential Defense for Employees Fired for Facebooking, Terminated for Twittering, Booted for Blogging, and Sacked for Social Networking', Washington University Law Review, 89(3), pp. 639-640.) William Smith and Deborah Kidder pointed out the significance of the generational difference between the young generations and the older ones and how these differences can influence the labour market situation of young people. (Source: Smith, W. P. and Kidder, D. L. (2010) 'You've been tagged! (Then again, maybe not): Employers and Facebook', Business Horizons, 53(5), p. 497.) The generation of those who have grown up with the Internet has a different attitude towards it, expecting that their privacy would be protected in the online world. (Source: Newell, B. C. (2011) 'Rethinking Reasonable Expectations of Privacy in Online Social Networks', Richmond Journal of Law and Technology, 17(4), pp. 18-19.)

1085 Instagram, Snapchat Adoption Still Surging in US and UK - Facebook's appeal fading further among teens and young adults (2017) eMarketer. Available at: https://www.emarketer.com/Article/InstagramSnapchat-Adoption-Still-Surging-US-UK/1016369 (Accessed: 10 November 2017)

${ }^{1086}$ Harding, E. (2017) Even teenagers are growing tired of social media: Two thirds say they would not mind if it had never been invented, Daily Mail. Available at: http://www.dailymail.co.uk/news/article4950268/Even-teenagers-growing-tired-social-media.html (Accessed: 10 November 2017) 


\section{(B) Delimitation of social media and social network sites}

Social media and social network sites are similar, but not synonymous concepts. Both of them are based on Web 2.0 and are centred around user-created content. ${ }^{1087}$ However, their exact delimitation might differ based on the opinion of different authors, but usually SNSs are considered to be one form of social media. ${ }^{1088}$

315. Definition of social network sites. When attempting to find a universal definition describing SNSs, one comes across numerous definitions as well. ${ }^{1089}$ The situation is exacerbated given that different sites can serve different purposes. Establishing one unique definition is also made more difficult by the myriad of the existing SNSs. The thematics of these sites can vary: for example, while Facebook, YouTube, Instagram and Twitter are "general" social network sites (they are destined for everyone, without bearing special thematics), LinkedIn and Viadeo are business centered social network sites, Academia and ResearchGate are for researchers, CouchSurfing is for travellers, etc.

1087 According to the OECD, user-created content is " $i$ ) content made publicly available over the Internet, ii) which reflects a certain amount of creative effort, and iii) which is created outside of professional routines and practices." Vickery, G. and Wunsch-Vincent, S. (2007) Participative Web and User-Created Content. Web 2.0, Wikis and Social Networking. OECD Publishing. p. 9. See more in Idem. p. 18.

1088 Jue, A. L., Marr, J. A. and Kassotakis, M. E. (2010) Social Media at Work. How Networking Tools Propel Organizational Performance. San Francisco: Jossey-Bass. p. 50.; Klausz, M. (2016) A közösségi média nagykönyve: hogyan vidd sikerre céged és önmagad. Budapest: Athenaeum. p. 71.; Flynn, N. (2012) The Social Media Handbook. Policies and Best Practices to Effectively Manage Your Organization's Social Media Presence, Posts, and Potential Risks. San Francisco: Pfeiffer. p. 332.; Kaplan, A. M. and Haenlein, M. (2010) 'Users of the world, unite! The challenges and opportunities of Social Media', Business Horizons, 53(1), p. 62.

1089 According to the OECD, social network sites "enable users to connect to friends and colleagues, to send mails and instant messages, to blog, to meet new people and to post personal information profiles." Vickery, G. and Wunsch-Vincent, S. (2007) Participative Web and User-Created Content. Web 2.0, Wikis and Social Networking. OECD Publishing. p. 38.

Nancy Flynn defines social networks as "online platforms where users create profiles, post content, share information, and socialize with others." Source: Flynn, N. (2012) The Social Media Handbook. Policies and Best Practices to Effectively Manage Your Organization's Social Media Presence, Posts, and Potential Risks. San Francisco: Pfeiffer. p. 332.

According to Nathalie Dreyfus, social network sites "[...] are online communication platforms, which allow the user to join or to create a network of users who share a common interest. They stand as a website which, after a registration which is usually free and requires providing information (name, birthday, e-mail address), allows to access a platform of exchange and dialogue." Cited in: Costes, L. (2011) "Réseaux sociaux : nouveaux enjeux et nouveaux défis pour les entreprises', Revue Lamy droit de l'immatériel ex Lamy droit de l'informatique, (74), p. 132.

After analysing the arising legal challenges and the given answers in relation to law and social network sites, Valère Ndior proposes the following legal definition, according to which "the common essential criteria of social networks would be to constitute a web hosting platform, which act as technical intermediate in order to provide to the public, for personal or for professional reasons, means and spaces of communication or interaction with other users. The owner of the social network account act as content publisher on a profile presumed to constitute a public space, except if the owner demonstrates that the contacts who he/she approved constitute a community of interest within which the data published remains under his/her control." Source: Ndior, V. (2015) 'Le réseau social : essai d'identification et de qualification', in Ndior, V. (ed.) Droit et réseaux sociaux. Issy-les-Moulineaux: Lextenso (Collection LEJEP) p. 35. 
National SNSs also exist, destined for people living in a given region or country, such as the late iwiw in Hungary, Copains d'avant in France, Weibo in China or Mixi in Japan. ${ }^{1090}$

316. Ludovic Pailler identified two reference definitions: for US scholars it is the one defined by danah $m$. boyd $d^{1091}$ and Nicole B. Ellison, while European scholars mostly refer to the definition established by the WP29. ${ }^{1092}$ According to danah $\mathrm{m}$. boyd and Nicole B. Ellison, social network sites are "[...] web-based services that allow individuals to (1) construct a public or semi-public profile within a bounded system, (2) articulate a list of other users with whom they share a connection, and (3) view and traverse their list of connections and those made by others within the system." 1093,1094 Based on the definitions established in the article of boyd and Ellison, Dick Stroud proposes to create a "checklist" with the main elements of these sites. These elements are: a) possibility to create private or public profiles b) identifying a network of contacts c) messaging, communicating with the contacts d) content sharing such as photos or videos e) add-value content. ${ }^{1095}$

According to the WP29, social network services are "[...] online communication platforms which enable individuals to join or create networks of like-minded users. "1096 The WP29 complements this definition by identifying three common characteristics of social network sites: (1) users share their data in order to create profiles or a description of themselves, (2) possibility of posting user-generated content, such as videos, photos, etc. (3) providing a list of contacts and possibility to interact with these contacts. ${ }^{1097}$ Lamia El Badawi also proposes to identify the common characteristics of SNSs, which are - in my

\footnotetext{
1090 See more on the different types of social network sites in: Ndior, V. (2015) 'Le réseau social : essai d'identification et de qualification', in Ndior, V. (ed.) Droit et réseaux sociaux. Issy-les-Moulineaux: Lextenso (Collection LEJEP), pp. 17-19. and Clarke, R. (2014) 'Privacy and Social Media: An Analytical Framework', Journal of Law, Information and Science, 23(1), p. 172.

1091 danah m. boyd writes her name in lower case on purpose. See: boyd, danah m. (2017) 'what's in a name?', https://www.danah.org/name.html.

1092 Pailler, L. (2012) Les réseaux sociaux sur internet et le droit au respect de la vie privée. Bruxelles: Larcier. pp. 16-17.

1093 boyd, danah m. and Ellison, N. B. (2008) 'Social Network Sites: Definition, History and Scholarship', Journal of Computer Mediated Communication, 13(1), p. 211.

${ }^{1094}$ Based on this definition, the Council of Europe states that "[a] social networking service is a platform which enables the building of social relations among people who share interests, activities, backgrounds or real-life connections. It is a web-based service that allows individuals to create a profile, to establish a list of users with whom to share views and to develop contacts within the system." Source: Council of Europe, Committee of Ministers (2015) Explanatory memorandum to Recommendation CM/Rec(2015)5 of the Committee of Ministers to member States on the processing of personal data in the context of employment. par. 45.

1095 Stroud, D. (2008) 'Social networking: An age-neutral commodity - Social networking becomes a mature web application', Journal of Direct, Data and Digital Marketing Practice, 9(3), p. 279.

1096 WP29 (2017) Opinion 2/2017 on data processing at work. 17/EN WP 249. p. 4.

1097 WP29 (2017) Opinion 2/2017 on data processing at work. 17/EN WP 249. p. 5.
} 
opinion - consistent with the above-presented definitions: the creation of a profile, the public exposure of contacts and the publishing of content. ${ }^{1098}$ The three characteristics profile, content, and contacts - are common to all SNSs, although it can differ which one of them is more emphatic. ${ }^{1099}$

However, despite the establishment of these common characteristics, the evolutive nature of SNSs should be taken into consideration. Without questioning the validity of the presented "reference definitions", Valère Ndior suggests adding other attributes, such as its extent of openness, the ways of connecting to it and its private or institutional nature, in order to better take into consideration the evolutive and hybrid nature of these sites. ${ }^{1100}$

317. Definition of social media. SocialMediaToday evokes the definitions provided by the Merriam-Webster dictionary. ${ }^{1101}$ The dictionary defines social media as "forms of electronic communication (such as websites for social networking and microblogging) through which users create online communities to share information, ideas, personal messages, and other content (such as videos)", ${ }^{1102}$ while social networking as "the creation and maintenance of personal and business relationships especially online". ${ }^{1103}$ According to Andreas M. Kaplan and Michael Haenlein, social media are "[...] a group of Internet-based applications that build on the ideological and technological foundations of Web 2.0, and that allow the creation and exchange of User Generated Content[,]"1104 while social network sites are "[...] applications that enable users to connect by creating personal information profiles, inviting friends and colleagues to have access to those profiles, and sending e-mails and instant messages between each other." 1105

\footnotetext{
${ }^{1098}$ El Badawi, L. (2014) 'La place des réseaux sociaux dans l'entreprise', Revue Lamy droit de l'immatériel, (103), pp. 108-109.

1099 Pailler, L. (2012) Les réseaux sociaux sur internet et le droit au respect de la vie privée. Bruxelles: Larcier. p. 17.

${ }^{1100}$ Ndior, V. (2015) 'Le réseau social : essai d'identification et de qualification', in Ndior, V. (ed.) Droit et réseaux sociaux. Issy-les-Moulineaux: Lextenso (Collection LEJEP), p. 15.

1101 Schauer, P. (2015) 5 Biggest Differences between Social Media and Social Networking, SocialMediaToday. Available at: http://www.socialmediatoday.com/social-business/peteschauer/2015-0628/5-biggest-differences-between-social-media-and-social (Accessed: 22 September 2017)

1102 Definition of social media (no date) Merriam Webster. Available at: https://www.merriamwebster.com/dictionary/social\%20media (Accessed: 22 September 2017)

1103 Definition of social networking (no date) Merriam Webster. Available at: https://www.merriamwebster.com/dictionary/social\%20networking (Accessed: 22 September 2017)

${ }_{1104}$ Kaplan, A. M. and Haenlein, M. (2010) 'Users of the world, unite! The challenges and opportunities of Social Media', Business Horizons, 53(1), p. 61.

${ }^{1105}$ Kaplan, A. M. and Haenlein, M. (2010) 'Users of the world, unite! The challenges and opportunities of Social Media', Business Horizons, 53(1), p. 63.
} 
318. According to Nancy Flynn, social media refers to "[a] category of Internetbased resources that facilitate user participation and user-generated content. Social media include but are not limited to social networking sites [...], microblogging sites [...], photoand video-sharing sites [...], wikis [...], blogs [...] and social bookmarking or news aggregation sites [...]." 1106

319. According to Clara Shih - in consistency with the above-presented definitions - the main difference between the two concepts is that while social media are content-oriented (they concentrate on the content - photos, videos, comments, etc. - the user is just a mere contributor), social network sites focus on human relationships (on profiles and relations). Of course, many social network sites also enable users to share content (e.g. likes, comments, photos or videos on Facebook), but their role is secondary, compared to relationships. ${ }^{1107}$ In contrast to social media, social network sites enable the individual to create his/her own profile, establish and develop relationship with others and to "live in the community" through the different services provided by these sites. ${ }^{1108}$ In sum, while content sharing is in the centre of social media, social network sites, as a form of social media, have a more personal character and focus on establishing and maintaining relationship between users.

Table 3: Most important distinctive criteria between social media and social network sites

\begin{tabular}{|l|l|}
\hline \multicolumn{1}{|c|}{ SOCIAL MEDIA } & \multicolumn{1}{c|}{ SOCIAL NETWORK SITES } \\
\hline content-oriented & user-oriented \\
\hline sharing content & creation and maintenance of relationships \\
\hline one-to-many communication & engagement with other users \\
\hline
\end{tabular}

Source: the author's own summary

320. Matters discussed in the dissertation. Social media and SNSs are closely related: they are both web-based platforms, based on Web 2.0 technologies, where usergenerated content plays a crucial role in their functioning. SNSs are often considered as a

\footnotetext{
${ }^{1106}$ Flynn, N. (2012) The Social Media Handbook. Policies and Best Practices to Effectively Manage Your Organization's Social Media Presence, Posts, and Potential Risks. San Francisco: Pfeiffer. p. 332.

1107 Shih, C. (2011) A Facebook kora. Budapest: Kiskapu Kiadó, p. 38.

1108 Bányai, E. (2016) Közösségi média. Közösség vagy média? Pécs: Pécsi Tudományegyetem Közgazdaságtudományi Kar. p. 70.
} 
type of social media, and even overlaps can be observed. ${ }^{1109}$ For the purpose of the thesis, their greatest difference is the emphasis regarding their main purpose: while on social media the focus is on publishing content, social network sites have more personal characteristics and are centred around establishing and maintaining relationships.

321. Activities both on social media and on social network sites can conflict with the interests of the employer, for example, the employee can jeopardize the employer's reputation in a blog entry (social media) or in a post on his/her Facebook account (social network site). However, the dissertation will primarily focus on the employee use of social network sites for the reason that, since they are centred around relationships, they are more closely connected to their personal lives than social media. As the presented definitions highlighted, in contrast to social media, SNSs are even more user-oriented and selfcentred, therefore the employee's personal life is more fundamentally influenced by them. Still, social media will not be excluded from the discussion in cases when the publication of certain facts on social media belongs to the personal sphere of the individual.

\section{§2. Functioning of social network sites}

322. It is necessary to present the technical functioning of these sites in order to be able to understand what legal challenges their use can lead to in the employment relationship. In the following paragraphs, the analysis will be conducted through examining different attributes of SNSs, such as what kind of information is available, who can publish content and who can access it.

\section{(A) What can be published?}

The first matter that must be examined is the type of content that can be published on SNSs. As a preliminary point it must be noted that content shared on SNSs can either relate directly to the employment (e.g. posting an opinion about someone's supervisor) or can relate to a topic not directly relevant to the employment relationship (e.g. expressing one's political opinion). ${ }^{1110}$

\footnotetext{
${ }^{1109}$ Certain platforms can be considered social media and social network at the same time (e.g. Facebook). Source: Burke, F. (2013) Social Media vs. Social Networking, Huffingtonpost. Available at: http://www.huffingtonpost.com/fauzia-burke/social-media-vs-socialne_b_4017305.html\%202017\%2002\%2027(Accessed: 22 September 2017)

${ }^{1110}$ Part II. will further adress the topic and will examine in detail what implications these two types of content might have on the employment relationship.
} 
323. Form. The whole idea of SNS is based on the active participation of the user, generating content. The form of the content can vary according to the given SNS, as they are structured differently, putting the emphasis on certain forms of sharing content. For example, Facebook makes it possible to share different kinds of content, starting with status updates, comments, likes, photos, videos, events, etc. YouTube is a video sharing platform, while Twitter provides micro-blogging service. On Instagram, users can share pictures (and short videos).

324. Subject. The subject of the content can also vary: even though it is up to the user to decide what to share, if the SNS has a specific purpose, it is likely that the content will follow that purpose (e.g. LinkedIn focuses on sharing information relating to the professional life of the user, while on Instagram or Facebook the user generally shares more personal information). Typically, on these sites (usually in their profile) users share personal details, such as their name, birthday, e-mail address, workplace, university they attended, relationship status, profile pictures, etc. Besides these descriptive personal data, users can share a wide range of other type of information, such as pictures, status updates, personal entries or videos - it completely depends on them what they are willing to share. ${ }^{1111}$ Users can also interact with others and express themselves through comments, posts or likes.

325. However, personal information about the users can be revealed not only by being actively engaged in SNS and explicitly sharing details of their personal lives. Besides actively publishing content, other "indirect" information created in the course of the normal use of SNSs, such as likes, contact list, events confirmed, membership in groups, etc. can reveal a lot about the individual. In sum, these sites can be extremely revealing as these data offer insight into the life of the individual, into his/her personality, beliefs, relationships, past, interests, current location or mood, etc. ${ }^{1112}$

\section{(B) Content relating to whom can be published?}

Naturally, a central role is occupied by the users of SNSs, as they constitute the primary actors behind the functioning of SNSs. However, it must also be examined

\footnotetext{
${ }^{1111}$ Except certain strict content that the site's algorithms try to ban, such as violence, nudity, etc.

1112 Users tend to act on these sites as if they were celebrities or public figures. Vallet, C. (2012) 'Le dévoilement de la vie privée sur les sites de réseau social. Des changements significatifs', Droit et société, (1), p. 171.
} 
whether information relating to other users or even non-users of these sites can appear on SNSs.

326. The user. As SNSs are based on the Web 2.0 technology and are centred around the individual, naturally the user himself/herself plays a central role in publishing personal information by filling out the profile, using the services or actively posting content.

327. Other users and non-users. In general, it is the user who decides to publish his/her personal data. Nevertheless, it must not be forgotten that it is also possible to publish data relating to third parties (e.g. posting a group photo, or posting a video of someone, checking-in indicating the current location, etc.). Users can tag each other, which means that they can identify someone else in their posts. In these cases, this third party to whom the information relates is usually aware of the publication through tagging. However, it is also possible to post something without (or against) the consent of another user or even without his/her knowledge, ${ }^{1113}$ or to upload data relating not only to other users, but also to non-users of SNSs. Therefore, it is not necessarily due to the individual's carelessness if (compromising) information is shared, as information can be uploaded by a third party. In such cases the individual loses control over his/her personal data. ${ }^{114}$

\section{(C) Who can access the content?}

After examining what can be published and by whom/relating to whom, it is necessary to examine who can have access to the shared content. The significance of the accessibility of the given content will gain utmost importance when it comes to assessing the private of public nature of these sites in Part II.

328. Privacy settings. The visibility of the content depends highly on the use of privacy settings, which enable users to decide to whom they disclose their personal data. These settings can differ from site to site. The settings can either be customized, enabling the user to fine-tune them, or follow the all or nothing approach, when the user can choose

1113 See, for example, the story of Graham Mallaghan, working at the library of University of Kent, who found out from an acquaintance that without his knowledge a Facebook group was created, named "For Those Who Hate The Little Fat Library Man" in order to insult him. The group had more than 300 hundred members. Source: Hammond, E. (2007) No place to hide, Financial Times. Available at: https://www.ft.com/content/f6182bc8-85e4-11dc-b00e-0000779fd2ac(Accessed: 9 November 2017)

${ }^{1114}$ Although it is possible to report a content uploaded by another user, it does not provide perfect control, as the individual might not be instantly aware of the post or examining the report might take time. 
between public settings and accessibility only to contacts/friends. ${ }^{1115}$ Evan North differentiated between public (available to the general public), semi-private (available to a certain group, such as friends or friends of friends) and private information. ${ }^{1116}$ For example, Facebook makes it possible to carefully tailor the privacy settings: from making every content public, to sharing them only with some chosen contacts or even with no one. It is also possible to fully customize these settings: theoretically it is possible to define different settings for every contact. Twitter and Instagram do not offer such detailed settings: either everything is public or everything is available only to friends.

329. However, challenges rise regarding the effective use of privacy settings. In practice, these settings can be difficult for a user to be understood and they are not always aware of the real audience of the content published. Also, service providers often change these settings. Content can even "escape" from the chosen settings, as users can control the visibility of their activity only on certain parts of the site. The privacy settings chosen by the user do not always apply, as usually it is possible to publish data outside of the user's profile. For example, generally it is possible to publish content on another user's profile e.g. to post a picture or make a comment - and in these cases the privacy settings chosen by this user will apply.

330. The elusive concept of "friend". In relation to the setting "available to friends", attention must be drawn to the fact that the concept of "friend" is elusive as in general, a user can have several hundreds of contacts (the average number of friends is 338). ${ }^{1117}$ Providing access "only" to friends can mean several hundreds of persons, while "friends of friends" can mean several thousands of users, making the given content accessible to an extremely large audience. The expression friend used in the offline world does not necessarily mean the same thing on SNSs: compared to their offline counterparts, online social networks are both vaster and present weaker ties between the individuals, as "the threshold to qualify as friend on somebody's network is low". ${ }^{1118}$

\footnotetext{
1115 Krishnamurthy, B. and Wills, C. E. (2008) 'Characterizing Privacy in Online Social Networks', Proceedings of the first workshop on Online social networks, Seattle, WA, USA, p. 38.

1116 North, E. E. (2010) 'Facebook Isn't Your Space Anymore: Discovery of Social Networking Websites', Kansas Law Review, 58(5), p. 1288.

1117 According to Brandwatch.com, in 2016, the average (mean) number of friends was 338, while the median (midpoint) number of friends was 200. Source: 47 Facebook Statistics for 2016 (2016) Brandwatch. Available at: https://www.brandwatch.com/blog/47-facebook-statistics-2016/(Accessed: 7 January 2017)

1118 Gross, R. and Acquisti, A. (2005) 'Information Revelation and Privacy in Online Social Networks', Proceedings of the 2005 ACM workshop on Privacy in the electronic society, p. 73.
} 
331. These "friends" are added to the contact list during years of social media use: (former) classmates from primary school, from high school or from university, colleagues from work, family members, etc. who - in the absence of the use of privacy settings - can all access the user's profile. The matter is further complicated by the fact that as SNSs are a relatively new phenomenon, clear social conventions regarding their use have not yet been established (e.g. when is it impolite to reject a friend request?). ${ }^{1119}$ Users accept friend requests even from strangers, as it was demonstrated by an experiment conducted by Sophos. In this experiment, $41 \%$ of the participating users accepted a friend request received from Freddy Staur, who was a profile created for a green frog. ${ }^{1120}$ However, other researches report increased consciousness from users, who are becoming more active in pruning and managing their accounts. ${ }^{1121}$

332. Visibility not determined by the individual. In the case of Facebook, users can post content to another user's so called "wall" or leave comments under content on his/her wall. In this case the visibility will be defined by the privacy settings chosen by the other user. It is also possible to post content in events or groups. The privacy settings of these events and groups will depend on the choice of their creator (or the administrators, if the creator has appointed one). ${ }^{1122}$ Naturally, if the user creates these platforms, it is the user who decides what privacy settings to apply; otherwise he/she will have to accept the fact that he/she cannot control to whom the content might become available. ${ }^{1123}$

333. One-to-one communication on SNSs. Usually, it is also possible to engage in one-to-one communication through sending a message to another user's or users' messaging inbox (e.g. Facebook Messenger or Instagram Direct). In such a case, the discussion will be available only to the participants, and non-participants cannot access it (unless they receive an invitation). Such messaging systems are very similar to e-mails.

1119 Van Eecke, P. and Truyens, M. (2010) 'Privacy and social networks', Computer Law and Security Review, 26(5), p. 536.

${ }^{1120}$ See more on this experiment in: Sophos Facebook ID probe shows $41 \%$ of users happy to reveal all to potential identity thieves (2007) Sophos. Available at: https://www.sophos.com/en-us/press-office/pressreleases/2007/08/facebook.aspx(Accessed: 7 January 2017)

1121 Madden, M. (2012) Privacy management on social media sites. Pew Research Center. Available at: http://www.pewinternet.org/ /media//Files/Reports/2012/PIP_Privacy_management_on_social_media_sit es_022412.pdf (Accessed: 21 May 2018)

${ }^{1122}$ On Facebook an event can be public (everyone sees it) or private (only invited guests see it), while a group can be public (everyone can see the members of the group and the posts in it), closed (the members are visible by everyone, but the posts are not) or secret (only people who have been granted access can see the members and the content).

${ }^{1123}$ On the functioning and challenges related to social network sites - such as the content published, the elusive concept of "friends" or the use of privacy settings - see also: Vallet, C. (2012) 'Le dévoilement de la vie privée sur les sites de réseau social. Des changements significatifs’, Droit et société, (1), pp. 163-188. 
Table 4: Functioning of social network sites: what, whose personal data can be published and to whom they are available

\begin{tabular}{|c|c|c|}
\hline \multirow{2}{*}{$\begin{array}{l}\text { TYPE OF PERSONAL } \\
\text { DATA }\end{array}$} & $\begin{array}{l}\text { Descriptive } \\
\text { personal data }\end{array}$ & $\begin{array}{l}\text { (e.g. name, e-mail address, phone } \\
\text { number, birthday, etc.) }\end{array}$ \\
\hline & Other personal data & $\begin{array}{l}\text { (e.g. photos, videos, likes, status updates, } \\
\text { etc.) }\end{array}$ \\
\hline \multirow{3}{*}{$\begin{array}{c}\text { PERSONS TO WHOM } \\
\text { PERSONAL DATA CAN } \\
\text { RELATE }\end{array}$} & User & \\
\hline & \multirow[t]{2}{*}{ Third party } & another user \\
\hline & & not user \\
\hline \multirow{3}{*}{$\begin{array}{c}\text { VISIBILITY OF } \\
\text { PERSONAL DATA } \\
(\text { PRIVACY SETTINGS })\end{array}$} & \multirow[t]{2}{*}{ All or nothing } & $\begin{array}{l}\text { public } \\
\text { (everyone on the Internet) }\end{array}$ \\
\hline & & $\begin{array}{l}\text { private } \\
\text { ("only" contacts of the user) }\end{array}$ \\
\hline & Customized & (e.g. Facebook) \\
\hline \multirow[b]{2}{*}{$\begin{array}{l}\text { "LOCATION" OF } \\
\text { PERSONAL DATA }\end{array}$} & User's own profile & privacy settings chosen by the user apply \\
\hline & $\begin{array}{l}\text { Other (other user's } \\
\text { profile, } \\
\text { groups) }\end{array}$ & $\begin{array}{l}\text { privacy settings chosen by another party } \\
\text { apply }\end{array}$ \\
\hline
\end{tabular}

Source: the author's own summary

334. In sum, users can share all kinds of personal data, typically relating to their private or personal life. It is also possible that third parties publish data relating to the user - excluding such content from the control of the employee. Although privacy settings can be applied in order to define which audience can have access to the content, there are two problems with these settings. First, if they follow the all-or-nothing approach, in the bestcase scenario they will allow access to contacts or friends, which was proved to be an elusive concept. Second, although customizable privacy settings theoretically enable the user to share the given content with a chosen audience, in practice the mastering of such settings is difficult. In practice, users are often mistaken regarding the audience that can have access to the given content. ${ }^{1124}$ Understanding the functioning of SNSs is inevitable in order to address the arising legal challenges associated with its use. On the one hand, - as it will be discussed in Section 2 - such a use raises several questions in terms of privacy and data protection law in general. On the other hand, besides these "general" data protection issues, challenges specific to the employment relationship arise as well: as employees are among users as well, their activities on SNSs might raise specific privacy and data protection questions in relation to their employment relationship.

${ }^{1124}$ Sprague, R. (2011) 'Invasion of the Social Networks: Blurring the Line Between Personal Life and the Employment Relationship', University of Louisville Law Review, 50(1), p. 15.; Kajtár, E. and Mestre, B. (2016) 'Social networks and employees' right to privacy in the pre-employment stage: some comparative remarks and interrogations', Hungarian Labour Law E-journal, (1), pp. 24-25. 


\section{Section 2: Legal implications and social network sites}

335. Existence of a "social media law"? Even though SNSs are relatively recent, it does not mean that they exist in a juridical vacuum. Discussions regarding the existence of a separate social media law have emerged. Daniel Solove aptly phrased it: "[n]ew technologies rarely give rise to questions we have never addressed before. More often they make the old questions more complex." 1125,1126 Indeed, applying existing rules - that were adopted in a different context - to these new phenomena can entail difficulties. ${ }^{1127}$ However, in the Anglo-Saxon community there is tendency to treat these problems as separate, ${ }^{1128}$ specific to social media, resulting in the creation of a "social media law". ${ }^{1129}$ In contrast to this approach, Valère Ndior suggests that SNSs should be attached to the already existing legal categories. ${ }^{1130}$ George Weir, Fergus Toolan and Duncan Smeed also argue that SNSs do not raise fundamentally new challenges but alter already existing threats. ${ }^{1131}$

336. SNSs did not bring into existence the collision of rights in the employment relationship, it had already existed before SNSs; but they altered it. Therefore, based on the above, I hold the view that there is no need to create a new social media law for employee privacy; instead, it should be examined whether and with what alterations already existing provisions can regulate the question.

\footnotetext{
1125 Solove, D. J. (2007) The Future of Reputation. Gossip, Rumor, and Privacy on the Internet. New Haven and London: Yale University Press. p. 105.

${ }^{1126}$ Bill Thompson expresses a similar opinion stating that these new innovations of the online world do not raise fundamentally new questions compared to the physical world. Thompson, B. (2007) 'The Breaking Wave: New Law for a Wired World?', International Review of Law, Computers \& Technology, 21(3), pp. 222-223.

1127 Costes, L. (2011) 'Réseaux sociaux : nouveaux enjeux et nouveaux défis pour les entreprises', Revue Lamy droit de l'immatériel ex Lamy droit de l'informatique, (74), p. 137.

${ }^{1128}$ Eric Goldman describes what phases Internet (and SNS) regulation went through and what exceptions were applied to it, treating it as a new emerging field of law. Goldman, E. (2009) The Third Wave of Internet Exceptionalism. Available at: https://blog.ericgoldman.org/archives/2009/03/the_third_wave.htm(Accessed: 20 January 2019).

${ }^{1129}$ Ndior, V. (2015) 'Le réseau social : essai d'identification et de qualification', in Ndior, V. (ed.) Droit et réseaux sociaux. Issy-les-Moulineaux: Lextenso (Collection LEJEP), p. 11.

${ }^{1130}$ Ndior, V. (2015) 'Le réseau social : essai d'identification et de qualification', in Ndior, V. (ed.) Droit et réseaux sociaux. Issy-les-Moulineaux: Lextenso (Collection LEJEP), 11-12.

1131 Weir, G. R. S., Toolan, F. and Smeed, D. (2011) 'The threats of social networking: Old wine in new bottles?', Information Security Technical Report, 16(2), p. 38.
} 
337. SNSs raise a multitude of legal questions in fields such as cyber bullying, providing proof in legal proceedings, defamation and libel, etc. ${ }^{132}$ However, addressing all these legal questions in detail would go beyond the scope of the dissertation. Consequently, Section 2 - in relation with the main subject of the dissertation - will focus on the right to respect for private life and on the right to data protection.

\section{§1. Documents addressing social network sites and privacy/data protection}

338. Despite the existence of the general data protection framework (such as the DPD or the GDPR), it is welcomed that different organs and institutions have recognized their importance and the need to address them specifically. As a result, they adopted various documents targeting especially social media and data protection law. ${ }^{1133}$ These documents usually emphasize the topicality and the importance of the subject and raise awareness to the privacy/data protection risks they can cause. However, they do not provide an exhaustive guidance, neither are they legally binding.

339. European Union. Among these documents, the first was the European Union Agency for Network and Information Security's (hereinafter referred to as: ENISA) position paper, entitled Security Issues and Recommendations for Online Social Networks (October 2007). ${ }^{1134}$ In this document, the ENISA recognizes the expansion of SNSs and analyses the different risks posed by them (such as for example data aggregation, secondary collection, identity theft or stalking), and the recommendations given in response to these risks, emphasizing the importance of raising awareness, reviewing the existing regulations or suggesting technical solutions.

340. In 2009, the WP29 adopted Opinion 5/2009 on online social networking. ${ }^{1135}$ The Opinion adopts a more practical point of view through the analysis of how the main points of the DPD could be applied to SNSs (such as who the data controller is, data security measures, how data subjects could exercise their rights, what information shall be provided to them, etc.). In 2018, the WP29 expressed its full support for the investigations conducted by national DPAs, taking place to examine recent data protection scandals (e.g.

\footnotetext{
${ }^{1132}$ For more on law and social media and/or SNSs see in: Stewart, D. R. (ed.) (2013) Social media and the law: a guidebook for communication students and professionals. New York and London: Routledge; Lambert, P. (2014) International Handbook of Social Media Laws. Haywards Heath: Bloomsbury

${ }^{1133}$ See Annex I. on the summary table concerning the most important international documents in the field of privacy, data protection, data protection and employment, and data protection and social network sites.

${ }^{1134}$ Security Issues and Recommendations for Online Social Networks (2007). Position Paper. ENISA.

1135 WP29 (2009) Opinion 5/2009 on online social networking. 01189/09/EN WP 163.
} 
Cambridge Analytica) and announced the establishment of a Social Media Working Group to develop a long-term strategy on the issue. ${ }^{1136}$

341. In the same year, different major SNS providers signed an agreement, entitled Safer Social Networking Principles for the EU, in consultation with the European Commission. ${ }^{137}$ This agreement especially targeted the protection of young users and minors, and aims to give guidance regarding how to minimize potential harm to them by outlining different best practices. ${ }^{1138}$ The document outlines the principles by which SNS providers should be guided as they seek to help minimize potential harm to children and young people, and recommends a range of good practice approaches which can help achieve those principles.

\section{International Working Group on Data Protection in} Telecommunications. ${ }^{1139}$ Another very important document is the "Rome Memorandum", issued by the International Working Group on Data Protection in Telecommunications (hereinafter referred to as: IWGDPT) in March 2008. ${ }^{1140}$ In this document, the IWGDPT enumerates the change of paradigm in the sharing of personal data, both regarding its unprecedented scale and the novelty that they are published at the initiative of the user himself/herself. The Memorandum details the risks related to social network sites (such as the not forgetting nature of the Internet, the deceptive notion of "friends" and community, the possible vetting of these sites by the employer, just to mention a few examples that can have relevance in the employment context, too) and then provides guidance to regulators and to the providers of these services on how these risks could be reduced.

\footnotetext{
1136 "Sorry is not enough": WP29 establishes a Social Media Working Group (2018). Available at: https://edps.europa.eu/sites/edp/files/publication/18-04-11_wp29_press_release_en.pdf (Accessed: 20 January 2019)

1137 Safer Social Networking Principles for the EU (2009). Available at: https://ec.europa.eu/digital-singlemarket/sites/digital-agenda/files/sn_principles.pdf (Accessed: 20 January 2019)

1138 Safer Social Networking Principles for the EU (2009). Available at: https://ec.europa.eu/digital-singlemarket/sites/digital-agenda/files/sn_principles.pdf (Accessed: 20 January 2019) p. 1.

1139 The International Working Group on Data Protection in Telecommunications (also called Berlin group as the secretariat is provided by the data protection authority of Berlin) was established in 1983 at the initiative of national data protection authorities in the world. It has among its members national data protection authorities, as well as representatives from the private and NGO sectors. Source: European Data Protection Supervisor (no date) Glossary. Available at: https://edps.europa.eu/data-protection/dataprotection/glossary/b_en(Accessed: 20 January 2019). Although the IWGDPT adopts proposals and recommendations that are legally not binding, due to its composition, these documents can serve as important guideline to countries as well.

${ }^{1140}$ International Working Group on Data Protection in Telecommunications (2008) Report and Guidance on Privacy in Social Network Services - "Rome Memorandum" -. 675.36.5. Rome
} 
343. International Conference of Data Protection and Privacy Commissioners. ${ }^{1141}$ In October 2008, the $30^{\text {th }}$ International Conference of Data Protection and Privacy Commissioners adopted the Resolution on Privacy Protection in Social Network Services. ${ }^{1142}$ The Resolution briefly describes the new challenges posed by social network sites and provides recommendations not only to service providers but also to users. These recommendations destined for users include a call for increased consciousness from users (notably regarding the use of pseudonyms and considering that they might be later confronted with the shared information, for example, during a job interview) and draw attention to the importance of respecting other individuals' privacy. ${ }^{1143}$

344. Council of Europe. In 2011, the Council of Europe's Parliamentary Assembly adopted a resolution on The protection of privacy and personal data on the Internet and online media, ${ }^{1144}$ in which the CoE emphasized the importance of privacy and data protection in the age of ICT developments. In 2012, the CoE adopted its Recommendation on the Protection of Human Rights with Regard to Social Networking Services. ${ }^{1145}$ The Committee of Ministers emphasized the growing role of SNSs in promoting (or hindering) the exercise or enjoyment of human rights. In the Appendixes of the Recommendation attention is drawn to the importance of what measures should be taken in order to make users capable of dealing with these platforms, how children and young people can be protected and how these platforms could operate.

345. The merits and shortcomings of these international legal documents. These documents are significant in acknowledging the importance of SNSs in modern societies and recognize the need to provide legal regulation. They identify the possible risks and suggest different solutions to cope with them, contributing to enhancing privacy and data protection, and also to raising awareness to the issue.

Still, since these documents do not have obligatory force, their enforcement in practice might face certain difficulties. As regards the subject of the dissertation, another

${ }^{1141}$ The International Conference of Data Protection and Privacy Commissioners is a global forum of data protection authorities, established in 1979, seeking to provide leadership in reaction to privacy and data protection on an international scale. The Conference is held at least once a year.

1142 30th International Conference of Data Protection and Privacy Commissioners (2008) Resolution on Privacy Protection in Social Network Services. Strasbourg

1143 30th International Conference of Data Protection and Privacy Commissioners (2008) Resolution on Privacy Protection in Social Network Services. Strasbourg, p. 2.

${ }^{1144}$ Council of Europe (2011) The protection of privacy and personal data on the Internet and online media. Resolution 1843 (2011)

1145 Council of Europe (2012) 'Recommendation CM/Rec(2012)4 of the Committee of Ministers to member States on the protection of human rights with regard to social networking services' 
significant lack is that these documents dealt with the question of SNSs from a general point of view and did not focus specifically on employment. During the research I have not found any legal document that would exhaustively co-regulate the specific question of privacy/data protection and social network sites in the employment context.

Despite the lack of a document exhaustively addressing employment and SNSs, it is a great achievement that the latest documents on privacy and data protection at work at least mention social network sites. Still, these documents usually contain only few provisions; they do not regulate the question exhaustively. Among these documents, the $C o E$ 's recommendation of the Committee of Ministers to member States on the processing of personal data in the context of employment $(2015)^{1146}$ and the Article 29 Data Protection Working Party's opinion on data processing at work (2017) $)^{1147}$ should be mentioned. These provisions will be addressed in detail in Part II. of the dissertation.

\section{$\S 2$. Social network sites and data protection}

346. Despite the fact that the general data protection regime - such as earlier the DPD and now the GDPR - is applicable to social network sites, in practice it is not always obvious how the general data protection rules laid down in different documents should be applied in the context of SNSs. In the following paragraphs, "general" data protection challenges will be presented, such as how the SNS's operator should comply with regulations in order to ensure individuals' right to data protection. The exhaustive examination of such questions extends beyond the scope of the dissertation, as the main focus of the thesis is concentrated on the joint examination of labour law and data protection law - addressed in detail in Part II. Therefore, in the following paragraphs only the questions worth further researching will be discussed in order to provide insight into this other field related to data protection.

347. Controllership and scope. In relation to the EU data protection framework, an important question is who can qualify as data controller. This question is of high significance as controllers are bound by several obligations laid down in the GDPR. It is uncontested that SNS providers qualify as data controllers ${ }^{1148,1149}$ and are subject to the

\footnotetext{
1146 "5.3. Employers should refrain from requiring or asking an employee or a job applicant access to information that he or she shares with others online, notably through social networking."

1147 See the section "5.1 Processing operations during the recruitment process".

1148 Kosta, E. et al. (2010) 'Data protection issues pertaining to social networking under EU law', Transforming Government: People, Process and Policy, 4(2), p. 196. and Garrie, D. B. et al. (2010)
} 
responsibilities of the data controller. However, the question arises whether an individual user who decides to upload personal data relating to another person qualifies as a controller.

348. A strict reading of the GDPR would result in qualifying the user as controller, as the user can determine the purposes (e.g. self-expression) and the means (e.g. choosing a video, a photo or a written post, etc.) of processing. ${ }^{1150}$ However, imposing controller's responsibilities on users is not without questions, as according to the household exception, the regulation should not be applied to processing "by a natural person in the course of a purely personal or household activity." 1151,1152

Under the DPD it was debated whether the household exemption applies (should apply) to SNS users or not; ${ }^{1153}$ as it was drafted before the Web 2.0 era, in the premature

'Data Protection: The Challenges Facing Social Networking', Brigham Young University International Law \& Management Review, 6(2), p. 131.; WP29 (2009) Opinion 5/2009 on online social networking. 01189/09/EN WP 163, p. 5.

Recital (18) of the GDPR clearly states that it applies to SNS operators (and to other actors who make it possible for users to use these services). The CoE adopts the same view when stating in par 45. of the explanatory memorandum of Recommendation $\mathrm{CM} / \operatorname{Rec}(2015) 5$ on the processing of personal data in the context of employment that "[c]ontrollers of social networking services are themselves bound to the principles of data protection and to the correspondent obligations, especially in terms of information, violations of terms of service and proportionality."

${ }^{1149}$ Besides determining who the controller is, it might also raise difficulties to differentiate between the controller and the processor when it comes to different actors providing services in relation to SNSs (e.g. SNS operator, user or application provider). They can simultaneously be qualified, as controllers and processors, depending on who is defining the purpose and means of the processing. On these questions see more in: Van Alsenoy, B. et al. (2009) 'Social networks and web 2.0: are users also bound by data protection regulations?', Identity in the Information Society, 2(1), pp. 68-69.; Van Eecke, P. and Truyens, M. (2010) 'Privacy and social networks', Computer Law and Security Review, 26(5), pp. 537-539.

${ }^{1150}$ Garrie, D. B. et al. (2010) 'Data Protection: The Challenges Facing Social Networking', Brigham Young University International Law \& Management Review, 6(2) p. 131.; Van Alsenoy, B. et al. (2009) 'Social networks and web 2.0: are users also bound by data protection regulations?', Identity in the Information Society, 2(1), p. 70.

${ }^{1151}$ Paragraph 2 of Article 3 of the DPD; Paragraph 2 of Article 2 of the GDPR

${ }^{1152}$ However, in a 2018 CJEU case, the CJEU held that the operator of a Facebook fan page is considered to be a controller. Source: CJEU (2018): Wirtschaftsakademie Schleswig-Holstein, Case C-210/16, ECLI:EU:C:2018:388, 5 June

1153 The starting point is the CJEU's Lindqvist decision, in which the court held that the household exception does not apply to cases when the individual publishes personal data on the Internet in a way that the data is accessible to an indefinite number of people. [CJEU (2003): Bodil Lindqvist, Case C-101/01, ECLI:EU:C:2003:596, 6 November, par. 47.] In conformity with this decision, according to the WP29, the household exemption applies to most SNS users, but it does not apply to those who use SNSs for professional purposes (e.g. acting on behalf of a company or association, or promoting commercial, political or charitable goals). Also, when access is granted to a high number of users or extends beyond self-selected contacts (e.g. access to profile is not restricted through privacy settings or the data is indexable by search engines), the use extends beyond the personal sphere. WP29 (2009) Opinion 5/2009 on online social networking. 01189/09/EN WP 163, pp. 5-6. In contrast, Patrick Van Eecke and Maarten Truyens argue that most users cannot rely on the exception and argue in favour of its strict application. (Van Eecke, P. and Truyens, M. (2010) 'Privacy and social networks', Computer Law and Security Review, 26(5), p. 540.) According to Rebecca Wong and Joseph Savirimuthu, it is unlikely that the (narrow interpretation of the) household 
stages of the Internet, it did not contain any provisions specifically aimed at SNSs. ${ }^{1154}$ However, the GDPR put an end to this discussion - contrarily to what had been previously stated in the Lindquist case $-{ }^{1155}$, as amongst the examples falling under the exception, it explicitly mentions the use of SNSs by individuals. Despite the GDPR regulating this issue, it is not without merit to recall different arguments from the previous discussions when the DPD was in force in order to nuance the picture. While it is true that subjecting SNS users to the same obligations as organisational data controllers, such as SNS operators, is not advisable, ${ }^{1156}$ nor is it realistic or enforceable; ${ }^{1157}$ at the same time it should be kept in mind that the formulation of the household exception took place before Web 2.0 technologies gaining ground, with the aim to cover innocuous processing. However, in the light of today's SNSs, storage capacity, network connectivity, the ease with which an individual can possibly publish detailed information relating to third parties, SNSs do not weigh the same as personal phone registers from the time of the adoption of the DPD. ${ }^{1158}$ So while the GDPR correctly acknowledged that users should not be subject to the same obligations as organisational controllers, the possible processing conducted by them could potentially do serious harm to third persons' rights, making it desirable to reevaluate the existing black and white situation. ${ }^{1159,1160}$

exception applies to users of SNSs (Wong, R. and Savirimuthu, J. (2008) 'All or Nothing: This is the Question? The Application of Art. 3(2) Data Protection Directive 95/46/EC to the Internet', John Marshall Journal of Computer \& Information Law, 25(2), p. 265.; while Brendan Van Alsenoy et al. argues that users definitely fall under the DPD if their profile is set to public, but it is disputable whether private profiles are covered by the exception. (Van Alsenoy, B. et al. (2009) 'Social networks and web 2.0: are users also bound by data protection regulations?', Identity in the Information Society, 2(1), p. 75.)

1154 Wong, R. (2008) 'Social Networking: Anybody is a Data Controller'. Available at: https://papers.ssrn.com/sol3/papers.cfm?abstract_id=1271668 (Accessed: 20 January 2019). p. 2.; Garrie, D. B. et al. (2010) 'Data Protection: The Challenges Facing Social Networking', Brigham Young University International Law \& Management Review, 6(2) p. 142.

1155 Klein, T. and Tóth, A. (eds) (2018) Technológia jog - Robotjog - Cyberjog. Budapest: Wolters Kluwer Hungary, p. 45.

1156 Garrie, D. B. et al. (2010) 'Data Protection: The Challenges Facing Social Networking', Brigham Young University International Law \& Management Review, 6(2) p. 133.

1157 Wong, R. (2008) 'Social Networking: Anybody is a Data Controller'. Available at: https://papers.ssrn.com/sol3/papers.cfm?abstract_id=1271668 (Accessed: 20 January 2019). p. 13.

1158 Van Eecke, P. and Truyens, M. (2010) 'Privacy and social networks', Computer Law and Security Review, 26(5), p. 539.

1159 Among the proposed solutions to this problem, drafting a new category for individual controllers (including, for example, SNS users) (Garrie, D. B. et al. (2010) 'Data Protection: The Challenges Facing Social Networking', Brigham Young University International Law \& Management Review, 6(2) p. 134.), or assessing the qualitative and quantitative change in sharing personal data (e.g. publishing a vast amount of videos possibly containing sensitive information) was raised. (Van Eecke, P. and Truyens, M. (2010) 'Privacy and social networks', Computer Law and Security Review, 26(5), p. 540.)

${ }^{1160}$ On the detailed analysis of the notion of controller and the scope of the household exception under the DPD see more in: Garrie, D. B. et al. (2010) 'Data Protection: The Challenges Facing Social Networking', Brigham Young University International Law \& Management Review, 6(2) pp. 127-152.; Van 
349. Determining the scope of the household exemption can raise very similar questions to those arising during the assessment of the private or public nature of SNSs during expressing oneself (to be further presented in Part II.); to which analysis the observation considering the material scope might serve as useful guidance. With regard to the household exception, the Lindqvist decision of the CJEU linked the exemption's applicability to two criteria: the processing must be carried out "in the course of private and family life" and personal data published on the Internet should not be available to an indefinite number of users on the Internet. ${ }^{1161}$ This raises the questions of access (private or public) and the scope of persons ("in the course of private and family life") having access to the content.

First, the decision created a separation between private and public access on the Internet. ${ }^{1162}$ However, in the context of SNSs this solution is criticised as being arbitrary, as even when privacy settings are used, the data might be available to a high number of contacts, ${ }^{163}$ allowing access to an audience beyond the legislator's original intent. ${ }^{1164}$ Rebecca Wong and Joseph Savirimuthu also qualifies this narrow dichotomy as undesirable, as it can inhibit the proper use of SNSs. ${ }^{1165}$ Second, in relation to the individuals who can have access to the content doubts arise, as a narrow interpretation might limit this to access only to family members, while a broad interpretation would allow access to other persons as well. ${ }^{1166,1167}$

Alsenoy, B. et al. (2009) 'Social networks and web 2.0: are users also bound by data protection regulations?', Identity in the Information Society, 2(1), pp. 65-79.; Wong, R. (2008) 'Social Networking: Anybody is a Data Controller'. Available at: https://papers.ssrn.com/sol3/papers.cfm?abstract_id=1271668 (Accessed: 20 January 2019); Wong, R. and Savirimuthu, J. (2008) 'All or Nothing: This is the Question? The Application of Art. 3(2) Data Protection Directive 95/46/EC to the Internet', John Marshall Journal of Computer \& Information Law, 25(2), pp. 241-266.; de Terwangne, C. (2015) 'L'exception concernant les traitements de données à des fins personnelles et domestiques de la directive 95/46 relative à la protection des données', Revue du Droit des Technologies de l'Information, (58), pp. 45-51.

1161 Van Alsenoy, B. et al. (2009) 'Social networks and web 2.0: are users also bound by data protection regulations?', Identity in the Information Society, 2(1), p. 73.

1162 Wong, R. and Savirimuthu, J. (2008) 'All or Nothing: This is the Question? The Application of Art. 3(2) Data Protection Directive 95/46/EC to the Internet', John Marshall Journal of Computer \& Information Law, 25(2), p. 247.

1163 Van Alsenoy, B. et al. (2009) 'Social networks and web 2.0: are users also bound by data protection regulations?', Identity in the Information Society, 2(1), p. 75.

${ }^{1164}$ Though with regard to SNSs, it would have been useful to specify the limits of the "indefinite number of users".

1165 Wong, R. and Savirimuthu, J. (2008) 'All or Nothing: This is the Question? The Application of Art. 3(2) Data Protection Directive 95/46/EC to the Internet', John Marshall Journal of Computer \& Information Law, 25(2), p. 256.

${ }^{1166}$ Wong, R. and Savirimuthu, J. (2008) 'All or Nothing: This is the Question? The Application of Art. 3(2) Data Protection Directive 95/46/EC to the Internet', John Marshall Journal of Computer \& Information Law, 25(2), p. 256. 
350. Lawful ground for processing. An SNS provider (or an application provider) might process personal data based on the grounds of consent, necessity for performance of a contract or the balancing of rights and interests. ${ }^{168}$ Here, it is especially interesting to present a few thoughts on the question of consent as a lawful ground of processing.

Although the GDPR made it clear that pre-ticked boxes should not constitute consent, ${ }^{1169}$ questions still arise, such as whether privacy policies make it possible to make an informed consent, ${ }^{1170}$ or whether the consent is truly voluntary. Users do not have the power to negotiate with the SNS provider, either they accept the privacy policy imposed on them as such, or they must refrain from using such services. Also, most sites do not have alternatives, which means that everyone is member of a specific site, then in order to be able to communicate with his/her friends, the user must choose this site, and not a similar one, with better data conditions of data processing. Today, given the importance of SNSs in everyday life and the fact that users do not have a true choice, the question arises whether the consent was truly voluntary or not.

351. Data protection principles. From a general data protection aspect different questions need to be answered regarding data protection principles. As data controllers, organizational data controllers must comply with the data protection principles. Different questions arise in relation to the principle of proportionality and necessity. First, when a user decides to register on an SNS, the question is whether the personal data that the user is obliged to provide in order to create an account are indeed necessary to use the service (e.g. being obliged to use his/her real name, or having the possibility to choose a pseudonym). ${ }^{1171}$ As regards the storage of personal data, questions might also arise in

\footnotetext{
${ }^{1167}$ For example, the Belgian Privacy Commission interpreted personal use in the context of sharing pictures as processing for the sole purpose of distribution among a selected ('definable') group of friends, family members or acquaintances, for example, sending them as an e-mail attachment or uploading them to a secured website, which is only available to the relevant family members and is not indexable by search engines. The Dutch Data Protection Authority also adopted a very similar approach. (Van Alsenoy, B. et al. (2009) 'Social networks and web 2.0: are users also bound by data protection regulations?', Identity in the Information Society, 2(1), p. 74.) However, in the light of the customizable privacy settings that certain SNSs provide to users, even SNSs can provide this level of privacy if the contacts are indeed limited in number and carefully chosen and authorized by the user, and no other persons can access the content.

1168 Van Eecke, P. and Truyens, M. (2010) 'Privacy and social networks', Computer Law and Security Review, 26(5), pp. 542-543.

1169 Recital (32) of the GDPR

1170 On certain issues regarding Facebook's privacy policies see more in: Jaeger, E. (2015) 'Facebook Messenger: Eroding User Privacy in Order to Collect, Analyze and Sell Your Personal Information', The John Marshall Journal of Information Technology \& Privacy Law, 31(3), pp. 393-421.

${ }^{1171}$ WP29 (2009) Opinion 5/2009 on online social networking. 01189/09/EN WP 163, p. 11.
} 
relation to necessity and proportionality as infringements are possible. An extreme example is pointed out by Evelyne Sørensen, who described how Facebook users could not practice self-censorship because even if they started to type something, then decided not to post but to delete it, Facebook store that information. ${ }^{1172}$ Up-to-dateness might also be questioned, as on these sites personal data back to several years can be aggregated. A solution might be to set the default settings to delete personal data published by users after a determined period (for example, 3 years), and those users who wish should take active steps and change the default settings.

352. Transparency is a crucial question as well. SNS operators lay down the rules and the conditions of using their services in their privacy policy in a unilateral document, the terms of which are solely defined by the site operator. The user does not have the possibility to negotiate those terms and conditions and has to accept them when registering to the service. Theoretically, users can learn more about data processing operations from these policies, in practice various difficulties arise: because of the lengthy wording, users usually do not read such policies, and even if they read them, they do not understand its provisions, and even if they understand them, they do not have the necessary background knowledge in order to make an adequate, informed decision. ${ }^{1173}$

353. SNS operators and the employment context. Although in the above data protection principles were examined from a general angle, these issues might have relevancy in the employment context as well. Having the possibility to use these sites under a pseudonym might "break" the connection between the employee and the employer, as it would make the identification of the user more difficult to a third party (compared to cases when the employee uses his/her real name and may even identify the employer on his/her profile). ${ }^{1174}$ Or, the aggregation of less data by default would result in employers being able to trace a limited past of the prospective employee or the employee. Privacy policies in their present form do not enable an average user to truly exercise control over his/her personal data. Informing users and raising awareness amongst them through a more appropriate, user-friendly way might enable more users to exercise their rights in a more

\footnotetext{
${ }^{1172}$ See more in: Sørensen, E. J. B. (2016) 'The post that wasn't: Facebook monitors everything users type and not publish', Computer Law and Security Review 32 (2016) pp., 32(1), pp. 146-151.

${ }^{1173}$ Solove, D. J. (2013) 'Introduction: Privacy-Self Management and the Consent Dilemma', Harward Law Review, 126(7), p. 1888. (See more: Idem pp. 1888-1893.)

${ }^{1174}$ Although it does not mean in any case that hiding under a pseudonym would enable employees to escape from all responsibility.
} 
conscious way and might contribute to their better understanding of the functioning of SNSs and the stakes relating to the processing of their personal data. ${ }^{1175,1176}$

\section{Section 3: Social network sites and blurred boundaries}

354. In connection with the main subject of the dissertation, SNSs can blur two boundaries: the boundaries of privacy and the boundaries of professional and personal life. On the one hand, $(\S 1)$ it has to be assessed whether and if yes, how SNSs can alter reasonable expectations of privacy, and whether they can influence what is considered to be covered by privacy nowadays. On the other hand, it is necessary to examine (\$2) that in the light of how ICT contributed to blurring the boundaries between professional and personal life, what specific problems, inherent to SNSs arise in this regard.

\section{\$1. Changed expectations of privacy}

Before addressing the questions of $(B)$ how SNSs altered the boundaries of privacy, what privacy means in the context of SNSs, it is necessary to consider $(A)$ what are the

\footnotetext{
1175 Technological and societal changes that occurred since the adoption of the DPD raises additional data protection questions as well. Luckily, the GDPR has addressed challenges through the modernization of the previous data protection rules: examples such as the right to data portability, the right to be forgotten, data protection by design, data protection by default or data protection impact assessment can be cited. On the novelties introduced by the (proposed) GDPR see more in: De Hert, P. and Papakonstantinou, V. (2012) 'The proposed data protection Regulation replacing Directive 95/46/EC: A sound system for the protection of individuals', Computer Law and Security Review, 28(2), pp. 130-142.; Costa, L. and Poullet, Y. (2012) 'Privacy and the regulation of 2012', Computer Law and Security Review, 28(3), pp. 254-262.

In relation to the recent privacy scandals, such as the Snowden revelations or the Cambridge Analytica scandal, the transfer of personal data is also a significant field. Especially with regard to the changes in the juridical landscape: such as the Schrems decision, invalidating the Safe Harbor agreement and the adoption of the Privacy Shield, in the field of data transfers between the EU and the US. See more on these scandals and data transfers in: Black, I. (2013) NSA spying scandal: what we have learned, The Guardian. Available at: https://www.theguardian.com/world/2013/jun/10/nsa-spying-scandal-what-we-have-learned (Accessed: 20 January 2019); Pintér, R. (2013) 'Yes, we (s)can!', Információs Társadalom, (3-4), pp. 28-42.; European Commission (2016) European Commission launches EU-U.S. Privacy Shield: stronger protection for transatlantic data flows. Press release. Brussels. Available at: http://europa.eu/rapid/press-release_IP-162461_en.htm(Accessed: 20 January 2019).; Commission Implementing Decision (EU) 2016/1250 of 12 July 2016 pursuant to Directive 95/46/EC of the European Parliament and of the Council on the adequacy of the protection provided by the EU-U.S. Privacy Shield (notified under document C(2016) 4176) (Text with EEA relevance)

See more on data protection and SNSs in: Kosta, E. et al. (2010) 'Data protection issues pertaining to social networking under EU law', Transforming Government: People, Process and Policy, 4(2), pp. 193-201.; Lukács, A. (2017) 'Adatvédelmi irányelv és rendelet, avagy hogyan változott a közösségi oldalakra vonatkozó szabályozás az Európai Unió adatvédelmi reformjával?’, in Homoki-Nagy, M. and Hajdú, J. (eds) Ünnepi kötet dr. Zakar András c. egyetemi tanár 70. születésnapjára. Szeged: Szegedi Tudományegyetem Állam- és Jogtudományi Kar, pp. 125-139., Van Eecke, P. and Truyens, M. (2010) 'Privacy and social networks', Computer Law and Security Review, 26(5), pp. 535-546.

1176 The employment specific aspect of these principles will be addressed in more detail in Part II.
} 
significance and the underlying reasons behind the use of SNSs and what role(s) do they play in individuals' lives?

\section{(A) Importance of social network sites}

355. As it was already mentioned, the popularity of SNSs is given by their capacity to fulfill three basic human needs: according to James Grimmelmann these needs are self-expression (identity), communication (relationships) and being part of a community. These needs constitute the basic elements of social interaction. First, through shaping their online profiles users can express their identity. Second, on SNSs users can communicate and maintain relations with others in several ways. Third, they can feel that they are part of a community and they can establish their social position within the community. ${ }^{1177}$

356. Creating identity. Desiring to express one's identity and to manage one's perceptions taken of the individual by third parties is not a novelty. ${ }^{1178}$ On SNSs users can present an image of themselves in various forms, where each feature provided by the SNS serves as a means for self-expression, be it a (profile) picture, a caption, filters, hashtags, likes, membership in a group, etc. ${ }^{1179}$ SNSs allow users to create a carefully shaped identity, where posts might be carefully planned, aiming to reflect the precise image that the user aims to diffuse towards his/her contacts. ${ }^{1180}$ SNSs are centred around the individual, creating personal, or "egocentric" networks. ${ }^{1181}$

357. Communication. Leigh A. Clark and Sherry J. Roberts note that technology has always had a significant impact on how people communicate (e.g.: telegraph, telephone, Internet, etc.) and SNSs should be considered as a next step of human interaction, therefore they shall receive adequate protection. ${ }^{182}$ Ways of communication naturally change over time and since the creation of the Internet, it has changed how users

\footnotetext{
1177 Grimmelmann, J. (2009) 'Saving Facebook', Iowa Law Review, 94(4), pp. 1151-1159.

1178 Notably see Erving Goffman's "impression management" describing how individuals aim to control the impressions that others might have of him/her. Goffman, E. (1956) The Presentation of Self in Everyday Life. Edinburgh: University of Edinburgh, Social Sciences Research Centre.

1179 Grimmelmann, J. (2009) 'Saving Facebook', Iowa Law Review, 94(4), pp. 1152-1153. Creating a perfect post has become an increasingly complex, well-planned act.

1180 Williams, A. (2009) Here I Am Taking My Own Picture, The New York Times. Available at: https://www.nytimes.com/2006/02/19/fashion/sundaystyles/here-i-am-taking-my-ownpicture.html (Accessed: 20 January 2019)

1181 boyd, danah m. and Ellison, N. B. (2008) 'Social Network Sites: Definition, History and Scholarship', Journal of Computer Mediated Communication, 13(1), p. 219.

1182 Clark, L. A. and Roberts, S. J. (2010) 'Employer's Use of Social Networking Sites. A Socially Irresponsible Practice', Journal of Business Ethics, 95(4), p. 508, p, 509, p. 518.
} 
use it. At the beginning of the $21^{\text {st }}$ century, its information-sharing nature started to thrive, ${ }^{1183}$ and has not stopped since, ${ }^{1184}$ leading to the phenomenon that it has become an integral part of everyday life: users share bits of their personal lives, be it pictures of a party, a holiday, Christmas celebration, a meal in a restaurant or drinks in a fancy bar. Today, being (actively) present on SNSs is even a societal expectation, reflected in the mantra of SNSs that if it is not posted to SNS, it did not happen. ${ }^{1185}$

358. Being part of a community. SNSs can let users establish their social position and enable them to be recognized members of the community, ${ }^{1186}$ which can manifest in several forms - either in the number of contacts, or in the number of likes received. When it comes to the reasons for using SNSs, the (informational) societal pressure is also an important factor. If everyone is present on these sites, staying out of them - in the age of information, when information is in the centre of life - can represent a serious disadvantage, as the user would not be able to use certain services and have the same possibilities as the other users. ${ }^{187}$ Users are bound to these services because they can only leave these sites with difficulties, because if they do so, they would leave all their friends, too. ${ }^{188}$ Also, being present on these platforms and keeping in touch with different contacts is crucial, as today "[c]onnectedness is social currency". 1189

359. SNSs as means of exercising human rights. Besides satisfying basic human needs, the Internet and SNSs can also play an important role in promoting the exercise of human rights. ${ }^{1190}$ The use of SNSs can also constitute a way of exercising fundamental rights. From a legal perspective, the Council of Europe's Committee of Ministers emphasized the importance of the Internet and SNSs in promoting the exercise and enjoyment of human rights and fundamental freedoms, stating that they can also enhance

\footnotetext{
1183 Sprague, R. (2008) 'Rethinking Information Privacy in an Age of Online Transparency', Hofstra Labor \& Employment Law Journal, 25(2), pp. 395-396.

1184 According to the site Brandwatch, in 2016, 6 new Facebook profiles were created in every second and the site generates 4 petabytes of data per day. Users generated 4 million likes per minute and uploaded 350 million photos per day. Source: 47 Facebook Statistics for 2016 (2016) Brandwatch. Available at: https://www.brandwatch.com/blog/47-facebook-statistics-2016/(Accessed: 7 January 2017)

1185 Silverman, J. (2015) 'Pics or it didn't happen' - the mantra of the Instagram era, The Guardian. Available at: https://www.theguardian.com/news/2015/feb/26/pics-or-it-didnt-happen-mantra-instagram-erafacebook-twitter (Accessed: 20 January 2019)

1186 Grimmelmann, J. (2009) 'Saving Facebook’, Iowa Law Review, 94(4), p. 1157.

1187 Cseh, G. (2013) ‘A közösségi portálok árnyoldalai', Infokommunikáció és jog, (2), p. 90.

1188 Mendel, T. et al. (2013) Étude mondiale sur le respect de la vie privée sur l'Internet et la liberté d'expression. Paris: Éditions Unesco (Collection Unesco sur la liberté de l'Internet). p. 38.

1189 Grimmelmann, J. (2009) 'Saving Facebook', Iowa Law Review, 94(4), p. 1158, pp. 1151-1159.

${ }^{1190}$ Hiselius, P. (2010) 'ICT/Internet and the Right to Privacy', Scandinavian Studies in Law, 56, p. 202.
} 
participation in social and political life and promote democracy and social cohesion. ${ }^{1191}$ Isabelle Falque-Pierrotin also emphasized the role of the Internet in promoting the exercise of individual and public liberties - especially freedom of expression and right to information - and argued that the exercise of these rights is inseparable from the question of privacy protection. ${ }^{192}$ One employment specific example can be the exercise of collective labour rights, as communication on SNSs might also serve the activity of trade unions, etc.

360. Right to social media? Such an enhanced importance of these platforms can raise the question: do individuals have a right to social media? With respect to employees' privacy and data protection this question is crucial, as it relates to whether and if yes, how employees can be told what behaviour they should adopt on these sites ${ }^{1193}$ or whether employees can be ordered to withdraw from the use of social media. Do employees have a "right to social media" in the light of the evolutive concept of private life interpreted as being able to live one's life as one wishes and in the light of the growing role of social network sites in everyday life? The phenomenon of adopting internal social media regulations poses the question whether the employer can restrict - and if yes, to what extent -, employees' use of SNSs? Can the employer order the employee to like certain content on these sites or to friend the employer?

361. In France, the Constitutional Council's decision on the Act furthering the diffusion and protection of creation on the Internet ${ }^{194}$ must be mentioned, in which the Constitutional Council had to take position in a slightly similar case. The act aimed to give the administrative authority, the High Authority for the dissemination of works and the protection of rights on the Internet ("Haute Autorité pour la diffusion des œuvres et la protection des droits sur internet", abbreviated as HADOPI) the power to impose penalties in the form of withholding access to the Internet. The Constitutional Council declared that the right to access to the Internet falls within the scope of the freedom of communication

\footnotetext{
${ }^{1191}$ Council of Europe (2012) 'Recommendation CM/Rec(2012)4 of the Committee of Ministers to member States on the protection of human rights with regard to social networking services'.

1192 Falque-Pierrotin, I. (2012) 'La Constitution et l'Internet', Les nouveaux cahiers du Conseil constitutionnel, (36), pp. 34-35.

${ }^{1193}$ For example, employers sometimes ask their employees to be actively present on these sites in order to enhance the employer's e-reputation. Source: Ray, J.-E. (2012) 'A propos de la révolution numérique. Actualités des TIC (mai-septembre 2012)', Droit social, (10), p. 936.

${ }^{1194}$ Conseil constitutionnel: décision $n^{\circ} 2009-580$ du 10 juin 2009
} 
and expression. ${ }^{1195}$ Although - in contrast to the US court - it did not acknowledge the existence of a fundamental human right to access to the Internet, it affirmed that the threats to the freedom to access the Internet are regarded as threats posed to the right to the free communication of ideas and opinions. ${ }^{196,1197}$

362. Considering the acknowledgement of public or social private life, the ECtHR's Niemitez decision should be mentioned although the decision did not directly relate to SNSs but to the Internet in general. Today aren't SNSs one of the principal forums where individuals "establish and develop relationships with other human beings"? ${ }^{1198,} 1199$ Does the right to informational self-determination not go beyond simply protecting privacy but aim to guarantee "the primacy of the individual, to be able to exercise his/her freedom"? ${ }^{1200}$ Therefore social media raises the question to what extent employees are free to use these platforms and how their behaviour can be restricted by the employer.

363. Neither in France nor in Hungary is the right to social media expressis verbis guaranteed. ${ }^{1201}$ However, considering the already presented role that social media

1195 The Constitutional Council stated that the freedom of expression is one of the most important human rights, and that " $[i] n$ the current state of the means of communication and given the generalized development of public online communication services and the importance of the latter for the participation in democracy and the expression of ideas and opinions, this right implies freedom to access such services." Decision $n^{\circ}$ 2009-580 of June 10th 2009, par. 12.

1196 'Commentaire de la décision $n^{\circ} 2009-580$ DC - 10 juin 2009 Loi relative à la diffusion et à la protection de la création sur internet' (no date) Les Cahiers du Conseil Constitutionnel, (27). Available at: http://www.conseil-constitutionnel.fr/conseil-

constitutionnel/root/bank/download/2009580DCccc_580dc.pdf(Accessed: 6 June 2018).p. 7.

1197 As an illustrative example a case from the US should be mentioned as it draws attention to the importance of SNSs in everyday life. In the US, in 2017 the Supreme Court of the United States ruled on the existence of the right to social media. In 2008 the state of North Carolina adopted a statute making it a felony for registered sex offenders to gain access - amongst others - to social media sites. The Supreme Court stated that "[North Carolina's] statute here enacts a prohibition unprecedented in the scope of First Amendment speech it burdens. Social media allows users to gain access to information and communicate with one another about it on any subject that might come to mind. [...] By prohibiting sex offenders from using those websites, North Carolina with one broad stroke bars access to what for many are the principal sources for knowing current events, checking ads for employment, speaking and listening in the modern public square, and otherwise exploring the vast realms of human thought and knowledge. These websites can provide perhaps the most powerful mechanisms available to a private citizen to make his or her voice heard." Therefore, States cannot adopt in their statutes a blanket ban on the use of these sites. Source: Supreme Court of the United States: Lester Gerard Packingham, Petitioner v. North Carolina, June 19, 2017

${ }^{1198}$ ECtHR (1992) Niemietz v. Germany, Application no. 13710/88, 16 December, par. 29.

1199 According to Alejandra Michel, it follows from the evolutive case law of the ECtHR, which is evolving in the light of the given societal and technological innovations, that it is possible that the individual's right to "establish and develop relationships with other human beings" is guaranteed on SNSs as well. Michel, A. (2016) 'L'utilisation des contenus postés sur les réseaux sociaux comme éléments de preuve d'un dommage', Revue du droit des technologies de l'information, (65), p. 105.

${ }^{1200}$ Conseil d'Etat (2014) Le numérique et les droits fondamentaux. Les rapports du Conseil d'Etat, p. 268.

1201 On the potential fundaments of a right to SNS see more in: Pailler, L. (2012) Les réseaux sociaux sur internet et le droit au respect de la vie privée. Bruxelles: Larcier. pp. 28-46. 
plays in personal life and the rights associated with it, it can be deducted from the general rules of both labour codes, namely from the provisions regulating how employees' rights can be limited, that as social media often constitute an important tool in exercising such rights, through the protection of these rights, the use of social media is protected as well. Therefore, employers can only limit the use of SNSs if certain requirements are met - as it will be examined in detail in Part II.

364. In sum, the use of SNSs is more than a discretionary choice of the individual. ${ }^{1202}$ They constitute the 21 st century way to fulfil basic human needs. Although it is not obligatory to use them, they have become part of the reality of the modern world, making it hard to completely avoid using these services. Of course, according to the temperament of the given user, the extent of being a silent observer or engaging actively in their use can differ. Naturally, employees are amongst SNS users as well.

While acknowledging that the appreciation of a case depends on the exact circumstances and that the employee can face labour law consequences if he/she oversteps the limits of such a use, it should be noted that for the above reasons the behaviour of employees who engage in SNSs and share a certain amount of personal data during such a use is not automatically considered as illegitimate. However, as their intended use naturally comes with the share of personal information and personal data, the question of what is considered to be private in the context of SNSs is raised.

\section{(B) Social network sites and the boundaries of privacy}

365. SNSs and the ever-changing concept of privacy. It was already demonstrated that privacy is a flexible, ever-changing concept. Besides the individual's attitudes towards privacy, privacy law is closely connected to technology, technological advances might call for changes in privacy laws, too. Naturally, SNSs raise different questions than printed letter or e-mails. As Jon L. Mills noted, "[a]n individual living in the 21 st century does not have the same reasonable expectation of privacy as a person living in the 1700s." 1203, 1204 Societal norms can also have an influence on what can be

1202 Del Riego, A., Sánchez Abril, P. and Levin, A. (2012) 'Your Password or Your Paycheck?: A Job Applicant's Murky Right to Social Media Privacy', Journal of Internet Law, 16(3), p. 23.

${ }^{1203}$ Mills, J. L. (2015) Privacy in the New Media Age. Gainesville: University Press of Florida. p. 160.

${ }^{1204} \mathrm{He}$ also draws attention to the fact that just because in the modern world it is easier to intrude into someone's private life, it does not mean that this intrusion should be considered acceptable and legitimate. According to him, today there is danger in accepting this intrusiveness because of the possible risk of causing 
considered private, and today it is a normal part of the $21^{\text {st }}$ century - especially for the younger generations - to expose one's private life in the online world. ${ }^{1205}$ Unlike in the "pre-SNS era" - it is considered normal to share events that used to be considered private. ${ }^{1206}$

366. The worst enemy of privacy on SNSs. One of the novelties brought by SNSs is not the mere change in the reasonable expectation of privacy, but also the phenomenon that a huge amount of this private information is published at the initiative of the users themselves. As a consequence, many privacy issues are created by the users themselves, ${ }^{1207}$ as it is the users' continuous activity that drives SNSs. ${ }^{1208}$ As Woodrow Hartzog noted, in the age of Warren and Brandeis the sanctity of private life was threatened by external parties, but today the Internet user has become his/her worst enemy. ${ }^{1209}$ It is unprecedented to observe during the history of mankind such an extensive and voluntary share of private information.

SNSs standardize and encourage the share of personal data. ${ }^{1210}$ Privacy and data protection consequences arise from the very nature of social network sites, as their whole functioning is based on the share of personal data. ${ }^{1211}$ Today, self-exposure is the choice of users: they decide to share all that information. ${ }^{1212}$ These attitudes have led to the phenomenon that users from all around the globe share their personal data in a quantity and quality never seen before, “[...] pushing at the boundaries of what societies see as a person's individual space[.]"1213

far-reaching consequences, namely the disappearance of our collective expectation of privacy. Source: Mills, J. L. (2015) Privacy in the New Media Age. Gainesville: University Press of Florida. p. 162.

1205 Newell, B. C. (2011) 'Rethinking Reasonable Expectations of Privacy in Online Social Networks', Richmond Journal of Law and Technology, 17(4), p. 2.

${ }^{1206}$ Henderson, J. J. (2013) 'The Boundaries of Free Speech in Social Media', in Stewart, D. R. (ed.) Social Media and the Law. A Guidebook for Communication Students and Professionals. New York, London: Routledge, p. 4.

1207 Qi, M. and Edgar-Nevill, D. (2011) 'Social networking searching and privacy issues', Information Security Technical Report, 16(2), p. 76.

1208 Stroud, D. (2008) 'Social networking: An age-neutral commodity — Social networking becomes a mature web application', Journal of Direct, Data and Digital Marketing Practice, 9(3), p. 208.

${ }^{1209}$ Hartzog, W. (2013) 'Privacy and Terms of Use', in Stewart, D. R. (ed.) Social Media and the Law. A Guidebook for Communication Students and Professionals. New York, London: Routledge, p. 54.

1210 Qi, M. and Edgar-Nevill, D. (2011) 'Social networking searching and privacy issues', Information Security Technical Report, 16(2), p. 75.

1211 North, E. E. (2010) 'Facebook Isn't Your Space Anymore: Discovery of Social Networking Websites', Kansas Law Review, 58(5), p. 1288.

1212 Rey, B. (2012) La vie privée à l'ère du numérique. Cachan: Lavoisier. p. 197.

1213 International Working Group on Data Protection in Telecommunications: Report and Guidance on Privacy in Social Network Services - “Rome Memorandum”. 3-4 March 2008. (675.36.5.) p. 1. 
367. Electronic exhibitionism. William A. Herbert describes this phenomenon as electronic exhibitionism, endemic to SNSs, which means "the increasing worldwide phenomenon of individuals eviscerating their own privacy by affirmatively or inadvertently posting and distributing private and intimate information, thoughts, activities and photographs via email, text messaging, blogs, and social networking pages." 1214 The expression exhibitionism has a negative connotation: one should refrain from automatically applying this expression to users actively engaging in SNSs. ${ }^{1215}$ It is a natural reaction to think that these individuals have given up their privacy; however, in reality this issue is more nuanced. ${ }^{1216}$ Even though in this scenario it is the users who decide to voluntarily share personal information, they still expect certain privacy through the limitation of the extensiveness of the exposure. ${ }^{1217,1218}$

368. Information relating to third parties. It comes from the very nature of these sites that, in order to use them properly, the sharing of personal information is needed.

1214 Herbert, W. A. (2011) 'Workplace Consequences of Electronic Exhibition and Voyeurism', IEEE Technology and Society Magazine, 30(3), p. 26.

1215 A possible clue to make a distinction between exhibitionism and the intended use of SNSs might depart from the notions of self-disclosure and self-presentation. While self-presentation is "communication of selfdata an individual might reveal to most any other person," self-disclosure is the "explicit communication of self-data another would otherwise not have access to." (Simms, M. (1994) 'Defining Privacy in Employee Health Screening Cases: Ethical Ramifications Concerning the Employee/Employer Relationship', Journal of Business Ethics, 13(5), p. 317.) Such a distinction might contribute to distinguishing between use that necessarily comes with the use of SNSs and use that reveals personal information beyond that extent; and thus determining the "hard core" of privacy on SNSs.

1216 Solove, D. J. (2007) The Future of Reputation. Gossip, Rumor, and Privacy on the Internet. New Haven and London: Yale University Press. p. 198.

1217 Solove, D. J. (2007) The Future of Reputation. Gossip, Rumor, and Privacy on the Internet. New Haven and London: Yale University Press. p. 198.

1218 In my opinion, understanding the active use of SNSs as a self-destruction of privacy, not meriting protection, is similar to the existing binary apprehension of privacy in the United States. In contrast to Europe and the protection granted to personal data shared on these sites, in the US a different privacy approach is taken. In the US, a strict "all or nothing" privacy approach exists, as privacy is apprehended as the binary of public and private. As soon as something is exposed to the public (meaning not kept as a secret), the information will no longer be considered private and it will lose protection provided by privacy laws. Such an approach does not take into consideration the grey area between the extremities of private and public, ignoring the concept of privacy in public. In reality, privacy is more complex than a mere private-public dichotomy. Most of the activities individuals conduct do not take place in the secrecy of one's home - and it does not mean that individuals aim to give up their right to privacy completely. Therefore, personal information uploaded to social network sites might receive no protection at all. Certain authors (such as Robert Sprague or Daniel Solove) argue that this all or nothing privacy approach might be outdated and a new approach might be needed to be adopted in US law. As technological and societal changes in the age of Warren and Brandeis called for new privacy laws, the technological and societal changes of today call for a change, too. In today's world privacy protection might be extended to cases when the user has posted personal or private information to the Internet, but has made steps towards protecting it from the public, for example, by using strict privacy settings only granting access to his/her closest connections. See more in: Sprague, R. (2008) 'Rethinking Information Privacy in an Age of Online Transparency', Hofstra Labor \& Employment Law Journal, 25(2), pp. 395-417, Solove, D. J. (2007) The Future of Reputation. Gossip, Rumor, and Privacy on the Internet. New Haven and London: Yale University Press, pp. 161-188. 
Naturally, the individual has the power to decide to what extent he/she is going to provide insight into his/her private life, and to which audiences he/she will grant access. As privacy is also dependent on the individual, it will vary from user to user how they will use these sites.

369. However, individuals' online presence is dependent not only on the given individual and on his/her choices: other users can also upload personal data relating to third parties. This can either be (ill-)intentioned or can constitute a natural part of selfdisclosure. The latter issue is complex because - although individuals do have the right to expose themselves online - in many cases exposing one's own life naturally comes with exposing information relating to another person(s) as well, since the individual's life is necessarily intertwined with that of others. ${ }^{1219}$ In any case, an individual does not exercise full control over his/her online presence and reputation. ${ }^{1220}$

370. The notion of privacy on SNSs. Therefore, in the light of the abovementioned factors, the question is: what does privacy mean in the context of SNSs? What is considered to be a reasonable use of SNSs in relation to privacy? Considering that in the European legal order privacy is understood as a flexible concept, which is not limited to secrecy but is also closely connected to self-determination, in the dissertation it is understood as the individual's right to decide how to live his/her life. However, in view of the technological and societal changes, should protection be extended to a certain extent to self-disclosing behaviour as well, ${ }^{1221}$ given the preponderant role SNSs play in establishing and maintaining relationships with others, shaping identity - acknowledged by the European legal order? ${ }^{1222}$

371. Although privacy in public is recognized by the ECtHR, the right traditionally covers cases where the individual's private life is revealed to the public

1219 Solove, D. J. (2007) The Future of Reputation. Gossip, Rumor, and Privacy on the Internet. New Haven and London: Yale University Press. p. 134. Although not naming or identifying the other individual can contribute to preventing privacy issues.

${ }^{1220}$ See more on the importance, value and fragility of online reputation, the difference between online and offline gossip, and the fundamental changes brought by the Internet in finding a balance between privacy and freedom of expression in: Solove, D. J. (2007) The Future of Reputation. Gossip, Rumor, and Privacy on the Internet. New Haven and London: Yale University Press

1221 Just as the law reacted to the appearance of photo and video cameras by setting limits to taking one's image and broadcasting it, now it is time to react to the changes brought by SNSs.

1222 See, for example, ECtHR (1992) Niemietz v. Germany, Application no. 13710/88, 16 December and ECtHR (2003): Peck v. the United Kingdom, application no. 44647/98, 28 January 
accidentally, ${ }^{1223}$ in contrast to SNSs, which are mainly fueled by users' self-disclosing behaviour. In relation to the right to respect for private life, it should be asked whether private life can be extended to social media and if yes, to what extent. Notably relations between "interference" and SNSs should be examined. Historically, the notion of correspondence aimed to cover letters, while today in principle it can cover all kinds of communication, regardless of whether it is a letter, an e-mail, an SMS or a tweet. ${ }^{1224}$ However, protection under the right to respect for private life is traditionally granted against "arbitrary interferences", and is not likely to cover cases where the individual himself/herself has decided to publicly share information or a statement - which is often the case when it comes to social media. ${ }^{1225,1226}$

372. Even if the right to respect for private life cannot be evoked, it does not mean that these statements do not receive any protection: contrary to the right to respect for private life, the right to data protection applies, regardless of whether SNSs are public or private spaces and the fact that the user himself/herself decided to make the information or statement publicly available. ${ }^{1227}$ Although the scopes of the right to respect for private life and the right to data protection are not identical, the personal data published often relates to the private life of the individual, making it possible for data protection to provide an alternative protection for the private life of the individual.

373. Existence of a dual approach? In my opinion, these observations open the floor for further investigating whether challenges related to SNSs in the employment context can successfully be examined under a dual, privacy-data protection approach. The question of whether employees can freely use these sites, and whether these sites are considered to be a private or public space seems to be more like a privacy-related question. In contrast to the right to respect for private, which is affected by the private or public

${ }^{1223}$ ECtHR (2004): Von Hannover v. Germany, Application no. 59320/00, 24 June; ECtHR (2003): Peck v. the United Kingdom, application no. 44647/98, 28 January

1224 Alleaume, C. (2016) 'La notion de droit à la vie privée', in Batteur, A. (ed.) Les grandes décisions du droit des personnes et de la famille. 2nd edn. Issy-les-Moulineaux: LGDJ, p. 459.

1225 Dupuis, M. (2013) 'La vie privée à l'épreuve des réseaux sociaux', Revue Lamy Droit Civil, (102), p. 41.

${ }^{1226}$ Labour courts have already addressed the question of private or public nature of these sites. Judges had to rule in several cases, and the practice of the courts was not always coherent, till in 2013 the Court of Cassation provided some guidance regarding the private or public nature of these sites, making the protection dependent on the use of privacy settings. Source: Denizeau, C. (2017) Droit des libertés fondamentales. 6th edn. Paris: Vuibert. pp. 282-284. As a consequence, protection provided by the right to respect for private life is limited when it comes to content publicly shared in social media. These relevant cases will be addressed in detail in Part II.

${ }^{1227}$ Dupuis, M. (2013) 'La vie privée à l'épreuve des réseaux sociaux', Revue Lamy Droit Civil, (102), p. 44. This is in harmony with the observations of the WP29 in Opinion 2/2017. 
nature of these sites, data protection requirements shall apply regardless of the nature of these sites or the content, providing protection to employees using these sites. Therefore, the employer regulating or limiting how employees can use these sites would primarily constitute a privacy-related question. Using the personal data available on these sites (e.g. dismissing an employee because of a Facebook post), or controlling whether employees comply with the restrictions imposed by him/her can be either a privacy question (is that post considered to be a private or a public content?) or a data protection question (how can the employer process that data?). This privacy-data protection dichotomy should not constitute a strict separation amongst the legal issues arising, it should rather mean that certain challenges are related to one right to a greater extent than to the other.

374. In sum, a broad understanding of privacy (see, for example, the already presented ECtHR case law, or the concept of personal life in French labour law) would mean that privacy comprises the individual being able to decide whether to use SNSs and how to use them. He/she can decide on which SNSs he/she is going to be a member and can also decide whether he/she wishes to be an active member of the site (e.g. joining groups or events, liking, posting content), what privacy setting he/she uses. However, as privacy is not an absolute right, admitting that it comprises the free use of SNSs does not empower the user to an unlimited use: the use of SNSs as part of privacy, must be reconciled with other rights and interests.

Examining privacy from a narrower angle focusing upon the concept of secrecy raises different kinds of questions, notably whether such a post can be considered public or private from the viewpoint of intrusion into the private sphere. Data protection can also play its part, as rules laid down by relevant data protection legislations are also applicable - regardless of whether the information itself is public or private - ensuring a different layer of protection during the use of SNSs.

\section{\$2. Blurring of work and personal life within social network sites}

375. In addition to the general indistinctness of the place of work, the time of work and the device used for work, the boundaries between professional life and personal life are blurred within SNSs as well. The assumption is that SNSs are used in the course of the personal life of the employee, although their use has in many instances become inseparable from the workplace. SNSs have not only altered the limits of privacy but have 
also provided new methods to investigate people, ${ }^{1228}$ as in many cases this information is easily accessible to third parties - such as to employers, for example. The following Sections will examine the main characteristics of SNSs, including the content, the users and the creator of the content, from the angle of blurred professional and personal life. ${ }^{1229}$

\section{(A) Content}

376. SNSs a priori suppose a leisure activity pertaining to the personal life of the individual (except for those employees whose job description contains the managing of an SNSs account). However, in certain cases the content published on these sites does not exclusively relate to personal matters, but to matters relating to the employment - making the employer interested (or even entitled) in regulating and or monitoring such activity, as it will be examined in Part II. In such cases the SNS activity of employees can have an effect on their employment relationships. This is particularly the case when the content directly relates to the employment. The most obvious way of connecting the workplace to the employee's SNSs activity is to publish something work-related. This can take various forms (such as a post, a comment, liking a page, joining an event, etc.) and substance (e.g. criticising the employer, sharing confidential information, discussing workplace conditions with colleagues, commenting under an article relating to professional matters, etc.).

377. In addition, even content without direct connection to the employment can result in adverse employment decisions, as it can incidentally have a negative impact on the employer. For example, Ashley Payne, an American high school teacher was dismissed for posting pictures of herself holding a pint of beer and a glass of wine in her hand during her trip to Europe. ${ }^{1230}$ A very similar case was Stacy Snyder's, who was training to be a teacher and was only few weeks from graduation. She uploaded a picture of herself to MySpace, taken of her at a party where she was wearing a pirate hat and was drinking from a plastic cup, while the caption said "drunken pirate". The photo was discovered by her

1228 Qi, M. and Edgar-Nevill, D. (2011) 'Social networking searching and privacy issues', Information Security Technical Report, 16(2), p. 74.

1229 The detailed analysis of the legal implications arising during their use will be addressed in Part II.

1230 Oppenheim, R. (2013) High School Teacher Files an Appeal in Case of Social Media Related Resignation, California Business Bitigation Blog. Available at: https://www.californiabusinesslitigation.com/2013/05/high_school_teacher_files_an_a.html(Accessed: 3 May 2018) 
school and supervisor, she was qualified as unprofessional and was denied her teaching degree. ${ }^{1231}$

378. In addition to the substance of SNS content, changes in relation to access to it must be addressed. While earlier employees' personal lives could be separated relatively easily, the novelty that SNSs brought regarding the content is that employees share information that the employer would not have had access to in the pre-SNS era (or only by making great efforts). Therefore, if the employer accesses the profile of the employee (or views his/her activity on SNSs), the employer might have a glimpse into the employee's personal life to an unprecedented extent.

\section{(B) Users}

379. Mixed audiences. When it comes to the audience, on SNSs users usually have colleagues, superiors, clients amongst their connections. ${ }^{1232}$ It means that depending on the choice of privacy settings that the given site offers and on whether the employee uses them, published content can become available to them too, giving a glimpse into the employees' online activities, often pertaining to their personal life.

If several colleagues are present on these sites, they might discuss work-related matters on these platforms - possibly making negative comments about the employer, as it is demonstrated by growing case law. ${ }^{1233}$ Employees continue to express themselves on SNSs just as if they were talking around the coffee machine, often without realizing the risks involved in such online expression. ${ }^{1234}$ In this case, due to the change of paradigm in the accessibility of such content, the discussion leaves the working environment and

1231 Rosen, J. (2010) The Web Means the End of Forgetting, The New York Times. Available at: https://www.nytimes.com/2010/07/25/magazine/25privacy-t2.html (Accessed: 11 May 2018)

1232 According to an article from 2011 written by Jean-Emmanual Ray, $55 \%$ of the employees' contacts is composed of colleagues, $16 \%$ of supervisors, $13 \%$ of clients and $11 \%$ of contractors. Source: Ray, J.-E. (2011) 'Facebook, le salarié et l'employeur', Droit social, 2, p. 132.

${ }^{1233}$ Countless examples could be listed where employees engaged in a discussion about work, such as the case Barbera v. Société Alten Sir (Conseil de Prud'hommes de Boulogne-Billancourt, 19 novembre 2010 10/00853), Cour de cassation, civile, chambre civile 1, 10 avril 2013, 11-19.530; CA Rouen Chambre sociale, 1 novembre 2011, $\mathrm{n}^{\circ} 11 / 01827$ - These cases and legal questions arising in relation to them will be treated in detail in Part II.) United States District Court, District of New Jersey: Pietrylo v. Hillstone Restaurant Group, No. 06-05754.); United States Court of Appeals for the Ninth Circuit: Konop v. Hawaian airlines, 236 F.3d 1035.

${ }^{1234}$ Duez-Ruff, V. (2012) 'Impact des nouvelles technologies sur le droit du travail : un salarié appartient-il virtuellement à son employeur?', Lexbase Hebdo - Edition Sociale, (498), p. 3. [Page number referring to the online version of the article downloaded from: http://www.lexbase-academie.fr.bcujas-ezp.univparis1.fr/revues-juridiques/6837680-impact-des-nouvelles-technologies-sur-le-droit-du-travail--un-salarieappartient-il-virtuellement-a- (Accessed: 15 August 2019)] 
becomes available to third parties, such as clients or other users, making it more probable to compromise the employer's reputation.

If the employer or the supervisor is present on SNSs, they can take a glimpse into the personal life of the (prospective) employee. If the employee does not apply privacy settings, gaining access is evident. In case the employer and the employee are "friends" on the SNS, the employer has the possibility to have access to a vaster amount of personal data. However, it is also worth remembering the existence of the hierarchal relationship between the parties and asking the question: if the employer sends a friend request to an employee, does the latter truly have the possibility to ignore it? ${ }^{1235}$

380. Larger audiences. The novelty brought by SNSs is that the employee has never had the possibility to potentially "reach out" to such a big audience. Perceptions of private and public are elusive, and the employee's post might become available to a considerably wider audience than he/she could potentially reach in the offline world. While formerly only those could do so who were physically present (e.g. gossiping around the coffee machine), today an SNS post can potentially reach a much larger audience and become accessible to several hundreds, even thousands of people. ${ }^{1236}$ Therefore, as the employee's online activity can go beyond the workplace, the employer is more intensely interested in ensuring that such posts do not infringe his/her rights or legitimate economic interests.

\section{(C) Creator of the content}

381. Identifying the employer. SNSs can make it easy to link employees' behaviour to the employer, as often the user can be identified as the employee of the given employer. This connection between employer and employee can be established in several ways. The most obvious way is if the employee himself/herself identifies the employer by naming him/her in the post or revealing the employer's identity in other ways, such as visual indications. As an example of the latter one, this identification can take place by wearing work uniform. In the International Union of Elevator Constructors, Local $50 v$.

1235 Though Jean-Emmanuel Ray notes that it is exceptional that an employee accepts a friend request coming from the employer. Source: Ray, J.-E. (2013) 'Facebook, espace public plus que privé. A propos de l'arrêt de la 1 ère Chambre civile du 10 avril 2013', Semaine sociale Lamy, (1599), p. 18.

${ }^{1236}$ However, one must stay realistic: in principle indeed, it is possible that a content can reach such a large audience, and indeed there are certain cases that went viral, but in practice most of such posts will stay harmless. Source: Towner, N. (2016) Social media at work. A practical guide for trade union reps. Edited by C. Ruhemann. London: LRD Publications (Labour Research Department Booklets). p. 5. 
ThyssenKrupp Elevator (Canada) Ltd. case an employee was dismissed after posting a video to the Internet which showed him having his genitals stapled to a wooden plank. The employer was identifiable from the video, as the employees wore their uniform during the recording. ${ }^{1237}$ Another example is the case of Ellen Simonetti, a flight attendant at Delta Airlines, who was fired for her blog where she uploaded provocative pictures of herself wearing her uniform. ${ }^{1238}$

382. Usually, users can indicate their place of employment on their profile, in which case it is easier to establish a connection between the employee and the employer than in the pre-SNS era. The audience of the given post might instantly (or just by a few clicks) know which employer the post relates to. ${ }^{1239}$ In exceptional cases, it is also possible that even if the employee does not reveal the employer's identity in the post, the employer might be identified later by another user. ${ }^{1240}$

383. "Spokespersons" of the employer. If the given content (post, comment) indicates somehow the affiliation to the employer, he/she might question whether the user published the content as a representative of the employer, or as a simple user $-{ }^{1241}$ creating confusion among other users. It is possible, for example, if the employee explicitly refers to his/her affiliation with the given employer, or if it is marked in the profile of the employee - in which cases employees' activities can be associated with the employer. Thus, activity on SNSs can raise the question whether and when the employee can be considered a spokesperson of the employer - and in what regards his/her behaviour can be controlled in order to ensure effective separation between professional and personal

1237 Kujawski, M. (2014) When Your Employees Go Too Far on Social Media, Social Media Today. Available at: https://www.socialmediatoday.com/content/when-your-employees-go-too-far-socialmedia (Accessed: 11 May 2018)

1238 Negroni, C. (2004) Fired Flight Attendant Finds Blogs Can Backfire, The New York Times. Available at: https://www.nytimes.com/2004/11/16/business/fired-flight-attendant-finds-blogs-can-

backfire.html (Accessed: 11 May 2018)

${ }^{1239}$ For example, Justin Hutchings from London, Ontario was fired in 2012 because he published offensive content ("It's about time this $b^{* * * *}$ died") to a memorial website of a teenager who committed suicide after being a victim of bullying for years. Mr. Hutchings identified his employer in his profile, and one of the users easily "tracked him down" from that information and reported his behaviour to his employer. Source: Sarin, P. (2012) Employees beware: The perils of posting on Facebook, rabble.ca. Available at: http://rabble.ca/columnists/2012/10/employees-beware-perils-posting-facebook (Accessed: 11 May 2018). ${ }^{1240}$ For example, in a case at the Court of Appeal of Besançon, the employee took part in a discussion taking place on the wall of a former colleague and though she did not name the employer in the discussion, the employer's identity was revealed later by another employee, after the employee disconnected from the site. (CA Besançon chamber sociale, 15 novembre 2011, 10/02642)

${ }^{1241}$ Such confusion can arise, for example, in cases when in the "bio" part the employer is identified, or when the employee explicitly states in a post or comment that he/she is an employee at the given workplace, or if the logo of the company is used as well as a profile picture or cover picture, making it possible to confuse the employee and the representative of the company. 
use. ${ }^{1242}$ The boundaries between professional and personal activity might be blurred by indicating their status as employee.

384. Disappearing anonymity. The importance of SNSs in this field is that they made it considerably easier to identify the user as the employee of a certain employer, creating a constant link between the employee's online behaviour and the identity of the employer. The offline counterpart of such a link would be to wear a sign on one's back, indicating the place of employment. This results in the phenomenon that today most users are more easily identified as the employee of a given employer, which creates a constant "bridge" between the employee's personal life and place of employment, and dissolves the previous boundaries between professional and personal life.

\section{Conclusions of Title 2}

385. Due to the growing popularity and proliferation of ICT, the boundaries of work and personal life are increasingly blurred - which phenomenon was addressed from the viewpoint of its effects on the place of work, time of work and equipment used for work. Then, it was also observed that in relation to employees' personal lives, SNSs which are ICT products as well - also contribute to the blurring of the boundaries between these two spheres.

386. SNSs especially increase the significance of the phenomenon of blurred boundaries in two regards. On the one hand, from the point of view of the user/employee, the sharing of (self-) information in relation to one's private/personal life can be observed. Users of SNSs typically share on SNSs private details regarding their (or other individuals') lives - details that were not (easily) accessible to the employer before the age of social media, allowing the employer to "enter" the employee's personal life to an unprecedented extent, raising privacy questions. One of the contradictions that the research had to overcome was how privacy protection can be granted to activities where the user himself/herself decides to disclose the personal information. In this regard, two observations were made. First, the use of SNSs has become a general phenomenon in modern societies and is beyond the individual's whim: moreover, it serves as a $21^{\text {st }}$ century method to fulfill certain basic human needs. Second, Title 1 asserts that privacy is a flexible concept, sensitive to technological and societal changes. Also, given the 
embeddedness of SNSs in everyday life, privacy should not automatically exclude the use of SNSs: the dissertation holds that privacy should be approached as the individual's right to decide how to live his/her life, thus using SNSs should be covered by privacy.

387. On the other hand, from the employer's viewpoint, such an activity can potentially reach a considerably bigger audience than in the offline world, exceeding the borders of the personal life of the employee and maybe even the work environment, jeopardizing the employer's rights in a hitherto unprecedented way. Also, such an activity can even be linked to the employer (either through aiming at him/her or through indicating the employees' workplace in the content or in the profile), creating a permanent contact between the employees' behaviour and the employer's identity - resulting in blurring the boundaries of professional and personal life within SNSs.

388. As a result, the already presented collision of employees' and the employer's rights arise in a more intense form. As the employer can gain unprecedented insight into the employees' private life (either through self-revelation or through the disclosure of other users), employees are increasingly interested in being able to effectively enforce and exercise their right to privacy and right to data protection. Also, as now employees are able to share various items of information that can have a connection with their employment with an extremely wide audience reaching far beyond their offline social network, employers are also increasingly interested in effectively protecting their rights, such as, for example, the right to reputation.

389. Although employees should be entitled to the right to privacy even on SNSs, this right to privacy must be balanced against and be interpreted in the light of rights and obligations arising from the employment relationship in order to establish the exact boundaries between personal and professional life on SNSs. After examining how this collision of rights has appeared in a more intense form, it will be the main aim of Part II. to assess - while keeping the blurred boundaries and the increased conflict of interests and rights in mind - exactly how this collision should be resolved in given areas of employment, where the exact boundaries should be drawn. 


\section{PART II.}

\section{RIGHT TO PRIVACY AND RIGHT TO DATA PROTECTION DURING THE MONITORING AND CONTROLLING OF THE USE OF SOCIAL NETWORK SITES IN THE EMPLOYMENT CONTEXT}

390. Starting point and matters to be examined. After examining the collision of rights and how SNSs have intensified it, it is necessary to address how exactly SNSs challenge the employment relationship. Questions can arise in various areas ranging from employers inspecting job applicants' Facebook profiles, through employees surfing on Instagram instead of performing work, to employees who heavily criticise their managers on SNSs. It is important to emphasize that SNSs did not give rise to fundamentally new questions, as all the examined conducts had existed well before their appearance (even without SNSs job applicants could lie in their CV, employees could waste working hours or could criticise their employer), and were subject to legal regulation as well. Rather, SNSs put these already existing legal rules into a new perspective: ${ }^{1243}$ they raise questions in relation to how the existing data protection and labour law rules can be applied to them. The novelty brought by the dissertation is that it provides a new and deep analysis of the "old" problem, through examining it during the whole existence of the employment relationship, focusing on the law of France and Hungary.

391. Throughout the employment relationship, the personal life of the individual can be affected in several ways. To address them in a systematic way, the individual's right to privacy/right to data protection was contrasted against the employer's various rights throughout the lifetime of the employment relationship. During recruitment, it will be examined how inspecting job applicants' SNS profiles in order to enforce the employer's freedom of contract can collide with applicants' rights. SNSs can seriously compromise working hours: it will be examined how their use (simply the fact of spending time on SNSs during working hours) can be controlled and monitored in accordance with the employer's right to monitor. Finally, besides the mere fact of using these sites, it will be addressed what kind of questions the employees' presence raises (typically their off-duty

1243 Maier, J. (2013) 'Cause for Termination in the Age of Social Media', in Law Society of Upper Canada, Employment law and the new workplace in the social media age. Toronto: Irwin Law, p. 282. 
conduct, covering cases when they post something to SNSs beyond working hours) in relation to the employer's right to reputation, protection of business secrets, etc.

392. Questions to be answered. Part I. aimed to prove that compared to the traditional forms of employee monitoring, SNSs increasingly blurred the boundaries of personal and professional life: the aim of Part II is to answer the overarching question: in the light of these blurred boundaries, where exactly should these boundaries be? How should the balance be determined between the employee's rights (right to privacy and right to data protection) and the employer's rights (e.g. right to reputation, freedom of contract, protection of business secrets, etc.)? Questions arise, such as how the already presented privacy and data protection framework should be applied to SNSs and what the arising challenges are. How exactly can (or should) SNSs be regulated or monitored as regards the different fields of the employment relationship? These questions will include - but will not be limited to - whether employers can look at the SNS profile of a job applicant, whether the personal use of SNSs during working hours can be prohibited or whether an employment relationship can be terminated due to a Facebook post, etc.

393. What Part II. intends to suggest is that these matters can be assessed both through a privacy approach and through a data protection one. Both privacy and data protection are crucial in ensuring the protection of the employee's personal life, during the whole employment relationship. However, depending on the given field of the employment relationship, either the right to privacy or the right to data protection can appear in a more emphatic way, giving rise to more substantial questions. This double approach is assessed through the division of regulation and monitoring: regulation mostly relates to imposing limitations on employees' use of SNSs, while monitoring aims to cover the processing and the use of personal data obtained from SNSs.

As such, the dissertation holds the view that recruitment can be more effectively assessed through data protection. The reason for this is that during this phase it is the monitoring of job applicants' online presence and the processing of their personal data which are more emphatic, and not the employer's potential to restrict such a use or to interfere with their personal lives. In the case of the use of SNSs at the expense of working hours, both the privacy and the data protection approaches are equally significant: the privacy approach is connected to the possible ban of the personal use of these sites, while data protection relates to the monitoring of such a ban. However, when it comes to employees' off-duty conduct, the right to privacy gains more importance, notably through 
the employer's possibility to sanction employees because of their conduct outside working hours.

394. Hypotheses of Part II. Part II. is composed of three Titles, examining the main areas where privacy and data protection questions arise in connection with SNSs: each Title will have one hypothesis. Hypothesis 2 aims to prove that in the phase of recruitment, the protection of job applicants' rights can be better ensured through regulating pre-employment SNSs screenings, instead of prohibiting them. Hypothesis 3 intends to prove that in most regards, the personal use of SNSs during working hours can be adequately addressed by applying the already existing rules relating to the monitoring of Internet and e-mail use. Hypothesis 4 aims to prove that as regards employees' activities and presence on SNSs, employers find themselves in an even more vulnerable position than in the pre-SNS era, which necessitates tilting the balance towards the protection of employer's rights.

395. References. Part II. focuses on French and Hungarian law and on how the question of SNSs can be addressed in these two legal systems. Thus, it will primarily focus on French and Hungarian acts, jurisprudence and documents issued by relevant national legal institutions. Although Part I. already dealt with it, as both France and Hungary are members of the same international organisations, references will be made to these institutions as well (e.g. CoE, EU). Also, references will be extended to other countries as well, as individual rights are gaining increasingly greater importance within labour law regulations in most countries. This tendency is universal, even though the way legislations deal with it can vary from country to country. ${ }^{1244}$ In addition, as the growing popularity of SNSs and its effects are not limited to France and Hungary but constitute a universal phenomenon, references will be made to other countries, notably for the purpose of providing illustrative examples and presenting unique legal solutions to the challenges posed by SNSs.

396. Structure of Part II. Part II. is composed of three titles, each covering a significant area of SNSs and labour law where questions regarding privacy and data protection arise. Title 1 will address questions relating to prospective employees and will examine the phase of recruitment. Then, Title 2 will discuss SNS use at the expense of working hours and will examine SNS use during working hours in detail. In Title 3, focus

1244 Trudeau, G. (2010) 'En conclusion...vie professionnelle et vie personnelle ou les manifestations d'un nouveau droit du travail', Droit social, (1), p. 78. 
will be put on the employees' activity and presence on SNSs, particularly outside working hours and on how such an activity can conflict with the employer's different rights. 


\section{Title 1: Concluding an employment contract in the context of online social network sites}

397. Characteristics of the pre-employment phase. Issues of privacy and data protection do not arise in relation to employees only, but are present in the preemployment phase as well. Spiros Simitis emphasized the importance of regulating prospective employees' right to data protection, noting that they constitute one of the groups mainly affected by the employer's need to obtain as much information as possible. ${ }^{1245}$ The specialty of pre-employment background checks is given by the fact that although there is no existing employment relationship between the parties, several data protection and labour law provisions are applicable to them. ${ }^{1246}$ Also, this relationship is characterised by a disparity between the parties: although formally the employment contract is concluded between two equally autonomous parties, de facto there is no equality between them: the applicant is in a more vulnerable position. ${ }^{1247}$

398. When it comes to SNSs, employers often turn to these services in order to find out as much as possible about applicants. However, when conducting such screenings, they can also access information relating to the personal life of the applicant, which leads to potential privacy and data protection issues. As a main rule, for the purposes of the thesis, what is meant by these screenings is the employer accessing the publicly available information on these sites - the case when he/she accesses concealed information will be addressed separately. Since in these cases the information is publicly shared at the initiative of the user, privacy issues are less dominant than data protection issues - which are independent of the individual's behaviour. ${ }^{1248}$ Therefore, the question of preemployment SNS screenings will be primarily dealt with from the aspect of data protection.

399. Topicality of pre-employment SNS screenings. SNSs have become a popular tool when it comes to recruitment, as they provide quick, easy and inexpensive

\footnotetext{
1245 Simitis, S. (1999) 'Reconsidering the Premises of Labour Law: Prolegomena to an EU Regulation on the Protection of Employees’ Personal Data', European Law Journal, 5(1), p. 54.

${ }^{1246}$ Kun, A. (2018) 'A digitalizáció kihívásai a munkajogban', in Homicskó, Á. O. (ed.) Egyes modern technológiák etikai, jogi és szabályozási kihívásai. Budapest: Károli Gáspár Református Egyetem Állam- és Jogtudományi Kar (Acta Caroliensia Conventorum Scientiarum Iuridico-Politicarum, XXII), p. 132.

${ }^{1247}$ Hajdú, J. (2004) 'Habilitációs tézisek'. Szegedi Tudományegyetem. p. 26.

1248 See the delimitation of privacy and data protection in Part I.
} 
access to a multitude of information, allowing one to draw conclusions about the applicants' character. ${ }^{1249}$ Before the widespread proliferation of SNSs, the employer had to assess a job candidate's aptitude for the job through the way of conducting interviews, ability or aptitude tests, questionnaires (or in extreme cases by hiring a private investigator), while today it might be sufficient to check the candidate's Facebook profile in order to have easy and cost-free access to a rich and significant amount of information relating to the capacities of the prospective employee. The ease, the cost-effective nature and the wide range of information potentially make SNSs a powerful tool during the recruitment process - however, the legality of such screenings must be examined. ${ }^{1250}$

400. Applicable law. To date, there exists no "Facebook Act" - either in France, or in Hungary - regulating explicitly the labour law and privacy/data protection aspects of SNSs. The alternative legislation to be applied in this case is the relevant provisions of the labour law regulations and data protection regulations: SNSs are not "terra nullius", the general principles of recruitment laid down in the labour codes, such as nondiscrimination, transparency, relevancy and confidentiality, apply to every method of recruitment, regardless of the technology used. ${ }^{1251}$ Besides the data protection regulation, the labour codes of both countries regulate the recruitment process, imposing limitations on the possible methods used. This protection applies regardless of the method used, therefore they include SNS background checks, too. ${ }^{1252}$ These provisions incorporate the most important data protection principles, such as purpose limitation, proportionality and prior notification.

401. Aim of the Title. The aim of the Title is to enumerate the legal issues arising in relation to these screenings and the possible answers given to them. Rules applying to data protection and labour law and to different methods of recruitment (so-called "traditional methods of recruitment") have already been elaborated: these rules are going to constitute the basis of the analysis. In the light of these rules, it will be examined what the

1249 Suder, S. (2014) 'Pre-Employment Background Checks on Social Networking Sites - May Your Boss Be Watching?', Masaryk University Journal of Law and Technology, 8(1), p. 124.

1250 Brown, V. R. and Vaughn, E. D. (2011) 'The Writing on the (Facebook) Wall: The Use of Social Networking Sites in Hiring Decisions', Journal of Business and Psychology, 26(2), p. 220.

${ }^{1251}$ Tricoit, J.-P. (2013) 'Recrutement, rupture du contrat de travail et TIC', La Semaine Juridique Social, (40), p. 10.

${ }^{1252}$ In contrast, approaching the question from a "privacy point of view", when the employee publicly shares some information, it goes beyond the protection offered by the right to respect for private life. Source: Tshilembe, A.-S. (2015) 'Vie privée - protection des données personnelles du travailleur: la question de l'embauche', in Martin, D., Morsa, M., and Gosseries, P. (eds) Droit du travail européen: questions spéciales. Bruxelles: Éditions Larcier, p. 700. 
issues arising specific to SNSs are, and whether such screenings should be allowed and if yes, under what conditions.

402. Questions to be answered. One of the questions that the Title aims to answer is what data protection (and privacy) issues arise in relation to pre-employment SNS screenings and how the protection of applicants' rights can be ensured. How can a balance be established between the applicants' rights and the employer's rights, and whether SNSs can be used during recruitment and if yes, with what conditions?

403. Hypothesis of Title 1. Title 1 aims to prove that applicants' rights can be better ensured through regulating pre-employment SNSs screenings, instead of prohibiting them (Hypothesis 2). As it will be explored throughout Title 1, applying pre-employment SNS screenings raises several data protection challenges. As a response to these challenges, different actors ${ }^{1253}$ have suggested the possibility of banning these screenings. However, the dissertation takes the view that the right to data protection can be better ensured by acknowledging the existence of these screenings, and thus regulating them instead of prohibition.

404. Structure and methodology of the Title. The Title is composed of two parts: Chapter 1 will focus on recruitment and the relevant labour law provisions, while Chapter 2 will deal with the arising data protection issues. Chapter 1 will be based on the comparison of the French and Hungarian systems, as it is possible under the GDPR to adopt Member State specific data protection regulation in the field of employment, giving room for certain differences between the legal systems. Chapter 2 will focus on data protection, and since the EU has a unified data protection law, there are basically no problems specific only to French or to Hungarian law. Therefore, the presentation of the issues itself will stay on an analytical ground from a more general scope, paying special attention to the solutions proposed by French and Hungarian legislation and case law. ${ }^{1254}$

1253 Gros, M. (2010) Recrutement: une Charte pour contrer les dérives liées aux réseaux sociaux, Le Monde Informatique. Available at: https://www.lemondeinformatique.fr/actualites/lire-recrutement-une-charte-pourcontrer-les-derives-liees-aux-reseaux-sociaux-29715.html(Accessed: 13 August 2019); CNIL (no date) Recrutement: l'employeur peut-il rechercher des données sur moi sur Internet? Available at: https://www.cnil.fr/fr/cnil-direct/question/354.; Kajtár, E. and Mestre, B. (2016) 'Social networks and employees' right to privacy in the pre-employment stage: some comparative remarks and interrogations', Hungarian Labour Law E-journal, (1), p. 36.; McGeveran, W. (2006) Finnish Employers Cannot Google Applicants. Available at: https://blogs.harvard.edu/infolaw/2006/11/15/finnish-employerscannot-google-applicants/ (Accessed: 2 July 2018).

${ }^{1254}$ In this context, not only the court's jurisprudence is meant by case law, but also the practice of DPAs. 


\section{Chapter 1: Labour law aspects of recruitment}

405. Questions arising in relation to pre-employment SNS screenings must be assessed in the light of the already established rules regarding recruitment. Both in France and in Hungary, limitations were placed on the "traditional" hiring methods (e.g. conducting a job interview or collecting references from the previous employer), addressing data protection questions under the auspices of labour law. However, these rules were elaborated when the methods mainly consisted of using personality tests, graphology tests, interviews, etc. - providing completely different kinds of personal data than SNSs nowadays. As a consequence, it must be examined whether SNSs affect the existing legal landscape.

406. Structure of the Chapter. Section 1 will present the employer's right standing against applicants' rights: the employer's aim during recruitment is to identify the best candidate and he/she has certain rights to achieve this aim. It will also present how SNSs can contribute to achieving this aim. Then, Section 2 will focus on the existing labour law regulation addressing the subject: it will present the relevant provisions of the FLC and HLC, and the relevant practice of the national data protection authorities. Although Chapter 1 will examine the subject from a more general angle and explicit focus will be put on SNSs in Chapter 2, even Chapter 1 will try to limit itself to the provisions that might be of relevance in the SNS context as well.

\section{Section 1: Identifying the best candidate}

The main aim of the employer during the recruitment is to identify and hire the best applicant. In order to achieve this aim, $(\S 1)$ the employer is entitled to choose with whom he/she wishes to contract and is interested in obtaining as much information as possible regarding applicants in order to make this decision. (\$2) SNSs can serve this information hunger of the employer and can highly contribute to identifying the right applicant.

\section{§1: The employer's side: freedom of contract}

\section{(A) The employer's interests in obtaining information}

407. The aim of the employer during recruitment. The employer's aim during the recruitment process is to identify and hire the most suitable candidate who would fit 
into the organisation. In order to achieve this aim, the employer is interested in knowing as much as possible about the candidate. The employer can either "screen in" for desired characteristics, or "screen out" possible unsuitable applicants. ${ }^{1255}$

Having a profound knowledge on not only the candidate's education and professional experience, but also on his/her personality and beliefs can contribute to assessing whether he/she could easily identify with the values of the specific employer. ${ }^{1256}$ Pre-employment background checks can contribute to higher productivity, increased quality and lower employee turnover, ${ }^{1257}$ and can also help to detect whether the employee has a history of misconduct. ${ }^{1258}$ The reason for wanting to explore the applicant's background is the employer's belief according to which "past performance is the best predictor of future behaviour." 1259

408. Information relating to professional capacities. Naturally, information on the education, previous work experience, language skills, computer literacy skills or leadership skills is undoubtedly connected to the professional life of the employee. Knowing whether the employee has the necessary qualification and experience, where he/she pursued his/her studies and worked prior to applying for the job is indispensable for deciding who is going to be employed. It goes without saying that the employer is interested in obtaining as much information as possible in these fields.

409. Importance of the personal traits of the applicant. Besides information bearing professional character, employers are interested in having a widest possible pool of information on applicants, including their personal lives. Though this interest can be distinct from the employer's rights in this field, as legal regulations aim to protect employees' personal lives, ${ }^{1260}$ it does not mean that the assessment of the personal traits is

1255 Befort, S. F. (1997) 'Pre-Employment Screening and Investigation: Navigating Between a Rock and a Hard Place', Hofstra Labor and Employment Law Journal, 14(2), pp. 367-368.

1256 Sprague, R. (2011) 'Invasion of the Social Networks: Blurring the Line Between Personal Life and the Employment Relationship', University of Louisville Law Review, 50(1), p. 6. citing Finder, A. (2006) 'For Some, Online Persona Undermines a Résumé', The New York Times. Available at: https://www.nytimes.com/2006/06/11/us/11recruit.html.

${ }^{1257}$ Kinsey, A. (no date) 'The Benefits of Pre-employment Screening'. James M. Sweeney and Associates, Inc. Available at: http://www.sweeneyinc.com/files/benefits_preemployment_screening.pdf(Accessed: 3 May 2018). p. 2.

1258 Kinsey, A. (no date) 'The Benefits of Pre-employment Screening'. James M. Sweeney and Associates, Inc. Available at: http://www.sweeneyinc.com/files/benefits_preemployment_screening.pdf(Accessed: 3 May 2018). p. 3.

1259 Sprague, R. (2008) 'Rethinking Information Privacy in an Age of Online Transparency', Hofstra Labor \& Employment Law Journal, 25(2), p. 399.

1260 See notably what has been discussed in relation to the FLC and HLC. 
to be completely excluded during the decision-making. Besides the professional capacities of the applicant, employers are also interested in assessing whether the personal traits of the applicant make him/her suitable for the given post. ${ }^{1261}$

410. When concluding an employment contract, the personality of the prospective employee has a key, determining importance, as it can highly influence his/her successful integration into the undertaking. SNSs can largely contribute to gaining information regarding the personality of the applicant.

Usually, traditional background searches focused on matters like résumé accuracy, educational backgrounds, driving records, and reference verification, etc. ${ }^{1262}$ In addition to formally assessing submitted CVs or conducting interviews, through background checks employers are interested in assessing the personal traits of the applicant - such as whether he/she is lazy or antisocial, or has provided false information during the application - in order to know whether they are going to be a good choice for the workplace or for the job. ${ }^{1263}$

With (SNS) background checks, employers can assess the applicant's personality in order to assess whether they are going to integrate well into the company. ${ }^{1264}$ The employer is interested in knowing whether the employees would fit well into the existing work community and would be able to effectively cooperate with colleagues. Also, personal sympathy can play a role: the employer is interested in employing someone with whom he/she can imagine working with.

Employers might also be concerned about the lifestyle (e.g. drug or alcohol consumption, expressing extreme political or religious views, etc.) and the reputation of the applicant, as the applicant's questionable conduct or poor reputation can have a negative impact on the employer. ${ }^{1265}$

\section{(B) Freedom of contract}

${ }^{1261}$ Lehoczkyné Kollonay, Cs. (ed.) (1997) A magyar munkajog I. Budapest: Kulturtrade Kiadó. p. 91.

1262 Jones, M., Schuckman, A. and Watson, K. (2007) 'The Ethics of Pre-Employment Screening Through the Use of the Internet', in McIntosh, D. et al. (eds) The Ethical Imperative in the Context of Evolving Technologies. University of Colorado Leeds School of Business. Available at: http://www.ethicapublishing.com/ethicalimperative.pdf (Accessed: 13 July 2016). pp. 53-54.

1263 Peebles, K. A. (2012) 'Negligent Hiring and the Information Age: How State Legislatures Can Save Employers from Inevitable Liability', William and Mary Law Review, 53(4), p. 1399.

${ }^{1264}$ Baumhart, P. B. (2015) 'Social Media and the Job Market: How to Reconcile Applicant Privacy with Employer Needs', University of Michigan Journal of Law Reform, 48(2), p. 508.

1265 Del Riego, A., Sánchez Abril, P. and Levin, A. (2012) 'Your Password or Your Paycheck?: A Job Applicant's Murky Right to Social Media Privacy', Journal of Internet Law, 16(3), p. 18. 
411. Legal relevance of the identity of the parties. From a legal perspective, the employment relationship is considered to be a personal, long-term legal relationship, ${ }^{1266}$ where the identity of the parties plays an important role: performing work in person is one of the primary qualifying attributes of the employment relationship, ${ }^{1267}$ having crucial importance. The HLC also defines among the employee's main obligations the obligation to perform work personally. ${ }^{1268}$ The employee cannot use a replacement, as the education, work experience, professional aptitudes are all connected to the person of the employee. ${ }^{1269}$

The intuitu personae character, meaning that the identity of the contracting parties is the essential element of the contract, ${ }^{1270}$ plays an important role in concluding the employment contract. ${ }^{1271}$ It means that the employer can take into consideration the person of the applicant, in order to ensure the good functioning of the workplace. ${ }^{1272}$ Although legal regulations impose limits on the extent of the information that can be asked (such as rules relating to the prohibition of discrimination, ${ }^{1273}$ or respecting personal $\operatorname{life}^{1274}$ ); considering certain subjective characteristics, such as the personality of the applicant, cannot be fully eliminated from the employment relationship. ${ }^{1275}$

412. Freedom to contract. The importance of the identity of the parties is manifested in the freedom to contract: a general principle of civil law stipulated both by the French ${ }^{1276}$ and by the Hungarian ${ }^{1277}$ civil codes. It means that the parties can freely

\footnotetext{
1266 Gyulavári, T. (ed.) (2012) Munkajog. Budapest: ELTE Eötvös Kiadó, p. 19.

1267 7001/2005. (MK 170.) FMM-PM együttes irányelv a munkavégzés alapjául szolgáló szerződések minősítése során figyelembe veendő szempontokról

1268 Item c of Subsection 1 of Section 52 of the HLC

${ }^{1269}$ Hajdú, J. and Kun, A. (eds) (2014) Munkajog. Budapest: Patrocinium, p. 194.

1270 "[A] personal service contract where the particular individual cannot be replaced". Source: Canadian National Railway Co. v. Norsk Pacific Steamship Co., [1992] 1 SCR 1021, 1992 CanLII 105 (SCC)

${ }^{1271}$ Rivero, J. and Savatier, J. (1978) Droit du travail. Paris: Presses Universitaires de France, p. 62.

1272 Péano, M.-A. (1995) 'L'intuitus personae dans le contrat de travail', Droit social, (2) p. 3. [Page number referring to the online version of the article downloaded from: https://cutt.ly/dwsvrDY (Accessed: 15 August 2019)]

${ }^{1273}$ Article L1132-1 of the FLC stipulates that no one should be a victim of discrimination during recruitment and refers to Act No. 2008-496 of 27 May 2008 on various provisions of adaptation to Community law in the field of the fight against discrimination ("loi $\mathrm{n}^{\circ} 2008-496$ du 27 mai 2008 portant diverses dispositions d'adaptation au droit communautaire dans le domaine de la lutte contre les discriminations"). Subsection (1) of Section 12 of the HLC also states that equal treatment should be respected in relation to employment, and Act CXXV of 2003 on Equal Treatment and Promotion of Equal Opportunities stipulates that the requirements laid down in the act shall apply to prior entering into the employment relationship [items a)-c) of Section 21].

1274 See Article L1221-6 of the FLC and Section 10 of the HLC imposing the protection of the personal life of applicants.

1275 Péano, M.-A. (1995) 'L'intuitus personae dans le contrat de travail', Droit social, (2) p. 4. [Page number referring to the online version of the article downloaded from: https://cutt.ly/dwsvrDY (Accessed: 15 August 2019)]

${ }^{1276}$ Article 1102 of the French Civil Code
} 
decide whether they wish to contract, with whom to contract and on which terms to contract. ${ }^{1278}$ For the subject of the thesis, deciding the person of the contracting party has special importance.

413. This freedom of contract covers the conclusion of the employment contract: the employer can decide with whom to conclude an employment contract and the future employee can choose where to apply. ${ }^{1279}$ Identified as a principle with constitutional value in French law, the employer has the freedom to choose his/her collaborators: ${ }^{1280}$ he/she has the possibility to have preferences when it comes to choosing between applicants. ${ }^{1281}$ The employee also has the freedom to choose whether he/she is going to apply for or accept a position, and can decide where to apply. ${ }^{1282}$

414. As a result, the interests of the employer demand to consider not only the candidate's professional capacities, ${ }^{1283}$ but also his/her personal traits. ${ }^{1284} \mathrm{He} / \mathrm{she}$ is legally entitled to take into consideration certain extra-professional elements of the applicant's life, ${ }^{1285}$ although legal regulations impose serious limitations regarding the intuitu personae character of the employment (e.g. discrimination, equality, individual freedoms). ${ }^{1286}$

\footnotetext{
${ }^{1277}$ Subsections (1) and (2) of Section 6:59 of Act V of 2013 on the Hungarian Civil Code

${ }^{1278}$ Vékás, L. (ed.) (2013) A Polgári Törvénykönyv magyarázatokkal. Budapest: Complex. p. 545.

${ }^{1279}$ Kiss, Gy. (2002) ‘A szerződéses szabadság átalakulása a munkajogban az alapjogok tükrében', in Czúcz, O. and Szabó, I. (eds) Ünnepi tanulmányok. Munkaügyi igazgatás, munkaügyi bíráskodás: Radnay József 75 . születésnapjára. Miskolc: Bíbor Kiadó, p. 268.; Radnay, J. (2008) Munkajog. Budapest: Szent István Társulat, p. 88

${ }^{1280}$ Conseil constitutionnel: décision n ${ }^{\circ} 88-244$ DC du 20 juillet 1988

${ }^{1281}$ Lyon-Caen, G. (1992) Les libertés publiques et l'emploi. Paris: la Documentation française (Collection des rapports officiels). p. 57.

${ }^{1282}$ Lyon-Caen, G. (1992) Les libertés publiques et l'emploi. Paris: la Documentation française (Collection des rapports officiels). pp. 57-58. Article XII of the Fundamental Law of Hungary

${ }^{1283}$ The employer can verify whether the applicant truly has the professional capacities necessary for the given job and whether information in the applicant's CV is authentic. Source: Cantero, I. and Coupez, F. (2014) 'L'utilisation des réseaux sociaux par l'entreprise : des risques maîtrisés ?', Revue Banque, (769), p. 39.

${ }^{1284}$ Teyssié, B. (1988) 'Personnes, entreprises et relations de travail', Droit social, (5), p. 375.; Arany-Tóth, M. (2008) A munkavállalók személyes adatainak védelme a magyar munkajogban, Szeged: Bába Kiadó, p. 112.

1285 Jacquelet, C. (2008) La vie privée du salarié à l'épreuve des relations de travail. Aix-en-Provence: Presses universitaires d'Aix-Marseille, p. 64.

${ }^{1286}$ Péano, M.-A. (1995) 'L'intuitus personae dans le contrat de travail', Droit social, (2), pp. 132-133.
} 


\section{$\S 2:$ Methods of recruitment: Internet and social network sites}

Different methods of selection help to provide the HR manager with a complete view of the candidate's aptitudes or inaptitudes, ${ }^{1287}$ through which the employer can obtain an extensive range of information regarding the candidate's professional aptitudes, his/her personality or even his/her private life. Besides the traditional methods of recruitment, such as conducting an interview, polygraph test, aptitude test, graphological tests, personality tests, medical tests, collecting references, etc., online background checks have gained considerable importance.

The advent of the Internet and SNSs has considerably changed what kind of information employers can discover regarding job candidates. They have become a popular recruitment method and gained ground in the phase of recruitment: in France, according to a survey conducted by RegionsJob in 2017, the huge majority of French employers (85\%) googled job candidates ${ }^{1288}$ in order to verify information provided by them and to learn about their personalities. ${ }^{1289}$ Although during the research no official statistics relating to the use of SNSs by Hungarian employers during the recruitment process was found, it can be assumed that with regard to the international scale of the use of SNSs, Hungarian employers are no exception. ${ }^{1290}$ This is not a phenomenon limited to these two countries: employers from other countries/continents often have recourse to SNSs during hiring. ${ }^{1291}$

${ }^{1287}$ Bokor, A. et al. (2007) Emberi erőforrás menedzsment. Budapest: Aula Kiadó, p. 150.

${ }^{1288}$ Dauvergne, G. (2017) 85\% des recruteurs font des recherches en ligne sur les candidats, Les Echos.fr. Available at: https://business.lesechos.fr/directions-ressources-humaines/ressourceshumaines/recrutement/030656487193-85-des-recruteurs-font-des-recherches-en-ligne-sur-les-candidats314060.php (Accessed: 20 June 2019). According to other surveys, this phenomenon already existed back in 2009 (Desfeuillet, X. (2009) Presque tous les employeurs consultent le profil Internet des candidats à l'embauche, Le Monde. Available at: https://www.lemonde.fr/societe/chat/2009/11/20/internautes-commentameliorer-son-image-sur-internet-un-expert-en-e-reputation-vous-repond_1270030_3224.html (Accessed: 20 June 2019). ) and in 2015 this number was $52 \%$ (Lhermenault, A. (2015) Réseaux sociaux: 52\% des employeurs ont déjà fait des recherches sur des candidats, Le Figaro. Available at: https://etudiant.lefigaro.fr/stage-emploi/actu/detail/article/reseaux-sociaux-52-des-employeurs-ont-dejafait-des-recherches-sur-des-candidats-15425/(Accessed: 20 June 2019).).

1289 A field experiment conducted by Matthieu Manant, Serge Pajak and Nicolas Soulié at Paris-Sud University affirmed the use of Facebook profiles as part of the recruitment process. Source: Manant, M., Pajak, S. and Soulié, N. (2014) Online social networks and hiring: a field experiment on the French labor market. [in press] Munich Personal RePEc Archive. Available from: https://papers.ssrn.com/sol3/ papers.cfm?abstract_id=2458468 [Accessed 2 February 2017].

${ }^{1290}$ Although references are made to such a practice. For example, Zoltán Szüts reported in an article that his students were typically employed after "cleaning" their Facebook profiles. Source: Szüts, Z. (2015) 'A Munka Világának Online Kommunikációs Kérdései', Opus et Educatio, 2(2), p. 29.

1291 According to survey conducted on behalf of Carreer Builder, in 2017 in the US $70 \%$ of employers screened applicants' social media profiles. Salm, L. (2017) $70 \%$ of employers are snooping candidates' social media profiles, Career Builder. Available at: https://www.careerbuilder.com/advice/social-mediasurvey-2017 (Accessed: 20 June 2019). 
415. Scope: personal vs. professional SNSs. The rich amount of personal data and information present on SNSs can contribute to the identification of the most suitable candidate. However, regarding the scope of the thesis, in the recruitment process a difference should be made between professional SNSs and personal SNSs. Professional SNSs (e.g. LinkedIn, Viadeo) have the aim to maintain a professional identity, make useful contacts and search for opportunities. In contrast, their personal counterparts (e.g. Facebook, Instagram) are primarily used for entertainment and to engage with the "friends" of the user. ${ }^{1292}$

Professional SNS profiles contain information primarily relating to the professional life of the individual: often information also present in the CV (education, work experience) completed with information typically not present in a $\mathrm{CV}$ but still having professional characteristics (work contacts, articles written by the individual, etc.). The professional or personal nature of the given SNS - together with the use(/lack) of the privacy settings - can have major importance when it comes to evoking the employee's right to respect for private life. ${ }^{1293}$ Naturally, the candidate's personal life is concerned to a lesser extent when it comes to the inspection of professional SNSs, ${ }^{1294}$ due to the fact they primarily contain information relating to the professional life of the individual, in contrast to personal SNSs, such as Facebook. For this reason, the following analysis will concentrate on personal SNSs, as their inspection might raise more severe privacy and data protection challenges or even infringements. ${ }^{1295}$

416. Advantages of online background checks. Conducting such background checks can be beneficial to the employer for two reasons. First, as it was already demonstrated in Part I, SNSs provide an unprecedented access to a wide range of information on prospective employees - both regarding information relating to

1292 Robles, P. (2012) Personal versus professional social networks: infographic, Econsultancy. Available at: https://econsultancy.com/personal-versus-professional-social-networks-infographic/(Accessed: 13 August 2019).

1293 Tshilembe, A.-S. (2015) 'Vie privée - protection des données personnelles du travailleur: la question de l'embauche', in Martin, D., Morsa, M., and Gosseries, P. (eds) Droit du travail européen: questions spéciales. Bruxelles: Éditions Larcier, pp. 699-700.

${ }^{1294}$ Instead of leading to issues, (especially) a professional account treated with due care can highly enhance the individual's chances of getting employed. Source: Byrnside, I. (2008) 'Six Clicks of Separation: The Legal Ramifications of Employers Using Social Networking Sites to Research Applicants', Vanderbilt Journal of Entertainment and Technology Law, 10(2), p. 457-458. On the positive role that SNSs can play during recruitment see more in: Szabó, R. (2016) 'Toborzási módszerek és lehetőségek a közösségi média korában', HR \& Munkajog, 7(1), pp. 36-39.

1295 Therefore, when using the expression SNS, a personal SNS should be understood by it, and not a professional SNS. 
professional capacities and personal traits. Applicants are often inaccurate or even dishonest when writing a résumé and have rehearsed answers to interview questions that hide their true personality traits. ${ }^{1296}$ However, SNSs can reveal a multitude of information.

The information obtained in such a way can be of interest to the employer in several regards. A study from 2010 conducted by Cross-Tab on the attitudes relating to "online reputation"1297 searches reveals that the following - quite extensive - reasons were considered in the recruitment process and led to the rejection of a candidate: concerns about the candidate's lifestyle; inappropriate comments and text written by the candidate; unsuitable photos, videos, and information; inappropriate comments or text written by friends and relatives; comments criticizing previous employers, co-workers, or clients; inappropriate comments or text written by colleagues or work acquaintances; membership in certain groups and networks; discovering that information the candidate shared was false; ${ }^{1298}$ poor communication skills displayed online and concerns about the candidate's financial background. ${ }^{1299}$

417. Second, these searches are extremely easy to be conducted, entail minimal costs and allow the employer to obtain a rich pool of information beyond the candidate's professional capacities, which in the pre SNS-era would have been more difficult and less cost-effective to obtain through the traditional methods. ${ }^{1300}$ They require only an electronic device capable of connecting to the Internet and an Internet connection. Then, the employer can easily inspect the candidate's profiles through a simple Internet search.

418. Disadvantages of online background checks. Despite providing such a huge amount of information with minimal costs and efforts, SNS background checks present certain risks as well. In particular, several legal issues arise during their use, with special regard to the right to privacy and the right to data protection and relating to

\footnotetext{
1296 Mooney, D. E. (2010) 'Employer on the Web Wire: Balancing the Legal Pros and Cons of Online Employee Screening', Idaho Law Review, 46(3), p. 737.

${ }^{1297}$ Meaning by online reputation the "[...] publicly held social evaluation of a person based on his or her behavior, what he or she posts, and what others (such as individuals, groups, and Web services) share about the person on the Internet." Cross-Tab (2010) Online Reputation in a Connected World. Available at: https://www.job-hunt.org/guides/DPD_Online-Reputation-Research_overview.pdf. p. 3.

1298 According to certain surveys, nearly half of the job applicants lie about their work history and education. Source: Sprague, R. (2008) 'Rethinking Information Privacy in an Age of Online Transparency', Hofstra Labor \& Employment Law Journal, 25(2), p. 398.

1299 Cross-Tab (2010) Online Reputation in a Connected World. Available at: https://www.jobhunt.org/guides/DPD_Online-Reputation-Research_overview.pdf(Accessed: 3 May 2018). p. 9.

1300 Brown, V. R. and Vaughn, E. D. (2011) 'The Writing on the (Facebook) Wall: The Use of Social Networking Sites in Hiring Decisions', Journal of Business and Psychology, 26(2), p. 220.
} 
discrimination as well. ${ }^{1301}$ These legal issues will be dealt with in detail in Chapter 2. Also, beyond legal arguments, conducting SNS background checks can have a detrimental effect: the employer's perception by job candidates might also be adversely affected: especially young job seekers would feel frustrated if the employer conducted a detailed online background check. ${ }^{1302}$

\section{Section 2: The traditional recruitment procedure}

419. Differentiation must be made between the information that the employer would like to obtain (as much information as possible) and between the information that he/she is legally entitled to obtain (regulated by labour law and data protection regulations). Despite the existence of the employer's right to choose with whom to contract, this right is not limitless. ${ }^{1303}$ Section 2 will examine the rules imposing limitations on the employer's information thirst.

Rules relating to the "traditional" recruitment procedure (e.g. tests, job interviews) were already elaborated especially by the doctrine and the practice of the data protection supervisory authorities. The following paragraphs will limit themselves to the presentation of the data protection rules in general during the recruitment phase, while their application and the specific data protection questions relating to SNSs will be discussed under Chapter 2.

420. First, it will be examined what rules constitute the general data protection framework during recruitment: the provisions of the labour codes and the practice of the data protection supervisory authorities will be presented. Then, rules relating to the protection of applicants' private life and job interviews will be addressed. Job interviews are chosen, as the scope of questions that can be asked provides a useful indication for tracing the boundaries of personal and professional life - which can be adequately applicable to SNSs as well.

1301 Del Riego, A., Sánchez Abril, P. and Levin, A. (2012) 'Your Password or Your Paycheck?: A Job Applicant's Murky Right to Social Media Privacy', Journal of Internet Law, 16(3), pp. 18-21.

1302 Byrnside, I. (2008) 'Six Clicks of Separation: The Legal Ramifications of Employers Using Social Networking Sites to Research Applicants', Vanderbilt Journal of Entertainment and Technology Law, 10(2), p. 475. Though back in 2008 (and in 2006, as the source referred to it) a pre-employment social media vetting might have been considered outrageous by candidates, today it has become a mainstream phenomenon, so it might be judged differently.

1303 Arany-Tóth, M. (2008) A munkavállalók személyes adatainak védelme a magyar munkajogban. Szeged: Bába Kiadó, p. 112. 


\section{§1: Labour law and applicants' rights}

As it was already referred to in Part I, both the FLC and the HLC contain provisions regulating employment and data protection. They also regulate the recruitment phase as well. Even though these provisions do not explicitly aim SNSs, they are adequately applicable to them as well.

\section{(A) Provisions of the labour codes}

Prior to discussing the issues specific to SNSs, it is necessary to review the data protection provisions of the labour codes. Before addressing (b) the data protection requirements laid down in the labour codes, it must be examined (a) whether these provisions are applicable to job applicants at all.

\section{(a) Applicability to job candidates}

421. Personal scope of the labour law regulations. Naturally, when it comes to the recruitment process, the subjects of the different recruitment methods are prospective employees and not employees. As these individuals are not yet employees, the question of the applicability of the labour law regulations might be raised and therefore should be clarified.

422. Personal scope of the FLC. The question whether the provisions of the labour code are applicable only to employees or they include prospective employees as well is not raised in French legislation. France was the first country in the European Economic Community to adopt a legislation specifically aiming to regulate recruitment methods: ${ }^{1304}$ since 1992 , due to the act relating to employment, the development of parttime work and unemployment insurance, ${ }^{1305}$ the FLC contains provisions explicitly

\footnotetext{
1304 Ray, J.-E. (1993) 'Une loi macédonienne? Étude critique du V de la loi du 31 décembre 1992. «Dispositions relatives au recrutement et aux libertés individuelles »', Droit social, (2), p. 109. Already back in 1985, the CNIL addressed the question of data protection and recruitment in one of its deliberations. See more in: CNIL (1985) Délibération portant adoption d'une recommandation relative à la collecte et au traitement d'informations nominatives lors d'opérations de conseil en recrutement. Délibération $n^{\circ} 85-44 \mathrm{du}$ 15 octobre 1985 .

1305 Act No. 92-1446 of 31 December 1992 on employment, the development of part-time work and unemployment insurance ("Loi n 92-1446 du 31 décembre 1992 relative à l'emploi, au développement du travail à temps partiel et à l'assurance chômage")
} 
regulating the recruitment process (Article L1221-6 - Article L1221-9), making it unquestionable that job applicants are covered by these provisions. ${ }^{1306}$

423. Personal scope of the HLC. In contrast to the FLC, the HLC contains no expressed provision regarding the hiring procedure, leaving room for certain questions. The HLC does not mention the expression "job applicant", it uses the term of employee. Even when determining the personal scope of the HLC, the word employee is used. ${ }^{1307}$ With respect to the recruitment phase, only a reference can be found in Subsection 1 of Section 10, which regulates statements and disclosure of information and states that "[an] employee may be requested to make a statement or to disclose certain information only if it does not violate his/[her] rights relating to personality, and if deemed necessary for the conclusion [...] of the employment relationship [.]"1308

424. These provisions raise an important point of law, such as: does the personal scope of the HLC cover the candidate, too? Opinions differ regarding this question. When examining this section, ${ }^{1309}$ Tibor Breznay mentions only the employee and not recruitment, ${ }^{1310}$ while Katalin Berki et al. stipulate that this provision only aims employees. ${ }^{1311}$ According to the Equal Treatment Advisory Board, the HLC's provisions are only applicable to employees and employers and therefore do not cover the recruitment process. ${ }^{1312}$ In contrast, according to Csilla Lehoczkyné Kollonay, the provisions aiming to ensure the protection of employees are applicable to the selection process, too. ${ }^{1313}$ Mariann Arany Tóth, and József Hajdú and Attila Kun are of the same opinion, namely that the personal scope of the provisions mentioned covers the candidate, too. ${ }^{1314,1315}$

\footnotetext{
1306 Not to mention the general formulation of Article L1121-1 of the FLC, not only aiming to protect employees, but every person.

1307 Subsection (1) of Section 2 of the HLC

1308 Subsection (1) of Section 10 of the HLC. Emphasis added by the author.

${ }^{1309}$ It should be mentioned that the sources below concern the previous HLC (Act XXII of 1992), which contained a similar provision. (Section 77)

1310 Breznay, T. (2002)A munka törvénykönyve egységes szerkezetben állásfoglalásokkal és magyarázatokkal. Bővített kiadás. Budapest: Kompkonzult. p. 115.

${ }^{1311}$ Berki, K. et al. (2008) A munka törvénykönyve magyarázata. 2nd edn. Budapest: Complex. p. 278.

1312 Az Egyenlő Bánásmód Tanácsadó Testület 1/2007. TT. sz. állásfoglalása az állásinterjún feltehető munkáltatói kérdésekről

1313 Lehoczkyné Kollonay, Cs. (ed.) (1997) A magyar munkajog I.Budapest: Kulturtrade Kiadó. p. 91.

1314 Arany-Tóth, M. (2008) A munkavállalók személyes adatainak védelme a magyar munkajogban. Szeged: Bába Kiadó, p. 114.; Hajdú, J. and Kun, A. (eds) (2014) Munkajog. Budapest: Patrocinium, p. 94.

1315 According to Jóri et al., the material scope of the act covers the hiring phase, too. Source: Jóri, A., Hegedűs, B. and Kerekes, Zs. (eds) (2010) Adatvédelem és információszabadság a gyakorlatban. Budapest: Complex, p. 278.
} 
The latter viewpoint is supported by the fact that the general reasoning of the HLC emphasizes that according to the general principle, unless contrary to labour law regulation, civil law rules constitute the underlying rules of the HLC. ${ }^{1316}$ When declaring the protection of personality rights in the employment context (Section 9), the HLC refers to the Civil Code - which states that every person is entitled to the protection of the personality rights. ${ }^{1317}$

Also, in the employment relationship a hierarchal relation can be found between the parties, the employee is in a position of existential vulnerability. ${ }^{1318}$ One of the aims of labour law is to counterweigh this vulnerability; in order to achieve this, labour law contains several provisions for the protection of the employee. ${ }^{1319}$ However, this existential vulnerability is not unique to the employee-employer relationship: it is (even more intensely $)^{1320}$ present before the conclusion of the employment contract, as - under the not always favourable labour market conditions - the candidate is typically not in the position to balance between concluding a contract and the violation of his/her fundamental rights. ${ }^{1321}$

425. Based on the above-mentioned arguments, it seems logical that the provisions protecting employees must be adequately applicable to candidates. The phrasing of Section 10 itself also suggests the applicability of these provisions to candidates as it regulates the case of concluding the employment contract - for which one needs to be a candidate and not an employee. ${ }^{1322}$

426. De lege ferenda suggestion. With regard to the above, as a de lege ferenda suggestion, it would be recommended to clarify in Hungarian law - similarly to French law - that the relevant data protection provisions of the HLC are also applicable to job

1316 T/4786. számú törvényjavaslat a Munka Törvénykönyvéről (2011). Elöadó: Dr. Matolcsy György nemzetgazdasági miniszter. Budapest. p. 86.

1317 Similarly, the basic principles of the Privacy Act are applied to every data processing, not only to the processing of personal data relating to employees.

${ }^{1318}$ However, it also has to be seen that this defencelessness does not characterize all employees. Bankó, Z. and Szöke, G. L. (2016) Issues of the digital workplace - The situation in Hungary. Pécs: JurInfo, pp. 43-44. 1319 Gyulavári, T. (ed.) (2013) Munkajog. ELTE Eötvös Kiadó. Budapest, p. 19.

1320 The Commissioner's Recommendation on job advertisements and on the activity of private recruitment agencies

${ }^{1321}$ Hajdú, J. (2005) A munkavállalók személyiségi jogainak védelme. Szeged: Pólay Elemér Alapítvány, p. 170.

1322 Arany-Tóth, M. (2008) A munkavállalók személyes adatainak védelme a magyar munkajogban. Szeged: Bába Kiadó, p. 114. 
applicants. Such a clarification might include the insertion of a subsection stating that these provisions are to be applied to job applicants as well. ${ }^{1323}$

\section{(b) Applicants' right to data protection in the labour codes}

427. While the FLC explicitly aims recruitment, the HLC does it in a more abstract way, through regulating employee statements and disclosure of personal information in order to conclude an employment relationship. These provisions echo data protection requirements such as purpose limitation, necessity, relevancy and transparency.

428. Recruitment in the FLC. Besides the general clause of Article L1121-1 stipulating the protection of individual and collective rights and freedoms, from Article L1221-6 to Article L1221-9 the FLC contains provisions explicitly regulating the recruitment process. In these provisions it expressly refers to the most important data protection principles, leaving no question regarding whether these principles are applied to the recruitment phase or not.

Article L1221-6 asserts the principle of finality, which requires that information asked from a job applicant in any form must only be processed for the aim of assessing the applicant's capacities to occupy the given employment or to evaluate his/her professional abilities. Therefore it aims to protect the applicant's extra-professional life through limiting the processing of personal data to the professional capacities of the applicant. ${ }^{1324}$ Moreover, it emphasizes the principle of necessity by stipulating that the information obtained must have a direct link and must be necessary for the proposed job or for the evaluation of professional aptitudes. The Article also prescribes that the applicant must reply in good faith to the information requests.

429. Article L1221-8 requires the employer to inform the applicants regarding the methods and techniques used for recruitment, prior to their application. It also declares that the results obtained with such methods and techniques are confidential. These methods and techniques must be relevant in the light of the objectives sought. Article L1221-9 further emphasizes the principle of transparency and the employer's obligation to inform applicants prior to the collection of personal data.

\footnotetext{
${ }^{1323}$ Such a subsection might be formulated as follows: "Subsection (6) of Section 10: Subsections (1)-(5) are also adequately applicable to job applicants."

${ }^{1324}$ For example, the employer can ask for a school certificate, proof of a degree, driving licence, but cannot ask for academic records or for personal files. Source: Radé, C. (2002) Droit du travail. 2nd edn. Paris: Montchrestien, p. 184.
} 
430. Data protection in the HLC. The HLC contains provisions relating to employee statements and disclosure of personal information - which covers the case of processing the job applicants' personal data through obtaining different kinds of information. The HLC also prescribes the purpose limitation principle; it defines the purpose of such processing, which is the conclusion of the employment relationship, ${ }^{1325}$ and in relation to this identifying the best candidate. ${ }^{1326}$ It further refers to the principle of necessity and adds that statements and disclosure must be necessary in order to conclude the employment relationship ${ }^{1327}$ - imposing limitations on the scope of information that can be processed. ${ }^{1328}$ Also, similarly to the FLC, the HLC also contains provisions with respect to informing candidates: it requires employers to inform candidates in writing prior to the data processing. ${ }^{1329}$ It means that information must be provided to applicants, thereby ensuring the transparency of the processing.

431. De lege ferenda suggestion. With regard to the grammatical formulation of the labour codes regulating data processing in the recruitment phase, a de lege ferenda suggestion is made. As these provisions were adopted before the vast proliferation of SNSs, their application to these Web 2. 0. services might raise certain concerns, as the grammatical formulation of the relevant provisions of the labour codes does not correspond perfectly with the reality of the information society. The FLC uses the expression "information requested" ("informations demandées") in the first subparagraph of Article L1221-6, while the HLC employs the expression "making a statement or disclosing certain information" ("nyilatkozat megtétele vagy adat közlése") in Subsection 1 of Section 10. Interpreting these provisions from a strict grammatical point of view would result in excluding information obtained by the employer through unilaterally accessing (without requesting) the prospective employee's SNS profile.

432. The aim of these provisions is to protect job candidates' rights during recruitment, regardless of the method used. Data protection requirements also apply to every processing during recruitment. So, despite this grammatical lack, the data protection requirements apply; still, it would be desirable to clarify the scope of protection. In order

\footnotetext{
1325 Subsection (1) of Section 10 of the HLC

${ }^{1326}$ Arany-Tóth, M. (2016) Személyes adatok kezelése a munkaviszonyban. Budapest: Wolters Kluwer. p. 29. 1327 Subsection (1) of Section 10 of the HLC

${ }^{1328}$ Usually information directly connected to the identity of the applicant is not considered to be essential for the conclusion of the employment contract. Source: Bankó, Z., Berke, Gy. and Kiss, Gy. (2017) Kommentár a munka törvénykönyvéhez. Budapest: Wolters Kluwer, p. 46.

${ }^{1329}$ Subsection (5) of Section 10 of the HLC
} 
that the grammatical formulation of these provisions better correspond with real-life conditions, it would be desirable to complete the regulation with the expression "collected" ${ }^{1330}$ reflecting better the reality of the methods of obtaining personal data in the age of the information society.

\section{(B) Practice of the data protection supervisory bodies}

433. Both the CNIL and the NAIH have addressed the question of the job applicant's right to data protection, emphasizing that the employer must respect data protection requirements during the recruitment as well and clarified how exactly employers should comply with these requirements in this context. They examined the proper use of different recruitment tools (e.g. lie detectors, personality tests, etc.) from a data protection point of view, giving substance to the general provisions of the labour codes. In the following, instead of the exhaustive presentation of the CNIL's and NAIH's practice, focus will be put on their conclusions which might be relevant in relation to SNSs.

\section{(a) France: the CNIL}

434. The CNIL issued a deliberation in 2002 on the collection and processing of personal information during recruitment, ${ }^{1331}$ in which it clarified the application of the data protection principles to the recruitment process. It stated that unless justified by the specific nature of the job, or by the legal regulation of a foreign country concerned by the post, generally - amongst others - information such as date of entry to France, information relating to family members (name, nationality, profession), height, weights, housing conditions or community life shall not be processed. The deliberation also states that it is prohibited to process personal data relating to the candidate's racial or ethnic origin, political opinion, religious or philosophical convictions, membership in a trade union, data relating to his/her health or sexual life ${ }^{1332}$ - without the consent of the applicant. Even in

1330 The following solution (suggestion marked in italics) is recommended as a de lege ferenda suggestion: Proposed Article L1221-6 of the FLC: "The information requested from or collected about a job applicant in any form whatsoever - shall only have the aim to assess his/her fitness for the proposed employment or his/her professional competence."

Proposed Subsection (1) of Section 10 of the HLC: "An employee may be requested to make a statement or to disclose certain information, or information relating to him/her can be collected only if it does not violate his/her rights relating to personality, and if deemed necessary for the conclusion, fulfilment or termination of the employment relationship."

${ }^{1331}$ CNIL (2002) Délibération portant adoption d'une recommandation relative à la collecte et au traitement d'informations nominatives lors d'opérations de recrutement. Délibération n02-017 du 21 mars 2002.

1332 General principle enshrined in Article 6 of the FDPA. 
the case of consent, the processing cannot lack a direct and necessary link to the job proposed. ${ }^{1333,1334}$

435. The CNIL reiterated this position in several of its documents. In 2013 it provided a list of information which is, as a main rule, not relevant, unless justified by particular circumstances. These items of information include, for example, date of arrival in France, original citizenship, family background, health status or community $\operatorname{life}^{1335}$ information which is often shared on SNSs by an average user. In its information sheets relating to employment, the CNIL also dealt with the phase of recruitment, and again it reiterated the importance of the principle of relevancy and the importance of being informed on the processing of applicants' personal data. ${ }^{1336}$

436. While previously the employer had to actively look for that information, today it is not uncommon to find this information within reach on SNSs. In addition, drawing conclusions from this information might matter, too. In another deliberation in $2007,{ }^{1337}$ the CNIL recognized the lack of relevancy and the very subjective nature of comments contained in files relating to applicants (and former employees). ${ }^{1338}$ So the conclusions drawn from the consultation of the profile of the applicant shall also present an objective nature.

\section{(b) Hungary: the Data Protection Commissioner and the NAIH}

437. In 2006 the Hungarian Data Protection Commissioner adopted a recommendation on job advertisements and on the activity of private recruitment agencies $^{1339}$ in order to ensure the uniform protection of job applicants' rights. In this

\footnotetext{
${ }^{1333}$ It should not be forgotten that, as demonstrated before, since 2002, the appreciation of the validity of employee consent as a legal ground of processing has considerably changed.

1334 The deliberation also treated the question of transparency and prior information of the individual, the exercise of the rights of the data subject and the prohibition of automated profiles.

1335 CNIL (2013) Les opérations de recrutement. Available at: https://www.cnil.fr/fr/les-operations-derecrutement (Accessed: 20 June 2019).

1336 CNIL (2018) Le recrutement et la gestion du personnel. Fiches pratiques. Travail \& Données personnelles. Available at: https://www.cnil.fr/sites/default/files/atoms/files/_travailvie_privee_recrutement_gestion_du_personnel.pdf (Accessed: 20 June 2019).

1337 CNIL (2007) Délibération $n^{\circ} 2007-374$ du 11 décembre 2007 sanctionnant la société X. Délibération n $2007-374$ du 11 décembre 2007.

1338 These comments included, for example, comments relating to the behaviour of the individual ("catastrophe", "liar and unreliable", "lame", "not great", "hygienic problems (smell) !!!!!", "so annoying"), comments relating to their health status ("disappeared after a depression", "depressive", "problems with alcoholism", "suffers from cancer, cannot work anymore") or comments relating to the personal or family relations ("girlfriend/friend of M. - not reliable", "does not live with her husband anymore", "wife of G."). 1339 ABI 167/A/2006-3.
} 
recommendation the Commissioner drew attention to the informational vulnerability of job applicants and the increased importance that he/she can follow and control the processing of his/her personal data during the hiring process. It is crucial that the applicant is aware to whom he/she is sending the information and knows where he/she can ask for information regarding the status of the decision. Therefore, job advertisements must contain information about the controller and about the contact information ensuring that the applicants can exercise their rights relating to the processing. In a case $\mathrm{e}^{1340}$ on the questions that can be asked during a job interview, the Commissioner noted that if the employer asks a question violating privacy rights, in order to prevent impairment of rights, the applicant can refuse to answer or can give an untruthful answer. ${ }^{1341}$

438. The former Hungarian Data Protection Commissioner extensively dealt with the issue of tests and data protection. According to him, a difference must be made between two types of the tests: between tests evaluating the professional suitability and readiness, and between tests relating to psychological and personality traits of the individual. ${ }^{1342}$ The former case relates to tests aiming to map the professional competences and expertise of employees, and indeed the employer is entitled to obtain that information, before and also during the employment. ${ }^{1343}$ In contrast, tests aiming to know the psychological or personality traits can enable the employer to draw conclusions relating to the individual's personal traits that can contribute to organizing work more effectively. Although this is a legitimate interest on the part of the employer, during the enforcement of this interest the employer must respect the employee's personality rights. ${ }^{1344}$

Relating to this case, the Commissioner also emphasized that depending on the characteristics of the given job, certain personality traits might have increased relevancy, these tests cannot be used on a general basis to a large group of employees: its use should be carefully planned and selected. Also, the tests should be limited to the examination of the personal traits essential for the employment, with the existence of a legitimate purpose. It was also recommended that an independent third party should analyse the tests. ${ }^{1345}$ In the same case, the Commissioner also stated that the psychological test should be based on the informed, voluntary consent of the employee. However, this statement has become

\footnotetext{
${ }^{1340}$ ABI 900/A/2006)

1341 ABI 900/A/2006)

1342 ABI 814/A/2004-8.

1343 ABI 814/A/2004-8.

1344 ABI 814/A/2004-8.

1345 ABI 814/A/2004-8.
} 
outdated since, as the case took place in 2004; later it was concluded that the voluntary nature of the consent is highly questionable and that the legitimate ground of balancing rights and interests might be better adapted to the employment context. ${ }^{1346}$ As on SNSs the employer has an unprecedented possibility to assess the personal traits of job applicants (and employees), these requirements will have high importance in the case of preemployment SNS screenings - as will be presented in Chapter 2.

439. In another case ${ }^{1347}$ the Commissioner dealt with a machine using digital face recognition destined to be applied during interviews. The machine would analyse the features of the applicant and draw consequences regarding his/her personality traits and behaviour. In relation to personality tests, the Commissioner laid down that the employee cannot be subjected to a method which would provide the employer data over which the individual does not have control. First, the result of the test should be transferred to the individual, who can then decide whether he/she consents to transfer it to the employer, providing him/her the possibility to make a decision. The Commissioner also outlines that there is another, more traditional method to effectively assess whether the employee is truly competent and well-suited for the job: probation.

440. In 2012 president of the NAIH Attila Péterfalvi et al. summarized what requirements an aptitude test must meet. ${ }^{1348}$ First of all, the principle of purpose limitation requires that it must be determined exactly what competences these tests aim to measure and how it is relevant regarding the employment relationship. In addition, the methods chosen must be able to assess these competences: they shall provide relevant data that can in reality contribute to achieving the purpose of the processing. As these tests are able to reveal information that the individual is not even aware of, first the individual should be informed of the result of test and then he/she can decide (and bear the consequences of refusing) whether the result can be transferred to the employer as well. Attention was raised also to the fact that these tests may inadvertently reveal information which has no relation to the purpose of the processing: these data should be erased.

1346 NAIH (2013)A Nemzeti Adatvédelmi és Információszabadság Hatóság ajánlása a munkahelyen alkalmazott elektronikus megfigyelörendszer alapvetö követelményeiröl. NAIH-4001-6/2012/V. Budapest, pp. 2-3.

1347 ABI 2550/K/2007-3.

1348 Péterfalvi, A. (ed.) (2012) Adatvédelem és információszabadság a mindennapokban. Budapest: HVGORAC, pp. 298-299. 


\section{$\S 2$ : Asking for information from applicants}

441. Special attention will be paid to job interviews, as they provide the employer the possibility to pose a vast amount of questions to the applicant, thus learning a little more about his/her personality. While in practice the employer might even ask questions relating to the personal life of the applicant, $(A)$ the previously presented data protection principles, such as purpose limitation or necessity, impose limitations to what kinds of questions can be asked. Following from the general labour law principles such as cooperation, $(B)$ the applicant also has certain tools to protect himself/herself against the unlawful questions of the employer.

442. It was already addressed both in France and in Hungary what questions can be asked during a job interview, thereby determining the boundaries of personal and professional life, and according to my opinion, these observations provide a useful guidance when it comes to the protection of applicants' personal lives on SNSs, as the observations can be adequately applied to identifying this boundary on these online platforms.

\section{(A) Job interviews}

443. Naturally, the employer is interested in knowing all the essential information about an applicant, including his/her personality as well. ${ }^{1349}$ During job interviews this information need is manifested in asking questions from the applicant: the employer is entitled and is required as well to pose questions. ${ }^{1350}$

\section{Questions to be asked during a job interview and Hungarian labour law.}

In line with the data protection principles, these questions can relate to the employment relationship or checking the aptitudes necessary for the job. ${ }^{1351}$ Therefore - just as it was the case when asking for information from the applicant - the questions must be connected to the professional life of the candidate, personal considerations should be excluded from the decision-making process.

\footnotetext{
1349 Bankó, Z., Berke, Gy. and Kiss, Gy. (2017) Kommentár a munka törvénykönyvéhez. Budapest: Wolters Kluwer, p. 45. and Arany-Tóth, M. (2008) A munkavállalók személyes adatainak védelme a magyar munkajogban. Szeged: Bába Kiadó, p. 112.

${ }^{1350}$ Duquesne, F. (2003) Droit du travail. 2nd edn. Paris: Gualino, p. 58.

${ }^{1351}$ Hajdú, J. (2005) A munkavállalók személyiségi jogainak védelme. Szeged: Pólay Elemér Alapítvány, p. 170. and Duquesne, F. (2003) Droit du travail. 2nd edn. Paris: Gualino, p. 58.
} 
445. However, it is difficult to exhaustively define what the questions belonging to this circle are, as it is difficult to exhaustively define what falls under the notion of "competency" in this context. ${ }^{1352}$ In France, a bulletin from 1993 provided certain clarification: the employer can obtain information relating to the applicant's competences, technical knowledge, adaptability, the ability to integrate into a team, etc. ${ }^{1353}$

446. Discrimination and personal data protection. Even though it is beyond the scope of the present dissertation to examine this question in detail, certain similarities still have to be outlined between discrimination and privacy/data protection. Information belonging to the personal life of the prospective employee or being beyond the scope of purpose limitation and data minimization often overlaps with what constitutes protected characteristics in discrimination law, ${ }^{1354}$ and the more information employers gather, the more they can be exposed to discrimination claims. ${ }^{1355}$

447. Discrimination might appear in the form of discriminative questions during interviews (e.g. question relating to the potential pregnancy of the applicant), or also through obtaining such information via SNSs. ${ }^{1356,} 1357$ On SNSs users typically share

\footnotetext{
${ }^{1352}$ Arany-Tóth, M. (2008) A munkavállalók személyes adatainak védelme a magyar munkajogban. Szeged: Bába Kiadó, p. 117.

1353 Radé, C. (2002) Droit du travail. 2nd edn. Paris: Montchrestien, p. 184.

${ }^{1354}$ See these characteristics in: Article 1 of Directive 2000/78/EC; Section 8 of Act CXXV of 2003 on Equal Treatment and Promotion of Equal Opportunities; Article L1132-1 of the FLC; Article 1of the Act No. 2008496 of 27 May 2008 on various provisions of adaptation to Community law in the field of the fight against discrimination.

1355 Lory, B. E. H. (2010) 'Using Facebook to Assess Candidates During the Recruiting Process: Ethical Implications', NACE Journal, 71(1), p. 38.

1356 See the field experiment conducted by Matthieu Manant, Serge Pajak and Nicolas Soulié at Paris-Sud University, justifying the existence of obtaining information to be the ground of discrimination on SNSs. In their experiment they created two fictitious job candidates and sent their applications (with identical cover letters and résumés) to different companies. They also created profiles for these two candidates and indicated their hometowns and spoken languages, in which the two candidates considerably differed. While the first candidate was born in a French city, the second one was born in Marrakesh and spoke Arabic. This information was only available on Facebook, not in the CV. As a result of the field experiment, they found that the first candidate received $40 \%$ more call-backs than the second one - which they thought is due to the subject's protected characteristic. Source: Manant, M., Pajak, S. and Soulié, N. (2014) Online social networks and hiring: a field experiment on the French labor market. [in press] Munich Personal RePEc Archive. Available from: https://papers.ssrn.com/sol3/ papers.cfm?abstract_id=2458468 [Accessed 2 February 2017].

1357 Discrimination in relation to SNSs is realised not only if the candidate's profile reveals protected characteristics: the procedure itself can also be discriminative - and therefore is to be avoided. These cases include when instead of inspecting equally every candidate's profiles, the employer decides to inspect the profiles of candidates pertaining to a certain race or to an age group. (Source: Byrnside, I. (2008) 'Six Clicks of Separation: The Legal Ramifications of Employers Using Social Networking Sites to Research Applicants', Vanderbilt Journal of Entertainment and Technology Law, 10(2), p. 464.) In addition to being discriminative, such a practice might also possibly infringe the data protection principle of fairness.
} 
information also falling under the scope of protected characteristics, such as religious or political view, relationship status, sexual orientation, etc.

448. One illustrative example is the case of Gaskell v. University of Kentucky from the US. The University of Kentucky created a hiring committee for the position of founding director for the university's astronomical observatory. Mr. Gaskell was the leading candidate, "clearly the most experienced" candidate and had "already done everything [the hiring committee] could possibly want the observatory director to do." However, the committee conducted an Internet search and found Mr. Gaskell's personal website, containing an article entitled Modern Astronomy, the Bible, and Creation. This article made the committee decide to hire another candidate, based on concerns relating to the religious views of Mr. Gaskell. ${ }^{1358}$

449. The Hungarian Equal Treatment Advisory Board. In Hungary, the Equal Treatment Advisory Board (“Egyenlő Bánásmód Tanácsadó Testület”) already regulated what kinds of questions cannot be asked during a job interview: in 2007 they issued a resolution on the questions that can be asked during a job interview. ${ }^{1359}$ In its resolution, the Equal Treatment Advisory Board emphasized that it is not possible to provide an exhaustive list of the questions that cannot be asked during a job interview because of being considered discriminative. The assessment of such questions must be based on a case-by-case basis, based on the given circumstances. Generally, it is prohibited to ask questions which are not necessary for assessing whether the potential employee is capable of performing the given job. By way of example, these include questions relating to the relationship of the applicant, to family life, to origins, to place of habitation, to sexual habits, to religious or to political views, etc. However, the Equal Treatment Advisory Board also draws attention to the fact that in some certain, exceptional cases the employer might be entitled to ask certain information relating to these matters.

450. The French Defender of Rights. In France the Defender of Rights issued a guide on how to recruit with the help of digital tools without discriminating. In the document attention was raised to SNSs, which are deemed to present an increased risk to the right of job applicants, especially when it comes to the inspection of personal SNS

\footnotetext{
${ }^{1358}$ Carlson, K. (2014) 'Social Media and the Workplace: How I Learned to Stop Worrying and Love Privacy Settings and the NLRB', Florida Law Review, 66(1), pp. 484-485.

1359 Az Egyenlő Bánásmód Tanácsadó Testület 1/2007. TT. sz. állásfoglalása az állásinterjún feltehető munkáltatói kérdésekről
} 
profiles - a common practice amongst recruiters. According to the Defender of Rights, the employer's access to such sites presents a considerable risk to the applicant's rights and highly enables the employer to make a biased decision. ${ }^{1360}$

451. To conclude, the employer's questions fall into two groups: questions relating to personal life and to professional life. If the question relates to the personal life of the applicant, the employer must not ask it, apart from certain strict exceptions ${ }^{1361}$ - thus ensuring the protection of the personal life of the applicant. However, if the question relates to the professional life, it is lawful to ask it. Although it is difficult to define a strict dividing line between these two spheres, as it was already seen, doctrine, data protection authorities and other institutions already gave numerous examples for these two categories, providing essential guidance.

\section{(B) The "right to lie"}

In case the employer does not respect the above limitations, the applicants have certain possibilities resulting from the general requirements set by labour law with the aim of protecting themselves against the unlawful questions of the employer.

452. Obligations of the parties. The $H L C$ contains a provision amongst the general requirements of conduct, declaring the obligation of cooperation. ${ }^{1362}$ During the performance of rights and obligations, the parties are obliged to act mutually taking into account the other party's rights and interests. ${ }^{1363}$ As a subset of this obligation of cooperation, the HLC also specifies the obligation to inform. ${ }^{1364}$ In this regard, it states that the parties must inform each other concerning all facts, information and circumstances, and any changes therein, which are considered essential from the point of view of concluding the employment relationship. ${ }^{1365}$ The $F L C$ also declares the principle of good faith, ${ }^{1366}$

\footnotetext{
${ }^{1360}$ Le Défenseur des droits (no date) Guide pratique pour les professionnels du recrutement. Recruter avec des outils numériques discriminer. Available at: https://www.defenseurdesdroits.fr/sites/default/files/atoms/files/636150490_int_valide_ft_fini_complet.pdf (Accessed: 27 June 2018). p. 14.

${ }^{1361}$ For example: ideologically oriented enterprises or faith-oriented enterprises ("entreprise de tendance").

1362 Subsection (2) of Section 6 of the HLC

1363 Cséffán, J. (2019) A Munka Törvénykönyve és magyarázata. Szeged: Szegedi Rendezvényszervező Kft, p. 19.

1364 Gyulavári, T. (ed.) (2017) Munkajog. 3rd edn. Budapest: ELTE Eötvös Kiadó, p. 74.

1365 Subsection (4) of Section 6 of the HLC

1366 Article L1222-1 of the FLC
} 
moreover, it specifically states that the job applicant is required to answer truthfully to the employer's information requests. ${ }^{1367}$

453. Obligation of cooperation during job interviews. In relation to job interviews, these obligations can be interpreted in such a way that the employee is obliged to answer questions that are directly related to the employment relationship $-{ }^{1368}$ expressly stated as such by the FLC. ${ }^{1369}$ It means that the candidate is expected to give the demanded information regarding his/her qualification, professional experience. The candidate must answer truthfully if the purpose of the question is to assess the aptitudes for the job, but if the question is not related to the employment relationship, he/she can refuse to answer or cannot be sanctioned if he/she has not given a truthful answer to the question violating personality rights. ${ }^{1370}$

454. Refusing to answer and the "right to lie". It follows from the general requirement of conduct of cooperation and obligation of information, as well as from the applicant's right to privacy and right to data protection, enshrined in the labour codes, that in case the employer asks questions going beyond the lawful scope enounced above, the applicant is not in breach of the obligations imposed on him/her if he/she does not provide a truthful answer to them. ${ }^{1371}$

455. Refusing to answer and the "right to lie" - on SNSs. All these rules provide the applicant the legal possibility to protect himself/herself against the unlawful questions asked by the employer during job interviews - recognizing the importance of such protection. However, in the case of SNSs, the scenario is different: instead of asking

\footnotetext{
${ }^{1367}$ Paragraph 3 of Article L1221-6 of the FLC

1368 Bankó, Z., Berke, Gy. and Kiss, Gy. (2017) Kommentár a munka törvénykönyvéhez. Budapest: Wolters Kluwer.

${ }^{1369}$ Paragraph 3 of Article L1221-6 of the FLC

1370 Berke, Gy. and Kiss, Gy. (eds) (2014) Kommentár a munka törvénykönyvéhez: kommentár a munka törvénykönyvéröl szóló 2012. évi I. törvényhez. Budapest: Wolters Kluwer, p. 60.; Bankó, Z., Berke, Gy. and Kiss, Gy. (2017) Kommentár a munka törvénykönyvéhez. Budapest: Wolters Kluwer, p. 61.; ABI (case 900/A/2006) and Le Lamy Droit Du Numérique (Guide), 2014 - Section 1 - Gestion Du Personnel Par Le Biais de L'informatique et Des Nouvelles Technologies de L'information', 2014.) p. 3. [Page number referring to the online version of the article downloaded from the website of the Cujas Library in Paris (Accessed: 19 December 2019)]

1371 Other authors only refer to the applicant's possibility to deny answering an unlawful question. (Source: Gyulavári, T. (ed.) (2017) Munkajog. 3rd edn. Budapest: ELTE Eötvös Kiadó, p. 134.) The wording chosen by Mariann Arany-Tóth also suggests the existence of a mere right to refusal. (Arany-Tóth, M. (2008) A munkavállalók személyes adatainak védelme a magyar munkajogban. Szeged: Bába Kiadó, p. 125.) However, in my opinion, providing the possibility to the applicant to merely refuse to answer an unlawful question does not provide effective protection, as then the applicant would instantly have to face the consequences of the refusal, while in the case of being able to provide an untruthful answer, the employer would not even necessarily notice the applicant's act.
} 
the question face-to-face from the applicant, thus providing the possibility whether to (truthfully) answer, in the case of SNSs the employer does not ask for the same information face-to-face, but checks it by himself/herself without the involvement of the applicant. Therefore, the applicant is unable to effectively protect his/her rights during SNS background checks.

\section{Chapter 2: Social network sites and arising data protection questions}

456. Part I. already presented the most important data protection requirements, which were laid down in the GDPR. However, obtaining personal data from SNSs raises certain challenges to these existing requirements, putting applicants' right to data protection at risk. The aim of Chapter 2 is to present the arising data protection issues in relation to SNSs and recruitment and suggest answers to these questions.

457. Chapter 2 is composed of two parts: Section 1 will discuss the most important principles of data processing, while Section 2 will focus on issues relating to access and transparency. Here, a refinement must be made: though in Part I. access and transparency were mentioned among the data protection principles, here they are discussed under separate headings. The reason for this separation is due to the other principles being more relevant regarding the content available on SNSs, transparency and access rather relate to the procedure of conducting pre-employment SNS background checks.

458. Scope of the data protection regulation during the recruitment. Before addressing the legal issues specific to data protection, it must be examined whether data protection rules can apply to the phase of recruitment, and especially to (which) SNSs. According to certain public perceptions, once they posted information online, it should not come as a surprise to users of SNSs that this information is used, for example, in the hiring process. ${ }^{1372}$ It cannot be emphasized enough that while privacy protection indeed might be affected by the behaviour of the user, data protection rules apply regardless of whether it was the user who published himself/herself the information. ${ }^{1373,1374}$

1372 Flaherty, P. and Whitmore, S. (2013) 'Privacy Protection in the Digital Workplace', in Law Society of Upper Canada, Employment Law and the New Workplace in the Social Media Age. Toronto: Irwin Law, p. 23. and Lory, B. E. H. (2010) 'Using Facebook to Assess Candidates During the Recruiting Process: Ethical Implications', NACE Journal, 71(1), p. 37.

1373 Dupuis, M. (2013) 'La vie privée à l'épreuve des réseaux sociaux', Revue Lamy Droit Civil, (102), p. 44.

1374 The contrary might be true for questions asked during a job interview. According to an EU study, prepared by Paul De Hert and Hans Lammerant, the questions that are asked during an interview do not 
459. EU perspective: the WP29 opinion. The material scope of the GDPR applies to automated means of processing and to manual processing if the processed personal data are contained or are intended to be contained in a filing system, ${ }^{1375}$ regardless of the methods used. Therefore, when processing takes place through SNSs, data protection rules apply. The WP29 explicitly addressed the question of pre-employment and SNSs and stated in its "Opinion on data processing at work" that just because the personal data are made publicly available by the applicant, it does not mean that requirements, such as the legal ground, necessity, etc. would not apply to this kind of processing. ${ }^{1376,1377}$

460. The NAIH. In 2016 the NAIH came to the same conclusion as the WP29 in its "Information notice on the basic requirements of data processing at work", emphasizing that data protection requirements - such as prior notification, necessity, respect of the chosen data protection settings - shall apply. ${ }^{1378}$ In a case relating to employment background checks, similar conclusions were drawn, supplemented by raising attention to the arising data protection challenges, such as the enforcement of accuracy, lawfulness and the rights of the data subject. ${ }^{1379}$ Therefore, SNSs during recruitment are subject to data protection regulations.

\section{Section 1: Questions relating to data processing principles}

461. Using SNSs to assess the suitability of job applicants poses several questions in relation to the enforcement of the data protection principles. These principles were already presented in Part I., which contains their more detailed presentation: here, brief reference will be made to their core attributes, then focus will be put on the SNSspecific questions. Although Title 1 focuses on the phase of recruitment, even at this stage

necessarily fall under the scope of data protection law, as they are not always processed by automated means or are not intended to form part of a filing system. Even if that is the case, these questions are clearly related to privacy. Source: De Hert, P. and Lammerant, H. (2013) Protection of Personal Data in Work-related Relations. Study PE 474.440. Directorate General for Internal Policies, Policy Department C: Citizens' Rights and Constitutional Affairs. Civil Liberties, Justice and Home Affairs, p. 40.

${ }^{1375}$ Recital (15) of the GDPR; Paragraph 1 of Article 2 of the GDPR

1376 WP29 (2017) Opinion 2/2017 on data processing at work. 17/EN WP 249. p. 11.

1377 The CoE also expressly refers to the importance of refraining from bypassing a candidate's (and employee's) chosen privacy settings and from collecting data without their knowledge through an intermediary, under another name or using a pseudonym. Council of Europe (2015) Recommendation CM/Rec(2015)5 of the Committee of Ministers to member States on the processing of personal data in the context of employment, 5. 3. and Council of Europe, Committee of Ministers (2015) Explanatory memorandum to Recommendation CM/Rec(2015)5 of the Committee of Ministers to member States on the processing of personal data in the context of employment, p. 7.

1378 NAIH (2016): A Nemzeti Adatvédelmi és Információszabadság Hatóság tájékoztatója a munkahelyi adatkezelések alapvetö követelményeiröl, p. 19.

${ }^{1379}$ NAIH/2016/4386/2/V 
it must be highlighted that the same or very similar data protection questions might arise in other phases of the employment relationship as well. As a consequence, what is going to be discussed in this Chapter might be adequately applicable to other phases.

462. A subtitle must be clarified: part $\S 2$ employs the expression "data quality principle", an expression missing from Part I's analysis on the most important provisions of the GDPR. "Data quality" is a reference to the OECD's data protection guidelines, and it means that "[p]ersonal data should be relevant to the purposes for which they are to be used, and, to the extent necessary for those purposes, should be accurate, complete and kept up-to-date." 1380 The same principles exist in the GDPR as well, ${ }^{1381}$ so in the dissertation the term data quality principle is used, which includes the principles of data minimisaton and accuracy laid down in the GDPR.

\section{(§1) Lawfulness and purpose limitation}

463. Before addressing issues relating to the data quality principles, two preliminary questions must be discussed: lawfulness and the purpose limitation principle. As it was already examined in Part I., lawfulness requires the processing to be based on one of the six legal grounds: having a legal ground is an obligatory pre-requirement to any processing. The principle of purpose limitation is one of the most significant data processing principles, ${ }^{1382}$ therefore reference to it must also be made.

\section{(A) Principle of lawfulness}

464. Possibly applicable legal grounds. Under the GDPR, every data processing shall have a legal ground. According to Edit Kajtár, out of the six legal grounds regulated by the GDPR three might possibly be applied: consent, the necessity of processing in order to enter into the contract and the balancing between the rights of the individual and the data controller's legitimate interest. [(a), (b) and (f) of Article 6 of the GDPR $]^{1383}$ The possible application of these legal grounds must be assessed.

\footnotetext{
${ }^{1380}$ OECD (1980) Guidelines on the Protection of Privacy and Transborder Flows of Personal Data, Article 8

1381 Such as principles of data minimisation and accuracy - already addressed in Part I.

1382 European Union Agency for Fundamental Rights and Council of Europe (2018) Handbook on European data protection law: 2018 edition. Luxembourg: Publications Office of the European Union, p. 122.

1383 Kajtár, E. (2015) 'Think it over! Pre-employment search on social network sites', in Vinković, M. (ed.) New Developments in EU Labour, Equality and Human Rights Law. Proceedings from the International Jean Monnet Conference "New Developments in EU Labour, Equality and Human Rights Law", Osijek 21 and 22 May 2015. Osijek: Josip Juraj Strossmayer University of Osijek Faculty of Law, p. 100.
} 
465. Consent. One might ask the question: can the applicant consent to conducting an SNS background check? The GDPR reinforced the requirements towards consent, questioning its applicability in the employment context. ${ }^{1384}$ One of the requirements of consent is to be freely given - which is not ensured in cases when there is a clear imbalance between the controller and the data subject. ${ }^{1385}$ As a hierarchal relationship is present between job applicants and employers, consent does not seem to be appropriate when it comes to the lawfulness of pre-employment SNS background checks. ${ }^{1386}$

466. The necessity of processing in order to enter into a contract. Another possible legal ground is the performance of a contract, when processing is necessary in order to take steps at the request of the data subject prior to entering into a contract: when without the processing of personal data the contract between the parties could not be executed, the processing of these data will be considered lawful. ${ }^{1387}$ However, according to the WP29, prior to entering into contract, conducting a detailed background check following a candidate's application should not be understood as a necessary measure for entering into contract. ${ }^{1388}$

467. Balancing of rights and legitimate interests. The application of the 'balancing test' is also dubious, as it is the employer's legitimate interest to identify the best candidate possible, but he/she can achieve this purpose with less intrusive methods. ${ }^{1389}$ Still, for the above-mentioned reasons, it seems to be the most appropriate legal ground applicable to the case of pre-employment SNS screenings.

${ }^{1384}$ Zsolt György Balogh et al. are of the same opinion, though according to them consent as a legal ground was generally accepted by Hungarian doctrine. Source: Balogh, Zs. Gy. et al. (2012) 'Privacy in the Workplace', in Essays of Faculty of Law University of Pécs: Yearbook of 2012. Pécs: University of Pécs Faculty of Law, pp. 16-17.

1385 Recital (43) of the GDPR

${ }^{1386}$ However, according to the (previous) Hungarian literature, the voluntary nature of consent was present prior to concluding the employment relationship - erroneously according to my opinion. Athough these opinions did not address SNS background checks but the recruitment in general, especially the case of presumed consent when the applicant initiated the processing by applying for a position. Source: Balogh, Zs. Gy. et al. (2012) 'Privacy in the Workplace', in Essays of Faculty of Law University of Pécs: Yearbook of 2012. Pécs: University of Pécs Faculty of Law, p. 16.

1387 Péterfalvi, A., Révész, B. and Buzás, P. (eds) (2018) Magyarázat a GDPR-ról. Budapest: Wolters Kluwer Hungary, p. 123.

1388 WP29 (2014) Opinion 06/2014 on the notion of legitimate interests of the data controller under Article 7 of Directive 95/46/EC. 844/14/EN WP 217. p. 18.

${ }^{1389}$ Kajtár, E. and Mestre, B. (2016) 'Social networks and employees' right to privacy in the pre-employment stage: some comparative remarks and interrogations', Hungarian Labour Law E-journal, (1), pp. 32-33.; Kajtár, E. (2015) 'Till Facebook Do Us Part? Social Networking Sites and the Employment Relationship', Acta Juridica Hungarica, 56(4), p. 271. 


\section{(B) Purpose limitation}

468. The purpose of pre-employment SNS background checks is the same as for the whole recruitment process: to identify the best applicant. Following from the freedom to contract, this purpose will be legitimate. As it was already addressed in Chapter 1, both the FLC and the HLC define the purpose of processing: the employer can only access personal data available on SNSs if it serves the purpose of assessing the professional capacities of the applicant. The applicant's personal life must not be subject to preemployment SNS background checks. Pre-employment SNS background checks can serve this purpose, as information available on these sites can contribute to assessing the professional capacities of the applicant.

469. What have already been stated regarding the employer's legitimate interests during recruitment (identifying the best candidate) apply to SNSs as well, the purpose is unchanged. However, even with the existence of a legitimate purpose, processing can become unlawful if other data quality principles are not met. The following pages will focus on presenting the data quality principles that the employer must respect in addition to purpose limitation.

\section{(\$2) Data quality principle}

The reliability of the information is closely connected to the data protection principles, but their enforcement during a pre-employment SNS background check is highly questionable ${ }^{1390}$ - as it will be demonstrated in the following paragraphs. As it was referred to in the introduction, the principle of data quality means that "[p]ersonal data should be relevant to the purposes for which they are to be used, and, to the extent necessary for those purposes, should be accurate, complete and kept up-to-date."1391

\section{(A) Principle of data minimization}

470. Principle of data minimization. According to the principle of data minimization, personal data must be adequate, relevant and limited to what is necessary in

\footnotetext{
${ }^{1390}$ Flaherty, P. and Whitmore, S. (2013) 'Privacy Protection in the Digital Workplace', in Law Society of Upper Canada, Employment Law and the New Workplace in the Social Media Age. Toronto: Irwin Law, pp. 21-22.

${ }^{1391}$ OECD (1980) Guidelines on the Protection of Privacy and Transborder Flows of Personal Data, Article 8
} 
relation to the purposes for which they are processed, ${ }^{1392}$ basically requiring that only the minimum necessary personal data shall be processed. The following paragraphs will deal with the two components of this principle: relevancy and necessity.

471. Relevancy. Relevancy is ensured by both labour codes through limiting recruitment methods to information which is connected to the professional life of the applicant. Although these provisions aim to protect applicants' personal lives by stating that during recruitment only necessary information relating directly to the professional capacities of the candidate can be processed, ${ }^{1393}$ the implementation of this principle is quite challenging in the context of SNSs. Even though it is true that several types of personal data might contribute to assessing the applicant's professional aptitudes (e.g. verifying professional experience, communication skills, etc.), SNS profiles might also contain personal data directly relating to the personal life of the applicant - not fulfilling the requirement of relevancy.

472. The legal issue is that this "legally consultable" data (information relating to the professional life) and data not meeting the requirement of data minimization (information relating to personal life) are inseparable on the profile of the user. ${ }^{1394}$ For example, the employer might be entitled to access a candidate's profile in order to identify the best candidate, to verify information from the $\mathrm{CV}^{1395}$ or to look for negative comments regarding the previous employer. However, at the same time he/she could automatically gain access to data which have no connection or relevancy to the legitimate purpose - e.g. relationship status, political opinion, hobbies, family members, etc.

This is a recent issue, as in the pre-SNS era this information usually would not have been available to the employer in the course of a traditional job interview. For example, while race, sex, age are (usually) evident when the employer conducts an interview, other factors (often available on SNSs), such as relationship status, political affiliation, etc. are

\footnotetext{
${ }^{1392}$ Item c) of Paragraph 1 of Article 5 of the GDPR

${ }^{1393}$ Article L1221-6 of the FLC and Subsection (1) of Section 10 of the HLC

1394 Kajtár, E. (2015) 'Till Facebook Do Us Part? Social Networking Sites and the Employment Relationship', Acta Juridica Hungarica, 56(4), pp. 271-272.

1395 Kajtár, E. (2015) 'Think it over! Pre-employment search on social network sites', in Vinković, M. (ed.) New Developments in EU Labour, Equality and Human Rights Law. Proceedings from the International Jean Monnet Conference "New Developments in EU Labour, Equality and Human Rights Law", Osijek 21 and 22 May 2015. Osijek: Josip Juraj Strossmayer University of Osijek Faculty of Law, p. 101.
} 
typically not discovered through an interview (unless shared by the applicant or asked by the employer). ${ }^{1396}$

473. Necessity. Any monitoring shall be proportionate and the least intrusive possible $^{1397}$ compared to the purpose of the processing. In the context of SNSs, the employer must also consider if he/she can obtain the desired information with less intrusive methods, whether the monitoring is truly needed, or the same result could be achieved through traditional forms of monitoring. ${ }^{1398}$ It means that he/she must assess whether having a job interview, conducting a professional aptitude test, asking recommendation from the previous employer, or checking a professional SNS (e.g. LinkedIn) instead of a personal one would be a more privacy-friendly solution, which can still provide the necessary information.

474. Differentiation must be made between two types of personal data: personal data relating to the professional capacities of the applicant and personal data relating to his/her personal life. Regarding the first category, it must be assessed whether the traditional methods of recruitment (interview, tests, etc.) are capable of providing the employer the information sought. Regarding the second category, it was already established that SNSs might provide a glimpse into the user's personal life to an extent never experienced before.

Although the requirement of relevancy should limit employers to collecting personal data relating only to the professional life of the applicant, however, again, on SNSs it is technologically impossible to only collect this minimum necessary data, as the personal data which - in harmony with data minimization - could be collected and personal data not corresponding to this principle are inseparable on these sites. ${ }^{1399}$ As a result, even if the employer accesses the applicant's SNS profile to obtain information fulfilling the data

\footnotetext{
1396 Byrnside, I. (2008) 'Six Clicks of Separation: The Legal Ramifications of Employers Using Social Networking Sites to Research Applicants', Vanderbilt Journal of Entertainment and Technology Law, 10(2), p. 463

1397 WP29 (2001) Opinion 8/2001 on the processing of personal data in the employment context. 5062/01/EN/Final WP 48. p. 4, p. 21, p. 25.; WP29 (2017) Opinion 2/2017 on data processing at work. 17/EN WP 249. p. 7.

1398 WP29 (2002) Working document on the surveillance of electronic communications in the workplace. 5401/01/EN/Final WP 55. p. 13.

1399 Kajtár, E. (2015) 'Think it over! Pre-employment search on social network sites', in Vinković, M. (ed.) New Developments in EU Labour, Equality and Human Rights Law. Proceedings from the International Jean Monnet Conference "New Developments in EU Labour, Equality and Human Rights Law", Osijek 21 and 22 May 2015. Osijek: Josip Juraj Strossmayer University of Osijek Faculty of Law, p. 101.
} 
protection requirements, he/she might automatically gain access to personal data that he/she is not entitled to process.

475. An exception might be the use of professional SNSs (e.g. LinkedIn). Professional SNSs operate with the aim of providing the users the possibility to shape their online identities relating to their professional lives. Usually, users on these sites limit themselves to sharing personal data relating to their professional life (e.g. education, work experience, professional connections, etc.) - unlike on Facebook, Instagram and other personal SNSs. The CNIL is of the opinion that the use of professional SNS sites is allowed, as on these sites users provide only information regarding their professional lives. However, the employer is not entitled to search for the profiles on personal SNSs. ${ }^{1400}$

\section{(B) Principle of accuracy}

476. Accuracy. The principle of accuracy requires that personal data shall be accurate and, where necessary, kept up-to-date. ${ }^{1401}$ Usually personal data are considered to be inaccurate if they do not correspond with reality and also if they are not complete or are embedded into the wrong context. ${ }^{1402}$ These requirements are highly endangered in several regards when it comes to data obtained from SNSs. First, it will be examined whether the applicant himself/herself can be correctly identified during pre-employment SNS background checks. Second, it will be addressed whether the author of the content can play a role in relation to accuracy. Third, questions relating to the possible conclusions drawn from the content itself will be addressed. Then, the time factor, up-to-dateness will be examined.

477. Accuracy and identifying the applicant. First, the principle of accuracy can be very important regarding the identification of the job applicant. Identifying the right applicant is crucial in order to avoid situations where the employer finds the wrong

\footnotetext{
1400 CNIL (no date) Recrutement: l'employeur peut-il rechercher des données sur moi sur Internet? Available at: https://www.cnil.fr/fr/cnil-direct/question/354.

A proposed German bill (though rejected in 2013) reached the same conclusion, by making a distinction between personal and professional SNSs, prohibiting the access to the first category, but permitting access to the second one. Source: Kajtár, E. and Mestre, B. (2016) 'Social networks and employees' right to privacy in the pre-employment stage: some comparative remarks and interrogations', Hungarian Labour Law Ejournal, (1), p. 36

${ }^{1401}$ Item d) of Paragraph 1 of Article 5 of the GDPR

1402 Rücker, D. and Kugler, T. (eds) (2018) New European General Data Protection Regulation. A Practitioner's Guide. München, Oxford, Baden-Baden: C.H. Beck, Hart, Nomos. p. 68.
} 
candidate $^{1403}$ and the prospective employee is mistakenly associated with the SNS activity of someone else. This scenario can happen for several reasons: especially if the applicant has a very common name (e.g. Kovács Péter or Pierre Martin) and/or there is no other publicly available personal data (e.g. profile picture) which can help to correctly identify him/her. ${ }^{1404}$ Associating the online activities with the wrong individual unquestionably infringes the principle of accuracy.

478. Accuracy and posting information online. Second, the employee might not have been the author of the given content - a profile can be hacked by a third party: for example, Sherry D. Sanders describes a hypothetical situation where an applicant's Twitter profile is hacked: the hacker posts racist comments in the name of the applicant - which the applicant does not see, as he has not accessed his Twitter account for months. ${ }^{1405}$ Besides hacking, even friends or colleagues can post, as a prank, in the name of the applicant (for example, if he/she leaves his/her device unattended): see, for example, the case of an employee of a security company whose colleagues uploaded a video of him to his Facebook page, showing him demonstrating his physical competences on a floor of the European Commission only reserved for commissioners - and was dismissed as a consequence. ${ }^{1406}$ In extreme cases even fake profiles can be created: Ian Byrnside describes the phenomenon of college students intentionally creating fake profiles of others who are considered to be competition, containing unflattering information - ruining his/her chances of finding employment. ${ }^{1407}$

479. Accuracy and conclusions drawn from SNSs. Third, processing personal data obtained from SNSs can often lead to the misinterpretation of the personal data. It is highly questionable how/whether the employer can make reliable conclusions from accessing candidates' SNS profiles. Teresa Coelho Moreira illustrates how certain

1403 Tenenbaum, J. M. (2012) 'Posting Yourself Out of a Posting: Using Social Networks to Screen Job Applicants in America and Germany. [pre-print]'. Available at: https://papers.ssrn.com/sol3/ Delivery.cfm/SSRN_ID2062462_code1805294.pdf?abstractid=2020477\&mirid=1(Accessed: 14 July 2016). p. 13. Jason Tenenbaum googled himself and found out that typing "Jason Tenenbaum" into Google returns results for another attorney from a neighbouring town - providing the possibility to easily mistaken the two persons.

${ }^{1404}$ Flynn, N. (2012) The Social Media Handbook. Policies and Best Practices to Effectively Manage Your Organization's Social Media Presence, Posts, and Potential Risks. San Francisco: Pfeiffer. pp. 20-21.

1405 Sanders, S. D. (2012) 'Privacy is Dead: The Birth of Social Media Background Checks', Southern University Law Review, 39(2), p. 243.

${ }^{1406}$ Lambert, P. (2014) International Handbook of Social Media Laws. Haywards Heath: Bloomsbury, p. 230.

1407 Byrnside, I. (2008) 'Six Clicks of Separation: The Legal Ramifications of Employers Using Social Networking Sites to Research Applicants', Vanderbilt Journal of Entertainment and Technology Law, 10(2), p. 471. 
information can have dubious interpretation, therefore contradicting the principle of data quality. For example, there are several ways for the employer to interpret the fact that certain candidates are available on these sites, while others are not (do those present on these sites have more developed skills relating to technology or are the others more conscious regarding privacy issues?), or that an applicant likes to travel (is he/she flexible or rather unreliable?). ${ }^{1408}$

480. Also, often the information originally posted was intended for a different audience, ${ }^{1409}$ and although in a legal way it does not exempt the user, it constitutes a problem that users may not be aware of the functioning of SNSs and may be mistaken regarding the public or private nature of the published content, ${ }^{1410}$ publishing something presuming that it would be accessible only to a narrow circle of users - e.g. only to friends -, but not to the employer. Personal data available on these sites can be inaccurate, incomplete and easily interpreted out of context, thereby giving a false impression of the user. ${ }^{1411}$ As a result, the quality of personal data is not guaranteed. ${ }^{1412}$

481. Up-to-dateness. Fourth, up-to-dateness: in the context of recruitment, up-todateness means that a decision should not be based on outdated information. However, it must be seen that the Internet does not forget - it is also true in the case of SNSs: on SNSs information is often available dating back years. This principle also has a close connection with the right to be forgotten.

482. If personal data are outdated, the requirements of relevancy and accuracy are more easily infringed. A prospective employee might have loved partying wildly at a younger age and might have provided a rich documentation of this activity on Facebook bearing no relevancy with regard to his/her professional aptitudes years later. People are

\footnotetext{
1408 Moreira, T. C. (2013) 'The Digital To Be or Not To Be: Privacy of Employees and the Use of Online Social Networks in the Recruitment Process', GSTF International Journal of Law and Social Sciences (JLSS), 2(2), p. 77.

${ }^{1409}$ In the age of SNSs, when everyone equipped with a smartphone may feel as a celebrity, online profiles do not reflect the professional capacities of a user. Source: Ghoshray, S. (2013) 'The Emerging Reality of Social Media: Erosion of Individual Privacy Through Cyber-Vetting and Law's Inability to Catch Up', The John Marshall Review of Intellectual Property Law, 12(3), p. 572.

${ }^{1410}$ See more Sprague, R. (2011) 'Invasion of the Social Networks: Blurring the Line Between Personal Life and the Employment Relationship', University of Louisville Law Review, 50(1), p. 15.; Kajtár, E. and Mestre, B. (2016) 'Social networks and employees' right to privacy in the pre-employment stage: some comparative remarks and interrogations', Hungarian Labour Law E-journal, (1), pp. 24-25.

1411 Ghoshray, S. (2013) 'The Emerging Reality of Social Media: Erosion of Individual Privacy Through Cyber-Vetting and Law's Inability to Catch Up', The John Marshall Review of Intellectual Property Law, 12(3), pp. 562-563.

1412 Szabó, E. Gy. (2010) ‘A személyes adatok védelmének kérdései a virtuális világban', in Talyigás, J. (ed.) Az internet a kockázatok és a mellékhatások tekintetében. Budapest: Scolar Kiadó, pp.pp. 58-59.
} 
able to change and to develop, but the unforgettable (and unforgivable) nature of the Internet might stigmatize them and might not let them change and "escape" from their past mistakes or their past selves. For example, a funny photo taken in high school years ago or a compromising content can have an impact on the future carrier options even if it is not relevant anymore. ${ }^{1413}$ Five seconds eternalized on the web can define someone's whole Internet presence. ${ }^{1414}$

483. Since the wide adoption of SNSs, years have passed, leading to the phenomenon that certain (early) users possess a digital footprint on these platforms dating back years. The right to be forgotten aims to ensure that individuals can "escape" from their online past. ${ }^{1415}$ It is alarming that especially young users have the tendency to share the most intimate details of their personal lives. ${ }^{1416}$ However, following from the very nature of the SNSs' function, the documentation of these "reckless" young years permanently stays on the Internet. Accessing that past information might lead to the consequence that the employer draws present conclusions from the past, ${ }^{1417}$ which may lead to coming to incorrect conclusions. ${ }^{1418}$

484. In conclusion, data quality principles are highly at stake when it comes to processing information obtained from applicants' SNS profiles - possibly raising the

1413 On the importance of forgetting see Mayer-Schönberger, V. (2011) Delete - The Virtue of Forgetting in the Digital Age. Princeton and Oxford: Princeton University Press and Székely, I. (2013) 'Jog ahhoz, hogy elfelejtsenek és töröljenek', Információs társadalom, 13(3-4), pp. 7-27.

${ }^{1414}$ In the US, Lindsey Stone was fired after her colleague posted a photo to Facebook, showing Ms. Stone engaging in disrespectful behaviour (giving a finger and imitating a scream) in the Arlington National (military) Cemetery - next to a sign asking for silence and respect. According to her, she did not think, it was just part of an inside joke between her and her colleague. However, the firing was not the only negative outcome for Ms Stone: the photo went viral and she became the target of extremely hostile comments from the Internet community. Since then, she started working for a new employer, but said that she was terrified that the new employer would find out about what had happened in the cemetery. "Those five seconds of her life is her entire Internet presence [.]" Source: Ronson, J. (2015) 'Overnight, everything I loved was gone': the internet shaming of Lindsey Stone, The Guardian. Available at: https://www.theguardian.com/technology/2015/feb/21/internet-shaming-lindsey-stone-jonronson (Accessed: 3 May 2018).

1415 Rosen, J. (2012) The Right to Be Forgotten, Stanford Law Review. Available at: https://www.stanfordlawreview.org/online/privacy-paradox-the-right-to-be-forgotten/ (Accessed: 13 August 2019).

1416 Mayer-Schönberger, V. (2011) Delete - The Virtue of Forgetting in the Digital Age. Princeton and Oxford: Princeton University Press. p. 3.

${ }^{1417}$ Hajdú, J. et al. (forthcoming) 'Közösségi média és munkajog - különös tekintettel a Facebook-ra alapított felmondásokra a hazai szabályozás és a nemzetközi joggyakorlat tükrében’, De iurisprudentia et iure publico (DIEIP).

1418 As an illustrative example see the hypothetical scenario in which an individual's whole online presence was determined by a 2-minute-long interview in which he expressed his controversial opinion on a certain topic. Source: Ghoshray, S. (2013) 'The Emerging Reality of Social Media: Erosion of Individual Privacy Through Cyber-Vetting and Law's Inability to Catch Up', The John Marshall Review of Intellectual Property Law, 12(3), p. 555. 
question of completely banning these searches, as it will be discussed later. It means on the one hand that the applicants' rights can be easily infringed, and on the other hand that the employer can easily base his/her decision on unreliable data. These issues mainly arise on personal SNSs, which contain more information relating to personal life due to their nature.

\section{(§3) Conducting the background checks}

485. In order to find a right balance between the employer's interest of choosing the best applicant and the applicant's rights, it is important that if the employer decides to conduct an SNS background check, he/she follows a systematic approach instead of performing it in an ad hoc way. Drafting internal policies, providing trainings and documenting ${ }^{1419}$ could be useful means to achieve this objective. On the following pages the scope of the information to be viewed, the procedure in which they should be treated and the question of who should conduct these background checks will be discussed.

486. Scope of information. It was proposed on several occasions ${ }^{1420}$ that the employer should only access professional SNSs, but access to personal SNSs should be prohibited. Through legitimizing the consultation of only professional SNSs - and banning that of personal SNSs -, it could be achieved that the personal life of the applicant is left unaffected by the screening, while the professional profiles can help the employer better judge the professional capacity of the applicant. However, as it will be discussed in $\S 2$, prohibition in itself is not considered to be an effective solution, as because of the invisibility of such searches, the technical feasibility of such prohibition is highly questionable.

487. Time factors must also be taken into consideration: to handle the challenges relating to outdatedness and to the right to be forgotten, - in a joint publication with with József Hajdú, Viktória Lechner and Attila Turi - we recommended as a de lege ferenda suggestion to introduce a time limitation period for the processing of personal data originating from SNSs. It would mean that in accordance with the general limitation period

1419 Brown, V. R. and Vaughn, E. D. (2011) 'The Writing on the (Facebook) Wall: The Use of Social Networking Sites in Hiring Decisions', Journal of Business and Psychology, 26(2), pp. 223-224.

1420 CNIL (no date) Recrutement: l'employeur peut-il rechercher des données sur moi sur Internet? Available at: https://www.cnil.fr/fr/cnil-direct/question/354. and a proposed Germna draft bill from 2010: Source: Kajtár, E. and Mestre, B. (2016) 'Social networks and employees' right to privacy in the preemployment stage: some comparative remarks and interrogations', Hungarian Labour Law E-journal, (1), p. 36. 
in labour law, ${ }^{1421}$ posts, pictures and other contents published to SNSs before that period should not be processed in the recruitment process. ${ }^{1422}$

488. Procedure. If the employer decides to conduct pre-employment SNS screening, he/she should do it through a fair and uniform procedure. Case-by-case or discriminatory screenings are to be avoided. ${ }^{1423}$ If for a position a screening is required, each applicant should be screened, preferably at the late stage of the selection process in order to minimize the number of applicants screened. ${ }^{1424}$

489. SNS pre-employment screenings should not be conducted on a general basis. Their application should be limited to those cases when they are truly necessary, for example, when the nature of the given job or the type of employer justifies it (e.g. it is more probable that background checks can be justified if the position comes with high responsibility). Prior to the screening, objective criteria should be established in relation to what exactly the employer aims to know about the applicant (For example, are there spelling mistakes on the profile? Is there content promoting hatred? Are there negative comments regarding the previous employer?) - in accordance with the principle of relevancy.

490. Persons conducting the background checks. In order to solve the problem of the inseparability of personal and work-related information, it is advisable that a third party - who will not participate in the decision-making - conducts the background check and transmits only the work-related information to the decision-makers. ${ }^{1425}$ Thus it can be avoided that the decision-maker would make the decision based on personal data not fulfilling the criteria of data minimization and proportionality.

${ }^{1421}$ In Hungary the general limitation period is 3 years [Subsection (19) of Section 286 of the HLC]. In contrast, French regulation contains several limitation periods: which seems to be the most relevant is 5 years in case of discrimination. (Article L1134-5 of the FLC)

1422 Hajdú, J. et al. (forthcoming) 'Közösségi média és munkajog - különös tekintettel a Facebook-ra alapított felmondásokra a hazai szabályozás és a nemzetközi joggyakorlat tükrében', De iurisprudentia et iure publico (DIEIP).

${ }^{1423}$ Brown, V. R. and Vaughn, E. D. (2011) 'The Writing on the (Facebook) Wall: The Use of Social Networking Sites in Hiring Decisions', Journal of Business and Psychology, 26(2), p. 223.

1424 Information Commissioner's Office (2011) The employment practices code. Available from: https://ico.org.uk/media/for-organisations/documents/1064/the_employment_practices_code .pdf [Accessed 1 February 2017], p. 23.

1425 Peebles, K. A. (2012) 'Negligent Hiring and the Information Age: How State Legislatures Can Save Employers from Inevitable Liability', William and Mary Law Review, 53(4), pp. 1428-1429.; Sprague, R. (2011) 'Invasion of the Social Networks: Blurring the Line Between Personal Life and the Employment Relationship', University of Louisville Law Review, 50(1), p. 32. 
In this regard, the proposition of Nathan J. Ebnet might be relevant to French and Hungarian law, despite being recommended in the first place to US law. He recommends the use of third-party background screening service. He cites the example of Social Intelligence: ${ }^{1426}$ a company offering to conduct pre-employment online background checks in accordance with the legal regulations in force. ${ }^{1427}$ According to the description on Social Intelligence's website, they primarily search for and flag user-generated content in the field of (a) racist, sexist, or discriminatory behaviour, (b) sexually explicit material, (c) threats or acts of violence and (d) potentially illegal activity. At the end of the process the employer can review the report which contains examples of the negative content found, but none related to protected characteristics or private information with no connection to the job. If no negative information is found, the report will state that "No Pertinent Information" was found. ${ }^{1428}$ Although Ebnet admits that involving a third party in the background check comes with extra expenses to the employer, he believes that the efficiency of these searches would transform this expense into an investment. ${ }^{1429}$

In addition to involving an independent third-party in the recruitment process, he also suggests adopting elements from the already existing US Fair Credit Reporting Act, covering credit reports. ${ }^{1430}$ Namely, he recommends to require the prior approval of applicants of such a screening taking place and to notify applicants if an adverse decision is made. ${ }^{1431}$ Therefore transparency would be ensured and applicants would have the possibility to explain certain compromising content. He argues that through the adoption of these measures, an adequate balance can be found between the employer's legitimate interests and applicants' rights.

1426 Social Intelligence (no date) Social Media Screening for Intelligent Hiring. Available
at: https://www.socialintel.com/(Accessed: 13 August 2019).
${ }^{1427}$ Bell, M. (2011) More employers using firms that check applicants' social media history, The Washington
Post. Available at: https://www.washingtonpost.com/lifestyle/style/more-employers-using-firms-that-check-
applicants-social-media-
history/2011/07/12/gIQAxnJYGI_story.html?noredirect=on\&utm_term=.1506923db7c6(Accessed: August 2018).

1428 Social Intelligence (no date) The Social Media Hiring Report. Available at: https://www.socialintel.com/how-it-works/ (Accessed: 16 August 2018).

${ }^{1429}$ Ebnet, N. J. (2012) 'It Can Do More Than Protect Your Credit Score: Regulating Social Media PreEmployment Screening with the Fair Credit Reporting Act', Minnesota Law Review, 97(1), p. 327.

1430 The Fair Credit Reporting Act was adopted in 1970 and aims to regulate the collection and reporting of credit information about consumers, with the purpose of ensuring accuracy of the information collected. Ebnet, N. J. (2012) 'It Can Do More Than Protect Your Credit Score: Regulating Social Media PreEmployment Screening with the Fair Credit Reporting Act', Minnesota Law Review, 97(1), pp. 312-314.

${ }^{1431}$ Ebnet, N. J. (2012) 'It Can Do More Than Protect Your Credit Score: Regulating Social Media PreEmployment Screening with the Fair Credit Reporting Act', Minnesota Law Review, 97(1), pp. 326-327. 
491. Another type of third-party intermediary was suggested by Peter Baumhart. In response to the growing phenomenon of employers asking for applicants' passwords, he suggests the involvement of an information escrow agent in the pre-employment background check. The information escrow agent would act as an intermediary between the parties to whom applicants could disclose their passwords and employers could provide a list of information that needs to be flagged. ${ }^{1432}$ The employer would only receive the red flags relevant to the employment and no other irrelevant information. While the intrusion into the applicant's privacy exists, it is present to a lesser extent compared to the situation when the employer asks for the password. ${ }^{1433}$

Although it would be incompatible with French and Hungarian laws to legitimize a system where the applicant should provide his/her login credentials, some elements of these two solutions might be adapted to the legal system. The idea of involving an intermediary into the recruitment process could and should be adequately implemented although it would be better suited in the form of a third-party background screening service. With the participation of these third parties it could be prevented that the employer accesses data irrelevant to the employment - eliminating the issues in relation to the inseparability of professional and personal life during pre-employment SNS background checks.

\section{Section 2. Access and transparency of processing}

492. As data protection requirements apply even if the information was publicly made available by the applicant and is easily available, the employer still must inform applicants that an SNS background check might take place. It should be indicated prior to the recruitment - for example, in the job advertisement - that an SNS background check will be conducted during the selection process, and it should state precisely which sites will be checked and what the lawful information that the employer aims to obtain is. ${ }^{1434}$, 1435 However, in practice, this principle is often violated especially due to the (§1)

\footnotetext{
1432 Baumhart, P. B. (2015) 'Social Media and the Job Market: How to Reconcile Applicant Privacy with Employer Needs', University of Michigan Journal of Law Reform, 48(2), pp. 524-525.

${ }^{1433}$ Baumhart, P. B. (2015) 'Social Media and the Job Market: How to Reconcile Applicant Privacy with Employer Needs', University of Michigan Journal of Law Reform, 48(2), pp. 526-527.

${ }^{1434}$ Mikkelson, K. (2010) Cybervetting and Monitoring Employees' Online Activities: Assessing the Legal Risks for Employers. The Public Lawyer, 18 (2), p. 6.

${ }^{1435}$ NAIH (2016) A Nemzeti Adatvédelmi és Információszabadság Hatóság tájékoztatója a munkahelyi adatkezelések alapvetö követelményeiröl. Budapest, p. 19.
} 
invisibility of such searches. Besides transparency, it has also importance (\$2) how the employer can gain access to the information.

\section{(\$1) Access and transparency}

493. Principle of direct collection. According to the principle of direct collection, it is desirable that when it is possible, employers collect personal data directly from the individual concerned. ${ }^{1436}$ Although even before the expansion of SNSs the employer had different possibilities to obtain personal data not directly from the prospective employee (e.g. investigation, asking the previous employer for recommendation), with the advent and expansion of SNSs it has become considerably easier to collect personal data not directly from the data subject. ${ }^{1437}$ This fundamentally affects the ways of accessing personal data, giving room on the one hand for $(A)$ invisible searches and on the other hand for $(B)$ searches bypassing the individual's choice of privacy settings. These new ways of access also have serious implications for the transparency of processing.

\section{(A) Invisible background checks}

494. Transparency versus invisibility. The principle of transparency is highly at stake, as these SNS background checks often stay invisible for the applicant. What is meant by invisible background check is the employer accessing the publicly available profiles of the applicant - without his/her awareness. Often - depending on the (non) use of privacy settings - gaining access to a job applicants' profile is effortless and provides access to a wide amount of personal data. For example, the employer/recruiter might access the applicant's profile from outside of the SNS (if the privacy settings are set to public), or (if the privacy settings make the content available to other users) he/she can have access to the candidate's profile from his/her or the company's profile. Either way, access is fast, easy to conduct and cost-effective - and the individual is not necessarily aware of the conducted search.

1436 This principle is enshrined in the Council of Europe (2015) Recommendation CM/Rec(2015)5 of the Committee of Ministers to member States on the processing of personal data in the context of employment. 5. 1.: "Employers should collect personal data directly from the data subject concerned. When it is necessary and lawful to process data collected from third parties, for example, to obtain professional references, the data subject should be duly informed in advance."

${ }^{1437}$ Kajtár, E. (2016) Dignity at Work: Employee's Personality Rights in the 21st Century. Pécs: University of Pécs, Faculty of Law (PMJK Monographs 6). p. 149. 
495. Theoretically, labour law and data protection provisions are able to adequately regulate pre-employment SNS screenings. However, their enforcement in practice is highly problematic, as these screenings stay undetected, ${ }^{1438}$ often applicants are not aware that an adverse decision was based on an SNS background check. In practice, they (or DPAs) have limited chance to find out about the existence of such searches: for example, it might be possible that the applicant discovers the existence of a background check during the job interview, for example, if an employer asks questions about an event that he/she learned during an Internet search. ${ }^{1439}$ Still, besides these extreme cases, it is quasi impossible for the applicant to prove (or know) that the decision was based on the content found on SNSs. ${ }^{1440}$

496. Transparency and rights of the data subject. As a result, the legal issue is that the job applicant might not even be aware of the fact that a processing takes place which is contrary to the requirement of transparency. Knowing about the existence of a processing is a precondition to exercising the rights of the data subject. In the case of invisible searches, the applicant will not know what data the employer has access to, how he/she will interpret that information: the requirement of prior information and the principle of transparency guaranteed by the data protection regulation will be infringed.

497. Transparency is closely related to the exercise of the rights of the data subject: it follows from the invisible nature of these searches that the job applicant cannot participate in the data processing and cannot exercise his/her rights relating to data processing, as he/she might not even know about the processing. In addition, because of the high unreliability of personal data collected from SNSs, the infringement of rights might be considerable. Due to the challenges relating to the principle of accuracy, it is very easy to misinterpret those data, as they are taken out of context - and the user has no chance to participate in the processing. ${ }^{1441}$ The information vulnerability of the job

1438 Pók, L. (2012) ‘A közösség hálójában - Közösségi oldalak munkajogi vonatkozásai’, Infokommunikáció és jog, (1), p. 13.

1439 McGeveran, W. (2006) Finnish Employers Cannot Google Applicants. Available at: https://blogs.harvard.edu/infolaw/2006/11/15/finnish-employers-cannot-google-applicants/ (Accessed: 2 July 2018). Though the article did not detail it, in my opinion revealing the existence of a background check might be possible through accidentally seeing documentation, or by the interviewer asking questions that without a background check would not have been asked.

${ }^{1440}$ Kajtár, E. (2015) Till Facebook Do Us Part? Social Networking Sites and the Employment Relationship. Acta Juridica Hungarica, 56 (4), p. 278.

${ }^{1441}$ See, for example, the case of Nathalie Blanchard, who was diagnosed with major depression and went on sick-leave. However, all of a sudden, her insurance company cut her benefits because they saw photos of her on Facebook, in which she went to the beach, had fun with her friends, and went to bars. Therefore, the 
applicant might be considerable, therefore ensuring his/her participation in the processing and guaranteeing the exercise of the above-mentioned rights is crucial. If the true participation of the data subject through informing him/her about the existence of the screening and the exercise of the data subjects' rights are ensured, compliance with data protection regulation is realized, as a consequence of which the hiring decisions could be based on reliable data more effectively, thus serving the purpose of identifying the best candidate.

498. Providing prior information to applicants is crucial in ensuring the transparency of processing. However, as Attila Péterfalvi et al. noted, if providing prior information can jeopardize the principle of accuracy, the information should be kept to the necessary extent. ${ }^{142}$ The employer should inform employees that an SNS background check will be conducted during the selection process, state precisely which sites will be checked and what the lawful information that the employer aims to obtain is. ${ }^{1443}$ Also, a contact should be provided to applicants, where they could turn in case they wanted to exercise their rights of data subject. Applicants should be given the possibility to consult and if necessary, to rectify the personal data processed.

\section{(B) Other ways of access}

499. Invisible searches are not the only way to access data on SNSs although they constitute the most evident way of access. Other, more intrusive practices exist which can provide the employer access to a candidate's profile. Among these "other ways of access" differentiation is made between two groups: obtaining access to content available to other users and obtaining access to content available to the user himself/herself. ${ }^{1444}$

company judged that she is not sick anymore. However, what was not known to them was that Ms. Blanchard performed these activities on her doctor's orders, as part of her healing process. Source: Depressed woman loses benefits over Facebook photos (2009) CBC News. Available at: http://www.cbc.ca/news/canada/montreal/depressed-woman-loses-benefits-over-facebook-photos1.861843(Accessed: 3 May 2018).

1442 Péterfalvi, A. (ed.) (2012) Adatvédelem és információszabadság a mindennapokban. Budapest: HVGORAC, p. 299. However, such statement might raise the question whether in relation to SNSs employees can alter the result of the background checks by taking certain steps (e.g. applying privacy settings) and hindering access to the profile.

${ }^{1443}$ Mikkelson, K. (2010) 'Cybervetting and Monitoring Employees' Online Activities: Assessing the Legal Risks for Employers', The Public Lawyer, 18(2), p. 6.

1444 The ways of accessing that are grouped into these two categories are from: Engler, P. and Tanoury, P. (2007) 'Employers Use of Facebook in Recruiting', in McIntosh, D. et al. (eds) The Ethical Imperative in the Context of Evolving Technologies. University of Colorado Leeds School of Business, pp. 65-66. Available at: http://www.ethicapublishing.com/ethicalimperative.pdf (Accessed: 13 July 2016)..; Park, S. (2014) 
500. Obtaining access to content available to other users. Under this category it is supposed that the applicant has used privacy settings and made steps towards concealing information from certain categories of users and the employer would like to bypass those settings and gain access to more information than by default he/she is allowed to. He/she can do so by friending the applicant, asking the applicant to change the privacy settings or ask a friend of the applicant who is employed at the workplace to provide access through his/her own profile.

501. Obtaining access to content available to the user himself/herself. In this case the interference in the applicant's private life is more serious, as through these means the employer can access an extremely wide circle of information - even those only available to the data subject. In the most serious case hacking might also be imaginable. ${ }^{1445}$ During a job interview the employer might ask the applicant to log in to his/her profile and "show the employer around" or can ask for the applicant's password.

502. Asking for applicants' password is not an uncommon phenomenon, ${ }^{1446}$ especially in the US, where the States enacted several password protection acts in order to ensure the protection of applicants' rights. ${ }^{1447,1448}$ As an illustrative example, see the hiring policy of the city of Bozeman in the US, resulting in a public outcry. In 2009 the Bozeman Daily Chronicle aired an article describing the excessive online pre-employment background checks conducted by the city. For years, the city systematically asked

'Employee Internet Privacy: A Proposed Act that Balances Legitimate Employer Rights and Employee Privacy', American Business Law Journal, 51(4), p. 790.

1445 That was the case of a Finnish employer, where two managers intercepted an employee's private communication on Facebook and were accused of hacking and were finally sentenced. Source: Lambert, P. (2014) International Handbook of Social Media Laws. Haywards Heath: Bloomsbury. pp. 307-308.

1446 Reacting to this emerging issue, even Facebook published an announcement in which it encouraged applicants/employees not to provide their passwords to the employer and called upon employers not to ask for passwords. Facebook newsroom (2012) Protecting Your Passwords and Your Privacy. Available at: https://newsroom.fb.com/news/2012/03/protecting-your-passwords-and-your-privacy/ (Accessed: 13 August 2019).

1447 This was especially a concern in the US. Against these phenomena various password protection acts were enacted. See more in: Sprague, R. (2014) 'No Surfing Allowed: A Review \& Analysis of Legislation Prohibiting Employers from Demanding Access to Employees' \& Job Applicants' Social Media Accounts', Albany Law Journal of Science and Technology, 24(3), pp. 481-513. and Del Riego, A., Sánchez Abril, P. and Levin, A. (2012) 'Your Password or Your Paycheck?: A Job Applicant's Murky Right to Social Media Privacy', Journal of Internet Law, 16(3), pp. 1, 18-26.

1448 There were also reported cases in Canada, where the Office of the Information \& Privacy Commissioner for British Columbia had to react to a case concerning an employer asking for job applicants' passwords. Source: Office of the Information \& Privacy Commissioner for British Columbia (no date) Summary of the Office of the Information and Privacy Commissioner's Investigation of the BC NDP's use of social media and passwords to evaluate candidates. P11-01-MS. Available at: https://www.oipc.bc.ca/mediationsummaries/1399 (Accessed: 8 July 2019). 
prospective employees to provide their login credentials (username and passwords) to SNSs they were present on as part of their general recruiting practice. ${ }^{1449}$

503. Infringement of the applicant's rights. In these cases, the applicant's right to respect for private life is infringed as the employer gains access to information that the applicant intended to conceal from him/her or even not to publicly share with anyone (e.g. chat messages). Also, by using the privacy settings and customizing access to the content, the applicant exercises his/her right to informational self-determination - which is bypassed by the employer.

From a data protection viewpoint, bypassing the privacy settings is not compatible with EU or national legislation either. The CoE, the WP29 and the NAIH all stated that only the publicly available personal data can be used in the recruitment process, ${ }^{1450}$ while the CNIL completely excluded personal SNSs from the process: ${ }^{1451}$ therefore no corresponding legal ground can be found in these regulations. In addition, it constitutes a problem that when the applicant is requested to act (accept friend request, change the privacy settings, log into or provide password), the hierarchal relation between the parties poses a challenge. If the applicant complies with the request, the voluntary nature of this act is highly questionable. When instead of the applicant, a common friend, an employee is asked to provide access through his/her own profile, ${ }^{1452}$ the drawbacks of the hierarchal relation are manifested between the employee and the employer. In the latter case transparency issues might also arise, as the applicant is not necessarily aware that an employee provided access to his/her profile.

\section{(C) Regulating instead of prohibiting}

\footnotetext{
1449 Ricker, A. (2009) City requires Facebook passwords from job applicants, Bozeman Daily Chronicle. Available at: https://www.bozemandailychronicle.com/news/city-requires-facebook-passwords-from-jobapplicants/article_a9458e22-498a-5b71-b07d-6628b487f797.html (Accessed: 3 May 2018)

${ }^{1450}$ Council of Europe (2015) Recommendation CM/Rec(2015)5 of the Committee of Ministers to member States on the processing of personal data in the context of employment, 5. 3. and Council of Europe, Committee of Ministers (2015) Explanatory memorandum to Recommendation CM/Rec(2015)5 of the Committee of Ministers to member States on the processing of personal data in the context of employment, $\mathrm{p}$. 7.; NAIH (2016) A Nemzeti Adatvédelmi és Információszabadság Hatóság tájékoztatója a munkahelyi adatkezelések alapvetö követelményeiröl. Budapest, p. 19.

1451 CNIL (no date) Recrutement: l'employeur peut-il rechercher des données sur moi sur Internet? Available at: https://www.cnil.fr/fr/cnil-direct/question/354.

${ }^{1452}$ In a Belgian case in 2011 the employer gained access to an employee's account by asking another employee to communicate him a certain content. Lambert, P. (2014) International Handbook of Social Media Laws. Haywards Heath: Bloomsbury. p. 230.
} 
504. Prohibiting SNS screening. The hypothesis of Title 1 is that instead of prohibiting the conduct of pre-employment SNS background checks, they should rather be regulated. Certain steps were made towards prohibiting SNS background checks: in France an agreement was signed between different professional associations, aiming to achieve that employers do not use search engines and SNSs for recruitment. ${ }^{1453}$ Others differentiated between personal and professional SNSs: the CNIL also expressed that personal SNSs should not be consulted in the recruitment process as they reveal a multitude of information pertaining to the private life of the applicant. ${ }^{1454,1455}$ A German draft bill from 2010 adopted the same position and prohibited access to personal SNS profiles, while allowing to use information from professional SNSs. ${ }^{1456}$ In Finland, due to the principle of direct collection, it is forbidden to google applicants ${ }^{1457}$ or to perform an SNS background check. ${ }^{1458}$

505. Regulating pre-employment SNS background checks. In contrast to the opinions arguing that SNS background checks should be prohibited, other solutions welcomed the regulation of SNS background checks, instead of prohibiting them. It was already discussed that the WP29 expressed how the data protection requirements shall apply to SNS screenings, ${ }^{1459}$ indirectly implying that these searches are not prohibited. In the UK, the Information Commissioner's Office's (hereinafter referred to as: ICO) Employment Practices Code, instead of banning these searches, laid down the

${ }^{1453}$ A Compétence Egale (no date) Charte réseaux sociaux, Internet, Vie Privée et Recrutement. Available at: https://www.michaelpage.fr/sites/michaelpage.fr/files/Charte_rxseaux_sociaux_internet_vie_privxe_et_re crutement.pdf(Accessed: 13 August 2019). Gros, M. (2010) Recrutement: une Charte pour contrer les dérives liées aux réseaux sociaux, Le Monde Informatique. Available at: https://www.lemondeinformatique.fr/actualites/lire-recrutement-une-charte-pour-contrer-les-derives-lieesaux-reseaux-sociaux-29715.html (Accessed: 13 August 2019).

1454 CNIL (no date) Recrutement: l'employeur peut-il rechercher des données sur moi sur Internet? Available at: https://www.cnil.fr/fr/cnil-direct/question/354.

1455 This standpoint is further nuanced by doctrine: Caroline Fel and Emmanuel Sordet argue that if the applicant's SNS profile is accessible to the public, his/her right to privacy is not infringed if the employer accesses the profile. Source: Fel, C. and Sordet, E. (2010) 'L'utilisation des réseaux sociaux par l'entreprise et ses collaborateurs', JCP S (édition sociale), (29), p. 22.

${ }^{1456}$ Finally, for reasons of lack of consensus, the proposed bill was rejected in 2013. Source: Kajtár, E. and Mestre, B. (2016) 'Social networks and employees' right to privacy in the pre-employment stage: some comparative remarks and interrogations', Hungarian Labour Law E-journal, (1), p. 36.

1457 McGeveran, W. (2006) Finnish Employers Cannot Google Applicants. Available at: https://blogs.harvard.edu/infolaw/2006/11/15/finnish-employers-cannot-google-applicants/ (Accessed: 2 July 2018).

${ }^{1458}$ Knaaplia, S., Koskela, I. and Havia, S. (2018) Employment \& labour law in Finland, Lexology. Available at: https://www.lexology.com/library/detail.aspx?g=b03caa90-2830-4194-a967-6cceaa561e7e (Accessed: 17 July 2018)

${ }^{1459}$ WP29 (2017) Opinion 2/2017 on data processing at work. 17/EN WP 249, p. 11. 
requirements towards pre-employment vetting, such as notifying applicants. ${ }^{1460}$ In 2016 the $N A I H$ in its "Information notice on the basic requirements of data processing at work" argued that it would not be reasonable to prohibit the use of SNSs in the recruitment process. ${ }^{1461}$ The NAIH also noted that it is permissible to make conclusions from the profiles but further processing operations such as making copies of the profile, storing or transferring it are prohibited. ${ }^{1462}$

506. Even though banning pre-employment SNS screenings would indeed constitute a straightforward solution and in theory would eliminate all the data protection challenges discussed throughout Title 1, in practice this solution seems unreasonable because of the invisibility of such searches and because of its benefits. ${ }^{1463}$ Due to the ease and the invisibility of these searches, in practice it seems to be more effective to allow conducting them while providing guidance on how to comply with the data protection requirements than completely prohibiting such screenings - also corresponding better with the reality of social media. Regulated SNS pre-employment background checks could contribute to ensuring accessibility, accuracy, relevancy and other principles, ${ }^{1464}$ thus respecting individuals' rights to a greater extent - in contrast to "clandestine" searches. However, as even in the case of regulation these searches stay invisible and evade enforcement, one might ask why regulation would be a better solution when prohibition is judged to be ineffective.

507. Employer's interest in regulating SNS background checks. The answer is because employers as well are interested in conducting background checks in accordance with data protection requirements. It would be necessary and welcomed that employers realize that it is also in their own interest to comply with the data protection regulation for two reasons. On the one hand, in the case of non-compliance with the data protection requirements, they can face various consequences in which the GDPR has become more severe: they can face administrative fines up to 20 million euros, or in the case of an

1460 Information Commissioner's Office (2011) The employment practices code. Available at: https://ico.org.uk/media/for-

organisations/documents/1064/the_employment_practices_code.pdf(Accessed: 8 October 2018), p. 23.

1461 NAIH (2016): A Nemzeti Adatvédelmi és Információszabadság Hatóság tájékoztatója a munkahelyi adatkezelések alapvetö követelményeiröl, p. 19.

1462 NAIH (2016): A Nemzeti Adatvédelmi és Információszabadság Hatóság tájékoztatója a munkahelyi adatkezelések alapvetö követelményeiröl, p. 19.

${ }^{1463}$ Kajtár, E. and Mestre, B. (2016) 'Social networks and employees' right to privacy in the pre-employment stage: some comparative remarks and interrogations’, Hungarian Labour Law E-journal, (1), p. 38.

${ }^{1464}$ Ebnet, N. J. (2012) 'It Can Do More Than Protect Your Credit Score: Regulating Social Media PreEmployment Screening with the Fair Credit Reporting Act', Minnesota Law Review, 97(1), p. 326. 
undertaking, up to $4 \%$ of the total worldwide annual turnover. ${ }^{1465}$ However, because of the invisibility of these searches, this scenario has little practical relevance.

On the other hand, the issues relating to the data protection principles highly question the relevancy, necessity, reliability, up-to-dateness and accuracy of the obtained data. If no safeguards are applied during the screenings, this practice could be counterproductive in choosing the best candidate possible. This means that not only prospective employees' rights might be infringed but the employer would base his/her decision on unreliable data. Because of invisibility, it is of key importance that employers realize that - in addition to respecting applicants' rights - it also serves their own interests to comply with the data protection regulation and avoid screening in an inefficient or illegal way. If the employer is aware of these potential risks and proceeds accordingly, these risks can be eliminated. ${ }^{1466}$ Ensuring the participation of the applicant and considering that too much information does not necessarily help making the decision can be the means to achieve that. ${ }^{1467}$

\section{(\$2) Role of the applicant}

508. Although it is the employer who is in a more dominant position as he/she defines the methods used during the recruitment, leaving no decision-making position for the employee, and conducts the background check himself/herself, it is important to realize that applicants can also take steps towards ensuring the protection of their rights in the $21^{\text {st }}$ century. Although data protection applies irrespective of whether the applicant is oversharing or posting once in a lifetime, applicants can also take further steps in order to actively practice their right to informational self-determination and they can highly contribute to preventing the occurrence of negative consequences in the hiring process: both in the field of preventing the rise of these issues and also in detecting them after they have occurred.

(A) Increased consciousness during the use of SNSS

\footnotetext{
1465 Article 83 of the GDPR

1466 Byrnside, I. (2008) 'Six Clicks of Separation: The Legal Ramifications of Employers Using Social Networking Sites to Research Applicants', Vanderbilt Journal of Entertainment and Technology Law, 10(2), p. 471.

1467 Byrnside, I. (2008) 'Six Clicks of Separation: The Legal Ramifications of Employers Using Social Networking Sites to Research Applicants', Vanderbilt Journal of Entertainment and Technology Law, 10(2), p. 474.
} 
Through the adoption of a more conscious behaviour while using and posting to SNSs - in accordance with the right to informational self-determination requiring data subjects to be an active part in the processing -, applicants can increasingly contribute to the protection of their rights - while still enjoying the possibilities provided by SNSs. With such conduct, the major part of problems might even be prevented.

509. Using privacy settings. Concerning the appropriate audiences, the use of privacy settings is a crucial point. The CNIL emphasizes the importance of actively managing the privacy settings in order to control which audiences can have access to the content on their profiles. ${ }^{1468}$ For example, Facebook gives users the possibility to use differentiated privacy settings - in theory it is possible that every friend of the user has access to a different content on the profile. ${ }^{1469}$ By effectively using the privacy settings, it would be possible to shape the online identity into an "employer-friendly" version, where the employer (or users with whom the employee is not friends) can only have access to one part of the profile - for example, to a part only containing professional information, while access is reserved to the closest friends of the user.

Even though $100 \%$ safe protection does not exist, and a very determined employer can somehow bypass privacy settings, most employers encountering the barriers imposed by data protection settings would not start to hack the profile in order to gain access to it. Even with such minimal precaution a considerable part of the problems - except for the extreme cases - could be successfully prevented.

510. Sharing the right content. Besides applying at least basic privacy settings, it is crucial that the applicant should be aware of what kind of information he/she shares and with which audience. Regarding the content shared, at the $30^{\text {th }}$ International Conference of Data Protection and Privacy Commissioners it was advised that SNS users carefully consider what kind of personal data they publish on these sites and whether they

\footnotetext{
1468 CNIL (no date) Maîtriser les informations publiées sur les réseaux sociaux. Available at: https://www.cnil.fr/fr/maitriser-les-informations-publiees-sur-les-reseaux-sociaux (Accessed: 26 February 2017) and Cornesse, I. (2011) 'Quand la CNIL vient au secours des salariés', Revue Lamy Droit des affaires, 58 , pp. 52-53.

${ }^{1469}$ To stay with the example of Facebook, before sharing something, the applicant should think over what the right form for the given content is: would he/she want to share - for example, holiday pictures - in an album accessible to all Facebook users, or "only" to all of his/her friends, to his/her closest friends or in a private group destined for communication with the closest friends, or in a private message, etc.?
} 
publish any personal data to these sites. They should not forget that they might be later confronted with that information in a different context, for example, in a hiring process. ${ }^{1470}$

Although the use of privacy settings can provide certain protection, it is safer if users do not rely heavily on them and, in addition, carefully think over whether to post or not to post. ${ }^{1471}$ There exists a so-called Grandmother rule, which can help users to judge the appropriateness of material published on SNSs: according to this rule, users should only share information on SNSs that they would feel comfortable to share with their grandmother. ${ }^{1472}$

511. Respecting the rights of others. Privacy is a collective matter: what a user does might affect another user. ${ }^{1473}$ In the age of Web 2.0 individuals do not owe a perfect control over their online presence. ${ }^{1474}$ Even if someone is conscious regarding his/her ereputation, other users can publish information relating to third parties. It is important that users should refrain from publishing personal data relating to other users without their consent (e.g. pictures and tagging). ${ }^{1475}$

\section{(B) E-reputation and awareness}

Managing e-reputation ${ }^{1476}$ does not consist simply of the single act of abstaining from posting certain content: it should be continuously monitored. Even if the individual himself/herself does not use SNSs, it is recommended to monitor possible online presence in order to be able to detect any possibly compromising information and take the necessary steps. In order to promote such behaviour, raising awareness is crucial, so that individuals can have knowledge of the possible risks and adopt a more conscious behaviour.

$147030^{\text {th }}$ International Conference of Data Protection and Privacy Commissioners Strasbourg, 17 October 2008 p. 2.

1471 Pók, L. (2012) 'A közösség hálójában - Közösségi oldalak munkajogi vonatkozásai’, Infokommunikáció és jog , (1), p. 13.

1472 Byrnside, I. (2008) 'Six Clicks of Separation: The Legal Ramifications of Employers Using Social Networking Sites to Research Applicants', Vanderbilt Journal of Entertainment and Technology Law, 10(2),p. 474.

1473 boyd, danah (2011) 'Networked Privacy'. Personal Democracy Forum, New York, NY, 6 June. Available at: http://www.danah.org/papers/talks/2011/PDF2011.html (Accessed: 28 February 2017).

1474 Szabó, E. Gy. (2010) ‘A személyes adatok védelmének kérdései a virtuális világban’, in Talyigás, J. (ed.) Az internet a kockázatok és a mellékhatások tekintetében. Budapest: Scolar Kiadó, p. 58.

1475 30th International Conference of Data Protection and Privacy Commissioners Strasbourg, 17 October 2008 p. 2.

1476 According to the CNIL, e-reputation is the online image of the individual, composed of every piece of information relating to the individual available online, e.g. blog, videos, photos either published by the individual or by others. Source: CNIL (2011)L'e-réputation en questions. Available at: https://www.cnil.fr/fr/le-reputation-en-questions-0 (Accessed: 4 April 2017). 
512. Monitoring e-reputation. The user should also control his/her digital identity by monitoring what information is available regarding him/her on the Internet for example, typing his/her name into a search engine in order to monitor whether third persons have posted information relating to him/her. ${ }^{1477}$ Such content could have been posted by the individual or by other parties (see, for instance, the example of creating fake profiles for competition), or can simply give results of individuals sharing the same name.

If the applicant is aware of the content which the employer might have access to, he/she can make the necessary steps to remove that content. ${ }^{1478}$ Either he/she can ask the third party to remove the content, or can report it, or can even use online reputation management services. These online reputation management services help users track, verify online information or shape online personas. ${ }^{1479}$

513. Not only information published by third parties should be monitored: regularly reviewing the content previously published by the user himself/herself (e.g. pictures from years before) and removing what is not relevant any more can also play an important role.

514. Raising awareness amongst users. In order to ensure the active and effective participation of individuals, it is crucial that individuals are aware of the basic functioning of these sites, the issues in relation to their right to data protection and the possible consequences of the use of SNSs. As an example, in France, the CNIL takes very forward-thinking steps in informing users on what behaviour they should adopt in order to take steps to protect their own privacy. They actively engage in social media and promote their activity. They publish information notices, informing users in a plain, concise language on their rights or on how to protect them. Two documents relate directly to the subject of the present Chapter: an article entitled "Job applicants: protect your own

1477 CNIL (2011) L'e-réputation en questions. Available at: https://www.cnil.fr/fr/le-reputation-en-questions0 (Accessed: 4 April 2017).

1478 Byrnside, I. (2008) 'Six Clicks of Separation: The Legal Ramifications of Employers Using Social Networking Sites to Research Applicants', Vanderbilt Journal of Entertainment and Technology Law, 10(2), p. 474.

1479 Kennedy, N. and Macko, M. (2007) 'Social Networking Privacy and Its Effects on Employment Opportunities', in Larsen, K. R. and Voronovich, Z. A. (eds) Convenient Or Invasive: The Information Age. Ethica Publishing.

Available at: http://www.ethicapublishing.com/inconvenientorinvasive/2CH12.pdf (Accessed: 10 December 2019), p. 11. (Page number referring to the online version of the article.) 
reputation on the web!" 1480 and a poster entitled "10 pieces of advice to stay clean on the web."1481, 1482 The first document aims directly job applicants and includes pieces of advice, such as think before posting, manage e-reputation, highlight content that puts the user in a favourable light, pay attention to tags and to privacy settings. The second document is more general and provides practical advice to users of the Internet, such as the use of privacy settings, respecting the privacy of others, managing e-reputation, using several e-mail addresses and pseudonyms, choosing passwords, etc.

515. In contrast to this active, awareness raising activity of the CNIL, in Hungary, the NAIH has room for improvement. Even though on the website of the NAIH rich documentation is available including the annual reports, cases and information notices, these are official documents, lacking a plain language. To date the NAIH is not present in social media. Although different information notices and other materials were published in the field of children's online data protection, ${ }^{1483}$ their awareness raising activity is not as comprehensive as the CNIL's.

516. Suggestion for the NAIH. As a suggestion it would be recommended for the NAIH to become present in social media in order to make its activity more available for individuals - such as the CNIL in France. Although this would not instantly resolve challenges relating to data protection and employment, it would constitute an important step in raising awareness and promoting the right to data protection.

\section{Conclusions of Title 1}

517. It was demonstrated that it is the employer's natural need to be interested in knowing as much as possible about job applicants in order to identify and hire the most

1480 CNIL (2014) Candidats à l'emploi: protégez votre réputation sur le web! Available at: https://www.cnil.fr/fr/candidats-lemploi-protegez-votre-reputation-sur-le-web (Accessed: 19 August 2018).

${ }^{1481}$ CNIL (2016) 10 conseils pour rester net sur le web. Available at: https://www.cnil.fr/fr/10-conseils-pourrester-net-sur-le-web (Accessed: 19 August 2018).

1482 Other, more general articles advise users on how to adopt a more privacy and data protection conscious use on the Internet and on SNS, e.g. how to secure their accounts through adopting appropriate passwords, what precautions to adopt when using a public WIFI, how to use privacy settings etc. See these articles in: CNIL (no date) Configurer ses outils. Available at: https://www.cnil.fr/fr/configurer (Accessed: 5 November 2018).

${ }^{1483}$ They were published in the frame of the project entitled "Key to the World of the Net!" and aimed to ensure the protection of children in the online world. A study was published together with different videos, quizzes and advice. The materials are available at the following site: NAIH (no date) Adatvédelemröl fiataloknak 'kulcs a net világához' projekt. Available at: https://www.naih.hu/adatvedelemr-l-fiataloknak-kulcs-a-net-vilagahoz--projekt.html (Accessed: 19 August 2018). 
suitable individual for the given post. From a legal perspective, this interest is manifested in the freedom to contract, meaning that the employer is entitled to choose with whom he/she would like to conclude an employment relationship - for which he/she needs to obtain certain information to assess the aptitude of the applicant during the recruitment. However, during this recruitment procedure the applicant is entitled to the right to privacy and the right to data protection.

Due to the vast amounts of information available on these sites, employers often use SNSs during recruitment. SNSs put these already existing rights into a new light: the proliferation of using SNSs during the recruitment resulted in the emergence of a new kind of privacy and data protection issues. These issues were analysed in detail throughout the Title.

One of the de lege ferenda suggestions concerned the legal "acknowledgement" of SNSs as an often-used recruitment tool: it was suggested that the relevant provisions of the FLC and the HLC on data protection should be amended to include cases when the employer does not ask the applicant to provide certain information but obtains the information sought unilaterally, without involving the applicant in the process. The latter is typically the case of SNSs, when employers access the publicly available profiles of the applicant. This grammatical clarification of the labour codes would make it unequivocal that SNSs do not evade legal regulations - even despite the fact that it is usually the applicant who made the information available. Another de lege ferenda suggestion related to Hungarian labour law and opted for clarifying that the provisions of the HLC are to be applied to job applicants as well - as it is already the case with the FLC.

518. Prohibition or regulation? It was also discussed whether it should be prohibited to conduct pre-employment SNS background searches in order to better protect applicants' personal lives. ${ }^{1484}$ After having examined the existing viewpoints, the dissertation adopts the position that it would be unreasonable to prohibit such searches: instead, they should be tolerated and regulated regarding how exactly they should be conducted in order to effectively protect applicants' rights. The main reason for opting for such a viewpoint is that even if these searches are legally prohibited, they stay invisible,

1484 This was the matter where differences were found between the French and Hungarian approach: the NAIH argued that it would not be reasonable to ban the employer from looking at publicly available data on SNSs (even on personal SNSs), while the CNIL argued that the screening of personal SNSs should be prohibited. 
making it easy and effortless to bypass such a prohibition. Therefore, it would be more reasonable to make employers realize ${ }^{1485}$ that it is also their interest to control themselves while executing these searches and comply with the legal regulations and not to conduct unlimited background checks. Indeed, respecting the data protection requirements primarily has the purpose of enforcing applicants' rights, but secondarily it also serves the interests of the employer, as non-compliance with these requirements would provide the employer with unreliable data, which may result in sorting out an otherwise perfect applicant and being counterproductive in relation to the aim of finding the best applicant. As a solution, employers should understand how to screen properly, in order to avoid screening in an inefficient or illegal way.

519. Issues relating to data quality. As for the data protection principles, the most problematic areas were authenticity, accuracy and relevancy of the personal data. Not respecting these requirements does not only infringe the right to data protection, but also leads to the processing of unreliable, inaccurate data. As a de lege ferenda suggestion it was recommended to set a time limit: the employer should not use personal data published on SNSs before a certain time period - set according to the limitation period in labour law.

520. Transparency. Transparency - and in connection with it the invisibility of the searches - is important not only because it makes the prohibition of searches unreasonable, but also because it can highly contribute to the enforcement of the data quality principles through ensuring the applicants' participation. It was also argued that besides exercising data subjects' rights, individuals should adopt a more conscious behaviour in relation to their online presence and e-reputation.

521. In conclusion, instead of "googling" applicants in an ad hoc way, systematic, well-planned searches should be encouraged - if they are necessary at all. It always depends on the given job whether such searches are necessary, or they can be replaced by a job interview or probation. The necessity and the exact conditions of conducting these searches must be assessed on a case-by-case basis: it is impossible to provide a universal solution, applicable in all cases, only the criteria of how to conduct them should be established.

\footnotetext{
${ }^{1485}$ A recommendation related to the awareness raising activity of the DPAs - as they would play a crucial role in making employers understand the importance of respecting data protection requirements during SNS screenings. As part of this activity it is recommended for the NAIH to become present in social media as well - the online presence of CNIL might serve as a possible source of inspiration.
} 
If these screenings are absolutely necessary, it is recommended that they should be conducted in a uniform manner, preferably at the late stage of recruitment, according to pre-established criteria and with the involvement of a third party - as it was presented in Chapter 2. Regarding the information to be assessed, the employer should only access data that is publicly available. If the employee uses privacy settings, or in any way limits access to his/her profile, this "concealed" information should be left out from the screening: the privacy settings chosen by the user shall not be bypassed in any way. Such regulated background checks can establish the balance between the employer's legitimate interests and the applicants' rights. 


\section{Title 2: The use of social network sites at the expense of working hours}

522. Issues posed by SNSS. SNSs can have an important effect on working hours. The main issue that they represent is that a huge number of employees spend their working hours surfing on SNSs instead of working - seriously compromising the interests of the employer, who lawfully expects the employee to work during working hours. It was already demonstrated that one of the employee's main obligation is to perform work: this obligation can be violated by the personal use of SNSs during working hours.

An employment relationship necessarily comes with the limitation of certain rights and the autonomy of the employees, ${ }^{1486}$ meaning, for example, that the employee is not free to spend working time as he/she wishes. It is the very nature of employment that the employee must perform work under the subordination of the employer. ${ }^{1487}$ It follows from the main labour law principles that employers have the contractually based right to determine the work and to control whether the employees perform their contractual obligations. ${ }^{1488}$

523. Subjects treated. In Title 2, emphasis will be put on the examination of using SNSs at the expense of working hours, with the main focus on the traditional (typical) employment contract. ${ }^{1489}$ Therefore, the assessment of the content of SNS posts is not as relevant as in the case of examining the employees' exercise of freedom of expression or behaviour outside working hours: what is important is that the employee used SNSs during working hours. Although it is possible to publish excessive criticism, libel or harm the employer's legitimate interest in other ways during the working hours as well, these issues will be further discussed under Title 3 .

524. Legal foundations. The starting point is that the employer has the right to regulate the personal use of the devices provided by him/her and has the right to monitor

${ }^{1486}$ Kardkovács, K. (ed.) (2012) A Munka Törvénykönyvének magyarázata. Budapest: HVG-ORAC Lap- és Könyvkiadó, p. 40.

1487 Cour de cassation, 22 juillet 1954 (Bull. civ. IV, no 576) referred to in: Le Lamy social (2019) 150. Définition du contrat de travail. Available at: shorturl.at/adoty (Accessed: 12 August 2019)

${ }^{1488}$ Hendrickx, F. (2002) 'Protection of workers' personal data in the European Union, Two studies'. EC. p. 97.

${ }^{1489}$ Although the case of the bring your own device phenomenon will be addressed as well. 
whether the employee complies with his/her instructions. ${ }^{1490}$ One of the employees' main obligations is the obligation to perform work during working hours, while the employer is entitled to monitor whether employees comply with that obligation.

In French law, the notion of employment contract itself refers to employees' obligation to work. ${ }^{1491}$ The employee is obliged to perform the work for which he/she has been hired, ${ }^{1492}$ and arising from the intuitu personae nature of the employment relationship, he/she has to do it in person. ${ }^{1493}$ In addition, he/she is subject to a requirement of availability: he/she is obliged to be at the employer's disposal and follow his/her orders without being able to freely carry on his/her personal affairs. ${ }^{1494}$ The employee also has to respect working hours and follow the instructions of the employer. ${ }^{1495}$ From the employer's perspective, it is a confirmed principle in jurisprudence that the employer has the right to control and monitor the activity of employees during working hours. ${ }^{1496}$

Similarly, in Hungarian law, the very definition of employment contract refers to the employees' obligation to perform work, ${ }^{1497}$ and the employees' other obligations give further guidance on the substance of this obligation. ${ }^{1498}$ The employees' two most important obligations are to perform work and to be at the disposal of the employer during working hours. ${ }^{1499}$ The employee should not just show up at the workplace, he/she has to spend his/her whole worktime performing work of high quality and quantity. If the employee is present at the workplace but spends his/her time, for example, reading or

1490 WP29 (2002) Working document on the surveillance of electronic communications in the workplace. 5401/01/EN/Final WP 55. p. 24.

${ }^{1491}$ As an employment contract is "a convention according to which a person engages in performing work for another person under its subordination for remuneration." Source: Cour de cassation, 22 juillet 1954 (Bull. civ. IV, no 576) referred to in: Le Lamy social (2019) 150. Définition du contrat de travail. Available at: shorturl.at/adoty (Accessed : 12 August 2019)

1492 Ouaissi, H. (2017) Droit du travail : de l'individuel au collectif. 2nd edn. Bruxelles: Bruylant. p. 141.

1493 Favennec-Héry, F. and Verkindt, P.-Y. (2016) Droit du travail. 5th edn. Issy-les-Moulineaux: LGDJ Lextenso éditions. p. 421.

${ }^{1494}$ Article L3121-1 of the FLC

1495 Ministère du travail, de l'emploi, de la formation professionnelle et du dialogue social (2015) Guide pratique du droit du travail. Paris: La Documentation française. p. 90.

${ }^{1496}$ Cour de cassation, chambre sociale, 14 mars 2000, N 98-42090; Cour de cassation, chambre sociale, 4 juillet 2012, $\mathrm{N}^{\circ}$ 11-30266; Cour de cassation, chambre sociale, 18 mars 2008, $\mathrm{N}^{\circ} 06-45093$

${ }^{1497}$ Subsection (2) of Section 42 of the HLC: "Under an employment contract:

a) the employee is required to work as instructed by the employer;

b) the employer is required to provide work for the employee and to pay wages."

${ }^{1498}$ Subsection (1) of Section 52 of the HLC: "Employees shall:

a) appear at the place and time specified by the employer, in a condition fit for work;

b) be at the employer's disposal in a condition fit for work during their working time for the purpose of performing work;

c) perform work in person, with the level of professional expertise and workmanship that can be reasonably expected, in accordance with the relevant regulations, requirements, instructions and customs[.]"

${ }^{1499}$ Gyulavári, T. (ed.) (2013) Munkajog. 2nd edn. Budapest: ELTE Eötvös Kiadó, p. 254. 
sending instant messages instead of performing work, the employer is entitled to terminate his/her relationship. ${ }^{1500}$ On the other side, the employer is entitled to give instructions regarding the organization of work ${ }^{1501}$ and has the right and obligation to control employees' work and maintain work discipline: as a consequence, he/she may apply detrimental legal consequences in the case of the employee's breach of obligation. ${ }^{1502}$ Therefore he/she can monitor - respecting the requirements set by Sections 9-11/A of the HLC - whether employees respect their obligations and spend their working time performing work.

525. Main questions to be answered. Although today it is a well-established principle that " $[w]$ orkers do not abandon their right to privacy and data protection every morning at the doors of the workplace [,] "1503 drawing the exact lines of these rights can pose questions. Because of the subordinate relationship between the employees and the employer, these rights have to be balanced against the employer's legitimate economic interests.

Regulating and monitoring the use of SNSs can concern the employee's right to privacy, while the monitoring necessarily comes with the processing of personal data and falls under the scope of the data protection legislation, meaning that the data protection requirements aiming to ensure the employees' right to personal data protection shall be respected during such monitoring. Therefore, the main question that Title 2 intends to answer is: how do the rights of the employee collide with the employer's rights? More precisely, whether and to what extent can the employer interfere with employees' personal lives through regulating the personal use of social media during working hours and how is it possible to monitor compliance?

526. Main hypothesis of Title 2. Title 2 intends to prove that in most regards, the personal use of SNSs during working hours can be adequately addressed through the already existing rules relating to the monitoring of Internet and e-mail use (Hypothesis 3). Neither of the two labour codes or the data protection acts regulate specifically employee monitoring jointly with SNSs. Therefore SNSs must be assessed in the light of the rules

\footnotetext{
1500 Gyulavári, T. (ed.) (2013) Munkajog. 2nd edn. Budapest: ELTE Eötvös Kiadó, p. 257.

1501 While the employee must also perform work according to the employer's instructions. Source: 7001/2005. (MK 170.) FMM-PM együttes irányelv a munkavégzés alapjául szolgáló szerződések minősítése során figyelembe veendő szempontokról.

1502 Gyulavári, T. (ed.) (2013) Munkajog. 2nd edn. Budapest: ELTE Eötvös Kiadó. p. 249.

1503 WP29 (2002) Working document on the surveillance of electronic communications in the workplace. 5401/01/EN/Final WP 55. p. 4.
} 
laid down in the labour codes relating to employee monitoring in general. ${ }^{1504}$ Also, the practice of the courts and the data protection supervisory authorities elaborated the detailed conditions of certain types of monitoring - amongst them the monitoring of Internet and email.

As social media and SNSs are Internet based platforms which enable to post certain content and to communicate with other users, the rules relating to Internet and e-mail monitoring are adequately applicable to employees' use of social media during working hours. However, SNSs have certain characteristics that make it necessary to enumerate the special issues raised by them, in order to be able to judge whether already established rules need adjustments and if yes, in what regards. A great difference compared to e-mail monitoring is that while sending e-mails usually necessarily comes with the job (meaning that the employee might use the same platform for work and personal purposes), as a main rule, messaging on SNSs is usually not part of a job at all and is purely personal. Therefore, while the access of an e-mail account can be associated with working as well, accessing an SNS (regardless of whether it is for surfing or communicating) supposes personal activity.

527. A double approach should be adopted, as it must be taken into consideration that when an employee surfs SNSs (e.g. the Facebook or Instagram newsfeed), this activity is like surfing the Internet; whereas when using the instant chat messaging services incorporated into these platforms (e.g. Facebook Messenger, Instagram Direct), more emphatic similarities with the regulation of the use and monitoring of $e$-mail can be observed. Title 2 aims to prove that these already elaborated rules are capable of adequately regulating the case of SNSs as well, with the application of minimal adjustments, taking into consideration the specificities of SNSs.

528. Starting point: regulation of monitoring of the Internet and e-mail. As the use of SNSs is based on the use of the Internet, the already elaborated rules of monitoring employees' personal use of the Internet are applicable to the personal use of SNSs as well. The already presented general rules of monitoring are adequately applicable to Internet monitoring as well. Both French and Hungarian legal systems have already addressed the question of monitoring employees' use of the Internet and e-mail. 
In French law, the CNIL's standpoint is that the employer is entitled to regulate the use of the Internet and e-mail by imposing limitations on its personal use for the purpose of guaranteeing the security of the network and preventing abusive personal use. However, certain personal use is usually tolerated if it is reasonable and does not affect security or productivity. ${ }^{1505}$ At the core of the regulation a presumption is found: e-mails are presumed to be of professional nature, unless the employee obviously indicates the personal character of the messages - imposing limitations on the employer's right to monitor them, giving room for the employee's right to respect for private life. ${ }^{1506}$ The employer cannot have access to those messages even if the personal use was forbidden, unless authorized to do so by a judge. ${ }^{1507}$ However, the employer can freely access professional e-mails: ${ }^{1508}$ he/she can have access to them even without the employee's presence. ${ }^{1509,}{ }^{1510}$ In contrast, in the case of Internet connections, no such exception exists: Internet connections and the sites visited are presumed to be professional so the employer can have access to them. ${ }^{1511,1512}$

In Hungary, the legal situation is slightly different as, due to the amendment of the HLC in 2019, a provision was added regulating explicitly the use of electronic equipment provided by the employer. ${ }^{1513}$ The HLC now stipulates that unless the parties agreed otherwise, the employee can use the equipment provided by the employer exclusively for professional purposes. It also adds that during the monitoring of such use, the employer can only process data in relation to the employment relationship. The amendment corresponds with the prevailing view in doctrine related to the legislation prior to this amendment, arguing that the employer is free to decide whether he/she allows the personal

\footnotetext{
1505 CNIL (2018) Les outils informatiques au travail. Fiches pratiques: Travail \& données personnelles

1506 Cour de cassation, chambre sociale, 30 mai 2007, $\mathrm{N}^{\circ}$ 05-43102. "However, the correspondences sent or received by the employee at the workplace are presumed to have a professional character, so the employer may open them without the presence of the concerned employee, except if they are identified as personal." Source: Cour de cassation, chambre sociale, 11 juillet $2012 \mathrm{n}^{\circ} 11-22.972$

1507 La Rédaction D.O. (2013) 'Diffusion des bonnes pratiques en matière de protection des données personnelles des salariés’, JCP S (édition sociale), (7), p. 3.

${ }^{1508}$ CNIL (2010) Guide pour les employeurs et les salariés. Les guides de la CNIL. p. 19.

${ }^{1509}$ CNIL (2018) Les outils informatiques au travail. Fiches pratiques: Travail \& données personnelles

1510 However, certain limits are imposed on the employer's access in line with the general principle of proportionality: it is forbidden to automatically receive a copy of each message or to use a key logger program. CNIL (2018) Les outils informatiques au travail. Fiches pratiques: Travail \& données personnelles. 1511 "[...] the connections made by an employee on websites during working hours from an IT tool provided by the employer for the performance of work are presumed to have a professional nature so the employer can look into them for the purpose of identifying them, without the presence of the employee." Cour de cassation, chambre sociale, 9 juillet 2008, $\mathrm{N}^{\circ}$ 06-45800; Cour de cassation, chambre sociale, 9 février 2010, $\mathrm{N}^{\circ} 08$ 45253

1512 Again, this access is not limitless: the use of key logger programs or storing information related to the sites visited for a period longer than 6 months is prohibited. Griguer, M. (2013) 'Protection des données personnelles : conformité et bonnes pratiques des entreprises', Cahiers de droit de l'entreprise, (1), p. 75. ${ }^{1513}$ Subsections (2) and (3) of Section 11/A of the HLC
} 
use of the Internet, and if yes, to what extent. ${ }^{1514}$ Then, the extent of the monitoring will be highly dependent on whether the employer has allowed personal use or not: in Hungarian law as well, more extensive protection is afforded to personal communication/use of the Internet.

529. Structure of Title 2. The case of SNS use during working hours will be examined by taking a double, privacy-data protection/regulation-monitoring approach: attaching privacy to the regulation of SNS use, and data protection to the monitoring of compliance with the regulation. First, in Chapter 1 it will be addressed to what extent employees' right to private life is extended to the workplace, namely: do they have the "right" to use social media during working hours and how can the employer regulate or prohibit their use? Then, in Chapter 2 it will be discussed what data protection requirements must be enforced during the monitoring of whether employees comply with the employer's regulation. Therefore, regulation and monitoring will be treated separately.

\section{Chapter 1: Possible prohibition of personal use of SNSs during working hours}

The regulation of the personal use of SNSs (and within this subject the question of possibly prohibiting its use) will be treated from a privacy angle. When regulating such a use, the employee's right to privacy can be affected, as since the Niemietz case it is established that "[r]espect for private life must also comprise to a certain degree the right to establish and develop relationships with other human beings [,]" ${ }^{1515}$ which are very often established at the workplace. ${ }^{1516}$ The personal use of the employer's electronic devices can constitute a way to establish relationship with others. It is undisputable that as a main rule, the employer is entitled to decide whether he/she allows the personal use of the Internet, e-mail (and SNS). However, the question that needs to be considered is whether the use of SNSs - one of today's main platforms of communicating and establishing relation with others - can be completely prohibited during working hours?

1514 Arany-Tóth, M. (2016) Személyes adatok kezelése a munkaviszonyban. Budapest: Wolters Kluwer. p. 107.; Berke, Gy. and Kiss, Gy. (eds) (2014) Kommentár a munka törvénykönyvéhez: kommentár a munka törvénykönyvéröl szóló 2012. évi I. törvényhez. Budapest: Wolters Kluwer. p. 62.; Németh, J. (2013) 'Internet és közösségi háló mint munkaeszköz', Infokommunikáció és jog, (1). pp. 37-38.; Kun, A. (2013) 'Közösségi média és munkajog - avagy „online” munkaidőben és azon túl', Munkaügyi Szemle, (3), p. 13., Szőke, G. L. et al. (2012) Munkahelyi adatvédelem. Nemzeti jelentés - Magyarország. Available at: http://pawproject.eu/en/sites/default/files/page/web_national_report_hungary_hu.pdf (Accessed: 21 October 2016). p. 34.

1515 ECtHR (1992) Niemietz v. Germany, Application no. 13710/88, 16 December, par. 29.

${ }^{1516}$ ECtHR (1992) Niemietz v. Germany, Application no. 13710/88, 16 December, par. 29. 
The starting point of Chapter 1 will be the already elaborated set of rules in the field of regulating/prohibiting the personal use of the Internet and e-mail - addressed in Section 1. Then, Section 2 will examine what kind of new challenges SNSs raise compared to the existing regulation, and in the light of these challenges, how their personal uses should be regulated.

\section{Section 1. Employees' right to personal life within the workplace: regulating personal use of the Internet and e-mail during working hours}

The examination of the already established regulation in the field of Internet and email monitoring can constitute the basis for the further examination of the main subject. This is because of the similarities between the Internet/e-mail and SNSs: as SNSs are Internet based platforms, they allow the user to "surf" on them (like on the Internet); and they also allow the employee to communicate with other users (like in the case of e-mail). Regulating the personal use of the Internet and e-mail was already addressed by regulations: detailed rules were elaborated both at (\$1) the international level (amongst which focus will be put on the European regime) and at (\$2) the national level.

\section{\$1. Outlook to European law}

Under European law, attention should be paid especially to documents issued by the EU's WP29, and by the CoE's ECtHR. The WP29's documents provide useful and detailed guidance to Member States, while the ECtHR recently addressed the question of employee monitoring, putting this already existing phenomenon into a new perspective. Besides, contracting parties, such as France or Hungary are also obliged to take into consideration the ECtHR's decisions both during legislation and the application of law. ${ }^{1517}$ Therefore the documents of the WP29 and the ECtHR's decisions are of high importance in relation to the national regulation (and monitoring discussed in detail in Chapter 2) of SNS use at the expense of working hours.

(A) EU perspective: the WP29's documents

1517 Rózsavölgyi, B. (2018) 'Mikor lehet jogszerü a munkáltató ellenőrzése? - az Emberi Jogok Európai Bírósága Nagykamarája Bărbulescu kontra Románia ügyben hozott ítéletének iránymutatásai’, Munkajog, 2(1), p. 47. 
530. Opinions of the WP29. The WP29 expressed in the Working document on the surveillance of electronic communications in the workplace, already presented in Part I, that it is up to the employer to decide whether he/she allows the personal use of the Internet and if yes, to what extent. ${ }^{1518}$ However, the working document does not address the question whether a complete ban is possible, it only adds, without providing legal arguments, that a blanket ban seems to be impractical and unrealistic, as the Internet has gained a huge importance even during work. ${ }^{1519}$.

531. Although the WP29 mostly deals with monitoring and the extent of prohibition/regulation, in its Opinion 2/2017 on data processing at work the WP29 explicitly refers to employees' "legitimate right to use work facilities for some private usage". ${ }^{1520}$ When stating that, the WP29 referred to the ECtHR's Halford case ${ }^{1521}$ and Bărbulescu case. ${ }^{1522}$ However, according to my opinion, these references do not truly show the existence or the content of employees' right to use the employer's equipment for personal use, as the formulation of their reasoning rather suggests that it is only ensured that the use of such devices by employees for personal purposes might be covered by Article 8 of the ECHR.

532. The WP29's latter conclusion might be more crystallized through Paul De Hert's and Hans Lammerant's study relating to European workplace privacy/data protection, which referred to the ECtHR case law: ${ }^{1523}$ therefore this study might help more to better understand employees' "right to private usage". In the study they pointed out that employees' have their rights even within the workplace, meaning that although the existence of the employer's right to decide how his/her equipment can be used (and to monitor compliance) is not questioned, it is limited not only by the employees' right to privacy (including the protection of communication), but also by their right to communication. This results in the fact that the employer cannot prohibit all private

\footnotetext{
1518 WP29 (2002) Working document on the surveillance of electronic communications in the workplace. 5401/01/EN/Final WP 55. p. 24

1519 WP29 (2002) Working document on the surveillance of electronic communications in the workplace. 5401/01/EN/Final WP 55. p. 24

1520 WP29 (2017) Opinion 2/2017 on data processing at work. 17/EN WP 249. p. 14.

1521 "telephone calls made from business premises as well as from the home may be covered by the notions of 'private life' and 'correspondence' within the meaning of Article 8 paragraph 1" ECtHR (1997) Halford v. the United Kingdom, Application no. 20605/92, 25 June, par. 44.

1522 Although in a reference to the 2016 judgement and not to the 2017 Grand Chamber judgement. They referred to the ECtHR stating that the employer can only monitor the use to a limited and proportionate extent.

${ }^{1523}$ Notably to the case of Halford and Copland.
} 
communication. Although he/she can prohibit the privative use of certain telecommunication means, this should not mean that employees can be left without any alternative to communicate. ${ }^{1524}$

(B) CoE: the ECtHR's case law

The ECtHR's case law in the field of monitoring employees' use of the employer's equipment (such as telephone, the Internet, e-mail) ${ }^{1525}$ has not addressed the extent to which personal use can be prohibited (whether the employer has the possibility to ban it completely), it rather focused on the existence of the right to privacy, which is a separate issue and will be discussed in relation to monitoring. ${ }^{1526}$ However, cases such as the Bărbulescu v. Romania (2017) directly address the question, and the Libert v. France case (2018) also contains some important observations.

\section{(a) Case of Bărbulescu v. Romania}

533. Case of Bărbulescu v. Romania. The Bărbulescu v. Romania (2017) case can serve as an important starting point when it comes to both regulating and monitoring the personal use of SNSs. The applicant, Mr. Bărbulescu was dismissed for using the Internet and a Yahoo account for private purposes against the prohibition of the employer also, the account was created at the initiative of the employer. The employer found this out by monitoring the use of the equipment. Although Mr. Bărbulescu was informed that the personal use if IT equipment was prohibited, he was not informed as concerns the details of the implementation of the monitoring which, as it turned out, registered all content of his communication for a certain period.

1524 De Hert, P. and Lammerant, H. (2013) Protection of Personal Data in Work-related Relations. Study PE 474.440. Directorate General for Internal Policies, Policy Department C: Citizens' Rights and Constitutional Affairs. Civil Liberties, Justice and Home Affairs. p. 53.

${ }^{1525}$ E.g. Halford v. the United Kingdom, Copland v. the United Kingdom

1526 Though in the Copland case the ECtHR remarked in par. 42. that "[t]he applicant in the present case had been given no warning that her calls would be liable to monitoring, therefore she had a reasonable expectation as to the privacy of calls made from her work telephone", implying that unless given prior notification, the employee can reasonably think that the equipment can be used for personal purposes as well. (Source: Rózsavölgyi, B. (2018) 'Mikor lehet jogszerü a munkáltató ellenőrzése? - az Emberi Jogok Európai Bírósága Nagykamarája Bărbulescu kontra Románia ügyben hozott ítéletének iránymutatásai’, Munkajog, 2(1), p. 43.) 
534. Besides elaborating the rules relating to monitoring, ${ }^{1527}$ the decision is also significant for what it stated on social private life. In this case the ECtHR acknowledged the existence of "social private life" and ruled that "[...] an employer's instructions cannot reduce private social life in the workplace to zero. ${ }^{1528,}{ }^{1529}$ In this context private social life means the possibility for the individual to develop his/her social identity, ${ }^{1530}$ and the ECtHR noted that instant messaging services constitute one form of leading a private social life. ${ }^{1531}$ The ECtHR also stated that restrictions on an individual's professional life may fall within Article 8 in the case that they have "repercussions on the manner in which he or she constructs his or her social identity by developing relationships with others."1532 Even in the workplace, respect for private life and for the privacy of correspondence continues to exist, although it may be restricted to a necessary extent. ${ }^{1533}$ Thus, the complete ban of personal communication seems to restrict the private social life of employees to an unreasonable extent.

\section{(b) Case of Libert v. France}

535. Case of Libert v. France. Even though it mainly relates to the storage of personal files on the employer's computer, the Libert v. France (2018) case ${ }^{1534}$ contains some important observations. The case related to the opening of personal files stored on a work computer. The applicant, employee of the French national railway company (SNCF), was dismissed after the seizure of his work computer revealed that he stored a considerable number of pornographic files and forged documents. The applicant argued that the employer violated Article 8, by accessing those files in his absence.

In its judgement the ECtHR recalled that the employer has the right to ensure that employees use the equipment provided by him/her for executing their work in compliance

1527 Costes, L. (2017) 'CEDH : surveillance des courriels d'un employé à son insu constitutive d'une violation du droit au respect de la vie privée et de la correspondance', Revue Lamy droit de l'immatériel, (140), p. 35

${ }^{1528}$ ECtHR (2017) Bărbulescu v. Romania, Application no. 61496/08, 5 September, par. 80.

1529 The ECtHR also had important remarks as regards the monitoring of itself, to be treated in $\S 2$.

${ }^{1530}$ ECtHR (2017) Bărbulescu v. Romania, Application no. 61496/08, 5 September, par. 70.

${ }^{1531}$ Colonna, J. and Renaux-Personnic, V. (2017) 'Vie privée et surveillance des communications du salarié : la position de la Cour européenne des droits de l'Homme; Note sous Cour Européenne des Droits de l'Homme, grande Chambre, 5 septembre 2017, arrêt numéro 61496/08', La Gazette du Palais, (43), p. 2. [Page number referring to the online version of the article downloaded from: https://www.gazette-dupalais.fr/article/GPL309w2/ (Accessed: 15 August 2019)]

${ }_{1532}$ ECtHR (2017) Bărbulescu v. Romania, Application no. 61496/08, 5 September, par. 71.

${ }^{1533}$ ECtHR (2017) Bărbulescu v. Romania, Application no. 61496/08, 5 September, par. 80.

${ }^{1534}$ ECtHR (2018) Libert v. France, Application no. 588/13, 22 February 
with their contractual obligations and applicable regulation. ${ }^{1535}$ The employee's files identified as personal receive more protection, as according to French law they can only be opened if there is a risk or a particular event and in the presence of the employee or if he/she has been properly notified of it - contrary to files presumed to be of professional nature. ${ }^{1536}$ The ECtHR confirmed the principle that the employee is entitled to the right to respect for private life even within the workplace, and that files obviously identified as personal, stored on the computer provided by the employer for work purposes, might pertain to the private life of the employee. ${ }^{1537}$ Although the decision does not mention a right to use the employer's equipment for personal purposes, through providing protection to the personal files stored on work computers, certain tolerance is manifested, suggesting that a complete ban of personal use would not be feasible. ${ }^{1538}$

\section{\$2. Regulation at the national level: France and Hungary}

Besides the regional level, detailed rules were elaborated at the national level as well, including French and Hungarian law. When assessing the legitimacy of a complete ban of personal use in the French and the Hungarian system, first $(A)$ the fundaments of protecting employees' personal lives will be discussed mostly through presenting the labour codes and scholars' opinion on the subject. Then $(B)$ the DPA's position will be examined. Finally, $(C)$ relevant case law will be examined, with the aim of tracing the line between abusive personal use, and personal use that should be tolerated by the employer ${ }^{1539}$ thereby determining the possibility to apply legal consequences against employees who use the Internet/e-mail/SNSs for personal purposes during working hours.

\section{(A) Private/personal life at work}

\footnotetext{
1535 ECtHR (2018) Libert v. France, Application no. 588/13, 22 February, par. 46.

${ }^{1536}$ Cour de cassation, chambre sociale, 17 mai 2005, $\mathrm{N}^{\circ} 03-40017$

${ }^{1537}$ ECtHR (2018) Libert v. France, Application no. 588/13, 22 February, par 25.

1538 On the Libert case see more in: Sipka, P. and Zaccaria, M. L. (2018) 'A munkáltató ellenőrzési joga a munkavállaló munkahelyi számítógépén tárolt magánadatai fölött’, Munkajog, 2(2), pp. 45-49., Marchadier, F. (2018) 'La protection des données informatiques stockées sur l'ordinateur professionnel du salarié à titre du droit au respect de la vie privée', JCP G Semaine Juridique (édition générale), (15), pp. 59-63.; NasomTissandier, H. (2018) 'L'importance de la charte informatique dans la justification de mesures de surveillance des salariés', Jurisprudence sociale Lamy, (451), pp. 12-14.

${ }^{1539}$ Márton Leó Zaccaria observed the employees' increasing possibilities due to technological development: today employees often feel limited in their rights when the employer wants to restrict or prohibit such personal use, while even before the proliferation of ICT and SNSs it was not an established practice that employees spend their working hours writing letters to their friends. Source: Zaccaria, M. L. (2016) 'Munkavállalók a világhálón - "Megosztani ér?”, HR \& Munkajog, 7(10), p. 16.
} 
536. France. The FLC contains no direct provision aiming to regulate the use of the employer's equipment and its monitoring. However, an important principle, namely the respect of the employee's right to respect for private life within the workplace (during the use of the company's equipment) was established by the jurisprudence, which serves as a basis for the further analysis of the relevant rules. In France, the Court of Cassation's landmark ${ }^{1540}$ Nikon decision ${ }^{1541}$ must be first mentioned. ${ }^{1542}$ The case related to an employee of the Nikon France Society, who was dismissed for serious misconduct particularly for using the company's equipment for personal purposes - which was provided for him for professional purposes. The Court of Cassation - which granted employees an extremely (even too) favourable position ${ }^{1543}$ - affirmed that the employee has the right to respect for private life, especially to the secrecy of correspondence, even during working hours, at the workplace. ${ }^{1544}$

The Court of Cassation held that that "the employee is entitled, even during work hours and at his/her workplace, to have the intimacy of his/her private life respected; that this implies in particular the secrecy of correspondence; that the employer may not therefore, without violating this fundamental freedom, examine personal e-mails sent and received by an employee through a computer provided as a work tool, and this applies even if the employer has forbidden the non-professional use of the computer [.]" Therefore, the Court of Cassation admitted the existence of an autonomous sphere reserved for the intimacies of private life, which must be respected even if the employer has prohibited personal use. However, through referring to Article L. 1121-1 of the FLC, ${ }^{1545}$ the decision maintains the possibility of limiting these rights, within the borders set by legislation. ${ }^{1546}$ The essence of the decision is based on the protection of the employee's private life within

\footnotetext{
${ }^{1540}$ Dupuis, M. (2001) 'La vie privée à l'épreuve de l'Internet: quelques aspects nouveaux', Revue Juridique Personnes et Famille, (12), p. 5. [Page number referring to the online version of the article downloaded from: https://lamyline-lamy-fr.bcujas-ezp.univparis1.fr/Content/Document.aspx?params=H4sIAAAAAAAEAMtMSbF1CTEwMDC0MDM3MbFQK0stKs 7Mz7MNy0xPzStJVXNxDHG0LUkuj3T09Y4sKiyqyPV0dPKqKverzAMAsnFdMDwAAAA=WKE (Accessed: 15 August 2019)]

${ }^{1541}$ Cour de cassation, chambre sociale, 2 octobre 2001, $\mathrm{n}^{\circ}$ 99-42.942

${ }^{1542}$ Although it relates to case law, due to the high importance of the Nikon case, it will be discussed in part (A) instead of part (C).

${ }^{1543}$ Gautier, P.-Y. (2001) 'La preuve hors la loi ou comment, grâce aux nouvelles technologies, progresse "la vie privée" des salariés', Recueil Dalloz Sirey, (39), p. 3150.

${ }^{1544}$ Kocher, M. (2013) 'La protection des données des salariés : que reste-t-il de l'arrêt Nikon ?', Legicom, (1), p. 129.

${ }^{1545}$ Back then Article L. 120-2 of the FLC.

${ }^{1546}$ Kocher, M. (2013) 'La protection des données des salariés : que reste-t-il de l'arrêt Nikon ?', Legicom, (1), p. 132.
} 
the workplace. ${ }^{1547}$ However, recognizing such protection does not mean that the employer cannot ban or sanction abusive personal use. ${ }^{1548}$

Thus, the Court of Cassation questioned the strict separation of professional and personal life, through acknowledging the respect of private life within the workplace. ${ }^{1549}$ The decision had a great impact: while it was recognized that it made a huge step in recognizing employees' right to respect to private life within the workplace, ${ }^{1550}$ it was also pointed out that potential abuses on the part of the employees might also take place. ${ }^{1551}$ The decision might seem paradoxical insomuch as it put employers in a difficult position as, although they could order employees not to use equipment for private purposes, they were not allowed to lawfully open private letters, even if they violated the employer's orders. ${ }^{1552}$ Later on, this principle became more nuanced through the adoption and application of the previously mentioned presumption of professional character of communication. ${ }^{1553}$ Even though the Nikon decision did not address whether employees' have the right to use the employer's equipment for personal purposes, it afforded protection to personal use, even if it took place contrary to the employer's internal regulation.

537. As regards the regulation of the personal use of the Internet and e-mails, the starting point is that as Internet connection and e-mails are perceived as a work tool necessary for the execution of work, the employer can regulate and control their use. ${ }^{1554}$ However, according to the majority opinion, the total prohibition of the personal use of the Internet and e-mail would be considered illegitimate, as such a prohibition would be inconsistent with the principle of proportionality laid down in Article L1121-1 of the

\footnotetext{
1547 Gautier, P.-Y. (2001) 'La preuve hors la loi ou comment, grâce aux nouvelles technologies, progresse "la vie privée" des salariés', Recueil Dalloz Sirey, (39), p. 3149. Its reasoning can be reduced to the following syllogism: everyone has the right to respect for private life, and more precisely to the secrecy of correspondence; private life can take place within the workplace; as a result, opening a communication addressed to the employee violates the employee's rights.

1548 Rapport de la Cour de Cassation 2001: A. Contrat de travail 1. Exécution.

${ }^{1549}$ Lyon-Caen, G. (2001) 'Débat autour de l'arrêt Nikon France', Semaine sociale Lamy, (1046) p. 10.

1550 According to Jean Hauser, if private life flows into the workplace, it also raises the question of whether the work can flow into the private life of the employee. Source: Hauser, J. (2002) 'Vie privée du salarié : Email, domicile, sacs, bermudas et survêtement', RTD Civ., (1), p. 72.

1551 Kocher, M. (2013) 'La protection des données des salariés : que reste-t-il de l'arrêt Nikon ?', Legicom, (1), p. 130.

1552 Vigneau, C. (2002) 'Information Technology and Workers' Privacy: the French Law', Comparative Labor Law \& Policy Journal, 23(2), p. 357.

1553 This question will be further addressed in Section 2.

${ }^{1554}$ Féral-Schuhl, C. (2018) Cyberdroit. Le droit à l'épreuve de linternet. 7th edn. Paris: Dalloz. p. 394.
} 
FLC. ${ }^{1555,}{ }^{1556}$ Personal use to a reasonable extent, for legitimate purposes such as urgent personal communication should be tolerated. ${ }^{1557}$

Jean-Emmanuel Ray expresses that even though in theory the employer is entitled to completely ban the personal use, ${ }^{1558}$ in reality the situation is more nuanced, as in practice the enforcement of such a ban is not feasible. As in the $21^{\text {st }}$ century ICT are part of everyday life, it would be disproportionate to sanction an employee for conducting simple, everyday activities such as for calling a family member in an urgent situation, or for buying plane tickets for his/her holiday during the work pause - if the activity did not constitute abuse. ${ }^{1559}$ Today, these simple everyday activities are often conducted through different SNSs. Jean Louis Denier expressed a similar opinion in 2003, arguing that although no legal constraint of providing "private" use of company equipment weighs on the employer, other factors, especially the blurred boundaries of professional and personal life make it more realistic to tolerate a certain personal use. ${ }^{1560}$ Then, the next step is to define the limits of tolerable personal use - which will be mostly curved out by the jurisprudence of French courts.

538. Hungary. In Hungary, when assessing whether the employee committed misconduct, the starting point is that employers have the discretional right to decide whether they allow the personal use of the Internet or not. ${ }^{1561}$ This standpoint was further nuanced by the amendment of the HLC in 2019, explicitly determining at the statutory level that unless agreed otherwise, the employee should use the work equipment exclusively for professional purposes. ${ }^{1562}$ Prior to the amendment, the HLC stated that the employee's private life cannot be subject to monitoring: instead of such a declaration

\footnotetext{
1555 Grangé, J. and Froger, C. (2003) 'Cyber-Monitoring in the French Workplace', International Business Lawyer, 31(5), p. 216.

1556 However, the contrary was expressed by Paul-Henri Antonmattei, who was of the opinion that the complete ban of non-professional use seems legally justified, as the employee has the right to respect to his/her personal life at the workplace, and not the right to personal life. Source: Antonmattei, P.-H. (2002) 'NTIC et vie personnelle au travail', Droit social, (1), p. 39.

1557 Grynbaum, L., Le Goffic, C. and Morlet-Haïdara, L. (2014) Droit des activités numériques. 1st edn. Paris: Dalloz. p. 888.; Cour de cassation (2006) Rapport annuel 2005. L'innovation technologique. La documentation française, Paris. pp. 111-112.

${ }^{1558} \mathrm{He}$ also stated in another article that "[...] legally, access to the web at the workplace is not (yet) a right [...]”. Source: Ray, J.-E. (2011) 'Facebook, le salarié et l'employeur', Droit social, (2), p. 139.

${ }_{1559}$ Ray, J.-E. (2001) Le droit du travail à l'épreuve des NTIC. 2nd edn. Rueil-Malmaison: Liaisons. pp. $95-$ 97.

${ }^{1560}$ Denier, J.-L. (2003) 'L'utilisation privative des NTIC d'entreprise', Les cahiers du DRH, (89), p. 32.

1561 Berke, Gy. and Kiss, Gy. (eds) (2014) Kommentár a munka törvénykönyvéhez: kommentár a munka törvénykönyvéről szóló 2012. évi I. törvényhez. Budapest: Wolters Kluwer. p. 62.

1562 Subsection (2) of Section 11/A of the HLC
} 
(especially with regard to the fact that other acts ensure the protection of the private life of the individual) emphasis is put on the employee being able to use work equipment solely for professional purposes. ${ }^{1563}$

Such a formulation suggests that a complete ban of personal use is possible. As regards SNSs, according to the Commentary of the HLC, the employer can prohibit employees using SNSs during working hours. ${ }^{1564}$ Such a complete ban seems feasible, even accessing sites from the employees' own device can be prohibited. ${ }^{1565}$

539. This position was already supported prior to the amendment by a number of scholars - although they usually added that despite the possibility of a complete ban, the employer should consider tolerating a certain use. They usually started their analysis by differentiating between whether the employer has authorized personal use or not, implying that it is his/her right to decide whether personal use is allowed. According to Janka Németh, the employer can choose from among three scenarios: banning the use of the Internet completely, ${ }^{1566}$ only banning the personal use of the Internet or not placing restrictions on the employees' use of the Internet. ${ }^{1567,} 1568$ Then, the scale of monitoring is influenced by which scenario was chosen by the employer. ${ }^{1569}$ It is also important to consider the period when the banned activity takes place: during periods when the employee is not busy, or at the direct expense of his/her obligations (e.g. a salesperson ignoring customers and surfing on Facebook). ${ }^{1570}$

Gábor Kártyás, Rita Répáczki and Gábor Takács add further nuances to this position and note that the employer is entitled to completely prohibit the personal use during

1563 T/4479. számú törvényjavaslat az Európai Unió adatvédelmi reformjának végrehajtása érdekében szükséges törvénymódosításokról (2019). Előadó: Dr. Trócsányi László igazságügyi miniszter. Budapest, p. 102.

1564 Berke, Gy. and Kiss, Gy. (eds) (2014) Kommentár a munka törvénykönyvéhez: kommentár a munka törvénykönyvéről szóló 2012. évi I. törvényhez. Budapest: Wolters Kluwer. p. 62.

1565 Kun, A. (2013) 'Közösségi média és munkajog - avagy „online” munkaidőben és azon túl', Munkaügyi Szemle, (3), p. 13.

1566 Though she questions the efficacity of such a measure, as the Internet can be used for work as well.

1567 Németh, J. (2013) 'Internet és közösségi háló mint munkaeszköz', Infokommunikáció és jog, (1), pp. 3839.

1568 Or, as Edit Kajtár phrased it, the employer can choose between banning, restricting and regulating the use of the Internet. Kajtár, E. (2016) Dignity at Work: Employee's Personality Rights in the 21st Century. Pécs: University of Pécs, Faculty of Law (PMJK Monographs 6). p. 119.

${ }^{1569}$ If the employer decided to allow the personal use of these sites, the employee cannot be sanctioned for using them in compliance with the rules, while the non-conform use can lead to legal consequences, especially if the banned use takes places during working hours and the content visited is compromising. Source: Kártyás, G. and Kozma-Fecske, I. (2016) 'Szerelmes levelek a munkahelyi postafiókban', HR \& Munkajog, 7(3), p. 17.

${ }^{1570}$ Kun, A. (2013) 'Közösségi média és munkajog - avagy „online” munkaidőben és azon túl', Munkaügyi Szemle, (3), p. 13. 
working hours: it is up to him/her to decide whether personal use is allowed and to what extent. However, they also note that in most of the jobs - jobs which do not require constant physical and mental presence - it is not counterproductive if the employee consults these sites for short periods from time to time. On the contrary, a complete ban might be counterproductive in these cases. ${ }^{1571}$ They also argue that with regard to the principle of mutual cooperation, in situations of major importance (e.g. the employee's wife is about to give birth, etc.), the employer should try to make an exception from the ban. ${ }^{1572}$ In relation to communication, Edit Kajtár argued that even though the employer can decide what policy to adopt, the reasonable personal use of the professional e-mail account is usually tolerated. ${ }^{1573,} 1574$ In my opinion, these intermediate standpoints adequately take into consideration the realities of SNSs through allowing a certain tolerance relating to their personal use.

\section{(B) Position of the DPAs}

540. Position of the CNIL. The CNIL expressed on several occasions that although the employer can decide how to regulate the personal use of his/her equipment, it is recommended that a reasonable personal use is tolerated rather than applying a complete ban. In relation to the Internet, they stated that completely prohibiting the use of the Internet for non-professional reasons does not seem realistic in the information society and seems disproportionate in regards to the applicable legal provisions. They also add that a reasonable use, which is not likely to undermine the conditions of professional network access, does not question productivity and is usually socially accepted by most companies and administrations. ${ }^{1575}$

\footnotetext{
1571 Kártyás, G., Répáczki, R. and Takács, G. (2016) A munkajog digitalizálása. A munkajog hozzáalkalmazása a digitális munkakörnyezethez és a változó munkavállalói kompetenciákhoz. Kutatási zárótanulmány. Budapest. pp. 77-78.

1572 Kártyás, G., Répáczki, R. and Takács, G. (2016) A munkajog digitalizálása. A munkajog hozzáalkalmazása a digitális munkakörnyezethez és a változó munkavállalói kompetenciákhoz. Kutatási zárótanulmány. Budapest. pp. 78-79.

1573 Kajtár, E. (2016) Dignity at Work: Employee's Personality Rights in the 21st Century. Pécs: University of Pécs, Faculty of Law (PMJK Monographs 6). p. 122.

1574 Although she did not address the question explicitly, Mariann Arany Tóth states that the complete ban of the personal use of the Internet realises interference with the right to freely develop one's personality. (Source: Arany Tóth, M. (2011) 'A munkavállaló emberi méltóságának védelme a munkaviszonyban', Miskolci jogi szemle, 6(1), p. 144.) As such interference must meet certain - already presented - requirements, the legitimacy of a complete ban might be questioned.

1575 Bouchet, H. (2004) La cybersurveillance sur les lieux de travail. Paris, la Documentation française: Commission nationale de l'informatique et des libertés. p. 23.; CNIL (2005) Guide pratique pour les employeurs. Les guides de la CNIL, p. 11.; CNIL (2010) Guide pour les employeurs et les salariés. Les
} 
541. In relation to the personal use of the professional e-mail account, the CNIL stated that receiving and sending personal messages in reasonable ${ }^{1576}$ proportions is generally and socially accepted. ${ }^{1577}$ However, despite certain tolerance, the employer has several possibilities to regulate and impose limits on personal use, such as filtering unauthorized websites or forbidding the access to certain sites (e.g. pornographic sites) or the downloading of files or videos, or the access to chat or personal e-mail accounts. ${ }^{1578}$

\section{Position of the former Data Protection Commissioner and the NAIH.} Neither the former Data Protection Commissioner, nor the NAIH has explicitly addressed the question of whether the complete prohibition of the personal use of the Internet and email is possible. The cases of the Data Protection Commissioner mainly dealt with the scope of monitoring, ${ }^{1579}$ and differentiated between the cases when the employer allowed personal use and when the use was only permitted for work purposes. ${ }^{1580}$ However, instead of addressing the extent of the regulation, these cases were focused on monitoring. One case $^{1581}$ took a stand on whether a complete ban is advisable or not: it is advisable that the employer limits the use of the Internet to those websites which are necessary for the work, as due to the principle of data minimization, compliance can be better enforced with such a limitation during monitoring.

543. The NAIH published two comprehensive documents in the field of employee monitoring: the already presented Recommendation on the basic requirements of

guides de la CNIL, p. 18.; CNIL (2018) Les outils informatiques au travail. Fiches pratiques: Travail \& données personnelles.

1576 The CNIL provides examples of draft clauses for internal regulations relating to the personal use by stating that "only websites with a direct and necessary link to the professional activity are intended to be visited provided that connection time does not exceed a reasonable time and has utility in terms of the functions or mission to carry out. One-time consultations within reasonable limits for personal use regarding Internet pages that are not contrary to the public order and morality and do not incriminate the interests and the reputation of the organisation is tolerated." Cited in: Duez-Ruff, V. (2012) "Impact des nouvelles technologies sur le droit du travail : un salarié appartient-il virtuellement à son employeur?', Lexbase Hebdo - Edition Sociale, (498), p. 6. [Page number referring to the online version of the article downloaded from: http://www.lexbase-academie.fr.bcujas-ezp.univ-paris1.fr/revues-juridiques/6837680-impact-des-nouvellestechnologies-sur-le-droit-du-travail--un-salarie-appartient-il-virtuellement-a- (Accessed: 15 August 2019)]

1577 Bouchet, H. (2004) La cybersurveillance sur les lieux de travail. Paris, la Documentation française: Commission nationale de l'informatique et des libertés, p. 25.

1578 Féral-Schuhl, C. (2018) Cyberdroit. Le droit à l'épreuve de linternet. 7th edn. Paris: Dalloz. p. 395.

1579 On the summary of the Data Protection Commissioner's and the NAIH's activity see more in: AranyTóth, M. (2016) Személyes adatok kezelése a munkaviszonyban. Budapest: Wolters Kluwer; Szőke, G. L. et al. (2012) Munkahelyi adatvédelem. Nemzeti jelentés - Magyarország. Available at: http://pawproject.eu/en/sites/default/files/page/web_national_report_hungary_hu.pdf (Accessed: 21 October 2016).

1580 ABI 570/A/2001, ABI 790/A/2001, ABI 866/A/2006-3., ABI 40/K/2006, ABI 1767/K/2006-3., ABI 531/A/2004

1581 ABI 800/K/2008-3. 
electronic monitoring at the workplace (2013) and Information notice on the basic requirements on data processing at work (2016). However, the Recommendation governs electronic monitoring (and focuses mainly on CCTV surveillance) and it does not address the employer's power to completely forbid personal use: it only refers to the employee's obligation to work and to be at the employer's disposal. ${ }^{1582}$ The Information notice states in relation to Internet and e-mail monitoring that, before implementing the monitoring, it is recommended that the employer adopts an internal policy in which he/she informs employees regarding the access to which sites is blocked/whether the employees can use their professional e-mail for personal purposes - without further investigating the legitimacy of a complete ban. ${ }^{1583}$ Neither of the documents refers explicitly to the use of SNSs during working hours.

\section{(C) Case law: abusive personal use and "Facebook firings"}

544. Case law. Case law has an important role in defining where the boundaries between abusive and reasonable personal use are. In France, courts have provided rich case law in this field. In contrast, Hungarian case law is minimal in the subject, ${ }^{1584}$ making it difficult to systematically compare the two jurisprudences, as it is difficult to find common grounds and criteria for comparison. As such, the analysis of the jurisprudence will be mainly based on French case law, with the aim of making de lege ferenda suggestions to the Hungarian law makers.

French courts reflect the position of scholars and the CNIL, as courts usually tolerate the reasonable personal use of the employer's equipment, but validate dismissals if the employee manifested an abuse while using these devices. ${ }^{1585}$ Their case law can contribute

1582 NAIH (2013) A Nemzeti Adatvédelmi és Információszabadság Hatóság ajánlása a munkahelyen alkalmazott elektronikus megfigyelörendszer alapvetö követelményeiröl. NAIH-4001-6/2012/V. Budapest, p. 2.

1583 NAIH (2016) A Nemzeti Adatvédelmi és Információszabadság Hatóság tájékoztatója a munkahelyi adatkezelések alapvetö követelményeiröl. Budapest, p. 25, p. 30.

1584 According to Máté Dániel Szabó and Iván Székely, those who were victims of privacy infringements usually do not turn to courts, but rather to the data protection authority. Therefore, the practice of the former Commissioner became case law supplementing the courts' application of law. Source: Szabó, M. D. and Székely, I. (2005) 'A privacy védelme a munkahelyen', in Szabó, M. D. and Székely, I. (eds) Szabad adatok, védett adatok. Budapest: BME GTK ITM, p. 116. and p. 119.

A 2012 report also stated the lack of case law in the field of employee monitoring. Source: Szöke, G. L. et al. (2012) Munkahelyi adatvédelem. Nemzeti jelentés - Magyarország. Available at: http://pawproject.eu/en/sites/default/files/page/web_national_report_hungary_hu.pdf (Accessed: 21 October 2016).

1585 Grynbaum, L., Le Goffic, C. and Morlet-Haïdara, L. (2014) Droit des activités numériques. 1st edn. Paris: Dalloz. p. 888 
to defining what use is considered to be abusive or reasonable. This question is important because employees can face various consequences if they use SNSs despite the ban, or contrary to the employer's regulation: in serious cases they can even be dismissed from the workplace.

545. France. The Court of Cassation and regular courts have already ruled on the personal use of the Internet/e-mail on several occasions. The following paragraphs will examine the French courts' position on defining the limits of an abusive personal use. The length/number of connections were the criteria the most often referred to (time spent on these sites, number of pages visited, and amount of downloaded material), as using the employer's equipment for personal purposes on a regular basis is not an acceptable behaviour. ${ }^{1586}$ However, the exact limits of such a use must be defined more precisely. Other, secondary criteria, such as the nature of the sites visited or making professional mistakes can also be of importance.

546. The length/number of connections often played an important role in these cases: the Court of Appeal of Bordeaux ruled that using the Internet for personal purposes for one hour during a week is not abusive. In this case, the employee used the Internet connection - despite the ban set in the internal regulation - for personal purposes, for 6.5 hours over a period of more than six weeks. The court ruled that this use cannot be considered excessive and in itself cannot serve as a basis of dismissal, considering that otherwise her behaviour was irreproachable, and the pages visited posed no threat to the employer. ${ }^{1587}$ In another case, between a hospital and a doctor, the Court of Appeal of Paris found that the dismissal reasoned by the permanent problem of ensuring the respect and the security of patients was not well-founded, as the doctor who accessed pornographic sites (without any paedophilic character) did it without any frequency - not daily, not weekly and not even monthly -, and for not a long time. ${ }^{1588}$ The length of connection is also significant as pointed out by the Court of Appeal of Paris, which stated that the presentation of a list of websites consulted by the employee is not sufficient to qualify as professional failure, as the proof of the time spent by the employee out of the professional field is ,missing. ${ }^{1589}$

\footnotetext{
${ }^{1586}$ Cour de cassation, chambre sociale, 14 mars 2000, $\mathrm{n}^{\circ} 98-42.090$

${ }^{1587}$ CA Bordeaux, Chambre sociale, section A, Arrêt du 15 janvier 2013

${ }^{1588}$ CA Paris, Pôle 6, 3ème ch., 15 novembre 2011, nº 09/09 398

${ }^{1589}$ CA Paris, Pôle 6, 6ème ch., 6 février 2013, n $11 / 03458$
} 
547. Dismissal was not well-founded in a case where a web manager was dismissed for publishing 1,336 non-professional tweets during working hours (over a 16month-long period), as the Court of Appeal of Chamberry found that supposing that the writing and the publication of one tweet takes one minute, the time spent with this activity does not exceed 5 minutes per day. In addition, the employee was not subject to any working hours and his job required him to be constantly connected to the Internet. ${ }^{1590}$ The Court of Appeal of Lyon held in a case where an employee used his work computer for personal purposes on six occasions (4 times during May and 2 times during June) contrary to the explicit ban laid down in the internal policy - that although this conduct constitutes a violation his obligations arising from the employment contract, the dismissal was disproportionate compared to the violation committed. ${ }^{1591}$ The Court of Appeal of Basse-Terre found that contrary to the employer's allegations - according to which the employee used her work computer for very personal purposes abusively and without authorization,-- the employee's conduct of creating nine personal files over a period of one year could not serve as a basis for dismissal. (Moreover, the internal regulation allowed personal use to a moderate extent, with the respect of the employee's obligation of loyalty.) ${ }^{1592}$ The dismissal of an employee was without an actual and serious basis in a case at the Court of Cassation, in which an employee was dismissed for "illegal and repetitive downloading", but in reality he visited a downloading site for two and a half minutes. ${ }^{1593}$, 1594

548. In contrast to these decisions, the Court of Cassation found the use abusive, and as such the dismissal justified for serious misconduct of the employee in a case when the employee spent 41 hours during the period of one month by surfing the Internet for personal purposes. ${ }^{1595}$ The Court of Cassation came to the same conclusion in a case in which an employee connected to not work-related sites - and among them to social media - more than 10,000 times during a period of 18 days. ${ }^{1596}$ The Court of Cassation held that an employee who violated his contractual obligations and the internal regulation's ban on

\footnotetext{
${ }^{1590}$ CA Chambéry, 25 févr. 2016, RG n $15 / 01264$

${ }^{1591}$ CA Lyon, 18 novembre 2011, $n^{\circ} 11 / 01261$

${ }^{1592}$ CA Basse-Terre, chambre sociale, 13 octobre 2014, N de RG: 13/01046

${ }^{1593}$ Cour de cassation, chambre sociale, 29 octobre 2014 , $\mathrm{N}^{\circ} 13-18173$

1594 Although it should be added that besides the downloading the sites, the employee visited webpages for personal purposes on numerous occasions. However, as the reasoning of the dismissal only mentioned downloading, activity other than downloading from downloading sites fell beyond the scope of the case.

1595 Cour de cassation, chambre sociale, 18 mars 2009, $\mathrm{N}^{\circ} 07-44247$

1596 Cour de cassation, chambre sociale, 26 février 2013, $\mathrm{N}^{\circ} 11-27372$
} 
the personal use of the Internet by sending one of his colleagues 178 e-mails accompanied by videos having sexual, humorous, political and sporty character from his work computer committed a breach of obligations, and his dismissal was therefore well-founded. ${ }^{1597}$

The Court of Appeal of Nimes stated the abusive nature of surfing on the web for 8.5 hours over a period of less than 2 months - in this case the 8.5 hours was the minimal time spent surfing the web. It also found that the dismissal of the employee was justified, but in contrast to the previously cited case, ${ }^{1598}$ the employee made professional mistakes, which, in addition, could be related to the excessive personal use of the Internet. ${ }^{1599}$ The Court of Appeal of Pau stated that regular access to SNSs (e.g. Facebook), to a personal e-mail account (Hotmail), to dating sites and to a lingerie site (where the employee exercised commercial activity) during working hours resulted in her not being able to perform her work, therefore, the court confirmed the dismissal. ${ }^{1600}$ The Court of Appeal of Rennes also found that personal use during $20 \%$ of working time is abusive. ${ }^{1601}$ The Court of Appeal of Paris found the dismissal of an employee justified, who despite the ban laid down in the company's internal regulation and a previous warning, used the Internet for personal purposes. The court affirmed that the digital consumption of $97 \mathrm{MB}$ and $195 \mathrm{MB}$ over the period of two days, exceeding the amount used by all other employees together, was abusive. ${ }^{1602}$ The Court of Appeal of Aix en Provence confirmed the dismissal of an employee who spent one hour per day surfing on the Internet for personal purposes, despite the ban of the internal regulation. On numerous occasions, the employee deliberately and repeatedly violated the internal regulation and connected to the Internet during working hours, at the expense of working time - as a result, the dismissal for gross misconduct was found valid. ${ }^{1603}$

549. The nature of the content visited/sent might also be of importance: if the employee visits sites with rough content, it can serve as a criterion for assessing the abusive nature. The Court of Cassation held that unlawful conduct, such as the sending of

\footnotetext{
${ }^{1597}$ Cour de cassation, chambre sociale, 18 décembre 2013, $\mathrm{n}^{\mathbf{0}} 12-17.832$

1598 CA Bordeaux, chambre sociale, section A, Arrêt du 15 janvier 2013, where the court took into consideration that the employee's behaviour was otherwise irreprochable, except for the personal use.

${ }^{1599}$ CA Nîmes, 2 avril 2013, $\mathrm{n}^{\circ}$ 12/02146

${ }^{1600}$ CA Pau, chambre sociale, Arrêt du 13 juin 2013

${ }^{1601}$ CA Rennes, 7e chambre prud'homale, 20 novembre 2013, $\mathrm{n}^{\circ} 12 / 03567$

${ }^{1602}$ CA Paris, Pôle 6, 5ème ch., 19 janvier 2012, n 10/04 071

${ }^{1603}$ CA d'Aix en Provence, 17eme chambre, arrêt au fond du 13 janvier 2015
} 
anti-Semitic messages can constitute a basis of dismissal. ${ }^{1604}$ In the already presented case of the Court of Appeal of Paris ${ }^{1605}$ between a hospital and a doctor, the court took into consideration that the pornographic sites that were visited did not have any paedophilic character - even though as a main rule, the Court of Cassation found that consultation and animation of pornographic sites on work equipment is not covered by the notion of private life. ${ }^{1606}$ In the case before the Court of Appeal of Pau, ${ }^{1607}$ the court also remarked that besides accessing SNSs and personal e-mail accounts, the employee also accessed a lingerie site, where, in addition, she exercised commercial activity. ${ }^{1608}$ Besides assessing the length of personal use, the Court of Appeal of Bordeaux ${ }^{1609}$ also took into consideration that the pages visited posed no threat to the employer.

550. Professional mistakes as a result of being distracted due to the personal use can also have importance. When judging the use to be abusive, the Court of Appeal of Nîmes ${ }^{1610}$ considered that the employee made professional mistakes due to the excessive personal use of the Internet. In another case at the Court of Appeal of Bordeaux, ${ }^{1611}$ the absence of mistakes served as a ground for not establishing the abusive nature of personal use.

551. The conclusion that can be drawn from these cases in relation to SNSs is that several factors can have a determining effect when judging the excessive nature of the use. Usually the length of the period spent on these sites is extremely important: if the employee spends a significant part of his/her working hours on Facebook, the abusive use might be established. Also, the frequency of the connections might be a decisive factor: if the employee uses SNSs for personal reasons on a regular basis, it will also be taken into account when assessing an abusive use. However, if he/she occasionally accesses these sites, or accesses them for short periods, the use is unlikely to be considered excessive. However, these observations are only valid if the employee's performance is not affected

\footnotetext{
${ }^{1604}$ Cour de cassation, chambre sociale, du 2 juin 2004, 03-45.269 and Castets-Renard, C. (2011) 'Vie privée du salarié et TIC: attention à la violation de la charte informatique !', Revue Lamy droit de l'immatériel, (69), p. 34.

${ }^{1605}$ CA Paris, Pôle 6, 3ème ch., 15 novembre 2011, n 09/09 398

${ }^{1606}$ Cour de cassation, chambre criminelle, 19 mai 2004, $\mathrm{N}^{\circ} 03-83953$ However, it must be noted that in the given case the employee had a very extensive use connected to the consultation of pornographic sites, storing files and sending messages as well.

${ }^{1607}$ CA Pau, chambre sociale, Arrêt du 13 juin 2013

${ }^{1608}$ CA Pau, chambre sociale, Arrêt du 13 juin 2013

${ }^{1609}$ CABordeaux, chambre sociale, section A, Arrêt du 15 janvier 2013

${ }^{1610}$ CA Nîmes, 02 avril 2013, n ${ }^{\circ}$ 12/02146

${ }^{1611}$ CA Bordeaux, chambre sociale, section A, Arrêt du 15 janvier 2013
} 
in a negative way by the personal use: if the employee becomes distracted and commits professional mistakes, or as a direct consequence neglects or violates his/her other obligations (e.g. a bus driver checking Facebook while driving, or a cashier ignoring customers because of Facebook), the abusive nature might be more easily established. Also, the content accessed might be taken into consideration: for example, visiting Facebook pages containing questionable material (e.g. accessing homophobic, racist, paedophilic content, etc.) might affect the decision. These criteria can be useful when it comes to assessing whether the employee used SNSs to an abusive extent in the light of the given circumstances of a case.

552. Hungarian case law. As it was already stated, in Hungary limited case law is available compared to France. Notably, one case ${ }^{1612}$ relating to the personal use of the Internet shall be mentioned, in which the Hungarian Supreme Court examined whether the personal use of the Internet and e-mail can constitute a basis for extraordinary termination. In this case the employee used his and also his colleague's computer for personal purposes, mainly to visit pornographic sites. According to the court, it is the employee's obligation to perform his/her work in a way that does not lead to the incorrect judgement of the employer or other persons - described in the HLC as well. ${ }^{1613}$ The employee, who had an important and confidential position, violated this essential obligation to a significant degree. The Hungarian Supreme Court ruled that infringing the employer's restrictions and using another employee's computer for this purpose constituted a serious breach of obligation, and the activity constituted legal ground for termination of employment.

553. Another decision relating to being late for work can be mentioned, which can be indirectly relevant to the use of SNSs during working hours, as being late for work is also contrary to the employee's obligation of appearing at work on time. Theoretically, being only a few minutes late constitutes a breach of obligation - although the consequences of this breach will depend on the length of being late. ${ }^{1614}$ The consequences of being late might also depend on the given job: ${ }^{1615}$ for example, being a few minutes late

\footnotetext{
1612 BH2006.64

1613 From such reasoning, Éva Pete drew the conclusion that the employer can legitimately impose the general prohibition on the personal use of the Internet. Source: Pete, É. (2018) 'A munkavállaló és a munkáltató személyiségi jogainak védelme a munkaviszonyban', in Mailáth György Tudományos Pályázat 2017. Díjazott dolgozatok. Budapest: Országos Bírósági Hivatal, p. 782.

1614 Kártyás, G. (2013) A késés öt szankciója, Adó Online. Available at: https://ado.hu/munkaugyek/a-kesesot-szankcioja/ (Accessed: 7 January 2020).

1615 Pintér, M. (2019) A „,csak még öt perc” munkajogi következményei, Adó Online. Available at: https://ado.hu/munkaugyek/a-csak-meg-ot-perc-munkajogi-kovetkezmenyei/ (Accessed: 7 January 2020).
} 
might come with different implications for an airplane pilot or for a maid. Although arriving at work relatively little late but regularly for longer periods of time might constitute the reason for the termination of employment as it constitutes a breach of obligation, ${ }^{1616}$ the Supreme Court of Hungary ruled that the motivation of the termination shall not be considered reasonable if a long-term employee is dismissed because he/she arrived late at the workplace once. ${ }^{1617,} 1618$

According to my opinion, this provision should adequately be applied to the case of using SNSs, and the exact circumstances of the case should be taken into consideration. By analogy, unless the employer allowed personal use, consulting SNSs on a regular basis even for short periods constitute a breach of the employee's obligations and might serve as a reason for dismissal. However, it might be different if the employee infringes the employer's instructions and checks Facebook one time, for 5 minutes. Also, there might be a difference if a newly hired employee does that on his/her first week or an employee who has worked there for years. Therefore, the exact consequence depends on the given context.

554. (De lege ferenda) suggestion. Despite the lack of extensive case law in Hungary, the criteria identified from French case law might be of help when it comes to assessing whether personal use was abusive or not. As such, the length of the connection, its frequency and the content visited can play an important role in the assessement. Similar criteria were already taken into consideration in Hungary (e.g. length and frequency were considered when it came to assessing being late for the workplace, and content of the visited webpage was taken into consideration when it came to assessing whether consulting pornographic content was capable of leading to the incorrect judgement of the employer or other persons). The difference between the two countries is that France applied these criteria in a more systematic way, which might serve as an example for Hungary in the future.

${ }^{1616}$ Halmos, S. and Petrovics, Z. (2014) Munkajog. Budapest: Nemzeti Közszolgálati Egyetem Közigazgatástudományi Kar. Available at: http://m.ludita.uninke.hu/repozitorium/bitstream/handle/11410/8585/Teljes\%20sz\%C3\%B6veg\%21 ?sequence=1\&isAllowed=y (Accessed: 16 November 2018), p. 121.

1617 Gyulavári, T. (ed.) (2013) Munkajog. 2nd edn. Budapest: ELTE Eötvös Kiadó, p. 200.

1618 However, being late constituted a legitimate reason for termination of the employment contract in a case when the employee was away from the workplace for hours without permission - exceeding by hours the negotiated period for being away, as a result leaving co-workers with an increased amount of work and jeopardizing the safety of the service provided. (Source: 18/2018. számú munkaügyi elvi határozat) In this case, the Curia took into consideration that the employee was hours late, without giving reason for his absence, misinformed his superior, and it also considered the consequences of the behaviour. 
555. Conclusions drawn from the national regulations. In France a certain tolerance towards the personal use of the Internet can be observed, as a complete ban seems to be incompatible with the principle of proportionality. On the other hand, in Hungary, the employer's right to regulate and even prohibit personal use seems to be more prevailing, as the legality of a complete ban was not questioned especially due to the amendment of the HLC, but it was not questioned either by the majority of the doctrine, by the Data Protection Commissioner or the NAIH. As SNSs are Internet based platforms, these provisions should concern them as well. A common characteristic between the two countries is that according to the case law (much more abundant in France), the gravity of the employee's breach of obligation is linked to the circumstances of the case. In such cases, even if the employee uses SNSs for personal reasons despite the ban of the employer, a dismissal or some other sanction might easily be considered disproportionate if the conduct lacks the abusive character.

556. As a result, the key question to be answered is: when will the use be considered abusive or excessive? No universal solution can be provided to this question; however, it was determined what the circumstances that are usually taken into consideration are. The most decisive factor was the number of connections (Has the employee accessed SNSs once? Occasionally? Monthly? Weekly? Daily?) and the length of time spent on these sites (1 hour per day? 1 hour per week? 5 hours per day?). Then, as secondary criteria, courts also took into consideration other circumstances which could influence the decision: the content accessed (Does it pose a threat to the security of the network? Is it compromising?), or the eventual effects on the work of the employee (Was the employee distracted and committed mistakes as result of the social media use?). Then, if in consideration of the above criteria the use is not regarded to be excessive, the dismissal is not founded - even in cases when the internal regulation completely forbids the personal use.

557. However, one important observation must be made in the light of the employees' possibility to use work equipment for private purposes to a non-abusive extent, even if the employer had prohibited such use: in relation to social media, these observations do not lead to the existence of an explicit right to use social media during working hours. Although certain authors came to the conclusion that employees have the 
right to use social media during working hours, ${ }^{1619}$ it is more appropriate to interpret these provisions as aiming to ensure certain kind of personal communication (and not being completely cut off from the outside world and being able, for example, to make an urgent personal call or e-mail), but not necessarily communication through social media. ${ }^{1620}$ In this context, employees' right to privacy means that even at the workplace they do not cease to be human beings, and they can establish relationships with others. Therefore, the employer can decide to completely ban the use of SNS during working hours as long as other alternatives of communication (e.g. telephone, e-mail) are provided.

\section{Section 2. New challenges brought by social network sites}

The analysis so far was based on the regulation of Internet and e-mail use. However, SNSs present certain characteristics that are specific to them, compared to the traditional monitoring of e-mail and the Internet - which must be addressed in order to assess whether existing rules adequately regulate the matter or adjustments are needed. Besides the most traditional situation addressed in Section 1 (employees connecting to SNSs from the employer's equipment, during working hours), SNSs add certain other criteria to the discussion that must be examined. $\S 1$ will analyse these characteristics, while $\S 2$ will enumerate that in the light of these challenges, how SNS use during working hours should be regulated.

\section{§1. Issues specific to SNSs}

In contrast to regulating the "default situation" - covering scenarios when the employee accesses SNSs from the work computer provided by the employer, during working hours, with the employer's power to restrict SNS use - SNSs have certain characteristics that must be examined. Notably, SNSs are not only accessed from work computers, but due to the proliferation of mobile devices (such as smartphones, tablets or smart watches), employees can consult these sites from their own devices. So, first, it must be addressed whether it constitutes a substantial difference if the employee does not use the employer's equipment, but his/her device to access SNSs? Second, it will be examined

\footnotetext{
${ }^{1619}$ For example, Blandine Allix interpreted the relevant provision of the FLC, the observations of the CNIL and the Nikon decision as giving the right to the employee to consult his/her Facebook account during working hours even if the employer prohibited such a use. Source: Allix, B. (2014) 'L'employeur, le salarié et Facebook', Feuillet Rapide Social F Lefebvre.

${ }^{1620}$ Baugard, D. (2015) 'L'usage par les salariés des réseaux sociaux', in Ndior, V. (ed.) Droit et réseaux sociaux. Issy-les-Moulineaux: Lextenso (Collection LEJEP), p. 77-78.
} 
whether the time of consulting SNSs has importance: namely, the case of employees accessing these sites during work pauses will be addressed. Then, it will be highlighted how SNSs can become a means to reveal conducts breaching the employee's obligation to work.

\section{(A) Using the employee's device}

558. Employees' or employer's device? It is necessary to examine whether there is a difference if the employer aims to ban the use of SNSs during working hours from the employees' own device? A challenge brought by technological development is that SNSs can be used not only on computers, but also on mobile devices such as smartphones, tablets or even smartwatches. These days more and more people have their own smartphones and other devices, which they take with themselves everywhere - to the workplace, too. It is also not uncommon that individuals have their own mobile Internet subscription, so the blocking of SNSs (e.g. through not providing Wi-Fi or blocking the access to SNSs) by the employer is not an option in these cases, as employees can access these sites from their own devices. Although the employer has the right to regulate and monitor the use of SNSs on his/her computer, it is necessary to examine whether the scenario will be different when the device constitutes the property of the employee.

559. Delimitation from BYOD. First, in the case of BYOD, employees bring their own devices with the purpose of carrying out their jobs. ${ }^{1621}$ In the case of BYOD, the employer and the employee jointly agree that instead of the employer providing the necessary working conditions as required by labour law, the employee's own device will be used for it. In such a case, it is obvious that personal use cannot be completely prohibited, and also during the monitoring the employer must pay increased attention to the employee's right to privacy and right to data protection. ${ }^{1622}$

560. Employee's device. From the phenomenon of BYOD it must be differentiated when the employee uses his/her personal device for personal reasons - still with possible professional consequences. It was already established that in the case of the employer providing the device, he/she has the right to ban personal use and to monitor compliance with the regulation - the detailed rules relating to monitoring will be examined

${ }^{1621}$ WP29 (2017) Opinion 2/2017 on data processing at work. 17/EN WP 249, p. 16.

1622 The HLC explicitly regulates this issue and states in Subsection (5) of Section 11/A that if the parties agreed that the employee is going to use his/her own equipment for work, the employer can only inspect information relating to the employment relationship. 
in Chapter 2. However, if the employee uses his/her own device to access SNSs during working hours, these rules will be slightly different, especially in the field of monitoring compliance.

Despite the employee being the owner of the device, the employer can still ban the personal use, as irrespective of who owns the device, ${ }^{1623}$ surfing on SNSs during working hours breaches the employee's obligation to work and to be at the disposal of the employer. ${ }^{1624}$ Therefore, as such personal use still comes at the expense of working hours, it can be sanctioned. ${ }^{1625}$ However, their monitoring will be possible to a lesser extent compared to the use of the employer's devices.

\section{(B) Work pauses}

561. Work pauses. The possible personal use during work pauses also has a close connection with the ownership of the device. When being the owner of the equipment, the employer is entitled to define the rules relating to the use of such devices and is even entitled to prohibit the employee to access SNSs from this equipment. As in this scenario the employer is the owner, this prohibition can be extended to work pauses as well.

However, the situation might be different when the employee intends to access SNSs from his/her own equipment during work pauses. In Hungary, working pauses are not considered to be working time: ${ }^{1626}$ during these periods employees are free from performing work or be at the disposal of the employer, making personal use (on their own devices) possible. ${ }^{1627}$ In France, as a main rule, working pauses should not be considered as effective working time, ${ }^{1628}$ meaning that the employee is free to decide how to spend them. Also, when calculating time spent with personal activity, the already presented (French) cases relating to the personal use of the Internet did not take into consideration lunch breaks, implying that personal use during this period is not considered as a breach of

${ }^{1623}$ Kun, A. (2013) 'Közösségi média és munkajog - avagy „online” munkaidőben és azon túl', Munkaügyi Szemle, (3), p. 13.

${ }_{1624}$ Proskauer Rose LLP (2014) Social Media in the Workplace Around the World 3.0. 2013/14 Survey. Available at: http://www.proskauer.com/files/uploads/social-media-in-the-workplace-2014.pdf (Accessed: 3 February 2017). pp. 7-8.

${ }^{1625}$ Ray, J.-E. (2018) Droit du travail: droit vivant. 26th edn. Paris: Wolters Kluwer France. p. 324.

${ }^{1626}$ Subsection (3) of Section 86 of the HLC

1627 Kártyás, G., Répáczki, R. and Takács, G. (2016) A munkajog digitalizálása. A munkajog hozzáalkalmazása a digitális munkakörnyezethez és a változó munkavállalói kompetenciákhoz. Kutatási zárótanulmány. Budapest. p. 78.

${ }^{1628}$ Unless during these periods the employee stays at the employer's disposal and complies with his/her guidelines, without being able to freely attend to his/her personal affairs. Article L3121-2 and Article L31211 of the FLC. 
obligation and that the employee is free to decide how to spend these pauses. ${ }^{1629}$ This means that theoretically, during work pauses the employee should be free to access and use social media from his/her device.

562. However, Attila Kun provided a more nuanced picture of pauses and personal use of one's own equipment. He pointed out that even if the use does not directly violate the employee's obligation to work (e.g. checking Facebook during a pause), the use of social media can have an indirect effect on work, by impairing employees' attention. It is one of the employees' obligation to "appear at the place and time specified by the employer, in a condition fit for work." 1630 The employee is fit for work if he/she is wellrested, is not under the effect of alcohol or drugs and can concentrate on working with all his/her senses, in the right physical and mental condition. ${ }^{1631}$ This condition traditionally concerned the consumption of drugs and alcohol and their possible effects on working but in the $21^{\text {st }}$ century the overuse of SNSs or being overexposed to screens constitute more recent cases. The mass of ever-changing information on social media might result in the fact that the employee receives more information than he/she can process, causing fatigue and reducing concentration, having a direct effect on work. ${ }^{1632,1633}$

563. As concerns the break time and the use of social media, it also has to be taken into consideration that the employer has the obligation to ensure safe working environment, and the employer has to monitor whether workplace safety rules are respected. ${ }^{1634}$ Different regulations ${ }^{1635}$ aim to ensure the protection of employees in the case of work with display screen equipment, requiring the employees to make pauses from staring at a screen. Therefore, if an employee works with a computer and spends his/her break looking at the screen of his/her smartphone surfing SNSs, the workplace safety regulations are infringed, as the employer has to ensure breaks for the employee from

\footnotetext{
${ }^{1629}$ See, for example: CA Nîmes, 2 avril 2013, $\mathrm{n}^{\circ}$ 12/02146

${ }^{1630}$ Emphasis added by the author. Source: item a) of Subsection (1) of Section 52 of the HLC

1631 Jónás, T. (2015) Mit jelent munkára képes állapotban lenni?, Jogászvilág. Available at: https://jogaszvilag.hu/cegvilag/mit-jelent-munkara-kepes-allapotban-lenni/ (Accessed: 7 January 2020).

1632 Kun, A. (2013) 'Közösségi média és munkajog - avagy „online” munkaidőben és azon túl', Munkaügyi Szemle, (3), p. 13.

1633 See the already presented case, in which the Court of Appeal of Nîmes established the connection between professional mistakes made by the employee and the excessive personal use of the Internet. Source: CA Nîmes, 2 avril 2013, n 12/02146

${ }^{1634}$ Subsection (4) of Section 51 of the HLC and Article L4121-1 of the FLC

1635 Article R4542-4 of the FLC and 50/1999. (XI. 3) decree of the Ministry of Health on the minimum health and safety requirements for work with display screen
} 
staring at a screen. ${ }^{1636}$ If the employee works on a computer and then uses his/her pause to access social media from his/her smartphone, no pause will be ensured, resulting in the breach of labour law regulations.

564. In conclusion, in addition to being able to regulate the personal use of the equipment provided by the employer, in theory the employer also has the possibility to prohibit such use from the employees' own devices during working hours (and even during work pauses). The reason for this is that regardless of the ownership of the device, the employee must respect working hours, and must stay in a condition fit for work, along with respecting workplace safety regulations - which might be influenced by the use of SNSs. However, in practice, if the (reasonable) personal use does not come at the expense of the employee's ability to work or does not lead to an extensive use of technology, the employer might consider allowing personal use on the employee's device given the realities of being an employee in the $21^{\text {st }}$ century. According to my opinion, even if the employer decides to adopt a strict, prohibitive policy, in most cases, it should not exclude the possibility for the employee to have a glance at social media from his/her own device.

\section{(C) SNSs as proof of unauthorized absences}

565. SNSs as proof. Besides surfing on SNSs during working hours, SNSs might also contribute to revealing other types of activities at the expense of working time: in several cases employees on sick leave are caught on social media being a picture of perfect health. However, this activity is not directly connected to the main subject of the thesis, but rather to the subject of social fraud; as in such a case the use of SNSs itself does not breach any employee obligation but rather reveals those breaches inadvertently. Still, due to the possible proliferation of such discoveries, this subject must be at least briefly addressed in the dissertation.

566. In those cases the employee's conduct comes at the expense of working hours - similarly to the already discussed scenario, at the workplace during working hours, when the employee surfs on Facebook instead of working - but outside the workplace. Such cases include employees reporting being sick, but in reality being in perfect health, or making false excuses in order to be able to skip work (e.g. funeral of a relative, etc.). Such

${ }^{1636}$ Németh, J. (2013) 'Internet és közösségi háló mint munkaeszköz’, Infokommunikáció és jog, (1), p. 40. 
behaviour existed before SNSs as well, however, due to these platforms, their discoverability have considerably changed, as SNSs sometimes can expose these conducts.

Even before SNSs, it was possible to reveal that the employee was on vacation in spite of claiming to be on sick leave; SNS made it much easier to publish and to access such information. However, early examples of self-exposure from the pre-SNS era also exist: see, for example, the case of a French employee who - while being on sick leave went abroad for vacation and sent a postcard to his employer from Yugoslavia. As a result of his act, he was dismissed, but the Court of Cassation stated that the dismissal was not justified, as the employee was in a period of suspension of his employment contract, thus the charges against him did not constitute a breach of the obligations under the employment contract as the employee had not committed an act of disloyalty. ${ }^{1637}$

567. However, SNSs made a change in this field, and can highly contribute to revealing conducts breaching working hours, which is demonstrated by the growing number of cases arising. For example, see the case of a French employee who posted to an SNS when returning from sick leave: "after two weeks and three days of holiday it's going to be very hard...", suggesting that instead of being sick, he went on a holiday. However, the court found that as the employee could provide medical documentation for the concerned period, the absence was medically justified, therefore his act could not constitute a misconduct. ${ }^{1638,1639}$

\footnotetext{
${ }^{1637}$ Cour de cassation du 16 juin $1998, \mathrm{n}^{\circ} 96-41558$

1638 CA Amiens, 21 mai 2013, $n^{\circ} 12 / 01638$

${ }^{1639}$ Such cases are not only rising in France or in Hungary:

Or see, for example, the case of Kevin Colvin, who was an intern at Anglo Irish Bank's North American arm and told his manager that he had to be absent from work because of a family emergency. However, photos of him posted to Facebook revealed to his supervisors that instead of a family emergency, he attended a Halloween party, dressed as a fairy. He was dismissed due to his action. Source: Funk, T. (2011) Social Media Playbook for Business. Reaching Your Online Community with Twitter, Facebook, LinkedIn, and More. Santa Barbara, Denver, Oxford: Praeger, p. 176

In the case Gill $v$ SAS Ground Services UK Limited Mrs. Gill worked as a customer services representative for SAS Ground Services, while in her free time she acted and modelled, and in relation to these activities possessed a Facebook account. She went on sick leave for reasons related to her health, but her Facebook entries and YouTube videos revealed that during this period she attended the London fashion week, where she auditioned 300 models and choreographed a fashion show. She was dismissed for gross misconduct. The tribunal held that this evidence was sufficient to state the misconduct. Source: In the employment tribunals: August 2010. Facebook entry and YouTube video led to amateur model's dismissal (2010) XpertHR. Available at: https://www.xperthr.co.uk/law-reports/in-the-employment-tribunals-august2010/104153/\#gill (Accessed: 20 September 2018).
} 
568. Except for very special cases, ${ }^{1640}$ it is not the use of SNS itself that breaches the employees' obligation in such a case; instead, social media serves as a tool revealing the breach of obligation. In such a scenario, the employee violates his/her obligation to work and to be at disposal, as exemption from these obligations is only possible under determined circumstances. Therefore, deceiving the employer through such conduct can even constitute the basis for dismissal. ${ }^{1641}$ However, when using such posts for decisionmaking, attention should be paid to the enforcement of the data quality principles ${ }^{1642}$ because information obtained from social media is often not reliable, ${ }^{1643}$ as it was already presented in relation to hiring.

\section{\$2. Additional factors to be considered}

It was seen that from a legal point of view, the employer is entitled to decide how to regulate the personal use of SNSs: it is up to him/her to decide whether personal use is allowed or not and if yes, to what extent. However, in addition to this legal background, additional, non-legal arguments should also be considered when deciding whether to adopt a permissive or a more prohibitive regulation.

569. Factors to consider. First of all, when deciding in relation to personal use, what should be taken into consideration is the exact job that the employee performs, as depending on the exact work tasks, the possibility of a permissive regulation might be automatically excluded. In jobs where constant attention is required (for example, a doctor performing an operation, a worker at a production line or a bus driver, etc.) using SNSs during work is not optional. The employer has the freedom of deciding what regulation to adopt mostly in the cases of employees performing clerical work.

570. Advantages of banning personal use. As it was demonstrated by the examined case law, employees can be creative when abusing their "rights" and can spend a considerable amount of time on these platforms. This is contrary to the employer's

\footnotetext{
${ }^{1640}$ Except for very special cases. See, for example, the case of a Swiss woman who said to her employer that she was sick, complaining to have migraine and that she needed to rest in a dark room without using any computer: then her colleagues reported her seen active on Facebook and changing her status. Source: Rácz, I. (2017) A közösségi média és a munkajog kereszttüzében. Available at: http://arsboni.hu/kozossegi-media-esmunkajog-kereszttuzeben/ (Accessed: 27 February 2018).

${ }^{1641}$ Horváth, L. and Gelányi, A. (2011) 'Lájkolni vagy nem lájkolni? A közösségi oldalak használatának munkajogi kérdései', Infokommunikáció és jog, (2), p. 61.

1642 NAIH/2016/4386/2/V.

${ }^{1643}$ For example, it is possible that the employee on sick leave uploads a holiday picture to Facebook - but taken months before.
} 
legitimate interests, as he/she is lawfully entitled to expect employees to spend their working hours working. Checking SNSs during working hours is realised at the expense of working hours. Also, it can contribute to decreasing productivity, through fragmenting the attention of the employee, who might as a result commit professional mistakes. Also, as it was referred to, excessive use of such devices can have consequences on the health of the employees, which can result in them leaving on sick leave. Such use can also endanger network security, entails the risk of receiving viruses and also contributes to the deterioration of the device.

The negative effects associated with the extensive use of technology are acknowledged by a growing number of individuals and organizations, encouraging initiatives such as organizing digital detoxes at workplaces. Instead of simply prohibiting SNS use, the employer can actively encourage employees to spend time away from screens by organizing a digital detox, which might turn out to be beneficial for both parties. ${ }^{1644}$

571. Disadvantages of banning personal use. In spite of being free to decide whether employees can use social media at the workplace or not, it should be taken into account that in today's information society it might be unrealistic to completely ban its personal use. Today - whether we accept it or not - it has become a reality that individuals, especially younger generations, ${ }^{1645}$ spend a considerable amount of time on SNSs and they would not like to be completely cut off from these sites during working hours. It has even become an expectation from employees not to be completely cut off from these platforms while being at work - and a strict prohibitive regulation can even deter young employees. ${ }^{1646}$ Checking these profiles occasionally for 5-10 minutes would not necessarily harm the employer, instead, it can even contribute to productivity. ${ }^{1647}$ Also, a

${ }^{1644}$ Such measures might include tech-free meetings, communicating to employees the importance of regular breaks, organizing screen-free activities (e.g. yoga class) setting up of a buddy system, etc. Source: May, T. (2018) 6 Ways to Introduce A Digital Detox to Your Employees (and Why it Could Boost Productivity), HR Daily Advisor. Available at: https://hrdailyadvisor.blr.com/2018/07/24/6-ways-introduce-digital-detoxemployees-boost-productivity/ (Accessed: 8 January 2020).

1645 As Jean-Emmanuel Ray put it neatly, for young people born with the Internet, "Not being able to be connected is like working in an office without a window.” Source: Ray, J.-E. (2009) 'Actualité des TIC (II). Rapports collectifs de travail', Droit social, 1, p. 23.

1646 Sanders, A. K. (2013) 'Obscenity, Sexting, and Cyberbullying', in Stewart, D. R. (ed.) Social Media and the Law. A Guidebook for Communication Students and professionals. New York, London: Routledge, p. 170.

1647 Long, M. C. (2018) How Social Media Actually Boosts Efficiency in an Office Environment, Adweek. Available at: https://www.adweek.com/digital/how-social-media-actually-boosts-efficiency-in-an-officeenvironment/(Accessed: 27 July 2019); Bizzi, L. (2018) Employees Who Use Social Media for Work Are More Engaged - but Also More Likely to Leave Their Jobs, Harvard Business Review. Available 
more permissive regulation can promote trust between the parties, and therefore contribute to a better work environment

572. Besides employees' expectation, it might also be taken into consideration that the boundaries between work and private life are more and more blurred. As employees can receive a work-related e-mail during the weekend or can finish a task (from their own computer) at home in the evening, they might also wish to check their social media profiles during working hours, or just see on the newsfeed what happened to their contacts. ${ }^{1648}$ Employees might even consider these "Internet pauses" as a reward in exchange for the stress that they are subject to or in exchange for the overtime, when work invaded their personal lives. ${ }^{1649}$ Today it seems unreasonable to completely cut off employees from social media during working hours.

573. The technical feasibility of a ban might also pose certain issues. Since a myriad of these platforms exists, the employer would probably be able to block only the most widely used ones (e.g. Facebook or Instagram), but not all of them - giving employees the possibility to bypass the ban and access sites that were not blocked. Also, a strict regulation might only urge employees to use their own devices to check SNSs making it more difficult for the employer to monitor it. ${ }^{1650}$

574. Conclusion of Chapter 1. In conclusion, it can be stated that primary expectation towards the employee is to work at the workplace, and employers both in Hungary and in France have extensive powers to define the extent of the personal use of the employer's equipment. However, completely banning the personal use of the equipment might raise questions related to privacy as the right to privacy comprises the right to establish relationships with others - which is often done through different tools of ICT, such as SNSs.

In France, regulation seems to be more permissive, as the majority of scholars state that a complete ban would be disproportionate: the right to privacy requires that the employee has certain ways of establishing relationships with others, completely forbidding

at: https://hbr.org/2018/05/employees-who-use-social-media-for-work-are-more-engaged-but-also-morelikely-to-leave-their-jobs (Accessed: 27 July 2019).

1648 Kajtár, E. (2015) 'Till Facebook Do Us Part? Social Networking Sites and the Employment Relationship', Acta Juridica Hungarica, 56(4), p. 269.

1649 Denier, J.-L. (2003) 'L'utilisation privative des NTIC d'entreprise', Les cahiers du DRH, (89), p. 32.

1650 Krischer Goodman, C. (2011) Social Networks Test Companies' Boundaries, The Miami Herald. Available at: http://www.pordesresidential.com/wp-content/uploads/2010/11/1-19-2011-miami-heraldbiz.pdf (Accessed: 10 March 2017). 
every possibility for personal communication is not allowed. Meanwhile in Hungary, according to the major opinion, legally it seems possible that the employer completely bans the personal use of the employer's equipment, even though several scholars have expressed their opinion - according to my view, correctly - according to which a complete ban would be unrealistic.

575. It is also worth noting that even in cases when the employee uses the Internet/e-mails/SNSs for personal purposes despite the explicit ban imposed by the employer, the use is tolerated by courts if it stays reasonable and is not abusive. What is considered to be reasonable use depends on the exact circumstances: (French) courts usually took into consideration the time spent on these sites, the frequency of visiting them, their nature, whether they adversely affected the employee's work performance. In relation to SNSs it means that an employee cannot be dismissed if he/she uses Facebook for 5 minutes, even if personal use is contrary to the employer's policy.

576. In addition to the legal considerations, a complete ban faces technical difficulties due to the high number of SNSs and to the growing number of employees owning portable electronic devices. It would also be unrealistic in the $21^{\text {st }}$ century. For all the above reasons, it might be more expedient for the employer to tolerate and allow personal use to a reasonable extent, under specific conditions set by him/her, tailored to the characteristics of the workplace. It is crucial that the employer clearly informs employees about the regulation that he/she chooses to apply and about the exact limits of what is considered to be reasonable personal use by him/her.

577. The employer has the right to decide whether to allow personal use (and to what extent) or whether it is prohibited. When making and implementing this decision, first, the employer should decide how he/she would like to regulate the personal use of SNSs. In the light of the above, (in most cases) it is recommended that the employer opts for a more permissive regulation, but strictly lays down its condition in order to avoid abuses. If personal use is allowed, it is crucial that employees are aware of the exact rules of such regulation. Regularly informing and educating employees through meetings or trainings might be a good way to inform them about the employer's expectations, ${ }^{1651}$ or the

1651 Krischer Goodman, C. (2011) Social Networks Test Companies' Boundaries, The Miami Herald. Available at: http://www.pordesresidential.com/wp-content/uploads/2010/11/1-19-2011-miami-heraldbiz.pdf (Accessed: 10 March 2017). 
employer can lay down the rules in an internal regulation or in a social media policy. ${ }^{1652}$ Rules relating to personal use must be clearly established, so that employees can comply with them. Therefore, stating that a reasonable use is allowed is not enough, it is highly recommended that the employer sets the exact limits and time periods (e.g. 20 minutes daily, or only during pauses, etc.).

\section{Chapter 2: Employees' right to data protection: monitoring employee use of SNSs during working hours}

578. The second aspect of the subject is that after imposing the rules on the personal use of SNSs, how can the employer monitor whether employees comply with the regulation? As information relating to the use of the Internet/e-mail is considered to be personal data, data protection requirements shall apply to the monitoring of the personal use of the Internet/SNSs. ${ }^{1653}$ When it comes to the monitoring of communication (e-mail or instant messaging services), an additional aspect has to be considered, namely that it is not solely the employee's right to privacy/right to data protection which is affected by monitoring, but also the sender's or recipient's rights. ${ }^{1654}$

While regulating the use of work facilities for personal purposes raised more privacy-related issues, a data protection approach is more emphatic in the case of monitoring compliance with the regulation. After determining that the employee's right to privacy does not cease to exist within the workplace - even in the case of the prohibition of the personal use of work facilities -, the determination of the extent of monitoring can be better assessed through a data protection approach. The limits and conditions of such monitoring can be identified through the application of data protection principles, such as transparency, purpose limitation, necessity and proportionality.

\footnotetext{
1652 See more on them in Chapter 2.

1653 WP29 (2001) Opinion 8/2001 on the processing of personal data in the employment context. 5062/01/EN/Final WP 48. p. 13.; Szőke, G. L. et al. (2012) Munkahelyi adatvédelem. Nemzeti jelentés Magyarország. Available at: http://pawproject.eu/en/sites/default/files/page/web_national_report_hungary_hu.pdf (Accessed: 21 October 2016). p. 28., p. 34.; CNIL (2010) Guide pour les employeurs et les salariés. Les guides de la CNIL. p. 2.

1654 WP29 (2002) Working document on the surveillance of electronic communications in the workplace. 5401/01/EN/Final WP 55. p. 21. Szőke, G. L. et al. (2012) Munkahelyi adatvédelem. Nemzeti jelentés Magyarország.

Available at: http://pawproject.eu/en/sites/default/files/page/web_national_report_hungary_hu.pdf (Accessed: 21 October 2016). p. 28.; Hegedüs, B. (2005) 'A munkahelyi elektronikus levelezés ellenőrzésének nemzetközi gyakorlata’, Infokommunikáció és jog, 2(10), p. 186.
} 
Chapter 2 will follow a similar structure as Chapter 1: first, the already elaborated rules on Internet and e-mail monitoring will be discussed, and then the specific characteristics of SNSs will be taken into consideration in relation to the existing legal framework.

\section{Section 1. Starting point: monitoring of the Internet and e-mail}

579. The right to monitor is inherent to the employment contract: its existence is unquestionable, though determining its lawful extent might pose certain questions. ${ }^{1655}$ Although the employee is entitled to the right to respect for private life even within the workplace, it does not override the employer's right to access work computers. ${ }^{1656}$ Again, similarly to what was already discussed in Chapter $1,(\S 1)$ first, the European framework will be examined, $(\S 2)$ followed by the national regulations.

\section{\$1. Outlook to European law}

When addressing the question of the monitoring of the use of the Internet/e-mails, observations are made as regards the extent and the exact rules relating to such monitoring, determining how data protection requirements should be respected. First, $(a)$ the WP29's documents and then the $(b)$ ECtHR's case law will be addressed in detail.

\section{(A) EU perspective: the WP29's documents}

580. Overview of the WP29's documents. Although the principles laid down in Opinion $8 / 2001^{1657}$ are valid in the case of e-mail and Internet monitoring, it was the 2002 Working document ${ }^{1658}$ in which the WP29 has addressed in detail the question of monitoring of e-mail and Internet use at the workplace. The Working document also points out the importance of the general data protection requirements, and then addresses the question of e-mail and Internet monitoring. In its Opinion 2/2017, ${ }^{1659}$ the WP29 enumerates the most common data protection problems specific to the employment

\footnotetext{
1655 Vigneau, C. (2002) 'Information Technology and Workers' Privacy: the French Law', Comparative Labor Law \& Policy Journal, 23(2), p. 355.

1656 Contamine, A. (2013) 'La surveillance du salarié', Revue Le Lamy de la Concurrence, (37), p. 157.

1657 WP29 (2001) Opinion 8/2001 on the processing of personal data in the employment context. 5062/01/EN/Final WP 48.

1658 WP29 (2002) Working document on the surveillance of electronic communications in the workplace. 5401/01/EN/Final WP 55.

${ }^{1659}$ WP29 (2017) Opinion 2/2017 on data processing at work. 17/EN WP 249
} 
context ${ }^{1660}$ and takes into account the technological development that occurred since the adoption of its previous documents, while stating that the conclusions laid down in the Working Document still remain valid. ${ }^{1661}$ Under the item "Processing operations resulting from monitoring ICT usage at the workplace”, Opinion 2/2017 expressively deals with email and Internet monitoring at the workplace.

581. Prevention rather than detection. The WP29 emphasizes the importance of proportionality, transparency (e.g. by adopting policies). ${ }^{1662}$ The WP29's general standpoint is that instead of monitoring and detection, the emphasis should be placed on preventing the misuse of the employer's equipment. ${ }^{1663}$ This could be achieved by using programs that remind the employee of the misuse (e.g. warning windows, which pop up and alert the employee). ${ }^{1664,1665}$ This can suffice to prevent the misuse and the employee's visit to the website can be avoided. It follows from the requirement of subsidiarity that monitoring might not even be necessary, as the blocking of certain websites - for example, SNSs - can prevent employees from personal use. ${ }^{1666}$

582. Principle of proportionality and data minimization. According to the principle of proportionality and data minimization, the least intrusion possible must be made, so it is advisable that the employer avoid automatic and constant monitoring, unless it is necessary to ensure the security of the system. ${ }^{1667}$ When monitoring becomes necessary, due to the principle of proportionality, it should be first limited to the monitoring of traffic (number of mails sent, types of attachments, etc.), instead of

\footnotetext{
${ }^{1660}$ European Union Agency for Fundamental Rights and Council of Europe (2018) Handbook on European data protection law: 2018 edition. Luxembourg: Publications Office of the European Union, p. 332.

1661 WP29 (2017) Opinion 2/2017 on data processing at work. 17/EN WP 249. p. 12.

1662 WP29 (2002) Working document on the surveillance of electronic communications in the workplace. 5401/01/EN/Final WP 55. p. 14.

1663 WP29 (2002) Working document on the surveillance of electronic communications in the workplace. 5401/01/EN/Final WP 55. p. 4., WP29 (2017) Opinion 2/2017 on data processing at work. 17/EN WP 249. p. 15.

1664 WP29 (2002) Working document on the surveillance of electronic communications in the workplace. 5401/01/EN/Final WP 55. p. 5.

1665 According to the EDPS, it is more useful to watch the indicators (for example, volume of data downloaded) than the visited websites themselves and to take further steps only when there is a strong suspicion of misuse. Source: Buttarelli, G. (2009) 'Do you have a private life at your workplace? Privacy in the workplace in EC institutions and bodies'. 31st International Conference of Data Protection and Privacy, Madrid, 4-6 November.

1666 WP29 (2017) Opinion 2/2017 on data processing at work. 17/EN WP 249. p. 15.

1667 WP29 (2002) Working document on the surveillance of electronic communications in the workplace. 5401/01/EN/Final WP 55. p. 17.
} 
monitoring the content of the sites visited or the content of the messages sent. ${ }^{1668}$ Often, accessing the name of the sites visited is enough to detect the misuse of the computer (e.g. it is enough to know that despite a ban on personal use, the employee accessed the site www.facebook.com, it is not necessary to know exactly what content he/she looked for there) or, in several cases, a misuse can be detected by accessing traffic data (such as the participants and time of the communication) without accessing the content. ${ }^{1669}$

583. Monitoring of communication. As concerns the monitoring of communication, it poses an additional challenge that two persons' personal data are processed: the recipient's and the sender's. The privacy of both parties must be respected: in this regard, the respect of the rights of individuals outside the workplace might present a challenge. ${ }^{1670}$ However, in cases when the employee is given an e-mail account for purely personal use or is allowed access to a web-mail account, stricter rules apply: the monitoring of the content of messages is not legitimate (except for very limited cases - e.g. in relation to criminal activities), as the secrecy of correspondence outweighs the employer's legitimate interests in monitoring. ${ }^{1671}$

Often, the distinction between professional and personal communication is difficult (e.g. in the case when the employee uses his/her professional e-mail for personal purposes). However, compared to e-mail monitoring, a significant difference can be observed when it comes to SNS use: usually SNSs are used for personal purposes and only in exceptional cases for work. Therefore, as a main rule, communication taking place on SNSs is personal - and the conditions of monitoring should be more severe.

584. Principle of transparency. The principle of transparency requires employees to be informed regarding workplace monitoring. ${ }^{1672}$ The WP29 also suggests

1668 WP29 (2002) Working document on the surveillance of electronic communications in the workplace. 5401/01/EN/Final WP 55. pp.4-5., p. 17-18.

1669 WP29 (2002) Working document on the surveillance of electronic communications in the workplace. 5401/01/EN/Final WP 55. pp. 17-18.

${ }^{1670}$ In the cases of these individuals the employer should make reasonable efforts to inform them of the monitoring taking place if they can be affected by it. A solution to achieving this might be to insert warning notices to the outbound messages. Source: WP29 (2002) Working document on the surveillance of electronic communications in the workplace. 5401/01/EN/Final WP 55. pp. 17-18.

1671 WP29 (2002) Working document on the surveillance of electronic communications in the workplace. 5401/01/EN/Final WP 55. p. 21.

1672 WP29 (2002) Working document on the surveillance of electronic communications in the workplace. 5401/01/EN/Final WP 55. pp. 14-15. 
that the employee is informed as soon as misuse of the equipment is detected, in order to prevent future misunderstandings. ${ }^{1673}$

(B) CoE: the ECtHR's case law

585. Cases of Halford $v$. the UK and Copland v. the UK. Before addressing the more recent case law of the ECtHR, the Halford and Copland cases must briefly be mentioned, as both of them relate to the monitoring of employees. In the Halford $v$. the UK (1997) case the ECtHR ruled that phone calls made from business premises are covered by Article 8 of the ECHR and their interception constitutes an interference with Ms. Halford's right to privacy. ${ }^{1674}$ The ECtHR emphasized the importance of transparency in relation to the contracting states providing clear information in their legal order on the terms and conditions of such a (secret) monitoring. ${ }^{1675}$ In the Halford case it was held that no adequate provision in domestic law existed, resulting in the violation of Article $8 .{ }^{1676}$

586. In the Copland v. the UK case $e^{1677}$ Ms. Copland's telephone, e-mail and Internet usage was subjected to monitoring, without informing the applicant about it. Again, the ECtHR held that such communications are covered by Article 8 of the ECHR and that such monitoring is not in accordance with the law, with regard to the lack of notification. ${ }^{1678}$ Transparency is crucial, but Ms. Copland has received no warning that her communication would be subject to monitoring, ${ }^{1679}$ resulting in the violation of Article $8 .{ }^{1680}$

(a) Case of Bărbulescu v. Romania

587. ECtHR: Bărbulescu v. Romania. The Bărbulescu case defined the conditions that must be respected during employee monitoring. ${ }^{1681}$ Although the ECtHR's Grand Chamber ruled that national authorities did not strike a faire balance between the

1673 WP29 (2002) Working document on the surveillance of electronic communications in the workplace. 5401/01/EN/Final WP 55. p. 15.

${ }^{1674}$ ECtHR (1997) Halford v. the United Kingdom, Application no. 20605/92, 25 June, par. 44 and par. 48.

1675 ECtHR (1997) Halford v. the United Kingdom, Application no. 20605/92, 25 June, par. 49.

${ }^{1676}$ ECtHR (1997) Halford v. the United Kingdom, Application no. 20605/92, 25 June, par. 51.

${ }^{1677}$ ECtHR (2007) Copland v. the United Kingdom, Application no. 62617/00, 3 April

1678 European Union Agency for Fundamental Rights and Council of Europe (2018) Handbook on European data protection law: 2018 edition. Luxembourg: Publications Office of the European Union, p. 332.

${ }^{1679}$ ECtHR (2007) Copland v. the United Kingdom, Application no. 62617/00, 3 April, par. 42.

${ }^{1680}$ ECtHR (2007) Copland v. the United Kingdom, Application no. 62617/00, 3 April, par.44

1681 Costes, L. (2017) 'CEDH : surveillance des courriels d'un employé à son insu constitutive d'une violation du droit au respect de la vie privée et de la correspondance', Revue Lamy droit de l'immatériel, (140), p. 35. 
interests at stake and violated Article 8, not ensuring adequate protection of the applicant's right to respect for his private life and correspondence, ${ }^{1682}$ the existence of the employer's right to monitor remains uncontested. States have a broad margin of appreciation in determining the conditions of employee monitoring. However, such a monitoring cannot be limitless, proportionality and other safeguards are essential in order to make the monitoring lawful. ${ }^{1683}$

588. One of the significances of the decision is that the ECtHR provided an evaluation grid ${ }^{1684}$ and, in paragraph 121 of the judgement, elaborated 6 criteria that should be taken into account when assessing whether employee monitoring was lawful or not. These are:

- prior information: whether the employee has been notified of the possibility of monitoring correspondence and other communications, and of how this monitoring is implemented. The information should be provided prior to the processing and should be clear,

- extent of monitoring: what is the extent of the monitoring and the degree of intrusion into the employee's privacy? Distinction should be made between monitoring the content of communication or the flow of information. Also, it shall be assessed whether the monitoring's scope was limited in time and space, the number of people having access to the results, and whether all communications were subject to monitoring or only a part of them,

- employer's legitimate interests: whether the employer has legitimate reasons to justify the monitoring and the access to their content,

- less intrusiveness: whether the use of less intrusive methods would have been possible instead of accessing the content of communication,

- consequences for the employee: the consequences of the monitoring and how the result of the monitoring will be used by the employer,

- safeguards: whether the employee was provided adequate safeguards.

${ }^{1682}$ ECtHR (2017) Bărbulescu v. Romania, Application no. 61496/08, 5 September, par. 141.

${ }^{1683}$ Gheorghe, M. (2017) 'Considerations on the conditions under which the employer may monitor their employees at the workplace', Juridical Tribune, 7(2), p. 64.

${ }^{1684}$ Peyronnet, M. (2017) 'CEDH : la protection réaffirmée de la vie privée du salarié sur internet. CEDH 5 sept. 2017, Bărbulescu c. Roumanie, req. n 61496/08.', Dalloz actualité. 
589. The case and the decision attracted considerable attention of the media, ${ }^{1685}$ and it is an important milestone regarding employee monitoring. As the decisions of the ECtHR are binding for the contracting states, this decision has crucial importance with regard to the subject of the thesis. Especially two conclusions can be drawn: first, it was reinforced that the employee is entitled to the right to privacy: even in cases when he/she violates the ban on personal use, monitoring should be subject to strict conditions; and second, the ECtHR provided important criteria regarding what aspect shall be particularly assessed when it comes to the legitimacy of such monitoring. By this, the ECtHR struck a fair balance between employees' rights and the employer's legitimate interests. ${ }^{1686}$ Although the adaptation of French law to this decision should not pose problems, as in the case law of the Court of Cassation the balance between these two sides is already ensured in its decisions, ${ }^{1687}$ as well as in Hungarian law $-{ }^{1688}$ providing the criteria for the monitoring represents a significant guidance for both countries.

\section{(b) Case of Libert v. France}

590. ECtHR: Libert case. In the Libert v. France (2018) case ${ }^{1689}$ the ECtHR confirmed the French regulation by judging that the authorities struck a fair balance between the employee's rights and the employer's interest. ${ }^{1690}$ The ECtHR ruled that there

\footnotetext{
1685 In Hungary, especially after the decision of 2016, news portals were publishing articles entitled "From now on your employer can read your e-mails" etc. Source: Kártyás, G. and Kozma-Fecske, I. (2016) 'Szerelmes levelek a munkahelyi postafiókban', HR \& Munkajog, 7(3), p. 16.

1686 Andriantsimbazovina, J. (2017) 'L'encadrement stricte du contrôle par l'employeur de l'usage de la messagerie électronique du salarié ; Note sous Cour Européenne des Droits de l'Homme, grande Chambre, 5 septembre 2017, Barbulescu c/ Roumanie, numéro 61496/08', La Gazette du Palais, (41), p. 23.

1687 Andriantsimbazovina, J. (2017) 'L'encadrement stricte du contrôle par l'employeur de l'usage de la messagerie électronique du salarié ; Note sous Cour Européenne des Droits de l'Homme, grande Chambre, 5 septembre 2017, Barbulescu c/ Roumanie, numéro 61496/08', La Gazette du Palais, (41), p. 23.; Ray, J.-E. (2018) Droit du travail: droit vivant. 26th edn. Paris: Wolters Kluwer France.

However, according to Joël Colonna and Virginie Renaux-Personnic, while in the case of personal messages, French law is indeed compatible with the decision, it is not necessarily the case when it comes to the monitoring of professional mail. Source: Colonna, J. and Renaux-Personnic, V. (2017) 'Vie privée et surveillance des communications du salarié : la position de la Cour européenne des droits de l'Homme; Note sous Cour Européenne des Droits de l'Homme, grande Chambre, 5 septembre 2017, arrêt numéro 61496/08', La Gazette du Palais, (43), p. 45.

1688 Rózsavölgyi, B. (2018) 'Mikor lehet jogszerü a munkáltató ellenőrzése? - az Emberi Jogok Európai Bírósága Nagykamarája Bărbulescu kontra Románia ügyben hozott ítéletének iránymutatásai', Munkajog, 2(1), p. 48.

${ }^{1689}$ ECtHR (2018) Libert v. France, Application no. 588/13, 22 February

1690 Loiseau, G. (2018) 'La CEDH valide la jurisprudence de la Chambre sociale', La Semaine Juridique Social, (12), p. 11. [Page number referring to the online version of the article downloaded from: https://www.lexis360.fr/Document/vie_privee_du_salarie_la_cedh_valide_la_jurisprudence_de_la_chambre_ sociale_/zyiP_3vLY_y5rVWLGA3TgdU3HoxJt_utRta5bm5vCvQ1?data=c0luZGV4PTEmckNvdW50PTgw MiY=\&rndNum=1282688306\&tsid=search6_ (Accessed: 15 August 2019)]
} 
was no violation of Article 8, as the authorities acted within the margin of appreciation provided to them. The ECtHR noted that a balance had to be found between the employee's right to respect for private life and the employer's right to ensure that employees use the equipment provided by him/her for executing their work in compliance with their contractual obligations and applicable regulation. ${ }^{1691}$

591. The French courts applied the already elaborated rules in national jurisprudence, according to which employees' files stored on equipment provided by the employer are presumed to be of professional nature, allowing the employer to access them - unless the employee explicitly marks them as personal. ${ }^{1692}$ The opening of personal files was only permitted in the case of a risk or a particular event, in the presence of the employee or if he/she has been properly notified of it. ${ }^{1693}$

As soon as a computer is likely to be used for personal purposes, the monitoring of files potentially relating to the private life of the employee constitutes an interference in his/her private life, therefore, it must comply with the requirements making such an interference legitimate. ${ }^{1694}$ The ECtHR held that as French law described precisely in which circumstances and in which conditions such a measure was permissible, it complied with the requirements of Article 8, as it was in accordance with the law, pursued a legitimate aim in a democratic society. ${ }^{1695}$ The ECtHR was of the opinion that such a measure aimed to guarantee the rights of a third party, the employer, recognizing his/her legitimate interest in ensuring that employees use computer equipment that the employer provided them for work to execute their tasks, in accordance with their contractual obligations and with applicable regulation. ${ }^{1696}$ These measures were accompanied by adequate safeguards guaranteeing the respect of employees' rights, as the opening of personal files was only permitted in limited circumstances - both prescribed by regulation

\footnotetext{
${ }^{1691}$ ECtHR (2018) Libert v. France, Application no. 588/13, 22 February, par. 46.

1692 ECtHR (2018) Libert v. France, Application no. 588/13, 22 February par. 44.

${ }^{1693}$ ECtHR (2018) Libert v. France, Application no. 588/13, 22 February par. 44.

1694 Marchadier, F. (2018) 'La protection des données informatiques stockées sur l'ordinateur professionnel du salarié à titre du droit au respect de la vie privée', JCP G Semaine Juridique (édition générale), (15), p. 7. [Page number referring to the online version of the article downloaded from: https://www.lexis360.fr/Document/droit_au_respect_de_la_vie_privee_la_protection_des_donnees_informati ques_stockees_sur/vaS14U6Iwukx2jDaMX_gGIvPZpQXQbKfRC6B4fi9GSc1?data=c0luZGV4PTEmckNv dW50PTEwOSY=\&rndNum=1921247278\&tsid=search7_ (Accessed: 15 August 2019)]

1695 Nasom-Tissandier, H. (2018) 'L'importance de la charte informatique dans la justification de mesures de surveillance des salariés', Jurisprudence sociale Lamy, (451), p. 13.

${ }^{1696}$ ECtHR (2018) Libert v. France, Application no. 588/13, 22 February par. 46.
} 
and through the application of the courts. ${ }^{1697}$ Therefore, the way in which courts addressed the case was in accordance with Article $8 .{ }^{1698}$

592. The conclusion that can be drawn from the ECtHR's relevant case law is that the employer is indeed entitled to monitor employees. However, such a monitoring cannot be limitless; it must respect employees' rights. ${ }^{1699}$ It must meet the criteria such as being necessary, set by legal regulations, and the procedure must be transparent. With regard to SNSs, it means that the employer is entitled to monitor their use, however, only to a necessary extent, in order to achieve a legitimate purpose and only through giving detailed information to the employee. The scope of these criteria is further examined in national regulations.

\section{§2. Regulation at the national level: France and Hungary}

593. After examining what the "European norms" relating to monitoring are, it will be examined how France and Hungary regulate the question of monitoring SNS use at the workplace during working hours. The above-mentioned WP29 documents regulate the most important rules regarding the monitoring of employees' Internet use, while the relevant ECtHR case law provided the most important principles. However, these general requirements and principles must be assessed in a more detailed way - which was achieved at the national level.

First, it will be presented how France and Hungary decided to guarantee employees' right to data protection, and then, how the data protection principles are enforced. As the general protection of employees' rights has already been presented (principle of necessity, proportionality, transparency, etc.), here, focus will be put explicitly on the enforcement of these principles in the case of Internet and e-mail monitoring.

\section{(A) The outlines of regulation}

594. France. The FLC contains no direct provision in relation to the electronic monitoring of employees or their communication or Internet use. As it was already

1697 Sipka, P. and Zaccaria, M. L. (2018) 'A munkáltató ellenőrzési joga a munkavállaló munkahelyi számítógépén tárolt magánadatai fölött’, Munkajog, 2(2), p. 46.

1698 ECtHR (2018) Libert v. France, Application no. 588/13, 22 February, par. 53. Also see: Loiseau, G. (2018) 'La CEDH valide la jurisprudence de la Chambre sociale', La Semaine Juridique Social, (12), pp. 3037.

1699 Sipka, P. and Zaccaria, M. L. (2018) 'A munkáltató ellenőrzési joga a munkavállaló munkahelyi számítógépén tárolt magánadatai fölött’, Munkajog, 2(2), p. 47. 
addressed, in France, the Nikon decision laid down the principle that the employee has the right to respect for private life even while being at the workplace. ${ }^{1700}$ This protection was aimed at communication marked as personal, ${ }^{1701}$ resulting in a distinction between personal and professional communication. ${ }^{1702}$ However, this right is not without limits, the employer, as the person responsible for the functioning of the workplace, has the right to monitor employees. ${ }^{1703}$ In the workplace the employee is expected to work for his/her employer: therefore, the employer can access communication conducted at work, unless it is explicitly marked as personal. ${ }^{1704}$ In order to determine the nature of the communication, a presumption was established, according to which unless explicitly marked as personal, the communication is presumed to have a professional nature. ${ }^{1705}$ Then courts provided more guidance in relation to the application of this presumption.

595. Jurisprudence in France. Employers are entitled to monitor employees' activities during working hours, only their secret monitoring is prohibited. ${ }^{1706}$ Following from the rights and obligations of the parties, the employee's activity performed on the employer's equipment is presumed to have a professional character, ${ }^{1707}$ both e-mails ${ }^{1708}$ and Internet ${ }^{1709}$ connections. E-mails can be opened without the presence of the employee, and Internet connections can be consulted. The exception is when the e-mail message is clearly marked as personal. ${ }^{1710}$ The employee can identify e-mail as personal, for example, by placing a "warning" into the subject of the message or by creating a separate, personal folder within the account. Correctly identifying personal mails is crucial for the employee, as stricter rules apply to them: the Court of Cassation stated that " [...] unless there is a risk or a particular event, the employer may only open messages stored on the hard drive of the

\footnotetext{
${ }^{1700}$ Cour de cassation, chambre sociale, 2 octobre 2001, $\mathrm{n}^{\circ} 99-42.942$

${ }^{1701}$ Ray, J.-E. and Bouchet, J.-P. (2010) 'Vie professionnelle, vie personnelle et technologies d'information et de communication', Droit social, (1), p. 47.

1702 Kocher, M. (2013) 'La protection des données des salariés : que reste-t-il de l'arrêt Nikon ?', Legicom, (1), p. 131.

1703 Michel, S. (2018) 'TIC et protection de la vie privée du salarié', Bulletin Joly Travail, (2), p. 1. [Page number referring to the online version of the article downloaded from: https://www-lextenso-fr.bcujasezp.univ-paris1.fr/bulletin-joly-

travail/BJT110k3?em=TIC\%20et $\% 20$ protection $\% 20 \mathrm{de} \% 20 \mathrm{la} \% 20 \mathrm{vie} \% 20$ priv $\% \mathrm{C} 3 \% \mathrm{~A} 9 \mathrm{e} \% 20 \mathrm{du} \% 20$ salari $\%$

C3\%A9 (Accessed: 15 August 2019)]

${ }^{1704}$ Ray, J.-E. (2007) 'Actualités des TIC', Droit social, (9-10), p. 957.

1705 Kocher, M. (2013) 'La protection des données des salariés : que reste-t-il de l'arrêt Nikon ?', Legicom, (1), p. 131.

${ }^{1706}$ Cour de cassation, chambre sociale, du 14 mars $2000, n^{\circ} 98-42.090$

${ }^{1707}$ Cour de cassation, chambre sociale, 26 févr. 2013, $\mathrm{n}^{\circ} 11-27372$

${ }^{1708}$ Cour de cassation, civile, chambre sociale, 16 mai 2013, $\mathrm{n}^{\circ} 12-11.866$

${ }^{1709}$ Cour de cassation, civile, chambre sociale, 9 février $2010, \mathrm{n}^{\circ} 08-45.253$

${ }^{1710}$ Cour de cassation, chambre sociale, 11 juillet 2012, $\mathrm{n}^{\circ}$ 11-22.972; Cour de cassation, chambre sociale, 15 décembre 2010, $\mathrm{N}^{\circ}$ 08-42486; Cour de cassation, chambre sociale, 16 mai 2013, $\mathrm{N}^{\circ} 12-11866$
} 
computer identified as personal by the employee in the presence of the employee or if he/she has been properly notified of it [.]"1711 This requirement applies in the case of accessing the employee's SNS account as well: according to different courts, ${ }^{1712}$ the employer can get to know the content of the employee's Facebook account only in the presence of the employee - otherwise this proof will be considered unfair.

Internet connections from the work computer during working hours are presumed to be of professional nature - without the possibility to identify them as personal -, so the employer can look into them for the purpose of identifying them, without the presence of the employee. ${ }^{1713}$ Therefore the employee does not have the opportunity to mark the connection to Facebook as personal - it will automatically be presumed professional.

596. Standpoint of the CNIL. The CNIL also emphasized that employers are indeed entitled to limit and regulate how employees can use work devices and are entitled to monitor such a use, ${ }^{1714}$ through, for example, detecting viruses, filtering unauthorized sites, prohibiting downloading, monitoring the size of messages sent/received, etc. ${ }^{1715}$ It also confirmed that by default employees' activities conducted on the employer's equipment are presumed to be professional activity. ${ }^{1716}$ If messages are marked as personal (for example, in the subject of the message or registering the message in a specific folder), they are going to be protected by the secrecy of correspondence. ${ }^{1717}$ However, Internet connections and visited pages do not receive this protection, even if marked as favourites or added to certain bookmarks. ${ }^{1718}$ The CNIL also expressed more detailed recommendation in relation to the enforcement of the different data protection principles, such as transparency or necessity - which is going to be addressed in part (B).

597. Existing regulation in Hungary. The amendment of the HLC in 2019 made a significant change in the electronic monitoring of employees. While prior to the

\footnotetext{
${ }^{1711}$ Cour de cassation, chambre sociale, 17 juin $2009, \mathrm{n}^{\circ} 08-40.274$

1712 CA Rouen, Chambre sociale, 10 février 2015, $\mathrm{n}^{\circ}$ 14/03335; CA Caen, 1re chambre sociale, 27 janvier 2017, $\mathrm{n}^{\circ}$ 15/04417; CA Caen, 1 re chambre sociale, 27 janvier 2017, $\mathrm{n}^{\circ}$ 15/04402

${ }^{1713}$ Cour de cassation, chambre sociale, 9 juillet 2008, $\mathrm{N}^{\circ}$ 06-45800; Cour de cassation, chambre sociale, 9 février 2010, $\mathrm{N}^{\circ} 08-45253$

${ }^{1714}$ CNIL (2018) Les outils informatiques au travail. Fiches pratiques: Travail \& données personnelles.

1715 CNIL (2010) Guide pour les employeurs et les salariés. Les guides de la CNIL, p. 18, Bouchet, H. (2004) La cybersurveillance sur les lieux de travail. Paris, la Documentation française: Commission nationale de l'informatique et des libertés, p. 23.

1716 CNIL (2010) Guide pour les employeurs et les salariés. Les guides de la CNIL, p. 19.

1717 Bouchet, H. (2004) La cybersurveillance sur les lieux de travail. Paris, la Documentation française: Commission nationale de l'informatique et des libertés, p. 25.

${ }^{1718}$ CNIL (2018) Les outils informatiques au travail. Fiches pratiques: Travail \& données personnelles.
} 
amendment none of the provisions aimed explicitly at electronic monitoring, now Section 11/A contains direct provisions on the monitoring of work equipment. Besides declaring that unless agreed otherwise, work equipment can only be used for professional purposes, ${ }^{1719}$ it adds that during monitoring, the employer can only consult data connected to the employment relationship. ${ }^{1720}$ The HLC specifies what is considered to be data connected to the employment relationship: data which is necessary to monitor in compliance with the established rules relating to the use of work equipment. ${ }^{1721}$ Therefore, the extent of monitoring will be influenced by whether the employer has authorized personal use: if personal use is allowed, the employer can only monitor whether the conditions of personal use are respected; and if personal use is prohibited, the employer can only consult data to an extent allowing him/her to assess whether the data relates to the personal life of the employee or to the professional life. ${ }^{1722}$

598. Prior to the amendment, the extent of monitoring was also determined according to whether the employer has authorized the personal use or not. ${ }^{1723}$ In contrast to French regulation, protection is afforded not only to personal e-mails, but also to the authorised personal use of the Internet: if personal use was allowed, than it is not possible to monitor the use of the Internet. ${ }^{1724} \mathrm{I}$ share the view of Mariann Arany-Tóth, who adds that despite the authorization of personal use, monitoring should be allowed to control whether employees comply with the rules imposed on personal use. ${ }^{1725}$

599. Concerning e-mail monitoring, a distinction is made between personal and professional messages, and outgoing and incoming messages. However, as there is no established presumption created in order to establish whether the communication was professional or personal, the examination of the messages is conducted on a case-by-case basis. Also, in Hungarian regulation more attention is paid to the fact that individuals

${ }^{1719}$ Subsection (2) of Section 11/A of the HLC

${ }^{1720}$ Subsection (3) of Section 11/A of the HLC

${ }^{1721}$ Subsection (4) of Section 11/A of the HLC

1722 T/4479. számú törvényjavaslat az Európai Unió adatvédelmi reformjának végrehajtása érdekében szükséges törvénymódositásokról (2019). Előadó: Dr. Trócsányi László igazságügyi miniszter. Budapest, p. 102.

1723 Kártyás, G., Répáczki, R. and Takács, G. (2016) A munkajog digitalizálása. A munkajog hozzáalkalmazása a digitális munkakörnyezethez és a változó munkavállalói kompetenciákhoz. Kutatási zárótanulmány. Budapest, p. 17.

1724 Bankó, Z. and Szőke, G. L. (2016) Issues of the digital workplace - The situation in Hungary. Pécs: JurInfo, p. 65.; Pete, É. (2018) 'A munkavállaló és a munkáltató személyiségi jogainak védelme a munkaviszonyban', in Mailáth György Tudományos Pályázat 2017. Díjazott dolgozatok. Budapest: Országos Bírósági Hivatal, p. 782. See also: Data Protection Commissioner: 570/A/2001, 790/A/2001

1725 Arany-Tóth, M. (2016) Személyes adatok kezelése a munkaviszonyban. Budapest: Wolters Kluwer. p. 111-112. 
outside the organisation might be concerned by the monitoring, therefore their rights have to be respected as well: the extent of monitoring can be wider in the case of professional messages and outgoing messages. ${ }^{1726}$

600. Practice of the NAIH. It was already referred to that in Hungary in the field of employee monitoring, the practice of the Hungarian data protection supervisory authority bears special significance, acting as veritable case law. ${ }^{1727}$ As it was already mentioned, the $\mathrm{NAIH}^{1728}$ issued two crucial documents in the field of employee monitoring: Recommendation on the basic requirements of electronic monitoring at the workplace (2013) and Information notice on the basic requirements on data processing at work (2016), among which the second contains detailed rules relating to the monitoring of Internet and e-mail use.

601. In the information notice, first, the NAIH refined this position and stated that the employer is entitled to monitor whether employees comply with the internal regulation regarding the use of the equipment. ${ }^{1729}$ Then, it recommended certain best practices and drew attention to the data protection requirements that must be respected during such a monitoring (e.g. legal ground, necessity, transparency), and provided guidance in relation to how exactly the employer can comply with them. These requirements and the possible solutions given to them will be further addressed in part (B).

\section{(B) Data protection principles}

602. IP addresses, e-mail addresses, the websites visited all constitute personal data. As a consequence, their monitoring must comply with labour law legislation and data protection regulation as well. Both the French and the Hungarian data protection supervisory authorities already refined what data protection requirements must be respected during the monitoring and provided recommendations to comply with such

${ }^{1726}$ Bankó, Z. and Szőke, G. L. (2016) Issues of the digital workplace - The situation in Hungary. Pécs: JurInfo, p. 58.

${ }^{1727}$ Balogh, Zs. Gy. et al. (2012) 'Privacy in the Workplace', in Essays of Faculty of Law University of Pécs: Yearbook of 2012. Pécs: University of Pécs Faculty of Law, pp. 12-13.

${ }_{1728}$ On the case law established by the former Data Protection Commissioner see more in: Bankó, Z. and Szőke, G. L. (2016) Issues of the digital workplace - The situation in Hungary. Pécs: JurInfo and Szőke, G. L. et al. (2012)Munkahelyi adatvédelem. Nemzeti jelentés - Magyarország. Available at: http://pawproject.eu/en/sites/default/files/page/web_national_report_hungary_hu.pdf (Accessed: 21 October 2016).

1729 NAIH (2016) A Nemzeti Adatvédelmi és Információszabadság Hatóság tájékoztatója a munkahelyi adatkezelések alapvetö követelményeiröl. Budapest, p. 30. 
requirements. Notably, the principle of transparency and the principle of proportionality/necessity must be examined in detail.

\section{(a) Principle of transparency}

603. Principle of transparency. The general principle of transparency is also applicable when it comes to the monitoring of Internet/e-mail/SNS use at work. Regarding this principle, there are no differences compared to what was already presented: the principle of transparency requires that employees are aware of the processing prior to its start, and it is enshrined both at the international level and in French and Hungarian law. The covert surveillance of employees' activity on SNSs during working hours is not permitted. ${ }^{1730}$

604. In accordance with the principle of transparency, the CNIL emphasized the importance of informing employees about monitoring on several occasions. ${ }^{1731}$ The CNIL also drew attention to the growing practice of adopting internal regulations, which can indeed be a good way of informing employees, raising awareness, reminding them what kind of behaviour can represent a risk for the workplace. ${ }^{1732}$ The NAIH also encourages the adoption of such regulations, as they can constitute an effective way of informing employees of their obligations and of the expectations of the employer relating to the personal use of workplace equipment, as well as the rules relating to monitoring. ${ }^{1733}$

As regards informing employees, it is also said that prevention is more favourable than detection. Prior information on the use of SNSs at the workplace has key importance, as it would allow employees to be aware of the existing regulation in the workplace and to comply with it - which might make it possible to prevent monitoring ${ }^{1734}$ or misuses. ${ }^{1735}$ In the case of using social media for long periods, pop-up windows, or even applications analysing the time spent on the Internet can help employees to realize that they approached

\footnotetext{
1730 See, for example, the cases ABI 1012/K/2005-3, ABI 1723/P/2008, ABI 800/K/2008, ABI 235/K/2008 relating to the use of spyware, where the commissioner stated that the use of such a program is not compatible with the principle of proportionality and necessity.

${ }^{1731}$ CNIL (2010) Guide pour les employeurs et les salariés. Les guides de la CNIL, p. 18.

1732 Bouchet, H. (2004) La cybersurveillance sur les lieux de travail. Paris, la Documentation française: Commission nationale de l'informatique et des libertés, p. 11.

1733 NAIH (2016) A Nemzeti Adatvédelmi és Információszabadság Hatóság tájékoztatója a munkahelyi adatkezelések alapvető követelményeiröl. Budapest, pp. 25-26.

1734 NAIH (2016) A Nemzeti Adatvédelmi és Információszabadság Hatóság tájékoztatója a munkahelyi adatkezelések alapvetö követelményeiröl. Budapest, p. 25.

1735 Kártyás, G., Répáczki, R. and Takács, G. (2016) A munkajog digitalizálása. A munkajog hozzáalkalmazása a digitális munkakörnyezethez és a változó munkavállalói kompetenciákhoz. Kutatási zárótanulmány. Budapest, p. 67.
} 
or passed the time limit allowed by the employer. Regularly sending out reminders to employees regarding the rules on personal use can also be a recommended method. ${ }^{1736}$

\section{(b) Principle of proportionality}

605. Proportionality principle. Although the employer has the right to monitor, it should not be limitless: it is especially the proportionality principle that limits his/her rights during monitoring.

606. In France, Article L1121-1 of the FLC aims to ensure that employee monitoring is proportionate to the aim sought and is not a means to discipline employees without any other purpose. ${ }^{1737}$ As Christiane Féral-Schuhl remarks, in accordance with the principle of proportionality, employers should only monitor employees if the employee is suspected of abusive use, for example, because of abnormally long connections or an unusually huge amount of downloaded files. ${ }^{1738}$ According to the CNIL, first, monitoring should be conducted retrospectively, at a global level (e.g. at the level of the whole workplace or a service), therefore the examination of individual connections of a certain employee could be avoided. ${ }^{1739}$ Also, the use of key logger programs, or receiving an automatic copy of all messages is to be avoided. ${ }^{1740}$

607. In Hungary, the NAIH recommended the adoption of a staggered control system, where first looking at the subject and the sender can help to contribute to deciding whether the communication was of a professional or a personal nature - without having access to the content. ${ }^{1741}$ It is important that the employer cannot have access to the content of personal communication, or the pages visited - even if the employee violated the policies relating to personal use. ${ }^{1742,1743}$ Having access to such content is allowed only if

1736 NAIH (2016) A Nemzeti Adatvédelmi és Információszabadság Hatóság tájékoztatója a munkahelyi adatkezelések alapvetö követelményeiröl. Budapest, p. 26.

1737 Grynbaum, L., Le Goffic, C. and Morlet-Haïdara, L. (2014) Droit des activités numériques. 1st edn. Paris: Dalloz. p. 896.

${ }_{1738}$ Féral-Schuhl, C. (2018) Cyberdroit. Le droit à l'épreuve de linternet. 7th edn. Paris: Dalloz. p. 415.

${ }^{1739}$ CNIL (2005) Guide pratique pour les employeurs. Les guides de la CNIL. p. 11.

${ }^{1740}$ CNIL (2018) Les outils informatiques au travail. Fiches pratiques: Travail \& données personnelles.

1741 NAIH (2016) A Nemzeti Adatvédelmi és Információszabadság Hatóság tájékoztatója a munkahelyi adatkezelések alapvetö követelményeiröl. Budapest, p. 26.

1742 NAIH (2016) A Nemzeti Adatvédelmi és Információszabadság Hatóság tájékoztatója a munkahelyi adatkezelések alapvetö követelményeiröl. Budapest, p. 27.

${ }^{1743}$ By stating that, the NAIH refined the previous practice, according to which the content of such a communication was accessible to the employer if he/she obtained the consent of both the sender and the recipient. (Source: Szőke, G. L. et al. (2012) Munkahelyi adatvédelem. Nemzeti jelentés - Magyarország. Available at: http://pawproject.eu/en/sites/default/files/page/web_national_report_hungary_hu.pdf (Accessed: 21 October 2016). p. 30.) As Szöke et. al. noted, inconsistencies could be found in the practice of 
without that access it is not possible to establish whether the employee has breached the regulation related to personal use. ${ }^{1744,} 1745$

608. After narrowing down the search to professional messages, the employer can process more detailed information; but even in this case proportionality shall be respected and - depending on the exact circumstances - searches should be limited (e.g. in time, only to messages with an attachment, etc.). The employer should only have access after narrowing down the search as much as possible. ${ }^{1746}$ As there is no presumption in Hungarian regulation, as a main rule, the presence of the employee is requested in order to avoid the possible confusion of professional and personal messages; the employee can then indicate if the message is personal, thus avoiding having access to the content of personal messages. ${ }^{1747}$ However, even though the content of communication is protected, in such a case the employee would still have to face the legal consequences of personal use. ${ }^{1748}$

In relation to SNSs, this means that as a main rule, SNSs suppose personal use (in contrast to other Internet connections), employers should not access the content of these pages, as in most cases the purpose sought can be achieved by collecting data on the name/address of the sites visited (e.g. www.facebook.com), when they were accessed and for how long. ${ }^{1749}$

609. Conclusions of Section 1. In conclusion, the employer has the right to monitor employees' use of e-mail and the Internet in order to ascertain whether they have

the Data Protection Commissioner, mostly due to the uncertainties relating to the legal ground of processing. (Source: Szőke, G. L. et al. (2012) Munkahelyi adatvédelem. Nemzeti jelentés - Magyarország. Available at: http://pawproject.eu/en/sites/default/files/page/web_national_report_hungary_hu.pdf (Accessed: 21 October 2016). p. 28., p. 30.) However, since the establishment of the NAIH and the change of the legal environment in 2011-2012, one of the greatest changes in workplace data protection was the application of the legal ground of balancing interests - instead of the previously used consent. (Source: Bankó, Z. and Szőke, G. L. (2016) Issues of the digital workplace - The situation in Hungary. Pécs: JurInfo. p. 53.)

1744 Kártyás, G., Répáczki, R. and Takács, G. (2016) A munkajog digitalizálása. A munkajog hozzáalkalmazása a digitális munkakörnyezethez és a változó munkavállalói kompetenciákhoz. Kutatási zárótanulmány. Budapest, p. 67.

${ }^{1745}$ Recently, it has also appeared in the practice of the NAIH that according to the principle of fairness, the presence of the employee (or a person appointed by the employee) should be ensured, unless the matter is urgent or the employee does not work at the employer anymore. However, even in these cases, the (former) employee should be informed of the measures taken. Source: NAIH/2019/51/11., p. 19.

1746 NAIH (2016) A Nemzeti Adatvédelmi és Információszabadság Hatóság tájékoztatója a munkahelyi adatkezelések alapvetö követelményeiröl. Budapest, p. 27.

1747 NAIH (2016) A Nemzeti Adatvédelmi és Információszabadság Hatóság tájékoztatója a munkahelyi adatkezelések alapvetö követelményeiröl. Budapest, p. 27.

1748 Hegedüs, B. (2006) 'A munkahelyi hagyományos és elektronikus levelezés ellenörzése', Munkaügyi szemle, 50(6), p. 49.

1749 NAIH (2016) A Nemzeti Adatvédelmi és Információszabadság Hatóság tájékoztatója a munkahelyi adatkezelések alapvetö követelményeiröl. Budapest, p. 31. 
complied with the rules relating to their use. However, courts (notably the ECtHR and national courts), as well as data protection supervisory authorities (WP29, CNIL, NAIH) emphasized the importance of the respect of data protection principles along with providing recommendations on how to comply with them. This regulation will be basically applicable to SNSs, however, the specific characteristics of these services must be taken into consideration.

\section{Section 2. New factors to be considered - highlighted by SNSs}

Section 1 focused on the already existing regulation which is applicable to the monitoring of Internet and e-mail use. Although what was said is adequately applicable to SNSs as well, SNSs possess certain characteristics that distinguish them from the Internet and e-mail. First, these $(\S 1)$ characteristics will be examined, then $(\S 2)$ it will be addressed how exactly employers should monitor employees' SNS use in the light of the abovepresented legal regulations, considering the specificities of SNSs. The question that Section 2 aims to answer is that in consideration of the challenges brought by SNSs, how the employers should monitor the use of SNSs during working hours.

\section{§1. Specific issues raised by SNSs}

Despite their similarities to the Internet and e-mail, SNSs also have several specific characteristics, which raise new questions in relation to the application of the already established regulation. When discussing specific issues raised by SNSs, a difference must be made between two scenarios: SNS use constituting part of the employee's job description and not. For the purposes of the dissertation it will be presumed that, as a main rule, SNS use is not part of the employee's job, and the case when it is will be treated separately.

610. Main difference in relation to SNSS. When it comes to the monitoring of the personal use of SNSs, the main difference that can be observed compared to the monitoring of the personal use of the Internet and e-mail is the lack of the possible confusion of personal and professional use. In the case of Internet and e-mail monitoring, the main privacy/data protection issue lies in the fact that both the Internet and e-mail can be used for professional and for personal purposes as well, therefore, the confusion 
between professional and personal use is possible. ${ }^{1750}$ In contrast, in the case of SNSs, this confusion is not present, as SNSs are usually not used as a tool for work, but uniquely for personal purposes.

611. It means that in the case of surfing SNSs, no special challenges arise, as the principle according to which every Internet connection is presumed to have a professional nature is clearly laid down in French law. Although these connections do not receive more intense protection - as they are presumed to be of professional nature, in contrast to their clearly personal nature -, through the effective application of the proportionality principle (e.g. consulting the name of the site, instead of the exact content) the employee's right can be protected. In Hungary as well, the application of the proportionality principle ensures protection, despite the lack of such presumption.

612. However, the use of SNSs as messaging services might seem to be more problematic at first sight, especially in French law. In France, protection is afforded to personal correspondence when the employee marks the communication as personal. However, on instant chat messaging services on SNSs, users do not have appropriate means to identify the message as personal (as the field "subject" is missing) - which is a key criterion in order to trigger the protection afforded by the secrecy of correspondence. ${ }^{1751}$ In accordance with the existing legal framework, in the lack of identifying as such, the communication on SNSs is not presumed to be personal, despite the fact that SNSs are not even used for work.

However, contrary to this established presumption of professional nature, in 2017 the Court of Cassation - in the light of the presumption of professional nature - rejected the employer's arguments according to which accessing an employee's Facebook account by obtaining access to the professional cellphone of another employee was acceptable. ${ }^{1752}$ Instead, it ruled that regardless of the device used (even if it is the employer's), SNSs are included in the right to respect for the employee's private life - excluding the application

\footnotetext{
${ }^{1750}$ Féral-Schuhl, C. (2018) Cyberdroit. Le droit à l'épreuve de linternet. 7th edn. Paris: Dalloz. p. 420. and Grynbaum, L., Le Goffic, C. and Morlet-Haïdara, L. (2014) Droit des activités numériques. 1st edn. Paris: Dalloz. p. 902.; NAIH (2016) A Nemzeti Adatvédelmi és Információszabadság Hatóság tájékoztatója a munkahelyi adatkezelések alapvetö követelményeiröl. Budapest, p. 25.

${ }^{1751}$ In the case of e-mails, it is recommended to identify the message as personal either by storing them in a directory entitled "personal" or "private", or by indicating in the subject field "personal" or "private". (Source: CNIL (2018) Les outils informatiques au travail. Fiches pratiques: Travail \& données personnelles.) However, that is usually not an option when it comes to SNSs. A solution can be to place identification at the beginning of the message in order to appear in the preview of the message.

${ }^{1752}$ Cour de cassation, chambre sociale, 20 décembre 2017, № 16-19609
} 
of the presumption in the case of SNSs. Although I welcome such a solution as it grants protection to communication conducted on SNSs, it is unfortunate that no further details were provided regarding the background of adopting this solution. ${ }^{1753}$

613. All this means that in reality, corresponding through SNSs is more similar to the case of using a personal e-mail account. Naturally, as even personal e-mails received/sent through professional accounts are protected by the secrecy of correspondence, e-mails received/sent through a personal account should receive increased protection. ${ }^{1754}$ Employers cannot monitor e-mails from employees' personal accounts, they are covered by the secrecy of correspondence - and they cannot be used during litigation either. ${ }^{1755,} 1756$ This restriction applies even if the employee accesses the personal account from the work computer, ${ }^{1757}$ however, if e-mails transferred from a personal e-mail account are stored on the hard drive of the work computer, they are not presumed to have a personal character. ${ }^{1758,1759}$

614. In Hungary, as there is no presumption, the employer should examine on a case-by-case basis whether the correspondence was professional or personal. As SNSs $a$ priori suppose personal use, establishing that they have a personal nature should not constitute a specific problem, as due to the lack of presumption they are not presumed to be professional.

615. Using SNSs as part of the job. Although most job descriptions do not include the use of SNSs as part of the job, in certain cases it is conceivable that employees might use those for work purposes. One obvious example is the operation of the company's official social media account. In such cases accessing SNSs can be of professional nature: giving rise to possibly blurring personal and professional use.

1753 Mayoux, S. (2018) 'Licéité de la preuve recuillie sur Facebook par l'employeur', Jurisprudence sociale Lamy, (449), p. 25. See more on the case in Title 3.

1754 Lhernould, J.-P. (2016) 'Statut des courriels provenant de la messagerie personnelle du salarié', Jurisprudence sociale Lamy, (405), p. 11.

${ }^{1755}$ Cour de cassation, 26 janvier 2016, $\mathrm{n}^{\circ} 14-15.360$

1756 Unless exceptional circumstances are present, and safeguards are guaranteed - e.g. involvement of a bailiff, research limited to the messages in relation to the litigation. (Cour de cassation, 1ère chambre civile, 20 septembre 2017, $\mathrm{n}^{\circ} 16-13082$ ) The employer has to demonstrate to the judge the existence of a legitimate aim, and that a violation was already committed. Source: Griguer, M. (2010) 'Les réseaux sociaux sous le contrôle des DSI', Cahiers de droit de l'entreprise, (6), p. 63.

1757 Cour de cassation, chambre sociale, 7 avril 2016, $\mathrm{n}^{\circ} 14-27949$

${ }^{1758}$ Cour de cassation, chambre sociale, 19 juin $2013, \mathrm{~N}^{\circ} 12-12138$

1759 Just as in the case of storing personal files on a work computer, the employee should indicate that these messages are of personal nature. 
616. In French law, in such cases, the confusion of personal and professional use becomes possible so - just like in the case of "traditional" Internet and e-mail monitoring the rules elaborated to these monitorings shall be applied, which allow the employer to consult the sites visited as they are presumed to be of professional nature. A challenge involved in the use of the messaging functions of SNSs services is that, due to the lack of the field "subject", it is not possible to indicate in the subject field that personal communication takes place.

In this regard, the situation is similar to that of SMS messages, which are presumed to have a professional character, unless identified as personal: ${ }^{1760}$ however, technically it is not feasible to indicate the personal character of these messages, the employer has to access the content of the message to be able to know its personal nature. ${ }^{1761}$ Although this solution was proposed for SMSs, chat messages on SNSs have similar characteristics, making it possible to apply this method to them: the personal character can be signalled by placing identification at the beginning of the message (e.g. “!!!personal message!!!”) in order to appear in the preview of the message. ${ }^{1762}$

617. In Hungarian law, it is also a problem that messages sent within SNSs cannot be easily identified as personal. Therefore, distinguishing professional and personal use can be challenging. However, those said in relation to French law can successfully be applied to Hungarian law as well: indicating in the preview of the message that it is personal can constitute an effective way of separating professional messages from private ones. Also, the name of the corresponding party can be revealing ${ }^{1763}$ and can contribute to excluding certain messages. Besides, by ensuring the presence of the employee it can be achieved that the employer successfully distinguishes between personal and professional messages and does not access personal communication.

618. Employer's device vs. employee's device. It was already established that the employer is entitled to monitor the use of work equipment. However, it was already presented that the proliferation of mobile devices in everyday life raises specific questions

\footnotetext{
${ }^{1760}$ Cour de cassation, chambre commerciale, financière et économique, 10 février $2015, \mathrm{n}^{\circ}$ 13-14.779

1761 Lhernould, J.-P. (2015) 'Les SMS du salarié à la libre disposition de l'employeur?', Jurisprudence sociale Lamy, (385), p. 10.

1762 Adam, P. (2015) 'SMS, vie privée et portable professionnel : histoire (courte) d'un homme "sans territoire", Revue droit du travail Dalloz, (3), p. 193.

${ }^{1763}$ For example, Facebook allows giving nicknames to parties - which can constitute a way of showing the personal character of a message.
} 
when employees use their own devices to access SNSs during working hours. Although regulating their use seemed to be possible, their monitoring can pose specific questions. ${ }^{1764}$

619. In cases when the device is the employee's property, the employer is limited in monitoring their use; he/she cannot have access to the content/pages visited on these devices. ${ }^{1765}$ However, even if the employee succeeds in escaping from the prying eyes of the employer through accessing SNSs from his/her own device, an excessive use of these sites would come at the expense of the performance of work tasks, ${ }^{1766}$ allowing the employer to eventually detect the abuse and take the necessary steps.

Without the possibility to monitor personal devices, the activity of employees checking their Facebook can easily remain invisible. However, in certain exceptional cases the employer can still find out about such a use. One exception can be when the employee posts or likes something during working hours - despite the ban of social media use - and the time of the post or like reveals to the employer that the employee has infringed the limitation. Another exception can be manifested in the consequences of (abusive) personal use: if personal use has negative effects on working (e.g. committing mistakes, missing deadlines, etc.), the employer can sanction such behaviour in accordance with the relevant labour law regulations. ${ }^{1767}$

620. In conclusion, one of the main differences between Internet/e-mail monitoring and the monitoring of SNSs is the lack of possible confusion of personal and professional use. While the Internet and e-mail can serve both as a tool for work (communicating with co-workers, clients, obtaining information) and a tool for amusement (e.g. playing online games, booking a holiday, purchasing products online, etc.), SNSs are by default used for personal (amusement) purposes in most cases. An exception is notably when the use of SNSs is included in the job description, in which case the confusion

\footnotetext{
${ }^{1764}$ Kun, A. (2013) 'Közösségi média és munkajog - avagy „online” munkaidőben és azon túl', Munkaügyi Szemle, (3), p. 13.

1765 Proskauer Rose LLP (2014) Social Media in the Workplace Around the World 3.0. 2013/14 Survey. Available at: http://www.proskauer.com/files/uploads/social-media-in-the-workplace-2014.pdf (Accessed: 3 February 2017), p. 3.; Kun, A. (2013) 'Közösségi média és munkajog - avagy „online” munkaidőben és azon túl', Munkaügyi Szemle, (3), p. 13 and Ray, J.-E. (2018) Droit du travail: droit vivant. 26th edn. Paris: Wolters Kluwer France. p. 324.)

1766 Ray, J.-E. (2018) Droit du travail: droit vivant. 26th edn. Paris: Wolters Kluwer France. p. 324.

${ }^{1767}$ For example, an employee in Wales was dismissed in 2013 for accessing social network sites during working hours from his own device. Unfortunately, it was not documented how the employer became aware of such use. Source: Rudd, A. (2013) DVLA worker fired for using Facebook on his mobile phone during office hours, Mirror. Available at: https://www.mirror.co.uk/news/uk-news/dvla-worker-fired-usingfacebook-1903697 (Accessed: 25 July 2019).
} 
between accessing SNSs as part of the job or for personal reasons is present as well. Another difference is that on SNSs the absence of the "subject" field makes it complicated to mark the communication as personal.

\section{§2. Monitoring employees' SNS use}

It was already established on several occasions that the employer is entitled to monitor employees. Such a monitoring can include the monitoring of the use of the work equipment as well as the employee's respect of working hours. In Section 1 it was found that the employer is free to decide whether the personal use of work equipment is authorized or not and is entitled to monitor compliance with the established regulation. The following paragraphs contain recommendations regarding how employers should monitor whether employees respect the rules set up and what they should take into consideration when establishing monitoring. First, $(A)$ it will be discussed what rules should be established, then $(B)$ how they should be communicated to employees.

\section{(A) Rules of employee monitoring}

621. Prevention. As regards enforcing that employees comply with the rules of personal SNS use set by the employer, it is recommended that emphasis is put on prevention. If employees are aware of the rules (either it is a complete ban or a more permissive regulation), the emergence of several issues can be prevented. This can be achieved by informing them: raising their awareness through regularly reminding them of the rules or organizing trainings can be effective ways to achieve this goal.

Another way of prevention is to make it impossible for employees to engage in the prohibited behaviour. The most obvious means is to ban the access to SNSs. However, when opting for such a solution, employers should take the weak points into consideration: that it is not possible to prohibit access to all social media and SNS platforms, only to the most popular ones (e.g. Facebook, Instagram, YouTube, Twitter). Also, such a ban can only be put on the employer's equipment. Employees would still have the possibility to access these sites from their own devices.

622. Setting a reminder. If the employee tries to access a prohibited site despite the restrictions imposed on such a use, he/she should be reminded of the rules. For example, alerts and pop-up windows should be employed, which can remind the employee that he/she wants to access a prohibited page, or in the case of a more permissive 
regulation that he/she is approaching/exceeded the authorized time limit. ${ }^{1768}$ Such a measure can also contribute to enhancing compliance with the regulation and also to preventing misuse through raising employee awareness.

623. Monitoring SNSs. As a main rule, the employer should not gain access to the exact content visited or communication held in either countries with regard to the fact that SNSs are used for personal purposes, both in the case of surfing on them or using them as a means of communication. In accordance with the data protection principles, instead of accessing the content, the employer should settle for having access to the different indicators of the use (e.g. time spent on SNSs, or data traffic), as through that information he/she is perfectly capable of ascertaining whether personal use has taken place or not, or whether it has exceeded the allowed amount. ${ }^{1769}$

624. Distinguishing personal and professional use. In cases when the employer is in need of determining whether the use was personal or professional, it can be recommended to encourage employees who use SNSs as part of their jobs to indicate at the beginning of the message if it is personal in order to avoid confusion (e.g. "PERSONAL MESSAGE"). ${ }^{1770}$ The presence of the employee can also contribute to the protection of private life and data protection rights. ${ }^{1771}$

\section{(B) Social media policies}

625. Social media policies. It is not uncommon for employers to regulate the question of SNS use at the workplace in internal social media policies and it is a recommended practice by different organizations. ${ }^{1772}$ Usually, these policies aim to regulate behaviour both within and outside the workplace, and also the possible

1768 WP29 (2002) Working document on the surveillance of electronic communications in the workplace. 5401/01/EN/Final WP 55. p. 5.

1769 Buttarelli, G. (2009) 'Do you have a private life at your workplace? Privacy in the workplace in EC institutions and bodies'.31st International Conference of Data Protection and Privacy, Madrid, 4-6 November.

1770 Information Commissioner's Office (2011) The employment practices code. Available at: https://ico.org.uk/media/for-organisations/documents/1064/the_employment_practices_code.pdf (Accessed: 8 October 2018), p. 70.

${ }^{1771}$ French law even requires it: Cour de cassation, civile, chambre sociale, 17 juin 2009, 08-40.274

1772 See, for example, the survey conducted by Proskauer on social media in the workplace or the ICO's code of practice. Source: Proskauer Rose LLP (2014) Social Media in the Workplace Around the World 3.0. 2013/14 Survey. Available at: http://www.proskauer.com/files/uploads/social-media-in-the-workplace2014.pdf (Accessed: 3 February 2017) p. 23; Information Commissioner's Office (2011) The employment practices code. Available at: https://ico.org.uk/media/fororganisations/documents/1064/the_employment_practices_code.pdf (Accessed: 8 October 2018). p. 66. 
disciplinary sanctions that can be given in case of breach of the policy. ${ }^{1773}$ According to Teresa Coelho Moreira, the adoption of "rules of good conduct" or a "charter of informatics" is the most appropriate way to enhance the principle of transparency and to comply with legal obligations. ${ }^{1774}$ In a recommendation in 2013, the NAIH also held that the employer should adopt detailed internal policies relating to monitoring, guaranteeing the enforcement of the requirements set in the HDPA and the HLC. ${ }^{1775}$ The CNIL also pleaded in favour of adopting such documents. ${ }^{1776,1777}$

626. The FLC and internal regulations and charters. In France two types of these documents exist: these guidelines can either serve as a guidance regarding what conduct employees should adopt when it comes to the personal use of SNSs during working hours, or they can be part of the employer's internal regulation. ${ }^{1778}$ In the first case, these documents have informative roles, while in the second case they are considered supplements to the internal regulation and are binding both for the employee and for the employer. ${ }^{1779}$ However, it is important to note that it is not the existence of such a charter that qualifies the employees' actions as violation: even when there exists no such document, the breach of duty of the employee is established (e.g. obligation of work and being at the disposal of the employer). ${ }^{1780}$

627. The HLC and internal policies. According to the HLC, the employer can draft internal policies, ${ }^{1781}$ allowing the employer to unilaterally define obligations to be respected by employees. ${ }^{1782,1783}$ Such a policy can relate to the use of SNSs. ${ }^{1784}$ However,

\footnotetext{
1773 Thornthwaite, L. (2016) 'Chilling times: social media policies, labour law and employment relations’, Asia Pacific Journal of Human Resources, 54(3), p. 334.

1774 Moreira, T. C. (2016) 'The Electronic Control of the Employer in Portugal', Labour \& Law Issues, 2(1), p. 23.

1775 NAIH (2013) A Nemzeti Adatvédelmi és Információszabadság Hatóság ajánlása a munkahelyen alkalmazott elektronikus megfigyelörendszer alapvetö követelményeiről. NAIH-4001-6/2012/V. Budapest, p. 3. and NAIH/2019/51/11. p. 16.

1776 Bouchet, H. (2004) La cybersurveillance sur les lieux de travail. Paris, la Documentation française: Commission nationale de l'informatique et des libertés, p. 11.

1777 Even though the formal rules relating to the adoption of such policies are also important, as they do not substantially concern the limits of employees' personal lives, the analysis will rather concentrate on the content of such policies.

1778 Niel, S. (2007) 'Elaborer une charte informatique', Les cahiers du DRH, (130), pp. 37-38.

${ }^{1779}$ Kocher, M. (2013) 'La protection des données des salariés : que reste-t-il de l'arrêt Nikon ?', Legicom, (1), p. 133.

${ }^{1780}$ Nivelles, V. (2014) 'Les entreprises à l'épreuve des réseaux sociaux', Jurisprudence Sociale Lamy, (377378), p. 11.

${ }^{1781}$ Section 17 of the HLC

1782 Section 15 of the HLC

1783 Although it should be noted that according to Subsection (1) of Section 264 of the HLC "[e]mployers shall consult the works council prior to passing a decision in respect of any plans for actions and adopting
} 
the wide adoption of social media policies is not (yet?) a common phenomenon in Hungary. ${ }^{1785}$ However, certain exceptions can be mentioned, such as the social media policy of the Hungarian National Health Service ${ }^{1786}$ or the Hungarian National Savings Bank's policy. ${ }^{1787}$

628. Recommended content. The employer has extensive powers in setting the limits on personal use. A paper entitled "Social media and labour law - dismissal for Facebook posts in the light of Hungarian and international jurisprudence"1788 written by József Hajdú, Adrienn Lukács, Viktória Lechner and Attila Turi - amongst other matters examined the possibilities lying in internal social media guidelines in relation to social media. Although the research primarily focused of off-duty conducts on SNSs, ${ }^{1789}$ certain factors have relevancy when it comes to SNS use during working hours as well. It is crucial to emphasize that there exists no one-size-fits-all solution: the suggestions to be presented serve as a point of reference, which need to be tailored to the particularities of the specific work environment.

629. First, fundamental provisions should be laid down. In order to avoid misunderstandings, the definition of social media should be clarified. As the exhaustive enumeration of every SNS is not possible, it is recommended that the employer indicates a general definition of social media/SNSs and then by way of example specifies the most frequently used sites, known to most employees. The personal scope of the regulation is also crucial: the employer should clearly indicate to whom the regulation is applicable (e.g. a group of employees, all employees).

regulations affecting a large number of employees[,]" raising the question of the possible role of social partners in the process. In France the social and economic council of the workplace must be consulted for its opinion if the policy is adopted as part of the employer's internal regulation.

1784 Rácz, I. (2015) 'A közösségi média használatának árnyoldalai a munkaviszonyban', in Deres, P. and Grad-Gyenge, A. (eds) Acta Iuvenum Caroliensia VII. Budapest: Károli Gáspár Református Egyetem Államés Jogtudományi Kar, p. 295.

1785 Kártyás, G., Répáczki, R. and Takács, G. (2016) A munkajog digitalizálása. A munkajog hozzáalkalmazása a digitális munkakörnyezethez és a változó munkavállalói kompetenciákhoz. Kutatási zárótanulmány. Budapest, p. 67.

1786 Rácz, I. (2017)A közösségi média és a munkajog kereszttüzében. Available at: http://arsboni.hu/kozossegi-media-es-munkajog-kereszttuzeben/ (Accessed: 27 February 2018).

1787 Szilágyi, K. (2013) Facebook-szabályzat: beleszólhat- a munkáltató?, Adó Online. Available at: https://ado.hu/munkaugyek/facebook-szabalyzat-beleszolhat-a-munkaltato/ (Accessed: 15 November 2018).

1788 Közösségi média és munkajog - különös tekintettel a Facebook-ra alapított felmondásokra a hazai szabályozás és a nemzetközi joggyakorlat tükrében. A tanulmány az Igazságügyi Minisztérium jogászképzés színvonalának emelését célzó programjai keretében került megírásra.

${ }^{1789}$ It will be presented later in Title 3. 
630. Then, general rules of conduct should be laid down. Employees should be reminded of their obligations - notably the obligation to work - and that even though a reasonable personal use is tolerated, equipment should primarily be used for professional purposes, and working hours should be spent working and not surfing on SNSs.

631. Rules relating to the personal use of SNSs should clearly detail what kind of activity is permissible - the employer has extensive powers to regulate this matter. $\mathrm{He} / \mathrm{she}$ can impose limitations regarding the sites visited, the time spent on them and the period when they can be used. He/she can define what SNSs can or cannot be accessed during working hours and can even block access to sites. If personal use is permitted, time limitations can still be imposed on their use - e.g. 20 minutes of use is permitted daily. It might also be useful if the employer defines the period during which these sites can be accessed (e.g. as a sort of a "warming up" in the morning after arriving at the workplace). It is important to emphasize that even if personal use is tolerated to a certain extent, it should not in any case come at the expense of executing a task (e.g. when an employee should deal with customers).

632. Internal regulations can play an important role in French law when it comes to the presumption of professional nature of correspondence. The internal regulation can contain refinements as regards how exactly messages should be identified as personal: in such cases if the employee does not identify them as personal as required by the regulation, the employer can open them. ${ }^{1790}$ In the exceptional cases when employees might also use SNSs for professional purposes, therefore personal and professional use can mingle, the internal regulation can contain provisions regarding how employees should indicate that the communication on SNSs is private. Although compared to e-mails, in the case of SNSs it is considerably more difficult to identify the message as personal, it was demonstrated that certain measures might still be conceivable. The internal regulation can also restrict the employer's right to access the content of these messages ${ }^{1791}$ (e.g. only in the presence of the employee). ${ }^{1792}$

633. Such policies should also contain information on how exactly monitoring will be conducted in order to verify whether the employee complies with the rules made

\footnotetext{
${ }^{1790}$ Cour de cassation, chambre sociale, 4 juillet 2012, $\mathrm{N}^{\circ} 11-12502$

${ }^{1791}$ Cour de cassation, chambre sociale, 26 juin 2012, $\mathrm{n}^{\circ} 11-15310$

1792 Kocher, M. (2013) 'La protection des données des salariés : que reste-t-il de l'arrêt Nikon ?', Legicom, (1), pp. 129-140. p. 133.
} 
regarding personal use. As presented before, emphasis should be put on prevention, and the monitoring of traffic data should be preferred to the monitoring of the actual content/communication, while accessing the content of personal communication is not possible. If the policy is adopted as part of the internal regulation, breaching its provisions can result in applying disciplinary sanctions against the employee. ${ }^{1793}$ Therefore, these policies should remind employees that in the case of violating them and breaching obligations, sanctions can be applied.

\section{Conclusions of Title 2}

634. Regulation and monitoring. Employers lawfully expect employees to spend their working hours performing work - which is one of the employee's main obligations. However, in the $21^{\text {st }}$ century, as a result of the proliferation of ICT, employees can waste a considerable amount of their working time surfing on the Internet, writing personal messages, watching pictures, playing games, planning their holidays, comparing prices, watching news, etc. or - most importantly for the dissertation - consulting SNSs. The employer is entitled to regulate the use of work equipment and to monitor whether employees have complied with such regulation. However, the employer is not limitless in determining these rules: he/she must respect employees' right to privacy and right to data protection.

635. It was found that privacy and data protection can play shifting roles: regulation can be better assessed through a privacy angle, while monitoring through a data protection angle. When deciding how to regulate (prohibit or allow) the personal use of SNSs, it must be taken into consideration that the right to privacy comprises the right to establish relationships with others - for which the main place is one's workplace. As SNSs constitute one of the main forms of contemporary communications, this question was examined from this angle. When the employer monitors respect of the rules, privacy can be concerned as well (through the secrecy of correspondence), however, the rules of monitoring can be better determined by taking a more emphatic data protection approach, paying attention to the data protection principles such as necessity, proportionality and transparency.

${ }^{1793}$ Niel, S. (2007) 'Elaborer une charte informatique', Les cahiers $d u$ DRH, (130), p. 40. 
636. Possibility of a complete ban. It was found that employees have no "right to social media" during working hours: the employer can opt for the complete ban of such use. However, this position must be nuanced since according to the existing EU regulation, employees have the right to communication; they cannot be completely cut off from the outside world (e.g. in cases of family emergency). However, as long as employers ensure other ways of communication for employees (e.g. making a phone call or writing an email), they can freely decide to ban the use of SNSs.

637. Despite the possibility of such a ban, today it does not always seem reasonable to impose such a ban. On the one hand, this position is confirmed by the majority of scholars, ${ }^{1794}$ by the CNIL, and courts also demonstrated tolerance if the use was not abusive. ${ }^{1795}$ As such, determining the limits of abusive use has key importance. As a suggestion, the dissertation holds that when identifying whether personal use was abusive, the criteria identified from the analysis of French case law (number/length of connections, content visited, possible distraction) can serve as guiding criteria also for Hungary. On the other hand, the proliferation of portable devices makes it increasingly difficult to detect their (mis)use during working hours, which will pose questions in relation to the monitoring of such prohibition.

638. How to monitor? As a starting point of the analysis, the already existing regulations relating to the use of Internet and e-mails were examined: the question is already regulated both in France and in Hungary. While currently in Hungary some relevant provisions are to be found in the HLC, in France the FLC does not contain such provisions, and the detailed rules were crystallised by case law. In France this relevant case law is quite abundant, in contrast to Hungary, where instead of courts, the national DPA played an important role in determining the exact rules of prohibition and monitoring.

639. It was also held that SNSs combine the characteristics of the Internet and email: they allow users to search and surf (e.g. looking for a page on Facebook or browsing the news feed), send messages (e.g. Facebook Messenger or Instagram Direct), not to mention that they are web-based services. Therefore, the rules established for the

\footnotetext{
${ }^{1794}$ See, for example: Ray, J.-E. (2001) Le droit du travail à l'épreuve des NTIC. 2nd edn. Rueil-Malmaison: Liaisons. pp. 95-97.; Denier, J.-L. (2003) 'L'utilisation privative des NTIC d'entreprise', Les cahiers du DRH, (89), p. 32.; Kártyás, G., Répáczki, R. and Takács, G. (2016) A munkajog digitalizálása. A munkajog hozzáalkalmazása a digitális munkakörnyezethez és a változó munkavállalói kompetenciákhoz. Kutatási zárótanulmány. Budapest. pp. 77-78.

${ }^{1795}$ Especially in French case law, where more cases were found compared to Hungary.
} 
monitoring of the employees' use of the Internet and e-mail are essentially applied to SNSs as well. However, SNSs have certain characteristics that must be taken into consideration in contrast to the Internet and e-mail.

First, as a main rule, the use of SNSs supposes personal activity: as opposed to the Internet and e-mails, which both could serve as a working tool as well as personal entertainment, making it possible to create confusion when distinguishing personal and professional use. However, when a job comes with the use of SNSs, the confusion becomes possible again in the field of communication, and in such a case it is difficult to enforce the existing (French) regulation according to which messages are presumed to have a professional nature unless they are marked as personal. In the case of SNSs the issue is that in contrast to e-mails, instant messaging services incorporated in SNSs do not have a "subject" field, where employees can usually mark the message as personal. ${ }^{1796}$ Second, due to the proliferation of mobile devices, it is quite common that employees own their own device (e.g. smartphones), as well as a mobile Internet connection - which was not such a common phenomenon when the original rules were adopted. However, even despite these SNS specific challenges, the already established rules are capable of adequately addressing the personal use of SNSs.

640. Recommendations. As it was already elaborated throughout Title 2 , the first recommendation is that - unless required by the specific features of the given job or the workplace -, a complete ban of personal use is not recommended. Considering that SNSs play a huge role in everyday life and that the enforcement of such a prohibition involves technical difficulties because of the ease with which they can be accessed, a more permissive regulation seems to be more productive. Second, it is crucial that the exact limits of such a use are clearly determined and communicated to the employees and are consistently enforced as well. Then the monitoring of whether employees respect these rules must be in accordance with the legal requirements set in the relevant labour law and data protection law regulations. Recommendations relating to how this monitoring should be conducted are to be found in the last part of Title 2 .

\footnotetext{
1796 Although in Hungarian law such a presumption does not exist, the subject field could still be used to enforce the principle of proportionality and sign that the message is personal.
} 


\section{Title 3: Employees' engaging in social network sites with special regard to off-duty conduct}

641. During working hours, it follows from the employee's obligation to work that he/she can be limited in the use of SNSs. However, beyond working hours there is no such obligation to work, and as a result, it must be examined what other obligations the employee has that can justify the limitations in the use of SNSs during that period. Just as personal life flows into professional life, professional life flows into the personal life of the employee. As employees do not leave their rights at the doorsteps of the workplace every morning, they do not cease to be employees when they leave the workplace: they are still subject to certain obligations originating from the employment relationship. ${ }^{1797}$ On the one hand, employees are subject notably to the duty of loyalty, which can restrict the employee's freedom of action and interfere with his/her personal life by restricting employees' off-duty conduct to a certain extent. On the other hand, questions regarding the right to data protection also arise, in relation to employers who decide to monitor and/or to process employees' personal data obtained from SNSs.

642. Topicality of the subject. Criticising or complaining about the employer, making disparaging comments about the workplace or colleagues, or making "pranks" at the workplace have always existed. However, while earlier these statements did rarely leave the employees' close environment (e.g. gossiping around the coffee machine or criticizing the employer in a pub on Friday night or at a friends'/family gathering during the weekend), the advent of social media brought certain changes. Nowadays - as various examples will illustrate throughout Title 3 - it is not uncommon that employees let off steam on SNSs, which can even result in the termination of their employment. Compared to the "traditional" way of expressing negative opinion, SNSs pose new challenges. Notably, social media and SNSs brought a change of paradigm regarding especially the publicity of the statements or content. Depending on the chosen privacy settings, such

1797 Apart from the freedom of thought, all freedoms of the employee can bear some limitations in relation to the employment relationship. Waquet, P. (2002) 'Retour sur l'arrêt Nikon', Semaine sociale Lamy, (1065), p. 4. [Page number referring to the online version of the article downloaded from: https://lamyline-lamyfr.bcujas-ezp.univparis1.fr/Content/Document.aspx?params=H4sIAAAAAAAEAMtMSbF1CTEwMDC0MDY0MTNSK0stKs 7Mz7MNy0xPzStJVXNxDHG0LUkuj3T09Y4sKiyqyPV0dPKqKverzAMAvrJ6HTwAAAA=WKE (Accessed: 15 August 2019)] 
communication might take place in front of a considerably bigger, often public audience, ${ }^{1798}$ giving increased importance to the protection of employer's rights.

As a response, employers restrict more and more often what an employee can post or cannot post in social media (in internal social media policies, for example) or sanction employees for their conduct on SNSs in order to protect their business. It is increasingly common that employees' behaviour on SNSs exceeding the limits of freedom of expression results in the termination of employment. ${ }^{1799}$ This growing number of news ${ }^{1800}$ and cases ${ }^{1801}$ relating to "Facebook firings" manifests that employees are often not aware that their activity can result in dismissal and do not realize that even though the activity takes place within their personal lives, they could still suffer legal consequences.

643. Starting point. The starting point of Title 3 is that the examined conducts usually (although not always) take place outside the workplace, beyond working hours, by using the employees' own equipment, therefore in the course of employees' personal life, where employees are free to act as they wish. However, ensuing from the labour law regulation, this freedom is not limitless: employees are subject to certain obligations, which results in professional life flowing into personal life through imposing certain limitations on the employees' freedom of action. In French labour law, the case law relating to the termination of employment established exceptions to the main rule, namely that the dismissal cannot be based on the employee's personal life, unless certain conditions are met. ${ }^{1802}$ Through these exceptions, the boundaries of personal and professional life are outlined. In contrast, in Hungarian labour law, the HLC contains

\footnotetext{
${ }^{1798}$ For example, if the privacy settings are not used, the content can reach up to several hundreds of users, which is a change of paradigm compared to the few people who might have overheard a conversation in a pub at the next table.

1799 Kun, A. (2018) 'A digitalizáció kihívásai a munkajogban', in Homicskó, Á. O. (ed.) Egyes modern technológiák etikai, jogi és szabályozási kihivásai. Budapest: Károli Gáspár Református Egyetem Állam- és Jogtudományi Kar (Acta Caroliensia Conventorum Scientiarum Iuridico-Politicarum, XXII), p 133.

${ }^{1800}$ A simple Google search (e.g. "fired for Facebook", "Facebook-os felmondás", "licenciement Facebook") reveals a myriad of cases as regards employees whose employment relationship was terminated due to their use of Facebook. Or see, for example, the blog entitled "The Facebook Fired" where a compilation of Facebook firings is present. Source: The Facebook Fired. Available at: https://thefacebookfired.wordpress.com/(Accessed: 7 August 2019).

${ }^{1801}$ See, for example: CA Reims, chambre sociale, 9 juin 2010, $n^{\circ}$ 09/03205, CA Besançon, chambre sociale, 15 novembre 2011, $\mathrm{n}^{\circ}$ 10/02642, CA Reims, chambre sociale, 15 Novembre 2017, $\mathrm{n}^{\circ}$ 16/02786, CPH Boulogne-Billancourt (Section Encadrement), 19 novembre 2010, $\mathrm{n}^{\circ}$ 09/00343, Cour de cassation, chambre sociale, 20 déc. 2017, $\mathrm{n}^{\circ} 16-19609$, Cour de cassation, chambre sociale, 12 sept. 2018, n¹6-11.690, Taylor v Somerfield Stores Ltd. Case no: S/107487/07 Held at Aberdeen on 24 July 2007, Konop v. Hawaian Airlines, Konop v. Hawaian airlines ügy (United States Court of Appeals for the Ninth Circuit, 236 F.3d 1035.), Pietrylo v. Hillstone Restaurant Group ügy (United States District Court, District of New Jersey, No. 0605754.), LAG Hamm Urteil (vom 10. Oktober 2012 Az. 3 Sa 644/12), etc.

1802 Different for disciplinary and for non-disciplinary dismissal, as it will be presented in detail.
} 
provisions ${ }^{1803}$ which explicitly address employees' off-duty conduct, imposing certain limitation on them. The overarching question is how the existing regulation/case law should be applied to SNSs.

644. Main questions to be answered. Title 3 intends to determine the boundaries between personal and public activities in relation to employees' off-duty conduct on SNSs. In the light of the obligations incumbent on employees, first it should be determined whether using these platforms falls under private or personal life, or whether they rather constitute a public forum. Then it should be determined where exactly the boundaries of employees' freedom to act lie: this raises the question to what extent employers can restrict and sanction employees' conduct that took place outside their professional life - not in the workplace, during non-working hours, and with the help of the employee's device. Title 3 intends to answer with regard to the blurred boundaries: to what extent can professional life flow into the personal life of the employee? Are SNSs considered to be public or private platforms? Can SNSs constitute a reason for the termination of employment? Can the use of SNSs beyond working hours be prohibited? In what regards can the employee's online behaviour be limited?

645. Hypothesis. The hypothesis of Title 3 is that with respect to employees' activities on SNSs, in the light of the intensification that SNSs brought to the collision of rights, employers have found themselves in an even more vulnerable position. (Hypothesis 4). Traditionally, the hierarchal relationship between the parties in the employment relationship puts the employee in a more vulnerable position. ${ }^{1804}$ However, due to the changes brought by SNSs, the question of reversed vulnerability between the parties arises when it comes to employees' presence on SNSs. ${ }^{1805}$ Thus, Title 3 will examine the changes brought about by SNSs and whether they necessitate tilting the balance towards the protection of employer's rights - while at the same time the respect of employees' rights remains a crucial issue.

\footnotetext{
${ }^{1803}$ See Section 8 and notably Subsection (2) of Section 8 of the HLC.

1804 WP29 (2001) Opinion 8/2001 on the processing of personal data in the employment context. 5062/01/EN/Final WP 48. p. 23., WP29 (2017) Opinion 2/2017 on data processing at work. 17/EN WP 249. p. 23.; Gyulavári, T. (ed.) (2017) Munkajog. ELTE Eötvös Kiadó. Budapest. p. 34.

1805 See, for example: Kajtár, E. (2015) 'Európai ügyek a Facebook sötét oldaláról - A munkavállalók közösségi oldalakon tanúsított kötelezettségszegő magatartása’, in Horváth, I. (ed.) Tisztelgés: ünnepi tanulmányok Dr. Hágelmayer Istvánné születésnapjára. Budapest: ELTE Eötvös Kiadó, p. 199.; Balogh, Zs. Gy. et al. (2012) 'Munkahelyi adatvédelem a gyakorlatban', Infokommunikáció és Jog, 9(3), pp. 96-97.
} 
646. Matters to be examined and structure of Title 3. Employees' activity on SNSs can jeopardize the employer's rights in several ways - among which the form of the activity and the subject of the activity were chosen in the dissertation as main assessment criteria. The form of the activity can take different shapes. Either it can be an expression of opinion (typically manifested in posts or comments), or it can take other forms (e.g. video, photo) not containing explicit statements. Regarding the subject of the activity, it can either be connected directly to the workplace (e.g. criticizing the employer), or it can relate to a matter that has no direct connection to the workplace (e.g. publishing anti-Semitic comments under an article).

Chapter 1 will address the boundaries of employees' personal life and off-duty conduct by examining in what regard employees can be restricted while using SNSs and expressing themselves on these platforms. Chapter 2 will deal with enforcing these restrictions and will examine the possibilities that employers have for the enforcement of their rights, and the conditions (notably data protection) that they must respect when controlling employees' off-duty conduct on SNSs.

\section{Chapter 1: Off-duty conduct and private/personal life}

Theoretically, the employee's professional life and personal life are meant to be separated: into professional life, connected to the workplace; and into personal life, independent of the workplace, where the employee is free to act as he/she wishes. However, it was already demonstrated that due to the technological development, the boundaries of work and personal life are more and more blurred - which is increasingly true in the case of social media. ${ }^{1806}$ This is the reason why it is important to determine the boundaries between these two spheres in relation to SNSs and off-duty conduct, namely: to what extent can limitations be imposed on the employee's personal life? National regulations already addressed the question: in French law through the rules and jurisprudence relating to dismissal, while in Hungarian labour law, Section 8 of the HLC contains specific provisions on the employee's conduct outside working hours. Prior to addressing the specific questions raised by SNSs, the general rules in relation to dismissals will be presented.

1806 Ellickson, D. and Atkinson, M. (2013) 'When Can Your Employer "Unlike" You? Just Cause for Dismissal and Social Media', in The Law Society of Upper Canada, Employment Law and the New Workplace in the Social Media Age. Toronto: Irwin Law, p. 261. 
647. Off-duty conduct and private/personal life: principle. In French labour law the protection of employees' personal life appears through the rules relating to dismissal, as personal life must be respected during the decision-making. Differentiation is made between dismissal on personal and on economic grounds ${ }^{1807}$ - among which the former is relevant regarding the subject of the dissertation. ${ }^{1808}$ In the case of dismissal based on personal grounds, the reason for the dismissal is based on the person of the employee: the reason can either be disciplinary (supposing the sanctioning of the employee for his/her misconduct - "faute", e.g. breaching an obligation arising from the employment relationship) or non-disciplinary (e.g., professional incompetence, disagreement between the employee and the employer, etc.). ${ }^{1809}$

648. Although in the case of dismissal on personal grounds the reason for dismissal lies in the person of the employee, as a main rule, when dismissing an employee, the employer must respect the employee's personal (and private) life. According to the main principle set by French courts, the personal life of the employee is protected; dismissal cannot be based on the personal life. ${ }^{1810}$ However, it does not mean that the employee is completely free to do anything outside the workplace without eventual consequences, as there are exceptions when the employer may pronounce a disciplinary and a non-disciplinary dismissal - based on the personal life of the employee.

649. While in French law the starting point is that the dismissal should not be based on the personal life of the employee, and then the jurisprudence establishes certain exceptions, in Hungarian labour law, limitations are a priori imposed on employees' offduty conduct and courts examine whether employees acted in respect with these provisions. Sections 6-8 of the HLC contain provisions relating to common rules of conduct, determining how the parties should behave. Among these provisions Subsection (2) of Section 8 imposes limitation on employees' conduct during and outside working hours, while Subsection (3) regulates specifically the question of employees' freedom of

\footnotetext{
1807 Title 3 of Book II of Part I of the FLC

${ }^{1808}$ In the case of dismissal based on economic grounds, the dismissal is made by the employer for reasons not related to the employee himself/herself. In such a case, dismissal is motivated by economic reasons, originating either from the deletion or transformation of the employment of the employee concerned, or from a modification of an essential element of the employment contract which the employee refused. Paragraph 1 of Article L1233-3 of the FLC.

${ }^{1809}$ Grandguillot, D. (2016) L'essentiel du Droit du travail. 16th edn. Issy-les-Moulinaux: Gualino: Lextenso Éditions, p. 67.

${ }^{1810}$ Cour de cassation, chambre sociale, 20 nov. 1991, nº 89-44.605; Cour de cassation, chambre sociale, 14 mai $1997, \mathrm{~N}^{\circ} 94-45473$
} 
expression. These provisions aim to determine the legitimate extent to which employees can be bound to respect certain limitations imposed on their personal lives. In addition, Subsection (1) contains provisions on the protection of the employer's legitimate economic interests, while Subsection (4) on the protection of the employer's business secrets.

650. Exceptions: dismissal based on the personal life of the employee. In French labour law, the termination of the employment relationship based on the personal life of the employee can be either disciplinary or non-disciplinary. When it comes to disciplinary dismissals, in which case the dismissal is grounded on the misconduct of the employee, an element pertaining to the personal life can only justify a dismissal if it constitutes a breach of duty or obligations resulting from the employment contract. ${ }^{1811,1812}$ Through this statement, the Court of Cassation adopted a position similar to the one of the State Council's, which also expressed that an act of the employee realized outside the execution of the employment contract cannot be a reason for dismissal for misconduct, unless it constitutes an infringement of an obligation arising from the employment contract. ${ }^{1813}$ Although it is not perfectly clear the breach of which obligations can ground a disciplinary dismissal, ${ }^{1814}$ in relation to social media, the employee's obligation of loyalty will gain special importance.

In the case of a non-disciplinary dismissal, the reason for dismissal is not the misconduct arising from the breach of obligations, but is connected to the person of the employee. ${ }^{1815}$ In this case, the element of personal life justifies a dismissal if it causes a "characterised serious disorder" ("trouble objectif caractérisé") in the organization and the

${ }^{1811}$ Cour de cassation, chambre sociale, 23 juin 2009, $\mathrm{N}^{\circ}$ 07-45256.; Cour de cassation, chambre sociale, 3 mai 2011, $\mathrm{N}^{\circ} 09-67464$

1812 Or it must be connected to the professional life of the employee (e.g. committed in the workplace, or by using the employer's equipment). Source: Beyneix, I. and Rovinski, J. (2016) 'L'emprise de la vie professionnelle sur la vie personnelle', JCP S (édition sociale), (37), p. 37. ; Casaux-Labrunée, L. (2012) 'Vie privée des salariés et vie de l'entreprise', Droit social, (4), p. 339. and Icard, J. (2014) 'Faits commis en dehors des temps et lieu de travail mais rattachés à la vie de l'entreprise', Bulletin du travail (ancien nom Cahiers sociaux du barreau de Paris), (268), p. 642. The Court of Cassation referred to the criteria of connecting to the corporate life of the undertaking to confirm dismissal notably in its judgments of Cour de cassation, chambre sociale, 2 décembre 2003, $\mathrm{N}^{\circ}$ 01-43227 (withdrawal of a driver's driving licence because of driving in a state of drunkenness - even beyond working hours), or Cour de cassation, chambre sociale, 17 novembre 2011, $\mathrm{N}^{\circ} 10-17950$ (an employee benefiting from his functions as a guard in a castle stored and illegally manufactured alcohol in the castle).

${ }^{1813}$ Conseil d'État (2010): $\mathrm{N}^{\circ} 316856$, 4ème et 5ème sous-sections réunies, 15 décembre

1814 Casaux-Labrunée, L. (2012) 'Vie privée des salariés et vie de l'entreprise', Droit social, (4), p. 340. and Loiseau, G. (2011) 'Vie personnelle et licenciement disciplinaire', Recueil Dalloz Sirey, (23), p. 1569.

1815 See, for example, the homosexuality of a priest, a Renault employee buying a Peugeot car, a security agent committing shoplifting or a driver losing his driving licence in the course of his personal life - existing examples from French cases that are to be presented in the forthcoming footnotes. 
functioning of the workplace (taking into consideration the function and purpose of the workplace). ${ }^{1816}$ In the latter case it is not the element pertaining to the employee's personal life which in itself creates the disorder and results in the dismissal, but its repercussions on the functioning of the workplace - taking into consideration the employee's position. ${ }^{1817}$, ${ }^{1818}$ It is important that as there is no breach of an obligation arising from the employment, the dismissal for disorder can only constitute a non-disciplinary dismissal. ${ }^{1819,}, 1820$

651. In Hungarian law if the employee breached his/her obligations arising from the employment contract and did not act in accordance with the requirements set by the HLC, the employer is entitled to terminate the employment relationship. In Hungarian law as well, it is possible to dismiss the employee based on his/her breach of obligations, but also due to other personal features not constituting a breach - however, the appellation of these dismissals is different than in French labour law. In Hungarian labour law, a difference is made between termination by notice and dismissal without notice. ${ }^{1821}$

652. According to Subsection (2) of Section 66 of the HLC on termination by notice, "[a]n employee may be dismissed only for reasons in connection with his/her behaviour in relation to the employment relationship, with his/her ability or in connection

\footnotetext{
1816 Principle posed by the Painsecq case in 1991. In this case the Court of Cassation ruled that the dismissal of an assistant sacristan based on his homosexuality could only constitute a reason for dismissal if it caused a characterised serious disorder in the functioning of the undertaking. (Cour de cassation, chambre sociale, 17 avril 1991, $\mathrm{N}^{\circ}$ 90-42636 ) This principle was reinforced by the decisions of Cour de cassation, chambre sociale, 22 janvier 1992, $\mathrm{N}^{\circ}$ 90-42517 (a Renault employee bought a Peugeot car: the Court of Cassation ruled that in his private life the employee is free to buy the product of his choice and the simple acquisition of the car did not cause a characterised serious disorder); Cour de cassation, chambre sociale, 16 décembre $1998, \mathrm{~N}^{\circ} 96-43540$

1817 Waquet, P. (2006) 'Le "trouble objectif dans l'entreprise" : une notion à redéfinir', Revue droit du travail Dalloz, (5), p. 307.

${ }^{1818}$ For example, the Court of Cassation held that an employee, who worked as a security agent and outside of working hours committed shoplifting from one of the clients of the enterprise, discredited the employer and caused a disorder. (Cour de cassation, chambre sociale, 20 nov. 1991, $\mathrm{n}^{\circ} 89-44.605$ ) The same conclusion was reached in a case when a sales agent stole an article from a hypermarket that belonged to his sector and the client threatened to never work again with the employer. (Cour de cassation, chambre sociale, 3 déc. $2002, \mathrm{n}^{\circ} 00-44.321$ )

${ }^{1819}$ Cour de cassation, chambre sociale, 23 juin 2009, N 07-45256.; Cour de cassation, chambre sociale, 9 mars 2011, $\mathrm{N}^{\circ} 09-42150$

${ }^{1820}$ See more on private/personal life and dismissals in: Loiseau, G. (2011) 'Vie personnelle et licenciement disciplinaire', Recueil Dalloz Sirey, (23), pp. 1568-1569.; Richard de la Tour, J. (1999) La vie personnelle du salarié. Étude sur la jurisprudence récente de la Chambre sociale de la Cour de cassation. Cour de cassation. Available at: https://www.courdecassation.fr/publications_26/rapport_annuel_36/rapport_1999_91/etudes_documents_ 93/jean_richard_5796.html(Accessed: 12 July 2017); Casaux-Labrunée, L. (2012) 'Vie privée des salariés et vie de l'entreprise', Droit social, (4), pp. 339-342. See more on objective disorder in : Waquet, P. (2006) 'Le “trouble objectif dans l'entreprise" : une notion à redéfinir', Revue droit du travail Dalloz, (5), pp. 304-310. ${ }^{1821}$ Subsection (1) of Section 64 of the HLC
} 
with the employer's operations." 1822 Among these three cases, behaviour in relation to the employment relationship is important for the purposes of the dissertation. The employee's behaviour in connection with the employment relationship primarily consists of cases when the employee culpably violates obligations arising from the employment relationship. ${ }^{1823}$ Employees expressing their opinion on SNSs or public behaviour can be covered by this Section, and therefore can serve as reason for the termination of the employment. $^{1824}$

653. Termination without notice is possible when the employee either "willfully or by gross negligence commits a grave violation of any substantive obligations arising from the employment relationship;" 1825 or "otherwise engages in conduct that would render the employment relationship impossible."1826 The first case supposes a serious breach of duty ${ }^{1827}$ (basically being the equivalent to the French disciplinary dismissal), while in the second case maintaining the employment relationship becomes objectively impossible, with the lack of serious breach of duties ${ }^{1828}$ (similar to the French nondisciplinary dismissal, where the breach of duty is missing). Usually behaviour which is capable of shaking the trust between the parties can serve as a basis, ${ }^{1829}$ typically including cases connected to the employee's behaviour outside work making it impossible to maintain the employer relationship. ${ }^{1830}$ For example, a Facebook post might result in a loss of trust, ${ }^{1831}$ serving as a ground for termination without notice. ${ }^{1832}$

\footnotetext{
1822 Emphasis added by the author.

${ }^{1823}$ Gyulavári, T. (ed.) (2013) Munkajog. 2nd edn. Budapest: ELTE Eötvös Kiadó. p. 202.

E.g. refusing to comply with the employer's legitimate orders without valid grounds (BH1996. 286.), consuming alcohol during working hours or appearing at work being under the effects of alcohol consumption (BH1986. 384.), the development of conflict due to not respecting working hours and due to the behaviour of the employee (Csongrád Megyei Bíróság 2. Mf. 20. 566/1997.).

1824 Zaccaria, M. L. (2016) 'Munkavállalók a világhálón - “Megosztani ér?”, HR \& Munkajog, 7(10), p. 16.

1825 Item a) of Subsection (1) of Section 78 of the HLC

${ }^{1826}$ Item b) of Subsection (1) of Section 78 of the HLC

1827 E.g. revealing business secrets (Mfv. I. 10.264/2002/2.), consuming alcohol during working hours at a dangerous workplace (Szegedi Munkaügyi Bíróság 4. M. 1159/1994.), leaving the workplace on several occasions without authorization (BH 2008. 132.)

1828 Gyulavári, T. (ed.) (2012) Munkajog. Budapest: ELTE Eötvös Kiadó, p. 216.

${ }^{1829}$ Hajdú, J. and Kun, A. (eds) (2014) Munkajog. Budapest: Patrocinium, p. 167. E.g. he/she engages in conduct unworthy of his/her job by leading a lifestyle of revelry and alcoholism, substantiated suspicion of committing a serious criminal offence.

${ }^{1830}$ Cséffán, J. (2016) A Munka Törvénykönyve és magyarázata. Szeged: Szegedi Rendezvényszervezö Kft, p. 309., Gyulavári, T. (ed.) (2012) Munkajog. Budapest: ELTE Eötvös Kiadó, p. 216.

${ }^{1831}$ Kozma, A. (2013) 'Mire köteles a munkavállaló?’, HR \& Munkajog, 4(10), p. 10.

1832 Mfv.I.10.469/2013/4 Cited in: Cséffán, J. (2016) A Munka Törvénykönyve és magyarázata. Szeged: Szegedi Rendezvényszervezö Kft, p. 311.
} 
654. As such, both in France and in Hungary personal life is protected during the termination of employment. However, it does not mean that personal life can never constitute a reason for terminating the employment relationship: in the light of the obligations of the employee, both countries provide exceptions to this general rule, as well as the case when there is no breach of obligation, but the behaviour still has serious repercussions on the employment. In France, the limits of these exceptions were elaborated by case law, while in Hungary, Section 8 of the HLC itself already limits employees' behaviour in the course of their personal lives.

655. Structure of Chapter 1. After reviewing the general legal framework regulating dismissal, the specific features of SNSs must be addressed. Employees' off-duty conducts on SNSs can take several forms and can constitute a ground for disciplinary and non-disciplinary dismissal (France), as well as for termination by notice and without notice (Hungary). In order to exhaustively present these conducts, the differentiation proposed by certain scholars ${ }^{1833}$ will be followed, according to which the employee's conduct can relate, on the one hand, directly to the workplace (e.g. the content of activity relates to the workplace) or on the other hand, it can indirectly relate to the workplace (where the content of the activity is independent of the employment, the only connection to the workplace is the user's person, who is the employee). First, in Section 1 employees' behaviour directly connected to the employment will be examined, followed by employees' behaviour not directly connected to the employment in Section 2.

\section{Section 1. Online activity with direct connection to the employment}

656. Employees' SNS activity can relate to the employment in several ways: from complaining of the employer on a colleague's Facebook wall, ${ }^{1834}$ through liking the competition's Facebook page, ${ }^{1835}$ till sharing information relating to the clients of the employer ${ }^{1836} \ldots$ and the list goes on. Although the subject will be discussed from the angle

1833 Pók, L. (2012) 'Lájkolni szabad? Munkavállalói véleménynyilvánítás az új Munka Törvénykönyve tükrében', Infokommunikáció és jog, (4), p. 160.; Zaccaria, M. L. (2016) 'Munkavállalók a világhálón "Megosztani ér?"”, HR \& Munkajog, 7(10), p. 16.

${ }^{1834}$ CA Reims, chambre sociale, 9 juin $2010, n^{\circ} 09 / 03205$

1835 USA: District court for the Eastern District of Virginia: Bland v. Roberts, 4-11cv45 (E.D. Va.; Apr. 24 , 2012)

1836 Banktitkot sértett egy magyar mikroblog (2012) Index. Available at: https://index.hu/tech/2012/01/04/banktitkot_sertett_egy_magyar_mikroblogger/(Accessed: 7 September 2018). 
of French and Hungarian law, as the phenomenon is universal, reference and examples will be often taken from other jurisdictions as well, in order to illustrate certain matters.

657. During the research, the question of determining the boundaries of employees' personal lives was most often raised in relation to their $(A)$ freedom of expression on SNSs - where the question to be answered is whether and to what extent employees can express themselves outside of the workplace, a priori in the course of their personal lives. Nevertheless, freedom of expression is not the only conduct that can directly relate to the employment: employees have $(B)$ other ways that take place beyond the working hours but still have a direct connection to the employment. Such conduct can be, for example, the revealing of business secrets on SNSs or carrying out whistleblowing on SNSs. However, as a preliminary point, it should be observed that these "other" ways do not substantially challenge the boundaries of work and personal life and seem to raise specific issues in relation to employees' personal life to a lesser extent. ${ }^{1837}$

\section{§1. Employees expressing themselves on social network sites}

658. Employee expression and SNSs. As the growing number of news in media and litigations in courts demonstrate it, on SNSs employees often criticize employers, colleagues, clients in very harsh style, using offensive vocabulary - resulting in their dismissal. ${ }^{1838}$ An employee criticizing ${ }^{1839}$ the employer is not a new phenomenon, ${ }^{1840}$ but social media brought considerable changes in this field, raising the question whether the previously established rules are adequately applicable to this new situation, or whether

1837 Pók, L. (2012) ‘A közösség hálójában - Közösségi oldalak munkajogi vonatkozásai’, Infokommunikáció és jog, (1), p. 13.

1838 See, for example: Love, D. (2014) 17 People Who Were Fired For Using Facebook, Business Insider. Available at: https://www.businessinsider.com/17-people-who-were-fired-for-using-facebook-20147 (Accessed: 30 July 2019).; 14 Times People Got Fired For Posting On Facebook (no date) Awesome Inventions. Available at: https://www.awesomeinventions.com/fired-posting-on-facebook/(Accessed: $30 \mathrm{July}$ 2019).

${ }^{1839}$ However, in some cases the employee can go even further than mere criticism and can deliberately harm the employer's reputation. See, for example, the case of an employee who directly encouraged people not to support the employer, as it "ripped off a bunch [of people]." Source: Ellickson, D. and Atkinson, M. (2013) 'When Can Your Employer "Unlike" You? Just Cause for Dismissal and Social Media', in The Law Society of Upper Canada, Employment Law and the New Workplace in the Social Media Age. Toronto: Irwin Law, p. 264.

${ }^{1840}$ For example, employees expressing their opinion in relation to the employer through the publication of a book (BH2000. 267.), or through wearing a placard on the work uniform (BAG 2 AZR 620/80 1982. cited in: Jónás, T. (2010) 'Véleménynyilvánítási szabadság a munkaviszonyban', Pécsi Munkajogi Közlemények, $3(2)$, p. 38.) or through publishing an article containing the employee's negative opinion (1050/2004. számú munkaügyi elvi határozat). 
they should be modified. These changes concern particularly their publicity, permanence, style and the possible identification of the employer.

Regarding publicity, while earlier these statements did rarely leave the employees' close environment (e.g. gossiping around the coffee machine or criticizing the employer at a friends'/family gathering during the weekend), with the advent of social media they take place in front of a considerably bigger, often public audience - making it also easier to be discovered by the employer. Also, while criticising the employer orally was less discoverable and clearly less reproducible, on SNSs communication/content stays permanently, as it is not feasible to completely remove a content once it was published. ${ }^{1841}$ Another change is the style of communication: on the Internet users often use vocabulary that is different compared to what they would use face-to-face. ${ }^{1842}$ SNSs also facilitate identifying the employer of the author of the post, ${ }^{1843}$ creating a link between the employee's post and the employment. These observations suggest that the employee can cause increased damage to the employer, in contrast to statements made prior to the proliferation of SNSs.

659. France: obligation of good faith and employees' freedom of expression. First, the obligation of good faith ("obligation de loyauté") must be addressed, which imposes limitations on the employee's freedom of action. The obligation of good faith can also enter into collision with the employee's freedom of expression, making it necessary to address the specific limitations on freedom of expression. The employee's obligation of good faith originates from the Civil Code's (former) Article 1134, ${ }^{1844}$ stating that contracts shall be executed in good faith - a principle that applies to the parties of the employment relationship as well. ${ }^{1845}$ According to the obligation of good faith, the employee must refrain from disloyal conducts and notably has the duty of loyalty, duty of non-concurrence and duty of confidentiality - and more importantly for the subject of the thesis: exercising the freedom of expression in an abusive manner can constitute the violation of the

1841 As Jean-Emmanuel Ray referred to the classic proverb: "Words fly away, writings remain." underlying that once something was published on an SNS, it can be retrieved by a third party and used even years later. Source: Ray, J.-E. (2011) 'Facebook, le salarié et l'employeur', Droit social, (2), p. 133.

${ }^{1842}$ It is enough to take a look at the comment section under an article, where often complete strangers are at each other's throats and insult people using extremely offensive vocabulary - what most of them probably would not do during a face-to-face encounter.

${ }^{1843}$ E.g. especially if the employee identified his/her employer in the "bio" part, but a simple Google search on the user's name might reveal the employer's identity in a few seconds, or even other users can reveal it.

1844 Today, Article 1104 of the Civil Code.

1845 Article L1222-1 of the FLC: "Employment contracts must be performed in good faith." 
obligation of good faith. ${ }^{1846}$ The Court of Cassation also associated an obligation of probity with the obligation of good faith, ${ }^{1847}$ and an obligation of morality considering the functions of the employee. ${ }^{1848}$ This obligation of probity can be more specific in the case of ideologically or faith-oriented enterprises ${ }^{1849}$ (“entreprise de tendance"). ${ }^{1850}$

660. Such an obligation of good faith can collide with employees' freedom of expression: employees are entitled to the freedom of expression within and outside the workplace as well. ${ }^{1851}$ However, exercising this freedom cannot be limitless, the main obligation arising from the employment contract - notably the duty of loyalty - must be respected even beyond working hours. ${ }^{1852}$ The Court of Cassation formulated the principle of employees' freedom of expression in 1999, when it stated that "except in the case of abuse, the employee enjoys the freedom of expression within the workplace and outside of it; which can only be restricted by a restriction justified by the nature of the task to be performed and proportionate to the aim sought." 1853 This means that the employee is entitled to express his/her opinion as he/she wishes, including subjects relating to the employment, ${ }^{1854}$ even to criticise the employer, as long as these expressions are not insulting, defamatory or excessive. ${ }^{1855}$ If the employee oversteps the limits of the freedom of expression, he/she can be sanctioned for it - and in the most serious cases can be dismissed. ${ }^{1856}$

661. As regards SNSs and assessing whether employees can be sanctioned for expressing themselves on social media, it must be examined whether the expression constituted an abuse. However, prior to examining the abuse, first, (a) it must be examined

1846 Richard de la Tour, J. (1999) La vie personnelle du salarié. Étude sur la jurisprudence récente de la Chambre sociale de la Cour de cassation. Cour de cassation. Available at: https://www.courdecassation.fr/publications_26/rapport_annuel_36/rapport_1999_91/etudes_documents_ 93/jean_richard_5796.html(Accessed: 12 July 2017).

${ }^{1847}$ Cour de cassation, chambre sociale, 25 févr. 2003, $\mathrm{n}^{\circ} 00-42.031$

1848 Corrignan-Carsin, D. (2011) 'Vie personnelle - vie professionnelle : la cloison est-elle étanche ?', JCP S (édition sociale), (26), p. 40.

1849 An ideologically oriented enterprise is an enterprise which has a particular orientation, which can be syndical, political or religious.

${ }^{1850}$ Corrignan-Carsin, D. (2011) 'Vie personnelle - vie professionnelle : la cloison est-elle étanche ?', JCP S (édition sociale), (26), p. 40.

${ }^{1851}$ Cour de cassation, chambre sociale, 14 décembre 1999, № 97-41995

1852 Beyneix, I. and Rovinski, J. (2016) 'L'emprise de la vie professionnelle sur la vie personnelle', JCP S (édition sociale), (37), p. 39.

${ }^{1853}$ Cour de cassation, chambre sociale, 14 décembre 1999, N 97-41995

1854 Waquet, P., Struillou, Y. and Pécaut-Rivolier, L. (2014) Pouvoirs du chef d'entreprise et libertés du salarié: du salarié-citoyen au citoyen-salarié. Rueil-Malmaison: ÉdLiaisons (Droit vivant). p. 299.

${ }^{1855}$ Le Cohu, P. (2018) 'Un salarié peut-il critiquer son employeur sans être sanctionné ?', La Gazette du Palais, (10), p. 58.

${ }^{1856}$ Cour de cassation, chambre sociale, 25 janvier 2000 , N ${ }^{\circ} 97-45044$ 
whether the content was publicly accessible (the private or public nature of SNSs): did the employee's act belong within his/her private life? Then, (b) if the remarks are considered to be public and they were obtained lawfully, it can be examined whether they are of an abusive nature or not. ${ }^{1857}$

662. Freedom of expression in the HLC. Just like the FLC, the HLC also contains a declaration on good faith (and mutual cooperation) through stating that " $[i] n$ exercising rights and discharging obligations, the parties involved shall act in the manner consistent with the principle of good faith and fair dealing, they shall be required to cooperate with one another, and they shall not engage in any conduct to breach the rights or legitimate interests of the other party." 1858 However, in contrast to the FLC, in Section 8 , it is explicitly defined what the duties of the employee are when it comes to respecting the employer's rights and legitimate business interests.

Among these provisions Subsection (2) ${ }^{1859}$ of Section 8 imposes limitation on employees' conduct during and outside working hours, while Subsection (3) ${ }^{1860}$ regulates specifically the question of employees' freedom of expression. These provisions aim to determine the legitimate extent to which employees can be bound to respect certain limitations imposed on their personal lives. In addition, Subsection (1) ${ }^{1861}$ contains provisions on the protection of the employer's legitimate economic interests, while Subsection (4) ${ }^{1862}$ on the protection of the employer's business secrets.

\footnotetext{
1857 Grégoire, F. (2018) 'L'usage immodéré de Facebook peut conduire directement à Pôle emploi', JCP G Semaine Juridique (édition générale), (9), p. 437.

1858 Subsection (2) of Section 6 of the HLC

${ }^{1859}$ Subsection (2) of Section 8 of the HLC: "Workers may not engage in any conduct during or outside their paid working hours that - stemming from the worker's job or position in the employer's hierarchy - directly and factually has the potential to damage the employer's reputation, legitimate economic interest or the intended purpose of the employment relationship. The actions of workers may be controlled as defined in Subsection (2) of Section 9. When exercising such control, the workers affected shall be informed in writing in advance."

${ }^{1860}$ Subsection (3) of Section 8 of the HLC: "Workers may not exercise the right to express their opinion in a way where it may lead to causing serious harm or damage to the employer's reputation or legitimate economic and organizational interests."

${ }^{1861}$ Subsection (1) of Section 8 of the HLC: "During the life of the employment relationship, workers shall not engage in any conduct by which to jeopardize the legitimate economic interests of the employer, unless so authorized by the relevant legislation."

1862 Subsection (4) of Section 8 of the HLC "Workers shall maintain confidentiality in relation to business secrets obtained in the course of their work. Moreover, workers shall not disclose to unauthorized persons any data learned in connection with their activities that, if revealed, would result in detrimental consequences for the employer or other persons. The requirement of confidentiality shall not apply to any information that is declared by specific other legislation to be treated as information of public interest or public information and as such is rendered subject to disclosure requirement."
} 
663. The first problem that is encountered is that it is not evident how Subsections (1)-(3) of Section 8 relate to each other. ${ }^{1863}$ Although Subsection (1) relates to the jeopardizing of the employer's legitimate interest, and primarily covers competing activities, it is not unimaginable that judicial case law will add to this category employees' freedom of expression on the Internet, with regard to the frequent occurrence of such conducts. ${ }^{1864}$ Subsection (2) relates to employee behaviour outside working hours, while Subsection (3) deals with employees' freedom of expression: which is at the same time an activity conducted outside working hours. The stakes are high, as the different Subsections lay down different requirements towards the employee, against the different interests of the employer, and as a consequence they sanction different conducts (See Table 5 below).

Table 5: Assessment of Section 8 of the Hungarian Labour Code ${ }^{1865}$

\begin{tabular}{|c|c|c|c|c|}
\hline & & What conduct? & $\begin{array}{c}\text { Against what } \\
\text { rights/legitimate } \\
\text { interests? }\end{array}$ & How? \\
\hline \multirow{3}{*}{ 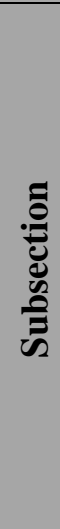 } & (1) & jeopardize & $\begin{array}{l}\text { - the legitimate economic } \\
\text { interests of the employer }\end{array}$ & $\begin{array}{l}\text { - during the life of the } \\
\text { employment relationship, } \\
\text { - unless so authorized by the } \\
\text { relevant legislation }\end{array}$ \\
\hline & (2) & $\begin{array}{l}\text { directly and factually } \\
\text { has the potential to } \\
\text { jeopardize }\end{array}$ & $\begin{array}{l}\text { - the employer's reputation, } \\
\text { - legitimate economic } \\
\text { interest, } \\
\text { - the intended purpose of the } \\
\text { employment relationship }\end{array}$ & $\begin{array}{l}\text { - during or outside their paid } \\
\text { working hours, } \\
\text { - stemming from the worker's } \\
\text { job or position in the } \\
\text { employer's hierarchy }\end{array}$ \\
\hline & (3) & $\begin{array}{l}\text { may lead to causing } \\
\text { serious harm or } \\
\text { jeopardize }\end{array}$ & $\begin{array}{l}\text { - the employer's reputation, } \\
\text { - legitimate economic and } \\
\text { organizational interests }\end{array}$ & \\
\hline
\end{tabular}

Source: the author's own summary

Although Subsection (1) of Section 8 sets forth a general rule of conduct that can be applied to behaviour outside working hours as well, it will be examined separately in part (B), for the reason that this provision mainly relates to competing activities, and not to freedom of expression. Compared to this general requirement, Subsection (2) of Section 8 narrows down the respect of the employer's legitimate interest with regard to the

1863 Pók, L. (2012) 'Lájkolni szabad? Munkavállalói véleménynyilvánítás az új Munka Törvénykönyve tükrében', Infokommunikáció és jog, (4), p. 162.

1864 Pók, L. (2012) 'Lájkolni szabad? Munkavállalói véleménynyilvánítás az új Munka Törvénykönyve tükrében', Infokommunikáció és jog, (4), p. 163.

1865 Except for Subsection (4), which does not raise specific questions as regards the boundaries of personal and professional life.

1866 The wording of the HLC employs the expression "legitimate economic interest" of the employer, instead of using the expression "rights". 
employee's job or position in the employer's hierarchy, therefore such a restriction could be applied in exceptional situations. Also, instead of simple jeopardizing, Subsection (2) of Section 8 requires the behaviour to have the potential to directly and factually jeopardize not only the employer's legitimate economic interests, but also the employer's reputation or the intended purpose of the employment relationship. It is not obvious whether this more detailed formulation has real content or simply constitutes a wordier formulation. ${ }^{1867}$ Moreover, Subsection (2) of Section 8 also refers to Section 9 on the restriction of employees' personality rights, requiring the same conditions to be applied when it comes to restricting personality rights. ${ }^{1868}$

664. Subsection (3) of Section 8 of the HLC contains a provision explicitly aiming to regulate freedom of expression through stating that: "[e]mployees may not exercise the right to express their opinion in a way where it may lead to causing serious harm or jeopardizing the employer's reputation or legitimate economic and organizational interests [,] "1869 but it is not specified whether it relates to behaviour during or outside working hours, or to expression relating directly or indirectly to the employment. When assessing expression connected to the employment, jurisprudence has already elaborated the limits of employees' freedom of expression, through posing three criteria. First, it must be taken into account whether the expression is indeed capable of jeopardizing or influencing the functioning and the efficiency of the employer; second, whether the employee has respected the obligation of moderation (regardless of whether the content was true or false) and third, regardless of whether the recipients can be identified or not. ${ }^{1870,1871}$

(A) Facebook: private or public space?

665. It was already referred to that both in France and in Hungary as a main rule, the dismissal cannot be based on employees' personal life. It will be presented in the

1867 Pók, L. (2012) 'Lájkolni szabad? Munkavállalói véleménynyilvánítás az új Munka Törvénykönyve tükrében', Infokommunikáció és jog, (4), p. 162.

${ }^{1868}$ Subsection (2) of Section 8 will be further presented in Section 2.

${ }^{1869}$ Subsection (3) of Section 8 of the HLC

1870 Conclusions drawn from BH2009.255. cited in Pók, L. (2012) 'Lájkolni szabad? Munkavállalói véleménynyilvánítás az új Munka Törvénykönyve tükrében’, Infokommunikáció és jog, (4), p. 162.

${ }^{1871}$ As these requirements were already clarified by the case law under the previous HLC, László Pók raises the question what the relations between Subsections (1), (2) and (3) are, whether specifying these three scenarios are substantially necessary. See more in: Pók, L. (2012) 'Lájkolni szabad? Munkavállalói véleménynyilvánítás az új Munka Törvénykönyve tükrében’, Infokommunikáció és jog, (4), p. 162-163. 
following paragraphs that employees often allege that as they published the contested content in the course of their private life, it does not constitute a valid basis for dismissal. While it is true that in this case employees usually publish the questionable matter during non-working hours, from their own devices, from a place other than the employer's premises, it is not evident whether these communications have a private or a public nature.

Determining whether SNSs are private or public spheres has importance in both examined countries. (a) In French labour law if the employee expressed himself/herself in the course of a private correspondence, then he/she cannot be sanctioned based on the content with regards to the protection ensured by the right to respect for private life. ${ }^{1872}$ The boundaries of public and private were determined by jurisprudence, ruling on several occasions on the nature of SNSs. (b) In Hungarian labour law, prior to the amendment in 2019, Subsection (1) of Section 11 of the HLC stipulated that the "[t]he private life of workers may not be violated[,]"1873 requiring the protection of employees' private lives. This is the reason why it is important to determine whether SNSs are considered to be a public or a private sphere, as it will influence the monitoring.

\section{a) Jurisprudence of French courts}

666. Importance of public or private communication. Regarding the criterion of constituting a private or public sphere, in a private sphere, each individual is entitled to express himself/herself as he/she wishes: in such a case, even using excessive language is acceptable. However, this protection ends when the individual leaves this private sphere the limits of which were set by case law. ${ }^{1874}$ If the employee expressed himself/herself in the course of a private correspondence, then he/she cannot be sanctioned based on the content with regards to the protection ensured by the right to respect for private life. ${ }^{1875}$ However, if the expression did not take place during a private correspondence, the case has to be assessed on the grounds of the freedom of expression (and it has to be examined

\footnotetext{
1872 Cour de cassation, chambre mixte, 18 mai 2007, $\mathrm{N}^{\circ}$ 05-40803

1873 Although the reasoning of the amendment argued that even without explicitly stating the prohibition of monitoring employees' private life, the existence of it is derived from the Fundamental Law and from the Civil Code. Source: T/4479. számú törvényjavaslat az Európai Unió adatvédelmi reformjának végrehajtása érdekében szükséges törvénymódositásokról (2019). Elöadó: Dr. Trócsányi László igazságügyi miniszter. Budapest. p. 102.

1874 Caron, M. (2018) 'Les limites à la liberté d'expression d'un salarié sur Facebook', Les Cahiers Sociaux, (305), p. 131.

1875 Cour de cassation, chambre mixte, 18 mai $2007, N^{\circ} 05-40803$
} 
whether abuse is present). ${ }^{1876}$ In sum, if the expression took place during a private conversation, the case should be examined from the angle of the right to respect for private life, meaning that the employee cannot be sanctioned, even if the expression was abusive. However, if the expression did not take place during a private conversation, the affair will be examined from the angle of freedom of expression, where abusive remarks can be sanctioned by the employer. ${ }^{1877}$

667. Therefore, it is of crucial importance to determine whether SNSs are considered to be private or public space. Usually private correspondence takes place if the message is exclusively destined to one or several natural or legal persons who are determined or individualized. ${ }^{1878}$ According to the Tribunal de Grande Instance de Paris, correspondence is protected if the content is exclusively destined by a defined person to another defined individual, in contrast to messages made available to the public. ${ }^{1879}$ Therefore, courts had to deal with the question of whether communication taking place on SNSs are covered by the notion of private correspondence. Especially the use of privacy settings - when access to the content is limited and maybe accessible only to the friends of the employee - raised questions regarding the nature of SNSs. ( $\alpha$ ) Courts already addressed this question; however, their rulings were not always uniform. ( $\beta$ ) Finally, the Court of Cassation clarified the issue; notably, through its Civil Chamber in 2013, and finally the Social Chamber in two decisions from 2017 and 2018.

\section{( $\alpha$ ) Assessment of the courts}

668. During the last few years lower courts received several cases in relation to "Facebook firings". Generally, it can be said that these cases concerned employees who were dismissed because they published remarks on SNSs (typically on Facebook), relating to the workplace, employer or colleagues, which the employer found abusive. Employees pleaded that these matters took place in the course of a private

1876 Corrignan-Carsin, D. (2018) 'Tenir des propos injurieux sur Facebook au sein d'un groupe fermé ne justifie pas un licenciement', JCP G Semaine Juridique (édition générale), (40), p. 1762.

1877 Loiseau, G. (2018) 'Réseaux sociaux et abus de la liberté d'expression : l'exception de cercle privé', $L a$ Semaine Juridique Social, (41), p. 23. and Corrignan-Carsin, D. (2018) 'Tenir des propos injurieux sur Facebook au sein d'un groupe fermé ne justifie pas un licenciement', JCP G Semaine Juridique (édition générale), (40), p. 1762.

1878 TI Puteaux, 28 sept. 1999. Cited in: Lepage, A. (2000) 'Pas d'échelle de responsabilité sur Internet en matière de diffamation', Communication Commerce Électronique, (2), p. 25.

1879 TGI Paris, 17e ch., 2 nov. 2000, n9725223011 cited in: Bitan, F. (2011) 'Fasc. 4740 : Courrier électronique', JurisClasseur Communication. 
conversation/correspondence; therefore, as they are entitled to the right to respect for private life, their dismissal could not legally be based on these remarks.

The decisions of the courts were not always coherent ${ }^{1880}$ regarding the private or public nature: though the exact circumstances could influence the decision, in some of them it was held that Facebook is a public sphere, ${ }^{1881}$ therefore the employer could take these remarks into consideration; while other decisions stated that the communication remained in the private sphere, therefore it was protected by the right to respect for private life. ${ }^{1882}$ However, several factors can influence the decision, such as the exact place where the content was published (e.g. on someone's own profile, on someone else's profile, in a private message, etc.), whether privacy settings were used (and if yes, exactly which settings were chosen) or whether the use of privacy settings could be proved.

669. Publishing content to the wall. One of the main factors to be considered is whether the employee published the content to his/her own wall or to another user's wall. In the case of publishing content to another user's wall, the employee loses control over the information, as it is subjected to the privacy settings chosen by the other user. In one case at the Court of Appeal of Reims, ${ }^{1883}$ the employee contested the warning for misconduct that, as the employer alleged, he received for abusing his freedom of expression and breaching his duty of loyalty by posting insulting and defamatory remarks against his supervisor. The remarks were published to the wall of another employee and were available to everyone: the employer argued that Facebook is a public space, while the employee argued that Facebook is rather similar to an e-mail account and is considered as private correspondence. The Court of Appeal of Reims recalled that it cannot be ignored that Facebook, which is accessible through a simple Internet access, does not always guarantee the necessary confidentiality. According to it, posting a remark to the wall of another user potentially exposes the content to the public - depending on the privacy settings chosen by the other party, the use of which was not proved in the case. In addition,

\footnotetext{
1880 As an illustrative example: on the very same day in cases relating to a dismissal based on the use of Facebook, the Court of Appeal of Besançon (CA Besançon, chambre sociale, 15 novembre 2011, $\mathrm{n}^{\circ}$ 10/02642) ruled that Facebook is considered to be public, while the Court of Appeal of Rouen (CA Rouen, chambre sociale, 15 novembre $2011, \mathrm{~N}^{\circ} 11 / 01827$ ) ruled that is private.

${ }^{1881}$ E.g. CA Reims, chambre sociale, 9 juin 2010, $\mathrm{n}^{\circ}$ 09/03205; CA Besançon, chambre sociale, 15 novembre 2011, $n^{\circ}$ 10/02642; CPH Boulogne-Billancourt (Section Encadrement), 19 novembre 2010, n 09/00343

1882 E.g.: CA Rouen, chambre sociale, 15 novembre 2011, n 11/01827 and CA Rouen, 15 novembre 2011, $\mathrm{N}^{\circ}$ 11/01830; CA Bordeaux, chambre sociale, section A, 12 février 2013, $\mathrm{n}^{\circ} 12 / 01832$; CA Rennes, 8e chambre prud'homale, 2 mars $2018, \mathrm{n}^{\circ} 16 / 07806$

${ }^{1883}$ CA Reims, chambre sociale, 9 juin 2010, $n^{\circ} 09 / 03205$
} 
a private correspondence supposes that a message should not be read by someone to whom it was not destined: in order to have a private conversation, the employee should have sent a private message through the messaging service of Facebook. ${ }^{1884}$ Therefore, the secrecy of correspondence was not violated by the employer.

The Court of Appeal of Besançon ${ }^{1885}$ had to rule in a case relating to the dismissal of an employee who had a discussion on the wall of a former employee abusing the freedom of expression. The employee held that the discussion was a private conversation, as it took place on the wall of the former employee, available only to his Facebook contacts. In contrast, the employer held that the conversation was public as it could have been available to every user and if the employee wanted to have a private conversation, he should have used the function of sending private messages. The Court of Appeal stated that the aim of Facebook is to display and create a network of contacts between different users, supposed to grow in an exponential way through the application of the principle "the contacts of my contacts become my contacts". Also, to a conversation taking place on the wall of a user, everyone could have access unless the user applied the privacy settings. It is the employee's responsibility to either use the alternatives offered by the site or, in the case of publishing content to another user's wall, to make sure prior to the publication that this user restricted access to his/her wall. Therefore, considering the basic nature and aim of the site and the fact that the employee had alternatives to ensure the private nature of the communication (through sending a private message), such conversation taking place on the wall is to be considered public.

670. However, when it comes to publishing content to the "wall", sometimes courts seem to ignore the functioning of Facebook. This is supported by the use of different terminology (e.g. publishing content to the "wall"1886 or to the "public wall" 1887 ). The word wall is particularly misused when a court stated that Facebook is considered to be a public space by its nature, unless the user takes precaution and creates "a wall" to prevent free access to the site. ${ }^{1888}$ The Court of Appeal of Pau ${ }^{1889}$ held that publishing content to the

\footnotetext{
${ }^{1884}$ The Court of Appeal of Rouen held that the private messaging system of Facebook is considered to be of private nature. Source: CA Rouen, chambre sociale, 10 février 2015, $\mathrm{n}^{\circ}$ 14/03335 and CA Rouen, chambre sociale, 15 mars 2018, $\mathrm{n}^{\circ}$ 15/06042

${ }^{1885}$ CA Besançon, chambre sociale, 15 novembre 2011, $\mathrm{n}^{\circ} 10 / 02642$

${ }^{1886}$ CA Montpellier, 4e chambre sociale, section A, 14 mars 2018, $\mathrm{n}^{\circ} 14 / 09173$

1887 CA Lyon, chambre sociale B, 22 novembre 2012, $n^{\circ} 11 / 05140$

1888 CA Fort-de-France, Chambre sociale, 21 décembre 2012, n ${ }^{\circ}$ 12/00053. In Facebook, a "wall" is not created: if the user decides to post something to his/her profile, it will go to the wall, where access can be restrained through the use of privacy settings.
} 
"private and public walls" without being able to prove that only the employee's contacts had access to the content on the "private wall" is considered to be public communication. Using the expression "private and public walls" is extremely confusing, as it is not clear what the Court of Appeal meant by that expression. In reality, every user has one "wall", which can be either public, private or customized depending on the chosen privacy settings.

671. Commenting. In another case at Court of Appeal of Reims, ${ }^{1890}$ an employee of the supermarket Cora was dismissed for a comment that he posted under a Facebook article of a journal, discussing the opening of the supermarket of Sundays. In his comment he encouraged customers to boycott the opening on Sundays and not to come to the supermarket on Sundays. The court of appeal started its analysis by pointing out that the employee is entitled to the freedom of expression both inside and outside the workplace. Then, it recalled that the expression constitutes an abuse if offensive, excessive or defamatory terms are employed. ${ }^{1891}$ According to the court of appeal, the language used was excessive. As regards the public/private nature of the expression, the court of appeal found that such a comment goes beyond the 12 users who liked the comment, as the journal itself had 112,000 followers, and the article received 453 likes; therefore, the comment could potentially have been read by numerous users. As a result, such an abuse on the part of the employee constituted the breach of the obligation of good faith, making it impossible to maintain his employment relationship.

672. Use of privacy settings. Usually, the use of privacy settings has crucial importance. ${ }^{1892}$ Employees often argue that content available to a limited audience such as "friends" or "friends and friends of friends" is considered to be private communication. Allowing access to friends and friends of friends is considered to be public: in 2011 the Court of Appeal of Rouen ${ }^{1893}$ held that depending on the use of the privacy settings,

\footnotetext{
${ }^{1889}$ CA Pau, chambre sociale, 6 septembre 2018, $\mathrm{n}^{\circ} 17 / 01648$

${ }^{1890}$ CA Reims, chambre sociale, 15 novembre $2017, \mathrm{n}^{\circ} 16 / 02786$

1891 Also, the employee used the expression "we", making it obvious that he was an employee of the concerned workplace. The court of appeal also took into consideration that the comments were posted only 2 days before the opening.

1892 As a reminder, before introducing customizable privacy settings, Facebook offered the choice of available only to friends, to friends and friends of friends, to every Facebook user and to everyone.

1893 CA Rouen, chambre sociale, 15 novembre 2011, $\mathrm{n}^{\circ}$ 11/01827 and CA Rouen, chambre sociale, 15 novembre $2011, \mathrm{~N}^{\circ} 11 / 01830$
} 
Facebook can be considered either a private space or a public space. ${ }^{1894}$ In the given case it was not proved whether the privacy settings chosen allowed access to an undetermined number of users (e.g. providing access to friends of friends), in a way that would make the conversation lose its private character. In addition, it was unknown how the employer had access to the content: it cannot be excluded that one of the participating users made him aware of the conversation. The Court of Appeal of Paris ${ }^{1895}$ reached a similar conclusion in relation to a case where an employee limited the access to the content (only available to friends), and though the employee had 449 friends, the employer could not prove that members of the management or clients were amongst these friends, and the only fact that a colleague transferred the page to the management is not enough to establish the public nature of the wall.

673. The employment tribunal ("conseil de prud'hommes") of Boulogne Billancourt ${ }^{1896}$ had to rule ${ }^{1897}$ in a case where an employee who worked as a recruitment officer at the Société Alten Sir was dismissed for serious misconduct for sharing remarks that were inciting to rebellion and were denigrating on one of her colleague's Facebook wall. The employment tribunal stated that this colleague chose the privacy settings of sharing the content with "friends and their friends", as such ensuring a public access to the remarks, with the possibility especially for colleagues and former colleagues to access them. Such an access exceeds the private sphere, therefore the content is a legitimate proof, and the employer did not violate the employee's right to respect for private life. ${ }^{1898}$ Such reasoning reflects common sense and is in line with the functioning of SNSs, ${ }^{1899}$ but still

1894 In contrast, the Court of Appeal of Douai held that participating in a social network site excludes confidentiality. Source: CA Douai, ch. soc., 26 janv. 2018, ${ }^{\circ}$ 16/0068 referred to in: Caprioli, É. A. (2018) 'Licenciement: obtention loyale de la preuve sur le réseau social Facebook afin de caractériser une faute grave', Communication Commerce Électronique, (6), p. 43.

${ }_{1895}$ CA Paris, Pôle 6, chambre 5, 20 septembre 2018, n 14/04515

1896 CPH Boulogne-Billancourt (Section Encadrement), 19 novembre 2010, nº 09/00343

1897 This case is quite significant and received much attention as it was the first decision in France addressing the private or public character of SNSs. Source: Sordet, E. (2010) 'Facebook, néfaste pour la vie privée (des salariés) ?', JCP G Semaine Juridique (édition générale), (48), p. 2228.

1898 The tribunal then assessed whether the expressions used were abusive - which subject will be treated in part (b).

1899 Hardouin, R. (2011) 'Facebook ou l'établissement de la frontière entre espace public et sphère privée', Revue Lamy droit de l'immatériel ex Lamy droit de l'informatique, (67), p. 55.; Ray, J.-E. (2010) 'Little Brothers are watching you', Semaine sociale Lamy, 1470, p. 12. 
ensures the possibility that if the appropriate steps are taken and limited access is set, it can be a private space. ${ }^{1900}$

674. Not limiting access will cause that the communication will take place in a public space. According to the Court of Appeal of Fort-de-France, Facebook is considered to be a public space by its nature, unless the user takes precaution and creates "a wall" to prevent free access to the site. ${ }^{1901}$ Courts held that publishing content to the "wall"1902 or to the "public wall", 1903 or "to the wall without using privacy settings to allow access only to the authorized persons", 1904 to "the wall to which every Facebook user had access", 1905 or to "a Facebook page without limiting the audience in any way"1906 is considered to be public communication. The Court of Appeal of $\mathrm{Pau}^{1907}$ held that publishing content to the "private and public walls" without being able to prove that only the employee's contacts had access to the content on the "private wall" is considered to be public communication. However, by stating that it is a public space because the employee was not able to prove that only his contacts had access to the content assumes that if only his contacts (which can mean a number up to several hundreds of users) had had access, the content would have been considered private.

675. The Court of Appeal of Bordeaux ${ }^{1908}$ stated that the public nature of the conversation could not be proved, as there was no available information relating to the number of friends of the employee, or to the chosen privacy settings. However, earlier the court of appeal held that the user can choose between different privacy settings, such as allowing access to friends, to friends of friends or to every Facebook user - where the latter would make the conversation lose its nature of private correspondence. This could be interpreted as meaning that if friends and friends of friends had access, then - according to the court - the private nature of the communication would be established. The Court of

\footnotetext{
1900 Picq, M. (2011) 'Facebook et les salariés : vie privée, liberté d'expression et humour', Revue des droits et libertés fondamentaux, (11), p. 2. [Page number referring to the online version of the article downloaded from: http://www.revuedlf.com/droit-social/facebook-et-les-salaries/\# (Accessed: 15 August 2019)]

${ }^{1901}$ CA Fort-de-France, chambre sociale, 21 décembre 2012, ${ }^{\circ} 12 / 00053$

1902 CA Montpellier, 4e chambre sociale, section A, 14 mars 2018, $n^{\circ} 14 / 09173$

${ }^{1903}$ CA Lyon, chambre sociale B, 22 novembre 2012, $n^{\circ} 11 / 05140$

${ }^{1904}$ CA Aix-en-Provence, 9e chambre A, 27 mars 2015, n 13/20847

1905 CA Versailles, 17e chambre, 4 octobre 2017, $\mathrm{n}^{\circ}$ 15/03872 and CA Aix-en-Provence, 17e chambre B, 4 février 2016, $n^{\circ} 14 / 13125$

${ }^{1906}$ CA Lyon, chambre sociale A, 13 mars 2013, $\mathrm{n}^{\circ} 12 / 05390$

1907 CA Pau, chambre sociale, 6 septembre 2018, $n^{\circ} 17 / 01648$

${ }^{1908}$ CA Bordeaux, chambre sociale, section A, 12 février 2013, n¹2/01832
} 
Appeal of Rennes ${ }^{1909}$ held that the bailiff stated that the employee's Facebook wall was accessible and therefore public, so communication on it was not considered as conversation between friends. However, it was not proven that the remarks were published on the wall. Therefore, they were reserved to friends and took place in a private setting. Thus, it is of great importance to define in a uniform matter whether SNSs are presumed to have a public or private nature as, if they are presumed to be public, the employee shall prove that despite all, the remarks were private, while if they are presumed to be private, the employer shall rebut the presumption by proving their public character. ${ }^{1910}$

676. Private messages. Communicating within the private messaging system usually does not pose challenge, as it is usually recognized by courts that sending messages through the instant messaging service is considered to be private communication. The Court of Appeal of Reims held that as private correspondence supposes that a message should not be read by someone to whom it was not destined to, in order to have a private conversation, the employee should have sent a private message through the messaging service of Facebook. ${ }^{1911}$ The Court of Appeal of Rouen ${ }^{1912}$ held that the private messaging system of Facebook is considered to be of private nature, while the Court of Appeal of Besançon remarked that sending private message within Facebook constitutes a solution to ensuring the private nature of communication on this primarily public sphere. ${ }^{1913}$

677. Forgetting to sign out. However, employees need to be cautious when accessing SNSs from their work computers as in certain cases private communication can lose its nature and protection. In a case in front of the Court of Appeal of Toulouse, ${ }^{1914}$ the court found that the conversation of an employee who forgot to disconnect from her Facebook account when accessing this site from her work computer, which therefore was visible on the screen of the computer by anyone present in the workplace, lost its private nature. In another case at the Court of Appeal of Caen ${ }^{1915}$ an employee accidentally accessed her colleague's Facebook account when typing Facebook into Google - as the

\footnotetext{
${ }^{1909}$ CA Rennes, 8e chambre prud'homale, 2 mars 2018, $\mathrm{n}^{\circ} 16 / 07806$

${ }^{1910}$ Inforeg (2015) 'Pouvoir disciplinaire : vie personnelle, vie professionnelle et Facebook', Cahiers de droit de l'entreprise, (6), p. 68.

${ }^{1911}$ CA Reims, chambre sociale, 9 juin 2010, $\mathrm{n}^{\circ}$ 09/03205

1912 CA Rouen, chambre sociale, 10 février 2015, $\mathrm{n}^{\circ}$ 14/03335 and CA Rouen, chambre sociale, 15 mars $2018, \mathrm{n}^{\circ} 15 / 06042$

${ }^{1913}$ CA Besançon, chambre sociale, 15 novembre 2011, $\mathrm{n}^{\circ} 10 / 02642$

${ }^{1914} \mathrm{CA}$ Toulouse, 4e chambre sociale, 2e section, 2 février $2018, \mathrm{n}^{\circ} 16 / 04882$

1915 CA Caen, 1re chambre sociale, 27 janvier 2017, n ${ }^{\circ}$ 15/04417 and CA Caen, 1re chambre sociale, 27 janvier $2017, \mathrm{n}^{\circ} 15 / 04402$
} 
latter forgot to sign out. There she saw her colleague's conversation that she found degrading, humiliating and violent, and reported it to the employer. However, when examining the documents provided by the parties, the court noted that when the employee accidentally accessed the Facebook account of the employee, she could have accessed the messaging system only after clicking on the button "messages" and then on this particular conversation. As such, the employer took into consideration messages that were identified as private (and without the presence of the employee) in irregular circumstances, not making it possible to rely on their content.

678. Conclusions. In sum, it is not unambiguous from courts' case law what exact conditions are necessary to be met in order to qualify the content on SNS as private and ensure the protection of the right to respect for private life to it: in the light of the circumstances of the given cases, courts either found that Facebook was a public sphere, ${ }^{1916}$ or a private one. ${ }^{1917}$

In most cases, courts - according to my opinion, correctly - ruled that Facebook is by nature a public sphere, except for the case of sending a private message, which was considered the most prominent example of ensuring private communication in this mainly public space. However, what is not clear is to what extent access should be limited, as courts mainly held that the content was deemed to be public because the user did not limit the access, but often stayed quiet regarding to what extent access should be limited. Although it seems accepted that a certain kind of limitation should be necessary in order to be qualified as private, for example, it is not clear whether access to friends is enough (also, such a concept is highly dependent on the number of friends as well). While the settings "friends and friends of friends" was deemed to provide access to an undetermined number of users and therefore was considered to be public, the formulation of other decisions suggested that only the "public" setting does not merit protection. In addition, questions of proof might constitute difficulties when addressing the private/public nature

1916 CA Reims, chambre sociale, 9 juin 2010, $\mathrm{n}^{\circ}$ 09/03205; CPH Boulogne-Billancourt (Section Encadrement), 19 novembre 2010, $\mathrm{n}^{\circ}$ 09/00343; CA Besançon, chambre sociale, 15 novembre 2011, $\mathrm{n}^{\circ}$ 10/02642; CA Reims, chambre sociale, 15 novembre 2017, $\mathrm{n}^{\circ}$ 16/02786; CA Montpellier, 4e chambre sociale, section A, 14 mars 2018, $\mathrm{n}^{\circ} 14 / 09173$, CA Lyon, chambre sociale B, 22 novembre 2012, $\mathrm{n}^{\circ}$ 11/05140; CA Aix-en-Provence, 9e chambre A, 27 mars 2015, $\mathrm{n}^{\circ}$ 13/20847; CA Versailles, 17e chambre, 4 octobre 2017, $\mathrm{n}^{\circ}$ 15/03872 and CA Aix-en-Provence, 17e chambre B, 4 février 2016, $\mathrm{n}^{\circ}$ 14/13125, CA Lyon, chambre sociale A, 13 mars 2013, n 12/05390

1917 CA Rouen, chambre sociale, 15 novembre 2011, $\mathrm{n}^{\circ} 11 / 01827$ and CA Rouen, chambre sociale, 15 novembre 2011, $\mathrm{N}^{\circ}$ 11/01830; CA Bordeaux, chambre sociale, section A, 12 février 2013, ${ }^{\circ} 12 / 01832$; CA Rennes, 8e chambre prud'homale, 2 mars 2018, $\mathrm{n}^{\circ}$ 16/07806; CA Versailles, 17e chambre, 7 février 2018, $\mathrm{n}^{\circ}$ $15 / 05739$ 
of SNSs, when it could not be proved with certainty who had access to the content. Because of the lack of clarity, it was much needed that the Court of Cassation pronounces on this question - which luckily happened during the last years.

\section{( $\beta$ ) Decisions of the Court of Cassation}

679. The Court of Cassation addressed the subject of private or public nature of SNSs notably in three cases. The first one was held by the Civil Chamber in 2013, ${ }^{1918}$ which contributed to unifying the divergent practice of lower courts. Then, in $2017^{1919}$ finally the Social Chamber issued a judgement in the subject - although it was heavily criticized by several authors. ${ }^{1920}$ Finally, in 2018, ${ }^{1921}$ the Social Chamber pronounced another judgement, which contains important guidance when it comes to assessing the nature of employees' communication on SNSs.

680. Court of Cassation: Civ. 1re, 10 avr. 2013, $n^{\circ} 11-19530$. In this case, the main question to be decided was whether the content published by an employee of Agence $d u$ Palais was considered as public or as non-public insults. The employee, the author of the remarks, posted content such as "should pass an act for exterminating pain-in-the-ass managers, like mine !!!” or "exterminating pain-in-the-ass managers" and "eliminate our bosses and especially uptight bosses [using a feminine noun in French language] who are ruining our lives!!!" She posted these matters to the sites Facebook and MSN, in a way that it was only available to a determined number of users (a group with 14 members), who she personally allowed to access the content.

681. Regarding the decision itself and its significance, in this case, the Cour de cassation ruled the first time ${ }^{1922}$ that " $[i] t$ is not a public insult if it is published on a social network account accessible only to authorized persons, in a very limited number by the author of the insults and who together form a community of interest." In order to be qualified as non-public insult, the following three conditions must be meet: limited number

\footnotetext{
${ }^{1918}$ Cour de cassation, chambre civile 1, 10 avril 2013, $\mathrm{N}^{\circ} 11-19530$

1919 Cour de cassation, chambre sociale, 20 décembre 2017, N 16-19609

1920 See notably the analysis provided by Grégoire Loiseau and Sébastien Mayoux. To be presented when analysing the decision.

${ }^{1921}$ Cour de cassation, chambre sociale, 12 septembre 2018, N $16-11.690$

1922 Pierroux, E. (2015) 'Facebook, Twitter et autres résaux sociaux: petites injures entres "amis"', La Gazette du Palais, (336-337), p. 5.
} 
of users has access, the owner of the profile has authorized them to participate in the conversation and they form a community of interest. ${ }^{1923}$

Regarding the limited number of users, it becomes clear that using the privacy settings "friends of friends" - the majority of user profiles - will not be included in this case. ${ }^{1924}$ However, an important question arises: how many friends are acceptable? Qualifying them as persona grata does not cover cases when the employee accepts (maybe several hundreds of) friend requests, but refers to a more personalized authorization when the user is truly aware to whom he/she has granted access, cases where "only" the "friends" of the user have access without further distinction, should not be qualified nonpublic. ${ }^{1925}$

When determining whether the participating individuals form a community of interest, ${ }^{1926}$ judges adopt a casuistic and intuitive approach through examining the in concreto aspects of the case, ${ }^{1927}$ as the exact notion of community of interest is yet to be determined. ${ }^{1928}$ According to the decision itself, a community of interest consists of persons bound by a common membership, shared inspirations or objectives. ${ }^{1929}$ In the light of this definition, a closed Facebook group assembling employees from the same workplace in order to discuss a specific matter or subject would be considered as a community of interest. ${ }^{1930}$

1923 Since this decision, lower courts also adopted the same approach, e.g. the Court of Appeal of Versailles recalled that it cannot be stated that Facebook is a public space if it is not contested that it was only limited to the "friends" of the employee who formed a community of interest and was only available only to those persons in a limited number, authorized by the employee. Source: CA Versailles, 17e chambre, 7 février $2018, \mathrm{n}^{\circ} 15 / 05739$

${ }^{1924}$ Ray, J.-E. (2013) 'Facebook, espace public plus que privé. A propos de l'arrêt de la 1 ère Chambre civile du 10 avril 2013', Semaine sociale Lamy, (1599), p. 17.

1925 Of course, the case is different if the user has 6 friends (15? 31?) or 873 friends.

1926 Through the concept of "community of interest" it is acknowledged that individuals usually address a specific group composed of several individuals - without the intention of reaching people outside of this circle. Source: Cassart, A. (2013) 'L'extension de la notion de communauté d'intérêts aux réseaux sociaux', Revue du Droit des Technologies de l'Information, (52), p. 102.

1927 Pierroux, E. (2015) 'Facebook, Twitter et autres résaux sociaux: petites injures entres "amis", La Gazette du Palais, (336-337), p. 6.

1928 See the definitions and approaches presented by Ronan Hardouin in: Hardouin, R. (2011) 'Facebook ou l'établissement de la frontière entre espace public et sphère privée', Revue Lamy droit de l'immatériel ex Lamy droit de l'informatique, (67), p. 55.

1929 This definition is very similar to the one proposed by professor Yves Mayaud. He defined community of interest as "common membership, shared inspirations or objectives [...] of persons who form an entity closed enough for not to be perceived as involving third parties in relation to the author of the remarks." Source: Mayaud, Y. (1998) 'De la mise en cause diffamatoire d'une gestion municipale : l'enjeu de publicité', Revue de science criminelle et de droit pénal comparé, (1), p. 104.

${ }^{1930}$ Ray, J.-E. (2013) 'Facebook, espace public plus que privé. A propos de l'arrêt de la 1 ère Chambre civile du 10 avril 2013', Semaine sociale Lamy, (1599), p. 16. 
Although today Facebook allows users to use differentiated and customized privacy settings (making it possible to easily grant access to members of the community of interest), several other sites (e.g. Twitter or Instagram) opt for the all or nothing approach, not making the use of tailored privacy settings possible.

682. Court of Cassation: Soc., 20 déc. 2017, $n^{\circ} 16-19609$. The employee, who worked at a foodservice company, was successively the victim of physical aggression when leaving the workplace and the victim of an attempted armed robbery within the workplace. The day after the attempted robbery, she was on leave because of her depressive state, and the employer made her sign a new employment contract. In order to declare the contract void due to the defect in consent, she provided proof establishing that even before the attempt she had been taking antidepressants and her state got worse due to the attack. In order to contest this argument, the employer produced as evidence information obtained from the work cellphone of (not the employee who contested the contract but) another employee. ${ }^{1931}$

683. The Court of Cassation ruled that "having noted that the minutes of the bailiff's report [...] requested by the company [...], relating to information extracted from the Facebook account of the employee, obtained from the work cellphone of another employee, information reserved to authorized persons, [...] the employer could not have access to them without posing a disproportionate and unlawful interference in the private life of the employee." In its reasoning by using both the expressions "disproportionate" and "unlawful", the Court of Cassation referred to two separate matters. ${ }^{1932}$ Grégoire Loiseau notes that this judgement was particularly wrongly reasoned, as it mixed the separate questions of the ways of obtaining proof (question of legality of proof) and tracing the private or public nature of SNSs (question of right to respect for private life). Therefore, according to him, this decision failed to make a significant contribution. ${ }^{1933}$

According to Sébastien Mayoux, it is important to note that it was the first time that the Social Chamber ever ruled in relation to Facebook, still, the decision is far from being

\footnotetext{
${ }^{1931}$ Péronne, G. and Daoud, E. (2018) 'Accès par l'employeur au compte Facebook du salarié et droit à la vie privée', Dalloz IP/IT, (5), p. 315.

1932 Ray, J.-E. (2018) 'Des "licenciements Facebook" à la sanction d'un "Like”?', Semaine sociale Lamy, (1830), p. 11.

${ }^{1933}$ Loiseau, G. (2018) 'Réseaux sociaux et abus de la liberté d'expression : l'exception de cercle privé', $L a$ Semaine Juridique Social, (41), p. 23.
} 
satisfying despite its importance and reveals a multitude of unanswered questions. ${ }^{1934}$ For the subject of the dissertation notably the (interconnected) questions of the way of obtaining access through the other employee and the question of when and whether these private matters can become public are relevant.

The decision is contrary to the previously established practice of courts according to which if the access to the content was restricted, the employer could not rely on it, and the same applied if he/she succeeded in obtaining it through a surreptitious way. However, if an individual who was originally granted access to the content decides to extract the information and to transmit it outside of the restricted access, it becomes public in a way that the employer can rely on it as proof. ${ }^{1935}$ However, the Court of Cassation did not state precisely the way the employer obtained access through the other employee: did the employee voluntarily shared the information with the employer or did the employer accessed the information through exercising his/her right to monitor the use of professional equipment? ${ }^{1936}$

The Court of Cassation also stays silent regarding when such private content might become public. In addition, if the decision is interpreted extensively, it can lead to the reexamination of the existing practice, as it would make quasi impossible for the employee to reveal those matters to the employer. ${ }^{1937}$ Besides, it was not specified what exactly is meant by information reserved to authorized persons. ${ }^{1938}$

In sum, although the Social Chamber of the Court of Cassation finally ruled in the case of Facebook, the decision did not really help to establish a clear practice, as it mixed two distinct areas: the protection of the private life of the employee and the way of obtaining proof. Besides, the decision also lacked precision. Therefore, it was still necessary that the Social Chamber pronounces a decision in which it establishes the legal

1934 Mayoux, S. (2018) 'Licéité de la preuve recuillie sur Facebook par l'employeur', Jurisprudence sociale Lamy, (449), pp. 24-25.

1935 Mayoux, S. (2018) 'Licéité de la preuve recuillie sur Facebook par l'employeur', Jurisprudence sociale Lamy, (449), p. 24.

1936 Mayoux, S. (2018) 'Licéité de la preuve recuillie sur Facebook par l'employeur', Jurisprudence sociale Lamy, (449), p. 24.

1937 Mayoux, S. (2018) 'Licéité de la preuve recuillie sur Facebook par l'employeur', Jurisprudence sociale Lamy, (449), p. 25.

1938 Icard, J. (2018) 'De l'incidence de la source d'une communication d'un salarié sur sa nature et sur son régime', Cahiers sociaux du Barreau de Paris, (304), p. 85. 
framework applicable to the exercising employees' freedom of expression on SNSs. Luckily, this happened in the decision of 18 September $2018 .{ }^{1939}$

684. Court of Cassation: Soc., 12 sept. $2018, n^{\circ} 16-11.690$. In this case, the Court of Cassation had to rule again in a case concerning an employee of Agence du Palais, for exchanging remarks eerily similar to those in the 2013 case of the Civil Chamber. The employee was member in a Facebook group entitled "Exterminating painin-the-ass managers", where she published insulting and offensive remarks relating to her employer. These remarks were only accessible to a closed group of 14 persons, authorized to have access by the owner of the account. As a result of her comments, she was dismissed for serious misconduct. ${ }^{1940}$

685. The Social Chamber held that "the disputed remarks do not constitute a serious misconduct if published on a Facebook account created by the employee, accessible only to persons authorized by him/her composing a closed group of fourteen people, as such comments constitute a conversation of private nature." By this, instead of referring to the wider notion of community of interest applied by the Civil Chamber in 2013, the Social Chamber applies the concept of private circle ("cercle privé") to determine the conditions of being qualified as private communication. Originating from copyright law, private circle in the context of social media and employment should refer to the circle of family and also to persons beyond family with whom private relations are usually maintained, designating a closed community or a network limited to close contacts who have close relations with each other or at least with one person from the group. ${ }^{1941}$ In relation to SNSs, it is important to evoke that the Court of Cassation already stated that the term "friend" used in the context of SNSs referring to contacts within these sites is not identical to the term friend used to describe relationships in the traditional sense of the term. ${ }^{1942}$ Therefore the private circle should not be merged with the online "friends" of the individual, as in order to be qualified as private communication, the determination of the

\footnotetext{
${ }^{1939}$ Loiseau, G. (2018) 'Réseaux sociaux et abus de la liberté d'expression : l'exception de cercle privé', $L a$ Semaine Juridique Social, (41), p. 23.

${ }^{1940}$ CA Paris, Pôle 6, chambre 8, 3 décembre 2015, n 13/01716

${ }^{1941}$ Loiseau, G. (2018) 'Réseaux sociaux et abus de la liberté d'expression : l'exception de cercle privé', $L a$ Semaine Juridique Social, (41), p. 24.

${ }^{1942}$ Cour de cassation, chambre civile 2, 5 janvier 2017, $\mathrm{N}^{\circ} 16-12394$
} 
persons who have access to the remarks is also necessary. ${ }^{1943}$ Also, the number of persons having access to the content should be limited.

Besides this close relation between the participants in the conversation, there are two other important conditions that have to be met in order to qualify the communication as private: the number of persons having access and the determination of the persons who have access to the remarks. Regarding the number of users, it should be low: therefore, the question arises what is considered to be a low number in this context? As it is impossible to give a precise answer adequate to all situations, it will be the trial judge's task to determine these boundaries. ${ }^{1944,} 1945$

686. Conclusions drawn from the decisions of the Court of Cassation. In sum, the use of privacy settings in itself (opting for the use of "private" profile, which in reality rather means "not public") does not automatically qualify the information as private. The use of privacy settings making content available only to "friends" is considered public in the age when users often have several hundreds of contacts on these sites. Having a limited number of contacts (although it is not evident what is considered to be limited number) in itself is still not enough: persons having access to the communication have to be part of a private circle, meaning that they must have some kind of close relationship with each other. In addition, they cannot have automatic access, their access has to be determined by the individual owning the account. For example, a small group of colleagues discussing work-related matters would fall under this category.

In the context of Facebook, it means that creating, for example, a private group, or customizing the privacy settings of the posts to only share content with the members of the private circle would be a way to ensure the private nature of communication. On other SNSs - which do not allow the use of customized privacy settings -, creating chat rooms (instead of discussing those matters on the profile of the individual) for those few, chosen persons (colleagues in the context of the dissertation) can be a way to ensure that the communication has a private nature.

b) Activities beyond working hours: the Hungarian Labour Code

1943 Corrignan-Carsin, D. (2018) 'Tenir des propos injurieux sur Facebook au sein d'un groupe fermé ne justifie pas un licenciement', JCP G Semaine Juridique (édition générale), (40), p. 1762.

${ }^{1944}$ Loiseau, G. (2018) 'Réseaux sociaux et abus de la liberté d'expression : l'exception de cercle privé', $L a$ Semaine Juridique Social, (41), p. 25.

${ }^{1945}$ For example, the Court of Appeal of Aix-en-Province held in a case that having 179 friends does not constitute a private space for exchange. Source: CA Aix-en-Provence, 5 février 2016, ${ }^{\circ} 14 / 13717$ 
687. Lack of Hungarian jurisprudence. In contrast to France, in Hungary, there is no abundant jurisprudence in relation to labour law and SNSs, ${ }^{1946}$ as such it should be examined whether conclusions drawn from the French case law can serve as a guidance for Hungary as well. In Hungary notably the following cases should be mentioned.

In 2013 the Curia ruled in the case of an employee who was dismissed due to his Facebook activity. ${ }^{1947}$ With the statements used in the post, the employee threatened and insulted the employer and encouraged the fellow employees to get organized against the employer. The court of first instance held that the post was available to anyone, thus it was a public post and its content was able to cause the misjudgment of the employer. ${ }^{1948}$ It also observed that the employee identified himself on his Facebook profile as an employee of the given employer - thus it was unquestionable who the post related to. The second instance court upheld this judgement and added that the post indeed could not be considered private and the language used overstepped the limits of the freedom of expression. The Curia affirmed this decision and argued that with the post in question the employee indeed breached his obligations, thus the dismissal was lawful.

Another case in Hungary related to a prosecutor, in which case the prosecutor's employment relationship was terminated due to the use of SNSs. The reason for termination was that the prosecutor shared three posts with political content during the election campaign in 2018. As a reaction to these posts, the prosecutor's office initiated disciplinary proceedings, and finally terminated the employment relationship of the prosecutor. ${ }^{1949}$ The prosecutor turned to court, which held at the first instance that two posts were protected by the prosecutor's freedom of speech, and only the third one constituted a disciplinary offence. ${ }^{1950}$ However, the court held that the sanction was

\footnotetext{
1946 Kardkovács, K. (ed.) (2016) A Munka Törvénykönyvének magyarázata. 3rd edn. Budapest: HVG-ORAC Lap- és Könyvkiadó, p. 47.

${ }^{1947}$ Mfv. 10.469/2013/4.

${ }^{1948}$ It is important to note that the decision was based on the previous $H L C$, more precisely on its item c of Subsection (1) of Section 103 stating that emplyoees shall "cooperate with their co-workers and perform work, and otherwise proceed in a manner without endangering the health and safety of others, without disturbing their work and causing financial detriment or damaging their reputation;"

1949 Pert nyert az ügyész, akit három Facebook-posztja miatt rúgtak ki (2019) Adózóna. Available at: https://adozona.hu/munkajog/Pert_nyert_az_ugyesz_akit_harom_Facebookpos_RUXHRH (Accessed: 9 January 2020).

1950 The first post was uploaded on $15^{\text {th }}$ of March (a national celebration day in Hungary), a picture of a flock of sheep where the prosecutor wrote the caption "this is all that I am going to remember about the celebration of today. I stayed at home, sleeping, watching movies, reading. I hope that this time next year I will have the mood to go out." On this day the political opposition held protests and also a peaceful march was organized. According to the court, this post did not constitute political activity and did not have an effect on the work of the prosecutor or an impact on the independency of the prosecutor's office.
} 
excessive, and instead of the termination of the employment relationship, it ordered to decrease the payment category of the prosecutor. ${ }^{1951}$ The prosecutor's office appealed the decision, but in November 2019 the second instance court took the same position. ${ }^{1952}$

688. "Facebook firings" and the media. In the media a growing number of news can be observed, reporting the case of employees who were sanctioned or dismissed based on their activities. For example, in 2009 a telecommunication employee was dismissed for publishing a post on his Twitter account (although on the official and not his personal one) in relation to the temporary shutdown of a competitor service provider. Albeit the post was intended to be humorous, the employer found it unprofessional and contrary to fair competition. ${ }^{1953}$ In 2016, an employee was dismissed for a Facebook post, in which he complained about the Sunday work that was ordered by the employer. Even though the post did not contain the employer's name, other employees commented it, and the employer found that by publicly questioning his measures, the employee discredited the employer and adversely influenced work ambiance. ${ }^{1954,1955}$ Despite the fact that it is indeed

The second post was sharing a picture from the page "those who have been banned from the page of Orbán" (This is a reference to Viktor Orbán, Prime Minister of Hungary). In the picture uniting hands were seen, with a logo of the opposing parties on them and with the text: "If 1 million users share this picture, there will be cooperation! Now is the time, now or never!". The court held that it belonged to the freedom of expression of the prosecutor to share such a post, as it did not cause direct disadvantage for the image of the prosecutor's office.

The third post was the most problematic one. The prosecutor shared an article on a political person who might have participated in a fraud affair. The prosecutor wrote the caption "well, every 'accused' can choose his/her defense, we will laugh at him/her at most. Good luck... yeah, and 8th of April." (8th of April 2018 being the date of the then upcoming elections.) According to the court, from the circle of friends it was revealed that he worked as a prosecutor and as such, the post indeed endangered the prestige of the prosecutor's profession.

1951 Német, T. (2019) Pert nyert az ügyész, akit három Facebook-posztja miatt rúgtak ki, Index. Available at: https://index.hu/belfold/2019/05/10/facebook_per_ugyesz_ugyeszseg_kirugas_itelet/ (Accessed: January 2020).

1952 Német, T. (2019) Jogerős: vissza kell venni a Facebook-posztjai miatt kirúgott ügyészt, Index. Available at: https://index.hu/belfold/2019/12/23/jogeros_vissza_kell_venni_a_facebookposztjai_miatt_kirugott_ugyeszt/ (Accessed: 9 January 2020).

1953 Kirúgták $\quad$ a $\quad$ twitterezö Vodafonost (2009) Index. Available at: https://index.hu/tech/cellanaplo/2009/12/09/kirugtak_a_twitterezo_vodafonost/(Accessed: 5 November 2018).

1954 Kirúgták, mert a Facebookon azt irta: Jó irányba halad a szekér? (2016) Index. Available at: https://index.hu/belfold/2016/10/15/az_allasaba_kerult_hogy_a_facebookon_azt_irta_jo_iranyba_halad_a _szeker/(Accessed: 15 November 2018).

1955 Or see, for example, the case of a chancellor of a university resigning as a result of a scandal after posting pictures of refugees (Lemondott Devecz Miklós, a szegedi egyetem kancellárja (2015) Index. Available at: https://index.hu/belfold/2015/09/28/lemondott_devecz_miklos_a_szegedi_egyetem_kancellarja/(Accessed: 3 May 2018).), a teacher posting about Nazi propaganda (Kirúgták a tanitónöt, aki két Hitler-kép között üzent a tankönyvekröl a Facebookon (2015) 444. Available at: https://444.hu/2015/09/10/kirugtak-a-tanitonot-akiket-hitler-kep-kozott-uzent-a-tankonyvekrol-a-facebookon/(Accessed: 15 November 2018).) - all being referred to througout the Title. 
a growing phenomenon in Hungary, the reliability of such news should be treated with caution. $^{1956}$

689. Doctrine. As the examination of Hungarian case law does not provide answer to the private-public nature of SNSs, attention should be paid to the doctrine. However, the arising challenge is that, compared to French doctrine, the number of Hungarian authors dealing with this subject is more limited. Moreover, the question of the private-public nature of SNSs is raised in a different context. When examining Subsection (2) of Section 8 of the HLC, it is likely that this Subsection can be applied to the off-duty SNS use of employees ${ }^{1957}$ - naturally, if other requirements are met. It was in relation to (former) Section $11^{1958}$ prohibiting the monitoring of employees' private lives that the question of whether off-duty SNS use falls under "private life" was raised.

690. At first sight, Section 8 and the protection of employees' private life might seem contradictory, as Section 8 seemingly authorizes the employer to monitor the private life of the employee, while former Section 11 stipulated that the employee's private life cannot be subjected to monitoring. Gábor Mélypataki and Zoltán Rácz resolve this contradiction by reasoning that difference should be made between the right to control (Section 8) and the right to monitor (Section 11). Namely, while Section 11 provides the employer a true power to monitor the employee (direct monitoring), Section 8 does not necessarily grant the right to monitor employees' behaviour outside working hours, but rather ensures the possibility to sanction the behaviour of the employee, as an indirect form of monitoring. ${ }^{1959}$

691. According to László Pók, although Section 8 authorizes the employer to restrict employees' behaviour outside working hours, the monitoring of such behaviour

\footnotetext{
1956 Such as the cases which were only available on the site "www.mindennapi.hu": one of them related to a Hungarian editorial enterprise whose employee published disparaging comments on the readers and cited from young girls' unpublished reader's letters - while the logo of the workplace was clearly visible in the blog posts. Source: Takács, G. (2011) Facebook-mánia: sokan a munkahelyüket is kockára teszik, mindennapi. Available at: http://www.mindennapi.hu/cikk/eletmod/facebook-mania-sokan-amunkahelyuket-is-kockara-teszik/2011-07-09/4869 (Accessed: 1 August 2019).

1957 Pók, L. (2012) 'A közösség hálójában - Közösségi oldalak munkajogi vonatkozásai’, Infokommunikáció és jog, (1), p. 15.

1958 It must be emphasized that despite without explicitly stating the prohibition of monitoring employees' private life, the protection of employees' private life is still derived from the Fundamental Law and from the Civil Code. Source: T/4479. számú törvényjavaslat az Európai Unió adatvédelmi reformjának végrehajtása érdekében szükséges törvénymódositásokról (2019). Elöadó: Dr. Trócsányi László igazságügyi miniszter. Budapest. p. 102.

1959 Source: Mélypataki, G. and Rácz, Z. (2018) 'A személyiségi jogok védelmének ütközése a munkajogban', in Auer, Á. et al. (eds) Ünnepi kötet a 65 éves Kiss György tiszteletére - Liber Amicorum in honorem Georgii Kiss aetatis suae LXV. Budapest: Dialóg Campus Kiadó, p. 679., p. 682.
} 
seems to be problematic, as it would be hard not to qualify behaviour outside working hours as pertaining to the private life of the employee. According to him, it is hardly acceptable to monitor employees' online SNS activity, conducted outside working hours and with the use of their own devices. ${ }^{1960}$ In contrast to this position, Edit Kajtár expresses a more nuanced opinion and recalls that the formulation of Section 11 allows the employer to monitor the behaviour of workers to the extent pertaining to the employment relationship, implying that the monitoring per se is not forbidden: if requirements are met, the employer might be allowed to monitor off-duty conducts as well. ${ }^{1961}$ Ildikó Rácz joins this position and argues that with regard to Section 8, although only to a limited extent, the employee's off-duty online behaviour can be subject to monitoring. ${ }^{1962}$

692. According to my opinion, it is correct to interpret the HLC's provisions as allowing the employer to monitor off-duty SNS use. However, this monitoring cannot be unlimited: as in Hungarian law as well the concept of private life is associated with concealment, and protection is afforded against intrusion into the private life of the individual. According to Gábor Mélypataki and Zoltán Rácz, the arising legal question is whether an SNS post can be qualified as private secret. According to them, through a background check, the employer might gain access to information which can be qualified as private secret. ${ }^{1963}$ However, they do not specify what scenario they mean by conducting background checks: the employer systematically going through the publicly available data on employees or the employer using stratagems to access data that the employee tried to seal from him/her? ${ }^{1964}$ Neither do they define what exactly is understood under private secret in this context, and as a result, it is difficult to assess what they understand by

1960 Pók, L. (2012) 'Lájkolni szabad? Munkavállalói véleménynyilvánítás az új Munka Törvénykönyve tükrében’, Infokommunikáció és jog, (4), p. 164.

1961 Kajtár, E. (2015) 'Európai ügyek a Facebook sötét oldaláról - A munkavállalók közösségi oldalakon tanúsított kötelezettségszegő magatartása', in Horváth, I. (ed.) Tisztelgés: ünnepi tanulmányok Dr. Hágelmayer Istvánné születésnapjára. Budapest: ELTE Eötvös Kiadó, p. 203.

Kajtár also interprets the HLC as it only forbids to violate employees' private life and does not forbid it to be the subject of monitoring. Although in my opinion this conclusion does not obviously follow from the wording of the HLC in Hungarian, it is indeed reflected in its official English translation.

1962 Rácz, I. (2015) ‘A közösségi média használatának árnyoldalai a munkaviszonyban', in Deres, P. and Grad-Gyenge, A. (eds) Acta Iuvenum Caroliensia VII.Budapest: Károli Gáspár Református Egyetem Államés Jogtudományi Kar, p. 285.

1963 Mélypataki, G. and Rácz, Z. (2018) ‘A személyiségi jogok védelmének ütközése a munkajogban', in Auer, Á. et al. (eds) Ünnepi kötet a 65 éves Kiss György tiszteletére - Liber Amicorum in honorem Georgii Kiss aetatis suae LXV. Budapest: Dialóg Campus Kiadó, p. 682.

1964 Although they argue that the application of a "snitch regime" through encouraging employees in internal policies to report their colleagues in case they detect a questionable SNS post is considered illegitimate. Mélypataki, G. and Rácz, Z. (2018) 'A személyiségi jogok védelmének ütközése a munkajogban', in Auer, Á. et al. (eds) Ünnepi kötet a 65 éves Kiss György tiszteletére - Liber Amicorum in honorem Georgii Kiss aetatis suae LXV. Budapest: Dialóg Campus Kiadó, p. 682. 
private secret in the context of SNSs (Accessing private messages somehow? A closed group? A profile accessible only to contacts?).

According to civil law, the concept of "private secret" refers to any data, information or knowledge the keeping or isolation of which the owner of the secret is interested in ${ }^{1965-}$ however, as it was addressed in Part I., privacy is a concept going beyond mere secrecy. With regard to the expressions "keep" or "isolate" the given information from the outside world, it is unlikely that the protection afforded to private secrets would apply to cases where the individual voluntarily decided to ignore the existence of privacy settings and to share the information publicly in social media. However, this concept can be evoked when the employer bypasses the employee's efforts to conceal the information, and somehow gains access to it; the consideration of SNSs as per se private spaces would constitute the complete ignorance of the basic functioning and nature of SNSs. It would be unreasonable to expect the employer not to look at the information which the employee voluntarily shared with the public. Of course, the situation might be different when the employee applied the privacy settings or made other steps to conceal the information from the public. Also, acknowledging the public character of such sites would not leave the employee without any protection, as data protection requirements must be met regardless of the public-private nature of SNSs. ${ }^{1966}$ According to my opinion, French jurisprudence found the balance (even though it still needs to be refined in certain detail) - and therefore could serve as an example for Hungary as well -, according to which SNSs are considered to be public spaces unless the employee restricted the access to a considerable extent. French courts have already identified important criteria that should be taken into consideration at the decision-making, such as the use of privacy settings, the nature of the people who can have access to the post, etc. - which might serve as a guidance for Hungarian courts as well when they decide in similar cases.

(B) Criticising the employer?

1965 ‘A magántitokhoz való jog és a know-how’ (no date) Polgári Jogi Kodifikáció, 8(5), p. 15.

1966 The NAIH already addressed the question from a data protection point of view: though it made statements in relation to the recruitment phase, these statements can be adequately applied to the case of employees' off-duty conduct and SNSs. According to the NAIH, it would be unrealistic to expect employers not to consult all these freely available information on prospective employees. Source: NAIH (2016) $A$ Nemzeti Adatvédelmi és Információszabadság Hatóság tájékoztatója a munkahelyi adatkezelések alapvetö követelményeiröl. Budapest, p. 19. 
693. In France, employees' freedom of expression comprises the right to criticize the employer or the workplace. ${ }^{1967}$ However, the limit of this freedom is abuse: abuse is clearly identified in cases when freedom of expression no longer serves the freedom of expressing opinions and impart information objectively presenting a link with the professional activity, but rather constitutes a way of incriminating the morality or integrity of the employer or one of the managers, denigrating a supervisor or jeopardizing the employer's reputation or image. ${ }^{1968}$ In Hungarian law as well, it was already elaborated that although the employee has the right to freedom of expression, including that he/she can criticize the employer, it does not mean that he/she can express his/her opinion in a way contrary to the economic and organizational interests of the employer, harming or jeopardizing them, ignoring the requirement of moderation. ${ }^{1969}$

694. In relation to SNSs it is not uncommon that the posts serving as a basis for dismissal contained excessive expressions and abused the employee's freedom of expression. As a result, it must be examined what the limits of such freedom are on SNSs. First (a) French case law will be addressed, $(b)$ followed by Hungarian regulation.

\section{a) Abusing freedom of expression: France}

695. The employee's expression constitutes an abuse if he/she uses insulting, defamatory or excessive remarks. ${ }^{1970}$ The limits of defamation and insults are defined by the Act on the freedom of press, ${ }^{1971}$ while defining what constitutes an excessive remark depends on the context. ${ }^{1972}$ It can be determining, for example, if the remark has left the workplace and has become available to exterior persons, such as, for example, to clients. ${ }^{1973}$ The position of the employee is also important: naturally, when it comes to expression on social media, the expectations are also higher towards someone who is in a

${ }^{1967}$ For example, the Court of Cassation found that - amongst others - the employee has the right to criticize the employer's commercial policy, or a project of the undertaking, or has the right to hand out flyers questioning managerial practices at the exit of the workplace. Source: Loiseau, G. (2014) 'Le liberté d'expression du salarié', Revue droit du travail Dalloz, (6), p. 396.

1968 Loiseau, G. (2014) 'Le liberté d'expression du salarié', Revue droit du travail Dalloz, (6), pp. 400-401.

1969 1050/2004. számú munkaügyi elvi határozat

${ }^{1970}$ Cour de cassation, chambre sociale, 30 octobre $2002, \mathrm{~N}^{\circ} 00-40868$

1971 Article 29 of the Act of 29 July 1881 on the freedom of press: "any allegation or attribution of an act that damages the honour or reputation of the person or entity against which the allegation or attribution is made constitutes defamation[,]" and "[a]ny offensive expression, term of contempt or invective which does not contain a specific allegation constitutes an insult".

1972 Caron, M. (2018) 'Les limites à la liberté d'expression d'un salarié sur Facebook', Les Cahiers Sociaux, (305), p. 132.

1973 Caron, M. (2018) 'Les limites à la liberté d'expression d'un salarié sur Facebook', Les Cahiers Sociaux, (305), p. 132. 
higher position or is professionally recognized. ${ }^{1974,1975}$ Particularly three aspects of the subject will be examined: first, what kind of expressions are considered to be excessive, second, can humour or the use of smileys make the remarks lose their serious nature, and third, what importance the identification of the workplace/employer can have.

696. Use of excessive expressions. French courts already had to address the question of abuse in relation to expression on SNSs. The severity of the employee's acts was also well-founded in a case ${ }^{1976}$ in which an employee published a comment under a grotesque picture representing the effigy in wax of an obese Louis X. having crutches as the king of gout - in which he compared this king to his manager in an injuring way. During the preceding year, the manager had to wear crutches for months, as she had broken her leg. The comment said that "anyway, he seriously reminds me of a manager that I knew" and it was publicly available for months. According to the court, the conjunction of the reported facts results in the impossibility of the employment relationship.

For example, courts held that an employee who consoled a former employee who had recently been dismissed, stating on the wall of the latter that "yes, it is clear, this company disgusts me" and "yes, it is certain that you are going to find something, it will enable you to see other horizons, but it still sucks the way they did it, they deserve to have the shitty workplace set on fire" was violent and excessive. ${ }^{1977}$ In another case, ${ }^{1978}$ the employee acted in an disrespectful way and it constituted a serious misconduct when she qualified her colleagues as "piece of trash" or wished her colleague "a nice day with the fools", approved of calling her boss a "stupid fat asshole" who is "disgusting with [her] but she's not gonna get far with her enterprise", adding that "she works with big pussies". Also, an employee's comment in relation to the opening of the supermarket on Sundays using the expression "bunch of assholes" 1979 was considered to be an excessive term. ${ }^{1980}$ In

\footnotetext{
1974 Ray, J.-E. (2011) 'Facebook, le salarié et l'employeur', Droit social, (2), p. 136.

1975 That was the case when a recruitment officer - who is in contact with job applicants and prospective employees - published excessive remarks relating to the workplace in a public discussion. Source: $\mathrm{CPH}$ Boulogne-Billancourt (Section Encadrement), 19 novembre 2010, ${ }^{\circ}$ 09/00343

1976 CA Orléans, 28 février 2013, N 12/01717

1977 CA Besançon, chambre sociale, 15 novembre 2011, N $10 / 02642$

${ }^{1978}$ CA Toulouse, 4e chambre sociale, 2e section, 2 février 2018, $n^{\circ} 16 / 04882$

${ }^{1979} \mathrm{He}$ stated that "Goin there n workin on Sundays bunch of asshole its not you who wake up and who hav a family life do not piss us of by goin there Sundayy !!!!!!!"

${ }^{1980}$ CA Reims, chambre sociale, 15 novembre 2017, n 16/02786
} 
another case, ${ }^{1981}$ the court found the severity of the acts established when the employee posted a picture of a woman pointing a gun towards the lenses of the camera, with the description "feeling of the day" and repeated death threats against the personnel of the workplace. According to the court, as these remarks were not destined to a specific person, they did not constitute a death threat in a criminal law way; however, they had an extreme nature, as she alluded to committing a violent act against a part of the personnel.

697. Use of smileys. Today, it is part of popular culture that users use different smileys during online written communication, especially on informal sites such as Facebook. Smileys can "express" different feelings such as happiness, sadness, anger, etc. However, the exact meaning of smileys is harder to be interpreted than interpreting their equivalent feelings in the offline world. Therefore, employees might try to reason that due to the use of smileys, their remarks were not serious, but had a funny or humorous ${ }^{1982}$ nature instead of being excessive. ${ }^{1983}$

In the case of Barbera v. Sociéte Alten Sir ${ }^{1984}$ where employees participated in a conversation on one of their colleague's Facebook wall, the employee argued that the remarks that she wrote were only jokes and should not be taken seriously. She supported this statement by recalling that at the end of the remark she added "ha-ha-ha" (encouraging a colleague to join the local ritual and "piss [the manager] off" the "whole day without her noticing it" and then "make her life impossible for months, ha-ha-ha"), which therefore made the content humorous. However, the employment tribunal found that in this context these remarks ending with the phrase "ha-ha-ha" could not be interpreted in a humorous way and they were able to damage the employer's reputation and therefore the dismissal was well-founded.

The humorous character of the remarks was not established by the Court of Appeal of Paris $^{1985}$ in a case where the employee, a professor posted certain incriminating remarks in the Facebook group of his year. He made exchanges of particularly displaced familiarity with his students: he teased and taunted certain of them and said, amongst others, regarding

\footnotetext{
${ }^{1981}$ CAVersailles, 17e chambre, 7 février 2018, $\mathrm{n}^{\circ} 15 / 05739$

1982 According to the Court of Cassation, the use of a humorous style can be considered as an attenuating circumstance. Source: Dabosville, B. (2012) 'Les contours de l'abus d'expression du salarié', Revue droit du travail Dalloz, (5), p. 276. referring to Cour de cassation, chambre sociale, 2 février 2011, $\mathrm{N}^{\circ}$ 09-69351

1983 Picq, M. (2011) 'Facebook et les salariés : vie privée, liberté d'expression et humour', Revue des droits et libertés fondamentaux, (11).

${ }^{1984}$ CPH Boulogne-Billancourt (Section Encadrement), 19 novembre 2010, n 09/00343

1985 CA Paris, Pôle 6, chambre 9, 3 décembre 2015, n 15/04533
} 
the upcoming oral exams that "formal attire is required $[\ldots]$ the one who comes dressed as Jabba the Hutt, I will give him/her 20 out of $20,{ }^{1986}$ " or alluded to the fact that he could be bribed: "OK I admit, 10 euros for a bonus point, I give in". He defended himself by stating that he was not abusing his freedom of expression, as these remarks were humorous, they were taken out of their original context. However, according to the court, a professor engaging in such conduct of teasing his students and of adopting such familiarity, even if the students are of age, constitutes a wrongful conduct and an abuse of his freedom of expression. From these cases it seems that the excessive nature of the content does not seem to be affected by the use of smileys.

698. Identifying the subject of the expression of opinion. Being able to identify who is concerned in these posts can have an importance. Employees regularly argued that these remarks did not relate to the employer/workplace, and therefore they did not constitute a breach of their obligation arising from the employment contract.

699. In a case at the Court of Appeal of Besançon, ${ }^{1987}$ the employee took part in a discussion taking place on the wall of a former colleague and defended herself by arguing that she never named the employer in the discussion: the employer's identity was revealed later by another employee, after she had logged out from the site. However, according to the court of appeal, although the employee did not identify the employer, still, the latter was identified and the lack of intent of the employee to identify the employer had no effect as long as her imprudent conduct led to the same result - even if she had logged out from the site.

In another case at the Court of Appeal of Rennes, ${ }^{1988}$ the employee cited the lyrics of a song stating "the bosses, the bosses, they are like pigs"1989 and argued that it was not established that it related to the employer. However, the court noted that he posted this text as a response to an employee's post, which clearly related to the employer and all happened two days after there was a misunderstanding at the workplace in relation to premiums. From this context it was unquestionable that the text related to the employer. In the case ${ }^{1990}$ where the employee complained in an excessive comment regarding the

\footnotetext{
198620 is the highest mark that a student can have in the French educational system.

1987 CA Besançon, chambre sociale, 15 novembre 2011, $\mathrm{N}^{\circ} 10 / 02642$

${ }^{1988}$ CA Rennes, 8e chambre prud'homale, 2 mars 2018, n $16 / 07806$

1989 Song of Les sales majestés entitled Les patrons. In French the original lyrics was "les patrons, c'est comme les cochons".

${ }^{1990}$ CA Reims, chambre sociale, 15 novembre 2017, n 16/02786
} 
opening of the workplace (a supermarket) on Sundays, the fact that he used the expression "us" 1991 made it obvious that the comment came from an employee of the supermarket contributing to establishing the existence of the abusive nature of the remarks.

At the Court of Appeal of Fort-de-France ${ }^{1992}$ the employee did not contest the insulting nature of her remarks, ${ }^{1993}$ but argued that the remarks were not relating to her supervisors, but to a third person who was a manager in an association where she did voluntary work. The Court of Appeal did not accept this reasoning, as according to it, this phrase spoke for itself, especially because it was published in a particularly tense atmosphere, as the day before a meeting was organised, where the management composed of women originating from the French mainland - confronted the employees over a previous incident.

700. However, the Court of Appeal of Reims ${ }^{1994}$ did not find the link established between the employer and the employee's remarks in a case where the employee stated "our boss, he is really autistic, do you know a special centre where she could be treated?". The court remarked that on the one hand, no one was named in the text, and the expression boss ("chef" in French) is used not only to designate the professional relationship within the employment context. Also, even the employer itself was not certain who was targeted by this text (he hesitated between a colleague and a member of the management). Therefore, it was not unambiguous who this text was about, as consequence, it did not constitute a breach of the employee's obligation.

701. In conclusion, the criteria that can help French courts in assessing whether the expression used was excessive is the style used (which is not alleviated by smileys) and also the identifiability of the employer. French courts typically found that the use of excessive expressions is present when the employees expressed themselves through employing typically vulgar expressions or through serious content, such as death threats. Although employees might try to argue that these expressions were only humorous due to, for example, the use of smileys, such argumentation is not accepted by courts. Also, being able to identify the employer or the workplace can have an importance: without explicitly

\footnotetext{
1991 "Goin there n workin on Sundays bunch of asshole its not you who wake up and who hav a family life do not piss us of by goin there Sundayy !!!!!!!”

1992 CA Fort-de-France, chambre sociale, 21 décembre 2012, n¹2/00053

1993 "but when your management treats you like a last piece of shit, you can flip out, especially when it's a White who comes to make rules in your country"

${ }^{1994}$ CA Reims, chambre sociale, 9 juin $2010, \mathrm{~N}^{\circ} 09 / 03205$
} 
naming the person/company to whom the remarks are destined, courts often establish the link between the remarks and the workplace from the context.

\section{b) Freedom of expression: Hungary}

702. In Hungarian law the employee can express his/her critical opinion towards a supervisor or a colleague without being sanctioned/reprimanded for it if it is based on real facts and states nothing which is capable of disturbing the order and discipline at work or discredit or insult the employer. Therefore, an employee can express his/her opinion in a "neutral", not insulting way, without aiming to influence other employees, while the use of harsh words and unspeakable forms is not permissible. ${ }^{1995,1996}$ Although criticizing the employer is comprised in the right to freedom of expression, the employee cannot exercise this right by ignoring the requirement of moderation and jeopardizing the employer's interests, as that would constitute the infringement of the obligation of cooperation. ${ }^{1997}$ $\mathrm{He} /$ she cannot exercise this right by making any possible shortcomings public in the press, in a way detrimental or harmful to the economic and organizational interests of the employer. ${ }^{1998,} 1999$

703. When it comes to restricting employees' off-duty behaviour, Subsection (2) of Section 8 refers to the conditions set in Subsection (2) of Section 9, namely that such a restriction shall be strictly necessary for reasons directly relating to the intended purpose of the employment relationship and shall be proportionate for achieving its objective. Therefore, completely prohibiting employees to express their opinion in relation to the

1995 BH 1991/47.

${ }^{1996}$ For example, it is not considered to be the breach of the duty of cooperation if the employee - through exercising the freedom of expression - summarizes and presents information that was already said in a public hearing from the employees' point of view.

1997 1050/2004. számú munkaügyi elvi határozat

1998 1050/2004. számú munkaügyi elvi határozat

${ }^{1999}$ However, the following case should be mentioned, which did not take place in social media or did not involve the use of excessive expression, yet it resulted in the breach of Section 8. In the case the employee, who worked as a teacher in the very school attended by his child as well, signed a petition as a parent with the aim to achieve that the same teachers teach the pupils for a certain period of time. As a result, the employer asked him to provide a report containing what he would propose as a solution to the situation and also why he took a position against the school. According to the employee, asking for such a report is contrary to the freedom of expression.

The Curia noted that the letter was then intended to be forwarded to supervisory institutions as well and contained a statement that "we believe that the change would influence the educational and mental development of our children in a negative way." According to the Curia, the content of the letter was capable of questioning the legality and appropriateness of the employer's measure - as a result, the employer's request of a report did not breach the right to freedom of expression. Source: Kúria, Mfv.II.10.609/2017, par. 25. 
employment seems contrary to the principle of proportionality, while it is legitimate to impose limitations on the way they do it.

704. Employers are not the only target of employees' posts: they can also aim at colleagues. According to a decision ${ }^{2000}$ relating to sexual harassment, it was held that the obligation of cooperation comprises mutual respect and conduct taking into consideration the dignity of the other employees, therefore any conduct infringing these requirements can be sanctioned. However, the employee can express his/her opinion on the behaviour or professional conduct of a colleague in a way which is not offensive and does not influence other employees. $^{2001}$

Thus, the employee cannot post on SNSs content which would be disparaging, smearing, degrading or offensive in relation to his/her employer. The publication of such matters is considered as a breach of obligation. ${ }^{2002}$ However, what was stated in relation to French law is adequately applicable to Hungarian law as well: the boundaries of expressing opinion in an excessive way are already established, SNSs do not fundamentally change these boundaries, they rather favour the use of more excessive expressions, which an employee/user normally would not use in an offline, face-to-face communication.

705. The Constitutional Court provided more criteria as regards the limits of employees' freedom of expression in Decision No. 14/2017. (VI. 30.). In this decision the Constitutional Court examined the limits of employees' freedom of expression, ${ }^{2003}$ and draw attention to the already existing criteria in this field. Among them it must be examined (1) whether the content has a connection to public life or professional life, ${ }^{2004}$ (2) whether it is composed of facts or rather constitutes a value judgement, ${ }^{2005}$ (3) whether the

\footnotetext{
${ }^{2000}$ BH 2006.201.

${ }^{2001}$ BH 1991. 47.

${ }^{2002}$ Kun, A. (2013) 'Közösségi média és munkajog - avagy „online” munkaidőben és azon túl', Munkaügyi Szemle, (3), p. 15.

2003 The original case related to an employee who worked as a human resources management specialist at the employer. In his free time he published blog entries to a blog dealing with HR questions, with the aim of sharing knowledge, identifying himself as an expert in the field. The employer found out about the blog, and terminated the employment relationship with the reason that the employee jeopardized the employer's legitimate interests and breached his obligation of confidentiality through posting blog entries in a field and in a subject where he was directly involved in his workplace. Source: Mfv. 10.655/2013/6.

${ }^{2004}$ In the present case the Constitutional Court held that publishing the blog entries belonged to the professional life and did not constitute a public affair ("közügy"), as such they were not afforded protection as a fundamental right, suggesting that the expression is protected to an increased extent if it relates to the discussion of public affairs. Source: Decision No. 14/2017. (VI. 30.) of the Constitutional Court, par. 40.

2005 The Constitutional Court held that opinions expressing value judgment require greater tolerance, whereas as regards statements expressing facts or rumors, greater care can be required from the employee (both when
} 
expression caused damage, (4) whether the employee acted in good faith ${ }^{2006}$ and (5) what sanctions were applied by the employer. ${ }^{2007}$

706. In conclusion, different factors should be taken into consideration when assessing whether an expression on SNSs is included in employees' freedom of expression: the criteria that can determine the easiest way is whether the expression was excessive which can notably be determined through the style used. However, the existence of other criteria might be more challenging, such as whether it was a public expression or not, ${ }^{2008}$ whether it related to a public affair, etc.

c) Is a "like" considered as expressing opinion?

707. Is a "like" considered to be an expression of opinion? An expression can take several shapes, such as posting, commenting, writing a blog entry (supposing the user actively creates content), etc. Although the presented cases mostly concerned expression as a post or a comment, the question still arises whether - in contrast to creating content simply "liking" an already existing content on social media can be considered as an expression of the employee's opinion?

708. Different solutions appeared to address this question: a US and a Belgian case will be addressed briefly, as they relate directly to this matter and might serve as an example to France and Hungary in similar cases. In 2012, in the US in a case relating to whether a "like" is considered to be a manifestation of free speech (and therefore entitled to legal protection under the first amendment) adverse decisions were adopted by the district court and the court of appeal. The case related to six employees who, during the campaign of the re-election of the sheriff, liked Facebook pages supporting the sheriff's opponent. After the re-election of the sheriff, they alleged that they were not reappointed because of exercising their freedom of expression and contested the decision. The district court held that simply liking a Facebook page is insufficient to merit constitutional

the opinion relates to a public affair or when it is not). Source: Decision No. 13/2014. (IV. 18.) of the Constitutional Court, par. 41.

2006 The expression should not receive protection if it merely or intentionally aims to damage the employer's reputation or to insult the employer/supervisor/etc. Source: Decision No. 14/2017. (VI. 30.) of the Constitutional Court, par. 33.

${ }^{2007}$ Decision No. 14/2017. (VI. 30.) of the Constitutional Court, par. 34.

2008 To determine this, the analysis of French case law and the above-drawn conclusions from it might constitute a guiding point. 
protection, as no actual statements were made through liking. ${ }^{2009}$ However, the court of appeal ruled that by liking the content, the employees unmistakably approved of the opponent's candidacy, and added that from a constitutional point of view there was no difference between liking the page, or expressing the same support through typing a supportive message. According to the court of appeal, liking the opponent's Facebook page is to be deemed equivalent to displaying a political sign in one's front yard - which is accepted as substantive speech. ${ }^{2010}$

In Belgium, the labour court of Liège had to rule in a case where an employee was dismissed for liking controversial content relating to "quenelle", which can be interpreted as a disputable sense of humour, with publicly known anti-Semitic connotation. The antecedents were that in 2013 the employee posted links to his Facebook wall, relating to "quenelle". Following these posts, the employer organised a meeting and made the employee sign a written commitment, stating that in the future he is not going to post such controversial content, as it can influence other employees and might put him and his posts in false light. However, in 2014 he liked content relating to "quenelle" and was dismissed as a result. The labour court of Liège held that a "like" can be understood as a sign of interest, but also as an approval, and in the light of the commitment that he had signed, it constituted the expression of the employee's opinion and validated the dismissal. ${ }^{2011,2012}$

709. However, "likes" might not always mean that the given individual truly likes or approves of the content. Meanings of likes are not always unambiguous, as was pointed out by Emmanuel Netter. He underlined that over a thousand people "liked" an article which appeared in Le Monde entitled "Argentina: several French killed after a collision of helicopters". At that time pressing the like button was the only way to rapidly express "emotion", besides writing a comment or clicking on the "neutral" share button. So, what does "like" mean in this context? Did users like the fact that they were rapidly informed of the event? Or the style of the article? Did they express their support to the

${ }^{2009}$ United States: District court for the Eastern District of Virginia: Bland v. Roberts, 4-11cv45 (E.D. Va.; Apr. 24, 2012)

${ }^{2010}$ United States: Court of Appeals for the Fourth Circuit: Bland v. Roberts, No. 12-1671, Filed: September 23,2013

${ }^{2011}$ Cour du travail de Liège (3e ch.) - Arrêt du 24 mars 2017 - Rôle n ${ }^{\circ}$ 2016-AL-94

2012 In Switzerland a user was fined for liking defamatory posts written by a third party that accused an animal rights activist of anti-Semitism, racism and fascism. The court held that by liking the content, he endorsed and further distributed the comments. Source: Riley, C. (2017) Man fined \$4,000 for 'liking' defamatory posts on Facebook, CNN. Available at: https://money.cnn.com/2017/05/31/technology/facebooklike-defamation-switzerland/ (Accessed: 15 October 2018). 
victims' families? Did they truly like what happened? The signification of the use of a simple like button can often be ambiguous; therefore one must be careful before drawing conclusions from it. ${ }^{2013}$ According to László Pók, considering a "like" as expressing opinion would lead to an exaggerated, unrealistic approach, which would unnecessarily restrict employees' possibilities to use SNSs. According to him, a like does not necessarily express the employee's endorsement, but rather raises attention to a matter, making it unreasonable to draw far-reaching conclusions. ${ }^{2014}$

710. However, it should be mentioned that ever since Facebook introduced the so-called "reaction" buttons in 2016, more nuanced reactions can be expressed than a simple like, such as "like", "love", "ha-ha", "wow", "sad" and "angry". Although this function gives users the possibility to express other types of feelings, in line with the above-mentioned doubts relating to the meaning of "like", a simple "reaction" should not necessarily be treated as the user's substantive attitude towards a matter.

711. To summarize, different views exist regarding whether a like constitutes freedom of expression or not. These views illustrate that it is challenging to provide an answer to this matter valid under all circumstances. Thus, circumstances of the specific case should be taken into consideration (such as whether liking was a one-time activity or it is regular, existence of a previous warning) as they can be determinant when assessing a case. First, it is even possible to accidentally hit the like button (either from a computer, but especially from the small screen of a smartphone), therefore far-reaching conclusions should not be drawn from a few likes. Naturally, the situation is different if the employee systematically likes content that can place the employer into a disadvantageous situation or be otherwise compromising. Second, special circumstances can justify the strict appreciation of likes, such as previous warnings addressed to the employee. That was the case in the previously presented labour court of Liège's decision, where raising awareness and warning the employee were determining factors in judging the dismissal to be lawful.

\footnotetext{
2013 Netter, E. (2015) 'La liberté d'expression sur les réseaux sociaux en droit français', in Ndior, V. (ed.) Droit et réseaux sociaux. Issy-les-Moulineaux: Lextenso (Collection LEJEP), p. 54.

2014 Pók, L. (2012) 'Lájkolni szabad? Munkavállalói véleménynyilvánítás az új Munka Törvénykönyve tükrében', Infokommunikáció és jog, (4), p. 163.
} 
Nothing indicated that the court would have arrived at the same conclusion if the employee had not been explicitly warned before. ${ }^{2015}$

\section{(\$2) Other conducts}

Employees might - intentionally or negligently - jeopardize the employer's legitimate interests and rights in other ways than by expressing their opinion. Notably, the cases of $(A)$ revealing confidential information and business secrets and $(B)$ jeopardizing the employer's legitimate economic interests through working for the competition must be mentioned. However, these cases seem to raise specific privacy issues to a lesser extent, ${ }^{2016}$ compared to freedom of expression on SNSs. In my opinion, revealing confidential information or business secrets on SNSs or engaging in a competing activity does not substantially raise questions in relation to the personal life of the employee and to the established/blurred boundaries of personal and professional life. As the focus of the thesis is on employees' personal life, these cases will be presented only briefly in the following paragraphs. Also, through social media and SNSs, employees can eternalise and share $(C)$ various pranks with the public, which might jeopardize or damage the employer's reputation.

\section{(A) Business secrets}

712. Protection of the employer's business secrets. In France employees are required not to reveal information that they obtained during exercising their functions. ${ }^{2017}$ Some, such as union representatives, employee advisors, the delegation of the members of the personnel of the social and economic committee ${ }^{2018}$ are bound by the professional secret and obligation of discretion. Similarly to French regulation, Subsection (4) of Section 8 of the Hungarian Labour Code states that employees have the obligation to respect confidentiality and the employer's business secrets. ${ }^{2019}$ Although through the advent of social media the possible disclosure of business secrets on these platforms is a

\footnotetext{
2015 Wery, E. (2018) Perdre son emploi à cause d'un “J'aime”? C'est possible, Droit \& Technologies. Available at: https://www.droit-technologie.org/actualites/perdre-emploi-a-cause-dun-jaime-cestpossible/ (Accessed: 15 October 2018).

${ }^{2016}$ Pók, L. (2012) ‘A közösség hálójában - Közösségi oldalak munkajogi vonatkozásai’, Infokommunikáció és jog, (1), p. 13.

${ }^{2017}$ Lahalle, T. (2016) Droits et obligations des parties. JurisClasseur Travail Traité Fasc. 18-1, par. 146.

2018 Article L2143-21, Article L1232-13, Article L2315-3 of the FLC

${ }^{2019}$ Subsection (4) of Section 8 of the HLC

More detailed regulation is to be found in Act LIV of 2018 on the protection of business secrets.
} 
growing issue due to the ease of using these platforms and the lack of awareness of employees $^{2020}$ (especially the use of professional SNSs, such as LinkedIn can raise problems), ${ }^{2021}$ the examination of these questions is beyond the scope of the dissertation as they primarily relate to the employer's personality rights and not to the personality rights of the employees.

713. Business secrets and SNSs. SNSs can serve as a means to reveal confidential information. ${ }^{2022}$ As the advent of social media made it easier to commit abuses and to discover them, in the case of employees' expression, the discoverability or revealing business secrets either intentionally or negligently is higher as well. In one of the French cases, although it related to the public sphere, a police officer's employment was terminated for revealing confidential information on SNSs. The officer was substituting someone at the municipal police as a technical assistant and a disciplinary dismissal was given for breaching his professional obligations, which consisted in revealing SNS pictures and other information relating to the organisation of the municipal police, and especially to the video surveillance system applied in the municipality. ${ }^{2023}$

Hungarian media reported the case in which the employee, who was chief legal counsel at a bank, sent a message to his girlfriend, stating that he is investigating someone's case. Although he did not identify the client - who was a well-known actor -, he used his monograms, and added that as the case seems to be problematic, now he can have revenge for a certain Hungarian television show. As he named the show, the client became identifiable through his monograms. His girlfriend shared this message and commented it as "[t]hat's how things go when one's boyfriend is a chief legal counsel at a

\footnotetext{
2020 Warren, M. and Pedowitz, A. (2011) 'Social Media, Trade Secrets, Duties of Loyalty, Restrictive Covenants and Yes, the Sky is Falling', Hofstra Labor and Employment Law Journal, 29(1), p. 100.

2021 Németh, J. (2013) A közösségi média használata munkáltatói szemmel, Jogászvilág. Available at: https://jogaszvilag.hu/szakma/a-kozossegi-media-hasznalata-munkaltatoi-szemmel/ $\quad$ (Accessed: 6 September 2018).

${ }^{2022}$ For example, one employer in Canada terminated the employment relationship of a maintenance employee for reasons of breaching confidentiality, who - after a patient committed suicide - posted two pictures of the scene to social media. Source: Maier, J. (2013) 'Cause for Termination in the Age of Social Media', in Law Society of Upper Canada, Employment law and the new workplace in the social media age. Toronto: Irwin Law, p. 297.

${ }^{2023}$ Conseil d'État (2017): № 393320 (ECLI:FR:CECHR:2017:393320.20170320), 3ème - 8ème chambres réunies, 20 mars
} 
big Hungarian bank!" On the ground of sharing bank secrets, his employment was terminated. 2024,2025

714. Whistleblowing. In relation to restricting employees as regards revealing information that they learned during the exercise of their functions, the phenomenon of whistleblowing should be mentioned. ${ }^{2026}$ Employees can benefit from the publicity of SNSs and can also use them as platforms to realize whistleblowing, and to raise the public's attention to illegal acts, abuses or misdeeds taking place within the workplace. ${ }^{2027}$ Technically, in these cases the employee commits a breach of obligation (as revealing illegal acts of the employer will damage the employer's reputation, and/or will consist of revealing confidential information that would have otherwise stayed hidden). For several reasons ${ }^{2028}$ SNSs might constitute a forum to reveal those illegal acts - in which case the employee's online activity on SNSs will realize the breach. Even though whistleblowing

2024 Banktitkot sértett egy magyar mikroblog (2012) Index. Available at: https://index.hu/tech/2012/01/04/banktitkot_sertett_egy_magyar_mikroblogger/(Accessed: 7 September 2018).

2025 An Austrian court held the violation of bank secret in the case where the employee, who was a cashier in a bank, engaged in a conversation on his Facebook wall, relating to the reappearance of - previously missing - 15,000 euros. Source: Kajtár, E. (2016) Dignity at Work: Employee's Personality Rights in the 21st Century. Pécs: University of Pécs, Faculty of Law (PMJK Monographs 6). p. 161.

${ }^{2026}$ Both in France (Act N. 2016-1691 of 9 December 2016 on transparency, the fight against corruption and the modernization of the economy) and in Hungary (Act CLXV of 2013 on Complaints and Public Interest Disclosures) a whistleblowing act regulates these matters. Also, the EU's new whistleblowing directive [Directive (EU) 2019/1937 of the European Parliament and of the Council of 23 October 2019 on the protection of persons who report breaches of Union law] regulates the question at an EU-wide level.

2027 For example, in 2006, Michael De Kort, who worked as a project manager at the global company Lockheed Martin in the aerospace, defence, security, and technologies industry. In 2004 he became aware of certain security risks in relation to ships that were sold to the US coastguard. He repeatedly reported those security risks to his supervisors, who did not react to this. Then, he uploaded a 10-minute-long video to YouTube, in which he presented these security risks in detail. Source: Original-See other copy if this version is frozen (2006) YouTube. Available at: https://www.youtube.com/watch?v=qd3VV8Za04g\&t=316s (Accessed: 16 April 2018).

Brandon Huber worked at the Golden Corral restaurant, where he noticed that the meat that was to be prepared was stored outside the restaurant, directly next to the rubbish bins, in not acceptably hygienic conditions. According to him, after he reported this to the management, they did nothing to solve the situation. In response, he made a video, in which he showed how meat was stored and uploaded it to YouTube. Source: Golden Corral food stored by dumpster so health inspector won't see it, employee says (2013) YouTube. Available at: https://www.youtube.com/watch?v=yb0yrdDOy0g (Accessed: 16 April 2018).

Johannes Izak Beaurain worked as a nurse in the Groote Schuur Hospital in the Republic of South-Africa. On several occasions he reported different abuses, which were investigated, but finally were not found wellestablished. He did not agree with the outcome of the investigations, and he revealed the alleged abuses to the public in a Facebook post. He was dismissed for his actions, and he challenged the decision at court. However, the court held that Mr. Beaurain's allegations were not well-established. Source: Ngake, P. (2016) Whistle-blowing on Social Media. Available at: http://www.seesa.co.za/whistle-blowing-on-socialmedia/ (Accessed: 22 April 2018).

${ }^{2028}$ E.g. rapidity, ease, size of the audience that might be reached, etc. 
through SNSs raises several challenges, ${ }^{2029}$ in my opinion such conduct does not substantially concern the boundaries of employees' personal lives, as it reveals something that the employer committed, instead of revealing a part of the employee's personal life. For this reason, it will not be addressed in detail in the dissertation.

\section{(B) Employer's legitimate economic interests and rights and competition}

\section{Protection of the employer's legitimate economic interests and rights.} According to Subsection (1) of Section 8 of the HLC, "during the existence of the employment relationship, employees shall not engage in any conduct which would jeopardize the legitimate economic interests of the employer, unless so authorized by the relevant legislation." This provision requires employees to refrain from such conduct. ${ }^{2030}$ There exists no exhaustive list enumerating what conducts are capable of jeopardizing the employer's legitimate economic interest and therefore what limitations can be imposed on employees: particularly, performing work for another employer should be mentioned, but limitations on employees' freedom of expression or the obligation to respect the employer's business secrets also fall into these categories ${ }^{2031}$ - the latter two are regulated by specific provisions.

Under Subsection (1) it is already elaborated what conducts the employee should refrain from, such as, for example, the employee performing work for another employer, creating competition under any legal relationship, contributing to the activity of a competing business, etc. ${ }^{2032}$ In this regard, social media does not represent a substantial challenge, as its use does not affect the freedom of action and through it the boundaries between personal and professional life; instead, it can contribute to the discoverability of the possible infringement.

\footnotetext{
${ }^{2029}$ See more on whistleblowing and social media in: Hajdú, J. and Lukács, A. (2018) Whistleblowing és a közösségi média szerepe a korrupció elleni fellépésben. Budapest: Nemzeti Közszolgálati Egyetem.

2030 T/4786. számú törvényjavaslat a Munka Törvénykönyvéről (2011). Előadó: Dr. Matolcsy György nemzetgazdasági miniszter. Budapest.

${ }^{2031}$ Kardkovács, K. (ed.) (2016) A Munka Törvénykönyvének magyarázata. 3rd edn. Budapest: HVG-ORAC Lap- és Könyvkiadó, p. 44.

${ }^{2032}$ See more on the subject and on the relevant case law in: Kardkovács, K. (ed.) (2016) A Munka Törvénykönyvének magyarázata. 3rd edn. Budapest: HVG-ORAC Lap- és Könyvkiadó pp. 44-45.; Ember, A. (2015) 'A munkáltató jogos gazdasági érdekének a védelme', in Lajkó, D. and Varga, N. (eds) Alapelvek és alapjogok. Szeged: Szegedi Tudományegyetem Állam- és Jogtudományi Doktori Iskola, pp. 115-119.; Szladovnyik, K. and Horváth, I. (2016) 'A munkáltató jogos gazdasági érdekeinek védelme', Adó, 30(14), pp. 92-96.
} 
716. French labour law contains similar provisions in order to protect the employer's legitimate economic interest. Naturally, employees are subject to a noncompete obligation: ${ }^{2033}$ in the light of the duty of loyalty, they should not engage in competing activity. ${ }^{2034}$ For example, the Court of Cassation held that the following employees violated the duty of loyalty: an employee having a high position, who during his paid leave engaged in an identical activity at a directly competing company, in the same geographic zone, ${ }^{2035}$ or an employee, who worked as a mechanic, and during his sick leave had a vehicle repaired by asking another employee to help, but on his own behalf; ${ }^{2036}$ or the fact that an employee took part in a training at the employer's competitor constituted the breach of the duty of loyalty. ${ }^{2037}$

717. Posterior to the employment relationship. Similar challenges may arise not only during the existence of the employment relationship but after the employment relationship as well. According to French labour law, following from the fundamental principle of free exercise of a professional activity and Article L. 1121-1 of the FLC, ${ }^{2038}$ the parties can conclude that after the termination of the employment relationship, the employee should refrain from engaging in the same sector of activity as the employer. ${ }^{2039}$, ${ }^{2040}$ The exclusivity clause should also be mentioned here: although it does not concern the time period after the employment, in my opinion for the subject of the present dissertation it raises challenges similar to the ones encountered in the non-competition agreement. An exclusivity clause forbids the employee to engage in any other professional activity - even if the activity would not have a competing nature. ${ }^{2041}$

718. The $H L C$ states that the employer and the employee can decide to conclude a non-competition agreement, in which they state that the employee shall not engage in any conduct - for up to two years following the termination of the employment relationship -

${ }^{2033}$ Ray, J.-E. (2018) Droit du travail: droit vivant. 26th edn. Paris: Wolters Kluwer France. p. 443.

2034 Waquet, P., Struillou, Y. and Pécaut-Rivolier, L. (2014) Pouvoirs du chef d'entreprise et libertés du salarié: du salarié-citoyen au citoyen-salarié. Rueil-Malmaison: ÉdLiaisons (Droit vivant). p. 71, p. 311.

${ }^{2035}$ Cour de cassation, chambre sociale, 5 juillet $2017, \mathrm{~N}^{\circ} 16-15623$

${ }^{2036}$ Cour de cassation, chambre sociale, 21 octobre $2003, \mathrm{~N}^{\circ} 01-43943$

2037 Cour de cassation, chambre sociale, 10 mai 2001, No $99-40584$

${ }^{2038}$ Cour de cassation, chambre sociale, 10 juillet 2002 , $\mathrm{N}^{\circ} 00-45135$

2039 Waquet, P., Struillou, Y. and Pécaut-Rivolier, L. (2014) Pouvoirs du chef d'entreprise et libertés du salarié: du salarié-citoyen au citoyen-salarié. Rueil-Malmaison: ÉdLiaisons (Droit vivant). p. 309.

2040 The detailed conditions (being indispensable for the protection of the legitimate interest of the employer, limited in time, limited in space, providing financial counter value, taking into consideration the functions of the employee) were laid down by the Cour de cassation, chambre sociale, 10 juillet $2002, \mathrm{~N}^{\circ} 00-45135$ 2041 Waquet, P., Struillou, Y. and Pécaut-Rivolier, L. (2014) Pouvoirs du chef d'entreprise et libertés du salarié: du salarié-citoyen au citoyen-salarié. Rueil-Malmaison: ÉdLiaisons (Droit vivant). pp. 73-74., p. 313. 
by which he/she would infringe upon or jeopardize the rightful economic interests of the employer. ${ }^{2042}$ Usually these agreements pertain to future employment at the competition; however, they might as well stipulate that the employee should refrain from certain acts in social media. ${ }^{2043}$ Nonetheless, even in the absence of a non-compete agreement, general provisions laid down in civil and penal regulations will provide protection to the employer.

719. SNSs and non-compete agreements. SNSs do not only serve to keep in touch with friends and family, but employees also use these services to forge online relationships with colleagues, clients or customers (especially professional SNSs such as LinkedIn). Therefore, their use might constitute the violation of a non-compete agreement. Differentiation should be made particularly between two scenarios. First, while the use itself might not constitute a violation, SNSs can serve as evidence of violation, such as when former employees update their professional status, revealing their new position. ${ }^{2044}$ Second, SNS use itself might be considered as a violation when it comes to restraining from certain conduct: several questions arise, such as: does "friending" constitute a violation? Or accepting a friend request? How to prove who initiated the contact? Do concerned employees have to unfriend existing contacts with clients? Who has ownership of a LinkedIn account? $?^{2045}$

\section{(C) Employee "pranks"}

\footnotetext{
2042 Subsection (1) of Section 228 of the HLC

${ }^{2043}$ Pók, L. (2012) 'A közösség hálójában - Közösségi oldalak munkajogi vonatkozásai’, Infokommunikáció és jog, (1), p. 15.

${ }^{2044}$ For example, in the cases Cour d'appel, Paris, Pôle 1, chambre 3, 28 Mai $2013-\mathrm{n}^{\circ} 13 / 06055$ and Cour d'appel, Saint-Denis (Réunion), Chambre commerciale, 15 Juillet 2013 - $\mathrm{n}^{\circ}$ 12/01321 both employees who allegedly violated their non-compete agreements updated their professional status on LinkedIn. Source: Nivelles, V. (2014) 'Les entreprises à l'épreuve des réseaux sociaux', Jurisprudence Sociale Lamy, (377378), p. 12.

Another example is the case of Kelly Services, Inc. v. Marzullo in the US, in which the employer found out about the violation of the non-compete agreement through information posted on the employee's LinkedIn profile commenting on his new position. Source: Anderson, D. R. (2011) 'Restricting Social Graces: The Implications of Social Media for Restrictive Covenants in Employment Contracts', Ohio State Law Journal, 72(4), p. 896.

2045 See more on the arising questions and the answers that can be possibly given to them in: Anderson, D. R. (2011) 'Restricting Social Graces: The Implications of Social Media for Restrictive Covenants in Employment Contracts', Ohio State Law Journal, 72(4), pp. 881-908.; Warren, M. and Pedowitz, A. (2011) 'Social Media, Trade Secrets, Duties of Loyalty, Restrictive Covenants and Yes, the Sky is Falling', Hofstra Labor and Employment Law Journal, 29(1), pp. 99-114.; Mooney, J. A. (2013) 'Locked Out on LinkedIn: LinkedIn Account Belongs to Employee, not Employer', Intellectual Property \& Technology Law Journal, 25(6), pp. 16-18.
} 
720. Damaging the employer's reputation. Employees can also jeopardize the employer's reputation in more "creative" ways, notably through different "pranks". ${ }^{2046}$ According to the HLC and French labour law as well, the employee must respect the employer's reputation. ${ }^{2047}$ The issue is that in some cases these activities can be directly linked to the workplace, e.g. due to a uniform, taking place on the premises of the workplace etc., thus having possible consequences on the employee's employment relationship and/or on the employer's reputation.

721. Often, such behaviour also constitutes the violation of workplace rules (e.g. safety, health, hygiene). Examples include the US case, where the prank made by two employees of a restaurant chain seriously compromised the company's reputation in a few days. The two employees made a video and uploaded it to YouTube, in which one of them prepared food for delivery completely violating health-code standards (e.g. by putting cheese up his nose or nasal mucus on the sandwiches). Although the employees alleged that the food was never delivered, the video was seen by more than a million Internet users and caused a true crisis for the restaurant. ${ }^{2048}$ Similar examples include restaurant employees who bathed in the utility sink and eternalized this moment in social media. ${ }^{2049}$

Another case is the Taylor $v$ Somerfield Stores Ltd case from the UK. The case related to the termination of employment in a case where the employee uploaded a video to YouTube in which his colleagues during working hours, on the premises of the workplace, wearing the employer's uniform, hit him on the head with a plastic bag full of plastic bags. The employer found that the publication of such a video jeopardized its reputation. However, the employment tribunal ruled that the termination was unlawful, as there was no obvious connection between the video and the employer (the name of the employer was not visible on the uniform, only its colours could have given away its identity, while the video was recorded in a storage room, anonymous to an outsider). In addition, the video

\footnotetext{
2046 Besides jeopardizing the employer's reputation, such posts can also serve as evidence of breaching requirements of hygiene or workplace safety.

${ }^{2047}$ Subsection (2) of Section 8 of the HLC and the duty of loyalty (obligation de loyauté).

2048 Clifford, S. (2009) Video Prank at Domino's Taints Brand, The New York Times. Available at: https://www.nytimes.com/2009/04/16/business/media/16dominos.html(Accessed: 3 May 2018).

2049 Burger King worker fired for bathing in sink(2008) NBC News. Available at: http://www.nbcnews.com/id/26167371/ns/us_news-life/t/burger-king-worker-fired-bathingsink/\#.XUgxoo4zbct (Accessed: 5 August 2019) or Solé, E. (2019) Wendy's employee fired after taking a bubble bath in restaurant sink: 'It is obviously totally unacceptable', Yahoo. Available at: shorturl.at/bcuwG (Accessed: 5 August 2019).
} 
was only available for three days and was viewed by eight persons (three of them were managers at the company). ${ }^{2050}$

Sometimes such conduct can go beyond being a simple prank: in 2018 the employees of a well-known low-cost airline company made a "prank" by publishing a fake photo that later caught considerable media attention. They published a picture to Twitter, after a tense period due to repeated strikes, in which the employees were lying in their uniform on the floor and creating the impression that they were forced to sleep on the floor. However, the photo was staged as was revealed by the security footage published by the company. The company dismissed the employees for gross misconduct. ${ }^{2051}$

722. The circumstances that gained importance in the above cases - and which might be used in the future when assessing similar situations - were the following: the nature of the activity (Does the act itself relate to the workplace? The nature of the behaviour: does the act qualify as a breach of workplace safety rule, or is it ill-intentioned - or is it rather a harmless prank?), as well as the identifiability of the employer (Could the behaviour be linked to the employer? Did the employee wear a uniform? Or was the employer identifiable in another way?).

723. Conclusions of the Section. In conclusion, direct connection between the workplace and the employee's activity on SNSs can be established in several ways: the content can directly relate to the workplace/employer/colleagues (e.g. publishing negative opinion), it can take place at the workplace (e.g. bathing in restaurant sinks) or the employee can wear the employer's uniform in a picture. The most common form of possibly questionable content relates to the employees' expression and not to other conducts, such as pranks.

In the course of their personal life employees often think that they are free to do anything, including expressing themselves in social media - as it is demonstrated by the growing case law of "Facebook firings". Although both in France and in Hungary employees are entitled to the freedom of expression, which can even include the right to criticize the employer, this right is not unlimited: expressing themselves in an abusive

\footnotetext{
2050 Taylor v Somerfield Stores Ltd. Case no: S/107487/07 Held at Aberdeen on 24 July 2007

2051 Jolly, J. (2018) Ryanair sacks six cabin crew after 'staged' photo sleeping on airport floor, The Guardian. Available at: https://www.theguardian.com/business/2018/nov/07/ryanair-sacks-six-cabin-crewafter-staged-photo-sleeping-on-malaga-airport-floor (Accessed: 19 November 2018).
} 
way ${ }^{2052}$ can result in the termination of their employment relationship. Even though the personal lives of the employees are protected, the majority of case law and scholars correctly - found that expressing oneself on SNSs goes beyond the personal sphere, unless strict precautions are taken and the access is limited to a few other users who are in a close relationship. However, the existence of these criteria must be assessed on a case-to-case basis as no universal rule can be established.

The presented case law and media cases illustrated that on SNSs employees tend to use extreme or vulgar expressions, a harsh, insulting style. Combining this with the fact that these expressions are often available to the public (due to either not using the privacy settings or letting a big audience access it), and with the increased possibility to identify the employer, employees' off-duty behaviour on SNSs can cause considerable harm to the employer's reputation. This will be taken into account when the dissertation aims to establish the balance between the employees' and employer's rights.

\section{Section 2. Off-duty conduct without direct connection to the employment}

724. Posts independent of the employment. Although most articles dealing with off-duty conduct and SNSs focused on the limits of the employees' freedom of expression in relation to the employment, it is also important to address the question of employees' behaviour independent of the workplace: employees' posts on SNSs can relate not only to the workplace but also to other subjects, without a direct connection with the employment. As a preliminary point it should be noted that in such cases, the possible intrusion into the employees' private life is more intense, therefore if the application of a restriction or legal consequences is possible, it must meet even stricter requirements and safeguards than in the case of behaviour with a direct connection to the employment.

725. What was understood by direct connection to employment is expression explicitly aimed at the workplace/employer/colleagues or content recorded in a uniform or on the workplace premises. Indirect connection refers to cases other than direct connection: here, no link can be established with the workplace at first sight. However, such behaviour, too, can have consequences for the employment or can reflect badly on the employer: employees might express themselves in a way that can result in jeopardizing the employer's legitimate interests through especially inciting public outcry. This is notably

${ }^{2052}$ E.g. by using insulting or vulgar expressions. 
the case of expressing political opinion, ${ }^{2053}$ opinion in relation to current events, ${ }^{2054}$ news, religion, science (e.g. "flat Earth believers", antivaccination, esoteric, etc.) etc. ${ }^{2055}$ Besides freedom of expression, employees' lifestyles can also raise the question of whether such conduct can jeopardize the employer's legitimate interests, and if yes, what requirements should such behaviour fulfil? Such behaviour might be connected to revealing employee's lifestyles, such as the consumption of alcohol, ${ }^{2056}$ cigarettes, drugs, ${ }^{2057,} 2058$ or leading a promiscuous lifestyle - and documenting it on social media. Although it takes place purely in the course of the employees' private lives, employers might not be enthusiastic about employees documenting on Facebook their wild Saturday nights or the details of their love

2053 Although in the following case it was not the employee who decided to upload the content in question, SNSs still functioned as a channel for publicity: an employee got dismissed after the wide publication of a photograph of her in social media, where she is seen showing her middle finger towards the President of the US's motorcade. Source: Dvorak, P. (2017) Flipping off President Trump has changed Juli Briskman's life - and exposed our divisions, The Washington Post. Available at: https://www.washingtonpost.com/local/flipping-off-president-trump-has-changed-juli-briskmans-life-and-exposed-our-divisions/2017/11/07/19efab02-c3f6-11e7-afe9-4f60b5a6c4a0_story.html (Accessed: 14 August 2019).

${ }^{2054}$ See, for example, the case of a paramedic employee who, after an 88-year-old man opened fire in a museum, was injured but was finally saved by paramedics, expressed his disagreement and stated that it was the paramedics' chance to make a difference, and also suggested that the other guards should go to target practice. Source: Mgrditchian, G. (2015) 'Employment and Social Media Privacy: Employer Justifications for Access to "Private" Material', Rutgers Computer \& Technology Law Journal, 41(1), pp. 117-118.

Another example is the case of Justin Hutchings from London, Ontario, who was fired in 2012 because he published offensive content to a memorial website of a teenager who committed suicide after being a victim of bullying for years ("Thank God this B---- is Dead"). Mr. Hutchings identified his employer in his profile, and one of the users easily "tracked him down" from that information and reported his behaviour to his employer. Source: Sarin, P. (2012) Employees beware: The perils of posting on Facebook, rabble.ca. Available at: http://rabble.ca/columnists/2012/10/employees-beware-perils-posting-facebook (Accessed: 11 May 2018).

${ }^{2055}$ An example can be mentioned from Canada, where Christopher Maximillian Sandau, then hockey coach was fired for content on his Facebook profile, promoting Nazi propaganda. Parents and officials discovered the content. Source: Delta hockey coach Christopher Sandau fired over Nazi posts on Facebook (2014) CBC News. Available at: http://www.cbc.ca/news/canada/british-columbia/delta-hockey-coach-christophersandau-fired-over-nazi-posts-on-facebook-1.2825623 (Accessed: 3 May 2018).

${ }^{2056}$ See, for example, the already presented case of Ashley Payne, an American high school teacher, who was dismissed for posting pictures of herself holding a pint of beer and a glass of wine in her hand during her trip to Europe. Source: Oppenheim, R. (2013) High School Teacher Files an Appeal in Case of Social Media Related Resignation, California Business Litigation Blog. Available at: https://www.californiabusinesslitigation.com/2013/05/high_school_teacher_files_an_a.html (Accessed: 3 May 2018).

${ }^{2057}$ It is notably the case in the US, where in the absence of legislation guaranteeing such protection, employers can prohibit certain lawful off-duty conducts (e.g. smoking, dating). Source: Smith-Butler, L. (2009) 'Workplace Privacy: We'll Be Watching You', Ohio Northern University Law Review, 35(1), p. 76.

${ }^{2058}$ However, a strict separation is not possible between personal and professional life: although as a main rule these activities take place in the course of the employee's personal life, they can have an effect on his/her health resulting in labour law consequences as well (e.g. sick leave). 
(or even sexual) lives - especially if the individual can be linked to the workplace as an employee. $^{2059}$

726. To such cases $(\S 1)$ in French law a different set of rules is to be applied that of non-disciplinary dismissals - where it is not a breach of obligation that serves as a basis for the termination of employment but the existence of a so-called characterised serious disorder. In contrast, (\$2) in Hungarian labour law the same, already-presented provisions (Section 8) are applicable, with the difference that they should be interpreted in a stricter way, as employees' "purely" private lives are at stake. Also, in Hungarian law, it is possible to terminate the employment relationship without notice in cases when the employee did not commit a serious breach of duties but engaged in behaviour to shake the trust between the parties, ${ }^{2060}$ typically including cases connected to the employee's behaviour outside work, making it impossible to maintain the employment relationship. ${ }^{2061}$ For example, a Facebook post might result in a loss of trust, ${ }^{2062}$ serving as a ground for termination without notice. ${ }^{2063}$

\section{(§1) Non-disciplinary dismissals and characterised serious disorder}

727. Non-disciplinary dismissals. In French law according to the main principle, an element pertaining to the personal life of the employee cannot constitute misconduct. ${ }^{2064}$ As it was demonstrated, in order to pronounce a disciplinary dismissal, the employee must breach an obligation arising from the employment contract. However, the employer can still apply non-disciplinary dismissal ${ }^{2065}$ if the employee's actions realised in the course of

\footnotetext{
2059 This was the case when an employee had a blog where he shared his otherwise inappropriate opinion in a context where he did not criticise the employer, only mentioned him. In his blog, he identified himself as an employee and also shared pictures of himself taken at the workplace. The issue was that in the same blog, he also shared his admiration for Hitler and shared racist and violent content. Source: Ellickson, D. and Atkinson, M. (2013) 'When Can Your Employer "Unlike" You? Just Cause for Dismissal and Social Media', in The Law Society of Upper Canada, Employment Law and the New Workplace in the Social Media Age. Toronto: Irwin Law, p. 265.

${ }^{2060}$ Hajdú, J. and Kun, A. (eds) (2014) Munkajog. Budapest: Patrocinium, p. 167. E.g. he/she engages in conduct unworthy of his/her job by leading a lifestyle of revelry and alcoholism, substantiated suspicion of committing a serious criminal offence.

${ }^{2061}$ Cséffán, J. (2016) A Munka Törvénykönyve és magyarázata. Szeged: Szegedi Rendezvényszervező Kft, p. 309.; Gyulavári, T. (ed.) (2012) Munkajog. Budapest: ELTE Eötvös Kiadó, p. 216.

2062 Kozma, A. (2013) 'Mire köteles a munkavállaló?', HR \& Munkajog, 4(10), p. 10.

${ }^{2063}$ Mfv.I.10.469/2013/4 Cited in: Cséffán, J. (2016) A Munka Törvénykönyve és magyarázata. Szeged: Szegedi Rendezvényszervező Kft, p. 311.

${ }^{2064}$ Cour de cassation, chambre sociale, 16 déc. $1997, n^{\circ} 95-41.326$

${ }^{2065}$ It cannot be emphasized enough that regardless of the consequences that this act caused to the workplace, such a characterised serious disorder does not allow in itself to apply a disciplinary sanction against the employee. Source: Cour de cassation, chambre mixte, 18 mai 2007, N 05-40803
} 
his/her personal life caused a $(A)$ characterised serious disorder in the functioning of the workplace. ${ }^{2066}$ In such a scenario, it is not the employee's actions themselves that justify the dismissal, but rather the disruption in the functioning of the workplace: ${ }^{2067}$ the characterised serious disorder that is caused. (B) Such a characterised disorder can appear not only in the offline world, but on SNSs as well.

\section{(A) Characterised serious disorder}

728. Characterised serious disorder. In contrast to disciplinary dismissals, where the breach of obligation justifies the dismissal, in the case of a characterised serious disorder it is the sufficiently serious consequences of the employee's conduct for the functioning of the workplace which allow the employer to terminate the employment contract, ${ }^{2068}$ as the behaviour of the employee affects the functioning of the workplace to such an extent that it is not possible to continue to employ the employee without causing damage to the workplace. ${ }^{2069,} 2070$

729. When assessing the severity of the caused trouble, the judges take into consideration the nature of the duties of the employee, the company's purposes and the effects of the employee's behaviour outside and inside of the workplace. ${ }^{2071}$ Regarding the company's purposes, this requirement initially aimed ideologically oriented enterprises or faith oriented enterprises ("entreprise de tendance"), ${ }^{2072,2073}$ where the specific orientation

\footnotetext{
2066 The two regimes cannot be mixed: if the employer issues a disciplinary dismissal against an employee for causing a characterised serious disorder, courts will qualify the dismissal unjustified. Source: Baugard, D. (2015) 'L'usage par les salariés des réseaux sociaux', in Ndior, V. (ed.) Droit et réseaux sociaux. Issy-lesMoulineaux: Lextenso (Collection LEJEP), p. 87.

2067 Gillier, H. (2009) 'Vie personnelle et licenciement disciplinaire', Bulletin du travail (ancien nom Cahiers sociaux du barreau de Paris), (213), p. 213.

${ }^{2068}$ Inforeg (2015) 'Pouvoir disciplinaire : vie personnelle, vie professionnelle et Facebook', Cahiers de droit de l'entreprise, (6), p. 68.

${ }^{2069}$ Antonmattei, P.-H. (2012) 'Le licenciement pour trouble objectif', Droit social, (1), p. 10.

${ }^{2070}$ For example, the existence of a characterised serious disorder was established in a case when a director of a centre hosting protected persons was accused of sexual molestation of a minor (Cour de cassation, chambre sociale, du 21 mai 2002, 00-41.128), or in a case when an employee deliberately hit his girlfriend, herself an employee of the workplace as well, in the close proximity of the workplace and the incident gave rise to reactions from the stuff. (Source: Richard de la Tour, J. (1999) La vie personnelle du salarié. Étude sur la jurisprudence récente de la Chambre sociale de la Cour de cassation. Cour de cassation. Available at: https://www.courdecassation.fr/publications_26/rapport_annuel_36/rapport_1999_91/etudes_documents_ 93/jean_richard_5796.html (Accessed: 12 July 2017).)

${ }^{2071}$ Inforeg (2015) 'Pouvoir disciplinaire : vie personnelle, vie professionnelle et Facebook', Cahiers de droit de l'entreprise, (6), p. 68.

2072 Jacquelet, C. (2008) La vie privée du salarié à l'épreuve des relations de travail. Aix-en-Provence: Presses universitaires d'Aix-Marseille. pp. 270-271.

2073 An ideologically oriented enterprise is an enterprise which has a particular orientation, which can be syndical, political or religious.
} 
of the workplace can have an effect on the expectations towards the behaviour of an employee in the course of his/her personal life. ${ }^{2074}$ Later, it was extended to "everyday" workplaces not having a particular orientation, and the Court of Cassation acknowledged that even these enterprises can have such a purpose that can justify the dismissal of an employee based on his/her private live. ${ }^{2075}$ However, as such a dismissal should meet very strict requirements, it is rare that an ordinary enterprise can rely on a characterised serious disorder. ${ }^{2076}$ When it comes to the functions of the employee, it can be stated in general that the higher the position is, the more exemplary behaviour can be expected from the employee. $^{2077}$

730. Characterized and serious. When it comes to the characterised serious disorder itself, it is important to state that not any disorder can be qualified as such: as the denomination itself suggests, it has to be characterised and serious, implying that the disorder has to be sufficiently perceivable and obviously disturbing so that a third person could consider them as such. ${ }^{2078}$ It is not only the employer who should perceive the employee's acts as disturbing, but they have to be objectively qualified as disturbing for the functioning of the workplace. ${ }^{2079}$ Such a disorder must be more than a simple inconvenience created for the employer, and must be truly harmful for the employer. ${ }^{2080}$

The disorder should also be characterised, meaning that a slight disorder is not sufficient: it must be serious and persistent. ${ }^{2081}$ What needs to be assessed is whether the employee's actions have discredited the workplace, resulted in negative reactions from

\footnotetext{
2074 E.g. it can be reasonably expected that an employee working for political party A does not actively and publicly support political party B on his/her SNSs.

2075 Jacquelet, C. (2008) La vie privée du salarié à l'épreuve des relations de travail. Aix-en-Provence: Presses universitaires d'Aix-Marseille. p. 272.

2076 Perraki, P. (2015) La protection de la vie personnelle du salarié en droit comparé et européen : étude comparative des droits français, hellénique, britannique et européen. Paris: l'Harmattan. p. 438.

2077 Jacquelet, C. (2008) La vie privée du salarié à l'épreuve des relations de travail. Aix-en-Provence: Presses universitaires d'Aix-Marseille. p. 509.

2078 Jacquelet, C. (2008) La vie privée du salarié à l'épreuve des relations de travail. Aix-en-Provence: Presses universitaires d'Aix-Marseille. p. 276.

${ }^{2079}$ Perraki, P. (2015) La protection de la vie personnelle du salarié en droit comparé et européen : étude comparative des droits français, hellénique, britannique et européen. Paris: l'Harmattan. p. 440.

2080 Aubert-Monpeyssen, T. (2007) “"Trouble objectif dans l'entreprise” et libertés collectives du salarié', Revue droit du travail Dalloz, (10), p. 588.

${ }^{2081}$ Perraki, P. (2015) La protection de la vie personnelle du salarié en droit comparé et européen : étude comparative des droits français, hellénique, britannique et européen. Paris: l'Harmattan. p. 440
} 
clients, from the public or from employees, or have jeopardized the employer's interests considering its functions, responsibilities, its size, its sector of activity, reputation. ${ }^{2082,2083}$

\section{(B) Characterised serious disorder and social network sites}

731. Disorder and SNSs. Just like their behaviour in the offline world, employees' behaviour on SNSs can also result in a serious characterized disorder. Such might be the case when the employee posts an offensive content which results in public outcry and other users reporting the case to the employer. The advent of SNSs gains importance in two regards when it comes to non-disciplinary dismissal: on the one hand, it facilitates the discoverability of employees' behaviour and on the other hand, it can facilitate proving the existence of a disorder.

732. Discoverability. First, in order that a dismissal to be lawful on the ground of causing a characterised serious disorder, strict requirements must be met, as the purpose of the workplace and the functions of the employee must be considered in addition to determining the existence of a characterised serious disorder. What social media notably changed is the discoverability of such conducts: a possibly reprehensible conduct (e.g. buying a Peugeot car while working for Renault, being interested in swinger parties, practising psychic activity while being a doctor's assistant ${ }^{2084}$ ) can be widely "advertised" by users. ${ }^{2085}$ Due to the publicity of content published or activities taking place in social media, it is more probable that the reprehensible conduct of the employee becomes known

2082 Corrignan-Carsin, D. (2009) 'La Chambre sociale fixe les limites du pouvoir disciplinaire de l'employeur', JCP E Semaine Juridique (édition entreprise), (40), p. 46.

2083 On the characterised serious disorder see more in: Waquet, P. (2006) 'Le "trouble objectif dans l'entreprise" : une notion à redéfinir', Revue droit du travail Dalloz, (5), pp. 304-310.; Perraki, P. (2015) La protection de la vie personnelle du salarié en droit comparé et européen : étude comparative des droits français, hellénique, britannique et européen. Paris: l'Harmattan. pp. 435-447.; Jacquelet, C. (2008) La vie privée du salarié à l'épreuve des relations de travail. Aix-en-Provence: Presses universitaires d'AixMarseille. pp. 266-280. ; Antonmattei, P.-H. (2012) 'Le licenciement pour trouble objectif', Droit social, (1), pp. 10-13.

2084 These are references to the cases: Cour de cassation, chambre sociale, 22 janvier 1992, $\mathrm{N}^{\circ}$ 90-42517; Cour de cassation, chambre mixte, 18 mai 2007, $\mathrm{N}^{\circ}$ 05-40803 and Cour de cassation, chambre sociale, 21 oct. 2003, $\mathrm{n}^{\circ}$ 00-45.291. Although these conducts did not take place on SNSs, in my opinion they could have resulted in a characterised serious disorder if they had taken place on SNSs.

2085 Though the example does not relate to the employment, the scandal of a low-cost airline in 2019 can illustrate how widespread a simple post can become: after boarding, a passenger found that the woman seated next to him had a chair with no back. He took a picture of it and posted it to Twitter. The tweet soon went viral: it received more than 6,000 re-tweets, and appeared in the headlines of several news portals - while in reality the passenger was reassigned the seat and no one was sitting on the backless chair. In the pre-SNS age a similar story might have stayed within the circle of the passenger's friends and family. Source: Picheta, R. (2019) EasyJet was criticized for making passengers fly in backless seats -- except it didn't, CNN. Available at: https://edition.cnn.com/travel/article/easyjet-backless-seats-scli-gbr-intl/index.html (Accessed: 7 August 2019). 
by interested parties (e.g. clients, employees or the public) - while before, their discoverability by the employer remained more incidental.

733. Proof. Second, SNSs can highly facilitate proving the existence of an objective disorder, as the characterised disorder can be manifested also in negative reactions from clients, from the public or from employees. While earlier, in the pre-SNS era it required more time and effort to submit a complaint (e.g. buying an envelope, writing a letter, addressing and sending it), today e-mail and the official Facebook pages dedicated to a company have made it considerably easier and faster to express dissatisfaction or indignation relating to the conduct of an employee. As a result, possibly more people are keen to express their dissatisfaction on SNSs than in the offline world. It is another change that usually the style of these online complaints is also less official and more overheated $^{2086}$ - making it more plausible to establish indignation from these people.

734. Consequently, in such cases, the SNS post itself cannot be enough to establish the existence of a characterized serious disorder: its effects as well must be taken into consideration. However, SNSs made it easier to detect the public's indignation because if a post goes viral, it might result more easily in public outcry (e.g. messages sent to the employer, public comments under the post or under the shared post, its appearance in news portals): thus it is able to constitute the basis of a non-disciplinary dismissal.

\section{(§2) Off-duty conduct and the Hungarian Labour Code}

735. Compared to French law, in Hungarian regulation there is no such differentiation between disciplinary and non-disciplinary dismissals: ${ }^{2087}$ if the conditions required are met, Section 8 applies as well to off-duty behaviour not directly relating to the employment. More precisely, Subsection (2) on behaviour outside of working hours and Subsection (3) on employees' expression are of particular importance with regard to the subject. Although professional articles usually focus on the employees' freedom of expression, this question includes wider matters: besides expression, employees' behaviour (e.g. photo or video) should also be examined.

\footnotetext{
2086 Ray, J.-E. (2018) 'Des “licenciements Facebook” à la sanction d'un “Like”?', Semaine sociale Lamy, (1830), p. 12.

2087 Even though such categories do not exist in Hungarian law as the cases of dismissal are regrouped according to a different logic, it was already presented that in Hungarian law as well it is possible to dismiss an employee without the breach of obligations.
} 
736. In the case when the content published to SNS directly relates to the employment, the legal basis is provided by the employee's duty of loyalty, which means that the employee must not harm the employer's reputation. Although every employee is entitled to the freedom of expression, it was determined that following from their status as employees, this freedom is not limitless. In the case of content (or behaviour) not directly relating to the employment, stricter conditions must be met in order to be able to sanction the employee. Due to the visibility/publicity of SNS posts, a possibly compromising content can easily go viral and result in the other users' indignation - making it easier, compared to the pre-SNS age, to sanction the employee for behaviour committed solely in the course of his/her personal life.

\section{(A) Behaviour outside of working hours}

737. HLC and employee's conduct outside working hours. Although in the public sector it is accepted that public employees are bound by certain restrictions even outside working hours, it was questioned whether such restrictions can be applied to the employees of the private sector. ${ }^{2088}$ In Decision No. 56/1994 (XI. 10.), the Constitutional Court laid down important ground rules relating to public employees' behaviour outside working hours, and later the substance of it inspired Subsection (2) of Section $8 .{ }^{2089}$ Since the adoption of the HLC, as a new provision, it imposes restrictions on the behaviour of employees outside working hours, by stating that "[w]orkers may not engage in any conduct during or outside their paid working hours that - stemming from the worker's job or position in the employer's hierarchy - directly and factually has the potential to damage the employer's reputation, legitimate economic interest or the intended purpose of the employment relationship. "2090

738. Decision No. 56/1994 (XI. 10.). Although Decision No. 56/1994 (XI. 10.) relates to public servants ("közalkalmazott"), it provides a point of interpretation for restricting private employees' behaviour. ${ }^{2091}$ In this decision, the Constitutional Court

2088 See more on the subject and on the relevant case law in: Kardkovács, K. (ed.) (2016) A Munka Törvénykönyvének magyarázata. 3rd edn. Budapest: HVG-ORAC Lap- és Könyvkiadó p. 45.

2089 See more on the subject and on the relevant case law in: Kardkovács, K. (ed.) (2016) A Munka Törvénykönyvének magyarázata. 3rd edn. Budapest: HVG-ORAC Lap- és Könyvkiadó p. 45.

${ }^{2090}$ Subsection (2) of Section 8 of the HLC

2091 Pók, L. (2012) 'Lájkolni szabad? Munkavállalói véleménynyilvánítás az új Munka Törvénykönyve tükrében', Infokommunikáció és jog, (4), p. 161. 
examined a provision of the Act on the Legal Status of Public Servants, ${ }^{2092}$ stating that public employees shall behave in a way worthy of a public employee, taken into consideration his/her job and position, even outside the workplace. ${ }^{2093}$ Although the Constitutional Court did not find this provision unconstitutional, it identified the conditions of the application of such a rule. It highlighted that even within the public sphere differentiation must be made between public employees, as public servants bear public functions to a lesser extent than civil servants. In the case of the latter, the general underlying public interest is not present in the case of every public servant, and as a consequence, such a restriction should be subjected to the strict requirement of proportionality and necessity. Therefore, restricting public employees' behaviour outside the workplace is only necessary and proportionate if the behaviour is unworthy with regard to the job or position of the public employee and has a substantial and real, direct effect on it and causes the harm of the employer's interests. ${ }^{2094}$ However, in the case of private employees public functions are completely absent: here, the employer's private interests face employees' fundamental rights. ${ }^{2095}$

739. Subsection (2) of Section 8 (on employees' conduct during or outside paid working hours) of the HLC is connected to the obligation of cooperation incumbent upon the employer and the employee. The employment relationship is a long-term, trust-based relationship, which affects not only the parties' conduct during the performance of rights and obligations, but to a certain extent also the private life of the employee. This requirement is also enshrined among the employees' obligation, namely, that the employee shall perform work in such a way that demonstrates the trust vested in him/her for the job in question. ${ }^{2096}$ This means that the employee cannot behave in a way, even outside the workplace, that would influence maintaining his/her employment. Demonstrating trust vested in him/her for the job in question does not relate to the non-respect of the employees' obligations, but rather to circumstances making it impossible to maintain the employment. Naturally, the position of the employee within the hierarchy of the employer has importance when assessing the questioned behaviour. ${ }^{2097,2098}$

\footnotetext{
2092 Act XXXIII of 1992 on the Legal Status of Public Servants

${ }^{2093}$ Subsection (2) of Section 39 of Act XXXIII of 1992 on the Legal Status of Public Servants

${ }^{2094}$ Decision No. 56/1994 (XI. 10.) of the Constitutional Court

2095 Pók, L. (2012) 'Lájkolni szabad? Munkavállalói véleménynyilvánítás az új Munka Törvénykönyve tükrében', Infokommunikáció és jog, (4), p. 160.

${ }^{2096}$ Item d) of Subsection (1) of Section 52 of the HLC

${ }^{2097}$ Kozma, A. (2013) 'Mire köteles a munkavállaló?’, HR \& Munkajog, 4(10), p. 9.
} 
740. However, the restriction of employees' conduct outside working hours is influenced by two circumstances according to Subsection (2) of Section 8: by the employee's job or position within the employer's organisation and by the effects of the conduct. ${ }^{2099}$ Following from the requirement of what can normally be expected in the given circumstances, an employee's conduct is weighed differently according to his/her job or position within the hierarchy of the employer. According to László Lórodi, the nature of the employer should also be considered when judging, as there is a difference whether a factory worker out of thousands of workers publishes, for example, a sexually explicit content on social media, or if a teacher does that. ${ }^{2100}$ Regarding the effects of such conduct, the HLC regulates what kind of behaviours are capable of harming the employer's interests: the conduct must present a direct and factual potential to damage the employer's specified interests. ${ }^{2101,2102}$

741. Right to restrict. According to Subsection (2) of Section 8, it is possible to restrict employees' conduct, but a restriction is only permissible if it meets the requirements set in Subsection (1) of Section 9 relating to the restriction of personality rights. Namely, it must be deemed strictly necessary for reasons directly related to the intended purpose of the employment relationship and proportionate for achieving its objective. Subsection (2) also adds that when the employer exercises such control, the employees affected shall be informed in writing in advance.

742. Application to SNSs. These provisions laid down in Subsection (2) of Section 8 are applicable and therefore impose limits on the employees' online behaviour on SNSs. However, these limits must be interpreted very strictly: they depend on the position of the employee, and can only relate to behaviours which have the potential to directly and factually damage the employer's different interests. ${ }^{2103}$ Especially with regard to the absence of the public function in private sector employment law, such a restriction

\footnotetext{
2098 For example, the reason for terminating the relationship of trust can be the employees' expression of political opinion, or a content published on social media if it affects his/her employment. Source: Kozma, A. (2013) 'Mire köteles a munkavállaló?', HR \& Munkajog, 4(10), p. 10.

2099 T/4786. számú törvényjavaslat a Munka Törvénykönyvéről (2011). Előadó: Dr. Matolcsy György nemzetgazdasági miniszter. Budapest. pp. 99-100.

${ }^{2100}$ Lórodi, L. (2013) Mik azok a munkajogi alapelvek és mire valók? (1. rész), Munkajog Portál. Available at: http://munkajogportal.hu/mik-azok-a-munkajogi-alapelvek-es-mire-valok/ (Accessed: 6 September 2018). ${ }^{2101}$ Subsection (2) of Section 8 of the HLC

2102 This is a stricter requirement compared to Subsection (1) of Section 8, which requires simple jeopardizing.

${ }^{2103}$ Kun, A. (2013) 'Közösségi média és munkajog - avagy „online” munkaidőben és azon túl', Munkaügyi Szemle, (3), p. 14.
} 
should be limited to a narrow circle and to exceptional cases, to the case of severe harm of the employer's legitimate interests, when the possible harm exceptionally, in a welldefined way outweighs the employees' right to privacy. ${ }^{2104}$

743. Regarding the categories of persons, it is likely that executive employees ${ }^{2105}$ are primarily concerned by these provisions, requiring them to act according to more severe expectations. ${ }^{2106}$ On a case-by-case basis, not only executive employees, but those who have an outstanding importance in the functioning of the employer or who occupy a position of trust might be concerned as well. ${ }^{2107}$ Regarding the content of the behaviour, one picture taken in a bar seems to be tolerable, while a video showing an employee in a nearly unconscious drunken state might be proven problematic.

744. The criteria set for the case of behaviour having a direct connection with the employment (e.g. identifiability of the employer) can accordingly play a guiding role in the case of not having a direct connection. In addition, with regard to the lack of public function, limiting employees' behaviour and expression must be an exceptional measure. Its application might depend on the position of the employee, and should not be broadly interpreted. ${ }^{2108}$

\section{(B) Freedom of expression}

745. Expressing opinion not relating to the employment. In relation to Subsection (3), the reasoning of the HLC clearly states that the employees' freedom of expression cannot be restricted if the opinion is not connected to the employment. ${ }^{2109} \mathrm{I}$ understand these provisions, according to which the employees' expression cannot be restricted on the grounds of Subsection (3), however, in the light of Subsection (2) such an expression might be capable of directly and factually damaging the employer's reputation, legitimate economic interest or the intended purpose of the employment relationship. (In

\footnotetext{
2104 Pók, L. (2012) 'Lájkolni szabad? Munkavállalói véleménynyilvánítás az új Munka Törvénykönyve tükrében', Infokommunikáció és jog, (4), p. 161.

${ }^{2105}$ Subsection (1) of Section 208 of the HLC: “Executive employee' shall mean the employer's director, and any other person under his or her direct supervision and authorized - in part or in whole - to act as the director's deputy."

${ }^{2106}$ For example, different behaviour is expected from a secretary or from a CEO.

2107 Pók, L. (2012) 'Lájkolni szabad? Munkavállalói véleménynyilvánítás az új Munka Törvénykönyve tükrében', Infokommunikáció és jog, (4), p. 163.

${ }^{2108}$ For example, to cases when the employee is shown during an illegal activity (e.g. consuming drugs or violating other rules) or in a state of excessive consumption of alcohol.

2109 T/4786. számú törvényjavaslat a Munka Törvénykönyvéről (2011). Előadó: Dr. Matolcsy György nemzetgazdasági miniszter. Budapest. p. 99.
} 
extreme cases) expression on SNSs can fall under Subsection (2). For example, it is enough to think of cases relating to the promotion of Nazi propaganda or racist comments.

746. Even though they did not reach courts, certain cases were publicized: in 2013, a journalist was dismissed for an offensive comment, blaming the victim of a rape, ${ }^{2110}$ while in 2016 another journalist was dismissed for posting an excessive comment in a case related to sexual abuse. ${ }^{211}$ Although the following two cases are not from the private sector, they are worth mentioning in order to portray the growing topicality of the subject: in 2015 investigations were initiated against a primary school teacher who used her Facebook profile to inform parents and at the same time to share anti-Semitic posts. ${ }^{2112}$ The second case relates to the chancellor of a Hungarian university (the second highest position at the university), who posted a picture to Facebook - in a period when the whole Hungarian media was reporting about refugees arriving - in which there were 14 naked women in a boat. In the picture it was written: "finally, welcome refugees!" On his profile, the chancellor identified that he worked at the University and (more seriously) his profile picture was the logo of the University. The case resulted in a public outcry. The chancellor claimed he was not the author of the content but was a victim of a cyber-attack and finally gave in his resignation in order to spare the University from more humiliation. ${ }^{2113}$

747. In conclusion, different factors should be considered to determine whether the employees' expression not directly relating to the employment damaged/jeopardized the employer's reputation or legitimate economic interest. As in private employment employees do not have a public function, limiting their expressions (or sanctioning them) must relate to exceptional cases. First of all, the subject of the expression should be examined: expressions relating to subjects judged by public perceptions (e.g. promoting Nazi propaganda, hate speeches) might become subjects of such restrictions. The style can

\footnotetext{
${ }^{2110}$ Kirúgta munkatársát a Blikk, aki a Facebookon sértegette a megerőszakolt lányt (2013) HVG. Available at: https://hvg.hu/itthon/20130727_blikk_kirugas (Accessed: 22 November 2018).

2111 Kirúgták Facebook-posztja miatt Aczél Endrét (2016) Népszava. Available at: https://nepszava.hu/1090759_kirugtak-facebook-posztja-miatt-aczel-endret (Accessed: 15 November 2018).

${ }^{2112}$ Kúria (2019) Kúria tájékoztatója a Kúria M.I. tanácsa által tárgyaláson kívül elbírált Mfv.I.10.098/2019. számú ügyről. The Curia held that it is incompatible with the profession of teacher to post on a Facebook profile racist, exclusionary or extreme content. In its reasoning the court drew attention to the specific responsibilities teachers have, and their effects on teachers' expected behaviour outside the workplace. As teachers have increased responsibility in educating children, these expectations are higher towards them than towards a private sector employee.

2113 Lemondott Devecz Miklós, a szegedi egyetem kancellárja (2015) Index. Available at:https://index.hu/belfold/2015/09/28/lemondott_devecz_miklos_a_szegedi_egyetem_kancellarja/ (Accessed: 3 May 2018).
} 
also play a role: the use of excessive expressions (potentially constituting slander or defamation) or expressions representing heated feelings such as aggression or hate ${ }^{2114}$ might make the expression lose the protection. Finally, the position of the employee is important, as greater care is required from employees working in higher positions with increased responsibility. From among the above, these are the elements that should be analysed during the assessment of the expression in a given case.

748. Conclusions of Chapter 1. While employees' freedom of expression or behaviour outside working hours is already regulated both in France and in Hungary, SNSs put these already existing conducts into new perspective, through being platforms where employees often express themselves in an abusive and excessive way, possibly to a wide audience, with the increased possibility to identify the employer. This is true both in the case of expression/behaviour with a direct connection to the workplace and in the case of expression/behaviour with an indirect connection to the workplace.

749. While both in France and in Hungary the employee has the right to express himself/herself, even including the expression of a negative opinion towards the employer, this expression cannot constitute an abuse. In the case of an activity indirectly having a connection with the employment relationship, even stricter conditions must be met, as the activity is more closely connected to the personal life of the employee. Throughout Chapter 1 different criteria were identified (position of the employee, nature of the expression, public or private nature, etc.), which can help establish whether the employee overstepped the limits of his/her freedom of action granted by the relevant regulations.

${ }^{2114}$ See, for example, the case of Justin Hutchings from London, Ontario who was fired in 2012 because he published offensive content ("It's about time this $\mathrm{b}^{* * * *}$ died") to a memorial website of a teenager who committed suicide after being a victim of bullying for years. Mr. Hutchings identified his employer in his profile, and one of the users easily "tracked him down" from that information and reported his behaviour to his employer. Source: Sarin, P. (2012) Employees beware: The perils of posting on Facebook, rabble.ca. Available at: http://rabble.ca/columnists/2012/10/employees-beware-perils-posting-facebook (Accessed: 11 May 2018).

Or, see the case of an intern at a car factory who commented a picture in which firefighters sprinkled Syrian children with water in the summer heat. It was obvious from the picture that the children were having a good time. However, the intern commented that instead of water, a flamethrower would have been a better option. The employer was identifiable from the intern's Facebook profile, and outraged users reported the comment to the employer - who in response terminated the internship. Source: Goda, M. (2015) Felmondhatunk a munkavállalónak egy facebook bejegyzés miatt?, Munkajog Portál. Available at: http://munkajogportal.hu/felmondhatunk-a-munkavallalonak-egy-facebook-bejegyzes-miatt/ (Accessed: 27 May 2017). 


\section{Chapter 2: Regulating and monitoring employees' presence on SNSs}

750. In addition to determining the boundaries of employees' personal life when it comes to off-duty conduct and social media, Section 1 will examine this question from the employer's perspective: namely, how exactly monitoring and imposing restrictions on employees' behaviour can and should take place. In this regard, the employer's role and responsibility are crucial, as within a specific workplace he/she is the key actor when it comes to planning the conditions of monitoring and defining the limits of how employees should behave while using SNSs.

751. However, challenges relating to the use of SNSs go beyond the workplace, therefore, it is not only the employer's responsibility to solve the uncertainties and to prompt employees to adopt a more responsible conduct through drafting and implementing an internal social media policy. Rather, it is a complex matter, where the interaction of different actors in different fields is required - as it will be seen in Section 2. Outside the workplace, technological solutions and awareness raising can contribute to a more conscious use of SNSs (not only by employees but also by users in general), which in my opinion can highly contribute to preventing arising challenges with respect to the misconceptions surrounding the public-private nature and the general functioning of SNSs.

\section{Section 1. What can employers do?}

Employers' roles are crucial, as within the framework of the legal regulations, they can determine the exact behavioural requirements that employees must comply with, and they can also take a huge responsibility in raising awareness among employees. Under Section 1, it will be discussed what legal rules employers must respect during the monitoring and the regulation of employees' online activities. While assessing whether SNSs are of public or private nature, the privacy approach was dominant, when it comes to how the monitoring of employees' behaviour is possible, a data protection approach provides more answers. First, (\$1) it will be examined whether the employer can completely prohibit the use of SNSs - with regard to the increased harm employees can cause, then (\$2) it will be addressed what rules must be respected during monitoring employees' online activities. 
752. Reversed vulnerability? In relation to employee monitoring usually the employees' more vulnerable position is evoked, in contrast to the employer abusing his/her powers in monitoring employees (playing a local Big Brother by installing cameras everywhere, monitoring every keystroke employees make, recording every meter they drive in the company car, etc.). Gábor Mélypataki and Zoltán Rácz argued that although the employee can jeopardize the employer's legitimate interests through off-duty SNS behaviour, it is still the employee who is in the more vulnerable position. ${ }^{2115}$ However, other authors argue - in my opinion, correctly - in favour of the existence of a reversed vulnerability between the parties. Edit Kajtár argued that in contrast to these premises, when it comes to using SNSs, tables have turned, and it is the employer who is in need of an increased protection against employees' wrongful conduct. ${ }^{2116}$ The development of ICT has a huge impact on enforcing the employer's rights and legitimate interests, ${ }^{2117}$ resulting in the reversed vulnerability of the employer. ${ }^{2118}$ In the social media era it is true that it has never been easier for a few persons to cause huge damage to the employer's fragile reputation. On SNSs an ill-intentioned content - that is extremely easy to publish, only Internet connection and a few minutes are needed - can rapidly go viral, causing damage, which a simple employee could not easily do in the pre-Facebook age. ${ }^{2119}$ This "new" vulnerability has to be taken into consideration when establishing the balance between the employees' and the employer's rights.

753. Can an employer completely prohibit the use of SNS? From the employer's perspective, the most straightforward solution might seem to be the prohibition of the use of SNSs, preventing all the possible challenges. However, from a legal point of view, ${ }^{2120}$

\footnotetext{
2115 Mélypataki, G. and Rácz, Z. (2018) ‘A személyiségi jogok védelmének ütközése a munkajogban', in Auer, Á. et al. (eds) Ünnepi kötet a 65 éves Kiss György tiszteletére - Liber Amicorum in honorem Georgii Kiss aetatis suae LXV. Budapest: Dialóg Campus Kiadó, p. 683.

${ }^{2116}$ Kajtár, E. (2015) 'Európai ügyek a Facebook sötét oldaláról - A munkavállalók közösségi oldalakon tanúsított kötelezettségszegő magatartása', in Horváth, I. (ed.) Tisztelgés: ünnepi tanulmányok Dr. Hágelmayer Istvánné születésnapjára. Budapest: ELTE Eötvös Kiadó, p. 199.

2117 Majtényi, L. (2006) Az információs szabadságok: adatvédelem és a közérdekü adatok nyilvánossága. Budapest: Complex. p. 333.

2118 Balogh, Zs. Gy. et al. (2012) 'Munkahelyi adatvédelem a gyakorlatban', Infokommunikáció és Jog, 9(3), pp. 96-97.

${ }_{2119}$ Ray, J.-E. (2010) 'Little Brothers are watching you', Semaine sociale Lamy, (1470), p. 10. and Ray, J.-E. (2018) 'Des “licenciements Facebook” à la sanction d'un 'Like”?', Semaine sociale Lamy, (1830), p. 11.

${ }^{2120}$ Also, from a practical point of view, such a prohibition would only lead to the creation of profiles under fake names or pseudonyms.
} 
even taking into account the employer's increased vulnerability, this solution would raise several problems.

754. According to the former UN's Special Rapporteur on the promotion and protection of the right to freedom of opinion and expression, "[t]he Internet has become one of the most important vehicles by which individuals exercise their right to freedom of opinion and expression, and it can play an important role to promote human rights, democratic participation, accountability, transparency and economic development. [...] "2121 Access to the Internet does not only comprise exercising freedom of expression, but is also a means to exercise other rights, such as the right to education, the right to freedom of association, the right to full participation in social, cultural and political life and the right to social and economic development. ${ }^{2122}$ As SNSs are an important part of everyday life, the UN Special Rapporteur's words apply to their case as well. SNSs are more than simply a way of entertainment; they are important platforms of self-expression and communication. Besides, they also represent a way of collecting information, as they are one of the main platforms of learning about events of not only friends and acquaintances, but also of the world. Completely prohibiting employees to use them would constitute a very extreme measure, especially considering that they do not even hold public functions. ${ }^{2123}$ Proskauer Rose $L L P$, in its third annual global survey about social media use analysing the jurisdiction of sixteen countries from all over the world, ${ }^{2124}$ concluded that in none of the examined jurisdictions did the employer have the right to prohibit the use of social media per se. ${ }^{2125}$

755. As it was already discussed, both the FLC and the HLC require proportionality when it comes to restricting employees' rights - and although there exists no explicit right to social media, given its role in the $21^{\text {st }}$ century, completely prohibiting their use seems to constitute a disproportionate limitation of the employees' right to

${ }^{2121}$ La Rue, F. (2011) Report of the Special Rapporteur on the promotion and protection of the right to freedom of opinion and expression. UN General Assembly Sixty-sixth session. Promotion and protection of human rights. A/66/290. United Nations. par. 78.

${ }^{2122}$ La Rue, F. (2011) Report of the Special Rapporteur on the promotion and protection of the right to freedom of opinion and expression. UN General Assembly Sixty-sixth session. Promotion and protection of human rights. A/66/290. United Nations. par. 61.

2123 Pók, L. (2012) 'Lájkolni szabad? Munkavállalói véleménynyilvánítás az új Munka Törvénykönyve tükrében', Infokommunikáció és jog, (4), p. 161.

2124 The jurisdictions covered were Argentina, Brazil, Canada, China, Denmark, France, Germany, Hong Kong, India, Ireland, Italy, Japan, Spain, The Netherlands, the United Kingdom and the United States.

2125 Proskauer Rose LLP (2014) Social Media in the Workplace Around the World 3.0. 2013/14 Survey. Available at: http://www.proskauer.com/files/uploads/social-media-in-the-workplace-2014.pdf (Accessed: 3 February 2017). p. 10. 
privacy. As regards France, Jean-Emmanuel Ray expressed that prohibiting the use of SNSs from the employees' home seems to be problematic. ${ }^{2126}$ In Hungary, Edit Kajtár reached the same conclusion, stating that completely prohibiting employees from using social media would be extremely disproportionate. ${ }^{2127}$ Although limited to the expression of employees, Márton Leó Zaccaria likewise held that completely prohibiting the employee from expressing his/her opinion on SNSs would not be acceptable. ${ }^{2128}$ Based on the above views, I am of the opinion that in accordance with the requirements laid down in national regulations, complete prohibition is not possible ${ }^{2129}$ instead, the employer should only restrict the use of SNSs - the increased harm possibly caused by employees should be taken into consideration when determining the limits of such restriction. As a result, the employer is entitled to impose limitations on employees' conduct on SNSs - its suggested limits will be addressed in Section 2 .

\section{(§2) Employee monitoring and data protection}

When it comes to determining in detail the employer's available means in relation to controlling off-duty conduct on SNSs, in addition to the privacy approach (namely the public or private nature of these platforms), the assessment from a data protection point of view is needed in order to ensure the protection of employees' rights. First, parallel to the private-public nature of SNSs, as a preliminary question it should be assessed whether the systematic monitoring of these platforms is possible. Then, as the employer has several ways to access data, it should be examined $(A)$ what ways of access are considered to be lawful. Finally, $(B)$ the specific challenges relating to the enforcement of data protection requirements will be addressed.

756. Monitoring ${ }^{2130}$ and data protection. In addition to the privacy approach (the assessment of the public or private nature of SNSs), the matter can also be viewed from a data protection angle, meaning that it should be examined whether it is possible for the

\footnotetext{
${ }^{2126}$ Ray, J.-E. (2011) 'Facebook, le salarié et l'employeur', Droit social, (2), pp. 138-139.

${ }^{2127}$ Kajtár, E. (2016) Dignity at Work: Employee’s Personality Rights in the 21st Century. Pécs: University of Pécs, Faculty of Law (PMJK Monographs 6). p. 174.

${ }^{2128}$ Zaccaria, M. L. (2016) 'Munkavállalók a világhálón - "Megosztani ér?”, HR \& Munkajog, 7(10), p. 16.

${ }^{2129}$ Except for a very few cases - e.g. for individuals working in high positions in the military, in national security, etc.

${ }^{2130}$ In practice, usually three scenarios are employed: 1) no monitoring at all, 2) ad hoc monitoring (e.g. when managers and employees are connected on an SNS), 3) systematic, well-planned monitoring . Source: 7 Ways Employee Privacy Laws Impact Social Media in the Workplace (2018) Pryme Group. Available at: https://allpryme.com/employee-privacy-laws/employee-privacy-laws/ (Accessed: 14 August 2019).
} 
employer to systematically monitor the employees' online behaviour and presence. As it was already established, although usually it is the individual who decides to share the content on his/her profile, even if it is done without the use of the privacy settings, it does not mean that the employer can process the personal data in any way he/she wishes, without any limitations. The data protection requirements still have to be respected. ${ }^{2131}$

757. Can the employer monitor SNSs? In France, the monitoring of the publicly available information is possible. ${ }^{2132}$ If the employer monitors such a public content, the violation of the employee's right to respect for private life is not raised, ${ }^{2133}$ as it was the employee himself/herself who chose to publish the given content. However, it does not mean that such a control is exempt from legal requirements: data protection requirements, such as prior information, purpose limitation, proportionality, necessity, data quality, etc. are still going to be applicable. ${ }^{2134}$

758. As it was already pointed out, in Hungary, László Pók argued that as it would be hard not to qualify employees' behaviour outside of working hours as pertaining to their personal life, in the light of the HLC's provision on prohibiting the monitoring of employees' private lives, it is hardly acceptable to monitor employees' activity (beyond working hours, by using their own devices) on SNSs. This would leave the employer the possibility to discover the employee's expression only incidentally. ${ }^{2135}$ However, Edit Kajtár - in my opinion, correctly - argues that on the one hand, the HLC states that the employee can only be monitored to the extent pertaining to the employment relationship (and not during working hours). Therefore, if there is a connection between SNS use and the employment relationship, the monitoring per se is not forbidden. On the other hand, she also interprets the HLC as it only forbids to violate employees' private life and does not forbid it to be the subject of monitoring. ${ }^{2136}$ Therefore, the systematic monitoring of the

2131 Fel, C. and Sordet, E. (2010) 'L'utilisation des réseaux sociaux par l'entreprise et ses collaborateurs', JCP S (édition sociale), (29), p. 22.; NAIH/2016/4386/2/V.

${ }^{2132}$ Griguer, M. (2010) 'Les réseaux sociaux sous le contrôle des DSI', Cahiers de droit de l'entreprise, (6), p. 64.

2133 Fel, C. and Sordet, E. (2010) 'L'utilisation des réseaux sociaux par l'entreprise et ses collaborateurs', JCP S (édition sociale), (29), p. 22.

2134 Caprioli, É. A. (2012) 'Les propos tenus par une salarié sur Facebook peuvent justifier son licenciement', Communication Commerce Électronique, (4), p. 39.

2135 Pók, L. (2012) 'Lájkolni szabad? Munkavállalói véleménynyilvánítás az új Munka Törvénykönyve tükrében’, Infokommunikáció és jog, (4), p. 164.

${ }^{2136}$ Kajtár, E. (2015) 'Európai ügyek a Facebook sötét oldaláról - A munkavállalók közösségi oldalakon tanúsított kötelezettségszegő magatartása', in Horváth, I. (ed.) Tisztelgés: ünnepi tanulmányok Dr. Hágelmayer Istvánné születésnapjára. Budapest: ELTE Eötvös Kiadó, p. 203. 
employee's SNS activities is legitimate, provided that the employer respects other (data protection) requirements. ${ }^{2137}$

\section{(A) Access}

In practice, employers have several ways to access or to gain knowledge of employees' off-duty SNS conduct. It was already addressed in the frame of the present thesis that employers are allowed to consult the publicly available content posted by the employee. Even though this is the most obvious way of gaining access due to the lack of the use of privacy settings, other scenarios must also be examined, such as using schemes, friending an employee, and the case of receiving screenshots.

759. Schemes. Besides constituting an intrusion into the employee's personal life, the use of schemes would also be contrary to the data protection principle of fair processing. The employer cannot use schemes in order to obtain access to the content the employee shared. For example, a colleague cannot be asked to send a friend request to an employee in order to be able to provide screenshots in the case of the publication of a "suspicious" content. ${ }^{2138}$ It is also forbidden for the employer to ask another employee, member in a closed group, to report on the activity of other employees ${ }^{2139}$ or to use a pseudonym in order to trick the employee into accepting a friend request. ${ }^{2140}$ Creating a modern-day "snitch regime" through encouraging the employees to report on each other's online activities would be unlawful according to Mélypataki and Rácz. ${ }^{2141}$ This is in line with the data protection requirements, such as the fairness and the transparency of processing.

760. Friending an employee. In contrast to using a pseudonym or fake name when sending a friend request, friending an employee while using the employer's real name might reveal different issues. According to Julien Le Clainche, if the employer

2137 Rácz, I. (2015) ‘A közösségi média használatának árnyoldalai a munkaviszonyban', in Deres, P. and Grad-Gyenge, A. (eds) Acta Iuvenum Caroliensia VII.Budapest: Károli Gáspár Református Egyetem Államés Jogtudományi Kar, p. 285.

${ }^{2138}$ Ray, J.-E. (2018) 'Des “licenciements Facebook” à la sanction d'un “Like”?', Semaine sociale Lamy, (1830), p. 11.

2139 NAIH (2016) A Nemzeti Adatvédelmi és Információszabadság Hatóság tájékoztatója a munkahelyi adatkezelések alapvetö követelményeiröl. Budapest, p. 19.

${ }^{2140}$ Le Clainche, J. (2012) 'Expression des salariés sur internet : attention aux «faux amis »', Revue Lamy droit de l'immatériel ex Lamy droit de l'informatique, (81), p. 48.

${ }^{2141}$ Mélypataki, G. and Rácz, Z. (2018) ‘A személyiségi jogok védelmének ütközése a munkajogban', in Auer, Á. et al. (eds) Ünnepi kötet a 65 éves Kiss György tiszteletére - Liber Amicorum in honorem Georgii Kiss aetatis suae LXV. Budapest: Dialóg Campus Kiadó, p. 682. 
makes part of a "careless employee's" contact list, the employer having access to the disparaging remarks would be considered lawful. ${ }^{2142}$ Nevertheless, according to my opinion, the picture is more nuanced, especially when the employer sends a friend request to an employee. ${ }^{2143}$ Although it is true that in this scenario the employer does not apply any schemes, the voluntary nature of consenting to letting the employer access this online profile reserved for friends (because if it were set to public, the employer would not need to send a request) can be highly questionable. ${ }^{2144}$ Can an employee decline such a request without fearing the possible consequences? $?^{2145}$

761. As a reference, the CoE's and the WP29's already presented documents should be recalled. According to the CoE's 2015 Recommendation, ${ }^{2146}$ "[e]mployers should refrain from requiring or asking an employee [...] access to information that he or she shares with others online, notably through social networking." The explanatory memorandum states that when an employee decides to restrict access to his/her account, his/her will should be respected, and employers do not have the right to ask for access to the profile. ${ }^{2147,2148}$ Although the explanatory memorandum refers to the example of the employer asking for login credentials, sending a friend request to an employee - even if it is far from being as serious as an employer asking for username and password - constitutes requiring access to information as well. Such an interpretation is consistent with the WP29's viewpoint, which noted that "[t]here is no legal ground for an employer to require potential employees to 'friend' the potential employer, or in other ways provide

${ }^{2142}$ Le Clainche, J. (2012) 'Expression des salariés sur internet : attention aux «faux amis »', Revue Lamy droit de l'immatériel ex Lamy droit de l'informatique, (81), p. 48.

${ }^{2143}$ In the case when the employee initiates the act, in my opinion, no special legal challenges arise from a legal view.

${ }^{2144}$ However, in contrast to this opinion, Jean-Emmanuel Ray notes that it is exceptional that an employee accepts a friend request coming from the employer. Source: Ray, J.-E. (2013) 'Facebook, espace public plus que privé. A propos de l'arrêt de la 1 ère Chambre civile du 10 avril 2013', Semaine sociale Lamy, (1599), p. 18.

2145 Although as certain sites, such as Facebook, enable users to apply customized privacy settings, the employee could grant a very limited access to the employer without the latter realizing that he/she is among the "acquaintances" - therefore the employee can have his/her cake and eat it. However, this is not a satisfying solution, as in the case of SNSs with all or nothing privacy settings (e.g. Instagram), the employee cannot have recourse to this solution.

${ }^{2146}$ Council of Europe (2015) Recommendation CM/Rec(2015)5 of the Committee of Ministers to member States on the processing of personal data in the context of employment.

2147 Council of Europe (2015) Explanatory memorandum to Recommendation CM/Rec(2015)5 of the Committee of Ministers to member States on the processing of personal data in the context of employment. par. 46.

${ }^{2148}$ The explanatory memorandum also recalls that employers should not obtain access to employees' profile without their knowledge, using an intermediary, or using a fake name or a pseudonym. par. 45. 
access to the contents of their profiles. "2149 Although this provision refers to prospective employees, in my opinion it is adequately applicable to the case of employees as well, meaning that the employer should refrain from friending employees.

762. "Betrayal" of a colleague: receiving screenshots. In the presented French cases, it was quite frequent that the employer became aware of the disparaging remarks through another employee who had access to them and decided to let the employer know as well, typically by providing screenshots. ${ }^{2150}$ The employment tribunal of BoulogneBillancourt held that such a practice does not violate the employee's right to respect for private life. ${ }^{2151}$ According to the practice previously established by courts, ${ }^{2152}$ if an individual who was originally granted access to the content decides to extract the information and to transmit it outside of the restricted access (to the employer in this case), the employer can rely on it as proof. ${ }^{2153}$ As it was already presented, the Court of Cassation went against this already established practice in its 2017 decision, ${ }^{2154}$ extensively limiting employer's possibilities to obtain proof from SNSs. According to this decision, the employer can obtain proof if he/she is amongst the friends of the employee or if the employee's profile is set to fully public. ${ }^{2155}$

\section{(B) Data protection principles}

After determining that the existence of a systematic monitoring system can be legitimate, and the ways of access in which employers can obtain personal data, it is necessary to address the question of the enforcement of other data protection principles. It cannot be emphasized enough that just because the employee made the information freely available by not applying the privacy settings, it does not mean that the general data

\footnotetext{
${ }^{2149}$ WP29 (2017) Opinion 2/2017 on data processing at work. 17/EN WP 249. p. 11.

${ }^{2150}$ For example, this was the case in: CPH Boulogne-Billancourt (Section Encadrement), 19 novembre 2010, $\mathrm{n}^{\circ}$ 09/00343; CA Rouen, 26 avril 2016, n¹4/03517; Cour de cassation, Civ. 1re, 10 avr. 2013, n 11-19530; Cour de cassation, chambre sociale, 12 sept. 2018, $\mathrm{n}^{\circ} 16-11.690$

${ }^{2151}$ CPH Boulogne-Billancourt (Section Encadrement), 19 novembre 2010, ${ }^{\circ}$ 09/00343

2152 See, for example: CA Rouen, 26 avril 2016, $\mathrm{n}^{\circ}$ 14/03517; CA Paris, Pôle 6, chambre 5, 20 septembre 2018, $\mathrm{n}^{\circ}$ 14/04515. The Court of Appeal of Paris adopted a similar position in a case where the remarks were made in a Facebook group, where one of the participants invited the employer. Source: CA Paris, Pôle 6, chambre 9, 3 décembre 2015, $\mathrm{n}^{\circ}$ 15/04533

${ }^{2153}$ Mayoux, S. (2018) 'Licéité de la preuve recuillie sur Facebook par l'employeur', Jurisprudence sociale Lamy, (449), p. 24.

${ }^{2154}$ Cour de cassation, chambre sociale, 20 déc. $2017, \mathrm{n}^{\circ} 16-19609$

2155 Source: Mayoux, S. (2018) 'Licéité de la preuve recuillie sur Facebook par l'employeur', Jurisprudence sociale Lamy, (449), p. 25.
} 
protection requirements would cease to apply. ${ }^{2156}$ In the following paragraphs the specific aspects in relation to monitoring off-duty conduct will be addressed, such as (a) purpose limitation, necessity, proportionality, $(b)$ prior information and $(c)$ data quality.

\section{(a) Purpose limitation, necessity and proportionality}

763. Purpose limitation and necessity. Ensuring the employer's reputation, legitimate economic interests and protection of business secrets and confidential information are purposes that can justify the existence of monitoring, as online presence and reputation are of crucial importance in the $21^{\text {st }}$ century and an incriminating post might go viral in an extremely short time. In order to ascertain whether employees' online behaviour infringes these interests, it is necessary to monitor their public posts.

764. Principle of proportionality. Proportionality can be twofold: first, it can relate to the content of the monitoring and second, to the scope of the data processing operations. Regarding the first aspect, the employer can decide to look for certain keywords (e.g. the name of the employer) or to monitor the activity of certain employees (e.g. managers). ${ }^{2157}$ Second, as regards data processing operations, the employer is not empowered to store and analyse information relating to employees' public posts: in the light of the above-mentioned requirements, their storing is only possible if the content is compromising and the employer needs to obtain evidence of such conduct.

\section{(b) Prior information}

765. Prior information. Both in France and in Hungary, the employer is subject to the obligation of informing employees regarding the limitations of their rights, and the processing of their personal data. In relation to SNSs and off-duty conduct it means that although the employer can monitor the public posts/activity of the employee, employees must be informed of this practice, notably through internal regulations. ${ }^{2158,} 2159$ This

\footnotetext{
2156 Fel, C. and Sordet, E. (2010) 'L'utilisation des réseaux sociaux par l'entreprise et ses collaborateurs', JCP S (édition sociale), (29), p. 22.; NAIH/2016/4386/2/V.

Attila Kun made a similar statement, though in relation to discrimination, that the existence of discrimination cannot be excluded just because the individual shared the personal data. Source: Kun, A. (2013) 'Közösségi média és munkajog - avagy „online” munkaidőben és azon túl’, Munkaügyi Szemle, (3), p. 16.

${ }^{2157}$ However, it is important that the determination of the personal scope of monitoring cannot be arbitrary or discriminative.

${ }^{2158}$ Griguer, M. (2010) 'Les réseaux sociaux sous le contrôle des DSI', Cahiers de droit de l'entreprise, (6), p. 64.
} 
obligation of prior information only applies to cases where the employer decided to systematically monitor employees' online presence in order to verify compliance, and naturally does not apply to cases where a third person (e.g. another employee, client, etc.) informed the employer about the employee's online behaviour. ${ }^{2160}$

\section{(c) Principle of data quality}

766. Liability of screenshots. Data quality issues might arise in relation to the reliability of personal data obtained from SNSs. In a case at the Court of Appeal of Lyon, ${ }^{2161}$ when the employer learned about the remarks of the employee, he did not provide a bailiff's report, therefore only screenshots provided by other employees were available to support his statement - and the court of appeal held that, in contrast to a bailiff's report, they were not sufficient to support certain allegations of the employer. Copying a conversation might also be insufficient, as courts already ruled that copying and pasting a conversation - instead of a print screen - is insufficient proof, as from them, the accessibility of the account could not be assessed, ${ }^{2162}$ suggesting that a print screen might have been considered acceptable. This observation is also in line with the data quality principles. In Hungarian law as well, several practical questions arise in relation to the reliability of such proof. As there is no "Facebook firings" case law, ${ }^{2163}$ these questions are yet to be answered by courts.

767. Identifying the author of the remarks. Not only identifying to whom the remarks relate can be challenging, but also identifying the author of the remarks: the use of pseudonyms, usernames might hide the true identity of the post's author. In a case at the Court of Appeal of Pau, ${ }^{2164}$ the employee published the remarks to Facebook under a pseudonym. However, the text itself that he published contained enough elements to identify the place of employment, the name of his colleagues, information relating to his

2159 NAIH/2016/4386/2/V. and NAIH (2016) A Nemzeti Adatvédelmi és Információszabadság Hatóság tájékoztatója a munkahelyi adatkezelések alapvetö követelményeiröl. Budapest, p. 19.

${ }^{2160}$ However, following this act he/she has the obligation to inform the employee regarding the further processing.

${ }^{2161}$ CA Lyon, chambre sociale A, 24 mars 2014, $\mathrm{n}^{\circ} 13-03463$

2162 Baugard, D. (2015) 'L'usage par les salariés des réseaux sociaux', in Ndior, V. (ed.) Droit et réseaux sociaux. Issy-les-Moulineaux: Lextenso (Collection LEJEP), p. 86.

2163 Pók, L. (2012) 'A közösség hálójában - Közösségi oldalak munkajogi vonatkozásai’, Infokommunikáció és jog, (1), p. 13.

${ }^{2164}$ CA Pau, chambre sociale, 6 septembre 2018, $n^{\circ} 17 / 01648$ 
private and professional life, and the use of his real first name by other users who reacted to the text.

It is also possible that someone - especially with a common first name and family name - is mistaken for another user having the same name, therefore their online activities might be confused. However, while this might raise more heated issues in relation to recruitment (where the job applicant is an unknown person to the employer), during the course of the employment relationship several clues (e.g. having photos of himself/herself uploaded, indicating the place of employment, having several of other employees amongst his/her contacts, etc.) can indicate that the user is indeed an employee of the given employer - decreasing the possibility that such data quality questions arise.

768. Preliminary interviews and data quality. In relation to accuracy and reliability, the institution of preliminary interview might be of importance. In French law, when an employer considers terminating the employment, he/she must summon the employee to a preliminary interview before taking any decision. ${ }^{2165}$ During this preliminary interview, the employer presents the reasons for the proposed decision and listens to the explanations of the employee. ${ }^{2166}$ This interview is supposed to serve the protection of the employee, by giving him/her the possibility to provide an explanation to the allegations. Theoretically, such an interview could contribute to the effective enforcement of the data quality principles. However, in my opinion the cases where the data quality principles might be threatened regarding off-duty conducts and SNSs are very limited in practice. Such extreme cases might include hacking the employee's account (therefore he/she is not the author of the compromising content) or mistaking someone else's online activity for the employee's (e.g. through bearing the same name). A difference between the two countries is that in Hungarian labour law there is no such interview where the employee could explain himself/herself. However, as regards the rarity of the mentioned cases, such a preliminary interview in itself would not represent a solution to the arising challenges.

769. Conclusions of Section 1. In conclusion, with regard to the importance of SNSs nowadays, a complete prohibition of their use outside the workplace does not seem legally acceptable. However, as employees are bound by certain obligations outside the workplace, their use of SNSs can be restricted in accordance with the labour law and data

2165 Paragraph 1 of Article L1232-2 of the FLC

${ }^{2166}$ Article L1232-3 of the FLC 
protection requirements. Such a restriction is always dependent on the given circumstances, such as the position of the employee or the nature of the workplace, also the assessment of the activity must be based on a case-by-case basis. The employer has the right to monitor employees' activity on SNSs and whether they have complied with restrictions. However, during such a monitoring, data protection requirements must be respected. Notably regarding access, the employer can only process personal data that was publicly available (either for every Internet user or for every user of the given SNS) or that he/she has become aware of through another employee/user who voluntarily decided to share the given information with the employer. Prior information must also be given to employees, and efforts should be made to avoid possible issues arising with respect to the enforcement of the principle of data quality.

\section{Section 2. Best practices and recommendations}

Section 2 will enumerate what steps and measures can be taken in order to find a balance between the rights of the two parties and to avoid the emergence of issues related to the use of SNSs outside the workplace. First, $(\S 1)$ it will address what can be done within the workplace, aiming to examine the measures that might be adopted by employers. Then $(\$ 2)$ it will discuss what other factors can play a role beyond the workplace.

\section{§1. Inside the workplace}

As every workplace is different, it is impossible to provide a universal regulation applicable to all enterprises. Therefore, providing rules at the level of the workplace is crucial. For example, the employer can provide trainings or distribute informational materials in order to remind employees of their obligations and of the restrictions relating to their online behaviour. However, it is a more common solution to adopt social media policies - which will be presented in the following paragraphs.

\section{(A) Adopting internal social media policies}

770. In accordance with what was already stated in relation to internal social media policies regarding the use of SNSs during working hours, internal social media policies can constitute an effective way to clarify what behaviour employees can adopt on SNSs. Through laying down the good examples and the forbidden use of SNSs, such an 
internal policy can often be an effective way to prevent employees from abusing their freedom of expression. ${ }^{2167}$ When it comes to determining the content of such a policy, ${ }^{2168}$ it must be emphasized that it is not possible to draft a universal policy that could be applicable at every employer without changes. Due to the diversity of legal relationships, job descriptions and workplaces, what might be tolerable at one workplace might violate the reputation at another. During the drafting of such a document several factors shall be taken into consideration (e.g. the type of the workplace, its size, its place, etc.). Those stated here represent a point of reference, but they must be adjusted to the characteristics of the given workplace, such as the workplace environment, the nature of the work, level of employees' education, etc. There exists no one-size-fits-all solution. ${ }^{2169}$

771. Despite its advantages, in Hungary it is not a common practice for employers to adopt such documents. ${ }^{2170}$ However, in my opinion, with the growing number of employees (allegedly) abusing their rights, more and more employers will tend toward adopting an internal social media policy. One particular case happened within the National Ambulance Service, where an internal social media policy was created in response to paramedics taking pictures of unconscious patients and commenting them on Facebook. ${ }^{2171}$ Other employers also started to regulate these matters through adopting different

${ }^{2167}$ Griguer, M. (2010) 'Les réseaux sociaux sous le contrôle des DSI', Cahiers de droit de l'entreprise, (6), p. 64.; Pók, L. (2012) 'A közösség hálójában - Közösségi oldalak munkajogi vonatkozásai', Infokommunikáció és jog, (1), p. 15.

2168 The present part is highly based on the results of a research project conducted by József Hajdú, Adrienn Lukács, Viktória Lechner and Attila Turi between 2016-2017 entitled "Data protection challenges arising during the use of social network sites in the context of employment" ("A közösségi oldalak használata során felmerülő adatvédelmi jogi problémák a munkajog kontextusában”) financed by the Ministry of Justice of Hungary. (In the meantime the research was supplemented as it progressed.) The main result of the research was a paper entitled "Social media and labour law - dismissal for Facebook posts in the light of Hungarian and international jurisprudence" ("Közösségi média és munkajog - különös tekintettel a Facebook-ra alapított felmondásokra a hazai szabályozás és a nemzetközi joggyakorlat tükrében”). (To be published in De iurisprudentia et iure publico). In the frame of the research, we analysed several internal social media policies in order to establish the best practices that can be drawn from them.

In the research the following social media policies were analysed: Canada: Via Rail Canada, Red Cross; USA: Department of the Interior, Food and Drug Administration; Australia: Equestrian Australia, Volleyball Australia, National Library of Australia; UK: BBC; France: IUT de Rennes, Orange; Global: DELL, NVIDIA.

${ }^{2169}$ Hajdú, J. et al. (forthcoming) 'Közösségi média és munkajog - különös tekintettel a Facebook-ra alapított felmondásokra a hazai szabályozás és a nemzetközi joggyakorlat tükrében’, De iurisprudentia et iure publico (DIEIP)

${ }^{2170}$ Klausz, M. (2013) Megosztok, tehát vagyok: A közösségi média és az Internet szép új világa. Veszprém: Magánkiadás. p. 144.; Rácz, I. (2015) ‘A közösségi média használatának árnyoldalai a munkaviszonyban’, in Deres, P. and Grad-Gyenge, A. (eds) Acta Iuvenum Caroliensia VII.Budapest: Károli Gáspár Református Egyetem Állam- és Jogtudományi Kar, p. 295.

2171 Facebook-szabályzat a mentöknél - van apropója (2012). Available at: https://www.hrportal.hu/c/facebook-szabalyzat-a-mentoknel-van-apropoja-20120116.html (Accessed: 15 November 2018). 
measures. ${ }^{2172}$ In the absence of case law it is the employer's duty, and therefore it plays a gap-filling role, to draft and consistently implement internal social media policies in order to provide guidance to employees on the use of SNSs. ${ }^{2173,2174}$

772. While keeping in mind the impossibility of creating uniform policies applicable to every workplace, the following paragraphs will aim to draw attention to the most important elements of such a policy. It is recommended that employers include the following parts: the aim of the policy, fundamental definitions, scope, common rules of conduct, examples of conducts to be followed or avoided, monitoring of compliance (data protection), sanctions and references.

\section{(B) Recommended content of the policy}

773. The aim of the policy. Within this part, it is recommended that the employer declares the overall aim that he/she wants to reach by adopting the policy and to raise attention to the arising legal (privacy and data protection) challenges. In this part the employer could state that the policy's aim is to determine the conditions and requirements that employees shall respect during the use of SNSs. The policy's main aim is to establish a balance between the employer's rights and legitimate interests and the employees' right, through determining the boundaries of the employees' freedom of expression. The employer should emphasize that although in this scenario employees use SNSs outside the workplace, beyond working hours, from their own equipment, they are still bound by labour law regulation, meaning that they cannot say anything on these forums without facing the possible legal consequences for their employment relationship. Therefore, employees should use SNSs in a way that does not infringe the employer's or other users' rights.

774. Definitions. When it comes to definitions, it is recommended to provide a general definition of social media and SNSs, to provide certain examples of the most commonly used platforms - as the exhaustive enumeration of existing SNSs is not

\footnotetext{
2172 Szilágyi, K. (2013) Facebook-szabályzat: beleszólhat- a munkáltató?, Adó Online. Available at: https://ado.hu/munkaugyek/facebook-szabalyzat-beleszolhat-a-munkaltato/ (Accessed: 15 November 2018).

2173 Németh, J. (2013) A közösségi média használata munkáltatói szemmel, Jogászvilág. Available at: https://jogaszvilag.hu/szakma/a-kozossegi-media-hasznalata-munkaltatoi-szemmel/ $\quad$ (Accessed: 6 September 2018).

${ }^{2174}$ It is especially the case in Hungary, where there is no elaborated case law in the field - in contrast to France.
} 
possible. It is also advisable to remind employees that any kind of content can constitute an infringement: not only texts (e.g. post, comment), but also photos or videos. ${ }^{2175}$

775. In policies, differentiation should be made between official and non-official use. Official use (professional use) is when the employee either handles the official account of the workplace or acts as the official representative of the employer. Only those employees can act as such who were pre-authorized to do so. Non-official use (personal use) occurs when the employee uses his/her own profile as a private person (or as an employee), and not as the representative of the employer. Such a use can relate to matters connected to the workplace (e.g. expressing opinion in relation to professional questions, often as an employee of the given workplace) or to matters completely independent of the workplace.

776. Scope. The employer should define the scope of the policy. Regarding the personal scope, the employer should clearly state which employees (every employee, a group of them, etc.) the policy is applicable to. Amongst the material scope, it is advisable to differentiate between official and non-official use of SNSs and state that the present policy aims to regulate questions relating to non-official use. As non-official use raises the question of the boundaries of professional and personal life, this matter will be examined in detail. ${ }^{2176}$ It should also be emphasized that the policy applies to the off-duty use of SNSs (when at first sight no connection is present with the employment, as the employee does not use the employer's device, is outside of the workplace, beyond working hours), while specific provisions aim to regulate the use of SNSs during working hours. Amongst the temporal scope, employers should clearly indicate when the policy was adopted, and if it was updated, when it occurred.

777. Common rules of conduct. In addition to laying down the explicit rules and the restrictions applying to employees, internal regulations should also serve as a guidance as regards responsible use of SNSs. ${ }^{2177}$ The policy can constitute a good way to raise

\footnotetext{
2175 Equestrian Australia (2012) Social Media Policy. Available at: http://www.equestrian.org.au/sites/default/files/Social\%20Media\%20Policy.pdf (Accessed: 19 March 2017). p. 3.

${ }^{2176}$ In contrast, while official use should also be regulated, it does not raise specific privacy/data protection challenges, as such a use is basically part of the work.

2177 Németh, J. (2013) 'Az internet nem felejt - közösségi media-használatra alapított munkáltatói és munkavállalói felmondások’, Infokommunikáció és jog, (2), p. 98.
} 
awareness amongst employees regarding their responsibilities while using SNSs. ${ }^{2178}$ It is important to emphasize that SNSs are not terra nullius, and their use is subjected to the legal requirements. Employees should be made aware that nowadays the boundaries of work and personal life are blurred, and social media does not constitute an exception from this phenomenon. Therefore, the employee must respect the employer's legitimate interests even while using SNSs in the course of his/her personal life. This means that employees can register and use these sites, they can express their opinion, however, but they are not completely free to post anything without any restriction: ${ }^{2179}$ obligations arising from the employment contract are binding in the case of SNSs as well. But how exactly can an employee express his/her opinion on SNSs? It is important to emphasize that employees have the right to express themselves in matters relating to the workplace, but they have to respect their other obligations (e.g. duty of loyalty) arising from the employment relationship. Therefore, the employer can restrict employees' behaviour on SNSs, but this restriction cannot be limitless (e.g. the employer can prohibit the infringement of his/her reputation, but he cannot state that the employee is not allowed to criticise the employer at all). ${ }^{2180}$ The boundaries of these restrictions are going to be further addressed in the part "examples". It is even recommended that the employer provides an indicative list, determining which conducts in general are factually capable of damaging or jeopardizing the employer's legitimate interests. ${ }^{2181}$

Employees should also be reminded of general conducts to be adopted while using SNSs. Such conducts would include staying courteous and polite while using SNSs, ${ }^{2182}$ or being honest and accurate. ${ }^{2183}$ They should also be aware that in extreme cases, non-

2178 Fel, C. and Sordet, E. (2010) 'L'utilisation des réseaux sociaux par l'entreprise et ses collaborateurs', JCP S (édition sociale), (29), p. 22.

2179 See, for example: Department of the Interior (2010) Social Media Policy. Available at: https://edit.doi.gov/sites/doi.gov/files/migrated/notices/upload/DOI-Social-Media-Policy-Final-

Redacted.pdf (Accessed: 19 March 2017). p. 4.; Volleyball Australia Board (2012) Volleyball Australia Social Media Policy. Available at: http://www.volleyballaustralia.org.au/_literature_152757/Social_Media_Policy (Accessed: 19 March 2017). p. 2.

2180 NVIDIA (no date) Social Media Policy. Available at: http://www.nvidia.co.uk/object/social-mediaguidelines-uk.html (Accessed: 23 March 2017).

${ }^{2181}$ Rácz, I. (2015) ‘A közösségi média használatának árnyoldalai a munkaviszonyban', in Deres, P. and Grad-Gyenge, A. (eds) Acta Iuvenum Caroliensia VII.Budapest: Károli Gáspár Református Egyetem Államés Jogtudományi Kar, p. 301.

2182 Orange (no date) Social Media Guidelines. Available at: https://www.orange.com/sirius/smg/FR_Guides_Medias_Sociaux.pdf (Accessed: 22 March 2017).

2183 See Walmart's social media policy, which by the way was considered as a perfect policy by the National Labor Relations Board in the US in 2012. The policy is available on the last three pages of the report of Lafe E. Solomon, general counsel: Solomon, L. E. (2012) Memorandum OM 12-59. Office of the General Counsel 
appropriate use of SNSs can be qualified as a punishable act according to penal law regulation (e.g. libel, defamation).

778. It is also recommended that attention is drawn to the basic functioning of SNSs. Employees should be reminded that SNSs are essentially public forums, and a content might easily become available to a larger audience than originally intended by the employee. Therefore, the use of privacy settings is highly recommended. In the meantime, even when such settings are applied, caution should still be exercised, as it is still possible that the content will become available to a larger audience. Amongst other challenges, on the Internet the perception of anonymity might be deceiving, information can be easily misinterpreted as it can be taken out of its context and the Internet does not forget. For these reasons, it is strongly recommended that employees think over what they post to these sites, and they should keep in mind that they should only post content that they would feel comfortable with if it was broadcasted in the news, told to his/her mother or transferred to his/her supervisor. ${ }^{2184}$

779. Providing examples. In order to be truly helpful, SNS policies should provide concrete examples telling employees what they can and what they cannot do, providing real substance to the above-presented common rules of conducts (e.g. in what forms the employee can express his/her opinion, the use of what expressions indicates the existence of an abuse, etc.). As such, it can contribute to making employees understand exactly what expectations the employer has towards them when using SNSs.

780. During the use of SNSs employees should not suggest that they act as the representative of the employer. Therefore, the configuration (e.g. registering with the work e-mail address, using the logo of the employer, identifying the employer, etc.) of the user profile has key importance. ${ }^{2185}$ In order to achieve this separation of professional and

Division of Operations-Management. Available at: http://www.rc.com/documents/OM1259ActingGeneralCounselReportConcerningSocialMediaCases.pdf (Accessed: 30 November 2018).

${ }^{2184}$ See, for example: Canadian Red Cross (no date) Social Media Guidelines for Canadian Red Cross Staff and Volunteers. Available at: http://www.redcross.ca/crc/documents/What-We-Do/ViolenceBullying/partners/social-media-guidelines-2013.pdf (Accessed: 19 March 2017). p. 3., 4., 5. and DELL (no date) Global Social Media Policy. Available at: http://www.dell.com/learn/uk/en/ukcorp1/corp-comm/socialmedia-policy?c=uk\&l=en\&s=corp (Accessed: 23 March 2017).

${ }^{2185}$ IUT de Rennes (no date) Charte d'utilisation des réseaux/médias sociaux numériques IUT de Rennes. Available at: http://partages.univrennes1.fr/files/partages/Services/IUT_administration/Internet/doc/IUTrennesCharteRSN.pdf (Accessed: 21 March 2017), pp. 3-4. and Orange (no date) Social Media Guidelines. Available at: https://www.orange.com/sirius/smg/FR_Guides_Medias_Sociaux.pdf (Accessed: 22 March 2017).\#4 
personal life, employers can prohibit registering to SNSs using the professional e-mail address, or referring to the workplace or to the position of the employee in the user name or in the name. Regarding the use of the company's logo: the employer can completely prohibit its use, and it is especially recommended to prohibit its use as profile or cover picture. ${ }^{2186}$ However, indicating amongst the biographic data that the employee works at the given company should be allowed.

In order to prevent any confusion between official and non-official use, several policies suggested using a disclaimer indicating that the employee's remark does not reflect the employer's position. ${ }^{2187}$ However, the effectiveness of such a disclaimer is debated, as it might just draw unnecessary attention to the identity of the employer. ${ }^{2188}$

781. Even when the employee does not reveal the identity of his/her employer in the biographic information, there is no guarantee that this information will stay concealed. A comment originating from another user, or a simple Google search might easily reveal the identity of the user's employer. Therefore, during any use of SNSs, against any other user, employees should respect the other users' dignity and should not use excessive, insulting or defamatory expressions: employees should refrain themselves from committing libel or defamation, or inciting hatred. The publication of vulgar, humiliating jokes or content should be avoided. It is also forbidden to harass or attack competitors (e.g. through sending SPAM). Employees should publish an appropriate and respectful content, while staying honest and accurate. The publishing of misinformation should be quickly corrected. $^{2189}$

782. In addition to these general requirements, employees should respect the employer's reputation and cannot publish content that violates the reputation. The employee can still express his/her opinion (even if it is a negative one), however, it cannot constitute abuse or be seriously detrimental to or threaten the good reputation, legitimate

\footnotetext{
${ }^{2186}$ See the already presented case of the university chancellor and the post that made him resign.

2187 Walmart's policy in: Solomon, L. E. (2012) Memorandum OM 12-59. Office of the General Counsel Division of Operations-Management. Available at: http://www.rc.com/documents/OM1259ActingGeneralCounselReportConcerningSocialMediaCases.pdf (Accessed: 30 November 2018).

${ }^{2188}$ Kajtár, E. (2015) 'Európai ügyek a Facebook sötét oldaláról - A munkavállalók közösségi oldalakon tanúsított kötelezettségszegő magatartása', in Horváth, I. (ed.) Tisztelgés: ünnepi tanulmányok Dr. Hágelmayer Istvánné születésnapjára. Budapest: ELTE Eötvös Kiadó, p. 211.

2189 Walmart policy in: Solomon, L. E. (2012) Memorandum OM 12-59. Office of the General Counsel Division of Operations-Management. Available at: http://www.rc.com/documents/OM1259ActingGeneralCounselReportConcerningSocialMediaCases.pdf (Accessed: 30 November 2018).
} 
economic and organizational interests of the employer. The position of the employee is also important: the higher the position occupied is, the more loyal the employee should be. The use of language has key importance, vulgar, insulting, excessive expressions should be avoided, and the opinion should be of a neutral nature (even though it can even criticise the employer).

783. The employee should respect the employer's business secrets: confidential information cannot be shared on these sites. The same goes for the personal data of clients, sharing information relating to upcoming products, etc.

784. Monitoring of compliance. Besides regulating employees' conducts, employers can also monitor compliance with the rules set by the policy. However - in accordance with the general requirement of transparency laid down both by data protection and labour law regulations -, if the IT section starts to systematically monitor employees' online publicly available actions, they must be informed of these measures prior to the monitoring. It cannot be stressed enough that the employer can only monitor the public posts/activity of the employee (without using any schemes in order to gain access). Also, the requirement of prior information persists in spite of the fact that it is the employee who made the content public. ${ }^{2190}$

785. If the employer opts for monitoring, privacy and data protection matters are separated. If the employer monitors such a public content, the violation of the employee's right to respect for private life is not raised, ${ }^{2191}$ as it was the employee himself/herself who chose to publish the given content. However, it does not mean that such a control could be exempt from legal requirements: data protection requirements, such as prior purpose limitation, proportionality, necessity, data quality, etc. are still going to be applicable. ${ }^{2192}$

786. Sanctions. In the part "sanctions" employees' attention should be drawn to the fact that in the case of the non-respect of the regulation what (especially labour law related) legal consequences might be applied (e.g. issuing warnings, or even terminating the employment relationship).

\footnotetext{
${ }^{2190}$ Griguer, M. (2010) 'Les réseaux sociaux sous le contrôle des DSI', Cahiers de droit de l'entreprise, (6), p. 64.

${ }_{2191} \mathrm{Fel}$, C. and Sordet, E. (2010) 'L'utilisation des réseaux sociaux par l'entreprise et ses collaborateurs', JCP S (édition sociale), (29), p. 22.

${ }^{2192}$ Caprioli, É. A. (2012) 'Les propos tenus par une salarié sur Facebook peuvent justifier son licenciement', Communication Commerce Électronique, (4), p. 39.
} 
787. References. Finally, among references it is recommended that the employer refers to the legal basis of the policy (labour code, data protection act, etc.), to the other existing policies (e.g. code of ethics, code of conduct, etc.) and notes where the employee can obtain more information relating to the subject (both within the organisation, for example, from the HR team, and outside of it, for example, from a DPA).

\section{§2. Outside the workplace}

Albeit regulating and raising awareness internally is a crucial step towards preventing employee misuse of SNSs, other factors external to the workplace can also contribute to achieving this result. First, $(A)$ the development of different technological features can empower users to use SNSs in a more privacy-friendly way, while $(B)$ educating users at a societal level can contribute to adapting a more conscious attitude towards SNSs. ${ }^{2193}$

\section{(A) Technology}

788. From a technological point of view, SNS service providers can contribute to helping to establish the balance between the employer's legitimate interests and the employees' rights through the adoption of built-in privacy and data protection features. Although the documents examined during the research mainly aim to ensure enhanced privacy protection on SNSs in general ${ }^{2194}$ and do not focus specifically on challenges related to employment, their findings can be useful in the employment context as well. Here, those elements will be presented that have special significance when it comes to the use of SNSs and off-duty conducts.

789. Developing privacy settings. Through developing more customizable privacy settings (instead of the often used all or nothing approach), users would have the

\footnotetext{
${ }^{2193}$ It must be emphasized that these recommendations, such as technological developments and raising awareness/educating users, are crucial not only as regards off-duty conducts and SNSs but are also extremely important during all phases of employment: during the course of hiring and SNS use during working hours. Therefore, the findings of the following paragraphs can adequately be applied to other phases of the employment relationship as well.

2194 See, for example: 30th International Conference of Data Protection and Privacy Commissioners Strasbourg, 17 October 2008 Resolution on Privacy Protection in Social Network Services; Council of Europe (2012) 'Recommendation CM/Rec(2012)4 of the Committee of Ministers to member States on the protection of human rights with regard to social networking services'., WP29 (2009) Opinion 5/2009 on online social networking. 01189/09/EN WP 163., International Working Group on Data Protection in Telecommunications (2008) Report and Guidance on Privacy in Social Network Services - "Rome Memorandum” -. 675.36.5. Rome.
} 
possibility to exercise their right to informational self-determination and carefully determine what audiences can have access to what kind of content. Also, privacy setting should be by default enabled (therefore the user should decide not to use them, and not the other way around). ${ }^{2195}$ In several cases, the remarks were considered to be public because of the lack of use of the privacy settings, so this measure would contribute to decreasing the number of cases when the employee abuses his/her freedom of expression. ${ }^{2196}$

790. Using pseudonyms. The possibility to use pseudonyms is considered to be a way to contribute to better protecting privacy on SNSs. ${ }^{2197,}{ }^{2198}$ Although indeed it is a way to establish more effective privacy protection, it should be emphasized that it does not mean that employees are free or encouraged to state anything while hiding under pseudonyms. Regardless of the chosen username - whether it is the real name of the employee, a fake name, or a pseudonym - the employee's conduct should not overstep the limits of freedom of expression, as the limits drawn by labour law are still valid. In this regard, pseudonyms (if they are well-chosen) can contribute to making it more difficult to identify the link between the given content and the employer, through masking the true identity of the author of the content. However, as it could be seen from the case law, even pseudonyms do not guarantee $100 \%$ anonymity, as the identity of the author or of the subject of the remarks can be later identified by third persons (e.g. in a comment).

791. Protection against impulsive (or drunk) posting. Jean-Emmanuel Ray points to an application that can contribute to preventing employees from sending compromising e-mails while being under the influence of alcohol. ${ }^{2199}$ An application called Goggles allows users to practice self-control through verifying that the user indeed possesses his/her mental capacities. During certain previously set periods (e.g. from Saturday $21 \mathrm{~h}$ to Sunday $13 \mathrm{~h}$ ), if the user wants to send an e-mail, he/she has to solve

\footnotetext{
${ }^{2195}$ WP29 (2009) Opinion 5/2009 on online social networking. 01189/09/EN WP 163, p. 7. and International Working Group on Data Protection in Telecommunications (2008) Report and Guidance on Privacy in Social Network Services - "Rome Memorandum" -. 675.36.5. Rome, p. 6.

${ }^{2196}$ Although Article 25 of the GDPR on the requirement of data protection by default is a huge step ahead.

2197 30th International Conference of Data Protection and Privacy Commissioners (2008) Resolution on Privacy Protection in Social Network Services. Strasbourg; International Working Group on Data Protection in Telecommunications (2008) Report and Guidance on Privacy in Social Network Services - "Rome Memorandum" -. 675.36.5. Rome, p. 5.

${ }^{2198}$ For example, Facebook's Terms of Service states that users must "use the same name that [they] use in everyday life", rejecting the possibility to use pseudonyms.

${ }^{2199}$ For example, in the already discussed case of Taylor v Somerfield Stores Ltd., the employee posted the "incriminating" video to YouTube after having a few drinks with his colleagues and admitted that he probably would not have uploaded the video if he had been sober. Source: Taylor v Somerfield Stores Ltd. Case no: S/107487/07 Held at Aberdeen on 24 July 2007, par. 11.
} 
certain mental calculations, and if the solution is not found during one minute, the e-mail is not going to be sent. ${ }^{2200}$

Although this method was established for e-mails and would not prevent employees from exercising freedom of expression in an excessive way, with certain modifications it might contribute to decreasing the number of such remarks. A solution might be the development of an algorithm that would detect when a user posts a content containing excessive, extremely insulting expressions. Then after hitting the post button, a warning message might appear, informing the employee that insulting expressions were detected and asking the user's confirmation that despite the content, he/she still wishes to publish it. $^{2201}$

\section{(B) Raising awareness and educating}

792. Raising awareness has a crucial importance in order to contribute to the promotion of a more conscious SNS use and the prevention of the occurrence of labour law issues related to the use of SNSs. Awareness raising can take place at several levels, such as educating users in general, educating employees or even at the level of the legislator/judges.

793. It often seems that users (and amongst them, employees) do not even realize that they are not free to post anything to SNSs without bearing the consequences, or what they post to SNSs is not of private nature. When using such platforms, users should be aware of whether the information they share has public or private character and they should be aware of the consequences of choosing to share an information publicly. ${ }^{2202}$ Employees should be educated that their acts might abuse their freedom of expression even outside the workplace and beyond working hours. This could contribute to preventing

\footnotetext{
${ }^{2200}$ Ray, J.-E. (2009) ‘Actualité des TIC (II). Rapports collectifs de travail’, Droit social, (1), p. 34.

${ }^{2201}$ A similar idea was raised by Jay Parikh, a vice-president of Facebook, in relation to posting children's photos to Facebook. He said the service was considering setting up a system to notify parents who put photographs of children online without restricting their privacy settings. If a parent wanted to accidentally share a picture of his/her child with everyone, the system would notify this person that a child is in the picture, and ask whether he/she truly intended to share it publicly, instead of sending it in a message only destined to the members of the family. Source: Chazan, D. (2016) French parents 'could be jailed' for posting children's photos online, The Telegraph. Available at: https://www.telegraph.co.uk/news/worldnews/europe/france/12179584/French-parents-could-be-jailedfor-posting-childrens-photos-online.html (Accessed: 30 November 2018).

2202 Recommendation CM/Rec(2012)4 of the Committee of Ministers to member States on the protection of human rights with regard to social networking services (Adopted by the Committee of Ministers on 4 April 2012 at the 1139th meeting of the Ministers' Deputies), Appendix
} 
abuses of freedom of expression, as employees would be more aware regarding how social media works and by what legal rules and how they are bound.

794. Raising awareness is a complex matter, where several actors might have roles. Even though the employer can highly contribute to preventing these issues by laying down the rules to be respected through adopting internal social media policies, awareness raising at a more general, societal level would also be welcomed. This could be realised, for example, with the participation of DPAs ${ }^{2203}$ and with different state actions. Finally, as employees are not only passive actors waiting to be saved by DPAs or the state, their role and responsibility has crucial importance as well.

795. Role of the state. The state should take active steps in order to fight against "analphabetism"2204 and to educate users regarding the challenges of protecting private life in the age of ICT. Younger users' (under 15 years old) "civic-digital" education should be reinforced by raising their awareness relating to intimacy and identity. ${ }^{2205}$ Also, informing them on the privacy risks related to Internet use should be part of the education system, while steps should be taken to educate older users as well (e.g. developing online materials). ${ }^{2206}$

796. SNS providers. The different documents all emphasized ${ }^{2207}$ the SNS provider's responsibility as regards providing enough information and education to users regarding how they should use these sites, how privacy settings are used, what possible legal consequences SNS can have, how they can delete content, etc. Besides raising awareness, their role is crucial in determining the technical functioning of SNSs, for example, by establishing what types of data protection rules can be applied, whether it is possible to use pseudonyms, etc.

\footnotetext{
${ }^{2203}$ What was already said in the case of prospective employees in Title 1 should apply accordingly.

2204 Expression used by Jean-Emmanuel Ray in: Ray, J.-E. (2011) 'Facebook, le salarié et l'employeur', Droit social, (2), p. 133.

2205 Türk, A. (2011) La vie privée en péril: des citoyens sous contrôle. Paris: OJacob. p. 148.

2206 Mendel, T. et al. (2013) Étude mondiale sur le respect de la vie privée sur l'Internet et la liberté d'expression. Paris: Éditions Unesco (Collection Unesco sur la liberté de l'Internet). pp. 131-132.

2207 Council of Europe (2012) 'Recommendation CM/Rec(2012)4 of the Committee of Ministers to member States on the protection of human rights with regard to social networking services', Appendix.; WP29 (2009) Opinion 5/2009 on online social networking. 01189/09/EN WP 163, p. 7.; International Working Group on Data Protection in Telecommunications (2008) Report and Guidance on Privacy in Social Network Services - "Rome Memorandum" -. 675.36.5. Rome, p. 5.; ENISA (2007) Security Issues and Recommendations for Online Social Networks. Position Paper. p. 3.; 30th International Conference of Data Protection and Privacy Commissioners (2008) Resolution on Privacy Protection in Social Network Services. Strasbourg, p. 4.
} 
797. The employee. No matter how complex and well-structured a state's educational programme on the Internet and privacy is if users do not take steps to ensure their own protection. ${ }^{2208}$ Individuals as well should recognize that they have to play an active role in protecting their own privacy in the information society. ${ }^{2209}$ The already presented "Grandmother rule" 2210 should also apply in the case of employees, and not only prospective employees. Employees should recognize that SNSs do not always guarantee the desired level of confidentiality, and a content published can become available to a larger audience than originally intended to. As a response to these uncertainties relating to SNSs, Patrik Polefkó even suggests users should be a little paranoid, which means they have to keep in mind that on SNSs not everything is as it seems. ${ }^{2211}$

798. According to certain authors, such as for example Vanessa Nivelles, ${ }^{2212}$ or the Liga Szakszervezet (Liga Trade Union), ${ }^{2213}$ the best solution would be to refrain from any discussion relating to the workplace. However, according to my opinion, such conduct - although it would indeed eliminate the problem of employees abusing their freedom of expression - would self-restrict employees in a disproportionate way. According to the regulation, it is not forbidden to discuss work related matters or to express opinion in relation to the employment. What is forbidden is to do so in an excessive way. Ian Byrnside expresses his similar opinion (although in relation to prospective employees) arguing that job applicants should not erase their SNS profiles, but rather learn how to post according to the nature of these sites and keep in mind the possible consequences. ${ }^{2214}$

799. Educating the legislator and judges. However, it is not only employees who need to be educated on the functioning of the Internet and SNSs. It is an additional

\footnotetext{
2208 Mendel, T. et al. (2013) Étude mondiale sur le respect de la vie privée sur l'Internet et la liberté d'expression. Paris: Éditions Unesco (Collection Unesco sur la liberté de l'Internet). pp. 131-132.

2209 Székely, I. (2010) 'Kukkoló társadalom - avagy van-e még függöny virtuális ablakunkon?', in Talyigás, J. (ed.) Az internet a kockázatok és a mellékhatások tekintetében. Budapest: Scolar Kiadó, p. 119.

2210 Byrnside, I. (2008) 'Six Clicks of Separation: The Legal Ramifications of Employers Using Social Networking Sites to Research Applicants', Vanderbilt Journal of Entertainment and Technology Law, 10(2), p. 474.

${ }^{2211}$ Polefkó, P. (2011) 'Barátok és bizonytalanságok közt (5. rész) : avagy a közösségi oldalakról adatvédelmi szemszögböl', Infokommunikáció és jog, (44), p. 109.

2212 Nivelles, V. (2014) 'Les entreprises à l'épreuve des réseaux sociaux', Jurisprudence Sociale Lamy, (377378), p. 13.

2213 Szilágyi, K. (2013) Facebook-szabályzat: beleszólhat- a munkáltató?, Adó Online. Available at: https://ado.hu/munkaugyek/facebook-szabalyzat-beleszolhat-a-munkaltato/ (Accessed: 15 November 2018).

2214 Byrnside, I. (2008) 'Six Clicks of Separation: The Legal Ramifications of Employers Using Social Networking Sites to Research Applicants', Vanderbilt Journal of Entertainment and Technology Law, 10(2), p. 473.
} 
problem that sometimes even lawmakers or judges are not aware of the functioning of social media and other Internet-based platforms.

An illustrative example is Facebook founder and CEO, Marc Zuckerberg's two days of testimony before the US Senate in 2018, following the Cambridge Analytica scandal, where he received certain questions, which demonstrated complete ignorance of the basic functioning of these online services. Such questions included "Is Twitter the same as what you do?" (Twitter is a different platform), "If I'm email — if I'm mailing — emailing within WhatsApp [...]" (WhatsApp is a chat messaging system that is not capable of sending e-mails) and "Well, if [there will always be a version of Facebook that is free], how do you sustain a business model in which users don't pay for your service?" (by running ads). ${ }^{2215}$

Judges might not always fully understand the functioning of SNSs. Another example is pointed out by Marie-Claire Pottecher and Zartoshte Bakhtiari, who brought attention to the judge's observation in a case relating to the use of Twitter during working hours, according to which it takes one minute to make a tweet. However, according to the authors, the judge did not take into account how Twitter works in reality: constructing a tweet requires more time and attention than the one minute that it technically takes to write down 140 characters. ${ }^{2216}$ Another example is the already mentioned observation of the Court of Appeal of Pau's, ${ }^{2217}$ in which the court referred to the "private and public walls" of the user, applying quite confusing vocabulary, which can hardly be interpreted in the light of the true functioning of Facebook, as every user possess one "wall".

Naturally, in order to be able to adopt up-to-date legislation in the field of ICT or SNSs, it is crucial that lawmakers understand the functioning of these services that they aim to regulate. Also, judges must know and understand the functioning of these sites in order to make judgements correctly. If these actors are not aware of the most basic technical aspects of SNSs, the adoption and the application of laws might become problematic.

2215 See the transcript of the hearing at: Transcript of Mark Zuckerberg's Senate hearing (2018) The Washington Post. Available at: https:/www.washingtonpost.com/news/the-switch/wp/2018/04/10/transcriptof-mark-zuckerbergs-senate-hearing/?noredirect=on\&utm_term=.2547f6e741d5 (Accessed: 15 October 2018).

2216 Pottecher, M.-C. and Bakhtiari, Z. (2016) 'Travailler ou tweeter, le salarié n'a pas (forcément) à choisir', Cahiers sociaux du Barreau de Paris, (285), p. 234.

${ }^{2217}$ CA Pau, chambre sociale, 6 septembre 2018, n ${ }^{\circ}$ 17/01648 
800. Conclusions of Section 2. In conclusion, in order to successfully address the question of employees' use of SNSs outside the workplace, a complex approach should be adopted, taking measures at several levels: the employer, the state, SNS providers and the individual.

As there exists no one-size-fits-all solution, the employer's role is of particular importance within the workplace: the employer is the person who - taking into account the specificities of the workplace - can determine what exactly the rules to be followed are. It is recommended that these rules are laid down in internal social media policies, providing detailed guidance for employees and raising awareness among them regarding the use of SNSs and its possible (legal) consequences. Such policies can be means to adopt the general provisions laid down in the FLC and the HLC to the specific requirements of the given workplace.

At a more general level, raising awareness amongst the individuals has key importance, as it can influence or even make them more conscious while engaging in SNSs. The state itself can play a huge part by drawing attention to the data protection challenges through its different institutions. Also, the state might even "interfere" earlier through integrating the use of SNSs (and challenges relating to it) into public education courses, from a young age. It is also important that SNS providers develop technical features making it possible to effectively enhance privacy/data protection - therefore they determine the whole framework which is later going to be used by individuals. Also, they can play a role by providing general information to the public. Last but not least, the individual's role must be taken into account: in the first place, it is the individual who should engage in a responsible use of SNSs. Individuals have the greatest impact on the functioning of SNSs as they fuel these services with their personal data. They choose the content that they post, like or share, decide whether to use the privacy settings - thus are central actors in influencing the possible labour law consequences of their online behaviour.

\section{Conclusions of Title 3}

801. Change of paradigm. The number of terminations of employment is growing due to the extremities on the part of employees and employers as well - making it urgent to adequately regulate such matters. Despite the fact that employees could damage 
the employer's reputation through various conducts in the offline world as well, SNSs brought a change of paradigm, as they do not only blur the boundary of personal and professional life, but also facilitate sharing (even false) content impulsively and instantly (often resulting in the use of excessive expressions), increase their discoverability (as SNSs are often available to colleagues, clients, supervisors, etc.) and contribute to creating a link between the user and his/her employer (either through naming the employer or through indicating the employer on the profile). The hypothesis of Title 3 related to the possible existence of a reversed vulnerability between the employer and the employee when it comes to the collision of rights and interests: the dissertation holds that due to the presented features of SNSs, employees can potentially jeopardize/harm the employer's rights to an increased extent, tilting the balance towards the employer.

802. Throughout Title 3 the main differentiation was established between behaviour/content directly or indirectly relating to the workplace, and within these two categories between expressing opinion and other conducts (e.g. uploading photos or videos). Especially in relation to expressing their opinion, employees often use SNSs as a platform to release their anger or tension, forgetting that although they indeed act in their personal lives, they do not cease to be bound by certain obligations originating from their employment relationship. It is very important to note that even despite the changes that SNSs brought to employees' expression, they still have the right - within the limits set by regulation - to criticise their employer. The same goes for prohibiting the use of SNSs: a complete prohibition would seem disproportionate, while imposing limitations on their use is legitimate.

803. Privacy and data protection. As far as off-duty conduct and SNSs are concerned, challenges relating both to privacy and to data protection arise. Data protection questions might especially arise when the employer decides to systematically monitor employees' off-duty conduct on SNSs. However, the application of data protection principles gives rise to fewer doubts than in other phases of the employment (e.g. recruitment). In relation to privacy, it must be established where the balance should be found between the protection of the employee's personal life and the employer's rights. The main question to be answered was whether these platforms constitute a private or a public forum, as although it is not contested that these conducts take place in the course of the employees' personal life, an SNS post can reach an extremely large audience, which excludes the private character of such content. 
French courts, especially after the Social Chamber of the Court of Cassation ruled in the matter, came to the conclusion - according my opinion, correctly -, that as a main rule, SNSs are public platforms unless the user applies strict settings and considerably limits the circle of people who can access the content, both regarding their number and their relationship with each other. Even though in Hungary courts have not (yet) addressed this question, French jurisprudence can serve as an example when it comes to defining the nature of these sites.

804. Regulation of the protection of personal life. Even though these conducts take place in the course of the personal life of the employee, professional life flows into personal life, as the employee is still bound by certain obligations. In French law, it is through the obligation of loyalty that the employee's off-duty conduct is limited, while the HLC expressly states that even outside the workplace the employee is subject to certain restrictions. ${ }^{2218}$ Despite these limitations, the employee's personal life is protected: neither in French, nor in Hungarian labour law can personal life constitute a basis of dismissal unless certain conditions are met.

805. The main difference between France and Hungary is that in France cases relating to the termination of employment already reached the courts (and even the Court of Cassation); while in Hungary case law is very limited, although several cases have attracted media attention. Also, in France, the doctrine is more abundant as well, although certain scholars in Hungary also started to examine the question of SNSs and labour law.

2218 Although in French law it can be derived from the duty of loyalty that even outside the workplace the employee is bound by this obligation, an amendment of the FLC specifying the existence of this obligation outside the workplace - similarly to the HLC - might be welcomed. 


\section{GENERAL CONCLUSIONS}

806. Employee privacy and data protection. Protecting employees' rights, and more precisely their right to privacy and right to data protection is not a new phenomenon: its main rules were already established through addressing the different technological means enabling to monitor employees, such as through applying CCTV surveillance or monitoring the use of the Internet/computer/e-mail/telephone, etc. The detailed rules of such monitoring are already elaborated both at the international ${ }^{2219}$ and at the national level. ${ }^{220}$ It was established that employees are entitled to enjoy these rights not only outside, but also inside the workplace - but at the same time, originating from their status of employee, certain obligations continue to impose limits on their behaviour even outside the workplace, beyond working hours.

807. The employer's rights. Neither the right to privacy, nor the right to data protection is an absolute right. As opposed to them, the employer has various rights which can justify their restriction; e.g. right to property, right to reputation, right to the protection of legitimate economic interests - notably manifested in the employer's right to control and right to monitor employees' activities. In the phase of recruitment he/she is entitled to choose with whom he/she would like to contract - in order to assess the capacities of the applicant he/she is entitled to obtain information on the applicant. If privacy and data protection requirements are respected, this can include SNSs as well. In the case of SNS use at the expense of working hours, it follows from the obligations and rights of the parties that the employee is obliged to spend working hours performing work, while the employer is legally entitled to expect him/her to do so. In addition, as the person responsible for the organisation of work, the employer has the right to give instructions, define the use of workplace equipment and monitor compliance. When it comes to off-duty use of SNSs, the employees' presence on SNSs (through expressing their opinion or engaging in other conducts) can collide with the employer's right to reputation, the protection of business secrets, or with the rules relating to competition.

${ }^{2219}$ See, for example, the WP29 or the EDPS.

${ }^{2220}$ Notably through the practice of the data protection supervisory authorities; and in France also through courts' case law. 
808. SNSs and the intensification of the collision of rights. Despite the fact that this collision of rights already existed, the dissertation held that SNSs put it into a new perspective, through intensifying the collision between the employees' right to privacy and right to data protection ${ }^{2221}$ and the employer's rights (Hypothesis 1). The intensification is brought by the fact that on the one hand, through monitoring or regulating employees' use of SNSs, the employer can take a glimpse into the personal life of the employee to an extent never seen before, with ease, due to the vast amount of information shared on SNSs by users. On the other hand, the employee is capable of jeopardizing the employer's rights in more serious forms (e.g. Facebook "addiction", which can seriously affect working hours, or harming the employer's reputation in more severe ways as a result of the public nature of these sites, the style usually used on them, the possible identification of the employer, etc.) due to the change of paradigm brought by SNSs. Therefore, both parties are increasingly interested in enforcing their rights, resulting in the intensification of the collision of rights. Furthermore, it was also held that SNSs have contributed to the blurring of the boundaries between personal and professional life - which also challenges the establishment of a balance between the two sides.

809. French and Hungarian regulation. The analysis of the dissertation primarily focused on France and Hungary and was also highly determined by the membership of France and Hungary in the same international organisations (especially the EU and the $\mathrm{CoE}$ ). In both countries the general legal framework was already established (see particularly the FLC and the HLC), although without expressly mentioning SNSs: thus what had to be examined is how exactly existing rules can be applied to SNSs, whether there are adjustments needed, what the specific challenges raised by these platforms are.

Although legislations stayed at a general level not specifying SNSs, there are cases dealing with the question of SNSs - employment - employees' rights. The difference found between the two examined countries is that in France more abundant case law exists in this field, while in Hungary these cases are mainly reported in the media and have not necessarily reached courts (yet). As such, the dissertation held that the rules and criteria established by French courts might serve as an example for Hungarian courts in the future when they have to establish their own case law. Besides courts, the practice of the DPAs

\footnotetext{
2221 The use of SNSs can relate to the right to privacy, as in the dissertation the right to privacy was understood as the right to decide how to live one's life, including the possibility to decide whether to engage in using SNSs and how. As regards data protection, these sites contain a number of personal data, to the processing of which data protection requirements must be applied.
} 
must be mentioned: both the CNIL and the NAIH already addressed the question of SNSs - employment - data protection, however, neither of them did that in an exhaustive manner, they focused on one aspect of the subject. Consequently, the significance of the dissertation lies in the fact that it examines the subject exhaustively, aiming to analyse the situations which are encountered in everyday life the most frequently.

From the analysis of French and Hungarian regulations, the following de lege ferenda suggestions were proposed. The first de lege ferenda suggestion aims to better adapt to the realities brought by ICT and amongst them SNSs: it recommended the modifications of the FLC and the HLC, by not only regulating what kind of information can be requested from applicants/employees, but the wording of the relevant provisions should also include information that can be collected. ${ }^{222}$ Such an amendment would remove any uncertainty resulting from the strict grammatical interpretation of the existing provisions of the labour codes. The second de lege ferenda suggestion relates to the HLC and recommends clarifying in Hungarian law - and in French law alike - that the relevant data protection regulations of the HLC are applicable to job applicants as well. Such a clarification might include the insertion of a subsection stating that these provisions are to be applied to job applicants as well. ${ }^{2223}$

810. Application of the existing rules to SNSs. The application of the existing rules to SNSs was examined in three areas (recruitment, the use of SNSs at the expense of working hours, employees' activities and behaviour on SNSs), as SNSs raise different kinds of questions in these areas.

811. First, it must be examined: can the employer control and monitor employees' use of SNSs? Regarding monitoring, the answer is easy: yes, he/she can process publicly available data, but must do it respecting the right to data protection. It means that a legitimate legal ground, a legal purpose must be present, with the respect of data protection principles, etc. The control of the use of SNSs did not emerge in the pre-

\footnotetext{
2222 Thus, the following solution (suggestion in italics) is recommended as a de lege ferenda suggestion: Proposed Article L1221-6 of the FLC: "The information requested from or collected about a job applicant in any form whatsoever - shall only have the aim to assess his/her fitness for the proposed employment or his/her professional competence."

Proposed Subsection (1) of Section 10 of the HLC: "An employee may be requested to make a statement or to disclose certain information, or information relating to him/her can be collected only if it does not violate his/her rights relating to personality, and if deemed necessary for the conclusion, fulfilment or termination of the employment relationship."

${ }^{2223}$ Such a subsection might be formulated as follows: "Subsection (6) of Section 10: Subsections (1)-(5) are also adequately applicable to job applicants."
} 
employment phase, as in this phase the employer has no right to instruct prospective employees and to determine (or prohibit) the rules on how they can engage in SNSs. During working hours, it was established that the employer can regulate the use of SNSs as the employees are contractually obliged to spend their working hours performing work. However, although employees do not have a right to use SNSs in the workplace, they have the right not to be completely cut off from the outside world (e.g. to have the possibility to notify family members or friends in case of an emergency, etc.). Despite this legal possibility, it was recommended that, if possible, the use of SNSs should not be completely prohibited but rather allowed to a determined extent. As regards employees' activities on SNSs, it was held that the employer can also impose limitations on their use.

812. The main arising privacy and data protection challenges. During preemployment SNS background checks, it was held that the employer should not base his/her decision on the personal life of the employee, but on his/her professional capacities. However, as the personality of the applicant can also be taken into consideration, the exact boundaries of personal and professional life are blurred. SNSs raised the issue that the information that could be legally taken into consideration by the employer and the information that cannot are typically present on SNSs in an inseparable way. In addition, on SNSs the employer can access personal data in a quality and quantity never seen before, allowing him/her to access a wide range of information that would not have been available to him/her in the pre-SNS era. Does consulting the applicant's SNS profile constitute an intrusion into his/her private life? It was established that in cases when the individual posted certain information publicly, the intrusion was unlikely to occur, as it is not reasonable to expect the employers not to consult this publicly available information. ${ }^{2224}$ The protection of applicants' rights can also be approached from the aspect of data protection, as accessing and then using these data can be better assessed through data protection, since compared to the unclear boundaries between "personal" and "professional" information, data protection has a more exact terminology. In the field of data protection, data quality principles raised some important isssues, as the enforcement of this principle is extremely questioned.

\footnotetext{
${ }^{2224}$ In relation to access it was held that the employer can usually access information that was made publicly available. This means that the user has not applied privacy settings and is freely available to other users of SNSs. However, using stratagems (e.g. creating a fake profile to "friend" the employee, hacking, asking for a password, asking for changing the privacy settings - any method used to bypass the privacy settings or the intended audience chosen by the user) is not compatible with legal regulations.
} 
As regards pre-employment, one of the main challenges is related to the invisibility of SNS background checks, and thus to the enforcement of the protection of applicants' rights. As typically these searches stay invisible, it is highly questionable that the employer would subject himself/herself to the strict requirements imposed by data protection law. Thus, Hypothesis 2 held that due to these challenges (e.g. invisibility of background checks), the adoption of a more flexible regulation is needed, through aiming to make employers realize that respecting data protection requirements will lead to more reliable decision-making (otherwise they would be counter-effective in finding the most suitable applicant), thus constituting a more effective way to protect job applicants' rights than completely prohibiting these searches.

813. During working hours privacy questions were raised in relation to the possible prohibition of SNS use. Employees are entitled to privacy even within the workplace, and privacy also means the right to establish relationships with others, and today SNSs constitute a preponderant forum for communicating and staying in touch with contacts, thus the question was raised whether the employer can completely prohibit their use. It was found that the employer can freely determine the use of work equipment: the only limitation to be respected is that it must be ensured that in exceptional cases the employee is able to communicate. As SNSs are not the only means for communication, the employer can decide to completely prohibit their use. After establishing the bans (or limitations in the case of a more permissive regulation), the employer is also entitled to monitor whether employees complied with the rules. Such a monitoring was approached from the angle of data protection.

In the case of SNS use at the expense of working hours, fewer substantially new questions were raised compared to the other fields; as a consequence, Hypothesis 3 held that the existing rules established for the monitoring of the personal use of the Internet and e-mail are in most regards capable of adequately regulating SNSs as well - despite new challenges raised by SNSs (e.g. accessing SNSs from the personal devices of the employees or considering that as opposed to e-mail, on SNSs it is more difficult to identify their use as personal).

814. In the case of employees' presence and activities on SNSs, typically conducted outside the workplace, privacy questions were raised in relation to imposing limitations on the employees' freedom of action, by imposing rules on whether - and if yes, how - they can participate in SNSs. Following from the employees' obligations, 
naturally he/she can be expected to be subject to certain restrictions, however, these cannot be limitless. During the establishment of the legal limits of such restrictions, it should be taken into consideration that in the light of the intensification that SNSs brought to the collision of rights, employers have found themselves in an even more vulnerable position (Hypothesis 4). However, apart from certain exceptional cases, completely prohibiting the use of SNSs does not seem legally acceptable. Imposing limitations on their use is more feasible; however, the exact extent of such limitations is highly dependent on the workplace and on the position of the employee. Data protection questions were raised in relation to monitoring, when the employer decided to monitor or to use data available on SNSs in order to assess compliance or impose certain sanctions.

815. Recommendations. In the light of the above, different recommendations and proposals were made throughout the dissertation. It was held that in order to successfully address challenges posed by SNSs, a complex approach should be adopted, containing recommendations for the legal sphere (especially to lawmakers, judges and data protection supervisory authorities), for the employer (mostly aiming at the adoption of internal policies), for technology (encouraging SNS providers to adopt privacy and data protectionfriendly technological solutions) and finally for the individual himself/herself.

816. Recommendations for the legal sphere. ${ }^{2225}$ For all actors making decisions in the legal sphere (lawmakers, judges, members of data protection supervisory authorities) it is crucial to be aware of the exact functioning of SNSs in order to avoid inaccurate or hardly interpretable reasoning or rules - as it has already happened on different occasions. This can be achieved, for example, through organizing trainings.

817. Recommendations for data protection supervisory authorities. For data protection supervisory authorities it is recommended to issue a document or information notice in which they extensively lay down the most important rules with regard to SNSs and employment, ${ }^{2226}$ as such a document can highly contribute to the uniform interpretation of the privacy and data protection requirements relating to SNSs and labour law. ${ }^{2227}$ These rules would include, for example, specifying the public-private nature of SNSs, clarifying the applicability of the rules to SNSs, challenges and solutions relating to

\footnotetext{
2225 See the de lege ferenda suggestions above.

${ }^{2226}$ As they did in the case of traditional means of employee monitoring.

2227 Especially in Hungary, where there is considerably less case law, compared to France. In France, the drafting of such a document can rather serve as a summary of the existing rules elaborated by court decisions.
} 
data quality, ${ }^{2228}$ requirement of transparency and participation of the data subject, principle of proportionality (in relation to prohibiting or monitoring), assessment factors to be considered on a case-by-case basis (e.g. position of the employee, nature of the post, frequency and time spent on SNSs, publicity of posts, consequences of the post, antecedents, etc.). For the NAIH, it was suggested measuring whether more accessible online presence can be achieved - for example, through social media - possibly based on the example set by the French data protection supervisory authority. Although this would not instantly resolve challenges related to data protection and employment, it would constitute an important step in raising awareness and promoting the right to data protection.

818. Recommendations for the employer. The employer also plays an important role when it comes to SNSs and employment: as it was seen, it originates from the different rights and obligations imposed on the parties that the employer can control and monitor the employees' use of SNSs. It is the employer's right to determine - in accordance with legal regulations - the exact rules of such control and monitoring, considering the specificities of the given workplace. In addition to the legal obligation of prior information, it was recommended in the dissertation that the employers adopt internal social media policies in order to effectively communicate the rules and expectations relating to/towards employees. Also, organizing internal trainings in order to raise employees' awareness might be recommended.

819. Recommendations for service providers. As regards technology, SNS providers can also contribute to the protection of personal life by developing technical measures to enhance the protection. This can be achieved, for example, through enabling the users to use pseudonyms, the possibility of choosing customized privacy settings, and also through raising awareness.

820. Recommendations for the individual. Lastly, the (prospective) employee's role must be mentioned: despite the creation and existence of a protective legal

\footnotetext{
${ }^{2228}$ With regard to data quality, another suggestion proposed by the dissertation is that during the recruitment process - in order to handle the challenges relating to the outdatedness of personal data available on SNSs and to the right to be forgotten - a time limitation period for the processing of personal data originating from SNSs should be introduced. It would mean that in accordance with the general limitation period in labour law, posts, pictures and other contents posted on SNSs before that period should not be processed in the recruitment process. Source: Hajdú, J. et al. (forthcoming) 'Közösségi média és munkajog - különös tekintettel a Facebook-ra alapított felmondásokra a hazai szabályozás és a nemzetközi joggyakorlat tükrében', De iurisprudentia et iure publico (DIEIP)
} 
environment, it must not be forgotten that every user is responsible for his/her actions and behaviour on SNSs, and that they should actively participate in ensuring the protection of their own personal lives. They should be able and expected to make informed decisions as regards whether they should post something to SNSs, to what audience (choice of privacy settings), whether there can be any legal consequences. They should not upload content relating to third persons without their consent and should actively monitor their ereputation and make the necessary steps if they detect an anomaly. 


\section{BIBLIOGRAPHY - LIST OF LITERATURE AND SOURCES}

\section{Academic books and articles}

'A magántitokhoz való jog és a know-how' (no date) Polgári Jogi Kodifikáció, 8(5), pp. $15-16$.

Adam, P. (2013) 'Vie personnelle/vie professionnelle: une distinction en voie de dissolution ?', Le Droit Ouvrier, (780), pp. 431-444.

Adam, P. (2015) 'SMS, vie privée et portable professionnel : histoire (courte) d'un homme "sans territoire", Revue droit du travail Dalloz, (3), pp. 191-194.

Alleaume, C. (2016) 'La notion de droit à la vie privée', in Batteur, A. (ed.) Les grandes décisions du droit des personnes et de la famille. 2nd edn. Issy-les-Moulineaux: LGDJ, pp. 451-464.

Allix, B. (2014) 'L'employeur, le salarié et Facebook', Feuillet Rapide Social F Lefebvre.

Anderson, D. R. (2011) 'Restricting Social Graces: The Implications of Social Media for Restrictive Covenants in Employment Contracts', Ohio State Law Journal, 72(4), pp. 881-908.

Andriantsimbazovina, J. (2017) 'L'encadrement stricte du contrôle par l'employeur de l'usage de la messagerie électronique du salarié; Note sous Cour Européenne des Droits de l'Homme, grande Chambre, 5 septembre 2017, Barbulescu c/ Roumanie, numéro 61496/08', La Gazette du Palais, (41), pp. 22-23.

Antonmattei, P.-H. (2002) 'NTIC et vie personnelle au travail', Droit social, (1), pp. 3741.

Antonmattei, P.-H. (2012) 'Le licenciement pour trouble objectif', Droit social, (1), pp. 10-13.

Arany Tóth, M. (2008) 'Gondolatok a munkavállalók személyiségi jogainak védelméről a magyar munkajogban', Jogtudományi közlöny, 63(3), pp. 129-139.

Arany Tóth, M. (2011) 'A munkavállaló emberi méltóságának védelme a munkaviszonyban', Miskolci jogi szemle, 6(1), pp. 135-153.

Arany-Tóth, M. (2008) A munkavállalók személyes adatainak védelme a magyar munkajogban. Szeged: Bába Kiadó

Arany-Tóth, M. (2016) Személyes adatok kezelése a munkaviszonyban. Budapest: Wolters Kluwer

Arany-Tóth, M. (2019) 'A magánélet védelméhez való jog újraszabályozásának hatása a munkaviszonyban a magánélet védelméröl szóló törvény alapján (2. rész)', Munkajog, (3), pp. 27-34.

Aubert-Monpeyssen, T. (2007) “"Trouble objectif dans l'entreprise" et libertés collectives du salarié', Revue droit du travail Dalloz, (10), pp. 586-587.

Ba Sene, F. (2015) 'La protection constitutionnelle de la vie privée et familiale sur les réseaux sociaux en France', in Ndior, V. (ed.) Droit et réseaux sociaux. Issy-lesMoulineaux: Lextenso (Collection LEJEP), pp. 91-100.

Bailleul, C. and Jourdan, D. (2011) Contrat de travail: du recrutement à la rupture. 8th edn. Paris: Delmas

Balogh, Zs. Gy. et al. (2012) 'Munkahelyi adatvédelem a gyakorlatban', Infokommunikáció és Jog, 9(3), pp. 95-104.

Balogh, Zs. Gy. et al. (2012) 'Privacy in the Workplace', in Essays of Faculty of Law University of Pécs: Yearbook of 2012. Pécs: University of Pécs Faculty of Law, pp. 9-40. 
Bankó, Z. and Szőke, G. L. (2016) Issues of the digital workplace - The situation in Hungary. Pécs: JurInfo

Bankó, Z., Berke, Gy. and Kiss, Gy. (2017) Kommentár a munka törvénykönyvéhez. Budapest: Wolters Kluwer

Bányai, E. (2016) Közösségi média. Közösség vagy média? Pécs: Pécsi Tudományegyetem Közgazdaságtudományi Kar

Barbé, V. (2018) Essentiel du Droit des libertés fondamentales. Issy-les-Moulineaux: Gualino

Baugard, D. (2010) 'L'utilité de la Convention européenne des droits de l'homme en droit du travail', Droit et Patrimoine, (195), pp. 34-46.

Baugard, D. (2015) 'L'usage par les salariés des réseaux sociaux', in Ndior, V. (ed.) Droit et réseaux sociaux. Issy-les-Moulineaux: Lextenso (Collection LEJEP), pp. 75-89.

Baumhart, P. B. (2015) 'Social Media and the Job Market: How to Reconcile Applicant Privacy with Employer Needs', University of Michigan Journal of Law Reform, 48(2), pp. 503-533.

Befort, S. F. (1997) 'Pre-Employment Screening and Investigation: Navigating Between a Rock and a Hard Place', Hofstra Labor and Employment Law Journal, 14(2), pp. $365-422$.

Bello, A. (2012) 'Le licenciement pour motif tiré de Facebook : un changement ... dans la continuité', JCP S (édition sociale), (26) pp. 12-16.

Benalcázar, I. de (2003) Droit du travail et nouvelles technologies : collecte des données, Internet, cybersurveillance, télétravail. Paris: Montchrestien : Gualino

Bentham, J. (1995) The Panopticon Writings. Edited by M. Božovič. London, New York: Verso

Berke, Gy. and Kiss, Gy. (eds) (2014) Kommentár a munka törvénykönyvéhez: kommentár a munka törvénykönyvéröl szóló 2012. évi I. törvényhez. Budapest: Wolters Kluwer

Berki, K. et al. (2008) A munka törvénykönyve magyarázata. 2nd edn. Budapest: Complex

Beyneix, I. and Rovinski, J. (2016) 'L'emprise de la vie professionnelle sur la vie personnelle', JCP S (édition sociale), (37), pp. 35-39.

Bidet, A. and Porta, J. (2016) 'Le travail à l'épreuve du numérique', Revue droit du travail Dalloz, (5) pp. 328-334.

Bioy, X. (2016) Droits fondamentaux et libertés publiques. 4e édition. Issy-lesMoulineaux: LGDJ-Lextenso éditions (Collection Cours)

Birnhack, M. D. (2008) 'The EU Data Protection Directive: An engine of a global regime.', Computer Law \& Security Review, 24(6), pp. 508-520.

Bitan, F. (2011) 'Fasc. 4740 : Courrier électronique', JurisClasseur Communication

Blanpain, R. (2002) 'Employment and Labour Law Aspects. Setting the Scene. Asking the Right Questions?', in Blanpain, R. (ed.) On-line Rights for Employees in the Information Society. Use and Monitoring of E-mail and Internet at Work. The Hague: Kluwer Law International, pp. 35-44.

Bloustein, E. J. (1964) 'Privacy as an Aspect of Human Dignity: an Answer to Dean Prosser', New York University Law Review, 39(6), pp. 962-1007.

Bokor, A. et al. (2007) Emberi eröforrás menedzsment. Budapest: Aula Kiadó

Bölcskei, K. (2019) GDPR Kézikönyv 2.0. Budapest: Vezinfó Kiadó és Tanácsadó Kft

Bolton, R. L. (2014) 'The Right to Be Forgotten: Forced Amnesia in a Technological Age', The John Marshall Journal of Information Technology \& Privacy Law, 31(2), pp. 133-144.

Bond, M. (2018) Une introduction à la Convention européenne des droits de l'homme. Strasbourg: Conseil de l'Europe 
Boucher, P. (1974) ‘ «Safari » ou la chasse aux Français', Le Monde, 21 March, pp. 9-9.

Bouchet, H. (2004) La cybersurveillance sur les lieux de travail. Paris, la Documentation française: Commission nationale de l'informatique et des libertés

Bounedjoum, A. (2016) 'Réforme européenne des données personnelles: les nouveautés pour les droits des personnes', JCP E Semaine Juridique, (22), pp. 44-47.

Bourgeois, M. (2017) Droit de la donnée: principes théoriques et approche pratique. Paris: LexisNexis

Bourgeois, M.-B., Touranchet, L. and Alas-Luquetas, X. (2017) 'Le droit à la déconnexion', JCP S (Édition sociale), (24), pp. 15-18.

boyd, danah m. and Ellison, N. B. (2008) 'Social Network Sites: Definition, History and Scholarship', Journal of Computer Mediated Communication, 13(1), pp. 210-230.

Bozarth, J. (2010) Social media for trainers: techniques for enhancing and extending learning. San Francisco: Pfeiffer

Breznay, T. (2002) A munka törvénykönyve egységes szerkezetben állásfoglalásokkal és magyarázatokkal. Bővített kiadás. Budapest: Kompkonzult

Breznay, T. (ed.) (2006) A munkajog nagy kézikönyve. Budapest: Complex Kiadó

Brown, V. R. and Vaughn, E. D. (2011) 'The Writing on the (Facebook) Wall: The Use of Social Networking Sites in Hiring Decisions', Journal of Business and Psychology, 26(2), pp. 219-225.

Bruguière, J.-M. et al. (2017) 'Actualité du droit de l'internet (février - octobre 2016)', Revue Lamy Droit civil, (144)

Buitelaar, J. C. (2012) 'Privacy: Back to the Roots', German Law Journal, 13(3), pp. 171202.

Burgorgue-Larson, L. (2005) 'L'appréhension constitutionnelle de la vie privée en Europe: Analyse croisée des systèmes constitutionnels allemand, espagnol et français.', in Sudre, F. (ed.) Le droit à la vie privée au sens de la Convention européenne des droits de l'homme. Bruxelles: Bruylant, pp. 69-115.

Buttarelli, G. (2009) 'Do you have a private life at your workplace? Privacy in the workplace in EC institutions and bodies'. 31st International Conference of Data Protection and Privacy, Madrid, 4-6 November

Bygrave, L. A. (2004) 'Privacy Protection in a Global Context - A Comparative Overview', Scandinavian Studies in Law, 47, pp. 319-348.

Byrnside, I. (2008) 'Six Clicks of Separation: The Legal Ramifications of Employers Using Social Networking Sites to Research Applicants', Vanderbilt Journal of Entertainment and Technology Law, 10(2), pp. 445-477.

Cailleteau, C. (2018) 'Temps de travail et droit à la déconnexion', Lexbase Hebdo Edition Sociale, (750)

Cantero, I. and Coupez, F. (2014) 'L'utilisation des réseaux sociaux par l'entreprise : des risques maîtrisés?', Revue Banque, (769), p. 39.

Caprioli, É. A. (2012) 'Les propos tenus par une salarié sur Facebook peuvent justifier son licenciement', Communication Commerce Électronique, (4), pp. 37-40.

Caprioli, É. A. (2018) 'Licenciement: obtention loyale de la preuve sur le réseau social Facebook afin de caractériser une faute grave', Communication Commerce Électronique, (6), pp. 43-43.

Carbonnier, J. (1971) Droit civil. 1, Introduction. Les Personnes. 9th edn. Paris: Presses universitaires de France

Cariat, N. (2017) 'Respect de la vie privée et familiale', in Charte des droits fondamentaux de l'Union européenne. Bruxelles: Bruylant, pp. 161-183.

Carlson, K. (2014) 'Social Media and the Workplace: How I Learned to Stop Worrying and Love Privacy Settings and the NLRB', Florida Law Review, 66(1), pp. 479-509. 
Caron, M. (2018) 'Les limites à la liberté d'expression d'un salarié sur Facebook', Les Cahiers Sociaux, (305), pp. 131-133.

Casaux-Labrunée, L. (2012) 'Vie privée des salariés et vie de l'entreprise', Droit social, (4), pp. 331-345.

Cassart, A. (2013) 'L'extension de la notion de communauté d'intérêts aux réseaux sociaux', Revue du Droit des Technologies de l'Information, (52), pp. 101-106.

Castets-Renard, C. (2011) 'Vie privée du salarié et TIC: attention à la violation de la charte informatique !', Revue Lamy droit de l'immatériel, (69), pp. 33-35.

Cate, F. H. (1995) 'The EU Data Protection Directive, Information Privacy, and the Public Interest', Iowa Law Review, 80(3), pp. 431-443.

Clark, L. A. and Roberts, S. J. (2010) 'Employer's Use of Social Networking Sites. A Socially Irresponsible Practice', Journal of Business Ethics, 95(4), pp. 507-525.

Clarke, R. (2014) 'Privacy and Social Media: An Analytical Framework', Journal of Law, Information and Science, 23(1), pp. 169-191.

Coelho Moreira, T. (2016) 'The Electronic Control of the Employer in Portugal', Labour \& Law Issues, 2(1), pp. 1-27.

Collomp, E. (2010) 'La vie personnelle au travail. Dernières évolutions jurisprudentielles', Droit social, (1), pp. 40-43.

Colonna, J. and Renaux-Personnic, V. (2017) 'Vie privée et surveillance des communications du salarié: la position de la Cour européenne des droits de l'Homme; Note sous Cour Européenne des Droits de l'Homme, grande Chambre, 5 septembre 2017, arrêt numéro 61496/08', La Gazette du Palais, (43), pp. 43-45.

Combrexelle, J.-D. (2010) 'Vie professionnelle et vie personnelle', Droit social, (1), pp. 12-13.

Contamine, A. (2013) 'La surveillance du salarié', Revue Le Lamy de la Concurrence, (37), pp. 155-162.

Cornesse, I. (2011) 'Quand la CNIL vient au secours des salariés', Revue Lamy Droit des affaires, 58, pp. 52-53.

Corrignan-Carsin, D. (2009) 'La Chambre sociale fixe les limites du pouvoir disciplinaire de l'employeur', JCP E Semaine Juridique (édition entreprise), (40), pp. 44-47.

Corrignan-Carsin, D. (2011) 'Vie personnelle - vie professionnelle : la cloison est-elle étanche ?', JCP S (édition sociale), (26), pp. 38-41.

Corrignan-Carsin, D. (2018) 'Tenir des propos injurieux sur Facebook au sein d'un groupe fermé ne justifie pas un licenciement', JCP G Semaine Juridique (édition générale), (40), pp. 1762-1762.

Costa, L. and Poullet, Y. (2012) 'Privacy and the regulation of 2012', Computer Law and Security Review, 28(3), pp. 254-262.

Costes, L. (2011) 'Réseaux sociaux: nouveaux enjeux et nouveaux défis pour les entreprises', Revue Lamy droit de l'immatériel ex Lamy droit de l'informatique, (74), pp. 131-138.

Costes, L. (2017) 'CEDH : surveillance des courriels d'un employé à son insu constitutive d'une violation du droit au respect de la vie privée et de la correspondance', Revue Lamy droit de l'immatériel, (140), pp. 35-35.

Crane, C. (2012) 'Social Networking v. The Employment- at-Will Doctrine: A Potential Defense for Employees Fired for Facebooking, Terminated for Twittering, Booted for Blogging, and Sacked for Social Networking', Washington University Law Review, 89(3), pp. 639-672.

Crouzatier-Durand, F. (2013) Fiches de libertés publiques et droits fondamentaux. 2nd edn. Paris: Ellipses 
Cséffán, J. (2016, 2018, 2019) A Munka Törvénykönyve és magyarázata. Szeged: Szegedi Rendezvényszervező Kft

Cseh, G. (2013) ‘A közösségi portálok árnyoldalai’, Infokommunikáció és jog, (2), pp. 9095.

Dabosville, B. (2012) 'Les contours de l'abus d'expression du salarié', Revue droit du travail Dalloz, (5), pp. 275-282.

De Hert, P. (2008) 'Identity management of e-ID, privacy and security in Europe. A human rights view', Information Security Technical Report, 13(2), pp. 71-75.

De Hert, P. and Gutwirth, S. (2009) 'Data Protection in the Case Law of Strasbourg and Luxemburg: Constitutionalisation in Action', in Gutwirth, S. et al. (eds) Reinventing Data Protection? Springer, pp. 3-44.

De Hert, P. and Lammerant, H. (2013) Protection of Personal Data in Work-related Relations. Study PE 474.440. Directorate General for Internal Policies, Policy Department C: Citizens' Rights and Constitutional Affairs. Civil Liberties, Justice and Home Affairs

De Hert, P. and Papakonstantinou, V. (2012) 'The proposed data protection Regulation replacing Directive 95/46/EC: A sound system for the protection of individuals', Computer Law and Security Review, 28(2), pp. 130-142.

de Terwangne, C., Rosier, K. and Losdyck, B. (2016) 'Lignes de force du nouveau Règlement relatif à la protection des données à caractère personnel', Revue du droit des technologies de l'information, (62), pp. 5-56.

Del Riego, A., Sánchez Abril, P. and Levin, A. (2012) 'Your Password or Your Paycheck?: A Job Applicant's Murky Right to Social Media Privacy', Journal of Internet Law, 16(3), pp. 1, 18-26.

Denier, J.-L. (2003) 'L'utilisation privative des NTIC d'entreprise', Les cahiers du DRH, (89), pp. 31-34.

Denizeau, C. (2017) Droit des libertés fondamentales. 6th edn. Paris: Vuibert

Despax, M. (1963) 'La vie extra-professionnelle du salarié et son incidence sur le contrat de travail', Juris-Classeur Périodique. La Semaine Juridique. éd. G., (1776)

Dockès, E. (2004) 'Le pouvoir dans les rapports de travail: essor juridique d'une nuisance économique', Droit social, (6), pp. 620-628.

Duez-Ruff, V. (2012) 'Impact des nouvelles technologies sur le droit du travail : un salarié appartient-il virtuellement à son employeur?', Lexbase Hebdo - Edition Sociale, (498)

Dupuis, M. (2001) 'La vie privée à l'épreuve de l'Internet: quelques aspects nouveaux', Revue Juridique Personnes et Famille, (12), pp. 6-9.

Dupuis, M. (2013) 'La vie privée à l'épreuve des réseaux sociaux', Revue Lamy Droit Civil, (102), pp. 39-46.

Duquesne, F. (2003) Droit du travail. 2nd edn. Paris: Gualino

Durand, P. and Jaussaud, R. (1947) Traité de droit du travail. Tome I. Paris: Dalloz

Ebnet, N. J. (2012) 'It Can Do More Than Protect Your Credit Score: Regulating Social Media Pre-Employment Screening with the Fair Credit Reporting Act', Minnesota Law Review, 97(1), pp. 306-336.

El Badawi, L. (2014) 'La place des réseaux sociaux dans l'entreprise', Revue Lamy droit de l'immatériel, (103), pp. 108-119.

El Wafi, W. (2016) Perméabilité des frontières vies "personnelle et professionnelle » et usage des TIC : modèles d'articulation. Université de Lorraine

Ellickson, D. and Atkinson, M. (2013) 'When Can Your Employer "Unlike" You? Just Cause for Dismissal and Social Media', in The Law Society of Upper 
Canada, Employment Law and the New Workplace in the Social Media Age. Toronto: Irwin Law, pp. 259-280.

Ember, A. (2012) 'Meddig terjedhet a munkáltató ellenőrzési joga: avagy a munkavállaló munkáltató általi kamerás megfigyelésének aggályai’, Humánpolitikai szemle, (9), pp. 30-36.

Ember, A. (2015) ‘A munkáltató jogos gazdasági érdekének a védelme’, in Lajkó, D. and Varga, N. (eds) Alapelvek és alapjogok. Szeged: Szegedi Tudományegyetem Államés Jogtudományi Doktori Iskola, pp. 113-124.

Engler, P. and Tanoury, P. (2007) 'Employers Use of Facebook in Recruiting', in McIntosh, D. et al. (eds) The Ethical Imperative in the Context of Evolving Technologies. University of Colorado Leeds School of Business, pp. 61-74. Available at: http://www.ethicapublishing.com/ethicalimperative.pdf (Accessed: 13 July 2016)

Eriksson, M. (2006) 'Article 7. Respect for private and family life', in EU Network of Independent Experts on Fundamental Rights, Commentary of the Charter of Fundamental Rights of the European Union, pp. 78-89.

Falque-Pierrotin, I. (2012) 'La Constitution et l'Internet', Les nouveaux cahiers du Conseil constitutionnel, 36, pp. 31-44.

Favennec-Héry, F. and Verkindt, P.-Y. (2016) Droit du travail. 5th edn. Issy-lesMoulineaux: LGDJ Lextenso éditions

Favoreu, L. et al. (2015) Droit des libertés fondamentales. 7th edn. Paris: Dalloz

Fel, C. and Sordet, E. (2010) 'L'utilisation des réseaux sociaux par l'entreprise et ses collaborateurs', JCP S (édition sociale), (29), pp. 19-24.

Féral-Schuhl, C. (2010) Cyberdroit: le droit à l'épreuve de l'internet. 6th edn. Paris: Dalloz (Praxis Dalloz)

Ferenczy, E. (2010) 'Az adatvédelem külföldi szabályozása', Tudományos közlemények, (23), pp. 47-67.

Fézer, T. (2014) 'Harmadik rész: személyiségi jogok', in Osztovits, A. (ed.) A Polgári Törvénykönyvröl szóló 2013. évi V. törvény és a kapcsolódó jogszabályok nagykommentárja. I. kötet. Budapest: Opten Informatikai Kft., pp. 249-355.

Fialová, E. (2014) 'Data Portability and Informational Self-determination', Masaryk University Journal of Law and Technology, 8(1), pp. 45-55.

Finn, R. L. et al. (2013) 'Seven Types of Privacy', in Gutwirth, S. (ed.) European Data Protection: Coming of Age. Dordrecht: Springer, pp. 3-32.

Flaherty, D. H. (1999) 'Some reflections on privacy and technology', Manitoba Law Journal, 26(2), pp. 219-233.

Flaherty, P. and Whitmore, S. (2013) 'Privacy Protection in the Digital Workplace', in Law Society of Upper Canada, Employment Law and the New Workplace in the Social Media Age. Toronto: Irwin Law, pp. 9-29.

Flint, D. (2009) 'Law shaping technology: Technology shaping the law', International Review of Law, Computers \& Technology, 23(1-2), 5-11.

Flynn, N. (2012) The Social Media Handbook. Policies and Best Practices to Effectively Manage Your Organization's Social Media Presence, Posts, and Potential Risks. San Francisco: Pfeiffer

Fried, C. (1968) 'Privacy', The Yale Law Journal, 77(3), pp. 475-493.

Fritsch, C. (2015) 'Data Processing in Employment Relations; Impacts of the European General Data Protection Regulation Focusing on the Data Protection Officer at the Worksite', in Gutwirth, S., Leenes, R., and de Hert, P. (eds) Reforming European Data Protection Law. Dordrecht, Heidelberg, New York, London: Springer, pp. 147167. 
Funk, T. (2011) Social Media Playbook for Business. Reaching Your Online Community with Twitter, Facebook, LinkedIn, and More. Santa Barbara, Denver, Oxford: Praeger

Gaïa, P. (2004) 'La Charte des droits fondamentaux de l'Union européenne', Revue française de droit constitutionnel, (2), pp. 227-246.

Galántai, Z. (2003) E-privacy olvasókönyv. Dialógusok a privacyröl és az internetröl meg a cyberpornóról, a megfigyelésekröl és egyebekröl. Available at: https://mek.oszk.hu/04100/04134/html/ (Accessed: 18 November 2019)

Garrie, D. B. et al. (2010) 'Data Protection: The Challenges Facing Social Networking', Brigham Young University International Law \& Management Review, 6(2) pp. 127-152.

Gautier, P.-Y. (2001) 'La preuve hors la loi ou comment, grâce aux nouvelles technologies, progresse "la vie privée" des salariés', Recueil Dalloz Sirey, (39), pp. 3148-3153.

Gavison, R. (1980) 'Privacy and the Limits of Law', The Yale Law Journal, 89(3), pp. 421-471.

Geffray, E. (2014) 'La protection des données personnelles, élément clé à l'ère numérique', Légipresse, (320), pp. 515-516.

Gellert, R. and Gutwirth, S. (2013) 'The legal construction of privacy and data protection', Computer Law and Security Review, 29(5), pp. 522-530.

Gerety, T. (1977) 'Redefining Privacy', Harvard Civil Rights-Civil Liberties Law Review, 12(2), pp. 233-296.

Gheorghe, M. (2017) 'Considerations on the conditions under which the employer may monitor their employees at the workplace', Juridical Tribune, 7(2), pp. 62-69.

Ghoshray, S. (2013) 'The Emerging Reality of Social Media: Erosion of Individual Privacy Through Cyber-Vetting and Law's Inability to Catch Up', The John Marshall Review of Intellectual Property Law, 12(3), pp. 551-582.

Gillier, H. (2009) 'Vie personnelle et licenciement disciplinaire', Bulletin du travail (ancien nom Cahiers sociaux du barreau de Paris), (213), pp. 213-214.

González Fuster, G. and Gutwirth, S. (2013) 'Opening up personal data protection: A conceptual controversy', Computer Law and Security Review, 29(5), pp. 531-539.

Gormley, K. (1992) 'One Hundred Years of Privacy', Wisconsin Law Review, (5), pp. 1335-1441.

Görög, M. (2016) 'A magánélethez való jog mint a személyiségi jog újabb, magánjogi kódexben nevesített vonatkozása', in Balogh, E. (ed.) Számadás az Alaptörvényröl: tanulmányok a Szegedi Tudományegyetem Allam-és Jogtudományi Kar oktatóinak tollából. Budapest: Magyar Közlöny Lap- és Könyvkiadó, pp. 51-63.

Grabarczyk, K. (2011) 'Vie privée et nouvelles technologies', Revue des droits et libertés fondamentaux, (7)

Grandguillot, D. (2016) L'essentiel du Droit du travail. 16th edn. Issy-les-Moulinaux: Gualino: Lextenso Éditions

Grangé, J. and Froger, C. (2003) 'Cyber-Monitoring in the French Workplace', International Business Lawyer, 31(5), pp. 213-217.

Grégoire, F. (2018) 'L'usage immodéré de Facebook peut conduire directement à Pôle emploi', JCP G Semaine Juridique (édition générale), (9), pp. 437-437.

Griguer, M. (2010) 'Les réseaux sociaux sous le contrôle des DSI', Cahiers de droit de l'entreprise, (6), pp. 62-64.

Griguer, M. (2013) 'Protection des données personnelles : conformité et bonnes pratiques des entreprises', Cahiers de droit de l'entreprise, (1), pp. 73-76.

Griguer, M. (2017) '3 questions: Le droit à la déconnexion', La Semaine Juridique Entreprise et Affaires, (30-34), pp. 30-34. 
Griguer, M. and Schwartz, J. (2017) 'Les risques liés à l'implémentation du droit à la déconnexion dans l'entreprise', Cahiers de droit de l'entreprise, (2), pp. 50-52.

Grimmelmann, J. (2009) 'Saving Facebook', Iowa Law Review, 94(4), pp. 1137-1206.

Gross, H. (1967) 'The Concept of Privacy', New York University Law Review, 42(1), pp. 34-54.

Gross, R. and Acquisti, A. (2005) 'Information Revelation and Privacy in Online Social Networks', Proceedings of the 2005 ACM workshop on Privacy in the electronic society

Grynbaum, L., Le Goffic, C. and Morlet-Haïdara, L. (2014) Droit des activités numériques. 1st edn. Paris: Dalloz

Gutwirth, S. (2002) Privacy and the Information Age. Lanham: Rowman \& Littlefield Publishers Inc.

Gyulavári, T. (ed.) $(2012,2013,2017)$ Munkajog. Budapest: ELTE Eötvös Kiadó

Gyulavári, T. and Kun, A. (2013) 'A munkáltatói szabályzat az új Munka Törvénykönyvében', Magyar jog, 60(9), pp. 556-566.

Hajdú, J. (2004) 'Habilitációs tézisek'. Szegedi Tudományegyetem

Hajdú, J. (2005) A munkavállalók személyiségi jogainak védelme. Szeged: Pólay Elemér Alapítvány

Hajdú, J. and Kun, A. (eds) (2012) Munkajog I. Budapest: Patrocinium

Hajdú, J. and Kun, A. (eds) (2014) Munkajog. Budapest: Patrocinium

Hajdú, J. et al. (forthcoming) 'Közösségi média és munkajog - különös tekintettel a Facebook-ra alapított felmondásokra a hazai szabályozás és a nemzetközi joggyakorlat tükrében', De iurisprudentia et iure publico (DIEIP)

Halmos, Sz. and Petrovics, Z. (2014) Munkajog. Budapest: Nemzeti Közszolgálati Egyetem Közigazgatás-tudományi Kar. Available at: http://m.ludita.uninke.hu/repozitorium/bitstream/handle/11410/8585/Teljes\%20sz\%C3\%B6veg\%21?se quence $=1 \&$ is Allowed $=y$ (Accessed: 16 November 2018 )

Hardouin, R. (2011) 'Facebook ou l'établissement de la frontière entre espace public et sphère privée', Revue Lamy droit de l'immatériel ex Lamy droit de l'informatique, (67), pp. 54-55.

Hargitai, P. (tran.) (2005) Attila József Selected Poems. New York: iUniverse

Hartzog, W. (2013) 'Privacy and Terms of Use', in Stewart, D. R. (ed.) Social Media and the Law. A Guidebook for Communication Students and Professionals. New York, London: Routledge, pp. 50-74.

Hauser, J. (2002) 'Vie privée du salarié: E-mail, domicile, sacs, bermudas et survêtement', RTD Civ., (1), pp. 72.

Hegedüs, B. (2005) 'A munkahelyi elektronikus levelezés ellenőrzésének nemzetközi gyakorlata', Infokommunikáció és jog, 2(10), pp. 185-190.

Hegedűs, B. (2006) 'A munkahelyi hagyományos és elektronikus levelezés ellenőrzése', Munkaügyi szemle, 50(6), pp. 47-49.

Henderson, J. J. (2013) 'The Boundaries of Free Speech in Social Media', in Stewart, D. R. (ed.) Social Media and the Law. A Guidebook for Communication Students and Professionals. New York, London: Routledge, pp. 1-22.

Hendrickx, F. (2000) 'Data protection and codes of conduct: self-regulation versus legislative intervention', in Blanpain, R. (ed.) Multinational Enterprises and the Social Challenges of the XXIst Century: the ILO Declaration on Fundamental Principles at Work, Public and Private Corporate Codes of Conduct. (Bulletin of Comparative Labour Relations, 37), pp. 253-267. 
Hendrickx, F. (2001) 'Electronic Monitoring and Employment Privacy', in Blanpain, R. (ed.) The Evolving Employment Relationship and the New Economy. The Hague/London/New York: Kluwer Law International, pp. 247-250.

Hendrickx, F. (2002) 'Privacy and Employment Law: General Principles and Application to Electronic Monitoring', in Blanpain, R. (ed.) On-line Rights for Employees in the Information Society. Use and Monitoring of E-mail and Internet at Work. The Hague: Kluwer Law International, pp. 45-64.

Hendrickx, F. (2002) 'Protection of workers' personal data in the European Union, Two studies'. EC

Hennette-Vauchez, S. and Roman, D. (2017) Droits de l'homme et libertés fondamentales. 3rd edn. Paris: Dalloz

Herbert, W. A. (2011) 'Workplace Consequences of Electronic Exhibition and Voyeurism', IEEE Technology and Society Magazine, 30(3), p. 25-33.

Hess-Fallon, B., Maillard, S. and Simon, A.-M. (2015) Droit du travail. 24th edn. Paris: Sirey-Dalloz

Hiselius, P. (2010) 'ICT/Internet and the Right to Privacy', Scandinavian Studies in Law, 56, pp. 201-208.

Horinka, É. (2018) 'A munkavállaló és a munkáltató személyiségi jogainak védelme a munkaviszonyban', in Mailáth György Tudományos Pályázat 2017. Díjazott dolgozatok. Budapest: Országos Bírósági Hivatal, pp. 593-664.

Hornung, G. and Schnabel, C. (2009) 'Data protection in Germany I: The population census decision and the right to informational self-determination', Computer Law \& Security Review, 25(1), pp. 84-88.

Horváth, L. and Gelányi, A. (2011) 'Lájkolni vagy nem lájkolni? A közösségi oldalak használatának munkajogi kérdései’, Infokommunikáció és jog, (2), pp. 60-66.

Hughes, R. L. D. (2015) 'Two concepts of privacy', Computer Law and Security Review, 31(4), pp. 527-537.

Icard, J. (2014) 'Faits commis en dehors des temps et lieu de travail mais rattachés à la vie de l'entreprise', Bulletin du travail (ancien nom Cahiers sociaux du barreau de Paris), (268), pp. 642-642.

Icard, J. (2018) 'De l'incidence de la source d'une communication d'un salarié sur sa nature et sur son régime', Cahiers sociaux du Barreau de Paris, (304), pp. 84-85.

Inforeg (2015) 'Pouvoir disciplinaire: vie personnelle, vie professionnelle et Facebook', Cahiers de droit de l'entreprise, (6), pp. 67-69.

Inforeg (2017) 'De la difficulté d'appliquer le droit à la déconnexion à tous les salariés', Cahiers de droit de l'entreprise, (3), pp. 71-73.

Jacquelet, C. (2008) La vie privée du salarié à l'épreuve des relations de travail. Aix-enProvence: Presses universitaires d'Aix-Marseille

Jónás, T. (2010) 'Véleménynyilvánítási szabadság a munkaviszonyban', Pécsi Munkajogi Közlemények, 3(2), pp. 23-47.

Jónás, T. (2015) Mit jelent munkára képes állapotban lenni?, Jogászvilág. Available at: https://jogaszvilag.hu/cegvilag/mit-jelent-munkara-kepes-allapotbanlenni/ (Accessed: 7 January 2020)

Jones, M., Schuckman, A. and Watson, K. (2007) 'The Ethics of Pre-Employment Screening Through the Use of the Internet', in McIntosh, D. et al. (eds) The Ethical Imperative in the Context of Evolving Technologies. University of Colorado Leeds School of Business. Available at: http://www.ethicapublishing.com/ethicalimperative.pdf (Accessed: 13 July 2016). pp. 53-60.

Jóri, A. et al. (2018) A GDPR magyarázata. Edited by A. Jóri. Budapest: HVG-ORAC 
Jóri, A. (2005) Adatvédelmi kézikönvy. Budapest: Osiris Kiadó

Jóri, A. (2009) 'A magánszférajogok', in Jakab, A. (ed.) Az Alkotmány kommentárja II. Budapest: Századvég Kiadó, pp. 2167-2193.

Jóri, A. and Soós, A. K. (2016) Adatvédelmi jog: magyar és európai szabályozás. Budapest: HVG-ORAC

Jóri, A., Hegedüs, B. and Kerekes, Z. (eds) (2010) Adatvédelem és információszabadság a gyakorlatban. Budapest: Complex

Jourard, S. M. (1966) 'Some Psychological Aspects of Privacy', Law and Contemporary Problems, 31(2), pp. 307-318.

Jue, A. L., Marr, J. A. and Kassotakis, M. E. (2010) Social Media at Work. How Networking Tools Propel Organizational Performance. San Francisco: Jossey-Bass

Julien, M. and Mazuyer, E. (2018) 'Le droit du travail à l'épreuve des plateformes numériques', Revue droit du travail Dalloz, (3) pp. 189-198.

Kajtár, E. (2014) 'A munkáltatói utasítás helye a 21. század munkajogában', Jura, 20(2), pp. 214-224.

Kajtár, E. (2015) 'Európai ügyek a Facebook sötét oldaláról - A munkavállalók közösségi oldalakon tanúsított kötelezettségszegő magatartása', in Horváth, I. (ed.) Tisztelgés: ünnepi tanulmányok Dr. Hágelmayer Istvánné születésnapjára. Budapest: ELTE Eötvös Kiadó, pp. 199-213.

Kajtár, E. (2015) 'Think it over! Pre-employment search on social network sites', in Vinković, M. (ed.) New Developments in EU Labour, Equality and Human Rights Law. Proceedings from the International Jean Monnet Conference "New Developments in EU Labour, Equality and Human Rights Law", Osijek 21 and 22 May 2015. Osijek: Josip Juraj Strossmayer University of Osijek Faculty of Law, pp. 97-106.

Kajtár, E. (2015) 'Till Facebook Do Us Part? Social Networking Sites and the Employment Relationship', Acta Juridica Hungarica, 56(4), pp. 268-280.

Kajtár, E. (2016) Dignity at Work: Employee's Personality Rights in the 21st Century. Pécs: University of Pécs, Faculty of Law (PMJK Monographs 6)

Kajtár, E. and Mestre, B. (2016) 'Social networks and employees' right to privacy in the pre-employment stage: some comparative remarks and interrogations', Hungarian Labour Law E-journal, (1), pp. 22-39.

Kállai, P. (2017) 'Bărbulescu Románia elleni ügye', Fundamentum, 21(3-4), pp. 99-101.

Kalven, H. J. (1966) 'Privacy in Tort Law - Were Warren and Brandeis Wrong?', Law and Contemporary Problems, 31(2), pp. 326-341.

Kambellari, E. (2013) 'Employee email monitoring and workplace privacy in the European perspective', Iustinianus Primus Law Review, 8. Available at: https://cutt.ly/1rv83w7 (Accessed: 19 January 2019)

Kang, J. (1998) 'Information Privacy in Cyberspace Transactions', Stanford Law Review, 50(4), pp. 1193-1294.

Kaplan, A. M. and Haenlein, M. (2010) 'Users of the world, unite! The challenges and opportunities of Social Media', Business Horizons, 53(1), pp. 59-68.

Kardkovács, K. (ed.) (2012, 2016) A Munka Törvénykönyvének magyarázata. Budapest: HVG-ORAC Lap- és Könyvkiadó

Kártyás, G. and Kozma-Fecske, I. (2016) 'Szerelmes levelek a munkahelyi postafiókban', HR \& Munkajog, 7(3), pp. 14-17.

Kártyás, G., Répáczki, R. and Takács, G. (2016) A munkajog digitalizálása. A munkajog hozzáalkalmazása a digitális munkakörnyezethez és a változó munkavállalói kompetenciákhoz. Kutatási zárótanulmány. Budapest 
Kayser, P. (1995) La protection de la vie privée par le droit : protection du secret de la vie privée. 3rd edn. Aix-en-Provence; Paris: Presses universitaires d'Aix-Marseille; Economica

Kéfer, F. and Cornélis, S. (2009) 'L'arrêt “Copland" ou l'espérance légitime du travailleur quant au caractère privé de ses communications', Revue Trimestrielle des Droits de l'Homme, (79), pp. 779-793.

Kennedy, N. and Macko, M. (2007) 'Social Networking Privacy and Its Effects on Employment Opportunities', in Larsen, K. R. and Voronovich, Z. A. (eds) Convenient Or Invasive: The Information Age. Ethica Publishing. Available at: http://www.ethicapublishing.com/inconvenientorinvasive/2CH12.pdf (Accessed: 10 December 2019)

Kindt, E. (2015) 'Privacy and Data Protection Law: An Introduction'. IC1206 Training School: De-identification for privacy protection in multimedia content 07-11 October 2015, Limassol, Cyprus, 11 October

Kiss, Gy. (2002) 'A szerződéses szabadság átalakulása a munkajogban az alapjogok tükrében', in Czúcz, O. and Szabó, I. (eds) Ünnepi tanulmányok. Munkaügyi igazgatás, munkaügyi bíráskodás: Radnay József 75. születésnapjára. Miskolc: Bíbor Kiadó, pp. 259-276.

Kiss, Gy. (2003) 'A munkajog jogforrási rendszere és az alapjogok I.', Jura, 9(1), pp. 7995.

Kiss, Gy. (2005) Munkajog. 2nd edn. Budapest: Osiris Kiadó

Kiss, Gy. (2010) Alapjogok kollíziója a munkajogban. Pécs: Justis Tanácsadó Betéti Társaság

Kiss, Gy. (2015) Opportunities and limits of application principles and Civil Code rules in Hungarian labour law Crisis management with means of civil law. ELLN Working Paper No. 4.

Kiss, Gy. (2017) ‘A munkajog szabályozásának dilemmái’, Miskolci Jogi Szemle, XII(2), pp. 267-277.

Klausz, M. (2013) Megosztok, tehát vagyok: A közösségi média és az Internet szép új világa. Veszprém: Magánkiadás

Klausz, M. (2016) A közösségi média nagykönyve: hogyan vidd sikerre céged és önmagad. Budapest: Athenaeum

Klein, T. and Tóth, A. (eds) (2018) Technológia jog - Robotjog - Cyberjog. Budapest: Wolters Kluwer Hungary

Knight, A. and Saxby, S. (617) 'Global challenges of identity protection in a networked world', Computer Law and Security Review, 30(6), pp. 617-632.

Kocher, M. (2013) 'La protection des données des salariés: que reste-t-il de l'arrêt Nikon?', Legicom, (1), pp. 129-140.

Kokott, J. and Sobotta, C. (2013) 'The distinction between privacy and data protection in the jurisprudence of the CJEU and the ECtHR', International Data Privacy Law, 3(4), pp. 222-228.

Kommers, D. P. and Miller, R. A. (2012) The constitutional jurisprudence of the Federal Republic of Germany. 3rd edn. Durham and London: Duke University Press

Konvitz, M. R. (1966) 'Privacy and the Law: a Philosophical Prelude.', Law and Contemporary Problems, 31(2), pp. 272-280.

Könyves Tóth, P. (1990) 'Adatvédelem és információszabadság', Világosság, 31(8-9), pp. 621-629.

Könyves Tóth, P. (2010) 'Az adatvédelmi törvény metamorfózisai', Fundamentum, (2), pp. 53-61.

Koops, B-J. et al. (2017) 'A Typology of Privacy’, U. Pa. J. Int'l L., 38(2), pp. 483-577. 
Kosta, E. et al. (2010) 'Data protection issues pertaining to social networking under EU law', Transforming Government: People, Process and Policy, 4(2), pp. 193-201.

Kozma, A. (2013) 'Mire köteles a munkavállaló?', HR \& Munkajog, 4(10) pp. 8-14.

Kranenborg, H. (2014) 'Protection of Personal Data', in Peers, S. et al. (eds) The EU Charter of Fundamental Rights. A commentary. Oxford, Portland: Hart Publishing, pp. 223-265.

Krishnamurthy, B. and Wills, C. E. (2008) 'Characterizing Privacy in Online Social Networks', Proceedings of the first workshop on Online social networks, Seattle, WA, USA

Kubicek, B. et al. (2019) Working conditions and workers' health. Publications Office of the European Union, Luxembourg: Eurofound

Kun, A. (2013) 'Közösségi média és munkajog - avagy „online” munkaidőben és azon túl', Munkaügyi Szemle, (3), pp. 12-19.

Kun, A. (2018) 'A digitalizáció kihívásai a munkajogban', in Homicskó, Á. O. (ed.) Egyes modern technológiák etikai, jogi és szabályozási kihívásai. Budapest: Károli Gáspár Református Egyetem Állam- és Jogtudományi Kar (Acta Caroliensia Conventorum Scientiarum Iuridico-Politicarum, XXII), pp. 119-138.

Kuner, C. (2009) 'An international legal framework for data protection: Issues and prospects', Computer Law and Security Review, 25(4), pp. 307-317.

La Rédaction D.O. (2013) 'Diffusion des bonnes pratiques en matière de protection des données personnelles des salariés', JCP S (édition sociale), (7), pp. 3-7.

Lábady, T. (1995) 'A magánélet alkotmányos védelme (A házasság és a család védelme, a magánszférához való jog)', Acta Humana: Emberi jogi közlemények, (18-19), pp. 74-86.

Lahalle, T. (2016) Droits et obligations des parties. JurisClasseur Travail Traité Fasc. 18-1

Lambert, P. (2014) International Handbook of Social Media Laws. Haywards Heath: Bloomsbury

Lambert, P. and Rigaux, F. (1993) 'Perquisition au cabinet d'un avocat et droit au respect de la vie privée, de la correspondance et du domicile', Revue Trimestrielle des Droits de l'Homme, (15), pp. 467-481.

Lauth, M. (2009) Thematic Legal Study on assessment of data protection measures and relevant institutions. Report on Germany. FRA. Available at: https://fra.europa.eu/sites/default/files/role-data-protection-authorities-2009de.pdf.

Le Clainche, J. (2012) 'Expression des salariés sur internet: attention aux «faux amis "', Revue Lamy droit de l'immatériel ex Lamy droit de l'informatique, (81), pp. 45-50.

Le Cohu, P. (2018) 'Un salarié peut-il critiquer son employeur sans être sanctionné ?', La Gazette du Palais, (10), pp. 58-59.

Le Lamy Droit Du Numérique (Guide), 2014 - Section 1 - Gestion Du Personnel Par Le Biais de L'informatique et Des Nouvelles Technologies de L'information'

Le Lamy social (2019) 150. Définition du contrat de travail. Available at: shorturl.at/adoty (Accessed : 12 August 2019)

Lehoczkyné Kollonay, Cs. (ed.) (1997) A magyar munkajog I. Budapest: Kulturtrade Kiadó

Lepage, A. (2000) 'Pas d'échelle de responsabilité sur Internet en matière de diffamation', Communication Commerce Électronique, (2), pp. 24-26.

Lepage, A. (2006) 'La vie privée du salarié, une notion civiliste en droit du travail', Droit social, (4), pp. 364-377. 
Levin, A. and Sánchez Abril, P. (2009) 'Two Notions of Privacy Online', Vanderbilt Journal of Entertainment and Technology Law, 11(4), pp. 1001-1051.

Lhernould, J.-P. (2015) 'Les SMS du salarié à la libre disposition de l'employeur ?', Jurisprudence sociale Lamy, (385), pp. 9-11.

Lhernould, J.-P. (2016) 'Statut des courriels provenant de la messagerie personnelle du salarié', Jurisprudence sociale Lamy, (405), pp. 10-12.

Lock, T. (2019) 'Article 7 CFR. Respect for private and family life', in Kellerbauer, M., Klamert, M., and Tomkin, J. (eds) Commentary on the EU Treaties and the Charter of Fundamental Rights. United Kingdom: Oxford University Press, pp. 2115-2120.

Loiseau, G. (2011) 'Vie personnelle et licenciement disciplinaire', Recueil Dalloz Sirey, (23), pp. 1568-1569.

Loiseau, G. (2014) 'Le liberté d'expression du salarié', Revue droit du travail Dalloz, (6), pp. 396-402.

Loiseau, G. (2017) 'La déconnexion-Observations sur la régulation du travail dans le nouvel espace-temps des entreprises connectées', Droit social, (5), pp. 463-470.

Loiseau, G. (2018) 'La CEDH valide la jurisprudence de la Chambre sociale', La Semaine Juridique Social, (12), pp. 30-37.

Loiseau, G. (2018) 'Réseaux sociaux et abus de la liberté d'expression: l'exception de cercle privé', La Semaine Juridique Social, (41), pp. 22-25.

Lory, B. E. H. (2010) 'Using Facebook to Assess Candidates During the Recruiting Process: Ethical Implications', NACE Journal, 71(1), pp. 37-40.

Lukács, A. (2016) 'What is Privacy? The History and Definition of Privacy', in Gábor Keresztes (ed.): Tavaszi Szél 2016 Tanulmánykötet I. Budapest: Doktoranduszok Országos Szövetsége, pp. 256-265.

Lynskey, O. (2014) 'Deconstructing Data Protection: the "Added-Value" of a Right to Data Protection in the EU Legal Order', International and Comparative Law Quarterly, 63(3), pp. 569-597.

Lynskey, O. (2015) The Foundations of EU Data Protection Law. Oxford: Oxford University Press

Lyon-Caen, A. (2014) 'Libertés et contrôle dans l'entreprise. 20 ans après', Revue droit du travail Dalloz, (6), pp. 386-390.

Lyon-Caen, G. (1992) Les libertés publiques et l'emploi. Paris: la Documentation française (Collection des rapports officiels)

Lyon-Caen, G. (2001) 'Débat autour de l'arrêt Nikon France', Semaine sociale Lamy, (1046) pp. 8-11.

Maier, J. (2013) 'Cause for Termination in the Age of Social Media', in Law Society of Upper Canada, Employment law and the new workplace in the social media age. Toronto: Irwin Law, pp. 281-304.

Majtényi, L. (1995) 'Az adatvédelem és az információszabadság az alkotmányban', Acta Humana: Emberi jogi közlemények, (18-19), pp. 87-100.

Majtényi, L. (2002) 'Az információs szabadságok és az adatvédelem határai', Világosság, XLIII (2-3), pp. 56-107.

Majtényi, L. (2006) Az információs szabadságok: adatvédelem és a közérdekü adatok nyilvánossága. Budapest: Complex

Majtényi, L. (2008) 'Az információs jogok', in Halmai, G. and Tóth, G. A. (eds) Emberi jogok. Budapest: Osiris Kiadó, pp. 577-610.

Mali, P. (no date) GDPR Articles with Commentary \& EU Case Laws

Mandl, I. and Biletta, I. (2018) Overview of new forms of employment - 2018 update. Publications Office of the European Union, Luxembourg: Eurofound 
Mandl, I. et al. (2015) New forms of employment. Publications Office of the European Union, Luxembourg: Eurofound

Marchadier, F. (2018) 'La protection des données informatiques stockées sur l'ordinateur professionnel du salarié à titre du droit au respect de la vie privée', JCP G Semaine Juridique (édition générale), (15), pp. 59-63.

Marguénaud, J.-P. and Mouly, J. (2017) 'De l'accès des salariés à Internet à la rationalisation de l'influence de la Cour EDH sur les relations individuelles du travail', La Semaine Juridique - Édition Générale, (44-45), pp. 1992-1996.

Mayaud, Y. (1998) 'De la mise en cause diffamatoire d'une gestion municipale : l'enjeu de publicité', Revue de science criminelle et de droit pénal comparé, (1), pp. 104-105.

Mayer-Schönberger, V. (1997) 'Generational Development of Data Protection in Europe', in Agre, P. E. and Rotenberg, M. (eds) Technology and Privacy: The New Landscape. Cambridge: MIT Press, pp. 219-241.

Mayer-Schönberger, V. (2011) Delete - The Virtue of Forgetting in the Digital Age. Princeton and Oxford: Princeton University Press

Mayoux, S. (2018) 'Licéité de la preuve recuillie sur Facebook par l'employeur', Jurisprudence sociale Lamy, (449), pp. 23-26.

Mazeaud, A. (2014, 2016) Droit du travail. Issy-les-Moulineaux: LGDJ-Lextenso éditions (Domat Droit privé)

Mazeaud, V. (2015) 'La constitutionnalisation du droit au respect de la vie privée', Les Nouveaux Cahiers du Conseil constitutionnel, (48) pp. 7-20.

McCullagh, K. (2008) 'Blogging: self presentation and privacy', Information \& Communications Technology Law, 17(1), pp. 3-23.

McKay-Panos, L. (2007) 'Workplace Surveillance', LawNow, 32(2), pp. 44-50.

Mélypataki, G. and Rácz, Z. (2018) 'A személyiségi jogok védelmének ütközése a munkajogban', in Auer, Á. et al. (eds) Ünnepi kötet a 65 éves Kiss György tiszteletére - Liber Amicorum in honorem Georgii Kiss aetatis suae LXV. Budapest: Dialóg Campus Kiadó, pp. 677-684.

Mementos LMD - Droit du travail 2018

Mendel, T. et al. (2013) Étude mondiale sur le respect de la vie privée sur l'Internet et la liberté d'expression. Paris: Éditions Unesco (Collection Unesco sur la liberté de l'Internet)

Meyer, S. (1980) 'Adapting the Immigrant to the Line: Americanization in the Ford Factory, 1914-1921', Journal of Social History, 14(1), pp. 67-82.

Mgrditchian, G. (2015) 'Employment and Social Media Privacy: Employer Justifications for Access to "Private" Material', Rutgers Computer \& Technology Law Journal, 41(1), pp. 108-133.

Michel, A. (2016) 'L'utilisation des contenus postés sur les réseaux sociaux comme éléments de preuve d'un dommage', Revue du droit des technologies de l'information, (65), pp. 94-112.

Michel, S. (2018) 'TIC et protection de la vie privée du salarié', Bulletin Joly Travail, (2), pp. 149-152.

Miholics, T. (2015) 'Általános magatartási követelmények a munkaviszonyban', Magyar jog, 62(4), pp. 245-249.

Mikkelson, K. (2010) Cybervetting and Monitoring Employees' Online Activities: Assessing the Legal Risks for Employers. The Public Lawyer, 18 (2), pp. 3-7.

Mills, J. L. (2015) Privacy in the New Media Age. Gainesville: University Press of Florida

Moderne, F. (2012) La Convention européenne des Droits de l'Homme. 3rd edn. Paris: Dalloz 
Molfessis, N. (2004) 'Vie professionnelle, vie personnelle et responsabilité des commettants du fait de leurs préposés', Droit social, (1), pp. 31-39.

Molnár, I. and Jakab, É. (2008) Római jog. Szeged: Leges

Mooney, D. E. (2010) 'Employer on the Web Wire: Balancing the Legal Pros and Cons of Online Employee Screening', Idaho Law Review, 46(3), pp. 733-761.

Moreira, T. C. (2013) 'The Digital To Be or Not To Be: Privacy of Employees and the Use of Online Social Networks in the Recruitment Process', GSTF International Journal of Law and Social Sciences (JLSS), 2(2), pp. 76-80.

Moreira, T. C. (2016) 'The Electronic Control of the Employer in Portugal', Labour \& Law Issues, 2(1), pp. 1-27.

Morgenroth, T. (2016) La vie privée en droit du travail. Doctoral dissertation. Université Lille 2 - Droit et Santé

Mouly, J. (2012) Droit du travail. 6e édition. Rosny-sous-Bois: Bréal (Lexifac Droit)

Nasom-Tissandier, H. (2018) 'L'importance de la charte informatique dans la justification de mesures de surveillance des salariés', Jurisprudence sociale Lamy, (451), pp. 1214.

Ndior, V. (2015) 'Le réseau social : essai d'identification et de qualification', in Ndior, V. (ed.) Droit et réseaux sociaux. Issy-les-Moulineaux: Lextenso (Collection LEJEP) pp. 7-37.

Németh, J. (2013) 'Az internet nem felejt - közösségi media-használatra alapított munkáltatói és munkavállalói felmondások', Infokommunikáció és jog, (2), pp. 9698.

Németh, J. (2013) 'Internet és közösségi háló mint munkaeszköz', Infokommunikáció és jog, (1). pp. 37-41.

Netter, E. (2015) 'La liberté d'expression sur les réseaux sociaux en droit français', in Ndior, V. (ed.) Droit et réseaux sociaux. Issy-les-Moulineaux: Lextenso (Collection LEJEP), pp. 39-63.

Newell, B. C. (2011) 'Rethinking Reasonable Expectations of Privacy in Online Social Networks', Richmond Journal of Law and Technology, 17(4), pp. 1-62.

Niel, S. (2007) 'Elaborer une charte informatique', Les cahiers du DRH, (130), pp. 37-45.

Nissenbaum, H. (1998) 'Protecting Privacy in an Information Age: the Problem of Privacy in Public', Law and Philosophy, 17(5-6), pp. 559-596.

Nivelles, V. (2014) 'Les entreprises à l'épreuve des réseaux sociaux', Jurisprudence Sociale Lamy, (377-378), pp. 9-13.

North, E. E. (2010) 'Facebook Isn't Your Space Anymore: Discovery of Social Networking Websites', Kansas Law Review, 58(5), pp. 1279-1309.

Nyman-Metcalf, K. (2014) 'The Future of Universality of Rights', in Kerikmäe, T. (ed.) Protecting Human Rights in the EU. Controversies and Challenges of the Charter of Fundamental Rights. Heidelberg: Springer, pp. 21-36.

Otto, M. (2016) The Right to Privacy in Employment: a Comparative Analysis. Oxford, Portland: Hart Publishing

Ouaissi, H. (2017) Droit du travail: de l'individuel au collectif. 2nd edn. Bruxelles: Bruylant

Pailler, L. (2012) Les réseaux sociaux sur internet et le droit au respect de la vie privée. Bruxelles: Larcier

Park, S. (2014) 'Employee Internet Privacy: A Proposed Act that Balances Legitimate Employer Rights and Employee Privacy', American Business Law Journal, 51(4), pp. $\quad 779-841$.

Parker, R. B. (1974) ‘A Definition of Privacy’, Rutgers Law Review, 27(2), pp. 275-297. 
Péano, M.-A. (1995) 'L'intuitus personae dans le contrat de travail', Droit social, (2), pp. 129-138.

Peck, S. (2012) Social media, monitoring and surveillance at work - a practical guide for trade unionists. London: LRD Publ. (Labour Research Department Booklets)

Peebles, K. A. (2012) 'Negligent Hiring and the Information Age: How State Legislatures Can Save Employers from Inevitable Liability', William and Mary Law Review, 53(4), pp. 1397-1433.

Péronne, G. and Daoud, E. (2018) 'Accès par l'employeur au compte Facebook du salarié et droit à la vie privée', Dalloz IP/IT, (5), pp. 315-316.

Perraki, P. (2015) La protection de la vie personnelle du salarié en droit comparé et européen: étude comparative des droits français, hellénique, britannique et européen. Paris: l'Harmattan

Persson, A. J. and Hansson, S. O. (2003) 'Privacy at Work - Ethical Criteria', Journal of Business Ethics, 42(1), pp. 59-70.

Peskine, E. and Wolmark, C. (2016) Droit du travail. 11th edn. Paris: Dalloz (Hypercours Dalloz cours \& travaux dirigés)

Pete, É. (2018) 'A munkavállaló és a munkáltató személyiségi jogainak védelme a munkaviszonyban', in Mailáth György Tudományos Pályázat 2017. Díjazott dolgozatok. Budapest: Országos Bírósági Hivatal, pp. 768-807.

Péterfalvi, A. (2014) 'Személyiségi jogok - adatvédelem - információszabadság', Magyar jog, 61(9), pp. 486-489.

Péterfalvi, A. (ed.) (2012) Adatvédelem és információszabadság a mindennapokban. Budapest: HVG-ORAC

Péterfalvi, A., Révész, B. and Buzás, P. (eds) (2018) Magyarázat a GDPR-ról. Budapest: Wolters Kluwer Hungary

Petit, F. (2011) Droits des contrats de travail. Paris: Gualino

Petrik, F. (2014) 'Személyiségi jogok', in Wellmann, G. (ed.) Polgári jog: Bevezető és záró rendelkezések. Az ember mint jogalany. Öröklési jog. 2nd edn. Budapest: HVGORAC Lap- és Könyvkiadó, pp. 166-211.

Pettiti, L.-E., Decaux, E. and Imbert, P.-H. (eds) (1995) La Convention Européenne des Droits de l'Homme, commentaire article par article. Paris: Economica

Peyronnet, M. (2017) 'CEDH : la protection réaffirmée de la vie privée du salarié sur internet. CEDH 5 sept. 2017, Bărbulescu c. Roumanie, req. n 61496/08.', Dalloz actualité

Picq, M. (2011) 'Facebook et les salariés: vie privée, liberté d'expression et humour', Revue des droits et libertés fondamentaux, (11)

Pierroux, E. (2015) 'Facebook, Twitter et autres résaux sociaux: petites injures entres "amis", La Gazette du Palais, (336-337), pp. 4-8.

Pizzio-Delaporte, C. (2001) 'Libertés fondamentales et droits du salarié le rôle du juge', Droit Social, (4), pp. 404-412.

Plasschaert, E. (2017) 'La licéité du traitement de données personnelles du travailleur au regard du nouveau Règlement (UE) n 2016/679 sur la protection des données', in Ragheno, N. (ed.) Data protection \& privacy: le GDPR dans la pratique. Limal: Anthemis, pp. 105-118.

Pók, L. (2012) 'A közösség hálójában - Közösségi oldalak munkajogi vonatkozásai', Infokommunikáció és jog, (1), pp. 10-17.

Pók, L. (2012) 'Lájkolni szabad? Munkavállalói véleménynyilvánítás az új Munka Törvénykönyve tükrében', Infokommunikáció és jog, (4), pp. 160-165.

Polefkó, P. (2011) 'Barátok és bizonytalanságok közt (5. rész) : avagy a közösségi oldalakról adatvédelmi szemszögből', Infokommunikáció és jog, (44), pp. 109-110. 
Porta, J.et al.(2018) 'Libertés fondamentales, égalité de traitement et discrimination', Bulletin d'information de la Cour de Cassation, (887), pp. 15-18.

Posner, R. A. (1978) 'The Right of Privacy', Georgia Law Review, 12(3), pp. 393-422.

Post, R. C. (2001) 'Three Concepts of Privacy', Georgetown Law Journal, 89(6), pp. 2087-2098.

Pottecher, M.-C. and Bakhtiari, Z. (2016) 'Travailler ou tweeter, le salarié n'a pas (forcément) à choisir', Cahiers sociaux du Barreau de Paris, (285), pp. 233-234.

Poullet, Y. (2005) 'Pour une troisième génération de réglementations de protection des données', Jusletter. Available at: http://www.crid.be/pdf/public/5188.pdf (Accessed: 24 February 2018)

Prosser, W. L. (1960) 'Privacy', California Law Review, 48(3), pp. 383-423.

Prugberger, T. (2011) 'A munkaszerződés és a munkaviszonyból származó alapvető jogok és kötelezettségek a Munka Törvénykönyvének rekodifikációs tervezetében', Gazdasági élet és társadalom, (1-2), pp. 269-288.

Purtova, N. (2010) 'Private Law Solutions in European Data Protection: Relationship to Privacy, and Waiver of Data Protection Rights', Netherlands Quarterly of Human Rights, 28(2), pp. 179-198.

Qi, M. and Edgar-Nevill, D. (2011) 'Social networking searching and privacy issues', Information Security Technical Report, 16(2), pp. 74-78.

Rácz, I. (2015) 'A közösségi média használatának árnyoldalai a munkaviszonyban', in Deres, P. and Grad-Gyenge, A. (eds) Acta Iuvenum Caroliensia VII.Budapest: Károli Gáspár Református Egyetem Állam- és Jogtudományi Kar, pp. 279-305.

Radé, C. (2002) Droit du travail. 2nd edn. Paris: Montchrestien

Radnay, J. (2003, 2008) Munkajog. Budapest: Szent István Társulat

Rátkai, I. (2019) 'Új adatvédelmi szabályok a munkaviszonnyal összefüggésben', Munkajog, (2), pp. 69-75.

Ray, J.-E. (1992) 'Nouvelles technologies et nouvelles formes de subordination', Droit social, (6), pp. 525-537.

Ray, J.-E. (1993) 'Une loi macédonienne? Étude critique du V de la loi du 31 décembre 1992. "Dispositions relatives au recrutement et aux libertés individuelles »', Droit social, (2), pp. 103-114.

Ray, J.-E. (2001) Le droit du travail à l'épreuve des NTIC. 2nd edn. Rueil-Malmaison: Liaisons

Ray, J.-E. (2001) Le droit du travail à l'épreuve des NTIC. Rueil-Malmaison: Liaisons

Ray, J.-E. (2007) 'Actualités des TIC', Droit social, (9-10), pp. 951-961.

Ray, J.-E. (2009) 'Actualité des TIC (II). Rapports collectifs de travail', Droit social, 1, pp. 22-37.

Ray, J.-E. (2010) 'D'un droit des travailleurs aux droits de la personne au travail', Droit social, (1), pp. 3-11.

Ray, J.-E. (2010) 'Little Brothers are watching you', Semaine sociale Lamy, 1470, pp. 1013.

Ray, J.-E. (2011) 'Facebook, le salarié et l'employeur', Droit social, (2), pp. 128-140.

Ray, J.-E. (2012) 'A propos de la révolution numérique. Actualités des TIC (maiseptembre 2012)', Droit social, (10), pp. 934-939.

Ray, J.-E. (2013) 'Facebook, espace public plus que privé. A propos de l'arrêt de la 1 ère Chambre civile du 10 avril 2013', Semaine sociale Lamy, (1599), pp. 14-19.

Ray, J.-E. (2015) 'Actualité des TIC. Tous connectés, partout, tout le temps ?', Droit social, (6), pp. 516-527.

Ray, J.-E. (2018) 'Des “licenciements Facebook" à la sanction d'un "Like"?', Semaine sociale Lamy, (1830), pp. 10-12. 
Ray, J.-E. (2017, 2018) Droit du travail: droit vivant. Paris: Wolters Kluwer France

Ray, J.-E. and Bouchet, J.-P. (2010) 'Vie professionnelle, vie personnelle et technologies d'information et de communication', Droit social, (1), pp. 44-55.

Retzer, K. and Lopatowska, J. (2011) 'How to Monitor Workplace E-Mail and Internet in Europe: The Polish Perspective'. Privacy \& Security Law Report, Bureau of National Affairs. Available at: https://media2.mofo.com/documents/110718-privacy-andsecurity-law-report.pdf (Accessed: 2 May 2018)

Rey, B. (2012) La vie privée à l'ère du numérique. Cachan: Lavoisier

Rey, B. (2013) 'La vie privée au travail. Retour sur la place du privé en contexte hiérarchique à l'ère du numérique', Les Cahiers du numérique, 9(2), pp. 105-136.

Richard de la Tour, J. (1999) La vie personnelle du salarié. Étude sur la jurisprudence récente de la Chambre sociale de la Cour de cassation. Cour de cassation. Available at: https://www.courdecassation.fr/publications_26/rapport_annuel_36/rapport_1999 _91/etudes_documents_93/jean_richard_5796.html(Accessed: 12 July 2017)

Richard, J. (2016) 'Le numérique et les données personnelles : quels risques, quelles potentialités ?', Revue du Droit public (RDP), 1, pp. 87-100.

Rigaux, M. F. (1991) 'La liberté de la vie privée', Revue internationale de droit comparé, 43(3), pp. 539-563.

Rijckaert, O. and Lambert, N. (2012) Le respect de la vie privée dans la relation de travail. Waterloo: Wolters Kluwer Belgium

Rivero, J. (1982) 'Les libertés publiques dans l'entreprise', Droit social, (5), pp. 421-424.

Rivero, J. and Savatier, J. (1978) Droit du travail. Paris: Presses Universitaires de France

Rouvroy, A. and Poullet, Y. (2009) 'The Right to Informational Self-Determination and the Value of Self-Development: Reassessing the Importance of Privacy for Democracy', in Gutwirth, S. et al. (eds) Reinventing Data Protection? Springer, pp. 45-76.

Rózsavölgyi, B. (2018) 'Mikor lehet jogszerü a munkáltató ellenőrzése? - az Emberi Jogok Európai Bírósága Nagykamarája Bărbulescu kontra Románia ügyben hozott ítéletének iránymutatásai', Munkajog, 2(1), pp. 43-48.

Rücker, D. and Kugler, T. (eds) (2018) New European General Data Protection Regulation. A Practitioner's Guide. München, Oxford, Baden-Baden: C.H. Beck, Hart, Nomos

Rustad, M. L. and Paulsson, S. R. (2005) 'Monitoring Employee E-Mail and Internet Usage: Avoiding the Omniscient Electronic Sweatshop: Insights from Europe', $U$. Pa. Journal of Labor and Employment Law, 7(4), pp. 829-904.

Saint-Pau, J.-C. (2016) 'Art. 9 - Fasc. 10 : Jouissance des droits civils. - Droit au respect de la vie privée. - Définition conceptuelle du droit subjectif', JurisClasseur Civil Code

Sanders, A. K. (2013) 'Obscenity, Sexting, and Cyberbullying', in Stewart, D. R. (ed.) Social Media and the Law. A Guidebook for Communication Students and professionals. New York, London: Routledge, pp. 156-174.

Sanders, S. D. (2012) 'Privacy is Dead: The Birth of Social Media Background Checks', Southern University Law Review, 39(2), pp. 243-264.

Sári, J. and Somody, B. (2008) Alapjogok. Budapest: Osiris Kiadó

Savatier, J. (1992) 'La protection de la vie privée des salariés', Droit social, (4), pp. 329-336.

Schabas, W. A. (2015) The European Convention on Human Rights: a Commentary. Oxford: Oxford University Press 
Schoeman, F. D. (2007) 'Privacy: philosophical dimensions of the literature', in Schoeman, F. D. (ed.) Philosophical Dimensions of Privacy: An Anthology. Cambridge: Cambridge University Press, pp. 1-33.

Schultis, C. (2017) 'Le traitement de données dans le cadre des relations de travail dans le règlement sur la protection des données personnelles', Dalloz IP/IT, (5), pp. 265-267.

Schwartz, P. (1989) 'The Computer in German and American Constitutional Law: Towards an American Right of Informational Self-Determination', The American Journal of Comparative Law, 37(4), pp. 675-701.

Shapiro, F. R. (1985) 'The Most-Cited Law Review Articles', California Law Review, 73(5), pp. 1540-1554.

Shih, C. (2011) A Facebook kora. Budapest: Kiskapu Kiadó

Simitis, S. (1995) 'From the Market to the Polis: The EU Directive on the Protection of Personal Data, Iowa Law Review, 80(3), pp. 445-470.

Simitis, S. (1998) 'From the General Rules on Data Protection to a Specific Regulation of the Use of Employee Data: Policies and Constraints of the European Union', Comparative Labor Law and Policy Journal, 19(3), pp. 351-372.

Simitis, S. (1999) 'Reconsidering the Premises of Labour Law: Prolegomena to an EU Regulation on the Protection of Employees' Personal Data', European Law Journal, 5(1), pp. 45-62.

Simitis, S. (2010) 'Privacy - An Endless Debate', California Law Review, 98(6), pp. 19892006.

Simms, M. (1994) 'Defining Privacy in Employee Health Screening Cases: Ethical Ramifications Concerning the Employee/Employer Relationship', Journal of Business Ethics, 13(5), pp. 315-325.

Simon, É. (2005) 'Egy XIX. századi tanulmány margójára', Információs Társadalom, (2), pp. 32-43.

Sipka, P. and Zaccaria, M. L. (2018) 'A munkáltató ellenőrzési joga a munkavállaló munkahelyi számítógépén tárolt magánadatai fölött', Munkajog, 2(2), pp. 45-49.

Síthigh, D. M. (2008) 'The mass age of internet law', Information \& Communications Technology Law, 17(2), pp. 79-94.

Smith, W. P. and Kidder, D. L. (2010) 'You've been tagged! (Then again, maybe not): Employers and Facebook', Business Horizons, 53(5), pp. 491-499.

Smith-Butler, L. (2009) 'Workplace Privacy: We'll Be Watching You', Ohio Northern University Law Review, 35(1), pp. 53-81.

Solove, D. J. (2002) 'Conceptualizing Privacy', California Law Review, 90(4), pp. 10871156

Solove, D. J. (2007) The Future of Reputation. Gossip, Rumor, and Privacy on the Internet. New Haven and London: Yale University Press

Solove, D. J. (2011) Nothing to hide: the false tradeoff between privacy and security. New Haven \& London: Yale University Press

Solove, D. J. (2013) 'Introduction: Privacy-Self Management and the Consent Dilemma', Harward Law Review, 126(7), pp. 1880-1903.

Sólyom, L. (1983) A személyiségi jogok elmélete. Budapest: Közgazdasági és Jogi Könyvkiadó

Sólyom, L. (1988) ‘Adatvédelem és személyiségi jog’, Világosság, 29(1), pp. 53-60.

Sólyom, L. (2001) Az alkotmánybíráskodás kezdetei Magyarországon. Budapest: Osiris Kiadó

Sordet, E. (2010) 'Facebook, néfaste pour la vie privée (des salariés) ?', JCP G Semaine Juridique (édition générale), (48), pp. 2228-2228. 
Sprague, R. (2007) 'From Taylorism to the Omnipticon: Expanding Employee Surveillance Beyond the Workplace', The John Marshall Journal of Information Technology \& Privacy Law, 25(1), pp. 1-36.

Sprague, R. (2008) 'Orwell Was an Optimist: The Evolution of Privacy in the United States and Its De-Evolution for American Employees', The John Marshall Law Review, 42(1), pp. 83-135.

Sprague, R. (2008) 'Rethinking Information Privacy in an Age of Online Transparency', Hofstra Labor \& Employment Law Journal, 25(2), pp. 395-417.

Sprague, R. (2011) 'Invasion of the Social Networks: Blurring the Line Between Personal Life and the Employment Relationship', University of Louisville Law Review, 50(1), pp. 1-34.

Stroud, D. (2008) 'Social networking: An age-neutral commodity - Social networking becomes a mature web application', Journal of Direct, Data and Digital Marketing Practice, 9(3), pp. 278-292.

Suder, S. (2014) 'Pre-Employment Background Checks on Social Networking Sites - May Your Boss Be Watching?', Masaryk University Journal of Law and Technology, 8(1), pp. 123-136.

Sudre, F. (2015) La Convention européenne des droits de l'homme. 10th edn. Paris: Presses Universitaires de France

Sudre, F. (2018) 'La « vie privée » dans un contexte professionnel', La Semaine Juridique Edition Générale, (41), pp. 1054-1055.

Sulyok, M. (2017) Magánszféravédelem a tisztességes eljárásban - Az alapjogsértő bizonyítás összehasonlító alkotmányjogi vizsgálata. Doctoral dissertation. Szegedi Tudományegyetem

Supiot, A. (2000) 'Les nouveaux visages de la subordination', Droit social, (2), pp. 131145.

Supiot, A. (2002) Critique du droit du travail. Paris: Presses universitaires de France

Szabó, E. Gy. (2010) ‘A személyes adatok védelmének kérdései a virtuális világban', in Talyigás, J. (ed.) Az internet a kockázatok és a mellékhatások tekintetében. Budapest: Scolar Kiadó, pp. 43-65.

Szabó, M. D. (2004) ‘„Erős jogvédő szemlélettel, de a törvényi felhatalmazás keretein belül kell dolgoznunk.” Péterfalvi Attila adatvédelmi biztossal Szabó Máté Dániel beszélget', Fundamentum, VIII(4), pp. 37-43.

Szabó, M. D. (2005) 'Kísérlet a privacy fogalmának meghatározására a magyar jogrendszer fogalmaival', Információs Társadalom, (2), pp. 44-54.

Szabó, M. D. (2008) 'Nyilvános magánszféra - Hol a határ?', in Dezső, M. and Kukorelli, I. (eds) Ünnepi kötet Sári János egyetemi tanár 70. születésnapja tiszteletére. Budapest: Rejtjel Kiadó, pp. 329-341.

Szabó, M. D. and Székely, I. (2005) ‘A privacy védelme a munkahelyen', in Szabó, M. D. and Székely, I. (eds) Szabad adatok, védett adatok. Budapest: BME GTK ITM, pp. 115-148.

Székely, I. (2010) 'Kukkoló társadalom - avagy van-e még függöny virtuális ablakunkon?', in Talyigás, J. (ed.) Az internet a kockázatok és a mellékhatások tekintetében. Budapest: Scolar Kiadó, pp. 93-120.

Szekfü, A. (2007) Kommunikáció, nyilvánosság, esélyegyenlöség Magyarországon: a távírótól a Web 2.0-ig. Budapest: Gondolat, MTA-ELTE Kommunikációelméleti Kutatócsoport

Szőke, G. L. (2013) 'Az adatvédelem szabályozásának történeti áttekintése', Infokommunikáció és jog, (3), pp. 107-112. 
Szőke, G. L. (2015) Az európai adatvédelmi jog megújítása. Tendenciák és lehetöségek az önszabályozás területén. Budapest: HVG-ORAC

Szöke, G. L. (ed.) (2012) Privacy in the workplace. Data protection law and selfregulation in Germany and in Hungary. Budapest: HVG-ORAC Lap- és Könyvkiadó

Szőke, G. L. et al. (2012) Munkahelyi adatvédelem. Nemzeti jelentés - Magyarország. Available

at: http://pawproject.eu/en/sites/default/files/page/web_national_report_hungary_hu. pdf (Accessed: 21 October 2016)

Szücs, P. (2013) A munka törvénykönyve, 2012-1992. Budapest: CompLex

Szüts, K., Karsai, D. and Mándi, G. (2006) Az Alkotmánybíróság egyes határozatainak ismertetése. Budapest: Rejtjel Kiadó

Szüts, Z. (2015) 'A Munka Világának Online Kommunikációs Kérdései', Opus et Educatio, 2(2), pp. 26-30.

Tene, O. (2011) 'Privacy: The new generations', International Data Privacy Law, 1(1), pp. $15-27$.

Teyssié, B. (1988) 'Personnes, entreprises et relations de travail', Droit social, (5), pp. 374-383.

Thompson, B. (2007) 'The Breaking Wave: New Law for a Wired World?', International Review of Law, Computers \& Technology, 21(3), pp. 221-223.

Thornthwaite, L. (2016) 'Chilling times: social media policies, labour law and employment relations', Asia Pacific Journal of Human Resources, 54(3), pp. 332-351.

Tissot, O. de (1995) 'La protection de la vie privée du salarié', Droit social, (3), pp. 222 230.

Tobok, D. (2013) 'Social Network Recruiting: Implications of this New Hiring Model', in Law Society of Upper Canada, Employment law and the new workplace in the social media age. Toronto: Irwin Law, pp. 95-99.

Towner, N. (2016) Social media at work. A practical guide for trade union reps. Edited by C. Ruhemann. London: LRD Publications (Labour Research Department Booklets)

Tricoit, J.-P. (2013) 'Recrutement, rupture du contrat de travail et TIC', La Semaine Juridique Social, (40), pp. 9-14.

Trudeau, G. (2010) 'En conclusion...vie professionnelle et vie personnelle ou les manifestations d'un nouveau droit du travail', Droit social, (1), pp. 76-79.

Tshilembe, A.-S. (2015) 'Vie privée - protection des données personnelles du travailleur: la question de l'embauche', in Martin, D., Morsa, M., and Gosseries, P. (eds) Droit du travail européen : questions spéciales. Bruxelles: Éditions Larcier, pp. 645-702.

Türk, A. (2011) La vie privée en péril: des citoyens sous contrôle. Paris: OJacob

Vallet, C. (2012) 'Le dévoilement de la vie privée sur les sites de réseau social. Des changements significatifs', Droit et société, (1), pp. 163-188.

Van Alsenoy, B. et al. (2009) 'Social networks and web 2.0: are users also bound by data protection regulations?', Identity in the Information Society, 2(1), pp. 65-79.

Van Eecke, P. and Truyens, M. (2010) 'Privacy and social networks', Computer Law and Security Review, 26(5), pp. 535-546.

Vékás, L. (ed.) (2013) A Polgári Törvénykönyv magyarázatokkal. Budapest: Complex

Velu, R. and Ergec, J. (2014) Convention européenne des droits de l'homme. Bruxelles: Bruylant

Verkindt, P.-Y. (2010) 'Les “amis" de nos "amis"..', JCP S (édition sociale), (48), pp. 3-5.

Vickery, G. and Wunsch-Vincent, S. (2007) Participative Web and User-Created Content. Web 2.0, Wikis and Social Networking. OECD Publishing

Vigneau, C. (2002) 'Information Technology and Workers' Privacy: the French Law', Comparative Labor Law \& Policy Journal, 23(2), pp. 351-376. 
Vigneau, C. (2006) 'Protection of personal data (Article 8)', in Bercusson, B. (ed.) European Labour Law and the EU Charter of Fundamental Rights. BadenBaden: Nomos, pp. 115-131.

Vissy, B. (2015) 'Az információs önrendelkezési jog', in Pozsár-Szentmiklósy, Z. and Somody, B. (eds) Alkotmányos alapok. 2nd edn. Budapest: HVG-ORAC Lap- és Könyvkiadó, pp. 200-207.

Voigt, P. and von dem Bussche, A. (2017) The EU General Data Protection Regulation (GDPR). A Practical Guide. Springer

Waquet, P. (1994) 'Vie professionnelle et vie personnelle du salarié', Cahier Sociaux du Barreau de Paris, (64), pp. 289-292.

Waquet, P. (2001) 'La vie personnelle du salarié', in Droit syndical et droits de l'homme à l'aube du XXIe siècle: mélanges en l'honneur de Jean-Maurice Verdier. Paris: Dalloz, p. 513-524.

Waquet, P. (2002) 'Retour sur l'arrêt Nikon', Semaine sociale Lamy, (1065), p. 5-10.

Waquet, P. (2003) L'entreprise et les libertés du salarié. Paris: Editions Liaisons

Waquet, P. (2004) 'La vie personnelle du salarié', Droit social, (1), pp. 23-30.

Waquet, P. (2006) 'Le "trouble objectif dans l'entreprise" : une notion à redéfinir', Revue droit du travail Dalloz, (5), pp. 304-310.

Waquet, P., Struillou, Y. and Pécaut-Rivolier, L. (2014) Pouvoirs du chef d'entreprise et libertés $d u$ salarié: du salarié-citoyen au citoyen-salarié. Rueil-Malmaison: ÉdLiaisons

Warren, M. and Pedowitz, A. (2011) 'Social Media, Trade Secrets, Duties of Loyalty, Restrictive Covenants and Yes, the Sky is Falling', Hofstra Labor and Employment Law Journal, 29(1), pp. 99-114.

Warren, S. D. and Brandeis, L. D. (1890) 'The Right to Privacy', Harvard Law Review, 4(5), pp. 193-220.

Weir, G. R. S., Toolan, F. and Smeed, D. (2011) 'The threats of social networking: Old wine in new bottles?', Information Security Technical Report, 16(2), pp. 38-43.

Westin, A. F. (2003) 'Social and political dimensions of privacy', Journal of Social Issues, 59(2), pp. 431-453.

Whitman, J. Q. (2004) 'The Two Western Cultures of Privacy: Dignity versus Liberty', The Yale Law Journal, 113(6), pp. 1151-1221.

Wilkens, M. et al. (2018) Striking a balance: Reconciling work and life in the EU. Publications Office of the European Union, Luxembourg: Eurofound

Wolton, E. and Pompey, S. (2013) 'Données à caractère personnel et droit du travail', Revue de Jurisprudence Sociale (RJS), (4), pp. 215-220.

Wong, R. (2012) 'The Data Protection Directive 95/46/EC: Idealisms and realisms', International Review of Law, Computers \& Technology, 26(2-3), pp. 229244.

Wong, R. and Savirimuthu, J. (2008) 'All or Nothing: This is the Question? The Application of Art. 3(2) Data Protection Directive 95/46/EC to the Internet', John Marshall Journal of Computer \& Information Law, 25(2), pp. 241-266.

Zaccaria, M. L. (2016) 'Munkavállalók a világhálón - "Megosztani ér?”, HR \& Munkajog, 7(10), pp. 14-17. 


\section{Online sources}

"Sorry is not enough": WP29 establishes a Social Media Working Group (2018). Available at: https://edps.europa.eu/sites/edp/files/publication/18-0411_wp29_press_release_en.pdf (Accessed: 20 January 2019)

14 Times People Got Fired For Posting On Facebook (no date) Awesome Inventions. Available at: https://www.awesomeinventions.com/fired-posting-onfacebook/(Accessed: 30 July 2019)

47 Facebook Statistics for 2016 (2016) Brandwatch. Available at: https://www.brandwatch.com/blog/47-facebook-statistics-2016/(Accessed: 7 January 2017)

7 Ways Employee Privacy Laws Impact Social Media in the Workplace (2018) Pryme Group. Available at: https://allpryme.com/employee-privacy-laws/employeeprivacy-laws/ (Accessed: 14 August 2019)

A Compétence Egale (no date) Charte réseaux sociaux, Internet, Vie Privée et Recrutement. Available at: https://www.michaelpage.fr/sites/michaelpage.fr/files/Charte_rxseaux_sociaux_inter net_vie_privxe_et_recrutement.pdf(Accessed: 13 August 2019)

ATAWAD (no date) emarketing.fr. Available at: http://www.e-marketing.fr/DefinitionsGlossaire/ATAWAD-240581.htm ; (Accessed: 11 May 2018)

Bambu by Sprout Social (no date) Putting Downtime to Work: A Marketing Data Report. Available at: https://getbambu.com/blog/data/downtime-to-work-marketingreport/(Accessed: 20 January 2019)

Banktitkot sértett egy magyar mikroblog(2012) Index. Available at: https://index.hu/tech/2012/01/04/banktitkot_sertett_egy_magyar_mikroblogger/( Accessed: 7 September 2018)

Bathelot, B. (2015) Définition: ATAWAD, Définitions marketing. Available at: https://www.definitions-marketing.com/definition/atawad/ (Accessed: 15 May 2018)

Bell, M. (2011) More employers using firms that check applicants' social media history, The Washington Post. Available at: https://www.washingtonpost.com/lifestyle/style/more-employers-using-firms-thatcheck-applicants-social-mediahistory/2011/07/12/gIQAxnJYGI_story.html?noredirect=on\&utm_term=.1506923db 7c6(Accessed: 16 August 2018)

Bibby, A. (2016) You're being followed Electronic Monitoring and surveillance in the workplace. UNI/GS/06-2006/0035/EN. UNI Global Union. Available at: http://www.andrewbibby.com/pdf/Surveillance-en.pdf (Accessed: 11 May 2018)

Bizzi, L. (2018) Employees Who Use Social Media for Work Are More Engaged - but Also More Likely to Leave Their Jobs, Harvard Business Review. Available at: https://hbr.org/2018/05/employees-who-use-social-media-for-work-are-moreengaged-but-also-more-likely-to-leave-their-jobs(Accessed: 27 July 2019)

boyd, danah (2011) 'Networked Privacy'. Personal Democracy Forum, New York, NY, 6 June. Available at: http://www.danah.org/papers/talks/2011/PDF2011.html (Accessed: 28 February 2017)

Burger King worker fired for bathing in sink(2008) NBC News. Available at: http://www.nbcnews.com/id/26167371/ns/us_news-life/t/burger-king-workerfired-bathing-sink/\#.XUgxoo4zbct (Accessed: 5 August 2019) 
Burke, F. (2013) Social Media vs. Social Networking, Huffingtonpost. Available at: http://www.huffingtonpost.com/fauzia-burke/social-media-vs-socialne_b_4017305.html\%202017\%2002\%2027(Accessed: 22 September 2017)

Bygrave, L. A. (2001) The Place of Privacy in Data Protection Law. Available at: http://www.austlii.edu.au/au/journals/UNSWLJ/2001/6.html (Accessed: 28 February 2018)

Bylund, M. et al. (no date) PRIMA - Privacy Research through the Perspective of a Multidisciplinary Mash up. Available at: http://soda.swedishict.se/4046/1/PRIMA_final_DOC_17.pdf (Accessed: 12 March 2018)

Cambridge Dictionary (no date) 'ICT' in Business English. Available at: https://dictionary.cambridge.org/dictionary/english/ict (Accessed: 22 September 2019)

Canadian Red Cross (no date) Social Media Guidelines for Canadian Red Cross Staff and Volunteers. Available at: http://www.redcross.ca/crc/documents/What-WeDo/Violence-Bullying/partners/social-media-guidelines-2013.pdf (Accessed: 19 March 2017)

Chazan, D. (2016) French parents 'could be jailed' for posting children's photos online, The Telegraph. Available at: https://www.telegraph.co.uk/news/worldnews/europe/france/12179584/Frenchparents-could-be-jailed-for-posting-childrens-photos-online.html (Accessed: $\quad 30$ November 2018)

Clifford, S. (2009) Video Prank at Domino's Taints Brand, The New York Times. Available at: https://www.nytimes.com/2009/04/16/business/media/16dominos.html(Accessed: 3 May 2018)

Cross-Tab (2010) Online Reputation in a Connected World. Available at: https://www.jobhunt.org/guides/DPD_Online-Reputation-Research_overview.pdf(Accessed: 3 May 2018)

Dauvergne, G. (2017) 85\% des recruteurs font des recherches en ligne sur les candidats, Les Echos.fr. Available at: https://business.lesechos.fr/directionsressources-humaines/ressources-humaines/recrutement/030656487193-85-desrecruteurs-font-des-recherches-en-ligne-sur-les-candidats-314060.php (Accessed: 20 June 2019)

Definition of social media (no date) Merriam Webster. Available at: https://www.merriamwebster.com/dictionary/social\%20media (Accessed: 22 September 2017)

Definition of social networking (no date) Merriam Webster. Available at: https://www.merriam-webster.com/dictionary/social\%20networking (Accessed: 22 September 2017)

DELL (no date) Global Social Media Policy. Available at: http://www.dell.com/learn/uk/en/ukcorp1/corp-comm/social-mediapolicy?c=uk\&l=en\&s=corp (Accessed: 23 March 2017)

Delta hockey coach Christopher Sandau fired over Nazi posts on Facebook (2014) CBC News. Available at: http://www.cbc.ca/news/canada/british-columbia/delta-hockeycoach-christopher-sandau-fired-over-nazi-posts-on-facebook-1.2825623 (Accessed: 3 May 2018)

Department of the Interior (2010) Social Media Policy. Available at: https://edit.doi.gov/sites/doi.gov/files/migrated/notices/upload/DOI-Social-MediaPolicy-Final-Redacted.pdf (Accessed: 19 March 2017) 
Depressed woman loses benefits over Facebook photos (2009) CBC News. Available at: http://www.cbc.ca/news/canada/montreal/depressed-woman-loses-benefits-overfacebook-photos-1.861843(Accessed: 3 May 2018)

Desfeuillet, X. (2009) Presque tous les employeurs consultent le profil Internet des candidats à l'embauche, Le Monde. Available at: https://www.lemonde.fr/societe/chat/2009/11/20/internautes-comment-ameliorerson-image-sur-internet-un-expert-en-e-reputation-vousrepond_1270030_3224.html(Accessed: 20 June 2019)

Digital economy and society statistics - households and individuals (2018) Eurostat. Available at: https://ec.europa.eu/eurostat/statisticsexplained/index.php/Digital_economy_and_society_statistics__households_and_individuals\#Internet_usage (Accessed: 4 January 2018)

Dvorak, P. (2017) Flipping off President Trump has changed Juli Briskman's life - and exposed our divisions, The Washington Post. Available at: https://www.washingtonpost.com/local/flipping-off-president-trump-has-changedjuli-briskmans-life--and-exposed-our-divisions/2017/11/07/19efab02-c3f6-11e7afe9-4f60b5a6c4a0_story.html(Accessed: 14 August 2019)

ECtHR, Press Unit (2017) 'Q \& A. Grand Chamber judgment in the case of Bărbulescu v. Romania (application no. 61496/08)'. Available at: https://www.echr.coe.int/Documents/Press_Q_A_Barbulescu_ENG.PDF(Accesse d: 1 May 2018)

EDPS (no date) Glossary. Available at: https://edps.europa.eu/data-protection/dataprotection/glossary/b_en(Accessed: 20 January 2019

Employee monitoring update (2017) TaylorWessing. Available at: https://www.taylorwessing.com/globaldatahub/article-employee-monitoringupdate.html (Accessed: 1 May 2018).

Equestrian Australia (2012) Social Media Policy. Available at: http://www.equestrian.org.au/sites/default/files/Social\%20Media\%20Policy.pdf (Accessed: 19 March 2017)

Eurostat (no date) Glossary: Information and communication technology (ICT). Available at: https://ec.europa.eu/eurostat/statisticsexplained/index.php/Glossary:Information_and_communication_technology_(ICT) ( Accessed: 25 October 2019)

Facebook newsroom (2012) Protecting Your Passwords and Your Privacy. Available at: https://newsroom.fb.com/news/2012/03/protecting-your-passwords-and-yourprivacy/ (Accessed: 13 August 2019)

Facebook-szabályzat a mentőknél - van apropója (2012). Available at: https://www.hrportal.hu/c/facebook-szabalyzat-a-mentoknel-van-apropoja20120116.html (Accessed: 15 November 2018)

Goda, M. (2015) Felmondhatunk a munkavállalónak egy facebook bejegyzés miatt?, Munkajog Portál. Available at: http://munkajogportal.hu/felmondhatunk-amunkavallalonak-egy-facebook-bejegyzes-miatt/ (Accessed: 27 May 2017)

Golden Corral food stored by dumpster so health inspector won't see it, employee says (2013) YouTube.

Available at: https://www.youtube.com/watch?v=yb0yrdDOy0g (Accessed: 16 April 2018)

Goldman, E. (2009) The Third Wave of Internet Exceptionalism. Available at: https://blog.ericgoldman.org/archives/2009/03/the_third_wave.htm(Accessed: 20 January 2019)

Gros, M. (2010) Recrutement: une Charte pour contrer les dérives liées aux réseaux sociaux, Le Monde Informatique. Available at: 
https://www.lemondeinformatique.fr/actualites/lire-recrutement-une-charte-pourcontrer-les-derives-liees-aux-reseaux-sociaux-29715.html(Accessed: 13 August 2019)

Hammond, E. (2007) No place to hide, Financial Times. Available at: https://www.ft.com/content/f6182bc8-85e4-11dc-b00e-0000779fd2ac(Accessed:

9 November 2017)

Harding, E. (2017) Even teenagers are growing tired of social media: Two thirds say they would not mind if it had never been invented, Daily Mail. Available at: http://www.dailymail.co.uk/news/article-4950268/Even-teenagers-growing-tiredsocial-media.html (Accessed: 10 November 2017)

In the employment tribunals: August 2010. Facebook entry and YouTube video led to amateur model's dismissal (2010)XpertHR. Available at: https://www.xperthr.co.uk/law-reports/in-the-employment-tribunals-august2010/104153/\#gill (Accessed: 20 September 2018)

Instagram, Snapchat Adoption Still Surging in US and UK - Facebook's appeal fading further among teens and young adults (2017) eMarketer. Available at: https://www.emarketer.com/Article/Instagram-Snapchat-Adoption-Still-SurgingUS-UK/1016369 (Accessed: 10 November 2017)

Internet Growth Statistics (no date) Internet World Stats. Available at: http://www.internetworldstats.com/emarketing.htm (Accessed: 16 December 2016)

IUT de Rennes (no date) Charte d'utilisation des réseaux/médias sociaux numériques IUT de Rennes. Available at: http://partages.univrennes1.fr/files/partages/Services/IUT_administration/Internet/doc/IUTrennesCharte RSN.pdf (Accessed: 21 March 2017)

Jolly, J. (2018) Ryanair sacks six cabin crew after 'staged' photo sleeping on airport floor, The Guardian. Available at: https://www.theguardian.com/business/2018/nov/07/ryanair-sacks-six-cabin-crewafter-staged-photo-sleeping-on-malaga-airport-floor (Accessed: 19 November 2018)

Kártyás, G. (2013)A késés öt szankciója, Adó Online. Available at: https://ado.hu/munkaugyek/a-keses-ot-szankcioja/ (Accessed: 7 January 2020).

Keylogger: des dispositifs de cybersurveillance particulièrement intrusifs(2013) CNRS. Available at: http://www.cil.cnrs.fr/CIL/spip.php?article1954 (Accessed: 1 October 2018)

Kinsey, A. (no date) 'The Benefits of Pre-employment Screening'. James M. Sweeney and Associates, Inc. Available at: http://www.sweeneyinc.com/files/benefits_preemployment_screening.pdf(Access ed: 3 May 2018)

Kirúgta munkatársát a Blikk, aki a Facebookon sértegette a megerőszakolt lányt (2013) HVG. Available at: https://hvg.hu/itthon/20130727_blikk_kirugas (Accessed: 22 November 2018)

Kirúgták a tanitónöt, aki két Hitler-kép között üzent a tankönyvekröl a Facebookon(2015) 444. Available at: https://444.hu/2015/09/10/kirugtak-a-tanitonotaki-ket-hitler-kep-kozott-uzent-a-tankonyvekrol-a-facebookon/ (Accessed: November 2018)

Kirúgták $\quad a \quad$ twitterezö $\quad$ Vodafonost (2009) Index. Available at: https://index.hu/tech/cellanaplo/2009/12/09/kirugtak_a_twitterezo_vodafonost/(A ccessed: 5 November 2018)

Kirúgták Facebook-posztja miatt Aczél Endrét (2016) Népszava. Available at: https://nepszava.hu/1090759_kirugtak-facebook-posztja-miatt-aczelendret (Accessed: 15 November 2018) 
Kirúgták, mert a Facebookon azt irta: Jó irányba halad a szekér? (2016) Index. Available at: https://index.hu/belfold/2016/10/15/az_allasaba_kerult_hogy_a_facebookon_azt_i rta_jo_iranyba_halad_a_szeker/(Accessed: 15 November 2018)

Knaaplia, S., Koskela, I. and Havia, S. (2018) Employment \& labour law in Finland, Lexology. Available at: https://www.lexology.com/library/detail.aspx?g=b03caa90-2830-4194-a9676cceaa561e7e (Accessed: 17 July 2018)

Krischer Goodman, C. (2011) Social Networks Test Companies' Boundaries, The Miami Herald. Available at: http://www.pordesresidential.com/wpcontent/uploads/2010/11/1-19-2011-miami-herald-biz.pdf (Accessed: 10 March 2017)

Kujawski, M. (2014) When Your Employees Go Too Far on Social Media, Social Media Today. Available at: https://www.socialmediatoday.com/content/when-youremployees-go-too-far-social-media (Accessed: 11 May 2018)

L'usage des réseaux sociaux en France - Faits et chiffres (no date) Statista. Available at: https://fr.statista.com/themes/2761/l-usage-des-reseaux-sociaux-en-

france/ (Accessed: 4 January 2019)

Lemondott Devecz Miklós, a szegedi egyetem kancellárja (2015) Index. Available at: https://index.hu/belfold/2015/09/28/lemondott_devecz_miklos_a_szegedi_egyete m_kancellarja/(Accessed: 3 May 2018)

Lévai, R. (2017) Magyarok a közösségi médiában 2017 elején, Közösségi kalandozások. Available at: http://kozossegikalandozasok.hu/2017/01/04/magyarok-a-kozossegimediaban-2017-elejen/ (Accessed: 4 January 2019)

Lhermenault, A. (2015) Réseaux sociaux: $52 \%$ des employeurs ont déjà fait des recherches sur des candidats, Le Figaro. Available at: https://etudiant.lefigaro.fr/stage-emploi/actu/detail/article/reseaux-sociaux-52-desemployeurs-ont-deja-fait-des-recherches-sur-des-candidats-15425/(Accessed: $\quad 20$ June 2019)

List of countries that have banned Social Media for its citizens (no date) The Windows Club. Available at: https://www.thewindowsclub.com/list-of-countries-that-havebanned-social-media-for-its-citizens (Accessed: 21 October 2019)

Long, M. C. (2018) How Social Media Actually Boosts Efficiency in an Office Environment, Adweek. Available at: https://www.adweek.com/digital/how-socialmedia-actually-boosts-efficiency-in-an-office-environment/(Accessed: 27 July 2019)

Lórodi, L. (2013) Mik azok a munkajogi alapelvek és mire valók? (1. rész), Munkajog Portál. Available at: http://munkajogportal.hu/mik-azok-a-munkajogi-alapelvek-esmire-valok/ (Accessed: 6 September 2018)

Love, D. (2014) 17 People Who Were Fired For Using Facebook, Business Insider. Available at: https://www.businessinsider.com/17-people-who-were-fired-for-usingfacebook-2014-7 (Accessed: 30 July 2019)

Madden, M. (2012) Privacy management on social media sites. Pew Research Center. Available

at:http://www.pewinternet.org/ /media//Files/Reports/2012/PIP_Privacy_manageme nt_on_social_media_sites_022412.pdf (Accessed: 21 May 2018)

Manant, M., Pajak, S. and Soulié, N. (2014) Online social networks and hiring: a field experiment on the French labor market. [in press] Munich Personal RePEc Archive. Available from: https://papers.ssrn.com/sol3/ papers.cfm?abstract_id=2458468 (Accessed 2 February 2017)

May, T. (2018) 6 Ways to Introduce A Digital Detox to Your Employees (and Why it Could Boost Productivity), HR Daily Advisor. Available 
at: https://hrdailyadvisor.blr.com/2018/07/24/6-ways-introduce-digital-detoxemployees-boost-productivity/ (Accessed: 8 January 2020)

McGeveran, W. (2006) Finnish Employers Cannot Google Applicants. Available at: https://blogs.harvard.edu/infolaw/2006/11/15/finnish-employers-cannot-googleapplicants/ (Accessed: 2 July 2018)

Meixner, Z. (2004) Az Internet Rövid Története, HVG. Available at: http://hvg.hu/tudomany/20041203interhist (Accessed: 22 September 2017)

Most famous social network sites worldwide as of October 2018, ranked by number of active users (in millions) (2018) Statista. Available at: https://www.statista.com/statistics/272014/global-social-networks-ranked-bynumber-of-users/ (Accessed: 4 January 2018)

Negroni, C. (2004) Fired Flight Attendant Finds Blogs Can Backfire, The New York Times. Available at: https://www.nytimes.com/2004/11/16/business/fired-flight-attendantfinds-blogs-can-backfire.html (Accessed: 11 May 2018)

Német, T. (2019) Jogerös: vissza kell venni a Facebook-posztjai miatt kirúgott ügyészt, Index.

Available

at: https://index.hu/belfold/2019/12/23/jogeros_vissza_kell_venni_a_facebook-

posztjai_miatt_kirugott_ugyeszt/ (Accessed: 9 January 2020)

Német, T. (2019) Pert nyert az ügyész, akit három Facebook-posztja miatt rúgtak ki, Index. Available

at: https://index.hu/belfold/2019/05/10/facebook_per_ugyesz_ugyeszseg_kirugas_ite let/ (Accessed: 9 January 2020)

Németh, J. (2013) A közösségi média használata munkáltatói szemmel, Jogászvilág. Available at: https://jogaszvilag.hu/szakma/a-kozossegi-media-hasznalatamunkaltatoi-szemmel/(Accessed: 6 September 2018)

Ngake, P. (2016) Whistle-blowing on Social Media. Available at: http://www.seesa.co.za/whistle-blowing-on-social-media/(Accessed: 22 April 2018)

Number of social media users worldwide from 2010 to 2021 (in billions) (no date) Statista. Available at: https://www.statista.com/statistics/278414/number-of-worldwidesocial-network-users/ (Accessed: 20 January 2019)

NVIDIA (no date) Social Media Policy. Available at: http://www.nvidia.co.uk/object/social-media-guidelines-uk.html (Accessed: 23 March 2017)

Olfeo (2016) Etude 2016: La réalité de l'utilisation d'Internet au bureau. Available at: https://www.euromedia.fr/public/2016/12/etude-olfeo-2016-realite-utilisationweb-au-bureau.pdf (Accessed: 20 January 2019)

Oppenheim, R. (2013) High School Teacher Files an Appeal in Case of Social Media Related Resignation, California Business Litigation Blog. Available at: https://www.californiabusinesslitigation.com/2013/05/high_school_teacher_files_ an_a.html(Accessed: 3 May 2018)

Orange (no date) Social Media Guidelines. Available at: https://www.orange.com/sirius/smg/FR_Guides_Medias_Sociaux.pdf (Accessed: 22 March 2017)

Orange (no date) Social Media Guidelines. Available at: https://www.orange.com/sirius/smg/FR_Guides_Medias_Sociaux.pdf(Accessed: 22 March 2017)

Original-See other copy if this version is frozen (2006) YouTube. Available at: https://www.youtube.com/watch? $=q d 3 V V 8 Z a 04 g \& t=316 s \quad$ (Accessed: 16 April 2018) 
Pert nyert az ügyész, akit három Facebook-posztja miatt rúgtak ki (2019) Adózóna. Available

at: https://adozona.hu/munkajog/Pert_nyert_az_ugyesz_akit_harom_Facebookpos_R UXHRH (Accessed: 9 January 2020)

Picheta, R. (2019) EasyJet was criticized for making passengers fly in backless seats -except it didn't, CNN. Available at: https://edition.cnn.com/travel/article/easyjetbackless-seats-scli-gbr-intl/index.html (Accessed: 7 August 2019)

Pintér, M. (2019) A „,csak még öt perc” munkajogi következményei, Adó Online. Available at: https://ado.hu/munkaugyek/a-csak-meg-ot-perc-munkajogikovetkezmenyei/ (Accessed: 7 January 2020)

Platform work (2018) Eurofound.

Available

at: https://www.eurofound.europa.eu/observatories/eurwork/industrial-relationsdictionary/platform-work (Accessed: 13 August 2019)

Proskauer Rose LLP (2014) Social Media in the Workplace Around the World 3.0. 2013/14 Survey. Available at: http://www.proskauer.com/files/uploads/social-media-in-theworkplace-2014.pdf (Accessed: 3 February 2017)

Rácz, I. (2017) A közösségi média és a munkajog kereszttüzében. Available at: http://arsboni.hu/kozossegi-media-es-munkajog-kereszttuzeben/ (Accessed: 27 February 2018)

Ricker, A. (2009) City requires Facebook passwords from job applicants, Bozeman Daily Chronicle. Available at: https://www.bozemandailychronicle.com/news/cityrequires-facebook-passwords-from-job-applicants/article_a9458e22-498a-5b71b07d-6628b487f797.html (Accessed: 3 May 2018)

Riley, C. (2017) Man fined \$4,000 for 'liking' defamatory posts on Facebook, CNN. Available at: https://money.cnn.com/2017/05/31/technology/facebook-likedefamation-switzerland/(Accessed: 15 October 2018)

Robles, P. (2012) Personal versus professional social networks: infographic, Econsultancy. Available at: https://econsultancy.com/personal-versusprofessional-social-networks-infographic/(Accessed: 13 August 2019)

Ronson, J. (2015) 'Overnight, everything I loved was gone': the internet shaming of Lindsey Stone, The Guardian. Available at: https://www.theguardian.com/technology/2015/feb/21/internet-shaming-lindseystone-jon-ronson (Accessed: 3 May 2018)

Rosen, J. (2010) The Web Means the End of Forgetting, The New York Times. Available at: https://www.nytimes.com/2010/07/25/magazine/25privacy-t2.html (Accessed: 11 May 2018)

Rosen, J. (2012) The Right to Be Forgotten, Stanford Law Review. Available at: https://www.stanfordlawreview.org/online/privacy-paradox-the-right-to-beforgotten/ (Accessed: 13 August 2019)

Rudd, A. (2013) DVLA worker fired for using Facebook on his mobile phone during office hours, Mirror. Available at: https://www.mirror.co.uk/news/uk-news/dvla-workerfired-using-facebook-1903697 (Accessed: 25 July 2019)

Salm, L. (2017) 70\% of employers are snooping candidates' social media profiles, Career Builder. Available at: https://www.careerbuilder.com/advice/social-media-survey2017 (Accessed: 20 June 2019)

Sarin, P. (2012) Employees beware: The perils of posting on Facebook, rabble.ca. Available at: http://rabble.ca/columnists/2012/10/employees-beware-perils-postingfacebook (Accessed: 11 May 2018)

Schauer, P. (2015) 5 Biggest Differences between Social Media and Social Networking, SocialMediaToday.

Available 
at: http://www.socialmediatoday.com/social-business/peteschauer/2015-06-28/5-

biggest-differences-between-social-media-and-social (Accessed: 22 September 2017)

Silverman, J. (2015) 'Pics or it didn't happen' - the mantra of the Instagram era, The Guardian. Available at: https://www.theguardian.com/news/2015/feb/26/pics-or-itdidnt-happen-mantra-instagram-era-facebook-twitter (Accessed: 20 January 2019)

Social Intelligence (no date) Social Media Screening for Intelligent Hiring. Available at: https://www.socialintel.com/(Accessed: 13 August 2019)

Social Intelligence (no date) The Social Media Hiring Report. Available at: https://www.socialintel.com/how-it-works/ (Accessed: 16 August 2018)

Solé, E. (2019) Wendy's employee fired after taking a bubble bath in restaurant sink: 'It is obviously totally unacceptable', Yahoo. Available at: shorturl.at/bcuwG (Accessed: 5 August 2019)

Solomon, L. E. (2012) Memorandum OM 12-59. Office of the General Counsel Division of Operations-Management. Available at: http://www.rc.com/documents/OM1259ActingGeneralCounselReportConcerningSoc ialMediaCases.pdf(Accessed: 30 November 2018)

Szilágyi, K. (2013) Facebook-szabályzat: beleszólhat- a munkáltató?, Adó Online. Available at: https://ado.hu/munkaugyek/facebook-szabalyzat-beleszolhat-amunkaltato/ (Accessed: 15 November 2018)

Takács, G. (2011) Facebook-mánia: sokan a munkahelyüket is kockára teszik, mindennapi. Available at: http://www.mindennapi.hu/cikk/eletmod/facebook-mania-sokan-amunkahelyuket-is-kockara-teszik/2011-07-09/4869 (Accessed: 1 August 2019)

Tenenbaum, J. M. (2012) 'Posting Yourself Out of a Posting: Using Social Networks to Screen Job Applicants in America and Germany. [pre-print]'. Available at: https://papers.ssrn.com/sol3/

Delivery.cfm/SSRN_ID2062462_code1805294.pdf?abstractid=2020477\&mirid=1(A ccessed: 14 July 2016)

The Facebook Fired. Available at: https://thefacebookfired.wordpress.com/(Accessed: 7 August 2019)

Transcript of Mark Zuckerberg's Senate hearing (2018) The Washington Post. Available at: https://www.washingtonpost.com/news/the-switch/wp/2018/04/10/transcript-ofmark-zuckerbergs-senatehearing/?noredirect=on\&utm_term $=.2547 \mathrm{f6e} 741 \mathrm{~d} 5$ (Accessed: 15 October 2018)

Volleyball Australia Board (2012) Volleyball Australia Social Media Policy. Available at: http://www.volleyballaustralia.org.au/_literature_152757/Social_Media_Policy(A ccessed: 19 March 2017)

Wery, E. (2018) Perdre son emploi à cause d'un “J'aime"? C'est possible, Droit \& Technologies. Available at: https://www.droit-technologie.org/actualites/perdreemploi-a-cause-dun-jaime-cest-possible/ (Accessed: 15 October 2018)

Williams, A. (2009) Here I Am Taking My Own Picture, The New York Times. Available at: https://www.nytimes.com/2006/02/19/fashion/sundaystyles/here-i-am-taking-myown-picture.html (Accessed: 20 January 2019)

Wong, R. (2008) 'Social Networking: Anybody is a Data Controller'. Available at: https://papers.ssrn.com/sol3/papers.cfm?abstract_id=1271668 (Accessed: 20 January 2019) 


\section{LIST OF LEGISLATION, CASE LAW AND OTHER LAW RELATED DOCUMENTS}

\section{Legislative documents}

\section{International}

\section{$U N$}

United Nations (1948) Universal Declaration of Human Rights

United Nations (1966) International Covenant on Civil and Political Rights

United Nations (1990) Guidelines for the Regulation of Computerized Personal Data Files. Adopted by General Assembly resolution 45/95 of 14 December 1990

The right to privacy in the digital age (2015). A/HRC/28/L.27. United Nations, General Assembly.

Report of the Special Rapporteur on the right to privacy (2016). A/HRC/31/64. United Nations, General Assembly

ILO (1997) Protection of workers' personal data. An ILO code of practice. Geneva: International Labour Office.

ILO (2006) Recommendation concerning the employment relationship. No. 198. Geneva, 95th ILC session)

\section{$O E C D$}

OECD (1980) Guidelines on the Protection of Privacy and Transborder Flows of Personal Data

OECD (2013) Guidelines on the Protection of Privacy and Transborder Flows of Personal Data - revised

\section{Council of Europe}

CoE (1950): European Convention on Human Rights

CoE (1961): European Social Charter, ETS No.035, 18 October

CoE, Parliamentary Assembly (1970): Declaration on mass communication media and Human Rights, Resolution 428, 23 January 1970, Available at: http://assembly.coe.int/nw/xml/XRef/Xref-XML2HTMLen.asp?fileid=15842\&lang=en Accessed: 2018. 02. 28.

CoE (1981): Convention for the Protection of Individuals with regard to Automatic Processing of Personal Data, ETS No.108, 28 January

CoE (1989): Recommendation No. $R$ (89) 2 of the Committee of Ministers to Member States on the Protection of Personal Data Used for Employment Purposes. (Adopted by the Committee of Ministers on 18 January 1989 at the 423rd meeting of the Ministers' Deputies) 
CoE (1996): European Social Charter (revised), ETS No.163, 3 May

$\mathrm{CoE}$ (2011): The protection of privacy and personal data on the Internet and online media. Resolution 1843 (2011)

$\mathrm{CoE}$ (2012): 'Recommendation CM/Rec(2012)4 of the Committee of Ministers to member States on the protection of human rights with regard to social networking services'

CoE (2015): Recommendation CM/Rec(2015)5 of the Committee of Ministers to member States on the processing of personal data in the context of employment. (Adopted by the Committee of Ministers on 1 April 2015, at the 1224th meeting of the Ministers' Deputies)

CoE (2018): Modernised Convention for the Protection of Individuals with Regard to the Processing of Personal Data. CM/Inf(2018)15-final, Elsinore, Denmark, 18 May

\section{European Union}

Treaty on the Functioning of the European Union

Charter of Fundamental Rights of the European Union (2000)

Directive 95/46/EC of the European Parliament and of the Council of 24 October 1995 on the protection of individuals with regard to the processing of personal data and on the free movement of such data. OJ L 281, 23/11/1995 p. 31 - 50

Regulation (EC) No 45/2001 of the European Parliament and of the Council of 18 December 2000 on the protection of individuals with regard to the processing of personal data by the Community institutions and bodies and on the free movement of such data. OJ L 8, 12.1.2001, p. 1-22

Directive 2003/88/EC of the European Parliament and of the Council of 4 November 2003 concerning certain aspects of the organisation of working time. OJ L 299, 18.11.2003, p. $9-19$

Regulation (EU) 2016/679 of the European Parliament and of the Council of 27 April 2016 on the protection of natural persons with regard to the processing of personal data and on the free movement of such data, and repealing Directive 95/46/EC (General Data Protection Regulation). OJ L 119, 4.5.2016, p. 1-88

WP29 (2001) Opinion 8/2001 on the processing of personal data in the employment context. 5062/01/EN/Final WP 48

WP29 (2002) Working document on the surveillance of electronic communications in the workplace. 5401/01/EN/Final WP 55

WP29 (2004) Opinion 4/2004 on the Processing of Personal Data by means of Video Surveillance. 11750/02/EN WP 89

WP29 (2005) Working Party 29 Opinion on the use of location data with a view to providing value-added services. 2130/05/EN WP 115

WP29 (2007) Opinion 4/2007 on the concept of personal data. 01248/07/EN WP 136

WP29 (2009) Opinion 5/2009 on online social networking. 01189/09/EN WP 163

WP29 (2011) Opinion 13/2011 on Geolocation services on smart mobile devices. $881 / 11 /$ EN WP 185

WP29 (2011) Opinion 15/2011 on the definition of consent. 01197/11/EN WP187

WP29 (2014) Opinion 06/2014 on the notion of legitimate interests of the data controller under Article 7 of Directive 95/46/EC. 844/14/EN WP 217

WP29 (2017) Opinion 2/2017 on data processing at work. 17/EN WP 249 


\section{Other international institutions and bodies}

ENISA (2007): Security Issues and Recommendations for Online Social Networks. Position Paper

International Working Group on Data Protection in Telecommunications (2008) Report and Guidance on Privacy in Social Network Services - "Rome Memorandum" -. 675.36.5. Rome

International Working Group on Data Protection in Telecommunications (2013): Working Paper and Recommendations on the Publication of Personal Data on the Web, Website Contents Indexing and the Protection of Privacy. 675.46.32.

\section{National}

\section{France}

Code du travail

Code civil

Code pénal

Loi $\mathrm{n}^{\circ} 78-17$ du 6 janvier 1978 relative à l'informatique, aux fichiers et aux libertés

Loi n $82-689$ du 4 août 1982 relative aux libertés des travailleurs dans l'entreprise

Loi $n^{\circ}$ 92-1446 du 31 décembre 1992 relative à l'emploi, au développement du travail à temps partiel et à l'assurance chômage

Loi n 2016-1321 du 7 octobre 2016 pour une République numérique

'Commentaire de la décision $\mathrm{n}^{\circ}$ 2009-580 DC - 10 juin 2009 Loi relative à la diffusion et à la protection de la création sur internet' (no date) Les Cahiers du Conseil Constitutionnel, (27). Available at: http://www.conseil-constitutionnel.fr/conseilconstitutionnel/root/bank/download/2009580DCccc_580dc.pdf(Accessed: 6 June 2018)

Assemblé Nationale: Commission de réflexion et de propositions sur le droit et les libertés à l'âge du numérique, Mercredi 26 novembre 2014, Séance de 17 heures, Compte rendu $\mathrm{n}^{\circ} 08$, Available at: http://www.assemblee-nationale.fr/14/cr-comnum/1415/c1415008.asp Accessed: 2017. 02. 26.

Comité consultatif pour une révision de la Constitution, présidé par le doyen Georges Vedel (1993) Propositions pour une révision de la Constitution. Rapport au Président de la République

Commentaire: Conseil constitutionnel: décision n ${ }^{\circ}$ 2012-248 QPC du 16 mai 2012

Cour de cassation (2006) Rapport annuel 2005. L'innovation technologique. La documentation française, Paris

Détraigne, Y. and Escoffier, A.-M. (2009) La vie privée à l'heure des mémoires numériques. Pour une confiance renforcée entre citoyens et société de l'information. Rapport d'information 441. Sénat.

Exposé des motifs: Act No. 2016-1321 of 7 October 2016 for a Digital Republic

Le Défenseur des droits (no date) Guide pratique pour les professionnels du recrutement. Recruter avec des outils numériques sans discriminer. Available at: https://www.defenseurdesdroits.fr/sites/default/files/atoms/files/636150490_int_v alide_ft_fini_complet.pdf (Accessed: 27 June 2018)

Mettling, B. (2015) Transformation numérique et vie au travail 
Ministère du travail, de l'emploi, de la formation professionnelle et du dialogue social (2015) Guide pratique du droit du travail. Paris: La Documentation française

Rapport de la Cour de Cassation 2001: A. Contrat de travail 1. Exécution.

\section{Hungary}

Fundamental Law of Hungary (2011)

Seventh amendment of the Fundamental Law of Hungary, 28 June 2018

Act XX of 1949 on the Constitution of the Hungarian Republic

Act XXII of 1992 on the Labour Code

Act XXXIII of 1992 on the Legal Status of Public Servants

Act LXIII of 1992 on the protection of personal data and access to data of public interest

Act XCIII of 1993 on labour safety

Act CXII of 2011 on the Right to Informational Self-determination and Freedom of Information

Act I of 2012 on the Labour Code

Act $\mathrm{C}$ of 2012 on the Penal Code

Act V of 2013 on the Civil Code

Act LIII of 2018 on the protection of private life

50/1999. (XI. 3) decree of the Ministry of Health on the minimum health and safety requirements for work with display screen

T/4786. számú törvényjavaslat a Munka Törvénykönyvéröl (2011). Előadó: Dr. Matolcsy György nemzetgazdasági miniszter. Budapest

T/332. számú javaslat Magyarország Alaptörvényének hetedik módositása (2018). Előadó: Dr. Trócsányi László igazságügyi miniszter. Budapest

T/4479. számú törvényjavaslat az Európai Unió adatvédelmi reformjának végrehajtása érdekében szükséges törvénymódositásokról (2019). Előadó: Dr. Trócsányi László igazságügyi miniszter. Budapest

Az Egyenlő Bánásmód Tanácsadó Testület 1/2007. TT. sz. állásfoglalása az állásinterjún feltehető munkáltatói kérdésekröl 


\section{Court cases}

\section{International}

\section{Court of Justice of the European Union}

CJEU (1991): Union de Recouvrement des Cotisations de Sécurité Sociale et d'Allocations Familiales de la Savoie (URSSAF) v Hostellerie Le Manoir SARL, Case C-27/91, ECLI:EU:C:1991:441, 21 November

CJEU (2003): Bodil Lindqvist, Case C-101/01, ECLI:EU:C:2003:596, 6 November

CJEU (2003): Rechnungshof v. Österreichischer Rundfunk, Joined Cases C-465/00, C138/01 and C-139/01, ECLI:EU:C:2017:131, 20 May

CJEU (2008): Productores de Música de España (Promusicae) v Telefónica de España SAU, Case: C-275/06. ECLI:EU:C:2008:54, 29 January

CJEU (2010) Volker und Markus Schecke GbR and Hartmut Eifert $v$ Land Hessen, Joined cases C-92/09 and C-93/09, Opinon, ECLI:EU:C:2010:353, 9 November

CJEU (2010): Commission v Bavarian Lager, Case C-28/08 P, ECLI:EU:C:2010:378, 29 June

CJEU (2010): PPU. J. McB. v L. E., Case C-400/10, ECLI:EU:C:2010:582, 5 October

CJEU (2011): V v. European Parliament, Case F-46/09, ECLI:EU:F:2011:101, 5 July

CJEU (2018): Wirtschaftsakademie Schleswig-Holstein, Case C-210/16, ECLI:EU:C:2018:388, 5 June

\section{European Court (and Commission) of Human Rights}

ECtHR (1992): Niemietz v. Germany, Application no. 13710/88, 16 December

ECtHR (1997): Halford v. the United Kingdom, Application no. 20605/92, 25 June

ECtHR (2000): Amann v. Switzerland, Application no. 27798/95,16 February

ECtHR (2002): Christine Goodwin v. the United Kingdom, application no. 28957/95, 11 July

ECtHR (2002): Pretty v. the United Kingdom, application no. 2346/02, 29 July

ECtHR (2002): Société Colas Est and others v. France, Application No. 37971/97, 16 April

ECtHR (2003): Peck v. the United Kingdom, application no. 44647/98, 28 January

ECtHR (2007): Copland v. the United Kingdom, Application no. 62617/00, 3 April

ECtHR (2007): Evans v. the United Kingdom, application no. 6339/05, 10 April

ECtHR (2008): S. and Marper v. the United Kingdom, application nos. 30562/04 and 30566/04, 4 December

ECtHR (2010): Jehovah's witnesses of Moscow and Others v. Russia, application no. 302/02, 10 June

ECtHR (2012): Von Hannover v. Germany, applications nos. 40660/08 and 60641/08, 7 February

ECtHR (2014): S.A.S. v. France, application no. 43835/11, 1 July

ECtHR (2016) Bărbulescu v. Romania, Application no. 61496/08, 12 January

ECtHR (2017) Bărbulescu v. Romania, Application no. 61496/08, 5 September 
ECtHR (2018) Denisov v. Ukraine, Application no. 76639/11, 25 September

ECtHR (2018) Libert v. France, Application no. 588/13, 22 February

Commission of the ECtHR (1976): X v Iceland, application no. 6825/74, 8 May

Commission of the ECtHR: (1998) Pierre Herbecq and the Association Ligue des droit de l'homme v. Belgium, Applications № 32200/96 and 32201/96 (joined), 14 January

\section{Decisions of national courts and state institutions}

\section{France}

Conseil constitutionnel:

décision $\mathrm{n}^{\circ}$ 76-75 DC du 12 janvier 1977

décision $\mathrm{n}^{\circ} 88-244 \mathrm{DC}$ du 20 juillet 1988

décision $\mathrm{n}^{\circ}$ 94-352 DC du 18 janvier 1995

décision $n^{\circ}$ 99-416 DC du 23 juillet 1999

décision $\mathrm{n}^{\circ} 2009-580$ du 10 juin 2009

Conseil d'Etat (1980): Nº6361, Section, 1 février

Conseil d'Etat (2010): $\mathrm{N}^{\circ} 316856$, 4ème et 5ème sous-sections réunies, 15 décembre

Conseil d'Etat (2014) Le numérique et les droits fondamentaux. Les rapports du Conseil d'Etat

Conseil d'Etat (2017): No 393320 (ECLI:FR:CECHR:2017:393320.20170320), 3ème 8 ème chambres réunies, 20 mars

Cour de cassation:

chambre commerciale, financière et économique, 10 février 2015, $\mathrm{n}^{\circ} 13-14.779$

chambre sociale, 20 nov. 1991, $n^{\circ} 89-44.605$

chambre sociale, 3 déc. $2002, \mathrm{n}^{\circ} 00-44.321$

chambre sociale, 16 juin 1945

chambre sociale, 31 mai 1956, $\mathrm{N}^{\circ} 56-04323$

chambre sociale, 25 février $1988 . \mathrm{N}^{\circ} 85-40821$

chambre civile 1, 23 octobre 1990, $\mathrm{N}^{\circ} 89-13163$

chambre sociale, 17 avril 1991, $\mathrm{N}^{\circ}$ 90-42636

chambre sociale, 17 avril 1991, N 88-40.121

chambre sociale, 20 nov. 1991, n० 89-44.605

chambre sociale, 20 novembre 1991, $N^{\circ} 88-43120$

chambre sociale, 20 novembre 1991, $\mathrm{N}^{\circ} 89-4460$

chambre sociale, 22 janvier $1992, \mathrm{~N}^{\circ} 90-42517$

chambre sociale, 22 mai 1995, $\mathrm{N}^{\circ}$ 93-44078

chambre civile 1, 6 mars 1996, $\mathrm{N}^{\circ}$ 94-11273

chambre sociale, 13 novembre 1996, N 94-13187

chambre sociale, 14 mai $1997, \mathrm{~N}^{\circ} 94-45473$

chambre sociale, 16 déc. $1997, n^{\circ}$ 95-41.326 
16 juin $1998, n^{\circ} 96-41558$

chambre sociale, 16 décembre $1998, \mathrm{~N}^{\circ} 96-43540$

chambre sociale, 14 décembre 1999, $\mathrm{N}^{\circ}$ 97-41995

chambre sociale, 25 janvier $2000, \mathrm{~N}^{\circ} 97-45044$

chambre sociale, 14 mars $2000, \mathrm{n}^{\circ} 98-42.090$

chambre sociale, 19 décembre $2000, \mathrm{~N}^{\circ} 98-40.572$

chambre sociale, 10 mai $2001, \mathrm{~N}^{\circ} 99-40584$

chambre sociale, 2 octobre 2001, $\mathrm{n}^{\circ}$ 99-42.942

chambre sociale, 21 mai 2002, 00-41.128

chambre sociale, 9 juillet $2002, \mathrm{~N}^{\circ} 00-45068$

chambre sociale, 10 juillet 2002, $\mathrm{N}^{\circ} 00-45135$

chambre sociale, 30 octobre $2002, \mathrm{~N}^{\circ} 00-40868$

chambre sociale, 25 févr. 2003, $\mathrm{n}^{\circ} 00-42.031$

chambre sociale, 21 oct. $2003, \mathrm{n}^{\circ} 00-45.291$

chambre sociale, 21 octobre $2003, \mathrm{~N}^{\circ} 01-43943$

chambre sociale, 2 décembre 2003, $\mathrm{N}^{\circ}$ 01-43227

chambre sociale, 17 février 2004, $\mathrm{N}^{\circ}$ 01-45.889

chambre criminelle, 19 mai $2004, \mathrm{~N}^{\circ} 03-83953$

chambre sociale, 2 juin 2004, 03-45.269

chambre sociale, 17 mai 2005, $\mathrm{N}^{\circ} 03-40017$

chambre sociale, 30 novembre $2005, \mathrm{~N}^{\circ}$ 04-41206

chambre sociale, 26 avr. 2006, $\mathrm{n}^{\circ}$ 04-43.582

chambre mixte, 18 mai 2007, $\mathrm{N}^{\circ} 05-40803$

chambre sociale, 30 mai $2007, \mathrm{~N}^{\circ} 05-43102$

chambre sociale, 29 janvier $2008, \mathrm{~N}^{\circ} 06-45279$

chambre sociale, 18 mars $2008, \mathrm{~N}^{\circ} 06-45093$

chambre sociale, 9 juillet $2008, \mathrm{~N}^{\circ} 06-45800$

chambre sociale, 18 mars $2009, \mathrm{~N}^{\circ} 07-44247$

chambre sociale, 17 juin $2009, \mathrm{n}^{\circ} 08-40.274$

chambre sociale, 23 juin $2009, \mathrm{~N}^{\circ} 07-45256$

chambre sociale, 9 février $2010, \mathrm{~N}^{\circ} 08-45253$

chambre sociale, 17 février 2010, $\mathrm{N}^{\circ} 08-45298$

chambre sociale, 26 octobre $2010, \mathrm{~N}^{\circ} 09-42740$

chambre sociale, 15 décembre $2010, \mathrm{~N}^{\circ} 08-42486$

chambre sociale, 3 mai 2011, $\mathrm{N}^{\circ}$ 09-67464

chambre sociale, 17 novembre 2011 , $\mathrm{N}^{\circ} 10-17950$

chambre sociale, 9 mai 2012, $\mathrm{n}^{\circ} 11-13.687$

chambre sociale, 26 juin 2012, $\mathrm{n}^{\circ} 11-15310$

chambre sociale, 4 juillet $2012, \mathrm{~N}^{\circ} 11-12502$

chambre sociale, 4 juillet 2012, $\mathrm{N}^{\circ} 11-14241$

chambre sociale, 4 juillet 2012, $\mathrm{N}^{\circ} 11-30266$

chambre sociale, 11 juillet 2012, $\mathrm{n}^{\circ} 11-22.972$

chambre sociale, 26 février 2013, No 11-27372

chambre civile 1,10 avril 2013, $\mathrm{N}^{\circ} 11-19.530$

chambre sociale, 16 mai 2013, $\mathrm{N}^{\circ} 12-11866$

chambre sociale, 19 juin $2013, \mathrm{~N}^{\circ} 12-12138$

chambre sociale, 18 décembre 2013, $\mathrm{n}^{\circ}$ 12-17.832

chambre sociale, 29 octobre $2014, \mathrm{~N}^{\circ} 13-18173$

26 janvier $2016, \mathrm{n}^{\circ} 14-15.360$

chambre sociale, 7 avril 2016, $\mathrm{n}^{\circ} 14-27949$ 
chambre civile 2, 5 janvier $2017, \mathrm{~N}^{\circ} 16-12394$

chambre sociale, 5 juillet $2017, \mathrm{~N}^{\circ} 16-15623$

chambre sociale, 20 déc. $2017, \mathrm{n}^{\circ} 16-19609$

chambre sociale, 12 sept. $2018, \mathrm{n}^{\circ} 16-11.690$

chambre sociale, 28 novembre 2018 , N 17-20.079

CA Aix en Provence, 17eme chambre, arrêt au fond du 13 janvier 2015

CA Aix-en-Provence, 17e chambre B, 4 février 2016, $n^{\circ}$ 14/13125

CA Aix-en-Provence, 5 février 2016, n 14/13717

CA Aix-en-Provence, 9e chambre A, 27 mars 2015, n 13/20847

CA Amiens, 21 mai 2013, $n^{\circ}$ 12/01638

CA Basse-Terre, chambre sociale, 13 octobre 2014, $\mathrm{N}^{\circ}$ de RG: 13/01046

CA Besançon, chambre sociale, 15 novembre 2011, $\mathrm{n}^{\circ} 10 / 02642$

CA Bordeaux, chambre sociale, section A, 12 février 2013, n $12 / 01832$

CA Bordeaux, Chambre sociale, section A, Arrêt du 15 janvier 2013

CA Caen, 1re chambre sociale, 27 janvier 2017, $\mathrm{n}^{\circ} 15 / 04402$

CA Caen, 1re chambre sociale, 27 janvier 2017, $\mathrm{n}^{\circ} 15 / 04417$

CA Chambéry, 25 févr. 2016, RG n¹5/01264

CA Fort-de-France, Chambre sociale, 21 décembre 2012, n 12/00053

CA Lyon, chambre sociale A, 13 mars 2013, n 12/05390

CA Lyon, chambre sociale A, 24 mars 2014, $\mathrm{n}^{\circ} 13-03463$

CA Lyon, chambre sociale B, 22 novembre 2012, $\mathrm{n}^{\circ} 11 / 05140$

CA Lyon, 18 novembre 2011, $\mathrm{n}^{\circ} 11 / 01261$

CA Montpellier, 4e chambre sociale, section A, 14 mars 2018, $\mathrm{n}^{\circ} 14 / 09173$

CA Nîmes, 2 avril 2013, n 12/02146

CA Orléans, 28 février 2013, N 12/01717

CA Paris, Pôle 6, 3ème ch., 15 novembre 2011, nº 09/09 398

CA Paris, Pôle 6, 5ème ch., 19 janvier 2012, n 10/04 071

CA Paris, Pôle 6, 6ème ch., 6 février 2013, n 11/03 458

CA Paris, Pôle 6, chambre 2, 10 Janvier 2019 - $\mathrm{n}^{\circ}$ 18/08357

CA Paris, Pôle 6, chambre 5, 20 septembre 2018, ${ }^{\circ}$ 14/04515

CA Paris, Pôle 6, chambre 8, 3 décembre 2015, n $^{\circ}$ 13/01716

CA Paris, Pôle 6, chambre 9, 3 décembre 2015, $n^{\circ}$ 15/04533

CA Pau, chambre sociale, 6 septembre 2018, ${ }^{\circ} 17 / 01648$

CA Pau, Chambre sociale, Arrêt du 13 juin 2013

CA Reims, chambre sociale, 15 novembre 2017, $\mathrm{n}^{\circ}$ 16/02786

CA Reims, chambre sociale, 9 juin $2010, n^{\circ} 09 / 03205$

CA Rennes 6 février $2003 n^{\circ} 02-2859$

CA Rennes, 7e chambre prud'homale, 20 novembre 2013, n $^{\circ} 12 / 03567$

CA Rennes, 8e chambre prud'homale, 2 mars 2018, $\mathrm{n}^{\circ} 16 / 07806$

CA Rouen, Chambre sociale, 1 novembre 2011, ${ }^{\circ} 11 / 01827$

CA Rouen, 15 novembre 2011, $\mathrm{N}^{\circ} 11 / 01830$

CA Rouen, 26 avril 2016, $\mathrm{n}^{\circ} 14 / 03517$

CA Rouen, chambre sociale, 10 février 2015, n $14 / 03335$

CA Rouen, chambre sociale, 15 mars 2018, ${ }^{\circ} 15 / 06042$

CA Rouen, chambre sociale, 15 novembre 2011, $N^{\circ} 11 / 01827$

CA Rouen, chambre sociale, 15 novembre 2011, $\mathrm{N}^{\circ} 11 / 01830$

CA Toulouse, 4e chambre sociale, 2e section, 2 février 2018, $n^{\circ} 16 / 04882$

CA Versailles, 17 e chambre, 4 octobre $2017, \mathrm{n}^{\circ} 15 / 03872$ 
CA Versailles, 17e chambre, 7 février 2018, n $15 / 05739$

CPH Boulogne-Billancourt (Section Encadrement), 19 novembre 2010, n 09/00343

\section{Hungary}

Constitutional Court:

Decision No. 15/1991. (IV. 13.)

Decision No. 56/1994 (XI. 10.)

Decision No. 35/2002. (VII. 19.)

Decision No. 36/2005. (X. 5.)

Decision No. 32/2013. (XI. 22.)

Decision No.13/2014. (IV. 18.)

Decision No. 14/2017. (VI. 30.)

1050/2004. számú munkaügyi elvi határozat

18/2018. számú munkaügyi elvi határozat

7001/2005. (MK 170.) FMM-PM együttes irányelv a munkavégzés alapjául szolgáló szerződések minősítése során figyelembe veendő szempontokról

LB Pfv. IV. 21 028/2000. - BH2001/61.

Mfv.II.10.609/2017

Mfv. I. 10.264/2002/2.

Mfv. $10.655 / 2013 / 6$.

Mfv. 10.469/2013/4.

BH 1986. 384.

BH 1991. 47.

BH 1992.387.

BH 1996. 286.

BH 2000. 267.

BH 2005. 102.

BH 2006.201.

BH 2006.64

BH 2008. 132.

Fövárosi Ítélőtábla 2.Pf.20.429/2010/3

Csongrád Megyei Bíróság 2. Mf. 20. 566/1997.

Szegedi Munkaügyi Bíróság 4. M. 1159/1994.

Kúria (2019) Kúria tájékoztatója a Kúria M.I. tanácsa által tárgyaláson kívül elbírált Mfv.I.10.098/2019. számú ügyről

\section{Other countries}

Belgium : Cour du travail de Liège (3e ch.) - Arrêt du 24 mars 2017 - Rôle n ${ }^{\circ}$ 2016-AL94 
Canada: Canadian National Railway Co. v. Norsk Pacific Steamship Co., [1992] 1 SCR 1021, 1992 CanLII 105 (SCC)

UK: Taylor v Somerfield Stores Ltd. Case no: S/107487/07, Held at Aberdeen on 24 July 2007

USA: District court for the Eastern District of Virginia: Bland v. Roberts, 4-11cv45 (E.D. Va.; Apr. 24, 2012)

United States: Court of Appeals for the Fourth Circuit: Bland v. Roberts, No. 12-1671, Filed: September 23, 2013

USA: Konop v. Hawaian airlines (United States Court of Appeals for the Ninth Circuit, 236 F.3d 1035.)

USA: Supreme Court of the United States: Lester Gerard Packingham, Petitioner v. North Carolina, June 19, 2017

USA: Pietrylo v. Hillstone Restaurant Group (2009), Civil Case No. 06-5754 (FSH). United States District Court, D. New Jersey, 25 September.

USA: Superior Court of California, County of San Francisco, Uber Technologies, Inc., A Delaware Corporation vs. Barbara Berwick, CGC-15-54378, 2015

USA: United States Court of Appeals for the Ninth Circuit: Konop v. Hawaian airlines, 236 F.3d 1035

USA: United States District Court, District of New Jersey: Pietrylo v. Hillstone Restaurant Group, No. 06-05754

\section{Documents of the data protection supervisory authorities}

\section{France - CNIL}

CNIL (2005) Guide pratique pour les employeurs. Les guides de la CNIL

CNIL (2010) Guide pour les employeurs et les salariés. Les guides de la CNIL

CNIL (2017) Rapport d'activité 2016. Paris, La documentation française

CNIL (2018) L'écoute et l'enregistrement des appels. Fiches pratiques: Travail \& données personnelles

CNIL (2018) Le recrutement et la gestion du personnel. Fiches pratiques. Travail \& Données personnelles

CNIL (2018) Les outils informatiques au travail. Fiches pratiques: Travail \& données personnelles

CNIL (2002) Délibération portant adoption d'une recommandation relative à la collecte et au traitement d'informations nominatives lors d'opérations de recrutement. Délibération ${ }^{\circ} 02-017$ du 21 mars 2002.

CNIL (2007) Délibération $n^{\circ 2007-374 ~ d u ~} 11$ décembre 2007 sanctionnant la société $X$. Délibération n²007-374 du 11 décembre 2007.

CNIL (2013) Délibération de la formation restreinte $n^{\circ} 2012-475$ du 03 janvier 2013

CNIL (2011)L'e-réputation en questions. Available at: https://www.cnil.fr/fr/lereputation-en-questions-0 (Accessed: 4 April 2017)

CNIL (2013) Les opérations de recrutement. Available at: https://www.cnil.fr/fr/lesoperations-de-recrutement (Accessed: 20 June 2019) 
CNIL (2014) Candidats à l'emploi: protégez votre réputation sur le web! Available at: https://www.cnil.fr/fr/candidats-lemploi-protegez-votre-reputation-sur-le-web (Accessed: 19 August 2018)

CNIL (2016) 10 conseils pour rester net sur le web. Available at: https://www.cnil.fr/fr/10conseils-pour-rester-net-sur-le-web (Accessed: 19 August 2018)

CNIL (no date) Configurer ses outils. Available at: https://www.cnil.fr/fr/configurer (Accessed: 5 November 2018)

CNIL (no date) Maîtriser les informations publiées sur les réseaux sociaux. Available at: https://www.cnil.fr/fr/maitriser-les-informations-publiees-sur-les-reseauxsociaux (Accessed: 26 February 2017)

CNIL (no date) Recrutement: l'employeur peut-il rechercher des données sur moi sur Internet? Available at: https://www.cnil.fr/fr/cnil-direct/question/354.

\section{Hungary - Data Protection Commissioner and NAIH}

ABI 1012/K/2005-3

ABI 167/A/2006-3.

ABI 1723/P/2008

ABI $1767 / \mathrm{K} / 2006-3$.

ABI $235 / K / 2008$

ABI 2550/K/2007-3.

ABI 40/K/2006

ABI 531/A/2004

ABI 570/A/2001

ABI 790/A/2001

ABI 800/K/2008

ABI 800/K/2008-3.

ABI 814/A/2004-8.

ABI 866/A/2006-3.

ABI 900/A/2006

The Commissioner's Recommendation on job advertisements and on the activity of private recruitment agencies

NAIH (2013)A Nemzeti Adatvédelmi és Információszabadság Hatóság ajánlása a munkahelyen alkalmazott elektronikus megfigyelörendszer alapvetö követelményeiröl. NAIH-4001-6/2012/V. Budapest

NAIH (2016) A Nemzeti Adatvédelmi és Információszabadság Hatóság tájékoztatója a munkahelyi adatkezelések alapvetö követelményeiröl. Budapest

NAIH/2016/4386/2/V

NAIH/2019/51/11 


\section{Other, international, law related documents - reports, recommendations, activity reports, etc.}

\section{$\mathbf{U N}$}

ILO (2006) The employment relationship. Report V(1). International Labour Conference, 95th Session

ILO (2006) The employment relationship. Report V(2A). International Labour Conference, 95th Session

ILO (2007) 'The employment relationship: An annotated guide to ILO Recommendation No. 198 '

ILO (no date) Meetings of the European Labour Court Judges. Available at: http://www.ilo.org/global/about-the-ilo/how-the-ilo-works/departments-andoffices/governance/labour-law/judges/lang--en/index.htm(Accessed: 1 May 2018).

ILO (no date) The Future of Work We Want: A global dialogue. Available at: http://www.ilo.org/wcmsp5/groups/public/---dgreports/---

cabinet/documents/publication/wcms_570282.pdf (Accessed: 16 May 2018)

International Labour Office (2015) World employment and social outlook 2015: The changing nature of jobs. Geneva: ILO

International Labour Office, Governance and Tripartism Department and European Labour Law Network (2013) Regulating the employment relationship in Europe: A guide to Recommendation No. 198. Geneva: ILO

La Rue, F. (2011) Report of the Special Rapporteur on the promotion and protection of the right to freedom of opinion and expression. UN General Assembly Sixty-sixth session. Promotion and protection of human rights. A/66/290. United Nations

XVIIth Meeting of European Labour Court Judges (2009) General and national reports. Privacy in the workplace. ILO

CoE

Buttarelli, G. (2010) Study on Recommendation No. R (89) 2 on the protection of personal data used for employment purposes and to suggest proposals for the revision of the above-mentioned Recommendation. T-PD-BUR(2010)11. Strasbourg: The Bureau of the Consultative Committee of the Convention for the Protection of Individuals with Regard to Automatic Processing of Personal Data

$\mathrm{CoE}$ (2018): Explanatory Report to the Protocol amending the Convention for the Protection of Individuals with regard to Automatic Processing of Personal Data. Strasbourg, 10 October

CoE (no date) The European Social Charter. Available at: https://www.coe.int/en/web/european-social-charter (Accessed: 12 August 2019)

$\mathrm{CoE}$, Committee of Ministers (2015): Explanatory memorandum to Recommendation CM/Rec(2015)5 of the Committee of Ministers to member States on the processing of personal data in the context of employment

European Committee of Social Rights (2006) Statements of interpretation - Article 1-2. 2006_Ob_1-2/Ob/EN.

European Committee of Social Rights (2013) Activity Report 2012. Council of Europe European Committee of Social Rights (no date) Activity Report 2016. Council of Europe Guide sur l'article 8 de la Convention européenne des droits de l'homme. Droit au respect de la vie privée et familiale (2019). Conseil de l'Europe. Available 
at: https://www.echr.coe.int/Documents/Guide_Art_8_FRA.pdf (Accessed:

November 2019), pp. 12-19.

EU

EDPS (2015) Guidelines on personal data and electronic communications in the EU institutions.

Available

at:

https://secure.edps.europa.eu/EDPSWEB/webdav/site/mySite/shared/Documents/Sup ervision/Guidelines/15-12-16_eCommunications_EN.pdf(Accessed: 12 August 2019)

EDPS (2016) Guidelines on the protection of personal data processed through web services provided by EU institutions. Available

at: https://edps.europa.eu/sites/edp/files/publication/16-11-

07_guidelines_web_services_en.pdf(Accessed: 12 August 2019)

Eurofound and International Labour Office (2017) Working anytime, anywhere: The effects on the world of work. Joint ILO-Eurofound report. Luxembourg, Geneva: Publications Office of the European Union, International Labour Office

European Commission (2004) 'Second stage consultation of social partners on the protection of workers' personal data'

European Commission (2010) Communication from the Commission to the European Parliament, the Council, the Economic and Social Committee and the Committee of the Regions - A comprehensive approach on personal data protection in the European Union. COM(2010) 609 final. Brussels

European Commission (2010) Comparative study on different approaches to new privacy challenges, in particular in the light of technological developments. JLS/2008/C4/011 - 30'CE'0219363/00'28

European Commission (2012) Commission proposes a comprehensive reform of data protection rules to increase users' control of their data and to cut costs for businesses. Press release. Brussels. Available at: http://europa.eu/rapid/pressrelease_IP-12-46_en.htm(Accessed: 18 January 2019)

European Commission (2015) Digital Single Market Strategy for Europe. Communication from the Commission to the European Parliament, the Council, the European Economic and Social Committee and the Committee of the Regions COM(2015) 192 final. Brussels

European Commission (2016) A European agenda for the collaborative economy. Communication from the Commission to the European Parliament, the Council, the European Economic and Social Committee and the Committee of the Regions $\operatorname{COM}(2016) 356$ final. Brussels

European Commission (2018) The GDPR: new opportunities, new obligations. What every business needs to know about the EU's General Data Protection Regulation. Luxembourg: Publications Office of the European Union: European Union. Available at: https://ec.europa.eu/commission/sites/beta-political/files/dataprotection-factsheet-sme-obligations_en.pdf (Accessed: 30 October 2019)

European Union Agency for Fundamental Rights and Council of Europe (2018) Handbook on European data protection law: 2018 edition. Luxembourg: Publications Office of the European Union

Explanation on Article 7. Explanations relating to the Charter of Fundamental Rights (2007). 2007/C 303/02

Safer Social Networking Principles for the EU(2009). Available at: https://ec.europa.eu/digital-single-market/sites/digitalagenda/files/sn_principles.pdf (Accessed: 20 January 2019) 


\section{Other}

30th International Conference of Data Protection and Privacy Commissioners Strasbourg, 17 October 2008

30th International Conference of Data Protection and Privacy Commissioners (2008) Resolution on Privacy Protection in Social Network Services. Strasbourg

European Digital Rights (no date) 'Key aspects of the proposed General Data Protection Regulation explained: What are they? Why are they important? What are common misconceptions? What can be improved?' Available at: https://edri.org/files/GDPRkey-issues-explained.pdf(Accessed: 1 May 2018)

European Network of Legal Experts in the field of Labour Law (2009) Characteristics of the Employment Relationship. Thematic Report 2009. Contract No. VC/2008/1211

Information Commissioner's Office (2011) The employment practices code. Available from: https://ico.org.uk/media/fororganisations/documents/1064/the_employment_practices_code.pdf [Accessed 1 February 2017]

Office of the Information \& Privacy Commissioner for British Columbia (no date) Summary of the Office of the Information and Privacy Commissioner's Investigation of the BC NDP's use of social media and passwords to evaluate candidates. P11-01-MS. Available at: https://www.oipc.bc.ca/mediationsummaries/1399 (Accessed: 8 July 2019) 


\section{ANNEXES}

\section{Annex I. - Most important international documents in the fields of privacy - data protection - employment - social network sites (UN, CoE, EU)}

\begin{tabular}{|c|c|c|c|c|}
\hline & \multicolumn{2}{|c|}{ GENERAL } & \multicolumn{2}{|c|}{ SECTORAL } \\
\hline & $\begin{array}{l}\text { RIGHT TO } \\
\text { PRIVACY }\end{array}$ & $\begin{array}{l}\text { RIGHT TO DATA } \\
\text { PROTECTION }\end{array}$ & EMPLOYMENT & SOCIAL NETWORK SITES \\
\hline $\mathbf{U N}$ & $\begin{array}{l}\text { UDHR Art. } 19 . \\
\text { (1948) } \\
\text { ICPR Art. } 17 . \\
(1966)\end{array}$ & $\begin{array}{l}\text { Guidelines for the } \\
\text { Regulation of } \\
\text { Computerized } \\
\text { Personal Data Files } \\
\text { (1990) }\end{array}$ & $\begin{array}{l}\text { ILO: } \\
\text { Protection of } \\
\text { workers' personal } \\
\text { data. An ILO code } \\
\text { of practice (1997) }\end{array}$ & $\begin{array}{l}\text { The promotion, protection } \\
\text { and enjoyment of human } \\
\text { rights on the Internet } \\
\text { (2012) } \\
\text { Resolution on the right to } \\
\text { privacy in the digital age } \\
\text { (2013) }\end{array}$ \\
\hline $\mathrm{CoE}$ & $\begin{array}{l}\text { ECHR Art. } 8 . \\
(1950)\end{array}$ & $\begin{array}{l}\text { Convention } 108 \\
\text { (1981) }\end{array}$ & $\begin{array}{l}\text { Recommendation } \\
\text { on the "Protection } \\
\text { of Personal Data } \\
\text { Used for } \\
\text { Employment } \\
\text { Purposes (1989) } \\
\text { Recommendation } \\
\text { on the processing of } \\
\text { personal data in the } \\
\text { context of } \\
\text { employment (2015) }\end{array}$ & $\begin{array}{l}\text { Resolution on the } \\
\text { protection of privacy and } \\
\text { personal data on the } \\
\text { Internet and online } \\
\text { media (2011) } \\
\text { Recommendation on the } \\
\text { Protection of Human } \\
\text { Rights with Regard to } \\
\text { Social Networking } \\
\text { Services (2012) }\end{array}$ \\
\hline $\mathbf{E U}$ & $\begin{array}{l}\text { CFREU Art. } 7 . \\
(2000)\end{array}$ & $\begin{array}{l}\text { TFEU Art. } 16 . \\
\text { CFREU Art. } 8 . \\
\text { (2000) } \\
\text { DPD (1995) } \\
\text { GDPR (2016) }\end{array}$ & $\begin{array}{l}\text { WP29: } \\
\text { Opinion } 8 / 2001 \text { on } \\
\text { the processing of } \\
\text { personal data in the } \\
\text { employment } \\
\text { context (2001) } \\
\text { Working document } \\
\text { on the surveillance } \\
\text { of electronic } \\
\text { communications in } \\
\text { the workplace } \\
\text { (2002) } \\
\text { Opinion 2/2017 on } \\
\text { data processing at } \\
\text { work (2017) }\end{array}$ & $\begin{array}{l}\text { European Commission: } \\
\text { Safer Social Networking } \\
\text { Principles for the EU } \\
\text { (2009) } \\
\text { WP29: } \\
\text { Opinion 5/2009 on online } \\
\text { social networking (2009) } \\
\text { ENISA: } \\
\text { Security Issues and } \\
\text { Recommendations for } \\
\text { Online Social Networks } \\
\text { (2007) }\end{array}$ \\
\hline
\end{tabular}

